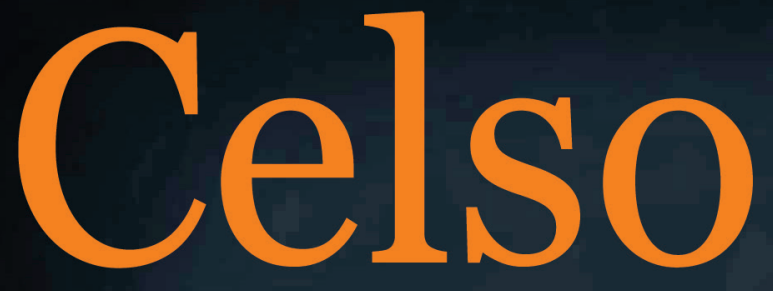

3
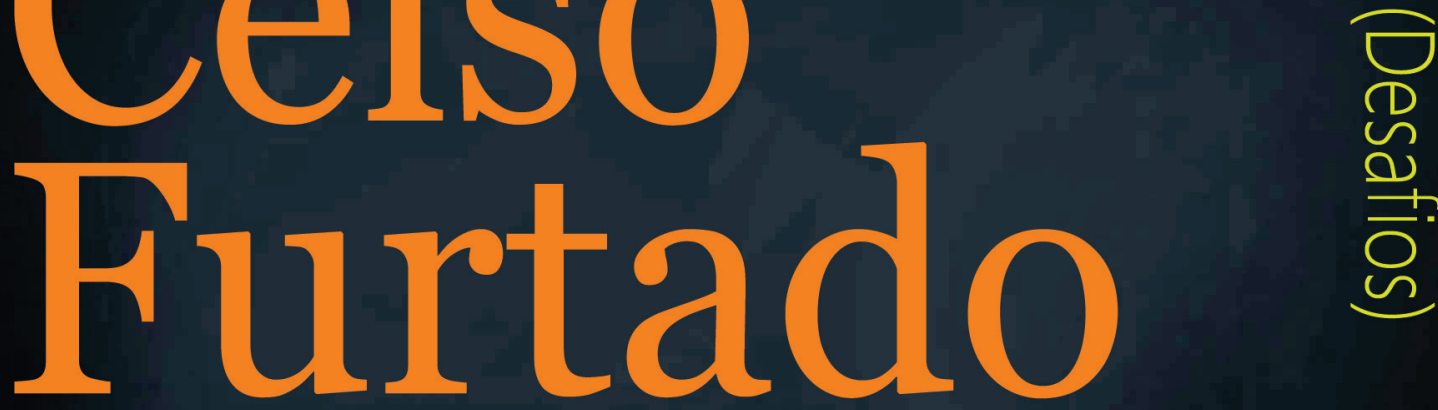

a esperança militante

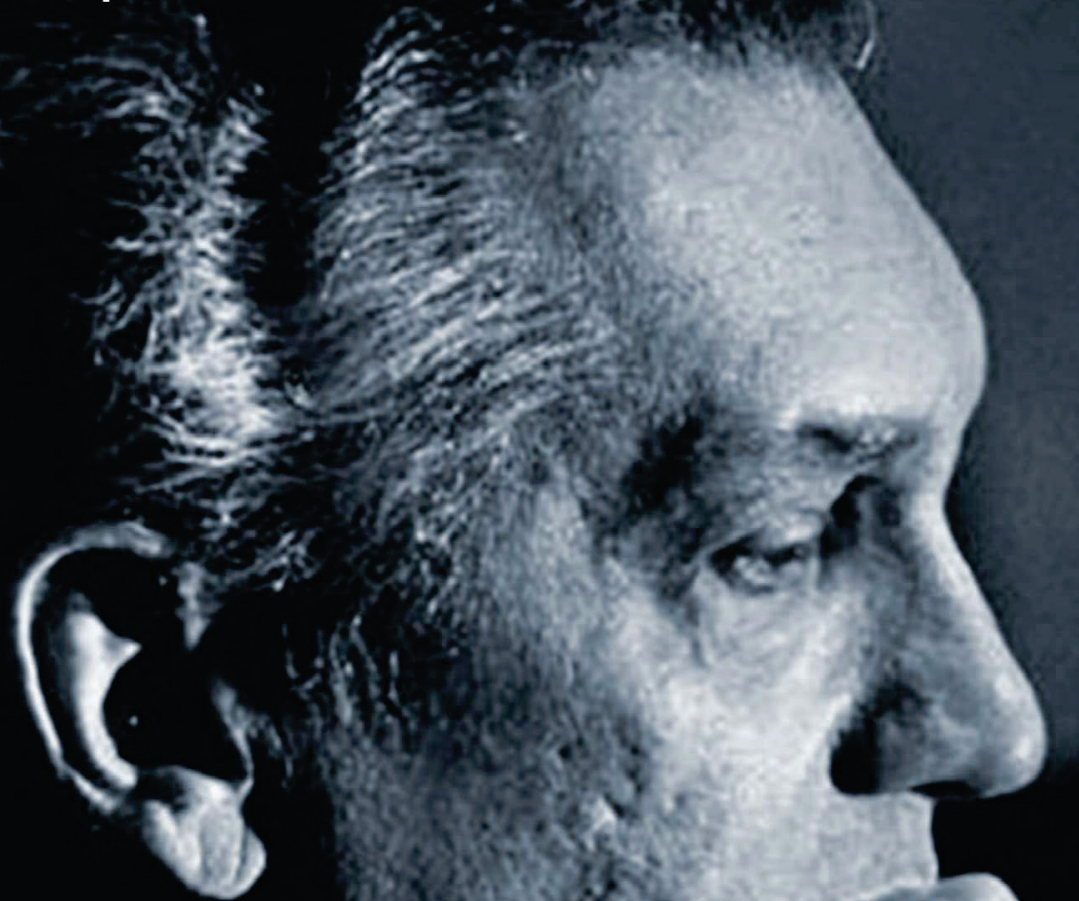

Cidoval Morais de Sousa Ivo Marcos Theis

José Luciano Albino Barbosa

(Organizadores)
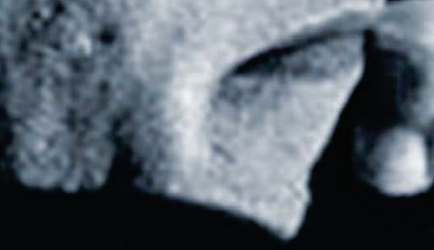

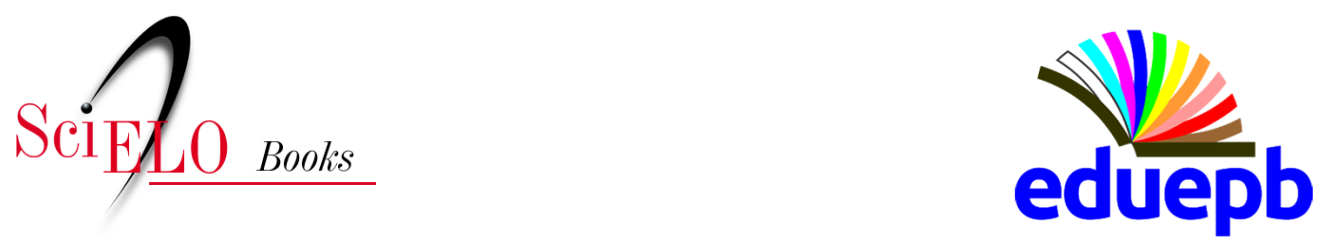

\title{
Celso Furtado: a esperança militante (Desafios): vol. 3
}

\author{
Cidoval Morais de Sousa \\ Ivo Marcos Theis \\ José Luciano Albino Barbosa \\ (orgs.)
}

\section{SciELO Books / SciELO Livros / SciELO Libros}

SOUSA, C. M., THEIS, I. M., and BARBOSA, J. L. A., eds. Celso Furtado: a esperança militante (Desafios): vol. 3 [online]. Campina Grande: EDUEPB, 2020, 462 p. Projeto editorial 100 anos de Celso Furtado collection, vol. 3. ISBN: 978-65-86221-12-1. https://doi.org/10.7476/9786586221688.

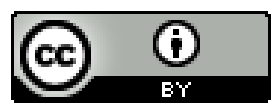

All the contents of this work, except where otherwise noted, is licensed under a Creative Commons Attribution 4.0 International license.

Todo o conteúdo deste trabalho, exceto quando houver ressalva, é publicado sob a licença Creative Commons Atribição 4.0.

Todo el contenido de esta obra, excepto donde se indique lo contrario, está bajo licencia de la licencia Creative Commons Reconocimento 4.0. 


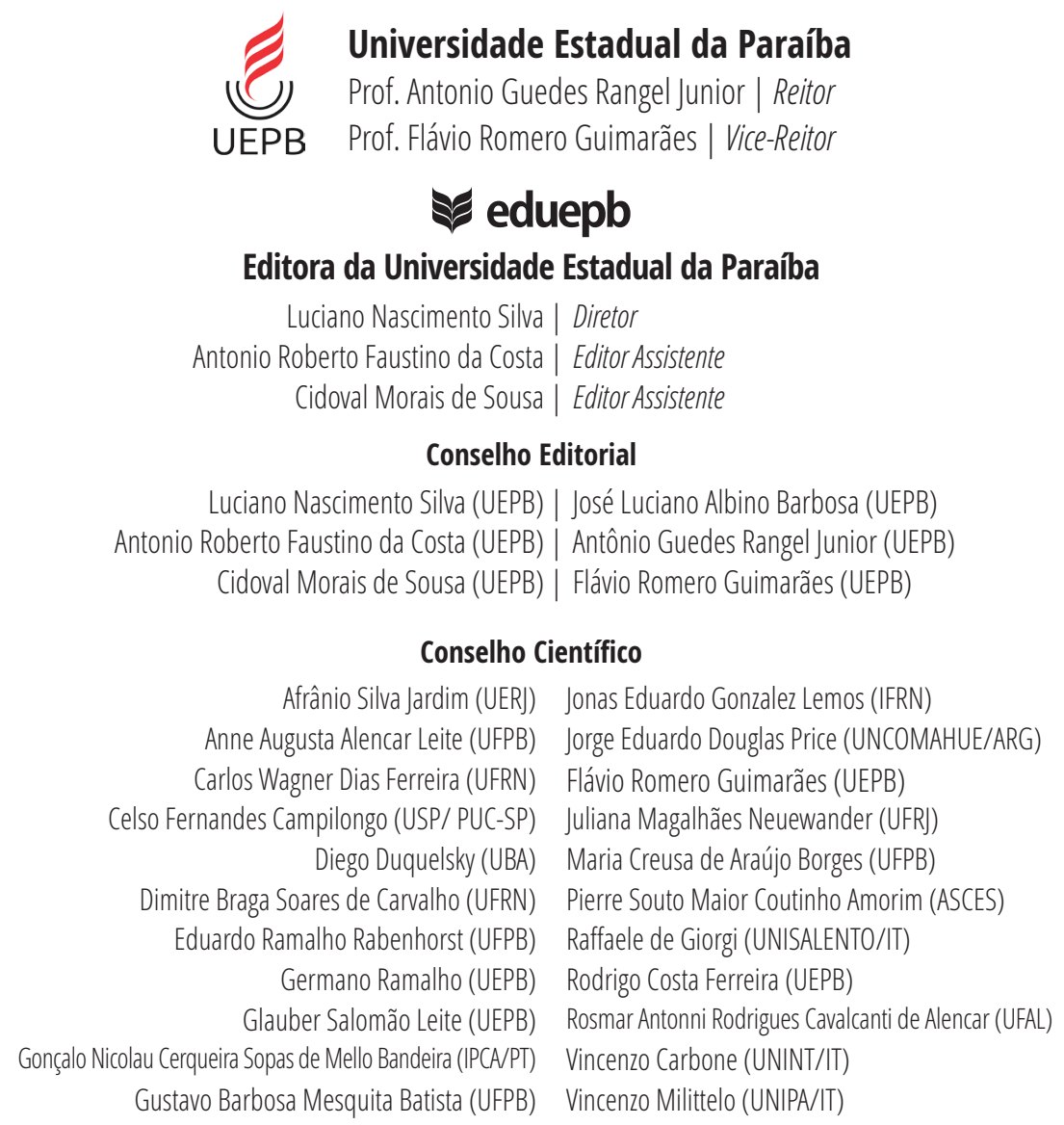

\section{Expediente EDUEPB}

Erick Ferreira Cabral | Design Gráfico e Editoração Jefferson Ricardo Lima Araujo Nunes | Design Gráfico e Editoraç̧ão Leonardo Ramos Araujo | Design Gráfico e Editoração Elizete Amaral de Medeiros | Revisão Linguística Antonio de Brito Freire | Revisão Linguística Danielle Correia Gomes | Divulgação

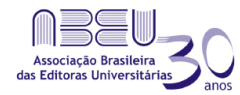

Editora filiada a ABEU

EDITORA DA UNIVERSIDADE ESTADUAL DA PARAÍBA

Rua Baraúnas, 351 - Bairro Universitário - Campina Grande-PB - CEP 58429-500 Fone/Fax: (83) 3315-3381 - http://eduepb.uepb.edu.br - email: eduepb@uepb.edu.br 
Cidoval Morais de Sousa

Ivo Marcos Theis

José Luciano Albino Barbosa

(Organizadores)

\section{Celso Furtado a esperança militante (Desafios) Vol 3}

AƯNIÃO eduepb

Campina Grande - PB 2020 


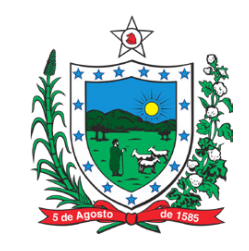

\title{
Estado da Paraíba
}

\author{
João Azevêdo Lins Filho | Governador \\ Ana Lígia Costa Feliciano | Vice-governadora \\ Nonato Bandeira | Secretário da Comunicação Institucional \\ Claudio Benedito Silva Furtado | Secretário da Educação e da Ciência e Tecnologia \\ Damião Ramos Cavalcanti | Secretário da Cultura
}

\section{EPC - Empresa Paraibana de Comunicação

\author{
Naná Garcez de Castro Dória | Diretora Presidente \\ William Pereira Costa | Diretor de Mídia Impressa \\ Alexandre Macedo | Gerente da Editora A União \\ Albiege Léa Fernandes | Diretora de Rádio e TV
}

\section{AU UNNIÃO}

BR 101 - KM 03 - Distrito Industrial - João Pessoa-PB - CEP: 58.082-010

Depósito legal na Câmara Brasileira do Livro.

C766 Celso Furtado: a esperança militante: vol.3.[Livro eletrônico]./Cidoval Morais de Sousa, Ivo Marcos Theis, José Luciano Albino Barbosa(Organizadores). -Campina Grande: EDUEPB, 2020. $4600 \mathrm{~Kb}$. - 464 p. il.

\section{Nota: "Projeto editorial 100 anos de Celso Furtado" ISBN 978-65-86221-12-1 (E-book) \\ ISBN 978-65-86221-13-8 (Impresso)}

1. Desenvolvimento regional - Brasil, Nordeste. 2.Celso Furtado (1920-2004). 3. Economista paraibano. 4. Celso Furtado - Cientista social. 5. Desenvolvimento econômico. 5.Desigualdades regionais. 6. Políticas de desenvolvimento - Brasil, Nordeste. I.Sousa, Cidoval Morais de (Organizador). II. Theis, Ivo Marcos (Organizador). III. Barbosa, José Luciano Albino(Organizador).

21. ed.CDD 338.99813

Ficha catalográfica elaborada por Heliane Maria Idalino Silva - CRB-15³68

\section{Copyright (C) EDUEPB}

A reprodução não-autorizada desta publicação, por qualquer meio, seja total ou parcial, constitui violação da Lei no 9.610/98. 


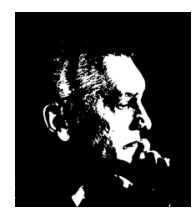

\section{Projeto Editorial 100 anos de Celso Furtado}

\section{Coordenação}

Cidoval Morais de Sousa

Ivo Marcos Theis

José Luciano Albino Barbosa

\section{Equipe}

Antonio Guedes Rangel Júnior

Angela Cristina Moreira do Nascimento

Thales Haddad Novaes de Andrade

Arão Azevedo

Hipólito Lucena

Antônio Roberto Faustino da Costa

Andreza Dantas Albuquerque

Milena Barros Marques dos Santos

Ângela Maria Cavalcante Ramalho

Andrea Carla de Azevêdo

João Morais de Sousa 



\section{Agradecimentos}

A trilogia Celso Furtado: a esperança militante é uma construção coletiva que se tornou realidade graças ao apoio de muitos parceiros e instituições. Dentre eles, destacamos: João Azevêdo Lins Filho (Governador da PB); Antonio Guedes Rangel Júnior (Reitor da UEPB); Maria José Lima Silva (PRPGP UEPB); Cátedra Celso Furtado PPGDR (UEPB/

UFCG); Luciano Nascimento (EDUEPB); Naná Garcez (EPC); Rosa Freire d'Aguiar (Jornalista e Tradutora); Carlos Brandão (IPPUR-UFRJ); Fernando Macedo (IE - Unicamp); Dom Jaime Vieira Rocha (OBSER$\mathrm{NE}$ ); Roberto Germano Costa (FAPESQ-PB); Roberto Saturnino Braga (Centro Internacional Celso Furtado); Monica Tejo Cavalcanti (INSA); Marcos Costa Lima (UFPE); Núcleo de Pesquisa em Desenvolvimento Regional (NPDR-FURB); REDE OBSERVADR; UNIFASB; SBPC. 

Na periferia são os cientistas os que mais facilmente adquirem uma visão global do mundo, pois a ciência é hoje um sistema de criação de conhecimentos organizado em escala planetária. A percepção da dependência em que nos encontramos resulta naturalmente dessa visão global. Isso aumenta a responsabilidade que cabe naturalmente aos cientistas como agentes da transformação social. Se os cientistas tomarem plena consciência da significação última do que produzem, como valores sociais e humanos, do contexto social em que estão inseridos e da situação de dependência a que tem sido relegado o nosso país, terão necessariamente - como cidadãos ou como força social organizada que contribuir de forma decisiva para colocar a ciência e a tecnologia a serviço da solução dos imensos problemas que enfrenta nossa sociedade.

(Celso Furtado - SBPC, Fortaleza, agosto de 1979) 



\section{Sumário}

\section{APRESENTAÇÃO, 15}

Abrindo cancelas

Tania Bacelar de Araujo

\section{INTRODUÇÃO, 21}

Uma agenda para pensar o desenvolvimento regional Cidoval Morais de Sousa

Ivo Marcos Theis

José Luciano Albino Barbosa

\section{PARTE I - DILEMAS EPISTEMOLÓGICOS E CONCEITUAIS}

O que é desenvolvimento regional? Uma aproximação a partir da realidade brasileira, 43 Ivo Marcos Theis

Pensando com o desenvolvimento regional: subsídios para um programa forte em desenvolvimento regional, 75 Marcos Antônio Mattedi

O desenvolvimento regional como fenômeno regional, 129 Jandir Ferrera de Lima

A dimensão regional do desenvolvimento: contribuições teóricas e experiências sul-americanas, 141 Virginia Elisabeta Etges 
PARTE II - POLÍTICAS, ESCALAS, TERRITÓRIOS

Política Nacional de Desenvolvimento Regional no Brasil: incapacidade ou não-acontecimento? Uma interrogação pendente, 165

Rainer Randolph

Escalas espaciais, território e desenvolvimento regional: notas para discussão teórica e metodológica, 193

Rogério Leandro Lima da Silveira

Para pensar as espacialidades e as temporalidades dos processos sociais regionalizados em conjuntura de crise disruptiva, 217

Carlos Antônio Brandão

Processos de apropriação espacial: contribuições para estudos futuros, 241

Thiago José Arruda de Oliveira

Waldecy Rodrigues

Ordenamento territorial e desenvolvimento regional: aproximações conceituais, 263

Lívia Gabriela Damião de Lima

Larissa da Silva Ferreira Alves

Diferenciais produtivos no espaço Semiárido brasileiro:

o caso do Ceará, 285

Maria Daniele Cruz dos Santos

Francisco do O' de Lima Júnior 
O desenvolvimento regional em Celso Furtado:

a coordenação federativa e as implicações institucionais, 311 Luciléia Aparecida Colombo

Thales Haddad Novaes de Andrade

Aristides Monteiro Neto

Federalismo Brasileiro: uma revisitação das contribuições de Celso Furtado, 327

Rosangela dos Santos Alves Pequeno

Fernando Cézar de Macedo

PARTE IV - COMUNICAÇÃO, EDUCAÇÃO E CULTURA

Aproximações entre estudos culturais e desenvolvimento regional: uma proposta teórico-metodológica para estudar a comunicação na interdisciplinaridade, 355

Ângela Cristina Trevisan Felippi

Grazielle Betina Brandt

Comunicação para o desenvolvimento regional, 375

Monica Franchi Carniello

Moacir José dos Santos

A Educação como fator de desenvolvimento regional, 397 Flávio Eliziário de Sousa

Mariane Freiesleben

Um olhar teórico-metodológico sobre processos de intervenção e de extensão para o desenvolvimento regional, 415 Cidonea Machado Deponti

Celso Furtado, o (sub) desenvolvimento numa perspectiva cultural e a criatividade nos Maracatus Nação

de Pernambuco, 431

Tiago Macedo Bezerra Maia

João Morais de Sousa 



\section{Apresentação}

\section{Abrindo cancelas ${ }^{1}$}

Tania Bacelar de Araujo²

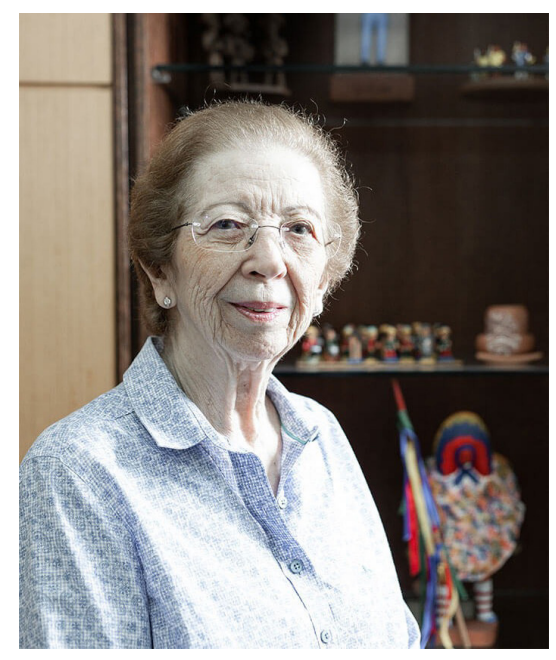

Centenário de nascimento de Celso Furtado ensejou muiTAS iniciativas, e isso foi muito importante, dada a contribuição deste ilustre brasileiro e seu exemplo como pensador que transformava reflexão em ação, sobretudo considerando o momento vivido pelo Brasil: a democracia sob constante ameaça e a economia imersa em crise estrutural, experimentando inusitada crise conjuntural provocada pela pandemia, tornando dramático o nosso quadro social.

1 Texto elaborado a partir da palestra de abertura do Seminário Virtual Centenário de Celso Furtado, no dia 26 de julho de 2020, que marcou, também, o lançamento do Volume 3 da Trilogia Celso Furtado: a esperança militante (Desafios). Vídeo disponível em: https://www.youtube.com/watch?v=tWYo9T5cJ_o\&t=8584s

2 Economista pela UNICAP, Socióloga pela Fafire, Mestre e Doutora em Economia pela Universidade de Paris I Panthéon-Sorbonne. É professora Emérita da UFPE. Foi diretora da Sudene e da Fundaj, Secretária de Planejamento e da Fazenda do Estado de Pernambuco, Secretária de Políticas de Desenvolvimento Regional do Ministério da Integração Nacional e Secretária de Planejamento da Prefeitura do Recife. 
Nesse contexto, merece referência especial a trilogia organizada pela Universidade Estadual da Paraíba (UEPB), Universidade Pública de um estado nordestino, justo a Paraíba, que, por conta da visão preconceituosa sobre nossa região, se transformou, recentemente, em sinônimo do Nordeste, no nosso grito uníssono: somos todos paraibanos! Trilogia que, entendo, ficará registrada na história como a mais importante homenagem entre todas que este centenário estimulou.

O grande objetivo da trilogia, da qual participei com muita honra, é o de homenagear, com reflexões de pessoas de diversas formações e visões, o centenário do nascimento deste grande brasileiro, Celso Monteiro Furtado, que dedicou sua vida a tentar entender e explicar o Brasil (que país é esse?), para propor estratégias e iniciativas que pudessem ajudar a transformar nosso pais, consolidando-o como uma verdadeira nação.

Dentre outras iniciativas semelhantes, destaco a da Associação Brasileira de Economistas pela Democracia (ABED), que também mobilizou muita gente para produzir a coletânea Celso Furtado: as lutas de um economista ${ }^{3}$, lançada no mesmo dia do nascimento do ilustre homenageado.

É estimulante ver reconhecido, como economista, alguém que, sempre valorizando a importância da economia na vida dos povos, nos ensinou que a dimensão econômica é apenas uma das dimensões da vida social. E que o agente econômico não é apenas um ente que toma decisões econômicas racionais - abstração exaltada por certas visões - mas, igualmente, um agente político e um ator social, que age influenciado pela cultura do ambiente onde atua, e que constrói elo fundamental da relação sociedade $x$ natureza.

Saído do sertão paraibano para o mundo, era um verdadeiro cientista: apoiava-se em teorias sólidas, conceitos claros, procedimentos cuidadosos, colocando-os sempre em diálogo com a realidade e, por isso, era capaz de revisitá-los e fazer avançar ideias, teses, interpretações e, especialmente, chegar a proposições para atuar na realidade. Quando se examina sua obra sobre o desenvolvimento - seu objeto central de preocupação - percebe-se que ele vai refinando e ampliando sua visão, sendo,

3 QUinTela, A.; GAlVÃO, A. C. F.; BOlaño, C.; PATRÍCIO, I.; MANZANO, M.; MACEDO, M. M.; LE COCQ, NELSON (ORGs). Celso Furtado: os combates de um economista. São Paulo: Fundação Perseu Abramo: Expressão Popular, 2020. Disponível em: https://fpabramo.org.br/publicacoes/wp-content/uploads/ sites/5/2020/o7/Celso-Furtado-Os-combates-de-um-economista_WEBFINAL3.pdf 
a meu ver, precursor da concepção contemporânea de desenvolvimento sustentável.

Para Furtado, desenvolvimento deve ser entendido como um processo de transformação que não se mede apenas pelo tamanho ou ritmo de crescimento do PIB, mas pelas condições de vida das pessoas, pela riqueza da vida cultural da sociedade, pela qualidade do ambiente institucional (no qual a democracia é fundamental) e pelo grau de interação saudável com a natureza.

Basta ler "O mito do desenvolvimento" para vê-lo, nos anos 1970, reafirmando a importância da dimensão social e ambiental, ou revisitar seu livro "Criatividade e dependência na civilização industrial", publicado no limiar dos anos 1980, para entender a importância que atribui à dimensão política e à autonomia cultural na vida de uma nação que se quer "desenvolvida" (aliás, ao ler este livro se entende porque foi Ministro da Cultura do Brasil).

Essa visão ampla alimentava seu desejo de transformar a realidade, em particular, a brasileira e, em especial, a nordestina.

E, embora tendo percebido a encalacrada em que nos metemos desde os anos 1980, e escreva um alerta nos anos 1990 no livro "Brasil: a construção interrompida”, prenúncio do que hoje vivemos, nunca deixou fechada a possibilidade de transformar para melhor a dura realidade brasileira.

Este livro traz, em um parágrafo denso, uma síntese de nossa trajetória, e um alerta:

\begin{abstract}
"Em meio milênio de história, partindo de uma constelação de feitorias, de populações indígenas desgarradas, de escravos transplantados de outro continente, de aventureiros europeus e asiáticos em busca de um destino melhor, chegamos a um povo de extraordinária polivalência cultural, a um país sem paralelo pela vastidão territorial e homogeneidade linguística e religiosa. Mas nos falta a experiência de provas cruciais como as que conheceram outros povos cuja sobrevivência chegou a ser ameaçada. E nos falta, também, um verdadeiro conhecimento de nossas possibilidades e, principalmente, de nossas debilidades. Mas não ignoremos que o tempo histórico se acelera, e que a contagem desse tempo se faz contra nós". ${ }^{4}$
\end{abstract}

Furtado sabia das travas de nossas heranças, mas tinha plena consciência de nossas potencialidades. Pressentia a dimensão da ruptura que vinha se dando nos padrões técnicos à escala mundial, no bojo da

4 FURTADO, C. Brasil: a construção interrompida. Rio de Janeiro, Editora Paz e Terra, 1992, 87p. 
revolução cientifico-tecnológica que se firmaria no século XXI, e nos estimularia a refletir sobre novas estratégias de desenvolvimento. Porque, como sertanejo, não desconhece a força bruta dos poderosos, mas não teme desafios e busca sempre resistir e se reinventar.

A melhor forma, portanto, de homenagearCelso Furtadoéesta:assumir a essência do povo nordestino e manter firme a disposição para construir novas estratégias de atuação e novas utopias possíveis. Homenageá-lo é continuar a disputa pela construção de um mundo melhor e insistir que o Brasil pode ser uma verdadeira nação, quando despertarmos seus potenciais latentes, um dos quais é a identidade nacional, construída na multifacetada base popular, que se expressa na nossa polivalência cultural.

As elites colonizadas não sabem o que é isso, como dizia outro paraibano ilustre: Ariano Suassuna, que fazia parte dos brasileiros que nunca foram à Disney, para espanto de uma dondoca carioca.

Não esqueçamos, também, que o Nordeste é um dos berços da nação brasileira. Lugar que Furtado, ao ver o resultado da modernização conservadora, acelerada no período em que ficou exilado, afirmou que continuava sendo síntese do Brasil: "O Nordeste é o espelho onde a imagem do Brasil se reflete com brutal nitidez". ${ }^{5}$ Este Nordeste que, hoje, em nome do Brasil, o homenageia.

Celso Furtado era alguém que - como disse o professor Cidoval Sousa, referindo-se à entrevista de José Otamar de Carvalho, constante do Volume 2 desta trilogia - "abria cancelas". ${ }^{6}$ Aquelas que fechavam acesso às estradas, à água - em pleno momento de seca - e à terra para plantar com autonomia, no interior paraibano e nordestino.

Cancelas, porém, que não conseguem bloquear a esperança e a determinação de muitos...

Algumas cancelas foram abertas, mas surgiram novas. E precisamos de faróis como a visão deixada por ele para identificá-las e construir maneiras de abri-las.

5 BACELAR, T. Revisitando a Questão Regional, in: Cadernos do Desenvolvimento, n. 1, Centro Internacional Celso Furtado de Políticas para o Desenvolvimento, Rio de Janeiro, 2006. Disponível em: http://www. cadernosdodesenvolvimento.org.br/ojs-2.4.8/index.php/cdes/article/ view/329/308

6 SOUSA, C.M.; THEIS, I. M.; ALBINO, J..L.B. Celso Furtado: a esperança militante (depoimentos). Campina Grande (PB): EDUEPB/UNIÃO, 2020. Disponível: http:// www.uepb.edu.br/download/documentos/documentos_2020/Celso-Furtado-Aesperanca-militante-Volume-2.pd 
Olhar para a frente, identificando desafios herdados e novos, como o fizeram os que contribuíram para este volume 3, ora apresentado. A proposta é buscar intervir no debate contemporâneo sobre o desenvolvimento com novas análises e soluções. E este volume reflete uma das mudanças mais relevantes ocorridas na região nordestina nos anos recentes: a ampliação e interiorização do sistema de ensino superior brasileiro, em especial, o público.

Os artigos deste volume dialogam com diversos pensadores e, de modo particular, com o nosso homenageado, Celso Furtado, a quem aplico a mesma frase que ele usou na despedida de Raul Prebisch da CEPAL, citada por Marcos Formiga, ex-Superintendente da SUDENE e hoje professor da UnB, na sua tese: "Para homens que se projetaram pela inteligência criadora e têm capacidade de influir pela força de suas ideias, não existem despedidas. Eles sempre estarão presentes"?

7 Ver: BACELAR, T. Um intelectual preocupado com a inserção do Brasil na ordem econômica, social e política contemporânea, em Teoria e Debate. Disponível em: https://teoriaedebate.org.br/2005/02/o1/celso-furtado-economista-e-cientista-social/\#: :text=Celso\%2oFurtado\%2C\%2odespedida $\% 2$ ode $\% 2$ oRa $\%$ C3\%BAl, Furtado\%2ofaleceu $\% 2$ oa os $\% 2084 \% 20$ anos.\&text=Em\%201939\%2omudou\%2Dse\%2opara,do\%2oBrasil\%2o(hoje\%2o UFRJ). 



\title{
Introdução
}

\section{Uma agenda para pensar o desenvolvimento regional}

\author{
Cidoval Morais de Sousa \\ Ivo Marcos Theis ${ }^{2}$ \\ José Luciano Albino Barbosa ${ }^{3}$
}

\section{À guisa de apresentação}

O PÓs-Segunda Guerra Mundial o termo DesenVolvimento
passou a ser utilizado para designar um processo de transformação social baseado em dois pilares: industrialização e renda. O desafio de reconstruir a Europa devastada e o avanço da potência militar soviética exigiram do capitalismo formas atualizadas de reprodução. Assim, o que passou a ser conhecido como produção em massa dizia respeito muito mais do que disciplinamento fabril e expansão do consumo. Significou, portanto, a definição de bases sociais, com ênfase nos países centrais, para a retomada de suas economias, sendo os Estados Unidos seu epicentro nervoso. Naquele contexto, desenvolvimento era algo atrelado, do ponto de vista acadêmico, à Economia ou, no máximo, à Sociologia Econômica.

1 Jornalista, doutor em Geociências pela Unicamp, professor e pesquisador da Universidade Estadual da Paraíba (UEPB), vinculado aos Programas de Pós-Graduação em Desenvolvimento Regional e Ensino de Ciências e Educação Matemática. Colabora com o PPGCTS da UFSCar.

2 Economista, $\mathrm{PhD}$ em Geografia Humana pela Eberhard-Karls Universität Tübingen (Alemanha), docente-pesquisador do Programa de Pós-Graduação em Desenvolvimento Regional da Universidade Regional de Blumenau (FURB), líder do Núcleo de Pesquisas em Desenvolvimento Regional, editor da Revista Brasileira de Desenvolvimento Regional e Bolsista de Produtividade em Pesquisa do CNPq.

3 Sociólogo, Doutor em Sociologia pela UFPB, professor efetivo da Universidade Estadual da Paraíba (UEPB), vinculado ao Departamento de Ciências Sociais e docente permanente do Programa de Pós-graduação em Desenvolvimento Regional. 
Ocorre que, no início dos anos de 1970, outras variáveis passaram a compor a cena. A questão ambiental se destacaria como preocupação crescente no debate mundial, muito em decorrência das implicações negativas causadas pelo processo de industrialização (uso de combustíveis fósseis, poluição dos oceanos, escassez da água potável etc.). Nesta linha, cresceria a preocupação, tanto política quanto acadêmica, sobre o desenvolvimento sustentável. O desenvolvimento, como conceito e prática, deslizou da Economia e assumiu a condição de tema transversal a outras áreas, tornando-se, assim, interdisciplinar. Muitos pesquisadores acompanharam tal mudança. Um deles foi Celso Furtado, principalmente quando intensificou sua análise crítica ao processo de subdesenvolvimento, típico do Brasil, que se mostrava desigual, concentrador de riqueza e predador dos recursos naturais.

Em termos contemporâneos, como se mostrará ao longo deste texto e desta coletânea, o desenvolvimento está presente, como temática de estudo, em Universidades do Interior brasileiro, com destaque para o enfoque regional em instituições estaduais, municipais e comunitárias. Pesquisas nas áreas de educação, saúde, cultura, segurança pública, como também investigação sobre Estado e Federalismo, estão na agenda e desafiam os pesquisadores da área. Falar sobre desenvolvimento, hoje, com destaque para a questão regional, remete às dimensões de espaço e poder. Em outras palavras, pensar sobre as escalas e levar em consideração as preocupações geográficas com suas redes e configurações políticas tem sido uma preocupação constante nos trabalhos sobre desenvolvimento regional no país ao longo das últimas décadas.

No caso particular de Furtado, mesmo que ele tenha se tornado mundialmente conhecido como economista, sua produção intelectual é de difícil classificação em termos de área de conhecimento. O seu foco de análise era o Brasil como totalidade, ou seja, as bases históricas e estruturais de sua formação e dinamismo tenso e contraditório. Para usar uma chave de compreensão da Sociologia de Marcel Mauss (2003), em Furtado está presente a ideia do fato social total, no sentido de que a vida social se define por múltiplas esferas (econômica, jurídica, cultural, psicológica etc.). O pensamento regional brasileiro contemporâneo, como veremos adiante, apoia-se em dois pilares que lhe conferem identidade: o estudo do Brasil profundo e a mobilização de diversas áreas do conhecimento, algo inquestionavelmente alinhado com as bases e inspirações furtadianas.. 


\section{A esperança militante}

Uma trilogia... é uma trilogia! E com este terceiro volume de Celso Furtado: a esperança militante finalizamos a tarefa. Lembremos: o primeiro volume reuniu textos que recuperaram a vida pública e a trajetória intelectual deste ilustre paraibano que se tornaria, tanto no campo das ideias quanto no terreno da ação, uma referência para o Brasil e para o mundo - daí se designá-lo "interpretações". Já para o segundo volume foram selecionados textos que correspondem a relatos de/entrevistas com quem conviveu, mais ou menos próximo, com o servidor público exemplar, o ministro comprometido, o professor atento e dedicado, o intelectual competente e, inclusive, o humano tão humano quanto todos/as os/ as seus/suas semelhantes - daí se batizá-lo de "depoimentos". O terceiro volume, finalmente, enfeixa textos que expressam, explícita ou implicitamente, a presença - nalguns casos, a influência e, noutros, até a herança (lições e legado) - do ilustre paraibano em seus respectivos afazeres cotidianos, sobretudo, como docentes e investigadores ligados à academia - daí se nominá-lo "desafios".

Talvez deva ser dito, inicialmente, que um número considerável dos 17 capítulos/textos que (além desta introdução) compõem o presente volume é inédito, enquanto uma parte deles já havia conhecido o mundo na forma de artigo publicado em algum periódico científico. Se se tomar como referência a sua origem, percebe-se uma considerável diversidade regional dos/as 27 autores/as que os assinam (29 no total, se inclusos os autores da introdução): eles/as vêm de quatro macrorregiões, embora, especialmente, do Nordeste e do Sul. Ademais, é notável que muitos dos docentes-pesquisadores que assinam esses capítulos/textos se encontram vinculados a programas de pós-graduação em desenvolvimento regional ou de seu entorno imediato - ponto a ser devidamente considerado mais à frente. E, por fim, outro aspecto que sobressai é a diversidade temática, destacando-se, aqui, a preocupação com aspectos teórico-metodológicoconceituais, com aspectos políticos - o problema das escalas e a questão federativa - e com aspectos educacionais, comunicacionais e culturais.

Se, nesta introdução, se fala de "uma agenda para pensar o desenvolvimento regional”, comecemos, então, por aí. A nossa intuição foi de associar os desafios postos pela obra de Celso Furtado com "desenvolvimento em escala subnacional”. Parece óbvio. Mas, requer uma breve explicação. Em primeiro lugar, como estamos falando do Brasil e desde o Brasil, portanto, de uma sociedade (uma economia, um país, uma formação social...) 
em específico, e partindo do pressuposto de que esta sociedade pode ser caracterizada como "subdesenvolvida", um olhar para a frente, comprometido, não pode ser lançado sobre outras sociedades. Daí concentrarmos a nossa atenção no Brasil e, a partir do legado de Celso Furtado, pensarmos o regional no Brasil.

Aqui cabe um breve parêntesis: mais que por outra razão qualquer, a passagem de Furtado pela CEPAL, certamente, levou-o a referir-se, em diversas ocasiões, à escala do subcontinente (no caso, à América Latina) quando usava o termo "região". Dois exemplos: em A hegemonia dos Estados Unidos e o subdesenvolvimento da América Latina, por exemplo, Furtado escreveu que, "excetuados casos especiais, as economias da região foram seriamente afetadas, ainda que em graus diversos, pelo declínio relativo do comércio internacional de produtos primários" (FURTADO, 1978, p. 79 - itálico nosso). Em Prefácio à nova economia política, ele registrou: "quando um grupo de economistas latino-americanos preparamos, em 1949, o primeiro Estudo Econômico da América Latina, dispúnhamos apenas de dados incompletos das balanças de pagamentos de uns poucos países da região" (FURTADO, 1977, p. 125 - itálico nosso). Está nítido, em ambos os casos, que "região", para o economista paraibano, era a América Latina. Contudo, foram também numerosas as ocasiões em que empregaria o termo "região" para referir-se à escala subnacional.

Um belíssimo exemplo salta do primeiro parágrafo do capítulo XXIII de Formação econômica do Brasil, sua opus magna: "Além da grande corrente migratória de origem europeia para a região cafeeira, o Brasil conheceu no último quartel do século XIX e primeiro decênio deste um outro grande movimento de população: da região nordestina para a amazônica" (FURTADO, 1977, p. 129 - itálicos nossos). Em Perspectivas da economia brasileira, dedicou um capítulo, especialmente, ao "problema das disparidades regionais" (FURTADO, 2012, p. 61-67). Em A fantasia desfeita, começou o prefácio com a lembrança de que, "ao concluir $A$ fantasia organizada, eu assinalara que as crescentes disparidades regionais constituíam sério desafio a quem se preocupasse com o futuro do Brasil e que, como nordestino, isso me preocupava particularmente" (FURTADO, 1989, p. 11 - itálico do autor).

Um último exemplo de que Furtado utilizava, competentemente, o termo região para referir-se à escala subnacional se pode encontrar em O longo amanhecer, aí postulando que, "no caso de uma reformulação constitucional, não seria fora de propósito discutir a possibilidade de 
uma esfera regional de poder" (FURTADO, 1999, p. 55 - itálicos nossos). Em síntese: e não vindo muito a propósito cada questão, cada situação, cada problema específico por ele considerado ao fazer menção ao "regional", interessa reter que, mesmo tendo utilizado "região" para também referir-se à América Latina, é inquestionável que nosso homenageado empregava o termo, e com inegável habilidade, tendo em vista a escala subnacional.

Em segundo lugar, como se está associando os desafios legados pela obra de Celso Furtado ao que vai no território de uma sociedade (uma economia, um país, uma formação social...) em específico - um território, em qualquer caso, diverso em suas características físico-ambientais e socioculturais, e socioeconômica e politicamente heterogêneo e desigual em algum grau -, miram-se, com curiosidade científica, as suas diversas partes constitutivas. Daí justificar-se a composição deste terceiro volume, no qual predominam contribuições de docentes e pesquisadores vinculados a programas de pós-graduação do campo do desenvolvimento regional (alguns, do planejamento urbano e regional). Ou seja, os afazeres profissionais da maior parte, dos/as autores/as que assinam os capítulos que integram o presente volume dizem respeito ao que se passa, precisamente, na escala subnacional.

Aqui também cabe um outro brevíssimo parêntesis: a ocupação intelectual com a escala regional tem já algumas décadas de história. Mas, são as determinações materiais concretas que convidam a pensar - às vezes, induzem mesmo a refletir - sobre uma certa problemática. As conhecidas vicissitudes do desenvolvimento brasileiro, suportavelmente desigual durante o auge do café, se tornaria incomodamente desigual com a industrialização. Localizando-se a atividade manufatureira privilegiadamente em São Paulo, o dinamismo econômico se concentraria no centro-sul do país. A "questão regional" se manifestaria em decorrência da intensificação de fluxos cada vez mais desiguais entre os espaços economicamente mais dinâmicos e a vasta periferia, esta, provedora de matérias-primas e, sobretudo, capital variável.

Celso Furtado não foi apenas o primeiro a perceber a natureza do processo de "atrasamento" do Nordeste, como também o que melhor o entendeu e explicou - e, quando teve a oportunidade, o que melhores recursos mobilizou para frear, quiçá, para inverter os fluxos econômicos que reproduziam "disparidades regionais" em escala ampliada no Brasil. Nos últimos 25 anos, cresceu no país a consciência de que a academia deveria fincar pés e dedicar suas energias no estudo dos problemas econômicos, 
sociais, ambientais e culturais na escala regional. Programas de pós-graduação em desenvolvimento regional, como sinalizamos acima, emergiram não em grandes metrópoles, mas, principalmente, em cidades médias; não na faixa litorânea, mas, sobretudo, no interior; não desde grandes universidades federais estabelecidas, mas, em sua maior parte, desde universidades estaduais e comunitárias. Aí, pois, se identifica, mais ou menos explicitamente, a influência das lições de Celso Furtado no que respeita ao território socioeconômica e politicamente heterogêneo e desigual, às "disparidades regionais" - que convidam a refletir e, às vezes, induzem mesmo a intervir sobre suas causas mais profundas e as possibilidades mais viáveis para o seu necessário enfrentamento.

Em terceiro lugar, por fim, cabe ligar, dialeticamente, o que se passa - inclusive, de uma perspectiva geográfica - em uma sociedade (uma economia, um país, uma formação social...) concreta com os desafios que brotam da obra de Furtado. Se é certo que ele usou com alguma parcimônia uma terminologia mais ao gosto do marxismo, não é menos certo que, quando recorreu a ela, o fez com maestria. Um exemplo - não o único - está no uso dos conceitos de "modo de produção" e "formação social", feito no já referido Prefácio a nova economia política (FURTADO, 1977). A sua evocação aqui tem o sentido de lembrar que o economista paraibano manejava com rara competência o instrumental teórico mais adequado para captar o movimento de uma sociedade subdesenvolvida, periférica e dependente como era - e continua sendo - o Brasil.

No entanto, Celso Furtado não se limitava em, meramente, captar o tal movimento. Sua preocupação fora, desde sempre, com a mudança política da situação que lhe chama atenção. Voltando ao termo região, que nesta coletânea está justificadamente privilegiada, o nosso homenageado não apenas sabia perfeitamente bem o que fazer com este conceito (uma representação do real, que se lhe apresentava como objeto de análise) quando referido à escala subnacional; mas, à luz do caso do Nordeste, também sabia perfeitamente bem que "região" era um termo com o qual podia definir concretamente um lócus de intervenção política. Para que fique mais evidente o que se acaba de indicar, cabe retornar, brevemente, ao prefácio de $A$ fantasia desfeita, quando ali se referiu ao "considerável esforço realizado, com a chamada Operação Nordeste, para mudar o rumo da história na região". Atente-se que, na sequência, ele afirmará que:

Esse esforço se inseria em amplo processo de mudança social, todo ele orientado para recuperar o atraso político e abrir espaço a fim de que parcelas crescentes da população 
regional assumissem na plenitude os direitos de cidadania. Verdadeiras mudanças não poderiam vir senão da renovação dos quadros políticos, com o aumento de sua representatividade e a rejeição, para um desvão da história, das velhas oligarquias (FURTADO, 1989, p. 11).

Note-se que a região é, aqui, desfetichizada. Ou seja, "região" não é uma abstração destituída de gente ou atividade produtiva, mas um espaço concreto de conflito, disputa e luta social. De fato, tornou-se uma categoria analítica central com a qual o economista paraibano captaria o movimento do "atrasamento" do Nordeste em sua plenitude e, simultaneamente, apontaria o/um caminho para romper com os seus condicionantes - políticos! - e instaurar um processo progressivamente emancipatório para o conjunto da população regional. Eis, portanto, o que, dialeticamente, liga uma sociedade concreta como a brasileira com os desafios que emergem de sua rica obra.

\section{As lições do mestre}

Ao longo desta trilogia chamamos Celso Furtado de mestre, seguindo a unanimidade dos intérpretes (volume 1); dos colaboradores e parceiros da Cepal, passando pelo BNDE (hoje BNDES), Sudene, Ministério do Planejamento, exílio e Ministério da Cultura (volume 2); e da nova geração de seguidores, que compõem a maior parte dos autores dos textos aqui publicados (volume 3). A palavra mestre tem duas características que se complementam: ela é substantivo e, ao mesmo tempo, adjetivo. Como substantivo, trata-se de pessoa dotada de excepcional saber, competência, talento em ciência ou arte, artífice, um artesão experiente, e, sobretudo, um indivíduo que ensina. Como adjetivo, quer dizer que é o principal, o gigante, o exemplar, o fundamental, o extraordinário, o inesquecível. Em outras palavras, Celso Furtado.

Não faltaram motivos, no decorrer das nossas carreiras científico-acadêmicas, para chamarmos Furtado de mestre, assim como não faltaram justificativas para os nossos interlocutores nesses três volumes a ele se referirem com essa deferência. Isso significa que, se há mestre, há também lições. Uma coisa é perguntar sobre o legado, e nos parece que muita gente já escreveu a esse respeito, outra é perguntar sobre as lições. O legado sempre se revela numa dimensão mais ampla, com pretensões de totalidade, como uma herança moral, por exemplo. As lições, por sua vez, não excluem essa dimensão, mas trazem o particular, a especificidade, a 
natureza pedagógica, a metodologia do fazer, do proceder, Elas trazem a experiência das trocas dialógicas, a predição e as advertências que sempre acompanham as boas lições.

Olhando para o que vimos e reunimos, particularmente, nos meses em que investimos mais energia neste projeto editorial, chegamos à seguinte conclusão: há muitas lições do mestre que precisam ser revisitadas e/ou compartilhadas, pela luz que lançam à compreensão e ao enfretamento dos tempos sombrios de um presente quase sem futuro. Como legado, é reconhecido que a vida e a obra do economista paraibano foram dedicadas a identificar, refletir e implementar estratégias para superar o subdesenvolvimento brasileiro. Suas contribuições, desde o final dos anos 1940, demonstraram que tanto o técnico quanto o cientista teriam de se debruçar sobre a forma de organização da Administração Pública para compreender a direção e a orientação do Estado como um importante centro de decisão.

Se tomarmos os intérpretes do volume 1 como ponto de partida para evidenciar o legado, a síntese a que chegamos é a seguinte: a obra de Furtado demonstra como a estrutura de produção brasileira e as instituições sociais marcaram a formação de um país regionalmente desigual, em que as elites rurais e urbanas sustentam, pela apropriação do Estado, seus interesses e privilégios. Furtado, ao mesmo tempo em que ofereceu ao Brasil um sistema teórico-metodológico complexo, histórico-estrutural, potente e aberto, atuou concretamente no sentido de orientar suas energias para a construção da nação. Se, para ele, o valor do cientista resulta da mobilização da imaginação e coragem, caberia, também, atuar no plano político, assumindo a responsabilidade de interferir no processo histórico.

A natureza das lições e a sua aplicabilidade são outro detalhe importante nas leituras da vida e obra do mestre. É certo, como bem frisou Szmrecsányi (2001), que a variedade e a importância de suas contribuições, obviamente, não podem ser caracterizadas com fidedignidade num artigo para periódico ou, no nosso caso, nos limites de um capítulo de livro. Destacamos, aqui, apenas aquelas que se repetiram, com mais intensidade, nas vozes e nos textos dos interlocutores que mobilizamos nos três volumes. E elas são de três naturezas: epistemológicas, técnicas e políticas.

Do ponto de vista epistemológico, Furtado: a) explicitou uma compreensão de ciência, com forte peso moral, considerando-a "a forma de conhecimento que, por excelência, capacita o homem para antecipar os 
acontecimentos, subordinar o mundo físico a seus propósitos e submeter outros homens ao seu domínio" (FURTADO, 2013: 484); b) dedicou atenção especial a conceitos que possibilitaram uma interpretação inovadora da formação socioeconômica do Brasil e da América Latina, como o de subdesenvolvimento; c) introduziu - para alguns, "fundou" -, no Brasil e na América Latina, os estudos sobre desenvolvimento regional; e d) construiu as suas contribuições analíticas e teóricas, adotando e defendendo o enfoque interdisciplinar, dedicando, de modo particular, uma de suas obras ao tema - Pequena introdução ao desenvolvimento: enfoque interdisciplinar (1980).

Celso Furtado tornou-se economista, assumindo que procurava exercer a profissão com o auxílio de outras disciplinas. Entre elas, era a história aquela que, desde cedo, lhe propiciou a visão ampla de que reiteradamente fala em seus textos. Embora economista de grande competência, com o domínio da teoria e do instrumental matemático, considerava que a realidade que queria entender - e explicar - não se prestava a uma tradução fidedigna se não amparada em uma episteme generosa, fundada em múltiplos saberes dialeticamente integrados e interligados. A partir daí é que se dedicou a estudar o fenômeno do desenvolvimento, a desvelar a sua contraparte na periferia, o subdesenvolvimento, e a oferecer um entendimento do Brasil contemporâneo. Não obstante seja Formação Econômica do Brasil uma obra de maturidade, publicada quando tinha menos de 40 anos, Celso Furtado foi aperfeiçoando a sua compreensão do Brasil (e da América Latina) ao longo dos anos em que exerceu cargos públicos e pode dedicar-se à academia.

Do ponto de vista técnico, Furtado também foi exemplar, como atesta o detalhado estudo de Tenório e Wanderley (2018): começou como um dos membros da "elite técnica", que tomou conta dos novos órgãos da administração pública, no DASP (Departamento Administrativo do Serviço Público), no início dos anos 1940, assumiu uma diretoria no BNDE, e chegou à gestão no primeiro escalão do governo federal em pelo menos três postos chaves: Superintendência da Sudene (1959), Ministro Extraordinário do Planejamento (1962) e Ministro da Cultura (1986). Destaca-se, desta dimensão, um Furtado que, desde cedo, se interessou por organização e planejamento, formação de administradores públicos, estudo pormenorizado das repartições e pelo entendimento das diferentes composições que as organizações poderiam assumir. É sobre esses temas que realiza seus primeiros trabalhos técnicos, enfatizando a necessidade de um novo perfil para o gestor público. 
Quanto a dimensão política há características na atuação de Furtado que são em si mesmas uma crítica virulenta à moderna tradição brasileira. Nascido em meio a realidades de mando, coronéis e cangaceiros, o economista de Pombal parece ter feito escola no enfrentamento dessas estruturas. Ao mandonismo, respondeu com democracia; à captura do Estado pelas elites agrárias, respondeu com republicanismo; às tentativas de barganha por maiores fatias do bolo a ser repartido pelo Estado, negociou firmemente em bases morais e éticas, "sem trair o principal", como diria Bacelar (2020); aos interesses mesquinhos e particularizados de governos, respondeu com políticas integradas de desenvolvimento, fortalecendo uma nova relação entre entes federados numa mesma região.

\section{A agenda da coletânea}

As contribuições enviadas para este volume foram, em grande medida, estimuladas por convites a investigadores que estavam, de alguma forma, vinculados a estudos, pesquisas, atividades de extensão e produções tecnocientíficas do campo do desenvolvimento regional. Foram mais de três meses de provocações, diálogos e coletas. Os textos recebidos e selecionados foram editados com a participação direta de seus respectivos autores. Entre leituras, devoluções dialógicas e ajustes, o resultado, já comentado acima, expressa, em nosso ver, o espírito da trilogia: a esperança militante. Tentamos, para efeito didático, e seguindo os volumes anteriores, fazer um arranjo temático: os conteúdos foram dispostos em quatro grandes blocos: Dilemas epistemológico-conceituais; Escalas, Políticas, Territórios; Federalismo; e Comunicação, Educação e Cultura. A seguir, uma pequena síntese crítica dos 17 textos que integram esta coletânea, como um convite à leitura e discussão.

$\mathrm{O}$ texto que abre o primeiro bloco - $O$ que é desenvolvimento regional? Uma aproximação a partir da realidade brasileira - do professor Ivo Marcos Theis, agenda pelo menos três grandes desafios: a) oferecer uma compreensão "um pouco mais contextualizada" do que é desenvolvimento regional, com uma boa leitura do panorama internacional; b) problematizar impactos e influência da obra de Celso Furtado nos estudos recentes sobre a problemática regional, tomando como referência empírica a produção intelectual que vem tendo lugar na universidade brasileira, em especial, nos programas de pós-graduação em desenvolvimento regional, mas também nos grupos de pesquisa e na atuação dos próprios pesquisadores, reservando uma atenção especial, também, para 
uma leitura crítica dos periódicos reconhecidos pela área; e c) fazer avançar uma formulação mais utópica de desenvolvimento regional a partir de uma aproximação da realidade sociocultural brasileira, que leve em consideração o seu passado colonial, o sofrimento dos povos originários e das populações compulsoriamente transplantadas, a presença das mulheres e a diversidade da natureza.

A proposição de Marcos Antônio Mattedi, no texto Subsídios para um programa forte em desenvolvimento regional, é que o desenvolvimento regional não constitui mais apenas o ponto de chegada que se alcança seguindo os caminhos traçados pela economia, pela geografia, pela sociologia, pela antropologia, pela ciência política, mas, também, o ponto de partida por meio do qual é possível compreender essa realidade de uma nova forma. Mattedi faz uma breve revisão das estratégias epistemológicas de concepções que podem ser adotadas para interpretar a cientificidade das relações entre desenvolvimento e região; analisa teorias do desenvolvimento regional para estabelecer um modelo conceitual que permita superar o que chama de abordagens bidimensionais; concentra-se na reformulação do conceito de desenvolvimento regional a partir dos subsídios extraídos do cálculo da indicação, desenvolvido a partir das contribuições de George Spencer-Brown; e fecha o capítulo apresentando princípios e bases epistemológicas para orientar a pesquisa e o pensamento com desenvolvimento regional.

Para Jandir Ferreira de Lima, em $O$ desenvolvimento regional como fenômeno regional, apesar de as teorias da localização terem introduzido os elementos distância, espaço e lugar no debate sobre a organização do espaço, eles não foram suficientes para explicar as desigualdades regionais. Segundo Lima, essas teorias têm como restrição os aspectos sistêmicos, complexos e relacionais do desenvolvimento socioeconômico. De forma ampla, a teoria do desenvolvimento regional busca, na visão de Lima, conhecer o papel do espaço, da política pública e dos territórios na melhoria da qualidade de vida e no progresso econômico das regiões. Por isso, interage com conceitos como centralidade, redes de informação, atração, repulsão, distância, ambiente de inovação, dentre outros, numa gama ampla de relações. Na leitura do autor, uma agenda de pesquisa nesse campo deveria se voltar, também, à dinâmica do subdesenvolvimento regional - um tema ainda esquecido pelos estudos regionais.

Na agenda da professora Virginia Elisabeta Etges, em $A$ dimensão regional do desenvolvimento: contribuições teóricas e experiências sul-americanas, a primeira década do século XXI foi marcada por importantes 
avanços na discussão sobre os processos territoriais de desenvolvimento. É nesse contexto que, segundo ela, a região, enquanto particularidade territorializada do processo geral de acumulação capitalista, adquiriu um novo sentido: ao mesmo tempo em que expressa formações socioeconômicas, ou sócio-espaciais, expressa, também, o contra-movimento à globalização. Na América do Sul, conforme a autora, vivemos, na atualidade, um forte movimento de resgate do sentido do desenvolvimento regional, ao mesmo tempo em que os interesses hegemônicos deixam suas marcas no território, através de organizações como a Iniciativa de Integração Regional Sul Americana (IIRSA). Entretanto, com o fortalecimento das regiões através de sua organização, como é o caso dos Conselhos Regionais de Desenvolvimento e dos Consórcios Intermunicipais, no sul do Brasil, a tensão entre as forças globalizantes e as forças regionalizantes vem se acentuando, evidenciando um marcante movimento sócio-territorial. Em outras palavras, se a ordem global busca impor, a todos os lugares, uma única racionalidade, as regiões, por sua vez, respondem ao mundo segundo diversos modos de sua própria racionalidade.

O ensaio Política Nacional de Desenvolvimento Regional no Brasil: incapacidade ou não-acontecimento?, de Rainer Randolph, começa com uma assertiva furtadiana: não é tarefa fácil captar a natureza do subdesenvolvimento. São muitas as dimensões e, nem sempre, as que estão visíveis são as mais significativas. A proposta do autor é identificar "a natureza daqueles que são responsáveis pelo desenvolvimento (e, por tabela, o não-desenvolvimento)". Para isso realiza quatro movimentos: a) indica a política de desenvolvimento regional em nível federal como assunto da investigação; b) empreende um grande esforço analítico para mostrar as limitações de se julgar o sucesso ou fracasso dessa política, partindo apenas de seus (aparentes) resultados; c) problematiza a dimensão dialética entre estrutura institucional e dinâmicas de atuação, no contexto da execução da políticas e d) tensiona que não há como adiantar respostas definitivas se as "falhas" da política têm a sua origem em certas incompetências ou apontam para sua compreensão como "não-acontecimento", na medida em que uma boa parte dos especialistas questiona até se devem ser consideradas ou não como políticas de desenvolvimento regional.

Em Escalas espaciais, território e desenvolvimento regional: notas para discussão teórica e metodológica, Rogério Leandro Lima da Silveira, enfatiza que escalas espaciais estão presentes em nossa vida, em nossas representações da realidade, em nossas ações, relações, lutas sociais. 
Também estão presentes nos processos sociais e econômicos e na construção e implementação das políticas públicas de planejamento e desenvolvimento regional. O ensaio, nesse contexto, recobra a importância das escalas espaciais ou geográficas na análise do território e dos processos de desenvolvimento e planejamento regional: apresenta o conceito de escala espacial e a necessária distinção com o conceito de escala cartográfica; reflete sobre a especificidade e a relação entre escala dos fenômenos, escala de análise e escala de ação; aborda a ideia-chave que fundamenta a compreensão de escalas como constructos sociais; ou seja, elas são produzidas, socialmente, por agentes concretos, em suas relações e estratégias políticas nos territórios; e, por fim, discute a relação entre a escala espacial e a dinâmica territorial, com a intenção de contribuir teórica e metodologicamente para a compreensão, análise dos processos e políticas de desenvolvimento regional.

O capítulo Para pensar as espacialidades e as temporalidades dos processos sociais regionalizados em conjuntura de crise disruptiva, de Carlos Antônio Brandão, agenda a necessidade de a área de desenvolvimento regional avançar em uma teorização do papel fundante das decisões cruciais dos agentes dominantes e seus contrapoderes, defendendo a realização de atividades de ensino, pesquisa e extensão que não negligenciem as estruturas constitutivas mais gerais e, ao mesmo tempo, não percam as lógicas das conjunturas mais particulares. A questão regional, no seu entendimento, deveria se expressar, antes de tudo, na forma de decisões ousadas, nucleadas na provisão de direitos e bens e serviços coletivos. As pesquisas e os cursos de pós-graduação em desenvolvimento regional deveriam continuar a mergulhar nas suas especificidades geográficas, históricas, estruturais e conjunturais dos seus respectivos mundos micro e mesorregionais, buscando captar toda a riqueza da diversidade e da complexidade de seus contextos e posicionalidades frente ao todo. Não deveriam, no entanto, flertar com concepções teórico-metodológicas conservadoras, que já demonstraram estar dissociadas de nossas formações e realidades socioeconômicas, territoriais, culturais e espaciais.

Para os autores de Processos de apropriação espacial: contribuições para estudos futuros, Thiago José Arruda de Oliveira e Waldecy Rodrigues, se a humanidade só conseguiu gerar riquezas apropriando-se de espaços ao redor do mundo, por que ainda persistem problemas elementares como as desigualdades de renda? Partindo dessa provocação, problematizam, historicamente, a relação entre espaço e sociedade e pontuam que, apesar de os Homo sapiens existirem a milênios, 'pouco se conhece 
sobre a nossa função no mundo'. Colocar essa evidência em forma de variável, segundo Oliveira e Rodrigues, é o principal desafio dos estudiosos da área de desenvolvimento regional. Para isso torna-se necessário que os próximos estudos elevem a variável felicidade humana a um nível de importância similar à da renda, patrimônio e serviços. Em relação à sua aplicabilidade no Brasil, em vista da infiltração do agronegócio na zona rural, do avanço das igrejas pentecostais e neopentecostais na sociedade e do tráfico de drogas nas cidades, esse tipo de análise possui um vasto campo de possibilidades. O principal desafio, com o já sinalizado, será inseri-lo, especialmente, nos estudos que tratam sobre desenvolvimento.

A proposição defendida, em Aproximações teóricas-conceituais entre ordenamento do território e desenvolvimento regional, por Lívia Gabriela Damião de Lima e Larissa da Silva Ferreira Alves (UERN), é que, considerando que o ordenamento do território (OT) é uma ferramenta fundamental a ser utilizada pelo Estado, no que diz respeito a organização espacial do território, o desenvolvimento regional (DR) não pode ser negligenciado. $\mathrm{O}$ Estado é enfatizado como um agente regulador, modificador e produtor do território. $\mathrm{O}$ trabalho se articula em dois movimentos: o primeiro aborda a concepção do ordenamento territorial, enquanto elemento fundamental na organização espacial do território, tendo o Estado como principal ator; e, no segundo, problematiza o conceito de desenvolvimento regional como elemento necessário no processo de ordenação do território, considerando a importância da efetivação de políticas descentralizadoras para o desenvolvimento.

A proposta do texto Diferenciais produtivos no Semiárido brasileiro: o caso do Ceará, de Maria Daniele Cruz dos Santos e Francisco do O' de Lima Júnior é analisar a estrutura produtiva assentada no Semiárido cearense nos anos 2000. Conforme os autores, ao longo da formação do território, os fenômenos percebidos na economia e no sistema urbano que acompanharam a tendência da urbanização foram: a) a modernização, dinamização e inserção de atividades produtivas; b) as políticas institucionais do Estado voltadas para o desenvolvimento do tripé indústria-lazer/turismo-agronegócios; c) o avanço econômico e populacional da Região Metropolitana de Fortaleza (RMF); d) alguns centros médios urbanos que polarizam o interior do estado; e) expansão das fronteiras da especulação imobiliária em todo o território do estado e; f) o processo de metropolização. Para Santos e Lima Júnior essas alterações casam, significativamente, com as mutações temporais ocorridas na 
estrutura produtiva cearense, mais especificamente no litoral e nos polos de desenvolvimento, objeto do estudo em questão.

Em O desenvolvimento regional em Celso Furtado: a coordenação federativa e as implicações institucionais, os autores Luciléia Aparecida Colombo, Thales Haddad Novaes de Andrade e Aristides Monteiro Neto tomam como pano de fundo as assimetrias federativas para defenderem que a Sudene representava uma arena de resolução de conflitos federativos, estabelecendo pontes entre o governo federal e os governos estaduais e, destes, entre si. Segundo eles, foi uma política institucional que priorizou experiências cooperativas, apesar da grande oposição formada em torno tanto da aprovação da lei que a instituiu formalmente, como da aprovação de seus planos diretores. Na assertiva dos autores, repensar a postura de Celso Furtado não apenas como um grande intelectual, mas, sobretudo, como um militante do planejamento regional é essencial, também nos turbulentos dias atuais. A atualidade de sua obra é, de fato, um respiro em meio à indefinição recorrente de planos de desenvolvimento regional que requerem a cooperação e a interlocução constante entre os entes federados para a obtenção de efetividade.

Os autores de Federalismo Brasileiro: uma revisitação das contribuições de Celso Furtado, Rosangela dos Santos Alves Pequeno e Fernando Cézar de Macedo, agendam uma leitura importante das contribuições de Celso Furtado sobre o federalismo brasileiro. Destacam, nesse contexto, duas questões: a concepção de federalismo de Furtado e a relevância da questão regional para o federalismo, como fator dinâmico no processo de desenvolvimento nacional. Os autores lembram que a compreensão de Furtado partiu do seu interesse por entender as transformações da economia brasileira. Entretanto, diante das desigualdades sociais e econômicas existentes entre as regiões brasileiras, a saída vista pelo economista paraibano era buscar, por meio de mecanismos cooperativos, uma melhor distribuição das atividades econômicas no país e um maior equilíbrio político entre os participantes da federação. Sob este prisma, a visão macroespacial na articulação e condução do processo de desenvolvimento da nação é contraposta à abordagem da atuação dos consórcios públicos, que potencializam ações de articulação microrregional na estrutura federativa brasileira atual.

A proposta do artigo Aproximações entre estudos culturais e desenvolvimento regional: uma proposta teórico-metodológica para estudar a comunicação na interdisciplinaridade, de Ângela Cristina Trevisan Felippi e Grazielle Betina Brandtx é de inserir a perspectiva comunicacional no 
campo do desenvolvimento regional, a partir de um viés orientado para a sua dimensão cultural. Observam que a cultura pode ser pensada enquanto produção e prática social, expressas por meio de representações simbólicas que impregnam o espaço geográfico. O texto concentra-se na importância dos lugares e dos territórios, reportando aos significados que o espaço adquire a partir da experiência pessoal de seus indivíduos. A atenção à dimensão cultural, por esse enfoque, agenda formas de valorizar a comunicação e incentivar o debate interdisciplinar no campo do desenvolvimento regional.

Para Monica Franchi Carniello e Moacir José dos Santos, autores do texto Comunicação e Desenvolvimento Regional, a reflexão sobre essa relação pode ser sistematizada em três abordagens: a difusionista, a participativa e a do bem-estar social. A mera presença de um sistema de mídia em uma região não garante seu uso aplicado ao desenvolvimento regional. Os fluxos de comunicação não se realizam de modo abstrato, pois estão vinculados aos processos sociais que os definem. A comunicação é uma variável fundamental para se investigar se o desenvolvimento em uma conjuntura regional ou nacional supera o espectro econômico e abrange aspectos relacionados às demais variáveis que caracterizam o desenvolvimento global. Assim, o desafio de investigar o desenvolvimento, segundo os autores, é situá-lo de modo permanente na conjuntura da dinâmica capitalista para se entender as características de sua consecução em um determinado momento histórico e espacialidade.

Considerando a diversidade temática da agenda de desafios que estamos tentando articular nesta coletânea, o artigo A educação como fator de desenvolvimento regional, de Flávio Eliziario de Sousa e Mariane Freiesleben, chama atenção para quatro questões importantes da relação Educação-Desenvolvimento: a) o papel do Estado na articulação, implementação e regulamentação das políticas públicas de desenvolvimento regional; b) uma compreensão inovadora de desenvolvimento que não opera sem a intervenção do Estado; c) o lugar e papel da educação como fator de desenvolvimento regional, no empoderamento de indivíduos e territórios; d) o papel dos Institutos Federais (e, de modo mais amplo, das IES Públicas) na articulação e construção de soluções coletivas e sustentáveis para o enfrentamento dos desafios críticos ao desenvolvimento das regiões mais vulneráveis. $\mathrm{O}$ conjunto de suas atividades, segundo os autores, passa a dar origem a uma força de atração de consumidores e empresas, contribuindo para gerar um crescimento econômico-social local/regional. 
No texto Um olhar teórico-metodológico sobre processos de intervenção e de extensão para o desenvolvimento regional, a proposta de Cidonea Machado Deponti é apresentar e discutir questões relacionadas aos processos de intervenção e de extensão em contextos de desenvolvimento regional. Para a autora, desenvolvimento é um processo de mudança social, complexo, multi-ator, multi-escalar, multidimensional, carregado de heterogeneidades de práticas, de processos e de políticas, sem limites definidos no tempo e no espaço, que avança e retrocede. Nos processos de intervenção, o termo mediação ganha foça e é constituído por múltiplos processos de negociação entre as partes envolvidas, nem de cima para baixo (top-down), nem de baixo para cima (buttom-up), mas de encontro, de interface, em que os diferentes conhecimentos se entrelaçam, tornando-se um híbrido, que valoriza tanto o conhecimento técnico quanto o saber-fazer. A mediação leva ao sentimento de pertencimento ao fazer parte do processo.

A agenda do texto Celso Furtado, o (Sub) Desenvolvimento numa perspectiva cultural e a criatividade nos Maracatus Nação de Pernambuco, de Tiago Macêdo Bezerra Maia e João Morais de Sousa se articula em três eixos propositivos: oferecer uma melhor compreensão da dimensão cultural dos processos e problemas do (sub)desenvolvimento, na América Latina e, sobretudo, no Brasil; evidenciar o papel da criatividade que, como força motriz, constitui a cultura, ao mesmo tempo em que é por ela é constituída no enfrentamento das questões que surgem diariamente na sociedade; e desvelar a criatividade e resistência da cultura popular e da religiosidade dos negros presentes nos Maracatus Nação de Pernambuco, à luz da perspectiva cultural furtadiana. Assim, o capítulo apresenta um panorama do diálogo de Furtado com a antropologia e, a partir deste, alguns dos aspectos mais relevantes das contribuições de suas reflexões culturais que marcam a atualidade e a urgência do resgate de seu pensamento.

\section{Papel dos intelectuais}

Em linhas gerais, a síntese acima procurou dar pistas aos leitores das preocupações, inquietações, agendas e desafios que marcam o conjunto dos textos selecionados para este volume. Retomando o que já dissemos, e partindo das contribuições dos capítulos que se sucedem ao longo das próximas páginas, podemos afirmar que o pensamento regional brasileiro se apresenta, hoje, com pelo menos cinco características importantes: a) 
o estudo do Brasil profundo, um traço importante que vem da obra de Furtado; b) uma agenda temática diversa em que o olhar para o território ganha ênfase como um importante ponto de partida; c) uma compreensão de desenvolvimento que se constrói nas contradições do mainstream e que também ganha corpo, não apenas como resultado de políticas de Estado ou Governos, mas como campo científico a partir do qual se propõe intervenções transformadoras (no fazer científico e na sociedade); d) a entrada em cena de novos atores e formações e a proeminência da interdisciplinaridade como horizonte do pensar e agir; e e) a configuração de uma tendência (também inspirada em Furtado) de não apenas apontar o problema ou fazer diagnósticos, mas de construir, de forma criativa, inclusiva e pertencida, as possibilidades de solução.

Não temos dúvidas de que o centenário de nascimento do mestre Furtado foi uma oportunidade, ímpar, para leituras e releituras de sua vasta obra, num contexto singular de crises, no qual a pandemia do Coronavírus é uma das expressões de esgotamento do atual modelo de desenvolvimento. O Brasil, como bem acentua Brandão, (2020), necessita construir estratégias e instituições capazes de conectar os canais de interação entre crescimento econômico, integração territorial, construção de cidadania social, ciência, tecnologia e inovação e aprimoramento de capacidades humanas emancipadoras. Entretanto, como Furtado (2002) mesmo lembrava, desarmar essa armadilha "não é tarefa simples". Segundo ele, somente a criatividade política impulsada pela vontade coletiva poderia superar esse impasse. Mas essa vontade, no seu entendimento, requeria um reencontro das lideranças políticas com os valores permanentes de nossa cultura e uma participação maior do povo no sistema de decisões. Sem isso, o desenvolvimento nem se alimentaria da autêntica criatividade de nosso povo, nem contribuiria para a satisfação dos anseios legítimos da nação. Eis, portanto, o grande desafio.

Por falar em desafio, Furtado cuidou de refletir sobre o que definia para si como "desafios". Pinçamos, aqui, o que parece ser suficientemente representativo do que, por um lado, deve ter animado os/as autores/as dos capítulos/textos que integram esta coletânea e, por outro, pode servir de inspiração - um convite! - para a sua leitura por parte de quem talvez já tenha tido sua curiosidade devidamente despertada. Em O capitalismo global, escreveu:

O desafio que se coloca no umbral do século XXI é nada menos do que mudar o curso da civilização, deslocar o seu eixo da lógica dos meios a serviço da acumulação num curto 
horizonte de tempo para uma lógica dos fins em função do bem-estar social, do exercício da liberdade e da cooperação entre os povos" (FURTADO, 1998, p. 64 - itálico nosso).

Que responsabilidade a daqueles/as que ousam compartilhar de tal pensamento, que assumem pretender cultivar alguma parte de suas lições e de seu rico legado! Arriscamos, todavia, o palpite de que o desafio do mestre está subjacente aos - sim, talvez imbricado com os - desafios que caracterizam as contribuições contidas neste terceiro volume em sua homenagem. Parece-nos, entretanto, que, ao final desta árdua, prazerosa e gratificante tarefa de articulação, organização e edição da trilogia, o que nos desafia com maior intensidade é assumirmos o grande papel que o mestre preconizava para os "trabalhadores intelectuais":

Cabe a estes aprofundar a percepção da realidade social para evitar que se alastrem as manchas de irracionalidade que alimentam o aventureirismo político: cabe-lhes projetar luz sobre os desvãos da história, onde se ocultam os crimes cometidos pelos que abusam do poder; cabe-lhes auscultar e traduzir as ansiedades e aspirações das forças sociais ainda sem meios próprios de expressão" (FURTAD̉O, 2002, p. 37).

Boa leitura!

\section{Referências}

ARAÚJO, Tania Bacelar. Celso Furtado: um intelectual com o pé no chão. In. SOUSA, Cidoval Morais; THEIS, Ivo Marcos; BARBOSA, José Luciano Albino. Celso Furtado: a esperança militante (vol 2). Campina Grande: EDUEPB/A UNIÃO, 2020. p. 247-269.

BRANDÃO, Carlos Antonio. Para pensar as espacialidades e as temporalidades dos processos sociais regionalizados em conjuntura de crise disruptiva. In. SOUSA, Cidoval Morais; THEIS, Ivo Marcos; BARBOSA, José Luciano Albino. Celso Furtado: a esperança militante (vol 3). Campina Grande: EDUEPB/A UNIÃO, 2020.

FURTADO, Celso. Formação econômica do Brasil. 15 ed. São Paulo: Nacional, [1959] 1977.

FURTADO, Celso. Prefácio a nova economia política. 2 ed. Rio de Janeiro: Paz e Terra, 1977. 
FURTADO, Celso. A hegemonia dos Estados Unidos e o subdesenvolvimento da América Latina. 3 ed. Rio de Janeiro: Civilização Brasileira, 1978.

FURTADO, Celso. A fantasia desfeita. Rio de Janeiro: Paz e Terra, 1989.

FURTADO, Celso. O capitalismo global. 2 ed. São Paulo; Rio de Janeiro: Paz e Terra, 1998.

FURTADO, Celso. Em busca de novo modelo: reflexões sobre a crise contemporânea. São Paulo: Paz e Terra, 2002.

FURTADO, Celso. O longo amanhecer: reflexões sobre a formação do Brasil. Rio de Janeiro: Paz e Terra, 1999.

FURTADO, Celso. Em busca de novo modelo: reflexões sobre a crise contemporânea. 2 ed. São Paulo; Rio de Janeiro: Paz e Terra, 2002.

FURTADO, Celso. Perspectivas da economia brasileira. Rio de Janeiro: Centro Internacional Celso Furtado de Políticas para o Desenvolvimento, [1958] 2012.

LOPES, Herton Castiglioni. Celso Furtado e o progresso técnico. Revista da Sociedade Brasileira de Economia Política. 43 / fevereiro 2016 maio 2016. P. 120-134. Disponível em: http://revistasep.org.br/index.php/ SEP/article/view/161 Acesso em 27/10/2020.

MAUSS, Marcel. Sociologia e Antropologia. São Paulo: Cosac Naify, 2003.

PEREIRA, Luiz Carlos Bresser. Método e paixão em Celso Furtado. In: SOUSA, Cidoval Morais; THEIS, Ivo Marcos; BARBOSA, José Luciano Albino. Celso Furtado: a esperança militante (vol 1). Campina Grande: EDUEPB/A UNIÃO, 2020. P. 85-113.

TENORIO, Fernando; WANDERLEY, Sergio. Celso Furtado: um economista a serviço da gestão pública (1943-1964). Rev. Adm. Pública, Rio de Janeiro, v. 52, n. 3, p. 507-526, June 2018. Available from <http://www.scielo.br/scielo.php?script=sci_arttext\&pid=So034-76122018000300507\&lng=en\&nrm=iso $>$. access on 28 Oct. 2020. https://doi.org/10.1590/o034-7612173859. 


\section{Parte I \\ Dilemas Epistemológicos e Conceituais}

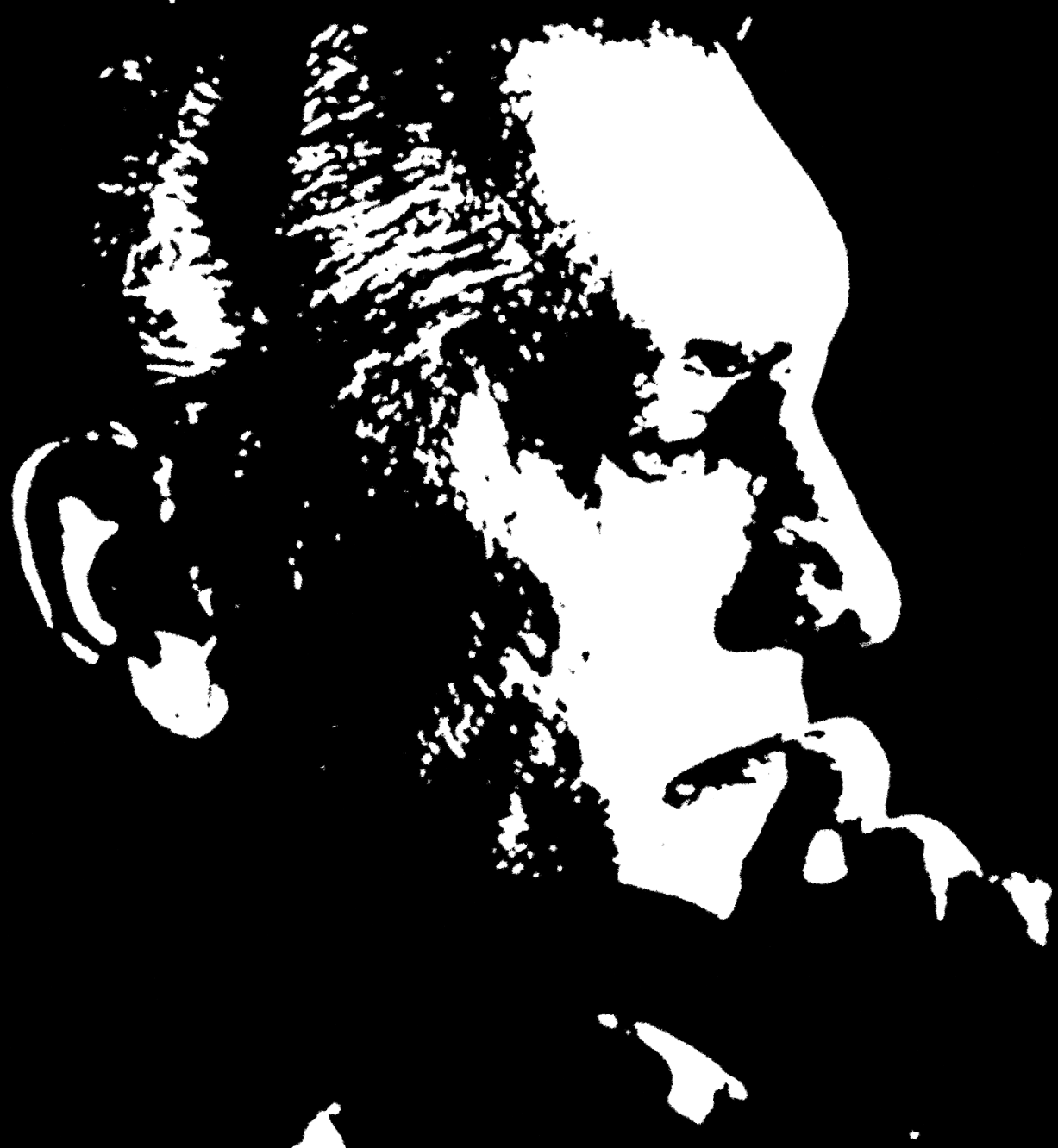





\title{
O que é desenvolvimento regional? \\ Uma aproximação a partir \\ da realidade brasileira
}

Ivo Marcos Theis ${ }^{1}$

\begin{abstract}
"Regionalmente deve ser estudada, sem sacrifício do sentido de sua unidade, a cultura brasileira, do mesmo modo que a natureza; o homem da mesma forma que a paisagem. Regionalmente devem ser considerados os problemas de economia nacional e os de trabalho"
\end{abstract}

(Gilberto Freyre, 2010, p. 71)

\section{Introdução}

EsTe ARTIGO é CONSAGRADO À PROBLEMÁTICA DO DESENVOLVIMENTO regional. Problemática é um termo que, aqui, se refere a algo que desperta/requer atenção e, por isso, demanda algum tipo de solução. Mas, o que, de fato, se procura fazer nas páginas a seguir é oferecer uma compreensão um pouco mais contextualizada do que seja, ou possa ser, desenvolvimento regional. Se bem tenha havido sucessivas tentativas de precisar melhor o que se pode entender por desenvolvimento regional, elas podem ser consideradas mal sucedidas. É evidente que nada assegura que precisamente esta tentativa experimente sorte maior. Entretanto, em contraposição aos louváveis esforços realizados até o presente, procurarse-á, nos limites de um artigo breve e tão objetivo quanto possível, definir minimamente o contexto no qual se possa formular uma noção mais precisa de desenvolvimento regional. Assim, a preocupação maior deverá ser com o quadro no qual se pode elaborar uma compreensão de desenvolvimento regional.

1 Economista, PhD em Geografia Humana pela Eberhard-Karls Universität Tübingen (Alemanha), docente-pesquisador do Programa de Pós-Graduação em Desenvolvimento Regional da Universidade Regional de Blumenau (FURB), líder do Núcleo de Pesquisas em Desenvolvimento Regional, editor da Revista Brasileira de Desenvolvimento Regional e Bolsista de Produtividade em Pesquisa do CNPq. 
Uma advertência importante: a preocupação de se oferecer um entendimento um pouco mais contextualizado de desenvolvimento regional precisa, ela mesma, ser contextualizada. Isto é, cabe informar devidamente em qual âmbito tal preocupação emerge e ganha sentido. Concretamente: o contexto é dado pelo subcampo do desenvolvimento regional, da área de Planejamento Urbano e Regional, que, como estabelece a CAPES, integra as chamadas Ciências Sociais Aplicadas. Portanto, sem excluir ex ante quaisquer outros interlocutores interessados ou afetos à problemática, procura-se, com este artigo, dialogar com aquelas e aqueles que militam - isto é, ensinam, orientam e pesquisam - nesta subárea da avaliação da pós-graduação brasileira. Que não haja dúvidas, pois, que, a despeito de simpatias e mesmo de afinidades com a produção intelectual que tem lugar fora da academia, mira-se uma interlocução, sobretudo, com aquelas e aqueles que se encontram vinculados a programas de pós-graduação em desenvolvimento regional. Ainda a respeito do âmbito: referir à CAPES e à pós-graduação brasileira significa limitar a problemática à realidade sociocultural brasileira ${ }^{2}$. Não se trata nem de desprezar o que vai fora das fronteiras nacionais nem de recear o enfrentamento do tema em um contexto internacional mais amplo. Se a preocupação é de contribuir para a construção do quadro acima referido, no qual se pode elaborar uma compreensão mais precisa de desenvolvimento regional, então se define o Brasil como lócus privilegiado e suas características socioculturais (como o idioma, a institucionalidade educacional etc.) como referências inamovíveis.

O artigo está dividido em sete seções principais, a primeira delas sendo esta introdução. O passo-a-passo que deve conduzir a uma compreensão mais precisa de desenvolvimento regional inicia pelo esboço de um breve panorama internacional. Destina-se alguma atenção à problemática do desenvolvimento regional fora do Brasil? O que se entende por desenvolvimento regional em outros países? A seção seguinte já avança em direção à perspectiva brasileira, elegendo como referência a obra de Celso Furtado. Como o economista paraibano identificou e analisou a problemática regional brasileira? Terá ela influenciado estudos mais recentes de/sobre desenvolvimento regional? Em seguida, procura-se examinar a questão regional a partir da produção intelectual que vem tendo lugar

2 Realidade que, evidentemente, é condicionada pelas condições materiais próprias ao modo de produção dominante (o capitalismo), no contexto de uma formação social periférica e dependente em relação às formações sociais que vêm coordenando/ comandando a economia-mundo. 
na universidade brasileira, em especial, nos programas de pós-graduação [PPG], mas também nos grupos de pesquisa e na atuação dos próprios pesquisadores. Afinal, que lugar tem aí desenvolvimento regional? Uma seção quase complementar é dedicada aos periódicos científicos que deveriam ser portadores, por assim dizer, da produção intelectual em/ sobre desenvolvimento regional. Como se caracteriza e quão representativo é o conjunto de revistas especializadas em desenvolvimento regional nas quais deságua a produção brasileira? A penúltima seção, talvez, a mais importante, é consagrada à formulação de uma proposição. Ela envolve três passos prévios, que, então, conduzem à identificação de três enfoques de desenvolvimento regional. Por fim, uma última seção é destinada às chamadas "considerações finais", em que não apenas se faz a habitual síntese do artigo, mas também se especula sobre as possibilidades de o desenvolvimento regional vir a atender as exigências de um campo de conhecimento autônomo.

\section{Breve panorama internacional}

Não obstante se pretenda definir minimamente o contexto no qual se possa elaborar uma noção mais precisa de desenvolvimento regional a partir de uma aproximação desde a realidade brasileira, parece conveniente tomar em consideração o que, a propósito, se entende por desenvolvimento regional fora do Brasil.

É desnecessário que se faça um esforço sobrehumano para verificar que a expressão desenvolvimento regional tem tradução em diversas línguas conhecidas. Com efeito, nos journals especializados, publicados em inglês, encontra-se, sem dificuldades, a expressão regional development. Nos periódicos especializados publicados em língua alemã é, igualmente, frequente a expressão Regionalentwicklung. Também nos periódicos especializados publicados em língua francesa é comum a expressão développement régional. Assim, evidentemente, também nos periódicos especializados publicados em espanhol ocorre a expressão desarrollo regional.

Assumindo-se, pois, que desenvolvimento regional tem tradução em vários idiomas, cabe perguntar o que se quer dizer com essa expressão em cada idioma e, principalmente, se o seu significado é, por assim dizer, convergente nas diversas línguas. A resposta está dificultada por vários motivos, entre eles: a) uma mesma língua (por exemplo, o inglês) pode ser compartilhada por diferentes países (por exemplo, EEUU e Índia), mas o seu uso em cada um deles pode levar a que palavras iguais (por 
exemplo, região) assumam diferentes significados; b) mesmo no interior de um país (por exemplo, Inglaterra) podem existir diferentes "correntes de pensamento" (por exemplo, "escolas de desenvolvimento regional"), para as quais termos (por exemplo, região) e expressões (por exemplo, desenvolvimento regional) iguais tendem a carregar valores próprios; c) como acontece com outras expressões, os significados de desenvolvimento regional, em diferentes línguas, podem modificar-se ao longo do tempo. De forma que se pode responder à questão formulada no início deste parágrafo apenas se se abstraírem as dificuldades referidas (entre diversas outras não mencionadas). Isto posto, e com base em fontes selecionadas ao acaso, que cobrem artigos científicos e livros, publicados ao longo dos últimos 50 anos, proceder-se-á a uma "verificação" do que pode significar desenvolvimento regional nas línguas conhecidas já mencionadas.

Algumas observações preliminares com relação à origem dos textos: a) dos oito, há sempre dois em cada um dos quatro idiomas (isto é, dois em inglês, dois em alemão, dois em francês e dois em espanhol); b) seis deles encontram-se em formato de artigo científico, enquanto dois são, de fato, livros; c) dois foram publicados na presente década, quatro na década dos anos 2000 e dois no século passado (um nos anos 1960 e outro nos anos 1980); d) os autores dos oito textos são de distintas nacionalidades. Apesar de, como informado acima, as fontes terem sido selecionadas ao acaso, o propósito nesta seção é examinar, brevemente, um conjunto de materiais que exploram a problemática do desenvolvimento regional em outros contextos socioculturais.

Dentre os textos aqui considerados, o de Casey J. Dawkins, professor da Universidade de Maryland, é por assim dizer o de maior fôlego. Trata-se de um "estado da arte", que oferece tanto uma abrangente revisão do campo do desenvolvimento regional quanto, também, uma "bibliografia anotada” da literatura teórica mais representativa. A compilação de Dawkins (2003) cobre materiais orundos de diversas disciplinas, com destaque para a economia (mainstream, diga-se) - que acaba sobrassaindo - e a geografia. Os temas em torno dos quais Dawkins (2003) elabora seu texto são: (a) as previsões teóricas referentes à convergência de renda per capita ao longo do tempo, (b) os pressupostos quanto à relevância das economias de escala para o desenvolvimento econômico, e (c) o papel do espaço na determinação dos mercados de trabalho em escala regional.

Um artigo mais recente, assinado por Frank Moulaert, Bob Jessop e Abid Mehmood, e publicado em International Journal of Urban Sciences, 
aborda o desenvolvimento regional da perspectiva de um instrumental que combina ação (agency), estrutura (structure), instituições (institutions) e discurso (discourse) - o que resulta no modelo ASID. O propósito revelado por Moulaert et al. (2016) é de, na análise de processos de desenvolvimento socioeconômico, obter significados relevantes em termos de suas dinâmicas espaço-tempo. Concretamente, o modelo ASID busca ligar teorias de médio alcance com a realidade empírica a partir de oito eixos de pesquisa, incluindo: ação econômica estratégica em desenvolvimento local, regulação jurídico-política em escala nacional e regional, organização socioeconômica local-regional etc.

O segundo mais antigo texto, publicado há mais de três decênios num importante periódico da geografia alemã, é de autoria de Martin Coy, atualmente, professor do Instituto de Geografia da Universidade de Innsbruck (Áustria). Debruçando-se sobre o desenvolvimento regional do Estado de Rondônia, no Norte brasileiro, Coy (1986) procurou examinar as implicações sociais, econômicas e políticas de programas de desenvolvimento regional, em especial, o Polonoroeste. Ao considerar que o modelo de desenvolvimento modernizante então vigente no Brasil produzia disparidades espaciais, Coy (1986), identificava a expressão desenvolvimento regional com programas governamentais (que criticava) e, potencialmente, com um planejamento orientado para o combate das desigualdades e da pobreza em espaços periféricos (caso de Rondônia).

Outro artigo em língua alemã é de autoria de Sabine Mühlinghaus. Ele foi publicado no início dos anos 2000 em Geographica Helvetica, conhecida revista da geografia suíça. $\mathrm{O}$ tema que recebe a atenção de Mühlinghaus (2002) já se encontra explicitado no título, ou seja, um desenvolvimento regional autônomo como estratégia para espaços rurais periféricos. Constatando que o processo de globalização aparecia, sobretudo, para espaços periféricos (a exemplo das regiões montanhosas da Suíça) como ameaça para a manutenção de postos de trabalho - principalmente, na agricultura e na produção manufatureira voltadas para o mercado doméstico - Mühlinghaus (2002) identificava desenvolvimento regional com estratégias baseadas em maior independência e autonomia das comunidades regionais.

O mais antigo dos textos é de autoria de J. C. Perrin (professor da Faculdade de Direito e de Ciências Econômicas, em Aix en Provence), tendo sido publicado no periódico francês Cahiers Orstom (Sci. Hum.) na segunda metade dos anos 1960. Relativamente longo, ele pode ser considerado um pequeno livro, já que alcança quase 60 páginas. Dividido em 
duas seções principais, na primeira delas examinam-se assim chamados 'esquemas de crescimento econômico' e 'o modelo regional'. Na segunda seção são passadas em revista as estruturas de crescimento e organização regional em 'países em vias de desenvolvimento'. O autor consagra a conclusão às 'possibilidades' de desenvolvimento regional. De qualquer forma, o que neste texto de Perrin (1967) logo fica evidente é uma preocupação maior, senão exclusiva, com aspectos econômicos.

Outro texto publicado em francês é da lavra de Amor Belhedi. Ele integra um livro - cujo título é La fracture territorial - que ganhou a superfície nesta década. O tema é o desenvolvimento regional numa perspectiva mais ampla, como já antecipa o seu subtítulo: problemáticas, objetivos e princípios. De fato, Belhedi (2012) explicita suas posições ao informar que desenvolvimento não se limita a prover uma dada população de bens materiais e econômicos. Pelo contrário, é preciso considerar o seu caráter de totalidade, de um todo indissociável, assim permitindo que o conceito inclua preocupações como: a redução de desigualdades territoriais, a promoção de justiça social e espacial, e a busca da dignidade como sua finalidade última. De maneira que Belhedi (2012) assume que desenvolvimento regional é uma questão de natureza política.

Dos dois textos publicados em espanhol, o primeiro é assinado por três pesquisadores vinculados ao Instituto Tecnológico de Oaxaca. O artigo em questão, que trata das desigualdades identificadas entre as grandes regiões do México, foi publicado numa importante revista daquele país, Problemas del Desarrolo. Considerando um período relativamente longo, de 1950 a 2003, Velasco et al. (2007) utilizam um sofisticado instrumental metodológico para mensurar a eficiência, a equidade e a sustentabilidade do desenvolvimento regional no México. Suas conclusões são de que a eficiência pode ser observada em grande parte do período, mas não a equidade nem a sustentabilidade. Na verdade, a preocupação com a questão ambiental é recente e as desigualdades regionais têm se agravado entre meados do século passado e o início do atual.

O ultimo dos textos aqui examinados é de autoria de Victor Ramiro Fernández, investigador argentino, vinculado à Universidad Nacional del Litoral, publicado em EURE, um dos mais prestigiosos periódicos sobre questões urbanas e regionais editados na América Latina. O tema são as possíveis estratégias de desenvolvimento regional, dado o então novo cenário da globalização - na realidade, Fernández (2001) emprega o termo glocalization. Passando em revista diversos enfoques regionalistas e confrontando-os com dados empíricos (que mostravam o agravamento 
das assimetrias inter e intra-regionais), Fernández (2001) colocaria em questão o otimismo daqueles que viam êxitos certos nas estratégias usuais de mobilização endógena de recursos - que desconsideravam a escala nacional - para promover o desenvolvimento regional.

O que, afinal, se entende por desenvolvimento regional "fora" do Brasil? Em apertada síntese, e considerando apenas os textos acima sumariados, podem-se identificar preocupações relativas a desigualdades sócio-espaciais, relações de poder, aspectos éticos e até questões metodológicas. Contudo, a dimensão econômica é a que predomina, por exemplo, em Dawkins (2003) e Perrin (1967), embora na maioria dos demais textos ela também se manifeste, pelo menos, implicitamente. De forma que, fora do Brasil, desenvolvimento regional pode ser reconhecido, fundamentalmente, como um processo econômico.

Visto, brevemente, o que se entende por desenvolvimento regional com o auxílio de textos publicados em outros países, pode-se voltar a atenção agora para a realidade sociocultural brasileira, associando-se a noção de desenvolvimento regional, inicialmente, à obra de um de seus mais representativos intelectuais.

\section{Desenvolvimento regional na perspectiva de Celso Furtado}

Grande parte da produção intelectual brasileira sobre desenvolvimento regional no período recente (isto é, nas últimas três a quatro décadas) faz referência, direta ou indiretamente, à obra de Celso Furtado (BERCOVICI, 2003; CANO, 1998 [1981]; DINIZ, 2009; OLIVEIRA, 1981; TAVARES, 2011). É, sem lugar à dúvida, uma razão suficiente para não se ignorar a sua importante contribuição. Por isso, nesta seção sumariamse e se comentam algumas publicações do economista paraibano em que a problemática do desenvolvimento regional emerge de forma mais destacada.

A mais importante obra de Celso Furtado - reconhecido clássico da história econômica do Brasil - indica não apenas que o tema deveria merecer atenção, mas também que a questão regional deveria ser adequadamente contextualizada. Por exemplo, ao referir-se à relevância do café na conformação territorial da economia brasileira, afirma:

o desenvolvimento da primeira metade do século XX apresenta-se como um processo de articulação das distintas regiões do país em um sistema com um mínimo de integração. O rápido crescimento da economia cafeeira - durante o meio século compreendido entre 1880 e 1930 - se por 
um lado criou fortes discrepâncias regionais de renda per capita, por outro dotou o Brasil de um sólido núcleo em torno ao qual as demais regiões tiveram necessariamente de articular-se [...] a região rio-grandense [...] foi a primeira a beneficiar-se da expansão do mercado interno induzido pelo desenvolvimento cafeeiro [...] A articulação com a região nordestina se faz por intermédio da própria economia açucareira [...] Por último a Amazônia se incluiu entre os beneficiários da grande expansão da região cafeeira-industrial (FURTADO, 1977, p. 237).

Pouco adiante, indicará como o processo de industrialização - conquanto favoreça a constituição do mercado interno por intermédio da 'articulação das distintas regiões do país em um sistema com um mínimo de integração' - concorrerá para o aumento das disparidades entre as regiões, à base da concentração de terras naquelas em que se vai verificar uma perda de importância da agricultura de subsistência:

Da perspectiva do território brasileiro, os espaços nos quais as terras permanecem mais concentradas são aqueles do Norte/Nordeste, nos quais diminuiu a relevância das lavouras tradicionais. Será essa dinâmica, impulsionada a partir dos anos 1930 pela industrialização, que alimentará não apenas as desigualdades sociais que se perpetuam no país, mas também as disparidades inter-regionais (FURTADO, 1977, p. 237-238).

Em "perspectivas da economia brasileira" (publicado em 1958), Celso Furtado procede a uma divisão em dois sistemas econômicos principais para identificar 'problemas de disparidade regional' no território brasileiro. Note-se que ele os associa ao desenvolvimento (industrial) orientado pela ação dos agentes privados no mercado, em consequência do que as desigualdades se vieram esgarçando no tempo:

Seria grave equívoco supor que esses problemas de disparidade regional se resolverão espontaneamente e que por isso não devem constituir preocupação central da política geral de desenvolvimento. Tudo indica que nos últimos 15 anos [...] as disparidades regionais se acentuaram. O desenvolvimento está contribuindo, portanto, para agravar essas disparidades e não para resolvê-las (FURTADO, 2012 [1958], p. 61).

Ao aí conferir centralidade à problemática regional, Celso Furtado convida a enfrentar as referidas disparidades, inscrevendo-a em um programa nacional de desenvolvimento: "As políticas regionais de desenvolvimento pressupõem uma compreensão dos objetivos nacionais de desenvolvimento" (FURTADO, 2012 [1958], p. 64). 
Nos anos 196o, num trabalho menos citado, o economista paraibano chegou a diagnosticar (e a propor estratégias para enfrentar) o que então chamou de 'descontinuidades subnacionais'. Diagnóstico e política, porém, se encaixavam em ousado esboço de 'teoria sobre estruturas espaciais', em que inferia serem os diversos critérios derivados da análise setorial e regional uma questão de decisão política (FURTADO, 1967).

Mais tarde, no início dos anos 1980, sobretudo, em "o Brasil pós-milagre”, a questão regional ganharia sofisticação na sua preocupação com o Nordeste. Para dela tratar, volta a distinguir o território brasileiro em dois espaços distintos, reiterando sua preocupação com as disparidades regionais, agravadas no período em que o país acelerara a sua industrialização:

Os problemas mais difíceis que nos afligem na fase atual, quando completamos um século de esforços pelos caminhos da industrialização, refletem de uma ou outra forma essa rachadura criada pelas dissimetrias entre as duas regiões que são as matrizes de nossa nacionalidade (FURTADO, 1981, p. 120).

No entanto, na sequência, Celso Furtado elabora um argumento que permitiria explicar a 'rachadura' diagnosticada: "Queiramos ou não, os grandes problemas do Brasil somente podem ser diagnosticados se se tem do país uma visão que leve em conta a fratura fundamental dessa desigualdade regional" (FURTADO, 1981, p. 120).

Seu argumento partirá, pois, da construção de 'uma visão que leve em conta a fratura' verificada no território. Tal visão não poderia cingir-se a considerar a região-problema, o Nordeste, dissociada da região na qual as forças produtivas se encontram mais desenvolvidas, o Centro-Sul. E que influência esta vinha exercendo sobre a região-problema? A resposta, na época, bastante original, era de que o Nordeste se tornara espaço de industrialização complementar à região mais desenvolvida:

As relações estruturais que vieram a prevalecer fazem que a industrialização nordestina seja, no essencial, uma prolongação do desenvolvimento industrial do Centro-Sul, e só secundariamente uma resposta aos requerimentos da população local (FURTADO, 1981, p. 122).

Pouco mais adiante, o argumento vai se completando. A realidade configurada pela 'rachadura', captada por uma visão ampla das assimetrias referidas, se explica pela necessidade do capital (acumulado na região mais desenvolvida) se expandir. A sua expansão implica, simultaneamente, uma desorganização das atividades tradicionais e a organização 
de atividades novas, mobilizadoras dos recursos agora disponíveis ${ }^{3}$, com vistas não ao atendimento de demandas concretas da população nordestina, mas à produção do que é definido desde a região mais desenvolvida:

ao transformar-se num espaço em que se localizam atividades industriais complementares da economia do CentroSul, o mercado de bens de consumo nordestino teve de adaptar-se à estrutura da oferta de produtos industriais que se origina na região de maior desenvolvimento relativo. A nova dependência reside exatamente na subordinação à lógica de uma industrialização que abarca o conjunto do país e é comandada do Centro-Sul, transformando-se o Nordeste em simples apêndice de um mercado dominado por uma clientela de nível de renda mais alto e onde se exacerbam as tendências consumistas (FURTADO, 1981, p 123-124).

Se, em escala nacional, a industrialização definida desde a região mais desenvolvida gerava desigualdades sociais e espaciais, a sua expansão em direção à região-problema tendia não somente a ampliar as distâncias entre os dois sistemas econômicos principais, como a gerar disparidades (sociais e intra-regionais) ainda maiores no Nordeste, na medida em que as decisões fundamentais tinham origem no Centro-Sul do país:

o quadro estrutural das relações inter-regionais que emergiu da industrialização recente opera no sentido de aprofundar a dependência do Nordeste: o mercado da região é cada vez mais um complemento do mercado do Centro-Sul e os investimentos industriais que aí se realizam subordinam-se à lógica da economia do Centro-Sul; destarte, as malformações do desenvolvimento desta última aparecem ampliadas na região mais pobre (FURTADO, 1981, p. 125).

O argumento furtadiano não apenas se valeria de dados empíricos que o comprovavam cabalmente, mas também repousava em uma interlocução com outras dimensões que, com elegância rara entre economistas, o completavam. Com efeito, poucas páginas adiante, Celso Furtado faria comparecer elementos - não-econômicos - que moldariam o quadro no qual contextualizaria seu argumento, com especial destaque para a cultura e a história, afirmando, por exemplo, que: "A identidade do brasileiro tem raízes em sua inserção regional, reflete um sistema de valores que cristalizou, a partir de elementos comuns ou não, em cada sub-região do imenso território do qual se assenhorou a Coroa portuguesa" (FURTADO,

3 De fato, aí afirma: “como ignorar que [a] 'ajuda' à industrialização levou à destruição de múltiplas atividades produtivas locais e inibiu a criação de outras, pois tendeu a tudo subordinar à lógica da integração com o Centro-Sul”? (FURTADO, 1981, p. 130). 
1981, p. 138). E, logo em seguida, assinalando um dos traços mais relevantes da formação do Brasil, observaria que: "O problema inicial era [...] o da fragilidade dos vínculos entre grupos de população espalhados em um vasto território, quase sempre articulados de forma autônoma a centros econômicos no exterior" (FURTADO, 1981, p. 139).

É certo que, com o tempo, neste vasto território, as diferentes regiões acabariam por articular-se umas com as outras, produzindo-se uma coesão interna mínima. Qual seria, porém, a alternativa a um desenvolvimento que se fundava na dependência das diversas regiões em relação a centros econômicos mais dinâmicos, que desconhecia identidades e valores, impondo sua lógica quase que inexoravelmente a todos os espaços que lhe são periféricos? Novamente, a resposta do economista paraibano surpreende por recorrer a elementos não-econômicos, afirmando que " $\mathrm{O}$ desenvolvimento do Nordeste terá que ser inventado na própria região a partir de sua realidade ecológica e do patrimônio cultural que cimenta a identidade dos nordestinos" (FURTADO, 1981, p. 152).

A "questão regional" ainda receberia atenção de Celso Furtado, como no capítulo sétimo - "O Nordeste: novo modelo de desenvolvimento?" de livro que publicaria pouco depois (FURTADO, 1982b). Contudo, ele retomaria o assunto, inclusive, recuperando a visão ampla com que já o havia abordado, em um breve, mas penetrante exame do federalismo brasileiro, observando:

Como somos um país com fronteiras que se deslocam permanentemente dentro do próprio território, nosso conceito de região é necessariamente dinâmico. Mas essa consciência de unidade nacional, dentro de um espaço que se expande, coexiste com o senso de identidade que se definiu historicamente em cada região particular. A identidade do brasileiro tem raízes em sua inserção regional... (FURTADO, 1999, p. 47).

Aí, como se percebe, explicitaria a sua preocupação com o desenvolvimento regional, contrastando a 'consciência da unidade nacional' - que, não por acaso, se afirmava com o centralismo que caracterizaria o primeiro governo Vargas 4 - com o sentimento de identidade regional. Neste período, em que se desencadearia no país "o verdadeiro processo de industrialização" (FURTADO, 1982a, p. 20), induzido pelo Estado e,

4 “A consolidação do poder central, que se esboça em 1930 e se confirma em 1937, dota o país de um centro de decisões com considerável autonomia vis-à-vis dos grupos econômicos tradicionais. Caem as barreiras aduaneiras entre estados e tomam-se muitas outras medidas visando a unificar o mercado nacional..." (FURTADO, 1982a, p. 22). 
por isso, mais autônomo em comparação com o que ocorrera anteriormente, articular-se-iam as regiões brasileiras entre si, constituindo, finalmente, uma unidade econômica com vinculações e complementaridades outrora inexistentes. Assim: "Sem desconhecer os aspectos negativos das desigualdades regionais que se agravavam, não se pode ignorar que nessa época [anos 1930] foi forjada uma sólida interdependência inter-regional" (FURTADO, 1999, p. 51). Mais adiante, ler-se-ia que "a industrialização apoiada no mercado interno deu origem a vínculos profundos entre regiões que antes mantinham entre si escassas relações econômicas" (idem, p. 52).

Ao meditar sobre como evoluiu o federalismo brasileiro, o economista paraibano parte de seu diagnóstico das disparidades regionais para propor uma alternativa ajustada à institucionalidade político-administrativa então vigente, sugerindo que:

não seria fora de propósito discutir a possibilidade de uma esfera regional de poder. A fórmula a ser encontrada deveria preservar os estados atuais e, mediante a inserção do poder regional, buscar corrigir os aspectos mais negativos das desigualdades demográficas e territoriais existentes (FURTADO, 1999, p. 55).

Reconhecendo que o processo de centralização promovido pelos governos militares se tenha exacerbado, ultrapassando os limites de governabilidade de regiões tão diversas em aspectos (tanto socioeconômicos e políticos quanto também culturais e ecológicos) essenciais, Celso Furtado recomendaria que a transferência de poder às instâncias locais e regionais se baseasse numa cuidadosa estratégia de planificação, de molde a contemplar os interesses e as necessidades identificáveis no território. Em suas palavras: "A descentralização regional do poder central deveria ser acompanhada de um planejamento plurianual que permitisse compatibilizar as aspirações das distintas regiões" (FURTADO, 1999, p. 56).

Que balanço se poderia fazer da contribuição de Celso Furtado para a questão regional no Brasil? Em apertada síntese, e considerando somente as publicações acima selecionadas (notando-se que entre a primeira e a última há um intervalo de 40 anos), pode-se reconhecer uma análise perspicaz da lógica econômica que tem governado o desenvolvimento brasileiro e suas repercussões sobre o território. Não obstante se manifestasse sobre economia como economista (que considerava um cientista social), examinou a problemática regional brasileira considerando suas inúmeras 
implicações. Se, porém, fosse preciso resumir o diagnóstico furtadiano, poder-se-ia vaticinar que ele desvendou a natureza do processo de desenvolvimento desigual que preside a economia brasileira, uma economia subdesenvolvida porque periférica; e se fosse preciso resumir a estratégia furtadiana para enfrentar o desenvolvimento regional desigual, poderse-ia sopesar que, desde uma visão global, ele privilegiou a política, em seu sentido mais nobre, como meio de desmontar os mecanismos que têm perpetuado e, mesmo, agudizado as disparidades inter-regionais no Brasil.

\section{Desenvolvimento regional na universidade brasileira}

Há, evidentemente, uma produção intelectual sobre desenvolvimento regional na universidade brasileira que tem origem em outras fontes. Talvez não seja despropositado indicar a influência que exerceram, entre outros, Gunnar Myrdal (1957), François Perroux (1950, 1955) e Albert O. Hirschman (1958) no debate sobre desenvolvimento regional a partir de meados dos anos 1950/início dos anos 1960. Mas, parece fora de dúvida que, nas últimas três a quatro décadas, tenha sido com a obra de Celso Furtado que, direta ou indiretamente, a produção intelectual oriunda da academia tenha estabelecido uma interlocução mais profícua para tratar da problemática regional no Brasil. O legado do economista paraibano tem sido uma referência importante para um número não desprezível de especialistas, entre eles, Otamar de Carvalho (2014), Pedro Bandeira (1999, 2007) e Liana Maria da Frota Carleial (1993, 2014).

Convém assinalar que, sobretudo, nos dois últimos decênios, uma larga parcela da produção intelectual sobre desenvolvimento regional na universidade brasileira vem tendo seu espaço privilegiado na pós-graduação. A agência que regula esta importante atividade ligada à educação superior do país é a Coordenação de Aperfeiçoamento de Pessoal de Nível Superior [CAPES]. Ela se ocupa de acompanhar a pós-graduação brasileira através de avaliações frequentes, classificando os diversos programas de pós-graduação [PPG] por critérios de qualidade. Os PPG encontramse vinculados a 49 grandes áreas que, por sua vez, se distribuem por três grandes "colégios" (Colégio de Ciências da Vida, Colégio de Ciências Exatas, Tecnológicas e Multidisciplinar, e Colégio de Humanidades). Poder-se-ia identificar "desenvolvimento regional" em PPG em diversas dessas 49 grandes áreas - por exemplo, enquanto linha de pesquisa e/ou área de concentração em algum PPG da grande área Geografia. 
Poder-se-ia identificar "desenvolvimento regional", também, em algum PPG da grande área Interdisciplinar. Interessam aqui, porém, os PPG ligados à grande área "Planejamento Urbano e Regional/Demografia".

Para proceder a uma aproximação dos PPG de desenvolvimento regional, convém, antes, caracterizar, minimamente, a grande área "Planejamento Urbano e Regional/Demografia". O primeiro dos PPG dessa grande área surgiu em Porto Alegre, na Universidade Federal do Rio Grande do Sul [UFRGS], em 1970. Dois anos depois, portanto, em 1972, foi criado o segundo PPG dessa grande área no Rio de Janeiro, na Universidade Federal do Rio de Janeiro [UFRJ] - ambos os PPG em "planejamento urbano e regional”. Desde então vem aumentando consideravelmente o número de PPG nesta grande área. Entretanto, um crescimento mais acentuado se daria nos anos 2000 - tanto na área "Planejamento Urbano e Regional/Demografia” como em toda a pós-graduação brasileira (CIRANI et al., 2015).

Após a avaliação quadrienal 2013-2016, realizada no segundo semestre de 2017, contam-se 48 PPG na grande área "Planejamento Urbano e Regional/Demografia" - um número extraordinário, se se lembrar que em princípios dos anos 1970 havia apenas dois PPG de/em "planejamento urbano e regional" no Brasil. Desses 48 PPG, quatro eram da área de "Demografia". Portanto, a área de Planejamento Urbano e Regional, propriamente, somava 44 PPG. Desses, nove eram Mestrados Profissionais, dois eram Doutorados (acadêmicos) ligados a Mestrados Profissionais e 33 eram PPG acadêmicos.

O "campo" (ou: a subárea) do "Desenvolvimento Regional", propriamente, abarcava 18 PPG acadêmicos e três Mestrados Profissionais. Isso equivalia a algo como $54 \%$ do total dos PPG acadêmicos e $33 \%$ dos Mestrados Profissionais da área de "Planejamento Urbano e Regional"; ou, considerando a grande área, 37\% e 30\%, respectivamente. Cabe lembrar que a história dos PPG desta subárea principia bem mais tarde. Com efeito, o primeiro PPG de Desenvolvimento Regional surgiu apenas em 1994, na Universidade de Santa Cruz do Sul [UNISC], no município de Santa Cruz do Sul, do Estado do Rio Grande do Sul. O segundo PPG de Desenvolvimento Regional surgiu no ano 2000, na Universidade Regional de Blumenau [FURB], no município de Blumenau, do Estado de Santa Catarina. O terceiro surgiu no ano de 2003, na Universidade Estadual

5 No momento em que se fazia a última revisão do texto (12 de junho de 2019), o número de PPG na grande área em questão chegava a 50. Para os fins aqui propostos, contudo, considerar-se-ão os dados da última avaliação quadrienal da CAPES. 
do Oeste do Paraná [UNIOESTE], no município de Toledo, do Estado do Paraná.

Aqui cabe destacar que os três primeiros PPG do "campo" (ou: da subárea) do Desenvolvimento Regional tiveram origem em Instituições de Ensino Superior não-privadas, mas também não-federais, localizadas em "municípios do interior" (isto é, não capitais), em "cidades médias" (isto é, não em grandes centros urbanos) dos três estados do Sul do Brasil - região reconhecida por diversas iniciativas, algumas pioneiras, baseadas no associativismo - num período de menos de 10 anos, entre a primeira metade dos anos 1990 e a primeira metade dos anos 200o. Trata-se, vale lembrar, de um momento em que a globalização neoliberal avançava sobre os países periféricos. No Brasil, passaram a ser adotadas medidas econômicas que teriam forte repercussão sobre o tecido social. A política econômica liberal então posta em marcha, baseada em elevadas taxas de juros, na privatização de empresas públicas e na abertura comercial, conduziu a uma reestruturação produtiva sem precedentes. Em consequência, aumentou o desemprego e caíram os rendimentos do trabalho. Portanto, pode-se afirmar, sem maior receio, que a criação dos primeiros PPG em Desenvolvimento Regional, entre princípios dos anos 1990 e o início dos anos 2000, constituiu uma resposta, encontrada na Região Sul, à globalização neoliberal que, então, já produzia seus graves efeitos econômicos e sociais no Brasil.

Talvez o surgimento dos demais 18 PPG desta subárea (inclusive, os três mestrados profissionais), que, evidentemente, se deu na sequência, também repouse nas mesmas motivações. No entanto, é provável que a principal responsável pela abertura dos novos PPG no "campo" do Desenvolvimento Regional seja a "interiorização" da pós-graduação brasileira. De fato, salvo exceções, os novos PPG em Desenvolvimento Regional foram criados em IES relativamente mais jovens, localizadas, em sua maioria, mais longe da imensa faixa litorânea ao longo da qual, historicamente, emergiram as mais antigas IES brasileiras.

É aí, pois, nos PPG de IES mais jovens do "interior" do Brasil, que vem tendo lugar uma interessante produção intelectual sobre desenvolvimento regional. Esta tem sido animada por fontes diversas, algumas já referidas. Contudo, parece inegável que, nos últimos três a quatro decênios, venha sendo, sobretudo, a obra de Celso Furtado que tem inspirado, direta ou indiretamente, a produção intelectual dessa banda mais nova da academia no tratamento da problemática regional brasileira. Há uma 
óbvia vantagem nisso: o desenvolvimento regional no Brasil vem sendo, cada vez mais, objeto de pesquisa das/nas próprias regiões brasileiras.

Considere-se a possibilidade de identificar a pesquisa em desenvolvimento regional, isto é, os grupos de pesquisa e os/as pesquisadores/as que se dedicam ao tema. O que há? E, sobretudo, que relação existe entre 'pesquisa' em desenvolvimento regional e 'pós-graduação' em desenvolvimento regional?

Tabela 1 - Grupos de Pesquisa em Desenvolvimento Regional, 2016

\begin{tabular}{l|c|c}
\hline Área de conhecimento & $\begin{array}{c}\text { Grupos de } \\
\text { Pesquisa }\end{array}$ & $\begin{array}{c}\text { \% em relação } \\
\text { ao total }\end{array}$ \\
\hline Grande Área de Sociais Aplicadas & 5.363 & 14,3 \\
\hline Área de Planejamento Urbano e Regional & 233 & 0,6 \\
\hline Subárea de Desenvolvimento Regional (a) & 608 & 1,6 \\
\hline Subárea de Desenvolvimento Regional (b) & 408 & 1,1 \\
\hline Subárea de Desenvolvimento Regional (c) & 121 & 0,3 \\
\hline Total & 37.640 & 100 \\
\hline
\end{tabular}

Fonte: CNPq < http://lattes.cnpq.br/web/dgp > Acesso: 03.02.2018

(a) Busca realizada combinando os campos "Nome do grupo", "Nome da linha de pesquisa" e "Palavra-chave da linha de pesquisa"; (b) busca realizada combinando os campos "Nome do grupo" e "Nome da linha de pesquisa"; (c) busca limitada ao campo "Nome do grupo".

Os dados do último Censo realizado pelo CNPq informavam que existiam mais de 37 mil grupos de pesquisa no Brasil ${ }^{6}$. A tabela acima permite verificar a importância relativa dos grupos de pesquisa que se dedicavam à problemática do desenvolvimento regional - apareça esta expressão como palavra-chave, como linha de pesquisa e/ou mesmo designe o grupo. Grupos de pesquisa que tinham desenvolvimento regional no nome eram pouco mais de 230 - o que equivale a somente $0,6 \%$ do total de grupos de pesquisa existentes no país. Este número parece demasiadamente modesto. Mas, a título de comparação, o número de grupos de pesquisa que tinham "desenvolvimento local" no nome eram apenas 29 , o dos que tinham "desenvolvimento territorial sustentável" no nome eram só cinco. Não há espaço, aqui, para se aprofundar a relação entre grupos

6 No momento em que se fazia a última revisão do texto (12 de junho de 2019), o número de grupos de pesquisa recenseado pelo CNPq permanecia inalterado. 
de pesquisa e pós-graduação, de forma que esta questão sugere investigação futura.

Quanto aos pesquisadores que se dedicam ao tema, os dados mais precisos são os gerados pelo Portal da Inovação [http://www.portalinovacao.mct.gov.br/pi/\#/pi] - aliás, este sendo alimentado por dados provenientes da Plataforma Lattes do CNPq. Por intermédio de um ranking, o Portal da Inovação permite identificar os pesquisadores segundo suas respectivas "competências", informando, por exemplo, a instituição em que eles atuam profissionalmente. $\mathrm{O}$ que acontece quando se pede a palavra-chave "desenvolvimento regional" nas competências? A lista dos 10 primeiros traz cinco pesquisadores sobre desenvolvimento regional que atuam como docentes em PPG da subárea de desenvolvimento regional; dos 10 seguintes, o número de pesquisadores sobre desenvolvimento regional que atuam como docentes em PPG da subárea chega a sete; somados, tem-se então 12 pesquisadores, entre 20 , sobre desenvolvimento regional que atuam como docentes em PPG da subárea de desenvolvimento regional, ou seja, $60 \%$. Isso parece revelar que, da perspectiva do/a investigador/a, a disseminação do tema "desenvolvimento regional” é impulsionada pela atuação de pesquisadores-docentes em PPG da subárea de desenvolvimento regional. De qualquer maneira, também esta questão sugere investigação futura.

Até aqui a atenção foi orientada para a pós-graduação como espaço privilegiado de larga parcela da produção intelectual sobre desenvolvimento regional na universidade brasileira, sobretudo, nas duas últimas décadas. Mas, e a graduação? Dificilmente, poder-se-ia examinar nesta breve intervenção a relevância da temática do desenvolvimento regional em cursos de graduação oferecidos por IES brasileiras. A razão é simples: inexistiam, no Brasil, cursos de graduação em desenvolvimento regional até pouco tempo atrás. Quanto à presença do tema "desenvolvimento regional” em outros cursos de graduação existentes, um levantamento aqui seria despropositado - embora deva ser registrado que em diversas IES brasileiras ele esteja presente. É o caso do Centro Universitário para o Desenvolvimento do Alto Vale do Itajaí [UNIDAVI], com sede no município de Rio do Sul, no Estado de Santa Catarina, que oferece um curso de graduação em "Ciências Econômicas e Desenvolvimento Regional”. Todavia, agora já existem cursos de graduação em desenvolvimento regional. No segundo semestre de 2014 iniciou a primeira turma do Bacharelado Interdisciplinar em Ciência e Tecnologia [BICT], oferecido pela UFRGS em seu Campus Litoral Norte, no município de 
Tramandaí, no estado do Rio Grande do Sul. O BICT/UFRGS do Campus Litoral Norte prevê quatro "terminalidades": Licenciatura em Geografia, Bacharelado em Engenharia de Gestão de Energia, Bacharelado em Engenharia de Serviços e Bacharelado em Desenvolvimento Regional. O BICT compreende um ciclo comum aos quatro cursos que dura três [3] anos e outro que dura dois [2] anos, correspondendo ao específico de cada curso, à "terminalidade" [https://www.ufrgs.br/campuslitoralnorte/ ensino/desenvolvimento-regional acesso em 0402 2018].

Que balanço se poderia fazer da contribuição da universidade brasileira para a questão regional no Brasil? Em primeiro lugar, pode-se notar que essa contribuição existe e tem se tornado cada vez mais importante; em segundo, a crescente relevância da universidade brasileira para a problemática regional pode ser atribuída, principalmente, à pós-graduação; em terceiro, também é certo que grupos de pesquisa e investigadores, em grande medida, ligados a PPG da subárea, são responsáveis por parcela considerável da produção intelectual em desenvolvimento regional; em quarto lugar, a temática do desenvolvimento regional também já alcançou a graduação, embora aí a sua presença seja quase imperceptível. O desafio que, então, se apresenta é o da qualidade dessa contribuição - o que, em tese, poderia ser revelado pela produção intelectual, com destaque para aquela que desemboca em periódicos científicos especializados.

\section{Desenvolvimento regional nos periódicos científicos}

É possível elaborar uma noção mais precisa de desenvolvimento regional, 'a partir de uma aproximação desde a realidade brasileira', tomando os periódicos científicos - isto é, revistas especializadas, que publicam artigos, ensaios e resenhas, impressas ou online (como passou a ser mais comum), com conselhos editoriais e normas bem definidas de publicação - como referência? Talvez, sim. Cabe, no entanto, advertir para algumas dificuldades. A primeira: está se falando de periódicos científicos publicados apenas no Brasil? Ou, também, de publicados em outros países? Se também nestes últimos, então, em quais idiomas? Como se sabe, em geral, incluem-se (por certa "vocação" da academia brasileira de internacionalizar-se, sobretudo, "em inglês") os publicados nos EEUU e no Reino Unido. Mas, como ficam os publicados em outras nações e outros idiomas? A segunda dificuldade: está se falando de periódicos apenas sobre desenvolvimento regional? Ou de periódicos que cobrem, entre diversos temas, também, desenvolvimento regional? É preciso, de qualquer 
maneira, que tragam desenvolvimento regional - ou desenvolvimento, ou regional... - no título e/ou entre as palavras-chave? Se outros periódicos podem ser considerados, então, qual é, por assim dizer, a fronteira tolerável? Poder-se-ia, por exemplo, passar a incluir nessa lista um periódico de biologia que publicasse um artigo de desenvolvimento regional? Ademais das mencionadas, há, evidentemente, inúmeras outras dificuldades, mas que, devido ao espaço exíguo, não podem ser referidas aqui.

De qualquer forma, as dificuldades apontadas acima são reais. Contudo, para contorná-las pode-se - e, dadas as circunstâncias, devese - eleger um critério que conta com o reconhecimento dos próprios editores dos periódicos: a sua avaliação, como vem sendo realizada, pela antes já mencionada CAPES. Cabe lembrar, uma vez mais, que essa agência regula a pós-graduação brasileira e, para tanto, considera a qualidade da produção intelectual do pessoal ligado aos PPG (docentes, pós-graduandos...). Tal produção, como se sabe, é publicada na forma de artigos científicos em periódicos indexados. Aqui se parte deste critério - isto é, do fato de que os periódicos que importam passaram por avaliação do chamado "Qualis Periódicos"7 - para se elaborar uma noção mais precisa de desenvolvimento regional a partir de uma aproximação desde a realidade brasileira. Então, tomando em conta o referido critério, temse a questão que aqui conta: em quais periódicos (indexados) têm sido publicados artigos científicos que correspondem à produção intelectual em desenvolvimento regional no Brasil?

\section{Quadro 1 - Revistas de/sobre desenvolvimento regional cf. Qualis Periódicos/CAPES}

\begin{tabular}{|c|c|c|c|}
\hline $\begin{array}{c}\text { Nome do } \\
\text { periódico }\end{array}$ & $\begin{array}{c}\text { Responsável pela } \\
\text { publicação }\end{array}$ & Endereço eletrônico & Qualis \\
\hline $\begin{array}{c}\text { Desenvolvimento } \\
\text { em Questão }\end{array}$ & $\begin{array}{c}\text { Programa de Pós-Graduação em } \\
\text { Desenvolvimento / Unijuí }\end{array}$ & $\begin{array}{c}\text { https://www.revistas. } \\
\text { unijui.edu.br/index.php/ } \\
\text { desenvolvimentoemques- } \\
\text { tao/index }\end{array}$ & $\mathrm{B} 2$ \\
\hline $\begin{array}{c}\text { Desenvolvimento } \\
\text { Regional em debate } \\
\text { [DRd] }\end{array}$ & $\begin{array}{c}\text { Programa de Mestrado em } \\
\text { Desenvolvimento Regional / } \\
\text { Universidade do Contestado }\end{array}$ & $\begin{array}{c}\text { http://www.periodicos. } \\
\text { unc.br/index.php/drd }\end{array}$ & $\mathrm{B} 3$ \\
\hline $\begin{array}{c}\text { Economía, Sociedad y y } \\
\text { Territorio }\end{array}$ & $\begin{array}{c}\text { El Colegio Mexiquense A.C. / } \\
\text { México }\end{array}$ & $\begin{array}{c}\text { https://est.cmq.edu.mx/ } \\
\text { index.php/est }\end{array}$ & $\mathrm{B} 1$ \\
\hline \multicolumn{2}{|c|}{} & \multicolumn{2}{|c|}{} \\
\hline
\end{tabular}

7 Ver https://sucupira.capes.gov.br/sucupira/public/consultas/coleta/veiculoPublicacaoQualis/listaConsultaGeralPeriodicos.jsf. 


\begin{tabular}{|c|c|c|c|}
\hline $\begin{array}{l}\text { Nome do } \\
\text { periódico }\end{array}$ & $\begin{array}{l}\text { Responsável pela } \\
\text { publicação }\end{array}$ & Endereço eletrônico & Qualis \\
\hline $\begin{array}{l}\text { EURE Revista Latino- } \\
\text { americana de Estudios } \\
\text { Urbano Regionales }\end{array}$ & $\begin{array}{l}\text { Instituto de Estudios Urbanos y } \\
\text { Territoriales, Pontificia Univer- } \\
\text { sidad Católica de Chile }\end{array}$ & $\frac{\text { http://www.eure.cl/index. }}{\text { php/eure }}$ & $A_{1}$ \\
\hline Informe GEPEC & $\begin{array}{c}\text { Programa de Pós-Graduação em } \\
\text { Desenvolvimento Regional e } \\
\text { Agronegócio / UNIOESTE }\end{array}$ & $\frac{\text { http://e-revista.unioeste. }}{\text { br/index.php/gepec }}$ & $\mathrm{B} 1$ \\
\hline $\begin{array}{l}\text { Revista Brasileira de } \\
\text { Desenvolvimento } \\
\text { Regional [RBDR] }\end{array}$ & $\begin{array}{c}\text { Programa de Pós-Graduação } \\
\text { em Desenvolvimento Regional } \\
\text { / FURB }\end{array}$ & 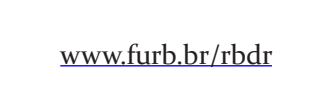 & $\mathrm{B}_{2}$ \\
\hline $\begin{array}{l}\text { Revista Brasileira de } \\
\text { Estudos Urbanos e } \\
\text { Regionais [RBEUR] }\end{array}$ & $\begin{array}{c}\text { Associação Nacional de Pes- } \\
\text { quisa e Pós-Graduação em Pla- } \\
\text { nejamento Urbano e Regional } \\
\text { [ANPUR] }\end{array}$ & $\frac{\text { http://rbeur.anpur.org.br/ }}{\underline{\text { rbeur }}}$ & $\mathrm{A} 2$ \\
\hline $\begin{array}{l}\text { Revista Brasileira de } \\
\text { Gestão e Desenvol- } \\
\text { vimento Regional } \\
\text { [RBGDR] }\end{array}$ & $\begin{array}{l}\text { Programa de Pós-Graduação } \\
\text { em Gestão e Desenvolvimento } \\
\text { Regional / UNITAU }\end{array}$ & $\begin{array}{l}\text { http://www.rbgdr.net/ } \\
\text { revista/index.php/rbgdr }\end{array}$ & $\mathrm{A} 2$ \\
\hline $\begin{array}{l}\text { REDES Revista do } \\
\text { Desenvolvimento } \\
\text { Regional }\end{array}$ & $\begin{array}{c}\text { Programa de Pós-Graduação } \\
\text { em Desenvolvimento Regional } \\
\text { / UNISC }\end{array}$ & $\begin{array}{l}\text { https://online.unisc.br/ } \\
\text { seer/index.php/redes }\end{array}$ & $\mathrm{B}_{1}$ \\
\hline $\begin{array}{c}\text { Revista Política e } \\
\text { Planejamento Regional } \\
\text { [RPPR] }\end{array}$ & $\begin{array}{l}\text { Ministério da Integração Nacio- } \\
\text { nal; Associação Nacional dos } \\
\text { Centros de Pós-Graduação em } \\
\text { Economia; Associação Nacional } \\
\text { de Pós-Graduação e Pesquisa } \\
\text { em Planejamento Urbano e } \\
\text { Regional; Instituto de Pesquisa } \\
\text { Econômica Aplicada }\end{array}$ & $\begin{array}{c}\text { http://www.revistappr. } \\
\text { com.br }\end{array}$ & $\mathrm{B}_{4}$ \\
\hline $\begin{array}{l}\text { RDE-Revista de Desen- } \\
\text { volvimento Econômico }\end{array}$ & $\begin{array}{c}\text { Programa de Pós-graduação em } \\
\text { Desenvolvimento Regional e } \\
\text { Urbano / UNIFACS }\end{array}$ & $\begin{array}{l}\text { http://revistas.unifacs.br/ } \\
\text { index.php/rde }\end{array}$ & $\mathrm{B}_{2}$ \\
\hline $\begin{array}{l}\text { RPD-Revista Paranaen- } \\
\text { se de Desenvolvimento }\end{array}$ & $\begin{array}{l}\text { Instituto Paranaense de Desen- } \\
\text { volvimento Econômico e Social } \\
\text { [IPARDES] }\end{array}$ & $\begin{array}{l}\text { http://www.ipardes.pr.gov. } \\
\text { br/ojs/index.php/revista- } \\
\text { paranaense/index }\end{array}$ & $\mathrm{B}_{2}$ \\
\hline
\end{tabular}

Fonte: Elaboração própria.

A lista acima traz apenas 12 periódicos, dois deles que publicam em espanhol (um do México, outro do Chile), os restantes 10, brasileiros, que publicam em português. Por que, por exemplo, a estadunidense Antipode ou a francesa Confins ou a espanhola Scripta Nova, reconhecidamente, importantes revistas deste (e para este) campo, não estão inclusas? A hipótese é de que investigadores brasileiros, vinculados ou não a grupos 
de pesquisa, ligados ou não a PPG, tendem a publicar, sobretudo, em periódicos brasileiros, talvez, em periódicos de outros países da América Latina. Voltando à lista: o ponto de partida é que o periódico seja destinatário da produção intelectual sobre desenvolvimento regional de pesquisadores brasileiros. Outro ponto importante é que todos os periódicos que integram a lista têm, pelo menos, cinco anos de existência - ou: cinco volumes publicados. Por fim, outro ponto é que todos devem ter passado pela avaliação do chamado “Qualis Periódicos” da CAPES. Já a razão para elaborar uma lista que contenha apenas 12 periódicos é arbitrária (poder-se-ia fazer uma lista menor ou maior). E a razão para que fossem incluídos exatamente estes 12 periódicos decorre de consulta um pouco mais cuidadosa ao "Qualis Periódicos" da área "Planejamento Urbano e Regional/Demografia”. Cumpre registrar que se consideraram os 18 PPG e os três Mestrados Profissionais em Desenvolvimento Regional, tanto para se aferir o destino da produção intelectual de seus docentes quanto para se verificar se algum dos PPG edita alguma revista.

Em síntese, além dos dois publicados, respectivamente, no México e no Chile, a lista dos 12 periódicos acima inclui sete publicados por PPG da subárea de desenvolvimento regional; entre os outros três, um é publicado pela ANPUR, outro pelo IPARDES e outro conjuntamente pelo Ministério da Integração Nacional e pelo IPEA. Em termos de avaliação, apenas três se encontram no extrato $\mathrm{A}$, sendo o melhor avaliado um periódico não brasileiro.

Tomando-se na devida conta o acima exposto, e dado ser esta uma lista mínima inicial, daqui emerge como novo desafio para o campo do desenvolvimento regional a necessidade de precisar melhor a lista, talvez, considerando/acrescentando outros critérios.

\section{Desenvolvimento regional: um novo "campo"?}

Nesta seção se pretende, com base no que se expôs até aqui, explorar a possibilidade de passar a tratar "desenvolvimento regional" como um possível novo campo ${ }^{8}$. Três breves passos serão dados com vistas a

8 Aqui se entendendo por campo um espaço que dispõe de alguma autonomia, portanto, que é governado a partir de normas e regras próprias. Apesar disso, um campo não pode ser dissociado de seu entorno, pelo qual é, em menor ou maior grau, condicionado. Internamente, um campo implica conflito entre os "agentes" que o integram, visando a conquista ou a preservação de posições. Hierarquias se estabelecem (e se desfazem) em conformidade com o "capital" detido por cada agente do respectivo 
formular uma proposição que convirja com este intento. Primeiramente, será importante recordar as disciplinas de "origem". Recorrendo a uma prosopopeia: de onde têm "falado" os estudos de desenvolvimento regional até aqui? Em segundo lugar, será preciso passar, uma vez mais, pela dicotomia 'conhecimento positivo' e 'conhecimento normativo', agora, desde o ponto de onde se busca formular uma noção de desenvolvimento regional que possa caracterizar um campo. E, por último, sugerir-se-á que, com desenvolvimento regional, se está na presença de uma "teoria de médio alcance", se não um pré-requisito, então, pelo menos, uma condição importante para o reconhecimento de desenvolvimento regional enquanto um campo de maior autonomia.

Primeiro passo: de que disciplinas têm partido os estudos conhecidos de desenvolvimento regional? Cabe lembrar que desenvolvimento regional pressupõe o desenvolvimento de uma região. Por isso, trata-se de perguntar: $\mathrm{O}$ que é região? O que é desenvolvimento? Sem lugar a dúvidas, as respostas têm sido buscadas, especialmente, na Geografia e na Economia. Contudo, desenvolvimento regional não resulta apenas do que aportam essas duas disciplinas. Evidentemente, não é o caso de insistir em contatos com o que é estranho ou distante, nem tampouco de forçar interfaces com "Planejamento Urbano e Regional" - isto é, com a área na qual está contida a subárea de desenvolvimento regional quando se lida com a pós-graduação. Aliás, cumpre lembrar que tanto Economia quanto Geografia constituem "áreas" autônomas na classificação da CAPES. Então, e voltando ao ponto, o que aqui se designa como desenvolvimento regional também se nutre de outras fontes, com destaque para a Sociologia, a Ciência Política, a Antropologia ${ }^{9}$, a História e, eventualmente, o Direito e a Arquitetura. De forma que, ao invés de limitar as vozes do que seja desenvolvimento regional ao que emana de

campo. Compromissos celebrados entre os agentes podem aplacar conflitos e assegurar, temporariamente, alguma estabilidade ao campo. Mas, se, por um lado, tensões internas podem ser contidas, por outro, ameaças oriundas do entorno também podem gerar insegurança. Se, como parece evidente, o entendimento de campo sugere constante movimento, então essa noção possui um caráter inequivocamente relacional (BOURDIEU, 2004).

9 Apenas para exemplificar, pode-se formular uma "acepção" ancorada na Antropologia segundo a qual "é a história que faz uma região [...] seus múltiplos planos não se encaixam em limites geográficos [...] A questão torna-se mais complexa quando [se indaga] de que história [se está] falando. Quem são seus protagonistas? Quais [são] as categorias discursivas acionadas? Como as narrativas de experiências são acionadas, contadas e recontadas? Quais [são] as categorias silenciadas?" (RENCK, 2004, p. 12). 
uma ou duas disciplinas, pode-se (e deve-se) mobilizar outros campos de conhecimento, já que - e este passa a ser um pressuposto daqui por diante - desenvolvimento regional tem assumido, talvez, mais destacadamente no âmbito dos PPG, um nítido caráter interdisciplinar ${ }^{10}$. Assim, outro desafio que se apresenta para os estudos do desenvolvimento regional consiste em inventariar a produção intelectual sobre desenvolvimento regional que tem origem não apenas na Economia e na Geografia (mais ou menos conhecida), mas, sobretudo, nas outras disciplinas acima referidas (mais ou menos desconhecida).

Segundo passo: no que se refere à dicotomia 'conhecimento positivo' e 'conhecimento normativo', é preciso reconhecer que ela não apenas está devidamente disseminada, mas também que parece suficientemente didática para indicar diferenças entre o que existe e o que se deseja que exista. Entretanto, a distinção entre o fato objetivo e concreto - que, em tese, corresponde à realidade tal como ela supostamente é - e a manifestação idealizada subjetiva - que indica como a realidade deveria ser - é, na verdade, inadequada para se diferenciar desenvolvimento regional enquanto dado empírico e enquanto propósito conscientemente delineado. A inadequação dessa distinção repousa em algumas dificuldades. Talvez a mais importante seja que a "realidade tal como ela supostamente é" não se distingue, assim, sem mais, da "realidade tal como ela deveria ser". Porque fato concreto e propósito delineado estão imbricados" ${ }^{11}$. Afinal, a realidade é dinâmica. A distinção entre uma dimensão positiva e uma dimensão normativa, como postulada pelo positivismo, é, em geral, arbitrária. E o caso do desenvolvimento regional não foge à regra. Dessa dificuldade decorre outra: a rigor, se houvesse desenvolvimento regional - seja lá o que isso signifique -, então, não existiria razão para se intervir na realidade, para se moldar essa realidade, enfim, para fazê-la tornar-se aquilo que ela deveria ser. De maneira que o fato consumado do desenvolvimento regional dispensaria a formulação de uma política de desenvolvimento regional. Daí se infere que a distinção é inadequada se a intenção do desenvolvimento regional se justifica apenas em face de um fato como a inexistência (ou melhor: o não-fato) de desenvolvimento regional. $\mathrm{O}$

10 Aliás, dependendo do sentido que se lhe conferir, parece pertinente reconhecer à expressão "desenvolvimento regional" também um caráter pluridisciplinar, multidisciplinar ou transdisciplinar (MATTEDI; THEIS, 2002).

11 De minha parte, simpatizo com a ideia de que "o objetivo não é compreender a realidade [como ela é], mas compreender [...] suas contradições como parte da luta para mudar o mundo" (HOLLOWAY, 2003, p. 177). 
fato contra o qual se posiciona qualquer intenção (uma "política") de desenvolvimento regional terá, pois, que ser a falta de desenvolvimento regional - falta que pode ser traduzida, por exemplo, por disparidades regionais. Assim, o fato da existência de desigualdades (sociais, econômicas, políticas...) entre regiões é o que convidaria a agir em favor de desenvolvimento regional, vale dizer, de uma redução nas disparidades regionais.

Terceiro passo: desenvolvimento regional é uma teoria? Ou não passa de uma hipótese? Na realidade desenvolvimento regional não é nem uma simples hipótese nem uma consistente teoria. É algo que se situa entre a hipótese e a teoria. Não sendo nem hipótese nem teoria, sugere-se que desenvolvimento regional seja uma teoria de médio alcance. Teorias desse tipo são:

teorias intermediárias entre as pequenas, mas hipóteses necessárias de trabalho que surgem [...] durante a rotina das pesquisas diárias e os amplos esforços sistemáticos para desenvolver uma teoria unificada capaz de explicar todas as uniformidades observadas de comportamento, organização e mudança sociais (MERTON, 1970, p. 51).

Essa modalidade de teorias, não sendo nem pequenas e insignificantes hipóteses nem grandes e consistentes teorias (como, por exemplo, os sistemas teóricos da economia, da sociologia etc.), é utilizada, sobretudo, como uma espécie de guia para investigações empíricas, ocupando:

\begin{abstract}
uma situação intermediária entre as teorias gerais de sistemas sociais, as quais estão muito afastadas das espécies particulares de comportamento, organização e mudança sociais para explicar o que é observado, e as minuciosas ordenadas descrições de pormenores que não estão de modo algum generalizados (MERTON, 1970, p. 51).
\end{abstract}

Abstrações também podem estar presentes em "teorias de médio alcance”. No entanto, estas se encontram bem mais próximas da realidade social em questão, de maneira que possam ser testadas empiricamente. Assim, as teorias de médio alcance, como se sugere no caso do desenvolvimento regional, por envolverem aspectos limitados da realidade social, não poderiam confundir-se com grandes teorias, não obstante sejam mais que simples hipóteses (MERTON, 1970, p. 51).

Dados os passos anunciados no início desta seção - isto é, a constatação de que desenvolvimento regional não deve ser limitado ao que emana de uma ou duas disciplinas, na medida em que, devido ao seu evidente 
caráter interdisciplinar, tende a se articular com outros campos de conhecimento; a consideração de que a distinção entre fato objetivo e concreto e manifestação idealizada subjetiva é inadequada para se diferenciar desenvolvimento regional como dado empírico, de um lado, e propósito delineado, de outro; e, a sugestão de que com desenvolvimento regional se esteja na presença de uma "teoria de médio alcance" - talvez estejam atendidas condições importantes para a formulação de uma proposição que contribua para o reconhecimento de desenvolvimento regional enquanto campo de maior autonomia.

$\mathrm{Na}$ expectativa de que essas condições estejam, de fato, atendidas, pode-se enfrentar a questão-chave: o que é desenvolvimento regional desde a perspectiva sociocultural brasileira? Como ponto de partida podese tomar a acima referida inadequação da distinção entre fato e intenção. Desenvolvimento regional é algo bom que não existe, em favor do que dever-se-iam mobilizar energias, em resposta a algo ruim que existe, isto é, desigualdades (sociais, econômicas, políticas...) entre regiões, as disparidades regionais. De que resultam mesmo essas disparidades regionais? Numa economia capitalista, o desenvolvimento das forças produtivas sobre dado território produz desigualdades, sobretudo, porque, em cada região, a provisão de meios de produção é, quantitativa e qualitativamente, diferenciada, assim como é diferenciada a produtividade de sua força de trabalho. Uma vez atuando a força de trabalho sobre os recursos produtivos mobilizados para a produção de mercadorias em cada região, no âmbito de dada formação nacional, o território será progressivamente alterado - de "meio natural" ele, progressivamente, se converte em "meio técnico-científico-informacional” (SANTOS; SILVEIRA, 2013). Essa divisão territorial do trabalho evoluirá para a coexistência de coordenação entre algumas grandes metrópoles, numerosas cidades médias, muitos pequenos centros urbanos - em que se desenvolverão atividades industriais e de serviços - e o espaço rural - em que, com auxílio cada vez maior da indústria, desenvolver-se-ão atividades primárias (agricultura, pecuária, mineração etc.). Essa divisão sócio-espacial do trabalho configura uma paisagem em permanente modificação, marcada pela produção contínua de desigualdades.

Desenvolvimento regional é algo bom com que se procura combater algo ruim (as desigualdades). No entanto, não existe apenas um remédio para as disparidades regionais. Não parece despropositado notar que a expressão "desenvolvimento regional" já sugere uma divergência em relação às desigualdades: é preferível desenvolvimento regional a 
disparidades regionais. Todavia, o que parece fundamental é que tem se mobilizado, pelo menos, três estratégias para se enfrentar as disparidades regionais (com suas respectivas implicações teóricas e políticas) - o que remete a um debate travado no âmbito da Geografia Econômica: para um primeiro enfoque, desigualdades só podem ser corrigidas pelo mercado; para outro, desigualdades só podem ser corrigidas pelo Estado; e, para o terceiro, desigualdades deveriam/poderiam ser evitadas pela superação das condições materiais que, continuamente, as recriam.

O primeiro enfoque recomenda deixar que o mercado se autorregule, sem intervenção, seja de grupos organizados da sociedade (os trabalhadores, através de sindicatos...), seja do Estado. Para os seus advogados, as desigualdades resultam de/são agravadas, precisamente, por demasiada intervenção estatal. A despeito de reconhecer a hegemonia dos liberais no debate, investir num detalhamento de seu argumento constituiria desperdício de tempo e papel escassos.

O segundo enfoque propõe a intervenção do Estado. O diagnóstico é de que o mercado autorregulado é uma ficção; deixando-se que funcione sem coordenação, inevitavelmente, produzirá desigualdades. Portanto, há dois pontos a considerar: é preciso (a) corrigir as desigualdades e (b) regular o mercado que as produz. Começando por este último, o Estado deve regular o mercado que gera desigualdades, por exemplo, por meio de leis etc. Assim, a presença do Estado, este agente incumbido de coordenar o mercado, atenuaria a geração de desigualdades sócio-espaciais. Já com relação às desigualdades diagnosticadas, para elas têm sido sugeridas - e, de fato, elas têm sido enfrentadas por - medidas ou políticas baseadas no crescimento econômico das regiões "perdedoras", com vistas a nivelá-las com as regiões "ganhadoras". Não é difícil perceber, aqui, um andar em círculos: os meios com que se sugere combater o mal são os mesmos que o provocam; ou, dito com todas as letras: as desigualdades inter-regionais diagnosticadas, resultantes de um crescimento econômico desigual, são, supostamente, melhor combatidas com... mais crescimento econômico - talvez, assegurando às regiões "perdedoras” taxas mais elevadas?! Um problema adicional se apresenta para os intervencionistas: empiricamente, as desigualdades estão por toda parte, crescendo por toda parte, apesar de se encontrar o Estado por toda parte. De maneira que a presença do Estado, ao invés de favorecer o enfrentamento das desigualdades, talvez tenha se tornado funcional à sua existência e continuidade.

$\mathrm{O}$ terceiro enfoque elege a autonomia de cada comunidade regional na definição de seu projeto societário. Aqui não se desconhece nem o 
mercado nem o Estado, nem tampouco se ignora a existência da moderna sociedade produtora de mercadorias, da qual o mercado e o Estado são instituições ancilares. Mas, precisamente por isso, o remédio mais indicado para combater as desigualdades sócio-espaciais não poderia cingirse às medidas postuladas pelos dois enfoques anteriores. $\mathrm{O}$ diagnóstico, aliás, é outro: mantida intacta a moderna sociedade produtora de mercadorias, com sua base produtiva e correspondente superestrutura, dado que aí incidem todos os efeitos do desenvolvimento geográfico desigual (THEIS, 2009; THEIS; BUTZKE, 2012), as disparidades inter-regionais tendem a se reproduzir continuamente. Logo, será inócua a espera passiva pela ação do Estado, por meio de políticas de desenvolvimento regional, para que se atenuem ou mesmo extingam as desigualdades sócio-espaciais. As desigualdades poderão ser extintas se os membros das comunidades regionais resistirem ativamente à permanente coacção do capital para que sejam destituídos do controle de seus meios de vida; sendo assalariados, se também ativamente reconquistarem os meios com os quais podem prover-se a si e aos seus das condições materiais e espirituais para uma vida digna. Em síntese: as desigualdades poderão ser extintas se os membros das comunidades regionais recuperarem sua autonomia (BÖHM; DINERSTEIN; SPICER, 2010; DINERSTEIN, 2013). Em uma formação social periférica e dependente (em relação às formações sociais que vêm comandando a economia-mundo) como a brasileira, é a utopia concreta $(\mathrm{BLOCH}, 2005)$ com que se pode formular uma noção de desenvolvimento regional.

\section{Considerações finais}

Este artigo foi dedicado à problemática do desenvolvimento regional. Entretanto, o que, realmente, se buscou fazer era oferecer uma compreensão um pouco mais contextualizada do que pudesse ser desenvolvimento regional. É preciso reconhecer que tem havido tentativas visando precisar melhor o que se pode entender por desenvolvimento regional. Todavia, em contraste com os esforços realizados até agora, procurou-se definir minimamente o contexto no qual se pudesse formular uma noção mais precisa de desenvolvimento regional. De maneira que a preocupação maior foi com o quadro no qual se poderia elaborar uma compreensão de desenvolvimento regional. Tal quadro, como se informou na introdução, tomaria o Brasil como lócus privilegiado e suas características socioculturais como referências inamovíveis. 
A que resultados se chegou? Em primeiro lugar, o breve panorama internacional esboçado logo na segunda seção permitiu que se verificasse que a problemática do desenvolvimento regional também recebe atenção em outros países. E o que se entende por essa expressão "fora do Brasil"? Embora outras preocupações possam ser identificadas (desigualdades sócio-espaciais, relações de poder, aspectos éticos, questões metodológicas etc.), predomina a compreensão de desenvolvimento regional como um processo essencialmente econômico.

Em segundo lugar, como se viu, a figura de Celso Furtado logo se destaca entre os numerosos estudiosos da questão regional no Brasil. Com efeito, o economista paraibano identificou e analisou com rara competência a problemática regional, desvendando a natureza do processo de desenvolvimento desigual que preside a economia brasileira, subdesenvolvida e periférica, e privilegiando a política como meio para desmontar os mecanismos que têm perpetuado as disparidades inter-regionais no Brasil. Por isso, sua obra vem influenciando estudos mais recentes de/ sobre desenvolvimento regional como, provavelmente, nenhuma outra.

Em terceiro lugar, nas últimas três décadas, a problemática regional tem sido examinada no Brasil, sobretudo, no ambiente das IES, em especial, no âmbito dos programas de pós-graduação. Como se procurou mostrar, os PPG vêm sendo, de fato, os principais responsáveis pela produção intelectual que tem tido lugar na universidade brasileira. A atuação dos grupos de pesquisa e dos próprios pesquisadores tem inegável relevância neste contexto. Mas, deve ter ficado evidente, sobretudo, que já não se pode falar de desenvolvimento regional sem fazer referência à pós-graduação no Brasil.

Em quarto lugar, isso é bastante perceptível quando se busca verificar o destino da produção intelectual em/sobre desenvolvimento regional. É óbvio que não se poderia fazer aqui um inventário exaustivo dos periódicos científicos. Contudo, a aproximação realizada permitiu que se caracterizasse o conjunto de revistas especializadas em desenvolvimento regional nas quais vem desaguando a produção intelectual brasileira. Não há dúvida, porém, que - por razões que não cabe explorar neste ponto - periódicos de desenvolvimento regional têm sido, comparativamente, menos bem avaliados.

Em quinto e último lugar, pode-se avançar em direção à formulação de uma proposição mais concreta, mas, não sem antes considerar que desenvolvimento regional não deve ser limitado ao que aporta $(\mathrm{m})$ uma ou duas disciplinas, dado o seu caráter interdisciplinar; a distinção entre fato 
objetivo/concreto e manifestação idealizada/subjetiva é inadequada para diferenciar desenvolvimento regional como dado empírico de propósito delineado; e, com desenvolvimento regional se está na presença não de uma pequena hipótese ou de uma grande teoria, mas de uma "teoria de médio alcance". Dados esses passos, distinguiu-se entre três enfoques na formulação de uma proposição mais concreta de desenvolvimento regional. E esse quadro que se acaba de esboçar talvez atenda às exigências envolvidas com o reconhecimento de um campo de conhecimento. Daqui em diante se abrem possibilidades variadas para se elaborar uma noção um pouco mais precisa e, ao mesmo tempo, mais utópica de desenvolvimento regional - 'a partir de uma aproximação desde a realidade sociocultural brasileira', que passe a dar alguma visibilidade e levar na devida conta o seu passado colonial, o sofrimento dos povos originários e das populações compulsoriamente transplantadas, a presença das mulheres, a diversidade da natureza.

\section{Referências}

BANDEIRA, Pedro. Participação, articulação de atores sociais e desenvolvimento regional (= Texto para Discussão, N. 630). Brasília: IPEA, 1999.

BANDEIRA, Pedro. Diferenças regionais quanto ao capital social e crescimento econômico no Rio Grande do Sul. REDES, 12 (1), p. 93-124, 2007.

BELHEDI, Amor. La fracture territoriale: la dimension spatiale de la révolution tunisienne. Tunis: Wassiti Editions, 2012.

BERCOVICI, Gilberto. Desigualdades regionais, Estado e constituição. São Paulo: Max Limonad, 2003.

BLOCH, Ernst. O princípio esperança I. Trad. Nélio Schneider. Rio de Janeiro: Ed. UERJ; Contraponto, 2005.

BÖHM, Steffen; DINERSTEIN, Ana C.; SPICER, André. (Im)possibilities of Autonomy: Social Movements in and beyond Capital, the State and Development. Social Movement Studies, 9 (1), p. 17-32, 2010.

BOURDIEU, Pierre. Os usos sociais da ciência: por uma sociologia clínica do campo científico. São Paulo: UNESP, 2004. 
CANO, Wilson. Desequilíbrios regionais e concentração industrial no Brasil, 1930-1995. Campinas: Unicamp/IE, 1998 [1981].

CARLEIAL, Liana M. F. A questão regional no Brasil contemporâneo. In: LEVINAS, L.; CARLEIAL, L. M. F.; NABUCO, M. R. (org.) Reestruturação do espaço urbano e regional no Brasil. São Paulo: Ed. Hucitec; Annablume, p. 35-58, 1993.

CARLEIAL, Liana M. F. O desenvolvimento regional brasileiro ainda em questão. Revista Política e Planejamento Regional, 1 (1), p. 1-21, 2014.

CARVALHO, Otamar de. Desenvolvimento regional: um problema político. Campina Grande: EDUEPB, 2014.

CIRANI, Claudia Brito Silva; CAMPANARIO, Milton deAbreu; MARQUES DA SILVA, Heloisa Helena. A evolução do ensino da pós-graduação senso estrito no Brasil: análise exploratória e proposições para pesquisa. Avaliação, 20 (1), p. 163-187, 2015.

COY, Martin. Regionalentwicklung in Rondônia (Brasilien): integrierte ländliche Entwicklung und politische Rahmenbedingungen. Geographische Zeitschrift, 74 (3), p. 177-185, 1986.

DAWKINS, Casey J. Regional development theory: conceptual foundations, classic works, and recent developments. Journal of Planning Literature, 18, (2), p. 131-172, 2003.

DINERSTEIN, Ana Cecilia. "La autonomía y sus imaginarios prácticos en permanente construcción”. In: DINERSTEIN, Ana Cecilia [et al.] (org.) Movimientos sociales y autonomía colectiva: la política de la esperanza en América Latina. Buenos Aires, Capital Intelectual, p. 23-38, 2013.

DINIZ, Clélio Campolina. Celso Furtado e o desenvolvimento regional. Nova Economia, 19 (2), p. 227-249, 2009.

FERNÂNDEZ, Victor Ramiro. Estrategia(s) de desarrollo regional bajo el nuevo escenario global-local: revisión crítica sobre su(s) potencialidad(es) y limites. Revista EURE, 28 (82), p. 43-63, 2001.

FREYRE, Gilberto. Sobre o "manifesto regionalista" de 1926. In: COHN, Sergio. Gilberto Freyre (= col. Encontros). Rio de Janeiro: Beco do Azougue, p. 62-97, 2010. 
FURTADO, Celso. Intra-country discontinuities: toward a theory of spatial structures. Social Science Information, 6 (6), p. 7-16, 1967.

FURTADO, Celso. Formação econômica do Brasil. 15 ed. São Paulo: Nacional, 1977.

FURTADO, Celso. O Brasil pós-“milagre”. 4 ed. Rio de Janeiro: Paz e Terra, 1981.

FURTADO, Celso. Análise do “modelo" brasileiro. 7 ed. Rio de Janeiro: Civilização Brasileira, 1982a.

FURTADO, Celso. A nova dependência: dívida externa e monetarismo. Rio de Janeiro: 4 ed. Paz e Terra, 1982b.

FURTADO, Celso. O longo amanhecer: reflexões sobre a formação do Brasil. Rio de Janeiro: Paz e Terra, 1999.

FURTADO, Celso. Perspectivas da economia brasileira. Rio de Janeiro: Centro Internacional Celso Furtado de Políticas para o Desenvolvimento, $2012[1958]$.

HIRSCHMAN, Albert O. The strategy of economic development. New Haven: Yale University Press, 1958.

HOLLOWAY, John. Mudar o mundo sem tomar o poder: o significado da revolução hoje. Trad. E. Sader. São Paulo: Viramundo, 2003.

MATTEDI, Marcos A.; THEIS, Ivo M. Cruzando fronteiras: conhecimento e interdisciplinaridade na pesquisa em desenvolvimento regional. REDES, 7 (2), p. 77-94, 2002.

MERTON, R. K. Sociologia: teoria e estrutura. Trad. M. Maillet. São Paulo: Mestre Jou, 1970.

MOULAERT, Frank; JESSOP, Bob; MEHMOOD, Abid. Agency, structure, institutions, discourse (ASID) in urban and regional development. International Journal of Urban Sciences, 20 (2), p. 167-187, 2016.

MÜHLINGHAUS, Sabine. Eigenständige Regionalentwicklung als Strategie für periphere ländliche Räume? Eine Untersuchung aus dem Schweizer Berggebiet. Geographica Helvetica, 57 (2), p. 127-134, 2002. 
MYRDAL, Gunnar. Economic theory and underdeveloped regions. London: Duckworth, 1957.

OLIVEIRA, Francisco de. Elegia para uma re(li)gião: Sudene, Nordeste, planejamento e conflito de classes. 3 ed. Rio de Janeiro: Paz e Terra, 1981.

PERRIN, J. C. Le développement régional: schémas d'analyse de l'économiste. Cahiers Orstom (Sci. Hum.), 4 (2), p. 7-6o, 1967.

PERROUX, François. Economic space: theory and applications. Quarterly Journal of Economics, 64 (1), p. 89-104, 1950.

PERROUX, François. Note sur la notion de póle de croissance. Économie Appliquée, N. 8, p. 307-320, 1955.

RENCK, Arlene. Narrativas da diferença. Chapecó: Argos, 2004.

SANTOS, Milton; SILVEIRA, Maria Laura. O Brasil: território e sociedade no início do século XXI. 17 ed. Rio de Janeiro; São Paulo: Record, 2013.

TAVARES, Hermes Magalhães. Desenvolvimento, região e poder regional: a visão de Celso Furtado. Revista Brasileira de Estudos Urbanos e Regionais, 13 (2), p. 11-26, 2011.

THEIS, Ivo M. Do desenvolvimento desigual e combinado ao desenvolvimento geográfico desigual. Novos Cadernos NAEA, v. 12, n. 2, p. 241-252, dez. 2009.

THEIS, Ivo Marcos; BUTZKE, Luciana. O paradoxo da geografia no capitalismo mundializado: revisitando a lei do desenvolvimento desigual e combinado. In: GALVÃO, Andreia et al. (org.) Capitalismo: crises e resistências. São Paulo: Outras Expressões, p. 83-110, 2012.

VELASCO, Andrés Enrique Miguel; MALDONADO CRUZ, Pedro; TORRES VALDEZ, Julio César. Desigualdad del desarrollo regional en México. Problemas del Desarrollo: Revista Latinoamericana de Economía, 38 (151), p. 87-102, 2007. 


\section{Pensando com o desenvolvimento regional: subsídios para um programa forte em desenvolvimento regional ${ }^{1}$}

Marcos Antônio Mattedi

\section{Introdução}

$\mathrm{O}$

DESENVOLVIMENTO REGIONAL ENCERRA UM PARADOXO CURIOSO: a relação entre desenvolvimento e região constitui uma realidade estudada por muitos pesquisadores, porém são poucos os pesquisadores que utilizam o desenvolvimento regional para estudar a realidade. Para podermos compreender esse impasse precisamos considerar, simultaneamente, como é formada esta comunidade de pesquisadores e quais são as estratégias empregadas para investigar essa temática. Isso envolve a consideração das regras morais que orientam as relações dos pesquisadores entre si e as regras técnicas que guiam as relações dos pesquisadores com a realidade. Mais precisamente, como foi formada essa comunidade científica e quais são as convenções teórico-metodológicas empregadas. Assim, por um lado, essa investigação pressupõe o entendimento de como surgiram os estudos, publicações, eventos, associações de pesquisadores, centros de formação; e, por outro, quais são os modelos empregados para o estudo do desenvolvimento regional.

1 Publicado originalmente em REVISTA BRASILEIRA DE DESENVOLVIMENTO REGIONAL, ISSN 2317-5443, DOI: 10.7867/2317-5443.2014V2N2Po59-105 (C) 2014 PPGDR/UNIVERSIDADE REGIONAL DE BLUMENAU. Disponível em: WWW. FURB.BR/RBDR.

2 Graduado em Ciências Sociais pela Universidade Regional de Blumenau (1991), mestrado em Sociologia Política pela Universidade Federal de Santa Catarina (1994) e doutorado em Ciências Sociais pela Universidade Estadual de Campinas (1999), com um estágio de pós-doutorado no Centre de Sociologie de L'Innovation-ENMP/Paris (2003). É docente-pesquisador do Programa de Pós-Graduação em Desenvolvimento Regional, da Universidade Regional de Blumenau, onde desde 2006 coordena o Núcleo de Estudos da Tecnociência (NET).. 
Até a Segunda Guerra Mundial o desenvolvimento e a região, assim como os problemas cognitivos políticos a eles relacionados, se mantiveram como variáveis estudadas isoladamente. É claro que a maior parte das ciências sociais, cada uma a sua própria maneira, sempre manifestou interesse sobre as relações entre desenvolvimento e região. Nesse sentido, a pesquisa sobre o desenvolvimento regional foi se produzindo e reproduzindo num cruzamento disciplinar em que se destacam a contribuição da ciência econômica, a geografia, a sociologia, a ciência política e a antropologia, tentando entender as causas e consequências da intervenção humana no território. Questões como a repartição da população, a localização das atividades produtivas, a formação das cidades, a degradação ambiental, o papel dos transportes etc. há muito são investigadas. Mas todo esse conjunto de dados empíricos que vão permitindo conceber e explicar as relações que se estabelecem entre desenvolvimento e região não institui uma forma autônoma de pensar com o desenvolvimento regional.

Assim, a área de conhecimento sobre o desenvolvimento regional se caracteriza pela produção de um volume crescente de informações, mas, apesar disso, não existe um acordo de como isso deve ser feito. Por isso, esse processo parece ser mais o efeito do retalhamento disciplinar do que a preocupação com o desenvolvimento regional. Temos uma abordagem econômica, geográfica, sociológica e antropológica que fraciona a compreensão do desenvolvimento regional. Quais as consequências do aumento progressivo de informações e, ao mesmo tempo, a dificuldade de estabelecer um acordo de como isso deve ser feito? As consequências mais evidentes são que possuímos muito conhecimento produzido sobre o desenvolvimento regional e pouco conhecimento produzido com o desenvolvimento. Isso significa que não existe ainda um consenso disciplinar sobre a estratégia teórica e metodológica que deve ser compartilhada entre esses pesquisadores para a produção do conhecimento sobre a relação entre desenvolvimento e região.

Em nosso ponto de vista, pensar o modo regional de desenvolvimento com o desenvolvimento regional é exercício reflexivo. À medida em que as regiões se desenvolvem, aumenta também o interesse pelo conhecimento do próprio desenvolvimento regional. Isso significa que quanto mais complexo se torna o padrão de desenvolvimento de uma região, maior a produção de conhecimento relacionado ao próprio desenvolvimento regional. E isso assinala que a própria capacidade de uma região pensar a si mesma pode se converter em um indicador de desenvolvimento 
regional. Parece haver aí uma relação de "coconstrução", no qual o desenvolvimento regional estimula sua própria compreensão e sua própria compreensão alimenta o desenvolvimento regional. O monitoramento reflexivo da relação entre desenvolvimento e região deve ser considerado, portanto, como uma via de mão dupla. A principal implicação desse processo diz respeito ao caráter regional das próprias teorias, afinal nenhuma teoria do desenvolvimento regional pode pretender uma validade global.

Assim, progressivamente, o desenvolvimento regional se impõe como objeto de preocupação científica, combinando uma grande variedade de interesses políticos e cognitivos. Por isso, uma das grandes dificuldades para pensar com o desenvolvimento regional constitui a inexistência de acordos teóricos e conceituais sobre as noções de desenvolvimento e região. Para estabelecer um programa forte em desenvolvimento regional necessitamos enfrentar esse paradoxo, ou seja, para poder conhecer com o desenvolvimento regional precisamos considerar três planos analíticos:

a) Plano epistemológico: determinar a cientificidade do que conhecemos como novo com a relação entre Desenvolvimento e Região;

b) Plano teórico: determinar quais são as principais características das interpretações da relação entre Desenvolvimento e Região;

c) Plano metodológico: determinar como podemos produzir conhecimento por meio da relação entre Desenvolvimento e Região.

A resposta a estas questões possibilita transpor os obstáculos que impedem a produção do conhecimento com o desenvolvimento regional.

Considerando as três dimensões cognitivas o objetivo deste capítulo, cumpre estabelecer os pressupostos analíticos necessários para pensar o modo regional de desenvolvimento por meio do desenvolvimento regional. Mais precisamente, sistematizar as consequências morais e lógicas que colocamos em operação quando estudarmos o modo regional do desenvolvimento.

Sabemos que a expressão desenvolvimento regional associa dois tipos de fenômenos. Essa operação é tão banal que, muitas vezes, não nos damos conta das consequências do conjunto dinâmico de possibilidades de associação que se estabelecem entre desenvolvimento e região. Por isso, para pensar com desenvolvimento regional é preciso superar um conjunto de obstáculos: a) o primeiro deles se refere à autocompreensão cientificista que os estudos do desenvolvimento regional possuem a respeito do processo de produção do conhecimento científico; b) o segundo 
diz respeito às teorias reducionistas dos usos disciplinares dos conceitos de desenvolvimento e região; c) e o terceiro alude a concepção bidimensional do desenvolvimento regional.

A operação cognitiva de superação desses obstáculos é o estabelecimento de um modelo relacional. O modelo relacional se propõe a apreender a realidade por meio de intersecções de fenômenos diferentes. Quando pensamos algo de forma relacional, estabelecemos uma analogia de semelhanças e diferenças. Trata-se, portanto, de uma dialógica na qual o desenvolvimento regional não é o ponto de chegada, mas o de partida. Aqui não se trata de transpor as descobertas realizadas numa determinada disciplina, mas de converter o desenvolvimento regional numa unidade cognitiva autônoma. Assim, pensar com o desenvolvimento regional o modo regional de desenvolvimento constitui estabelecer uma relação entre fenômenos transescalar. Considerando esses fatores, pensar com desenvolvimento regional constitui associar atributos relacionais cuja associação permite detectar dimensões da realidade por meio do contraste de fatores heterogêneos.

Por isso, nosso desafio nesse capítulo não se resume a pensar o desenvolvimento regional, mas pensar a realidade em termos de desenvolvimento regional. Aqui o desenvolvimento regional não constitui mais apenas o ponto de chegada que alcançamos seguindo os caminhos traçados pela economia, pela geografia, pela sociologia, pela antropologia, pela ciência política etc., mas também o ponto de partida por meio do qual compreendemos essa realidade de uma nova forma. Portanto, não se trata somente de recolher, comparar e avaliar as diversas estratégias de concepção e interpretação do desenvolvimento regional que foram sendo criadas e aplicadas em outras disciplinas, mas delinear uma plataforma cognitiva que permita influenciar o desenvolvimento dessas disciplinas. Mais precisamente, converter a relação entre desenvolvimento e região numa matriz explicativa que explique algo que a aplicação isolada dos conceitos de desenvolvimento e região não permite.

Nesse sentido, considerando esta problemática, o texto está estruturado em quatro partes. Por isso, na primeira parte, apresentaremos a breve revisão das estratégias epistemológicas de concepção que podem ser adotadas para interpretar cientificidade das relações entre desenvolvimento e região. Na segunda parte, efetuamos uma análise das teorias do desenvolvimento regional para estabelecer um modelo conceitual que permita superar as abordagens bidimensionais. Na terceira, nos concentramos na reformulação do conceito de desenvolvimento regional segundo os 
subsídios extraídos do cálculo da indicação desenvolvido a partir das contribuições de George Spencer-Brown. Para finalizar, como exercício de síntese, apresentaremos cincos princípios para orientar a pesquisa em desenvolvimento regional e, assim, propor as bases epistemológicas, teóricas e epistemológicas do pensamento com o desenvolvimento regional.

\section{A reflexividade do conhecimento com o desenvolvimento regional}

Para conseguirmos solucionar o paradoxo do desenvolvimento regional precisamos entender porque o conhecimento é produzido localmente, mas deve ser validado globalmente. Somente compreendendo como o conhecimento científico é produzido, entenderemos porque quanto mais se generalizam as descobertas sobre o desenvolvimento regional, menor se torna a nossa capacidade de pensar com o desenvolvimento regional. Por isso, antes de podermos estabelecer uma teoria do desenvolvimento regional, necessitamos conceber uma teoria do conhecimento com o desenvolvimento regional. Mais precisamente, trata-se de demarcar as diferenças entre o conhecimento produzido na economia, na geografia, na sociologia, na antropologia etc. e o conhecimento produzido com o desenvolvimento do modo regional de desenvolvimento. O conhecimento com o desenvolvimento regional comporta três especificidades cognitivas: a) causação contextual; b) distinção analógica; c) a autorreferência reflexiva.

O estudo com o desenvolvimento regional parte do pressuposto de que o desenvolvimento e a região estão analiticamente ligados por relações de influência mútua. Isso significa que o desenvolvimento e a região são inseparáveis dos contextos transacionais em que estão incrustados. E que quanto mais se desenvolve uma região, maiores são as interconexões e interdependências entre desenvolvimento e região. Estes contextos transacionais estão em constante transformação e, portanto, não podem ser descritos por meio de uma causação linear. Por isso, o desenvolvimento regional apresenta uma relação causal bidirecional, em que o desenvolvimento tem uma influência causal sobre a região e que, por sua vez, a região tem um efeito causal sobre o desenvolvimento. Aqui não se trata de descrever o desenvolvimento ou região, mas as relações de influência que se estabelecem entre eles. Ou seja, o conjunto e a regularidade de relações possíveis de serem estabelecidas entre desenvolvimento e região. 
Se dissermos que o conhecimento com o desenvolvimento regional é regionalmente situado, somos obrigados a situar nosso conhecimento regionalmente. Esse viés regional da operação de contextualização do conhecimento com o desenvolvimento regional só se torna evidente quando efetuamos uma analogia. Isso significa que nunca podemos afirmar nada sobre o desenvolvimento regional se não estabelecermos um parâmetro de comparação. Esse parâmetro de comparação retrospectiva que se direciona tanto internamente com modos anteriores de desenvolvimento regional, quanto mediante o contraste externo com modos discrepantes de desenvolvimento regional. Dito de outra forma, somente conseguimos pensar as relações entre desenvolvimento e região regionalmente quando comparamos com outras experiências de desenvolvimento regional no tempo e no espaço. Isso significa que o desenvolvimento regional é sempre relativo, porque, afinal, é sempre desigual.

Para ter validade, o conhecimento do desenvolvimento regional precisa ser aplicado a si mesmo. Isso quer dizer que o desenvolvimento regional constitui um conhecimento autorreferente. Essa abordagem pressupõe que cada contexto social estabelece uma forma específica de relacionar, simbolicamente e materialmente, desenvolvimento e região. Isso indica que tanto as concepções quanto as aplicações das noções de desenvolvimento e região, bem como a de desenvolvimento regional, são produzidas socialmente segundo o padrão de desenvolvimento regional. Ou seja, o entendimento da relação de causalidade existente entre desenvolvimento e região está associado reflexivamente a compreensão do contexto social. Portanto, para pensar com o desenvolvimento regional precisamos reconhecer a relação reflexiva que caracteriza o pensamento com o desenvolvimento regional. Em outras palavras, cada modo regional de desenvolvimento pressupõe um ritmo específico de circulação de conhecimento sobre o desenvolvimento de uma região.

Para a consideração da causalidade, distinção e a reflexividade na abordagem da relação entre desenvolvimento e região, é possível diferenciar duas "culturas epistêmicas" predominantes (KNORR-CETINA, 1999). Por um lado, destaca-se a estratégia epistemológica que procura integrar estas três pré-condições por meio da reprodução dos modelos de conhecimento desenvolvidos na abordagem dos fenômenos naturais. Trata-se, portanto, de tentar explicar a relação entre o desenvolvimento e a região pela redução das relações aos fatores mensuráveis, controláveis e manipuláveis mediante a replicação do método das ciências naturais. Por outro lado, é possível identificar uma estratégia que se caracteriza 
pela aplicação dos modelos extraídos das ciências humanas. Aqui, o objetivo é compreender o sentido e o significado da relação que se estabelece entre desenvolvimento e região por meio da consideração dos fatores subjetivos. Em grande medida, esse processo se manifesta no interior de cada disciplina de onde se extraem os subsídios para pensar o desenvolvimento regional (APEL, 200o).

Essas culturas epistêmicas prescrevem o que precisamos fazer quando descrevemos cientificamente a realidade com o desenvolvimento regional. Para elucidar esta questão, necessitamos estabelecer parâmetros de credibilidade e validade que nos habilitem a distinguir o conhecimento a respeito do desenvolvimento regional. $\mathrm{E}$ isso envolve a questão das possibilidades do conhecimento científico, ou melhor, os critérios para estabelecer a cientificidade de um enunciado ou teoria em desenvolvimento regional. Mais exatamente, isso implica explicitar que pressupostos compartilhamos quando produzimos conhecimento científico e o que distingue o conhecimento produzido com o desenvolvimento regional. Tratam-se dos acordos tácitos por meio do qual produzimos, justificamos e apresentamos as informações que descobrimos com o desenvolvimento regional. Olhando para as estratégias desenvolvidas para distinguir o conhecimento científico do conhecimento não-científico podemos diferenciar duas estratégias: a) parâmetros metodológicos e b) parâmetros institucionais (DUTRA, 1998, 2005).

Segundo o ponto de vista estático, a ciência constitui uma espécie de consenso sem coerção. Esse consenso fundamenta-se na crença de que existe um princípio único que permite demarcar a diferença entre o conhecimento científico e o não-científico. Essa diferença se estabelece por meio do contraste de teorias com a realidade conhecido como teste empírico. Assim, a ciência é concebida essencialmente como um exercício intelectual no qual as falhas são progressivamente eliminadas e o conhecimento é acumulado (BUNGE, 1989). Os exemplos mais conhecidos desta estratégia constituem o "principio de verificação" estabelecido pelo Positivismo Lógico e o "princípio de refutação" estabelecido pelo Racionalismo Crítico. O princípio de verificação estabelece que a validade de uma teoria decorre de seu método de verificação (CARNAP, 1970). Já o princípio de refutação estabelece que a validade de uma teoria resulta de seu grau de proibição (POPPER, 1980). Porém, seja de forma indutiva ou de forma dedutiva, o desempate é sempre estabelecido pelo contraste com a realidade. 
Segundo essa estratégia, o processo de certificação do conhecimento com o desenvolvimento regional passaria pela adoção do método científico. A ciência é vista como um tipo de conhecimento especial que elabora seus próprios critérios de validez. Isso significa que, como toda a ciência, também o desenvolvimento regional necessitaria ser fiel ao caráter experimental e a adoção de uma linguagem lógica e matemática de expressão do conhecimento. Desse ponto de vista, os problemas relativos ao conhecimento do desenvolvimento regional podem ser resolvidos reduzindo a validade das informações ao que pode ser observado empiricamente por meio de um método de determinação. Esse processo poderia ser reconstruído racionalmente e as observações "verificadas" ou "refutadas" por meio de uma comparação com a realidade. Nesse sentido, a debilidade associada à produção do conhecimento científico com o desenvolvimento regional decorreria da inexistência de regras lógicas de observação.

Essa solução apresenta alguns problemas, afinal uma teoria do desenvolvimento regional não pode ser reduzida a uma descrição do mundo. A transposição destes critérios comporta algumas dificuldades típicas da pesquisa em ciências sociais como, por exemplo, a dificuldade de controle experimental, a relatividade cultural das leis sociais, a natureza subjetiva dos temas de pesquisa, o viés valorativo da investigação social etc., e, principalmente, a constatação de que os indivíduos, grupos sociais e sociedades modificam seu padrão de desenvolvimento com a aquisição de novos conhecimentos. Constitui a tentativa de explicação de um fenômeno, ou o que é mais importante, de fenômenos que se relacionam socialmente. Trata-se, portanto, de saber se é possível estabelecer leis dos fenômenos sociais e, consequentemente, das relações entre desenvolvimento e região. No caso do desenvolvimento regional, o próprio desenvolvimento regional pode regular as leis concebidas sobre seu funcionamento a partir do controle do próprio desenvolvimento regional.

Por outro lado, existem as abordagens dinâmicas que sustentam que a cientificidade constitui uma convenção da comunidade científica. A validade de uma hipótese ou credibilidade de uma teoria é determinada segundo a aplicação de uma escala convencionada socialmente na comunidade científica (GELLNER, 1997). A comunidade científica se organiza em disciplinas que constituem as formas institucionais privilegiadas no qual a ciência se organiza, desenvolve, avalia e transmite a cultura instituída. Existem muitas variantes desse tipo de abordagem, mas a maior parte pode ser diferenciada em duas estratégias predominantes. Por um lado, o historicismo que sustenta que a cientificidade constitui um 
consenso cognitivo que resulta do compartilhamento de um paradigma (KUHN, 1989); e, por outro, a sociologia que estabelece que a cientificidade constitui o resultado de relações de dominação conflitivas entre os membros do campo científico (BOURDIEU, 1997). A cientificidade do conhecimento do desenvolvimento regional decorre, portanto, da forma como interpretamos a formação da comunidade científica.

A ideia segundo a qual a atividade científica é influenciada socialmente não é nova (MATTEDI, 2006). Para Kuhn, por exemplo, os impasses relacionados a produção do conhecimento com o desenvolvimento indicariam um estágio de formação da comunidade de pesquisadores do desenvolvimento regional pré-paradigmático, em que ainda não existe um padrão estabelecido de abordagem dos problemas relacionados a pesquisa em desenvolvimento regional. Já para Bourdieu, o paradoxo do desenvolvimento regional se explicaria porque esse campo de conhecimento ainda não se autonomizou de outras disciplinas, e a busca por reconhecimento e a acumulação do capital científico ainda não estrutura os pesquisadores do desenvolvimento regional em dominantes e dominados. Aqui, o caminho que leva a fundamentação do conhecimento produzido com o desenvolvimento regional envolve uma institucionalização disciplinar. Para esse segundo grupo, a cientificidade é consequência do consenso estabelecido dentro da comunidade científica.

Nessa segunda estratégia, o paradoxo do desenvolvimento regional decorreria da incapacidade dos pesquisadores de instituir as convenções disciplinares. Não se trata somente de generalizar o uso de um método pela força dos resultados, mas de instituir regras estritas de entrada na comunidade científica. Isso passa pela criação de uma disciplina universitária, bem como pela regulamentação de uma atividade profissional associada a formação. Deste ponto de vista, a estabilização da produção do conhecimento com o desenvolvimento regional constitui menos uma atividade cognitiva e mais uma atividade política. Contudo, não parece suficiente creditar os impasses relacionados a produção do conhecimento em desenvolvimento regional somente ao padrão de organização da comunidade científica. A incapacidade de instituição disciplinar na universidade e o padrão difuso de comunicação está associado ao fato de que o conhecimento com o desenvolvimento regional é produzido regionalmente.

Ocorre que a oposição entre essas duas culturas epistêmicas se manifesta também no interior do desenvolvimento das disciplinas que se ocupam do desenvolvimento. Por exemplo, temos uma tradição de pesquisa 
econômica que segue o modelo de cientificidade das ciências naturais e uma que segue o modelo das ciências sociais; temos geografia que se aproxima mais das ciências naturais e outra mais próxima das ciências sociais; temos sociologia que reproduz uma metodologia positivista, mas também uma sociologia baseada nas humanidades. Assim, não somente a produção do conhecimento com o desenvolvimento regional é tensionado por essas duas tradições epistemológicas, como também o conhecimento disponível sobre o desenvolvimento regional produzido pela economia, geografia, sociologia e ciência política exprime esta oposição. As relações de oposição e colaboração no interior de cada disciplina e entre as disciplinas que estudam o desenvolvimento regional torna o campo de estudo muito complexo.

Além disso, um dos aspectos menos observados é que o conhecimento do desenvolvimento regional não é monopolizado por cientistas em núcleos de pesquisa universitários. O conhecimento sobre o desenvolvimento regional costuma ser produzido também nas agências governamentais, sindicatos, associações produtivas, círculos, redes e grupos informais etc. e, portanto, os pesquisadores universitários e as regras acadêmicas não são as únicas estratégias de validação empregadas na área. Os detentores do conhecimento sobre o desenvolvimento regional constituem um grupo mais amplo e mais variado do que o circunscrito nas tradições disciplinares que se ocupam do desenvolvimento regional como, por exemplo, a economia, geografia, sociologia etc. Essa característica dota o conhecimento sobre o desenvolvimento regional de grande ambivalência e heterogeneidade de práticas. E, portanto, o conhecimento do desenvolvimento regional não está restrito a certos grupos sociais e lugares - ele apresenta uma "mestiçagem".

Do ponto de vista estático e dinâmico, a inexistência de uma fronteira nítida entre leigos e peritos potencializa a fragmentação e dificulta a certificação do conhecimento com o desenvolvimento regional. Considerando esse processo, é possível depreender duas estratégias de legitimação do conhecimento. A primeira recorre às recomendações prescritas pelas tradições positivistas e racionalistas que sugerem a necessidade de imposição de critérios rigorosos de justificação na produção do conhecimento com o desenvolvimento regional. Em outras palavras, isso significa a imposição de um método que certifique e padronize a produção do conhecimento com o desenvolvimento regional. A segunda volta-se para as tradições historicista e sociológica e estabelece a necessidade de institucionalização do campo de pesquisa. E quanto maior o reconhecimento social das 
informações produzidas, menor a autonomia da área de pesquisa com relação aos interesses políticos e econômicos do contexto social. Tanto na primeira quanto na segunda estratégia, o que se ganha em profundidade se perde em amplitude.

Embora esses dois modelos contribuam de diversas formas para conceber e fundamentar uma estratégia de pensamento com o desenvolvimento regional, eles não são satisfatórios para integrar disciplinarmente a causalidade, a distinção e a reflexividade. Existem muitas formas de resolver a ambivalência entre a concepção estática que concebe a ciência como uma atividade intelectual racional, e a concepção dinâmica, que concebe a ciência como uma atividade social institucionalizada. A produção científica de ponta e os compromissos disciplinares não dependem somente da dinâmica interna da ciência, seja em termos metodológicos, seja em aspectos institucionais. Mais precisamente, produzir conhecimento em desenvolvimento regional de ponta e, ao mesmo tempo, fazer com que esse conhecimento tenha validade regional não depende somente do método e da comunidade científica. Como a pesquisa com o desenvolvimento regional é produzida individualmente com baixos custos, o controle político subverte o controle dominante.

Para estabelecermos uma plataforma epistemológica que permita avaliar as particularidades causal, analógica e reflexiva inerentes ao conhecimento produzido com o desenvolvimento regional, necessitamos estabelecer uma nova estratégia de validação desse conhecimento científico. Mais exatamente, precisamos ultrapassar a fronteira que opõe a estratégia que reforça a lógica interna e a estratégia que reforça o contexto externo. A complexidade do programa de pesquisa em desenvolvimento regional nos obriga a avançar uma estratégia de integração, ou uma síntese. Não basta somente estabelecer critérios cognitivos para criação de novas teorias pelos peritos, mas também mecanismos que permitam valorizar e atribuir respeitabilidade ao conhecimento prático dos leigos. Pode-se dizer que o desenvolvimento regional constitui um conhecimento guiado pelo ensaio e erro, porém o que permite ensaiar e errar não é a aplicação de um método, mas as condições do contexto social, ou seja, uma "cultura epistêmica hibrida".

Existem várias iniciativas de fundamentação dessa cultura epistêmica hibrida. Talvez as mais conhecidas digam respeito aos modelos de junção derivados das plataformas pluri, multi, inter e transdisciplinar de enfocar a realidade (MORIN, 1987). Essas iniciativas foram concebidas visando superar dois desafios relacionados a produção do conhecimento 
científico: 1) os efeitos perversos da especialização disciplinar; 2) o aumento da complexidade dos fenômenos. Por isso, essas plataformas apresentam estratégias de interação disciplinar em níveis de complexidade diferentes, que podem se referir tanto ao simples contato entre disciplinas, quanto a justaposição de conhecimento até a superação disciplinar. Nesse sentido, as bases teóricas e metodológicas de cada disciplina são compartilhadas, ou melhor, intercambiadas entre diversas disciplinas em um grau de complexidade crescente. O resultado desse processo é a estabilização de uma nova plataforma cognitiva da qual são extraídas novas descobertas de um modo novo (GODARD, 1997).

Os esforços mais bem sucedidos para pensar com o desenvolvimento regional foram alcançados mediante essa plataforma cognitiva. Nesse sentido, o desenvolvimento regional é definido como uma síntese disciplinar (BENKO, 1999), ou uma espécie de "metaponto de vista". Um cruzamento no qual se reúnem as contribuições desenvolvidas em diversas tradições disciplinares como, por exemplo, a economia, a geografia, a sociologia, a antropologia, entre outras. Isto pressupõe, claro, reunir e combinar os resultados produzidos através destas investigações relativas ao desenvolvimento e a região. Segundo essa linha de fundamentação, o pensamento com o desenvolvimento regional se encontraria num estágio interdisciplinar, com a economia e a geografia estabelecendo as principais contribuições teóricas e metodológicas para interpretação das relações entre desenvolvimento e região (MATTEDI; THEIS, 2002). Nesta plataforma cognitiva, o desenvolvimento regional assume uma característica "caleidoscópica" que varia segundo a contribuição disciplinar.

Contudo, esta solução caleidoscópica comporta pelo menos alguns aspectos operacionais inconvenientes. O primeiro diz respeito ao fato que não existe pluri, multi, inter e transdisciplinaridade sem disciplinaridade, o que indica que se o desenvolvimento regional for uma área interdisciplinar ele nunca interagirá com outra área interdisciplinar. O segundo aspecto implica em que a interação entre disciplinas sempre acontece porque a ciência é produzida socialmente, o que significa que uma nova disciplina surge sempre da combinação de duas ou mais disciplinas. O terceiro é que esta solução oferece uma imagem distorcida do universo disciplinar, um ambiente desprovido de controvérsias. Mas, principalmente, esta solução versa somente sobre uma dimensão interna relativa aos fatores metodológicos e não leva em consideração os aspectos institucionais relacionados a organização social da comunidade de pesquisadores em desenvolvimento regional. Nesse sentido, esta estratégia 
aplicada ao desenvolvimento regional parece constituir uma falsa solução para um falso problema.

As principais reservas com relação a adoção destas estratégias para configurar cientificamente a causalidade, a reflexividade e a distinção referem-se ao duplo fechamento da forma de pensar com o desenvolvimento regional. Esse fechamento é, ao mesmo tempo, metodológico com as outras formas de conhecimento e disciplinar com relação aos não especialistas. Por isso, as estratégias estática e dinâmica baseiam-se num mesmo procedimento, reivindicam uma diferenciação tanto por meio da imposição de um método quanto pela instituição de uma disciplina. Trata-se, portanto, de fechar o desenvolvimento regional aos conhecimentos e produtores leigos. Por isso que as estratégias pluri, multi, inter e transdisciplinares não são suficientes, pois abrem somente a parte cognitiva do círculo, mas deixam a questão institucional obstruída. Este acordo oculto da oposição ortodoxa entre método-instituição deforma a atividade científica, afinal só podemos exigir rigor e disciplina aonde acreditamos que não existe.

Para pensar com o desenvolvimento regional de forma científica precisamos superar o panóptico dualista método-instituição. A sociedade em geral e os elementos sociais não devem ser vistos como fatores perniciosos na produção do conhecimento científico (MATTEDI, 2006). A validade do conhecimento científico não surge da força metodológica do método científico e da integração da comunidade científica de neutralizar as influências do contexto social, como nos leva a crer a solução proposta pela oposição ortodoxa. Ao contrário, o caráter social e interessado do conhecimento científico não deve ser visto como um defeito, mas como uma parte constitutiva e decisiva da sua força explicativa. Por isso, quanto mais uma teoria científica consegue mobilizar interesses sociais, mais científica ela se torna. E por isso não existe a necessidade de restringir e fechar o conhecimento com o desenvolvimento regional aos interesses da própria da própria comunidade científica, como sugerem as soluções estáticas e dinâmicas.

Uma iniciativa mais recente e vigorosa diz respeito aos subsídios extraídos dos chamados Estudos Sociais da Ciência e da Tecnologia - ESCT (HESS, 1997). Os ESCT compreendem uma tradição surgida a partir de três eixos de crítica ao padrão de desenvolvimento cientifico e tecnológico do pós-guerra. O primeiro eixo diz respeito ao irrealismo dos parâmetros positivistas de certificação do conhecimento científico; o segundo se refere aos efeitos disfuncionais da descrição da comunidade científica 
efetuada pelo programa mertoniano; o terceiro compreende o processo linear de formulação e de implementação das políticas de ciência e tecnologia (JASANOFF; MARKELE; PETERSEN; PINCH, 1994; HACKER; AMSTERDAMSKA; LYNCH; WAJCMAN, 2007). Em termos metodológicos, compreende duas estratégias: 1) o exame dos impactos da ciência e tecnologia na sociedade; 2) os impactos da sociedade na ciência e na tecnologia (MATTEDI; GRISOTTI; SPIESS; BENNERTZ, 2009). Isso significa que a pesquisa científica em desenvolvimento regional constitui uma atividade social.

Os resultados alcançados por meio deste tipo de abordagem nos últimos anos revelam que o conhecimento científico é um fenômeno social. Portanto, a exatidão, a objetividade e a utilidade científicas não são resultado da aplicação de critérios técnicos ou da integração da comunidade científica, mas apenas contingências sociais. Por isso a ciência em geral ea produção da pesquisa em particular somente se tornam possíveis quando os pesquisadores conseguem criar um contexto social no qual o conhecimento científico pode se estabilizar e reproduzir. Mais precisamente, isso significa que se quisermos estabilizar uma forma de pesquisa das relações entre desenvolvimento e região com o desenvolvimento regional precisamos considerar os vínculos existentes entre esta atividade científica e o contexto social. Isto significa que para o conhecimento com o desenvolvimento regional ser produzido é preciso existir condições sociais para que indivíduos e grupos possam criar, organizar, transmitir e difundir esta espécie de conhecimento nas próprias regiões.

Trata-se de relacionar a produção do conhecimento científico ao contexto social. O progressivo reconhecimento de que a ciência é moldada por circunstâncias contingentes locais vem modificando a percepção do processo de produção do conhecimento científico. Por um lado, a ênfase recai na análise de como os interesses sociais, políticos e disciplinares configuram o conteúdo do conhecimento (BARNES; BLOOR; COLLINS, 1996). Mas, também, essa atividade pode ser descrita como um circuito no qual o contexto social é resultado da atividade científica (LATOUR, 2000; CALON, 1995). As diferenças aqui residem nas formas de instrumentalização do contexto que oscila para o entendimento da atividade científica. Nosso desafio, portanto, consiste em substituir a forma de conceber o desenvolvimento regional na sociedade pela perspectiva que se preocupa com o elemento social do conhecimento com o desenvolvimento regional. Pensar com o desenvolvimento regional pressupõe uma teoria política do conhecimento. 
O modelo circulatório do conhecimento foi desenvolvido por Callon; Courtial; Penan (1995) e Latour (1995), e é conhecido como cinco horizontes da pesquisa científica. Este esquema distingue inicialmente cinco categorias de tarefas que constituem quatro horizontes de atuação profissional dos cientistas. A primeira refere-se a "mobilização do mundo", que diz respeito ao processo de produção de dados por meio da pesquisa com o desenvolvimento; a segunda diz respeito ao processo de "autonomização", que constitui formar pessoas capazes de entender e aplicar o conhecimento produzido com o desenvolvimento regional; a terceira tarefa compreende a criação de "alianças estratégicas", formar parcerias com o Estado e o setor produtivo visando mobilizar recursos para a realização de pesquisa; a quarta volta-se para "relações públicas", estabelecer uma imagem pública positiva do desenvolvimento regional junto a sociedade; somente quando estas atividades são realizadas temos a quinta tarefa: as teorias com o desenvolvimento regional.

Essa forma de conceber e fundamentar o conhecimento com o desenvolvimento regional permite o conhecimento com o desenvolvimento regional se justificar regionalmente pelo desenvolvimento. Como vimos, os critérios de cientificidade extraídos das tradições estática ou dinâmica baseiam-se no fechamento disciplinar e, portanto, subtraem a possibilidade de usarmos a dinâmica regional do desenvolvimento no conhecimento com o desenvolvimento regional. Isso significa, por um lado, a adoção do método científico e, por outro, o reconhecimento dos parâmetros de certificação da comunidade científica. Ao produzirmos conhecimento com o desenvolvimento regional não devemos tentar neutralizar por meio da metodologia e da reputação os efeitos que o contexto social exerce sobre o conhecimento. Resumindo, isso quer dizer simplesmente que o conhecimento com o desenvolvimento regional deve estabelecer um autoentendimento próprio de sua cientificidade, considerando as condições regionais de desenvolvimento.

Como dissemos, antes de estabelecermos uma teoria do desenvolvimento regional necessitamos de uma teoria do conhecimento com o desenvolvimento regional. Isto significa que o desenvolvimento regional é um conhecimento de segunda ordem e, mais precisamente, deve ter validade regional. Trata-se assim de substituir a perspectiva segundo a qual o conhecimento sobre desenvolvimento regional deve adotar regras estritas de produção do conhecimento e organização disciplinar. Vimos que não somente estas regras são irrealistas, mas também perniciosas, pois a validade e credibilidade de um enunciado científico depende de 
quem enuncia, das circunstâncias, do estilo discursivo e das motivações. Por isso, em nosso ponto de vista, esse processo envolve o reconhecimento de dois pressupostos fundamentais: 1) cada região tem uma forma específica de produção e apropriação do conhecimento sobre si mesma; 2) existe um grau de indeterminação considerável no conhecimento porque as relações entre desenvolvimento e região são instáveis.

O exame do processo de formação da área de conhecimento do desenvolvimento regional se caracteriza por uma assimetria entre volume crescente de informações e a ausência de acordo sobre como isso deve ser feito. Considerando os pressupostos cognitivos e institucionais, percebe-se que o conhecimento com o desenvolvimento regional não pode permanecer separado do contexto no qual desenvolvimento e região se relacionam. O problemático do pensamento com o desenvolvimento regional é que o regional do desenvolvimento não pode ser fechado metodologicamente e institucionalmente porque o desenvolvimento regional não é separado do conhecimento que se produz dele. Por isso, a consideração das précondições epistemológicas indicam que conhecimento produzido com o desenvolvimento regional possui três características principais:

1) causalidade: as relações entre desenvolvimento e região são contextuais; 2) distinção: as relações entre desenvolvimento e região só podem ser avaliada analogicamente; 3) reflexivo: o conhecimento com o desenvolvimento possui uma validade regional.

As particularidades causais, analógicas e reflexivas do conhecimento com o desenvolvimento regional pressupõem a superação das formas cientificistas de conceber a ciência, mas também a forma cientificista de pensar a ciência. Isso envolve o reconhecimento de que o conhecimento com o desenvolvimento regional é ativado por processos sociais contextualizados regionalmente pelo desenvolvimento. Deste ponto de vista, sabemos que antes de podermos determinar o que é o desenvolvimento regional, necessitamos estabelecer como as condições regionais do desenvolvimento tornam o conhecimento com o desenvolvimento regional possível. Ou seja, para uma região pensar a si mesma por meio do desenvolvimento regional, é preciso que existam algumas condições sociais para formulação e resolução da questão sobre as relações entre desenvolvimento e região. Se, no primeiro nível, consiste em determinar o que é o desenvolvimento regional regionalmente, no segundo, trata-se de determinar como podemos estudar regionalmente o desenvolvimento regional. 


\section{A causação contextual do conhecimento com o desenvolvimento regional}

As teorias do desenvolvimento regional se ocupam com uma questão simples: quais são relações que se estabelecem entre desenvolvimento $e$ região? Mais precisamente, que classes de influências podem ser observadas regularmente entre desenvolvimento e região. Sabemos que a correlação entre desenvolvimento e região não equivale necessariamente a uma causação, pois a correlação entre duas variáveis não implica uma causalidade. Uma relação de causa-efeito existe somente quando uma mudança em uma variável (independente) induz a mudança em outra (dependente). Isto significa que quando um primeiro conjunto de condições específicas é encontrado, haverá também um segundo conjunto de condições nas quais o primeiro origina o segundo. Parece, então, que as teorias do desenvolvimento regional deveriam descrever um contexto no qual certos valores de um fenômeno $\mathrm{X}$ correspondam sempre a certos valores do fenômeno Y. Isso significa que variações observadas no fenômeno Y são produzidas pela variação dos valores do fenômeno X.

Mas no estudo do desenvolvimento regional nem sempre é possível fechar o campo de análise. Ao contrário, é sempre possível alargar um sistema de relações entre variáveis e encontrar influências que ultrapassem ou transcendam a relação entre X-Y. A decisão de inclusão ou exclusão dos fatores em jogo é sempre uma decisão de ordem teórica e, portanto, nunca teremos garantias de que todas as variáveis relevantes estão incluídas na explicação e serão efetivamente controladas.

É nestes limites que se inscreve a verificação da co-variação, a direção causal e as variáveis exógenas da teoria do desenvolvimento regional. Isso significa que nem sempre é possível determinar com exatidão quais variáveis são importantes na ocorrência do efeito, pois no limite precisamos diferenciar o que antecede do que sucede. Ou seja, no estudo do desenvolvimento regional nem sempre podemos determinar com exatidão quando a região e o desenvolvimento são causa ou quando são consequência. Isso constitui o desafio teórico da explicação da causação contextual.

Nesse sentido, considerando a causalidade entre desenvolvimento e região, é possível estabelecer quatro estratégias de abordagem das relações de influência:

a) HIPÓTESE 1 - O desenvolvimento como um agente produtor da região: nesse tipo de abordagem o processo de desenvolvimento 
é considerado uma variável independente e a região uma variável dependente;

b) HIPÓTESE 2 - A região como um agente produtor do desenvolvimento: nesse tipo de abordagem a região é considerada uma variável independente que afeta o desenvolvimento, considerado como uma variável dependente;

c) HIPÓTESE 3 - Existe um processo de causação circular entre desenvolvimento e região: existe um processo de causação circular em que o desenvolvimento influencia a região e a região influencia o desenvolvimento;

d) HIPÓTESE 4 - Não existe relação causal entre desenvolvimento e região: nesse tipo de abordagem a relação de causalidade entre desenvolvimento e região se deve a uma ou mais variáveis espúrias.

Mais precisamente, a causação contextual compreende uma pluralidade de condições determinantes cuja verificação simultânea confere um grau de probabilidade à ocorrência de determinados resultados. Quando é possível, multiplicam-se as observações efetuadas em situações semelhantes, mostrando que a ocorrência de $\mathrm{X}$ favorece ou torna frequente a ocorrência de Y. Afinal, no estudo das relações entre desenvolvimento e região existe um esquema de interação combinando variáveis, ou grupos de variáveis independentes, que agem sobre uma variável ou variáveis dependentes. Trata-se de blocos de variáveis independentes integrando diversos conjuntos de fatores que afetam diferencialmente as variáveis dependentes. Essa forma de considerar a relação entre desenvolvimento e região baseia-se no reconhecimento de que para identificar uma relação causal entre desenvolvimento e região necessitamos analisar o contexto causal em que o desenvolvimento e a região se inserem, ou seja, o contexto da rede de relações entre variáveis.

Embora a lógica da inferência causal seja idêntica a outras situações, os procedimentos de análise do desenvolvimento regional são indiscutivelmente mais complexos e, portanto, menos formalizáveis. Nesse sentido, o desafio teórico da investigação da causação contextual consiste, portanto, em explicar a rede de relações subjacentes as variáveis independentes e dependentes e, sobretudo, em determinar a intensidade das relações de influências mútuas que ligam o desenvolvimento à região. Isso significa que a forma como se interpreta o intercâmbio entre desenvolvimento e região constitui um contexto formado pela interação de um grande número de variáveis. Além disso, a compreensão das regularidades 
envolve a construção de modelos teóricos que permitam entender os contextos de interação dessas variáveis. Esses modelos constituem instrumentos descritivos formados por um sistema de coordenadas conceituais que são aplicados para interpretar fenômenos e que vão sendo progressivamente ajustados. E servem para traduzir o contexto causal e identificar e medir a relação entre desenvolvimento e região.

Para compreendermos a causação contextual entre as variáveis desenvolvimento e região necessitamos desenvolver um modelo teórico. Porém, a construção de modelos teóricos constitui uma tarefa complexa na medida em que as relações entre essas variáveis não são lineares. Assim, as influências entre desenvolvimento e região variam à medida que o contexto muda e, consequentemente, as próprias teorias variam com a mudança do contexto. Desta forma, no sentido amplo, ou seja, o das interpretações das relações causais entre desenvolvimento e região, a teoria pode constituir uma conceitualização de termos que são empregados para a explanação do fenômeno empírico ad-hoc; no sentido restrito, a teoria exprime um sistema formal lógico que consiste num conjunto de conceitos inter-relacionados que permitem testar uma hipótese, visando assim descrição, explanação e predição de fenômenos. Trata-se, portanto, de construir um modelo analítico no sentido restrito para interpretar a lógica da direção causal entre desenvolvimento e região em cada contexto.

Existem duas formas básicas de conceber instrumentos descritivos para explicação da causação contextual entre desenvolvimento e região. $\mathrm{O}$ modelo dedutivo popperiano (teoria-antes-da-pesquisa): neste caso, primeiro formula-se um modelo teórico derivado do conhecimento existente; depois seleciona-se uma proposição ou hipótese derivada deste modelo; estabelece-se uma estratégia de pesquisa para testar a proposição; e se a proposição não for rejeitada pelo teste, aplica-se a teoria para explicar a casos particulares. O modelo indutivo mertoniano (pesquisa -antes-da-teoria): este tipo de abordagem inicia com a investigação de um fenômeno e se delineiam os seus atributos; em seguida, medem-se esses atributos numa variedade de situações; passa-se para a análise dos dados para determinar os padrões de variação; e, por último, constroem-se as teorias. Aqui a diferença entre os dois tipos de concepções de teorização diz respeito a possibilidade de isolar uma variável independente de forma precisa para explicar as relações entre desenvolvimento e região.

Um desafio adicional é que esse padrão de teorização se disseminou no interior das disciplinas que se ocupam da pesquisa do desenvolvimento 
e da região. Por exemplo, teremos uma abordagem econômica da relação entre desenvolvimento e região através da teoria-antes-da-pesquisa, ao mesmo tempo em que teremos uma interpretação por meio da pesquisa-antes-da-teoria; teremos uma abordagem geográfica no qual a relação entre desenvolvimento e região será operacionalizada através da teoria -antes-da-pesquisa e, paralelamente, outra abordagem geográfica no qual teremos pesquisa-antes-da-teoria, e assim por diante em todas as disciplinas que estudam o desenvolvimento regional. Com a produção e a reprodução destes modelos de análise, e o crescente contato interdisciplinar, torna-se cada vez mais complexo entender e sistematizar as estratégias de interpretação teóricas da relação entre desenvolvimento e região. Por isso, nem sempre é fácil reconstruir as continuidades e descontinuidades entre as diversas estratégias de abordagem.

Portanto, existem na paisagem esboçada pela economia, geografia, sociologia, antropologia e ciência política muitas controvérsias sobre os sentidos de interpretação teórica das relações entre desenvolvimento e região. Afinal, não é fácil isolar o desenvolvimento, a região, e estabelecer as ligações sobre a relação da territorialidade do desenvolvimento. E embora todos os pesquisadores do desenvolvimento regional estejam, direta ou indiretamente, interessados em compreender como o processo de desenvolvimento modifica a região e como a região afeta o desenvolvimento, existem ainda muitas controvérsias sobre a adequação de como isso deve ser feito. Assim, como as relações entre desenvolvimento e região são múltiplas, as combinações podem se revelar, muitas vezes, fenômenos distintos e até antagônicos. Mais precisamente, existe um processo de subdeterminação teórica na medida em que existe mais de uma teoria que explica o mesmo conjunto de relações, gerando inconsistências entre as teorias.

Para descrever a causação contextual parte-se sempre da relação entre o domínio e o que acontece nele. A dificuldade do estudo desta relação situa-se na existência de muitas combinações e, portanto, de respostas possíveis. Por exemplo, enquanto alguns teóricos consideram que a relação Desenvolvimento-Região existe independentemente de como esses fenômenos são experienciados socialmente de forma realista como entidades fixas, outros pesquisadores baseiam-se numa perspectiva de que a relação Desenvolvimento-Região resulta de um processo de mediação simbólica entre atores de forma construtivista. Assim, tratase de considerar como as variáveis desenvolvimento e região são transcodificadas operacionalmente na pesquisa. Por um lado, a relação entre 
desenvolvimento e região é traduzida pela forma de apropriação e, por outro, por forma de identificação. Por isso, para sistematizar a exposição, o primeiro conjunto de teorias será denominado "teorias do contêiner", enquanto que o segundo, "teorias do envelope".

As teorias do contêiner concebem a relação entre DesenvolvimentoRegião como uma espécie de processo que ocorre num recipiente. Neste tipo de teoria o procedimento de abordagem das relações causais entre desenvolvimento e região é bastante conhecido. Primeiro, isolam-se os domínios, acondicionam-se os fenômenos e se estabelecem relações entre eles como, por exemplo, recursos, populações, equipamentos, organizações, produção etc.; em seguida, procura-se observar como operam no assentamento e, consequentemente, busca-se determinar as relações de influência entre os fenômenos; na etapa seguinte, aplicam-se modelos teóricos que tentam explicar como os fenômenos interagem e permanecem juntos; o próximo procedimento consiste em avançar uma generalização efetuando uma comparação entre as semelhanças e diferenças entre os diversos contêineres; por último, com o suporte de uma base normativa sobre o que é desejável que aconteça nos contêineres se estabelece uma escala de declínio ou progresso da dinâmica do contêiner.

Comumente designam-se estas relações em função de suas propriedades materiais, combinando analiticamente características do mundo material e artefatos humanos. Por isso, neste tipo de análise, a região é concebida como uma realidade previamente existente e, frequentemente, vinculada a dimensão física do espaço aonde operariam certos fenômenos naturais, econômicos, sociais, culturais etc. Neste tipo de teoria podemos diferenciar duas variantes teóricas principais de explicação das relações causais entre desenvolvimento e região. Por um lado, existe um conjunto de abordagens que se ocupam das características do próprio recipiente; e, por outro, as abordagens que procuram observar como as relações entre os componentes formatam e configuram o recipiente. Considerando estes fatores, podemos diferenciar duas variantes das teorias: as que se ocupam com a distinção entre formas dos contêineres, e as que se ocupam com as diferenças entre as suas funções.

A primeira variante deste tipo de abordagem enfatiza as formas e sustenta que a relação entre desenvolvimento e região pode ser abordada considerando-se os recursos naturais, os ecossistemas e outros tipos de delimitações físicas. Aqui, o desenvolvimento constitui a mediação estabelecida entre o grupo social e os recursos existentes no meio. Nesse sentido, a relação entre desenvolvimento e região é considerada a partir dos 
vínculos de interdependência entre recursos naturais e as populações humanas. O desenvolvimento constitui o mecanismo por meio do qual os seres humanos e agrupamentos sociais relacionam-se com os recursos naturais que se estabelecem numa estrutura espacial distinta de outras regiões e de outras unidades territoriais maiores ou menores. As variações regionais são essencialmente produzidas pelos diferentes modos de transformar socialmente a natureza. A natureza influencia os modos de vida e o desenvolvimento da sociedade e, consequentemente, as diferenças e semelhanças entre as regiões (GOMES, 2012, p. 55).

A preocupação da investigação geográfica com os processos regionais não é nova (LENCIONI, 1999). Segundo o ponto de vista "determinista", o desenvolvimento de uma região relaciona-se aos constrangimentos da combinação de elementos do meio natural, ou seja, a disponibilidade dos recursos naturais e sua distribuição qualitativa e quantitativa no território. Com a noção de região natural, Friedrich Ratzel indicou que o grupo social que vive e produz sobre um território é também produto do território. Já do ponto de vista "possibilista" as regiões são o resultado das superposições históricas e dos dados naturais, destacando a importância das cidades, das indústrias e das questões econômicas etc. Para Vidal de la Blache, as relações entre sociedade e natureza caracterizam-se pela interferência do homem no espaço geográfico, pois considera o homem como um ser ativo atuando no ambiente físico, como mostra a noção de região geográfica. Trata-se de descobrir que parte do desenvolvimento regional está relacionado a natureza ou ao humano (CLAVAL, 1999).

Esses impasses analíticos da Geografia Tradicional, na abordagem da relação entre desenvolvimento e região por meio da noção de paisagem, receberam duas soluções epistemologicamente opostas. Por um lado, Richard Hartshorn formulou uma concepção dessa relação concebida ideograficamente como um caso único ou singular, enfatizando o caráter subjetivo do processo de diferenciação territorial. Segundo o autor, uma região constitui uma área de localização específica, delimitada mediante a adoção de critérios conceituais estabelecidos pelo pesquisador como uma "diferenciação de área" (HARTSHORN, 1969, p. 17). Por outro, destaca-se a resposta de Freed F. Schaefer que critica as dificuldades de operacionalização metodológica e assinala a necessidade da geografia estabelecer leis gerais da localização em termos nomotéticos. Esaas leis devem ser utilizadas para diferenciar porções distintas da terra chamada de "classes de área" e que contém combinação especial de tipos ou categorias de fenômenos (SCHAEFER, 1977). 
Essa controvérsia teórica sobre o sentido da interpretação do jogo de determinações recíprocas entre região e paisagem redefiniu as bases analíticas da relação entre desenvolvimento e região. O estudo regional do desenvolvimento passou a ser subordinado à solução dos impasses teórico-metodológicos da relação entre fenômenos físicos e humanos, visando determinar as individualidades regionais. Com a progressiva incorporação dos pressupostos positivistas e das técnicas quantitativas, as relações entre desenvolvimento e região foram reduzidas ao que podia ser observado empiricamente e traduzido em linguagem matemática. A concepção e aplicação de modelos matemáticos deslocou o estudo do desenvolvimento regional para a busca da demonstralidade de teorias e, principalmente, para o estabelecimento de previsões e projeções dos padrões regionais de desenvolvimento. Como consequência, se forma e dissemina uma nova forma de relacionar desenvolvimento e região conhecida como Nova Geografia (BEZZI, 2004).

Na crítica desenvolvida pela Nova Geografia a Geografia Tradicional subsumem dois fenômenos que se encontram relacionados. Por um lado, as transformações geopolíticas e a constituição de uma nova ordem mundial provocadas pelo final da Segunda Guerra Mundial; por outro, a substituição da plataforma indutivista pela plataforma dedutivista provocada pela repercussão dos trabalhos de K. R. Popper. O objetivo dessa viragem era dotar a geografia de instrumentos conceituais para a generalização das explicações espaciais e, desta forma, possibilitar uma compreensão mais geral da variação dos arranjos espaciais. Com esta transformação teórica e metodológica quantitativa posta em operação a partir da década de cinquenta, a explicação do desenvolvimento regional volta-se novamente para uma abordagem naturalista. Esta abordagem reduz a relação entre desenvolvimento e região a uma dimensão classificatória, estabelecida por técnicas estatísticas e por uma linguagem matemática, afastada da observação de campo (CORREA, 1986).

Considerada como uma classe de área, a região assume uma posição relativa em função das outras regiões. Classes de áreas são, portanto, abstrações analíticas que são estabelecidas pela caracterização dos indivíduos em relação às classes de área em termos estatísticos. Assim, uma região se converte num produto da causalidade da relação entre indivíduos e classes de áreas, estabelecida por meio da análise geométrica dos dados espaciais. Mais precisamente, a região se converte numa entidade abstrata definida pela unidade interna e diversidade externa. Com a adoção da abordagem sistêmica, proposta por Ludwig von Bertalanfly, o espaço 
passou a ser considerado pelos padrões articulados que os fenômenos apresentam (CHRISTOFOLETTI, 1982). Nesse sentido, a região deixou de ser um fenômeno único e passou a ser considerada como o estado interno do sistema que se modifica segundo as condições do ambiente, ou seja, o desenvolvimento regional constitui uma estrutura caracterizada pelas propriedades e pelas relações entre os seus elementos.

Quando as diferenças de concentração espacial e produtiva começaram a ser consideradas, surgem as primeiras interrogações da vertente funcional da relação entre desenvolvimento e região. O esforço se concentra na tentativa de compreender a lógica do processo de tomada de decisão empresarial nos investimentos produtivos. Mais precisamente, como os custos operacionais de transporte, essencialmente os de matérias primas e de comercialização, são considerados pelos produtores no desenvolvimento de uma atividade. Essa estratégia de interpretação do processo de localização das atividades produtivas pode ser interpretada como uma resposta alternativa a insuficiência das teorias econômicas clássicas, diante das especificidades das condições de transporte e de geração de energia da Alemanha no início do século XIX. A economia clássica ignorou os problemas locacionais da análise do processo econômico, tendo em vista os obstáculos que eles colocavam a aplicação da abordagem do aparato teórico marginalista de concorrência perfeita.

Assim, a preocupação com a relação entre desenvolvimento e região surge com a necessidade de compreender como as atividades agrícolas se distribuem ao redor de um centro urbano. Mais precisamente, o que produzir em determinado lugar? Johann Heinrich von Thünen (1780-1850) percebeu que existe uma relação entre o valor da terra e sua localização. Quanto mais próxima de um mercado consumidor central, mais elevado o valor da terra - ele definiu este fenômeno como "renda de localização". As culturas que ocupam anéis mais próximos geravam mais lucro, o que indica que o preço é determinado pelo local de produção. Assinala que para cada produto haverá uma distância limite a partir da qual a produção deixa de ser rentável, o que o leva a concluir que a localização de cada cultura obedece a lógica da redução dos custos de transporte (BENKO, 1999). Isto significa que quanto mais afastada da cidade, menor será o custo do transporte necessário. Esta investigação pioneira sobre as relações existentes entre a produção e a localização foi aprofundada no início do século XX.

Esta segunda vertente é também chamada de "teoria da localização" ou "escola alemã". Para Alfred Weber (1868-1958), essa vertente desloca 
o foco da localização para a industrialização, indicando que todo empreendimento industrial encontra-se no centro de uma rede de fluxos de entradas (matérias-primas, mão de obra, energia etc.) e saídas (produto para ser vendido), formando um Triangulo Locacional (SOUZA, 2009). Com base nestes recursos teóricos, Walter Christaller (1893-1969) destaca a distribuição espacial das cidades, procurando entender os fatores que determinam o número, tamanho e distribuição das cidades. Os resultados alcançados a partir desses arranjos espaciais das cidades ficaram conhecidos como Teoria dos Lugares Centrais. Mas será principalmente com as descobertas de Auguste Lösch (1906-1945) que surge a preocupação com a localização, região e comércio inter-regional (BENKO, 1999). Ele argumentará que as empresas se estabelecem onde a população estiver mais concentrada, formando uma hierarquia de áreas de mercado e centros urbanos e, assim, as regiões econômicas.

A preocupação com a relação entre desenvolvimento e região recebe um novo impulso decisivo com os estudos elaborados por Walter Isard, que desenvolve instrumentos teóricos fundamentais para compreensão das relações entre desenvolvimento e região. Para Isard, o sentido da análise do desenvolvimento regional consiste em determinar as regularidades nas variações de custos e preços no espaço (ISARD, 2003). As regularidades dos custos de transporte são uma função da distância e estabelecem um padrão de distribuição espacial da indústria, dos centros de consumo e da produção de matérias-primas. Assim, os núcleos urbanos estariam em um processo contínuo de ajustamento, através de forças centrípetas, pela economia de aglomeração, e forças centrífugas de deseconomias externas. Esses deslocamentos de populações e das atividades econômicas são determinados pelos meios de transporte, a existência de recursos naturais e a distribuição da população nas áreas periféricas.

Embora a teoria dos lugares centrais venha servindo de inspiração para o desenvolvimento de uma série de abordagens recentes, a compressão da relação entre desenvolvimento e região constitui o resultado de uma “mão invisível", como foi proposto na teoria dos lugares centrais. Como podemos observar, por um lado, desenvolvimento corresponde as atividades produtivas, e as atividades produtivas ao processo de tomada de decisão empresarial; por outro, a região equivale a local e o local é reduzido ao espaço físico. Nesse sentido, a mediação entre desenvolvimento e região se estabelece pela equivalência entre produção e localização através das diferenças e semelhanças que se estabelecem em termos de custo e benefício da distância no processo. Dessa forma, a dimensão regional 
do desenvolvimento é abstraída e tratada de forma pré-estabelecida e dependente do processo de desenvolvimento. A relação entre desenvolvimento e região ocorre pelas características econômicas do processo de ocupação, organização e exploração.

Uma segunda variante da preocupação com as funções dos contêineres foi sendo produzida e reproduzida dentro da tradição econômica, com base, principalmente, na economia urbana e na economia regional. Nesta estratégia, a relação entre desenvolvimento e região é concebida por meio da consideração de como os elementos do recipiente crescem, porque alguns recipientes são mais dinâmicos que outros e como em função disso os recipientes se diferenciam, como indica o Coeficiente de Localização de Homer Hoyt. Ou, dentro do jargão econômico, quais as relações que se estabelecem entre a concentração econômica e as descontinuidades espaciais. Em outras palavras, as vantagens e desvantagens relacionadas a concentração espacial de atividades agrícola, industrial ou de serviço, considerando tanto os efeitos desse processo em escala micro, quanto o efeito conjunto em escala macro. A resposta revelou-se um tanto tautológica, na medida em que a aglomeração local de produtores produz vantagens e essas vantagens aglomeram os produtores localmente.

Um primeiro enfoque desta segunda variante concentrou-se nos efeitos da organização espacial da produção sobre a relação entre desenvolvimento e região, considerando como os agentes econômicos selecionam a localização em escala macroeconômica. As contribuições mais conhecidas foram formuladas na década de cinquenta na análise da localização industrial através das contribuições de Alfred Marshall. Para Marshall, o desenvolvimento de região depende das relações que se estabelecem entre as economias e as deseconomias externas. Mais precisamente, as vantagens e desvantagens produtivas relacionadas com a concentração da atividade econômica, como disponibilidade de matéria-prima, acesso a mão de obra, mercados, transporte etc. A concentração das empresas facilita a difusão do conhecimento técnico e a concentração da mão de obra atrai atividades interligadas. Isso explica porque as pessoas e as atividades econômicas são induzidas a emigrar para as periferias urbanas ou distritos industriais, gerando aglomerações produtivas.

Depois da Guerra Mundial, a relação entre desenvolvimento e região passa ser considerada a partir da questão da variação e difusão do crescimento das regiões. Entre as principais teorias destacam-se os Polos de Crescimento de Perroux, da Causação Circular Cumulativa de Myrdal e dos Efeitos de Encadeamentos para Frente e para Trás de Hirschman. 
Essas teorias compartilham o interesse pelas interdependências setoriais como fator de localização das firmas de uma perspectiva macroeconômica, e destacando a papel do Estado. Mais recentemente, é possível isolar uma nova tendência, que considera as externalidades dinâmicas de tipo marshallianas, examinando o desenvolvimento regional como ajustamento estrutural de internos e externos à região. Nesta perspectiva, consideram-se aspectos como o mercado de trabalho, a oferta de insumos especializados e o intercâmbio tecnológico, como ilustram os trabalhos de Krugman. Com o passar do tempo, passaram a ser considerados também aspectos institucionais dos agentes de coordenação na atuação dos atores locais na organização do desenvolvimento regional.

Os pesquisadores da variante funcional acreditam que, à medida que as atividades dentro dos recipientes crescem, os recipientes - ou seja, as regiões - também crescem. Trata-se de entender os desequilíbrios gerados pelo processo de produção capitalista do Pós-Guerra, principalmente nos países em desenvolvimento (PEET; HARTWICK, 2009). Nesses países, o desenvolvimento é desigual, porque setores modernos se desenvolvem paralelamente aos setores tradicionais, provocando desequilíbrios regionais. Temos aqui, portanto, três formas de considerar o desenvolvimento regional: 1) a relação entre desenvolvimento e região é mediada pela atuação do mercado; 2) a relação entre desenvolvimento e região é mediada pela atuação governamental; 3) a relação entre o desenvolvimento e a região é mediada pela interação entre mercado, Estado e agentes. Apesar da questão do desenvolvimento regional estar presente, estas abordagens não a consideram. Além disso, elas compartilham a crença do progresso ilimitado e da modernização.

Como vimos, as teorias do contêiner concebem a região como uma espécie de receptáculo que recebe o desenvolvimento. Em sua grande maioria, constituem o resultado inevitável do progressivo encontro - e até mesmo convergência - entre a abordagem geográfica da economia e a abordagem econômica do espaço. Esse contato deu origem a uma verdadeira cascata de pesquisas, estudos e publicações que institucionalizou uma abordagem vigorosa do desenvolvimento regional. Porém, mesmo considerando a grande diversidade de domínios cobertos pela teoria do contêiner, destacam-se três núcleos principais: a localização das atividades produtivas, a organização do espaço e as interações entre os elementos. Apesar da aparente diferença, neste tipo de abordagem as relações entre desenvolvimento e região são analisadas em termos de custo-benefício que levam as pessoas e as atividades econômicas a se concentrarem 
ou dispersarem em determinados lugares. Assim, na maior parte dos casos, o desenvolvimento é reduzido à dimensão econômica e a região ao espaço físico.

Mas é claro que se observarmos o recipiente e a disposição e a interação dos elementos em seu interior, deixaremos na parte de fora um conjunto de fatores que também operam no contexto de causação da relação entre desenvolvimento e região. A abordagem do envelope caracteriza-se por considerar as posições que o desenvolvimento regional assume e possibilita no contexto social. Assim, deste ponto de vista, a dimensão regional do desenvolvimento apresenta uma complexidade e variação muito mais ampla que as abordagens do contêiner permitem perceber. Isto significa que, embora a relação entre desenvolvimento e regional pareça preceder ao ponto de vista que se tem desta relação, alguns pesquisadores compartilham a suposição construtivista segundo a qual é o ponto de vista que estabelece o nexo de relações entre desenvolvimento e região. Trata-se, portanto, de considerar a relação entre desenvolvimento e região como um fenômeno consensual ou conflitual.

Por isso, a questão que inicialmente interessava apenas aos economistas e aos geógrafos passou progressivamente a ser investigada também por sociólogos, cientistas políticos, antropólogos e outros pesquisadores das disciplinas das ciências sociais. Se no início o interesse no desenvolvimento regional decorria do reconhecimento de que os processos que impulsionam a relação entre desenvolvimento e região eram fundamentalmente de ordem econômica, hoje a atenção recai em aspectos tão diversos como, por exemplo, a sustentabilidade ambiental, a justiça social, a identidade regional etc. Pode-se dizer, assim, que o que é comum as teorias do envelope é o reconhecimento que o desenvolvimento regional constitui a expressão de uma ordem social. Assim, dependendo da abordagem considerada, a ênfase pode recair sobre um ou outro aspecto do desenvolvimento, convertendo a região em variável não fixa, mas dinâmica. Nesse sentido, a maior parte das controvérsias decorre da estratégia e o grau de autonomia conferido ao contexto social para descrever o desenvolvimento regional: ampla como representações sociais, restrita como conflitos sociais.

A versão ampla das teorias do envelope do desenvolvimento regional se relaciona aos resultados alcançados pela consideração dos fenômenos culturais. Baseia-se numa escala macro de corte fenomenológico das representações espaciais desenvolvidas a partir dos trabalhos realizados por Carl Ortwin Sauer (1889-1975), conhecidos como Escola de Berkeley 
(BUTTIMER, 1982). Nessa espécie de "geografia da percepção" (HOLZER, 2010), as paisagens estavam ligadas ao seu passado histórico, de modo que o presente se tornava inteligível somente mediante a compreensão das intencionalidades do homem na interação com o mundo, como o agente modelador da paisagem cultural (MATHEWSON, SEEMANN, 2008). A diferenciação das áreas constitui uma unidade chamada de paisagem cultural, por meio da qual as comunidades representam as relações que estabelecem na interação com o meio e com outras comunidades. Portanto, a relação causal entre desenvolvimento e região é produto de sequências históricas que vão se influenciando e se interpondo mutuamente e, desta forma, o desenvolvimento regional reflete e exprime a paisagem cultural.

A partir da década de oitenta, forma-se um novo padrão de abordagem em escala micro conhecido como Nova Geografia Cultural. Esta abordagem está associada tanto ao "cultural turn" provocado pela incorporação das análises hermenêuticas e semióticas da dimensão cultural dos fenômenos espaciais, quanto pela dimensão espacial dos fenômenos culturais. Este processo não envolve somente fatores físicos da paisagem, mas outros fatores como a língua, a religião, a etnicidade, a culinária etc., formando regiões culturais híbridas. Portanto, uma região constitui o produto da percepção espacial dos habitantes de um lugar, mas essas representações não são um processo de identificação cultural homogêneo e uniforme. Esta característica indica que as regiões não são entidades fixas, mas construções que se formam e transformam constantemente como meio e produto simultaneamente (CLAVAL, 1999). Nesse sentido, o desenvolvimento regional pode ser visto como uma criação social contingente dos agrupamentos humanos.

A variação restrita das teorias do envelope enfoca o desenvolvimento regional como um processo de disputa e conflito. A abordagem crítica reinterpreta os agentes da organização espacial por meio da teoria marxista (PEET, 1982). Procura mostrar como as contradições do modo capitalista de produção se exprimem no espaço: a expressão espacial do capitalismo. Do ponto de vista materialista histórico, o desenvolvimento regional não é neutro, mas o resultado da dialética entre o processo social e as formas espaciais. Nesse sentido, o desenvolvimento regional se converte na resposta local da rede de acumulação do capital (forças produtivas), da reprodução da força de trabalho (relações de produção) e dos processos ideológicos. Assim, a atenção do desenvolvimento regional se volta para a questão da diferença das condições de acumulação estabelecidas pela articulação dos modos de produção em sua dimensão espacial, 
que altera a forma e o ritmo de desenvolvimento gerando a diferenciação regional do desenvolvimento (LEFEBVRE, 1974).

A abordagem crítica procura entender como o capitalismo produz regiões desigualmente desenvolvidas. A desigualdade relaciona-se a articulação do modo capitalista de produção com os outros modos de produção que estruturam o espaço entre regiões dominantes e dominadas. $\mathrm{O}$ agente do processo de diferenciação centro-periferia constitui a divisão inter-regional do trabalho que polariza o espaço de circulação das mercadorias numa relação centro-periferia. A articulação de modos de produção transmite as contradições das relações capital-trabalho geradas nas regiões centrais para as demais regiões. Esse processo estabelece um desequilíbrio entre as regiões a partir dos níveis de especialização da força do trabalho que desencadeiam frequentes crises e conflitos inter -regionais. Portanto, a dimensão regional do desenvolvimento constitui o produto do processo de integração assimétrica, no qual a produção da riqueza numa região implica dialeticamente na reprodução da pobreza em outra, em termos de regiões expropriadoras de mais-valia de regiões expropriadas (HARVEY, 2006).

Se podemos falar de uma região cultural ou região em disputa, as relações causais entre desenvolvimento assumem uma nova configuração. Os fatores socioculturais recobrem o espaço, dotando a relação entre desenvolvimento e região de um significado específico em cada momento de estabelecimento e disseminação da identidade regional. Estas experimentações mostram que a sociedade está sempre em transformação num processo contínuo de abertura e fechamento que gera apropriação e incorporação regional do desenvolvimento. Um exemplo que ilustra bem este processo diz respeito a toponímia, afinal o processo de nomeação dos lugares constitui um instrumento de identificação e apropriação territorial, no qual a cultura adquire o estatuto de território (Corrêa, 2008). Neste caso, as relações entre região e desenvolvimento não configuradas em econômicas, como por exemplo, a divisão do trabalho, as condições de vida ou a centralidade dos lugares, ou físicas; mas também através de indicadores como forma de falar, identidade étnica, religião etc., tornando-se o que os indivíduos vivem no espaço.

Mas é preciso observar que a envelopagem sociocultural não é definitiva teoricamente. A produção dos valores, das crenças e das ideias, em síntese, a produção das representações, faz com que estes surjam e disseminem-se, formando um território somente quando as representações estão relacionadas a um contexto social. Por isso, a consenso e as disputas 
se formam e se transformam permanentemente agregadas a vida social, ou seja, são subordinadas ao ritmo de relações sociais e espaciais a que dão significado. Isto quer dizer que a causalidade entre desenvolvimento e região é uma construção coletiva, ao mesmo tempo simbólica e material, que associa o mundo social ao mundo natural em função de valores predominantes. Assim, o consenso e o conflito formam uma espécie lógica que se materializa num sistema de representação partilhado por pessoas de uma mesma comunidade. Aqui, procura-se entender a dimensão espacial dos fatos sociais, especialmente como o desenvolvimento regional desencadeia fenômenos de inclusão e exclusão, inclusive o próprio conhecimento do desenvolvimento regional enquanto produtor de cultura.

Vemos assim que, dependendo de como concebemos a relação causal entre desenvolvimento e região, temos um tipo de explicação para as diferenças e semelhanças de desenvolvimento entre as regiões. Na primeira estratégia de abordagem temos o desenvolvimento como entrada e a região como saída. A região converte-se numa unidade fixa em virtude da homogeneidade de determinadas características produtivas do processo de desenvolvimento como um fator dinâmico e é por isso que falamos de região extrativista, agrícola, industrial, têxtil etc. No segundo caso, a região é considerada porta de entrada da análise móvel e o desenvolvimento a porta de saída fixo. A consideração dessas abordagens é necessária, porém não são suficientes para estabelecer uma estratégia para pensar com o desenvolvimento regional. Afinal, reforçado por esse dualismo disciplinar, o pensamento com o desenvolvimento regional requer uma reformulação mais radical da teoria que a maior parte dos pesquisadores que estudam o desenvolvimento regional pode ou não estar disposta a aceitar.

As teorias do contêiner e do envelope refletem as ambivalências da abordagem da causalidade do desenvolvimento regional. Estas abordagens devem ser consideradas como ponto de partida, mas não o ponto de chegada da análise da relação entre desenvolvimento e região. Por um lado, elas exprimem a dicotomia entre natureza-sociedade, no qual se pode configurar a região tanto como um fenômeno fixo físico, quanto como cultural dinâmico; por outro lado, essas controvérsias refletem também a forma de conceber a relação do desenvolvimento seja de forma quantitativa, seja de forma qualitativa, que perpassam as questões relativas a interpretação ou explicação do desenvolvimento. O exame do desenvolvimento regional necessita de um dispositivo teórico que possibilite 
capturar as contribuições desses dois programas de pesquisa. Por isso, na redução do desenvolvimento regional - isto é, a dialética teórica que nos remete às teorias contêiner ou às teorias do envelope - perdemos também a riqueza relacional do desenvolvimento regional.

\section{A metodologia relacional do conhecimento com o desenvolvimento regional}

Para pensar com base no desenvolvimento regional necessitamos estabelecer condições metodológicas que permitam considerar as relações que emergem da consideração simultânea do desenvolvimento e da região. Estas condições metodológicas devem basear-se num conjunto de instrumentos conceituais que permitam capturar a dialética de determinações recíprocas que se estabelecem entre desenvolvimento e região. O propósito deste sistema de coordenadas conceituais visa superar a tendência da construção de tipologias ou empilhamento de experiências empíricas. Nesse sentido, um dos principais desafios consiste em conceber uma estratégia que permita combinar as múltiplas lógicas que operam e delimitam a relação entre desenvolvimento e região empiricamente. Desta forma, o desenvolvimento regional deve basear-se metodologicamente numa perspectiva integradora, combinando abordagens. Mais precisamente, trata-se aqui de estabelecer as condições metodológicas para a produção do conhecimento com o desenvolvimento regional.

Portanto, para conseguirmos pensar com o desenvolvimento regional necessitamos reconfigurar metodologicamente a abordagem da questão do desenvolvimento regional. Precisamos sintetizar as Teorias do Contêiner e as Teorias do Envelope, integrando a estratégia que consiste em colocar o desenvolvimento dentro da região onde o território se transforma em porta de entrada da análise, com a estratégia que se sustenta em colocar a região dentro do desenvolvimento em que o território se torna a porta de saída da análise. Para integrar estas abordagens bidimensionais e ampliar o potencial analítico do conceito de desenvolvimento regional precisamos deslocar o foco da análise para a questão das relações. Como vimos, muitos autores e teorias abordam implícita ou explicitamente esta relação, mas não conseguem extrair todas as consequências por não considerar a relação como um fato. Ao relacionarmos a noção de desenvolvimento à noção de região, reunimos todos os sentidos e significados criados em suas utilizações isoladas. 
A esta estratégia chamaremos de distinção analógica. Estabelecer uma distinção analógica na abordagem da realidade com o desenvolvimento regional pressupõe enfocar os fenômenos de uma forma relacional. Para entender o que fazemos quando abordamos um fenômeno por meio do desenvolvimento regional, precisamos determinar o que é específico do conhecimento produzido com o desenvolvimento regional. O desenvolvimento regional constitui um fenômeno contingente, que depende de fatores que variam constantemente e que afeta a si mesmo pelo conhecimento produzido regionalmente. Isto significa que pensar com o desenvolvimento regional não é entender a região e o desenvolvimento, mas a configuração que emerge da relação que se estabelece entre desenvolvimento e região. Ou seja, estudar essas relações significa considerar as condições que permitem seu próprio entendimento. A dificuldade de assumir esse ponto de vista é que as noções de desenvolvimento e região possuem uma história própria.

A expressão desenvolvimento significa criar uma vida melhor para todos (PEET, 2009). Porém, nem sempre foi assim. Em sua acepção original, entre os séculos XII e XIII, a expressão desenvolvimento significava "revelar" e "expor" (ANJOS FILHO, 2013). Somente no século XIX, quando foi associada à perspectiva evolucionista, seu uso passou a significar uma passagem de estágios. Encontra-se vinculada originalmente a uma noção organicista de crescimento e a uma visão teleológica de progresso histórico. Por isso, a utilização da expressão desenvolvimento indica uma mudança favorável, uma passagem de um estágio simples para um mais complexo, do inferior para o superior, do pior para o melhor. E está associada às ideias de crescimento, evolução, maturação etc. (ESTEVA, 200o). Além de comportar também a ideia de esperança e confiança na possibilidade de uma vida melhor. E a expressão tem sido progressivamente empregada para indicar processos contraditórios como crescimento econômico, satisfação de necessidade básicas e também sustentabilidade socioambiental.

A popularização da expressão desenvolvimento está associada ao famoso discurso de posse proferido por Harry S. Truman (1884-1972), em 20 de janeiro de 1949 (RIST, 1996). Conhecido como Four Point Speech, esse discurso inaugura a "era do desenvolvimento". Considerando o progresso econômico, técnico e científico, ele estabelece uma classificação das nações com base na díade desenvolvido/subdesenvolvido, ao afirmar que "Fourth, we must embark on a bold new program for making the benefits of our scientific advances and industrial progress available for the improvement and growth of underdeveloped áreas". Esta classificação se 
impôs devido a conjuntura histórica caracterizada pelo fim da Segunda Guerra Mundial, o processo de descolonização, a divisão do mundo em capitalista e comunista, e a hegemonia estadunidense. Nesse sentido, ao estabelecer essa diferenciação, o discurso de Truman dota a expressão desenvolvimento do significado de superar uma condição de atraso pela própria continuação de algo.

Mas ao longo das últimas cinco décadas a expressão desenvolvimento tem sido reinventada com base em diversos enfoques interpretativos. Por exemplo, segundo a Teoria da Modernização, o desenvolvimento dependia do crescimento industrial, da redistribuição da renda e da criação de uma nova elite dominante (ROSTOW, 1960). Já do ponto de vista da Teoria da Dependência, o desenvolvimento constitui uma questão social e política que depende da relação entre dominação internacional e dominação de classe interna, no qual o desenvolvimento periférico depende do central (SUNKEL, 1981). No Ecodesenvolvimento tem se destacado a dimensão ambiental do desenvolvimento relacionada a sobrecarga da capacidade assimilativa e regenerativa da natureza provocada pelo padrão predominante de desenvolvimento (SACHS, 2002). Nos últimos anos, o desenvolvimento tem sido objeto de um exame crítico radical e fala-se até mesmo de pós-desenvolvimento, descrevendo-se o desenvolvimento como expressão duma engenharia autoritária (PIETERSE, 2013).

Isto indica que o desenvolvimento constitui uma expressão muito controversa. Cada teoria do desenvolvimento pode ser vista como expressão de um discurso de apoio ou de oposição no processo de montagem da agenda, mobilização e construção de coalizões políticas. Portanto, o conhecimento sobre o desenvolvimento não é um simples registro que reflete a realidade, pois o sentido em que as pessoas pensam e falam sobre o desenvolvimento afeta as agendas, as políticas, as leis etc. (PIETERSE, 2013). Afinal, o desenvolvimento não constitui apenas um âmbito de pesquisa, mas também um campo de atuação. Por isso, o significado do conceito de desenvolvimento constitui um tema que é disputado politicamente, pois envolve a questão da estrutura e a distribuição dos benefícios. Quando se discute o desenvolvimento problematiza-se o controle e, portanto, consideram-se os fatores que, em diferentes níveis, afetam o início, o ritmo e a direção do desenvolvimento. Mais precisamente: os fatores que determinam quem ganha e quem perde com o desenvolvimento.

Por isso, o sentido e o significado da expressão desenvolvimento dependem do contexto em que é utilizada. Por um lado, o desenvolvimento tem sido descrito como o resultado dos efeitos produzidos pelas transformações 
socioeconômicas num território; por outro, pode ser descrito como uma ilusão, constituindo uma armadilha que serve para reproduzir assimetrias entre e nas regiões. Assim, ao mesmo tempo em que é estudado cientificamente por disciplinas como, por exemplo, a economia, a sociologia, a geografia, a antropologia etc., é denunciado também como uma ideologia que monopoliza e destrói a concepção e adoção de perspectivas alternativas de futuro. Na maior parte das vezes, a concepção de desenvolvimento que serve para um cientista ou pesquisador não é a mesma que serve a um técnico governamental, a um camponês, a um indígena, a um fazendeiro etc. Desta forma, o desenvolvimento pode ser caracterizado, ao mesmo tempo, como um objetivo e como um resultado, como um modelo ou como um processo, como uma política ou como uma meta.

Esse caráter politicamente negociado constitui, simultaneamente, a força e a fraqueza conceitual do desenvolvimento. Sua vitalidade e inventividade dependem de como os significados são modificados e ajustados para descrever e controlar os desafios econômicos, políticos, sociais, culturais e ambientais relacionados as transformações sociais. A consequência é que o significado do conceito de desenvolvimento depende das forças sociais que o conduzem e promovem. Considerando estes fatores, $\mathrm{o}$ desenvolvimento pode ser definido como um processo de mudança social. Indica um processo contínuo e cumulativo de transformação do contexto social. Assim, ao mesmo tempo em que o desenvolvimento descreve a mudança social, acaba também afetando o desenvolvimento da própria mudança social. Isto indica que o conhecimento sobre o desenvolvimento afeta as agendas e políticas que tratam do próprio desenvolvimento. Mais precisamente, pode-se dizer que o significado do desenvolvimento se desenvolve juntamente com os processos que procura descrever.

Já a etimologia da palavra região é bastante conhecida. Deriva do latim regere, composta pelo radical reg e que deu origem a expressões como regente, regra etc. No período do Império Romano a expressão regione designava áreas que se encontravam subordinadas a Roma. Uma interpretação possível sugere que a emergência da expressão denota a relação entre a centralização do poder em um local e a sua extensão sobre uma área de grande diversidade cultural, social e espacial. O esfacelamento do Império Romano seguiu esta forma de subdivisão, originando a organização feudal predominante da Idade Média. A igreja reforçou esse tipo de divisão utilizando aquelas unidades como base para o estabelecimento de sua hierarquia administrativa. O surgimento do Estado-nação redimensionou a problemática das unidades territoriais pela necessidade 
de união diante de um inimigo cultural, político, comercial, militar etc. (GOMES, 2012). A complexidade desse contexto histórico foi dotando a noção de região de características analíticas e políticas específicas.

A região constitui uma questão em constante disputa. Segundo Gomes (2012), a noção de região está relacionada a três dimensões principais: a) a dimensão política: a noção de região está relacionada a uma organização administrativa; b) a dimensão espacial: projeção dos fenômenos sociais e naturais no espaço; c) a dimensão disciplinar: tornou-se uma unidade de estudo científico. Estes três fenômenos produzem e reproduzem reciprocamente, dotando o conceito de região de uma complexidade crescente. Por exemplo, o estudo científico dos fenômenos sociais no espaço fomenta formas de controle político, ao mesmo tempo em que essas formas de controle regional estimulam novos padrões de organização social, o que modifica o conhecimento disponível sobre a região. Isso significa que a região constitui um fenômeno em constante transformação política, social e cognitiva. Essa característica contingente confere ao conceito de região um traço polissêmico e torna a operacionalização metodológica crítica.

Grande parte desses impasses está relacionado a utilização da noção de região por muitas disciplinas. Na geografia, por sua preocupação com espaço, a noção de região é muito controversa, ocasionando uma constante redefinição do seu sentido e significado em função das transformações disciplinares. Mas também tem sido empregada em matemática, na qual refere-se a um subconjunto dependente de um espaço topográfico. Em economia, refere-se a concentração espacial das atividades produtivas. Do ponto de vista da ciência política, tem sido utilizada para descrever o contrabalanço a uniformização e centralização do estado nacional. Somente recentemente a sociologia passou a ocupar-se da noção de região, disciplina na qual é utilizada para descrever o processo de diferenciação do tempo e do espaço em diferentes lugares. Seja para denotar localidade, espacialidade, regionalidade, regionalismo etc. essas diferenças constituem, ao mesmo tempo, um desafio analítico na medida em que essa noção encerra muitas controvérsias sobre sua aplicação.

Deste ponto de vista, a região constitui uma área delimitada pelo agrupamento de elementos que se diferenciam de outras áreas. Por isso, a noção de região evoca sempre a ideia de uma subdivisão, sendo que utilizamos a expressão região para caracterizar os limites de processos muito diversos, a exemplo de "região montanhosa", "região pobre", "região vulnerável”, "região sul”, "região grande” etc. A noção de região serve para 
organizar a informação geográfica e exprime uma forma de diferenciação do espaço que demarca uma unidade territorial. Assim, por um lado, a noção de região se refere a uma diferença de tamanho que assume significação somente de forma analógica e, por outro, a noção de região refere-se a também a uma relação entre dentro-fora. Mais precisamente, pressupõe que algo de específico acontece na escala regional de desenvolvimento, que não acontece na escala global e local. Portanto, região compreende uma escala de associação variável, ou seja, uma escala de grandeza que se inscreve entre o geral e o particular.

Um dos grandes desafios analíticos do conceito de região é que ele constitui o resultado de processos que são produzidos fora da formação regional. Esses processos compreendem o resultado da produção, ao mesmo tempo material e simbólica, de uma constelação de relações entre conhecimentos e espacialidades. Nesse sentido, uma região constitui uma condensação híbrida de redes de relações sociais em constante transformação; mais precisamente, uma região constitui o resultado de uma ordem social. Considerada desse ponto de vista, uma formação regional apresenta duas características analíticas principais: a localidade e a descontinuidade. A relação entre a localidade e a descontinuidade indica, por um lado, a rede de conexões entre lugares e, por outro, o caráter convencional da delimitação das fronteiras. Portanto, uma região ou uma formação regional não é uma entidade acabada, mas constitui uma condensação de instituições e práticas que são resultado contingente intra e inter-regionais em constante transformação.

A noção de região fundamenta-se na relação entre parte e todo. Esta relação pressupõe a consideração tanto da questão da divisão, quanto da proporção das partes (LENCIONI, 1999). Por um lado, isto significa que uma região deve sempre fazer parte de um todo maior, ao mesmo em que pode ser formada por partes menores. Por outro lado, a noção de região evoca uma relação de semelhança interna e diferenciação externa; ou seja, a caracterização de uma região pressupõe uma homogeneidade maior das partes internas e uma diferenciação com relação as partes externas. Isto indica que as relações entre a parte e o todo não são fixas, mas um fenômeno em constante transformação. As relações entre a parte e o todo se estabelecem em múltiplas dimensões entre o geral e o particular. E se uma região constitui uma parte diferenciada do todo, ela também deve apresentar uma descontinuidade com relação as outras partes que constituem o todo. Portanto, se uma região pode constituir, simultaneamente, uma parte e um todo, ela só pode ser compreendida de forma relacional. 
Portanto, ao relacionarmos desenvolvimento e região, percebemos que o desenvolvimento regional está em todo lugar em todo momento. Assim, não devemos esquecer que embora as noções de região e desenvolvimento possuam um sentido e um significado de aplicação isolado, para pensarmos com o desenvolvimento regional necessitamos de uma estratégia teórica que capture o seu conteúdo e efeito relacional. Por isso, precisamos formular uma teoria que descreva e explique o processo de causação contextual que se estabelece entre desenvolvimento e região. Isto pressupõe, claro, uma configuração teórica que capture o jogo de codeterminações recíprocas, no qual o desenvolvimento regional é percebido por uma consciência subjetiva, julgado por uma moral, gestado por uma política, ao mesmo tempo em que conforma a percepção, reforça a moral, reproduz a política. Nesse sentido, pode-se dizer que teoria do desenvolvimento regional deve se ocupar com as associações específicas que se estabelecem entre desenvolvimento e região em cada situação.

Considerando estes fatores, pode-se dizer que o conhecimento com o desenvolvimento regional constitui uma operação cognitiva eminentemente relacional. Essa relação se estabelece em dois planos metodológicos:

1) RELAÇÃO TEÓRICA: para conhecermos com o desenvolvimento regional necessitamos pensar relacionalmente. O desenvolvimento regional constitui um efeito emergente de uma relação. Isto significa que o conhecimento com o desenvolvimento regional não pode ser reduzido ao entendimento do desenvolvimento ou da região. Mais precisamente, desenvolvimento e região assumem um significado totalmente diferente daquele que os conceitos de desenvolvimento e região possuem quando considerados isoladamente. O desenvolvimento regional constitui um fenômeno que emerge de uma relação, portanto, o foco do conhecimento com o desenvolvimento regional não reside nem no desenvolvimento e nem na região, mas na mediação relacional. Afinal, o conhecimento com o desenvolvimento regional mostra um nível da realidade que só é observável pela mediação relacional. Portanto, não se trata somente de explorar a relação entre desenvolvimento e região, mas também de se considerar a dimensão regional do desenvolvimento como uma relação;

2) RELAÇÃO EMPÍRICA: $O$ conhecimento com o desenvolvimento regional se estabelece pela relação das diferenças entre configurações regionais de desenvolvimento. Isto significa que as diferenças de ritmo e frequência do desenvolvimento que existem internamente a uma região 
devem ser menores que as existentes externamente. Aqui, o interesse se concentra na consideração do efeito das interações que se estabelecem entre a dimensão interna e a dimensão externa por meio de uma comparação. $\mathrm{O}$ conhecimento com o desenvolvimento regional se estabelece pelo contraste entre configurações regionais de desenvolvimento. Um padrão de desenvolvimento só pode ser conhecido quando comparamos duas ou mais configurações regionais de desenvolvimento a partir da consideração de determinado um indicador, como, por exemplo, o PIB, o IDH, a Pegada Ambiental etc. Este pressuposto indica que as relações entre desenvolvimento e região são contingentes e, portanto, o que é expresso com a relação é sempre um contexto social.

Trata-se, portanto, de determinar o que conhecemos quando consideramos o modo regional de desenvolvimento de forma relacional. $\mathrm{O}$ que está sendo relacionado quando pensamos com o desenvolvimento regional? O que estamos relacionando quando configuramos o desenvolvimento regionalmente? Por um lado, o desenvolvimento constitui um feixe de mudanças que se estabelecem simultaneamente em várias dimensões: econômica, social, política, cultural, ambiental etc.; por outro, a região está ligada a diferenciação, ideia que a superfície da terra que pode ser configurada de forma diferente: uma variável física como uma bacia hidrográfica, uma variável política como uma SDR (Secretaria de Estado de Desenvolvimento Regional/Santa Catarina), uma variável econômica como região agrícola, uma variável social como região violenta, uma variável cultural como região católica etc. Ou seja, temos o desenvolvimento que indica mudança e temos a região que delimita a área. Nesse sentido, conhecer com o desenvolvimento regional significa relacionar um determinado ritmo de mudança ao tamanho do lugar e, portanto, relacionar Tempo-Espaço.

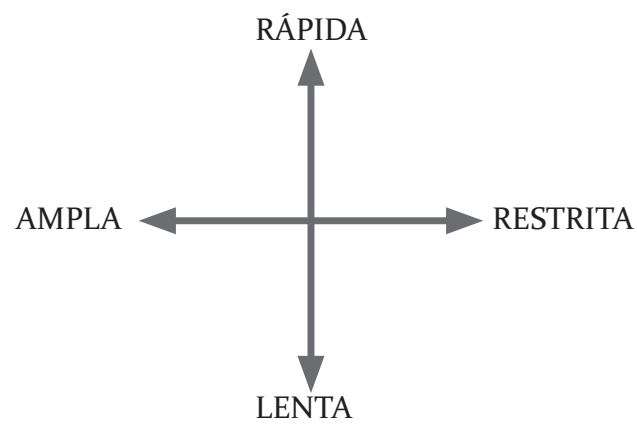


Este modelo permite representar e interpretar a relação teórica e empírica entre desenvolvimento e região. Ao pensarmos com o desenvolvimento regional um fenômeno, estamos sempre relacionando um determinando ritmo de mudança numa determinada área. Por exemplo, relacionando o crescimento do setor metal-mecânico numa área rural, observamos a mudança num período de tempo num determinado espaço que deve ser diferente. Podemos dizer, portanto, que enquanto a noção de desenvolvimento evoca a mudança no tempo, a noção de região situa este processo no espaço. Assim, a região constitui a escala de medida que dá visibilidade ao desenvolvimento. Define, portanto, o nível de análise em que vai ser considerada a ocorrência do fenômeno. Pensar com o desenvolvimento regional compreende, portanto, uma focalização, ou melhor, uma distinção topológica do processo de mudança. No limite, pode-se dizer que pensar com o desenvolvimento compreende relacionar uma concepção de tempo em uma concepção de espaço.

Para estabelecer esse modelo, o desenvolvimento e a região não podem ser definidos separadamente e devem ser concebidos de uma forma cointegrada. Sabemos que analiticamente temos que relacionar a área (região) e o que acontece nela (desenvolvimento). Os desafios desta operação são os de estabelecer uma relação que capture teoricamente o ritmo de mudança do desenvolvimento com as dimensões da área. Isto envolve, claro, a consideração dos processos que promovem a aceleração ou a retração da variável temporal (mudança), mas também a consideração dos processos de contração ou expansão da variável espacial (localização). Precisamos de um modelo (DUTRA, 2013) que permita exprimir o ordenamento básico deste processo e, assim, investigar a calibragem da relação entre desenvolvimento e região. A calibragem da relação entre desenvolvimento e região pode ser concebida e descrita analiticamente por meio do Cálculo da Indicação formulado por George Spencer-Brown (SPENCER-BROWN, 2011).

O Cálculo da Indicação foi proposto por Spencer-Brown num livro chamado The Laws of Form - LoF. A LoF constitui uma abordagem que começa e termina com a noção de distinção. Resulta da tentativa de Spencer-Brown de aplicar a Álgebra Booleana na construção de combinações de proposições (verdadeira ou falsa), para uma empresa de engenharia especializada em circuitos eletrônicos do sistema ferroviário britânico. Porém, Spencer-Brown rapidamente descobriu que a complexidade dos problemas do mundo real não podiam ser capturados por meio das ferramentas disponíveis na Álgebra Booleana. Por isso, Spencer-Brown 
desenvolveu um novo sistema de símbolos básico, envolvendo apenas o vazio e uma distinção no vazio. No Cálculo da Indicação ele mostra como o simples ato de estabelecer uma distinção cria um espaço. E, além disso, seguindo as implicações da LoF, Spencer-Brown, demonstrou também como o tempo emerge por meio de um processo de distinção. A disseminação das ideias da LoF tem influenciado muitas áreas de conhecimento tão diversas que vão da biologia (VARELA, MATURANA, 2002) à sociologia (LUHMANN, 2002).

A LoF de Spencer-Brown é um exame do que acontece quando uma distinção é feita. Segundo ele, a "distinção é uma continência perfeita." (2011, p. 1). O argumento de Spencer-Brown é que quando indicamos alguma coisa fazemos uma distinção. A unidade que diferencia o espaço marcado e o desmarcado é o que chama de distinção. Na medida em que toda distinção cliva um espaço, o espaço não marcado da distinção é o que se torna invisível quando é desenhada ou estabelecida uma distinção. Toda distinção, portanto, tem dois pontos: marcado e não marcado. Assim, por um lado, toda distinção contém o espaço não marcado que desaparece quando é desenhada a distinção. No entanto, por outro lado, a própria distinção desaparece quando o espaço marcado não é a própria distinção. Como assinala Spencer-Brown, "uma vez que é feita uma distinção, os espaços, estados ou conteúdos de cada lado da fronteira, sendo distintas, podem ser indicados." (SPENCER-BROWN, p. 1). Ela encerra: a) a indicação que a distinção marca; b) o resto não indicado do mundo; c) e a própria distinção que separa os estados indicados dos estados não indicados.

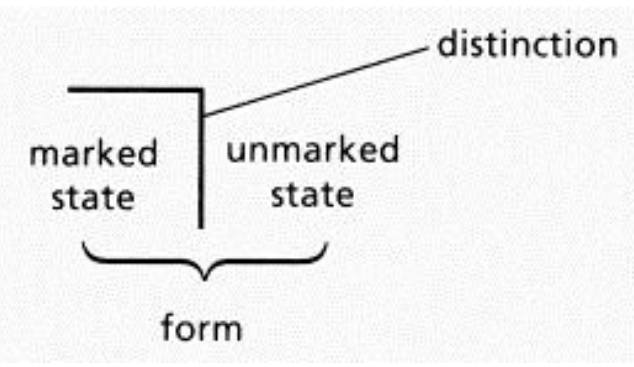

A forma é fixada para estabelecer uma fronteira. Cada forma contém dois lados que ela distingue. Mas forma não é somente a fronteira, ela contém também os dois lados que ela separa. Contudo, os dois lados não participam da mesma maneira no estabelecimento da forma. $\mathrm{O}$ uso 
operacional da forma só pode ser efetuado por meio da utilização de um dos lados da forma. A distinção é feita com uma intenção pragmática de designar um lado, mas não o outro. Isto quer dizer que o que se distingue, por conseguinte, tem de ser distinguido a partir da própria distinção. Para explicitar este processo, Spencer-Brown diferencia "indicação" de "distinção". Portanto, a forma constitui a condição de possibilidade de uma observação. Estabelecer uma forma de distinção é uma operação que requer tempo.

Por isso, primeiro precisamos esclarecer o Princípio de Distinção que delineia o uso da marca. Princípio de Distinção estabelece que o estado indicado pelo exterior de uma marca não é o estado indicado pelo seu interior. Decorre do Princípio da Distinção que o exterior de uma marca indica o estado desmarcado desde o seu interior, enquanto que o interior de uma marca indica o estado desmarcado desde o exterior. Nesse sentido, se considerarmos uma folha de papel em branco, ao fazermos uma marca, uma distinção, dentro desse vazio, estabelecemos uma polaridade. Por exemplo, se desenharmos um círculo no meio da folha, esta marca separa dois estados diferentes, que nós normalmente consideramos como "dentro" e "fora", e que Spencer-Brown chama de "Primeira Distinção". O restante do sistema pode, então, ser desenvolvido formalmente a partir dessas formas primitivas. Para expressar a distinção Spencer-Brown desenvolve uma nova notação. Em vez da utilização do círculo, Spencer-Brown expressa uma marca pela parte superior de um quadrado:

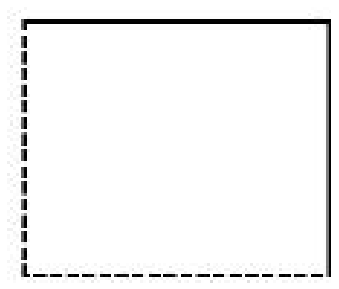

A distinção compreende uma operação, não um estado ou uma coisa. Por isso a LoF baseia-se em dois axiomas. Axioma 1 - Lei da Chamada: "o valor de uma chamada feita de novo é o valor da chamada" (SPENCERBROWN, 2011, p. 2). Axioma 2 - Lei do Cruzamento: "o valor de um cruzamento feito de novo não é o valor do cruzamento." (SPENCER-BROWN, 2011, p. 2). Por "chamada" devemos entender a confirmação da distinção. Para Lester-Brown, ao "chamar" a mesma indicação repetimos a 
indicação, confirmando a indicação. Enquanto que por "cruzamento" devemos entender o cancelamento da distinção. Ao cancelar escolhemos o estado não-marcado de mundo, ou o estado não indicado de distinção (BAECKER, 1999). Dito de uma forma mais simples, se uma distinção pode ser estabelecida por uma chamada, ela também pode ser cancelada por um cruzamento. Ou mais precisamente, quando estabelecemos uma distinção, estamos produzindo ou criando uma forma e, ao mesmo tempo, não representando, classificando ou simbolizando algo.

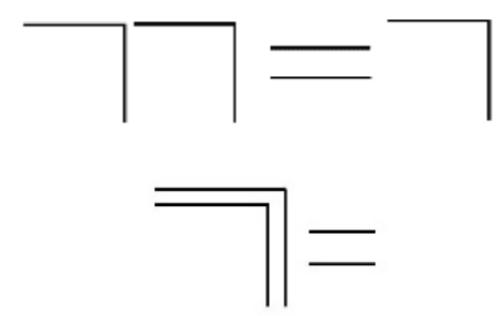

Spencer-Brown chama o espaço delimitado por qualquer distinção de forma da distinção. Segundo o autor, pode-se notar que cada lado da distinção marca dois grupos de referências. A primeira, ou referência explícita, constitui o lado de acordo como ele foi marcado, enquanto a segunda, ou implícita, refere-se ao outro lado que é pressuposto pela marcação. Nesta concepção, a distinção estabelecida constitui uma forma constituída por uma marca composta de duas partes - marcada e não-marcada. Assim, podemos supor que a calibragem entre desenvolvimento e região constitui uma forma de distinção. Isto significa que conhecer com o desenvolvimento constitui fixar marcações por meio da calibragem entre desenvolvimento e região. Primeiro, seleciona-se uma dimensão do desenvolvimento a uma concepção de região. Em seguida, calibra-se o ritmo de mudança desta dimensão do desenvolvimento com a abrangência da região. Por exemplo, considera-se como o setor têxtil opera modificações no setor econômico numa área definida fisicamente.

Um segundo aspecto importante relacionado a LoF diz respeito ao Re-entry ou "Segunda Distinção". A Segunda Distinção compreende a autorreferência e indica que a distinção estabelecida pelo desenvolvimento regional pode ser adotada para validar a própria capacidade de uma região distinguir o seu desenvolvimento. Por exemplo, se adotamos o IDH - Índice de Desenvolvimento Humano para caracterizar o padrão de desenvolvimento de uma região, e se essa região tiver um alto IDH, ela 
pode desconsiderar este indicador como parâmetro para caracterizar seu próprio padrão regional de desenvolvimento e adotar outro, como o IFB Índice de Felicidade Bruta, ou ainda, criar uma distinção própria e, assim, discordar de seu próprio desenvolvimento. Quer dizer que dependendo do tipo de distinção que adotamos para caracterizar o desenvolvimento regional, a própria distinção do desenvolvimento regional pode se modificar. Mais precisamente, o conhecimento com o desenvolvimento regional se desenvolve à medida que as regiões se desenvolvem regionalmente.

O mundo só pode ser observado por meio de distinções. Assim, temos a primeira e a segunda distinção. A primeira distinção divide o mundo em uma forma com dois lados, o visto e o não visto. A segunda distinção refere-se a distinção entre o observado e observador. Esta relação cria a diferença assimétrica entre os dois lados da forma. A distinção torna o mundo visível (estado marcado) e invisível (estado não-marcado). O mundo não marcado, o mundo como ele realmente é, no entanto, não é nem observável nem descritível (ROBERTS, 1999). O que o observador observa é o mundo marcado.

Por meio da LoF conseguimos perceber que pensar com o desenvolvimento regional constitui estabelecer marcações pela calibragem da relação entre desenvolvimento e região. Nesse sentido, a LoF mostra que ao fixarmos ou indicarmos um processo de mudança numa área estamos efetuando uma marcação. Esta indicação estabelece uma distinção entre a área marcada pelo desenvolvimento e a área não marcada pelo desenvolvimento. A área marcada pelo desenvolvimento compreende uma região e a área não marcada pelo desenvolvimento outra região. O que demarca a diferença entre uma região e outra constitui o processo de desenvolvimento considerado. Isto significa que, quando fixamos um ritmo de mudança social numa determinada área, estabelecemos uma indicação. Esta distinção constitui uma marca que se estabelece por meio da calibragem entre uma dimensão do desenvolvimento com uma demarcação regional.

Além disso, a LoF permite reinterpretar as teorias existentes. Vamos considerar duas interpretações das Teorias do Envelope comparativamente, tomando como exemploa Geografia Cultural ea Geografia Radical. A geografia cultural caracteriza-se pela consideração da dimensão simbólica em termos fenomenológicos da experiência vivida pelos indivíduos. Já a geografia radical baseia-se na materialidade enfatizando as contradições relacionadas aos modos de produção. Nesse sentido, a LoF permite descrever a operação cognitiva que efetuamos quando caracterizamos 
uma região por meio da consideração de uma determinada indicação. A indicação que demarca a fronteira entre uma região ou outra é de ordem cultural, no caso da geografia cultural, e de ordem econômica, no caso da geografia radical. Em ambas teorias existe uma relação entre o dentro e o fora, porém a indicação que demarca a fronteira é diferente. Portanto, a LoF permite compreender mais precisamente o processo de territorialização: a fronteira constitui uma distinção.

Pensar com o desenvolvimento regional constitui, portanto, determinar um território por meio da distinção estabelecida pela relação entre desenvolvimento e região. Ao relacionarmos desenvolvimento e região, fixamos um território e estabelecemos uma distinção por meio de uma marca. Esta marca fixa uma dimensão do desenvolvimento a uma região, estabelecendo uma distinção entre o dentro e o fora. O lado marcado constitui o lado de dentro, enquanto o lado não marcado constitui o lado de fora. Nesse sentido, pensar com o desenvolvimento regional significa estabelecer uma distinção relacionando desenvolvimento e região. Isto significa que ao conhecermos com o desenvolvimento regional distinguimos a distinção segundo a calibragem que utilizamos para relacionar desenvolvimento e região, ou seja, segundo a marca que utilizamos para separar o dentro e o fora de uma região pelo desenvolvimento. Mais precisamente, estabelecemos uma distinção relacionando um ritmo de mudança a extensão de uma área.

\section{Considerações finais}

O paradoxo do desenvolvimento regional decorre da crença em que o desenvolvimento regional constitui uma coisa no mundo e não uma forma de entender o mundo. Deste ponto de vista, o desenvolvimento regional está em todo lugar o tempo todo. Isto significa que o desenvolvimento regional diz algo muito importante sobre nós. Vimos que para aprender a pensar com o desenvolvimento regional precisamos entender como ele é representado no cotidiano, mas também como ele é utilizado no cotidiano científico. Precisamos saber o que as pessoas fazem quando falam com o desenvolvimento regional sobre o mundo e como as disciplinas científicas traduzem o desenvolvimento regional cientificamente. Isso impõe um exame triplo da relação entre desenvolvimento e região: a consideração do senso comum, a consideração do senso comum científico e o efeito combinado de ambos. Assim, por um lado, o desenvolvimento regional possui um sentido social e, por outro, uma operacionalização 
científica. No desenvolvimento regional a fronteira entre o político e o científico não é nítida.

O desenvolvimento regional encerra fenômenos diversos, múltiplos e complexos. O conhecimento com desenvolvimento regional compreende a operação cognitiva que permite posicionar o ritmo e abrangência da mudança por meio da relação entre tempo e espaço. Isto dota o conhecimento com o desenvolvimento regional de três características cognitivas inescapáveis:

a) O desenvolvimento regional é multidimensional: econômico, social, político, cultural e ambiental;

b) O desenvolvimento regional é multidirecional: significa simultaneamente progresso e retrocesso;

c) O desenvolvimento regional é multissignificativo: o sentido varia segundo os grupos sociais;

Quando supomos o estabelecimento de um Programa Forte em Desenvolvimento Regionalacreditamos nautilizaçãodo Desenvolvimento Regional na compreensão do mundo. Isto significa que a pesquisa com o desenvolvimento regional deve gerar novos conhecimentos, antes inacessíveis ou inexistentes. Pesquisar com desenvolvimento regional é pensar como o desenvolvimento cria regiões e como regiões afetam o desenvolvimento. Este conhecimento afeta o próprio desenvolvimento regional e baseia-se em cinco princípios:

1. O conhecimento com o desenvolvimento regional é irredutível: o desenvolvimento de uma região não pode ser reduzido somente a uma dimensão;

2. O conhecimento com o desenvolvimento regional possui uma causação circular: no desenvolvimento regional os efeitos tornam-se causas e as causas tornam-se efeitos;

3. O conhecimento com o desenvolvimento regional é relacional: o desenvolvimento regional constitui um fenômeno que emerge da relação entre desenvolvimento e região;

4. O conhecimento com o desenvolvimento é ambivalente: quando uma região se desenvolve resolve-se um conjunto de problemas, mas criam-se outros;

5. O conhecimento com o desenvolvimento regional é incerto: as consequências do desenvolvimento regional são imprevisíveis. 
Considerando esses princípios, a conversão do desenvolvimento regional de um tema de investigação para um instrumento de investigação pressupõe a incorporação de uma nova postura epistemológica, teórica e metodológica:

a) EPISTEMOLOGIA REFLEXIVA: o conhecimento com o desenvolvimento regional é autorreferente. As relações entre desenvolvimento e região são constantemente examinadas e configuradas por meio da informação gerada a partir das próprias pesquisas sobre o desenvolvimento regional, afetando o ritmo e a direção do desenvolvimento regional. Determinar a contextualidade das relações entre desenvolvimento e região depende das descobertas sucessivas extraídas do próprio conhecimento das relações entre desenvolvimento e região. Temos, então, uma situação que se caracteriza pela reentrada do conhecimento do desenvolvimento no próprio ritmo e direção do desenvolvimento regional. Por isso, o conhecimento com o desenvolvimento regional é um processo autorreferente, na medida em que a realidade regional do desenvolvimento que conhecemos é uma realidade construída pelo próprio conhecimento do desenvolvimento regional. Além de explicar a relação entre desenvolvimento e região, o conhecimento com o desenvolvimento regional interfere em como o desenvolvimento regional é formado. Isto significa que o conhecimento com o desenvolvimento regional constitui uma abordagem regional para problemas regionais. Em dimensões epistemológicas isto significa que o desenvolvimento regional constitui uma teoria que descreve a si mesma. O conhecimento do desenvolvimento regional não pode ser feito em algum lugar que não seja uma região. Assim, pesquisar o desenvolvimento regional significa fazer parte do processo de desenvolvimento regional. $\mathrm{O}$ conhecimento produzido com o desenvolvimento regional afeta o próprio desenvolvimento regional. O conhecimento do desenvolvimento regional faz parte da realidade que pretende descrever. Existe aqui, portanto, um aspecto deliberadamente reflexivo no conhecimento com o desenvolvimento regional, na medida em que deve ser examinado por critérios regionais.

b) TEORIA CONTEXTUAL: O desenvolvimento regional constitui uma unidade de análise que se caracteriza por uma causação relacional. Assim, pensar com desenvolvimento regional constitui uma técnica de relacionar fenômenos heterogêneos. A principal característica desta técnica refere-se a possibilidade de submeter o desenvolvimento e região a uma lógica relacional. Essa lógica relacional consiste em considerar 
como o modo regional de desenvolvimento divide o espaço, segundo a consideração de um processo de mudança específico. As consequências principais da aplicação desta técnica é o reconhecimento de que as divisões não são definitivas e, consequentemente, a variabilidade de relações entre desenvolvimento e região são praticamente infinitas. Portanto, as regiões não são submetidas sempre as mesmas variáveis, o que permite que um mesmo espaço contenha várias regiões. Nesse sentido, podemos conceber o desenvolvimento regional como um processo relativo, um momento de transformação das práticas e representações sociais que ocorrem em várias escalas temporais e espaciais, simultaneamente. As relações entre desenvolvimento e região são coordenadas contextualmente. Pensar com o desenvolvimento regional é fixar um processo de mudança num domínio. O fixamento de uma relação frequentemente oculta outras. Além disso, pensar com desenvolvimento regional implica pensar regionalmente. Para a solução de problemas regionais necessitamos de abordagens regionais: 1) teorias de alcance regional; 2) teorias produzidas regionalmente.

c) METODOLOGIA RELACIONAL: A terceira característica de pensar a realidade com o desenvolvimento regional é o reconhecimento de que as fronteiras são móveis e os territórios são estabelecidos mediante a calibragem entre desenvolvimento e região. Para produzirmos conhecimento com o desenvolvimento regional necessitamos estabelecer distinção entre processos de desenvolvimento que se estabelecem dentro e fora da região. Portanto, a produção do conhecimento com o desenvolvimento regional fundamenta-se num metodologia relacional em duas perspectivas: 1) uma relação entre desenvolvimento e região para estabelecer a distinção pela calibragem do ritmo de mudança a abrangência do lugar; 2) uma relação comparativa que visa estabelecer como se estabelecem as diferença e semelhança entre o dentro e o fora de cada região. Nesse sentido, a produção do conhecimento com o desenvolvimento regional fundamenta-se metodologicamente na possibilidade de combinar esta dupla relação empiricamente.

Estes são os elementos básicos para o estabelecimento de um Programa Forte em desenvolvimento regional. Mais precisamente: transformar o desenvolvimento regional de um tema de conhecimento de várias disciplinas, para uma forma disciplinar de produção de conhecimento. Em síntese, pode-se dizer que pensar com o desenvolvimento regional implica a adoção de três operações simultâneas: a) uma epistemologia reflexiva: 
a ideia de que o conhecimento com o desenvolvimento regional deve ser justificado regionalmente; b) uma teoria contextual: as teorias criadas com o desenvolvimento regional devem possuir um alcance regional; c) uma metodologia relacional: o conhecimento com o desenvolvimento regional deve ser produzido por meio de uma calibragem entre desenvolvimento e região. Trata-se agora de extrair as implicações dessa plataforma cognitiva por meio da pesquisa empírica.

\section{Referências}

ALCOFF, Linda Martín (Org.). Epistemology: the big questions. Oxford: Blackwell Publishers, 1998.

APEL, Karl Otto. Expliquer-comprendre: la controverse centrale des sciences humaines. Paris: Les Éditions du Cerf, 2000.

ATKINSON, David; JACKSON, Peter; SIBLEY, David; WASHBOURNE, Neil. Cultural geography: a critical dictionary of key concepts. London: I.B.Tauris \& Co Ltd, 2010.

BAECKER, Dirk. Problems of form. Stanford: Stanford University Press, 1999.

BARNES, Barry; BLOOR, David; HENRY, John. Scientific knowledge: a sociological analysis. Chicago: The University of Chicago Press, 1996.

BENKO, George. A ciência regional. Oeiras: Editora Cela, 1999.

BEZZI, Meri Lourdes. Região: uma (re)visão historiográfica - da gênese aos novos paradigmas. Santa Maria: Editora da UFSM, 2004.

BOURDIEU, Pierre. Les usages sociaux de la science: pour une sociologie clinique du champ scientifique. Paris: INRA Editions, 1997.

BUNGE, Mario. La investigación científica. Barcelona: Editorial Ariel, 1989.

BUTTIMER, Anne. Apreendendo o dinamismo do mundo vivido. In: CHRISTOFOLETTI, A. Perspectivas da geografia. São Paulo: Difel, 1982, p. 165-193.

CALLON, Michel. Four model for the dynamics of Science. In:JASANOFF, Sheila; MARKLE, Gerald E; PETERSEN, James C; PINCH, Trevor. 
Handbook of Science and technology studies. London: SAGE, 1995, p. 29-63.

CARNAP, Rudolf. Foundations of logic and mathematics. Chicago: University of Chicago Press, 1970.

CLAVAL, Paul. A geografia cultural. Florianópolis: Editora da UFSC, 1999.

2011 .

. Epistemologia da geografia. Florianópolis: Editora da UFSC,

CORRÊA, Roberto Lobato. Região e organização espacial. São Paulo: Editora Âtica, 1986.

. Região cultural - um tema fundamental. In: ROSENDAHL, Zeny; CORRÊA, Roberto Lobato. Espaço e cultura: pluralidade temática. Rio de Janeiro: Ed. UERJ, 2008.

CHRISTOFOLETTI, A. As características da Nova Geografia. In: CHRISTOFOLETTI, A. Perspectivas da geografia. São Paulo: Difel, 1982, p. 71-101.

CRESSWELL, Tim. Place: a short introduction. Oxford: Blackweel, 2004. DELANEY, David. Territory: a short introduction. Oxford: Blackweel, 2005 .

DUTRA, Luiz Henrique de Araújo. Introdução à teoria da ciência. Florianópolis: Editora da UFSC, 1998.

. Oposições filosóficas. A epistemologia e suas polêmicas. Florianópolis: Editora da UFSC, 2005.

ESTEVA, Gustavo. Desenvolvimento. In: SACHS, Wolfgang. Dicionário do desenvolvimento. Petrópolis; Editora Vozes, 2000, p. 59-83.

FILHO, Robério Nunes dos Anjos. Direito ao desenvolvimento. São Paulo: Editora Saraiva, 2013.

GELLNER, Ernest. Antropologia e política: revoluções no bosque sagrado. Rio de Janeiro: Jorge Zahar Editor, 1997. 
GODARD, Olivier. A relação interdisciplinar: problemas e estratégias. In: VIEIRA, Paulo Henrique Freire; WEBER, Jacques (Org.). Gestão de recursos naturais renováveis e desenvolvimento: novos desafios para a pesquisa ambiental. São Paulo: Cortez, 1997.

HARVEY, David. A produção capitalista do espaço. Sâo Paulo: Annablume, 2006.

HOLZER, Werther. O método fenomenológico: humanismo e a construção de uma nova geografia. In: ROSENDAHL, Zeny; CORRÊA, Roberto Lobato. Temas e caminhos da geografia cultural. Rio de Janeiro: Ed. UERJ, 2010, p. 37-71.

ISARD, Walter. History of regional science and the Regional Science Association International: the beginnings and early history. New York: Springer-Verlag, 2003.

KNORR-CETINA, Karin. Epistemic culture: how de sciences make knowledge. Cambridge: Harvard University Press, 1999.

KUHN, Thomas S. A estrutura das revoluções científicas. São Paulo: Pioneira, 1989.

LATOUR, Bruno. Ciência em ação. São Paulo: Editora da UNESP, 2000.

LEFEBVRE, Henri. La production de l'espace. L'Homme et la societé, Paris, v. 31, n. 31-32, p. 15-32, 1974.

LENCIONI, Sandra. Região e geografia. São Paulo: Edusp, 1999.

LUHMANN, Niklas. Theories of distinction: redescribing the descriptions of modernity. Stanford: Stanford University Press, 2002.

MASSEY, Doreen. For space. Los Angeles: SAGE, 2005.

MATHEWSON, Kent; SEEMANN, Jöon. A geografia histórico-cultural da Escola de Berkeley - um precursor ao surgimento da História Ambiental. Varia História, Belo Horizonte. v. 24, n. 39, jan./jun. 2008.

MATTEDI, Marcos A. Sociologia e conhecimento: introdução a abordagem sociológica do conhecimento. Chapecó: Argos, 2006.

MATTEDI, Marcos A; GRISOTTI, Marcia; SPIESS, Maiko R; BENNERTZ, Rafael. A coperformação das ciências e da sociedade. Entrevista com 
Michel Callon. Política \& Sociedade, Florianópolis, n. 14, p. 383-406, abr., 2009.

MATTEDI, Marcos; THEIS, Ivo M. Cruzando fronteiras: conhecimento e interdisciplinariedade na pesquisa em desenvolvimento regional. Redes, Santa Cruz do Sul, v. 7, n. 2, p. 77-94, 2002.

MATURANA, Humberto; VARELA, Francisco. A árvore do conhecimento: as bases biológicas da compreensão. São Paulo: Palas Athena, 2002.

MORIN, Edgar. O método III: o conhecimento do conhecimento 1. Lisboa: Publicações Europa-América, 1987.

MURDOCH, Jonathan. Post-structuralist geography. London: SAGE, 2006.

PEET, Richard. O desenvolvimento da Geografia Radical nos Estados Unidos. In: CHRISTOFOLETTI, A. Perspectivas da geografia. São Paulo: Difel, 1982, p. 225-268.

PEET, Richard; HARTWICK, Elaine. Theories of development: contentions, arguments, alternatives. London: The Guilford Press, 2009.

PIETERSE, Jan Nederveen. Development theory. London; Sage, 2013.' 'une croyance occidentale. Paris: Presses Des Sciences Po, 1996.

POPPER, Karl R. Conjecturas e refutações. Brasília: UNB, 1980.

RIST, Gilbert. Le développement: historie d'une croyance occidentale. Paris: Presses De Sciences Po, 1996.

ROBERTS, David. Self-reference in leterature. In: BAECKER, Dirk. Problems of form. Stanford: Stanford University Press, 1999, p. 27-45.

ROSTOW, W. W. The stages of economic growth. Cambridge University Press, 1960.

SACHS, Ignacy. Caminhos para o desenvolvimento sustentável. Rio de Janeiro: Garamond, 2002.

SACK, Robert David. Human territoriality. Cambridge: Cambridge University Press, 1986. 
SOJA, Edward W. Postmodern geographies: the reassertion of space in critical social theory. New York: Verso, 1989.

SOUZA, Nali de Jesus. Desenvolvimento regional. São Paulo: Atlas, 2009.

STOREY, David. Territories: the claiming of space. New York: Routledge, 2001.

SUNKEL, Osvaldo. El subdesarrollo latinoamercano y la teoría del desarrollo. México D. F.: Siglo Veintiuno, 1981.

WALLERSTEIN, Immanuel. Impenser la Science sociale: pour sortir du XIX siécle. Paris: PUF, 1991. 



\section{O desenvolvimento regional como fenômeno regional}

Jandir Ferrera de Lima ${ }^{1}$

\section{Introdução}

No dicionário da língua portuguesa, a PAlaVRa "FenÔMeno" 1 remete a fato ou evento que pode ser descrito e explicado cientificamente. Como o desenvolvimento regional pode ser entendido como etapa ou processo que explica como regiões atrasadas se tornaram regiões avançadas, então, a compreensão do desenvolvimento regional por parte dos pesquisadores das sub-áreas das Ciências Sociais Aplicadas e das Ciências Humanas impõe o uso e rigor do método cientifico e suas etapas.

A busca para compreender o fenômeno regional do desenvolvimento, em especial nas Ciências Sociais Aplicadas, remonta às teorias do desenvolvimento regional, que surgiram a partir dos anos 1960 como um contraponto às teorias da localização. Até a primeira metade do século XX, as contribuições de Johan-Heinriche Von Thünen, August Losch, Walter Christaller e Alfred Weber dominavam a cena na discussão da localização das atividades produtivas, da centralidade e hierarquia dos lugares. Consequentemente, essas contribuições explicavam o porquê determinados lugares eram mais atrativos que outros, em especial como o espaço se organizava a partir das suas atividades produtivas e áreas de mercado. Apesar de essas contribuições terem sido criadas no domínio da geografia, a Ciência Econômica absorveu os conceitos e elementos da geografia humana e regional, em especial aqueles relacionados à distância e localização, criando o que se convencionou chamar de economia espacial, ampliando o escopo de análise das teorias da localização.

1 Professor do Programa de Pós Graduação em Desenvolvimento Regional eAgronegócio (PGDRA) da Universidade Estadual do Oeste do Paraná (UNIOESTE). Pesquisador e bolsista do Conselho Nacional de Desenvolvimento Científico e Tecnológico (CNPq) e da Fundação Araucária (PR). Pesquisador associado do GRIR/UQAC e CRDT/Canadá E-mail: Jandir.lima@unioeste.br. 
Mais recentemente, a Ciência Econômica deu uma nova contribuição ao estudo da geografia e as teorias da localização propondo a chamada "nova geografia econômica”.

Na concepção do conjunto das teorias da localização, a organização espacial das redes de cidades servia para definir as áreas de mercado, a distribuição da população e a organização do espaço. Espaços mais atrativos à população, por consequência, estimulavam novas aglomerações, novas centralidades e áreas de mercado, num movimento cumulativo reordenando a hierarquia dos lugares. Isso demonstra que o espaço não é neutro e é reflexo das ações humanas (LACOUR; GASHET, 2002).

Apesar das teorias da localização terem colocado os elementos distância, espaço e lugar no debate sobre a organização do espaço, esses elementos não eram suficientes para explicar as desigualdades regionais. A forma como o espaço se organiza, a forma como os centros urbanos se formam e se articulam em função das atividades produtivas ainda demandam teorizações para explicar o porquê determinadas regiões, mesmo sem atrativos locacionais, avançam mais do que outras em termos de desenvolvimento. Ou seja, as teorias da localização têm como restrição os aspectos sistêmicos, complexos e relacionais do desenvolvimento socioeconômico. Nesse quesito, as teorias do desenvolvimento regional surgem para cobrir uma lacuna deixada pelas teorias da localização: explicar o fenômeno regional do desenvolvimento. O presente texto reflete a orientação da pesquisa na área de desenvolvimento regional, chama a atenção para o subdesenvolvimento regional, como elemento esquecido nas pesquisas; e, reflete o desenvolvimento como um componente da Ciência Regional como reflexo de uma orientação: a territorialidade do desenvolvimento.

\section{A pesquisa em desenvolvimento regional como um saber interdisciplinar}

A grande lição apreendida com as restrições e limitações das teorias da localização é que não se poder compreender o desenvolvimento regional de forma monodisciplinar. $\mathrm{O}$ fenômeno regional que conduz ao desenvolvimento regional exige uma visão multi e interdisciplinar, ou seja, exige o diálogo permanente com outras áreas do conhecimento. Tanto que em diferentes períodos do século XX, a ideia de desenvolvimento envolveu diversas nomenclaturas para atender suas diversidades e ser capaz de englobar uma concepção ligada a diferentes escolas do pensamento e ciências. 
É certo que a linha de análise a ser seguida pelos pesquisadores e pesquisadoras do desenvolvimento regional podem lhes remeter a um foco muito especifico de análise. Mas, a ideia do desenvolvimento como um processo multidimensional exige a compreensão de elementos tangíveis e intangíveis. Por exemplo, para Perroux (1979), o desenvolvimento é uma mudança social e mental. Essa mudança define e explica o processo que conduz ao crescimento econômico e a melhoria nas condições de vida das regiões. Essa concepção chamou a atenção para a necessidade de estudos que envolvessem a abordagem de desenvolvimento numa dimensão mais abrangente, mais sistêmica com outras disciplinas e áreas do conhecimento, pois enquanto o crescimento econômico remete a relações de produção, a melhoria nas condições de vida remete a psicologia e as relações sociais. E cada região tem especificidades, particularidades tanto físicas como sociais, que as diferenciam de outras, mesmo sob o mesmo sistema de produção. Assim, na evolução da economia espacial e da geografia humana, das teorias do desenvolvimento econômico e das próprias ciências sociais, surgiu a concepção de Ciência Regional, como ramo das ciências para explicar o fenômeno do desenvolvimento nas regiões.

O termo Ciência Regional foi forjado por Walter Isard ao final do século XX, numa tentativa de estimular o diálogo e um conjunto de teorizações que pudesse explicar o desenvolvimento regional. Além disso, estimular a discussão coletiva e englobar os pesquisadores de diferentes ramos do conhecimento científico, cujo objeto de análise é o desenvolvimento regional. A Ciência Regional, segundo Proulx (1996: 05) “(...) busca explicar as diferenças ambientais, sociais, culturais, políticas e econômicas entre as diferentes regiões que formam o território nacional (...)". A explicação das diferenças e desigualdades regionais embarcadas no conceito de desenvolvimento regional, como objeto de um grupo interdisciplinar de pesquisadores, marca uma nova etapa no pensamento do desenvolvimento. Então, o desenvolvimento e região, que antes eram apenas um objeto de pesquisa e preocupação dos economistas e geógrafos, ganha uma nova ênfase no trabalho dos historiadores, sociólogos, cientistas políticos, planejadores e antropólogos. Assim, a alcunha de "desenvolvimento regional", como uma etapa e um processo, apresenta dimensões que transcendem o corpo teórico de uma única escola de pensamento e demanda abordagens interdisciplinares. Ser pesquisador da área de desenvolvimento regional exige a capacidade de interagir com os conceitos de diversas áreas do conhecimento 
Com isso, a explicação do desenvolvimento de diferentes comunidades, que habitam espaços sub-nacionais e exploram recursos naturais de uma mesma magnitude, reside em conceitos e concepções muito mais amplas que a simples acumulação de riqueza física. As mudanças no modo de vida e o progresso das comunidades no âmago das regiões emergem como um desafio a novas abordagens de desenvolvimento, que congreguem uma série de fatores, elementos e particularidades regionais. Mais que os recursos materiais, há elementos intangíveis, e algumas vezes não quantificáveis, que influenciam a dinâmica socioeconômica das regiões e no seu estágio de desenvolvimento.

De uma forma bem ampla, a teoria do desenvolvimento regional busca conhecer o papel do espaço, da política pública e dos territórios na melhoria da qualidade de vida e no progresso econômico das regiões. Por isso, ela interage com conceitos como de centralidade, de redes de informação, de atração, de repulsão, de distancia, de ambiente de inovação, dentre outros, numa gama ampla de relações.

Enquanto na economia espacial e na teoria da localização são os elementos geográficos e suas particularidades que tem importância, nas teorias do desenvolvimento regional há um conjunto mais amplo de relações econômicas e sociais que tem como lugar de articulação as regiões. Isso não significa que a concepção de espaço perde importância, mas que as relações que se produzem nas regiões, sejam elas tangíveis ou intangíveis, conduzem a transformações no espaço e no perfil do desenvolvimento (CLAVAL, 1995).

A região surge como uma categoria de análise, porque congrega territórios, etnias e diferentes espaços. No entanto, a concepção da transformação dos povos é, em muitas ciências, material. Por isso, o papel das forças produtivas na transformação do espaço e das relações sociais ganhou relevância na ideia do desenvolvimento e como seu elemento de transformação. Mas, ao longo do tempo, coube às discussões do desenvolvimento regional incorporar um conhecimento multidisciplinar trazido pelas teorizações do desenvolvimento e agrega-las às teorias da localização para avançarem num novo campo do saber: a Ciência Regional. Em resumo, a teorização do desenvolvimento regional compõe a Ciência Regional, fundada por Walter Isard no final dos anos 1960.

No caso brasileiro, o avanço da pós-graduação stricto sensu na área Planejamento Urbano e Regional/Demografia (PUR/Demografia), acontece a partir da década 1970 e sua expansão significativa no inicio do século XXI. De o6 programas existentes em 1998, em 2016 já eram 47 
programas, o que perfez um crescimento médio de mais de $10 \%$ ao ano. Na mesma linha, o volume de discentes titulados saltou de 39 para 364 no mesmo período (CAPES, 2016). Isso demonstra a construção de uma nova linha de abordagem dentro da formação e pesquisadores regionalistas: a linha do desenvolvimento regional. Demonstra também a interiorização da pesquisa na área regional, que chegou às regiões periféricas do Brasil, haja vista que mais de 50\% dos cursos na área estão localizados fora das regiões metropolitanas e capitais estaduais. O conhecimento científico na área de desenvolvimento regional se transfere de centros tradicionais de pesquisa para centros localizados em regiões periféricas.

Além de contribuir para discutir o perfil do desenvolvimento, a construção de políticas públicas e ações para intensificar e melhorar o processo de desenvolvimento das regiões, os Programas na área PUR/ Demografia/Desenvolvimento Regional trazem ao debate um elemento que é inerente à Ciência Regional: a interdisciplinaridade. O documento da área (CAPES, 2016: o8-o9) aponta duas vertentes na definição da interdisciplinaridade: o dialogo e a colaboração entre as disciplinas cientificas, tanto na discussão acadêmica em classe como na pesquisa cientifica; os condicionantes históricos que conduzem a interdisciplinaridade, ou seja, ela produto das condições históricas e sociais da época na qual se vive. De certa forma, ao se tratar a categoria região e seu processo de desenvolvimento, no qual interferem elementos tangíveis e intangíveis, mensuráveis e imensuráveis, a interdisciplinaridade se impõe a determinadas linhas de pesquisa. Assim, cientes ou não, os programas e estudos na área de desenvolvimento regional, vinculados à área de Planejamento Urbano e Regional/Demografia/Desenvolvimento Regional da CAPES, vão construindo a Ciência Regional brasileira. E o desenvolvimento regional nada mais é do que um campo de saber dessa Ciência em construção.

\section{Desenvolvimento regional e Ciência Regional: uma nova orientação}

Ao longo dos últimos anos muitos estudos oriundos da geografia, ciências sociais, economia, dentre outros, discutiram conceitos e estratégias de desenvolvimento. Dentre eles, a ideia de polos de desenvolvimento, corredores de desenvolvimento, regiões de aprendizagem, clusters territoriais, distritos industriais, desenvolvimento local, desenvolvimento territorial. Esses estudos revelaram o interesse dos pesquisadores pela compreensão dos fenômenos regionais, em especial aqueles que explicam 
as migrações, o desempenho diferenciado de regiões isoladas ou com poucos recursos naturais, além da metropolização acentuada.

O que se percebeu foi que mais que uma atração fortalecida pelo progresso técnico, há regiões diferenciadas que conseguiram construir o processo de desenvolvimento de forma autônoma a partir de expertises ou recursos puramente locais. Por vezes, a construção do processo de desenvolvimento não é pacifica, mas plena de conflitos. O desenvolvimento não surge de forma equilibrada, mas causando tensões, quebrando paradigmas e construindo novas estruturas, ampliando contradições, que convivem com as antigas estruturas até sua substituição (FIJALKOW, 2002).

Da mesma maneira, apesar de tantas teorizações e intervenções regionais, se percebeu a dificuldade de algumas regiões em saírem do atraso para avançarem para estruturas mais modernas de desenvolvimento. Enquanto algumas regiões enriquecem, outras empobrecem. Então, nos últimos anos se observou que não se pode construir o processo de desenvolvimento sem o elemento territorial. Desenvolver implica no desenvolvimento humano e valorizando as forças vivas do território. $\mathrm{E}$ as forças vivas do território são as que exercem o poder e definem os rumos do processo de desenvolvimento. Então, desenvolvimento regional é um pacto territorial. Por vezes, nesse pacto, recursos que pareciam marginais e sem muita utilidade se tornam elementos de dinamismo e altamente lucrativos. Da mesma forma que grandes áreas urbanas se fortalecem a partir do mercado interno e de uma rede de serviços e produção industrial, as pequenas comunidades também guardam potenciais produtivos.

Isso remete as grandes temáticas que demandam mais e mais o foco da pesquisa em desenvolvimento regional, enquanto Ciência Regional: a territorialidade do desenvolvimento, os mecanismos para a intervenção da política pública, as metamorfoses e as redes de acumulação do capital entre cidades e áreas rurais e a manutenção do círculo vicioso da pobreza em escala regional e territorial.

A intervenção da políticas pública e sua relação com o círculo vicioso da pobreza foi explorado nos estudos de Myrdal (1978). O autor se questionou se as ciências sociais sozinhas são capazes de responder aos imperativos sociais e são capazes de fornecer respostas adequadas e elementos para se construir políticas públicas para a intervenção regional. A dúvida colocada pelo autor advém de seus estudos sobre a pobreza dos afrodescendentes nos Estados Unidos da América. No caso, o processo de desenvolvimento regional é um processo circular e cumulativo. Ou seja, a pobreza reforça a pobreza, a menos que por meio de políticas públicas se 
possa romper o círculo vicioso e criar um círculo virtuoso. Nesse caso, o mercado por si só não é capaz de conduzir o processo, que demanda instituições públicas de viés social, ações intervencionistas e investimentos sociais.

Já as relações entre polos urbanos áreas rurais demandam mais atenção à formação das cadeias produtivas e ao papel da liderança territorial. No caso da liderança territorial, o sentimento de pertencimento e a identificação com o território suscitam uma motivação adicional ao lucro para empreender e construir estruturas produtivas em locais pouco atrativos para alguns capitais. Já no final do século XX, Schultz (1971) argumentava que as pessoas são mais que força de trabalho repetitivo, elas também são recursos criativos. Para melhorar esses recursos criativos a valorização do ser humano, o desenvolvimento humano seria o principal foco da política pública de desenvolvimento regional. Construir desenvolvimento regional remete a construir cidadania nas regiões. Então, todo processo de desenvolvimento regional tem uma orientação: produzir desenvolvimento humano para superar o subdesenvolvimento.

\section{Subdesenvolvimento regional e o fenômeno regional}

Com os estudos clássicos de Celso Furtado, Gunnar Myrdal e outros teóricos do desenvolvimento econômico, em especial aqueles ligados à teoria da dependência, se descobriu que o subdesenvolvimento econômico não era meramente uma etapa do desenvolvimento. Mais do que diferenças entre o perfil do espaço que é considerado desenvolvido e aqueles que ainda não estão nesse estágio, a ideia de que o subdesenvolvimento tem uma dinâmica própria e se retroalimenta num processo cumulativo impôs aos estudos do desenvolvimento a necessidade de uma pesquisa propositiva de políticas públicas de desenvolvimento, tanto para os governos centrais quanto para os governos locais. No caso das lideranças locais, a proposição de atividades e ações em prol da transformação de economias e sociedades retardatárias em avançadas se tornou a principal demanda em termos de resultado de pesquisa.

É certo que o processo de desenvolvimento capitalista é desigual por natureza e produz a exclusão e dominação de regiões e sociedades. Por mais que as economias regionais se dinamizem, haverá sempre diferenças no perfil do crescimento econômico entre as regiões, bem como da distribuição dos benefícios desse crescimento econômico, que se reflete na polarização. Nas regiões polarizadas as relações econômicas 
internas são mais intensas que as mantidas com as regiões periféricas a ela. Internamente há uma relação de dependência, caracterizada pela hierarquização interna definida pelo perfil das economias urbanas e rurais. Em geral, as economias com um continuum urbano industrial são mais dinâmicas e dominantes em relação às economias urbanas com um continuum exclusivamente urbano rural. A existência desses dois tipos de continuum já demonstra que uma concertação territorial e a dualidade inerente ao processo de desenvolvimento regional (FERRERA DE LIMA, 2010).

Frente ao exposto, uma agenda de pesquisa do fenômeno regional pelos centros de pesquisa deve estar voltada também à dinâmica do subdesenvolvimento regional. Isso implica em assumir que o processo do desenvolvimento regional não ocorre em todas as regiões ao mesmo tempo, mas tem temporalidades e intensidades diferenciadas, que produzem contínuos espaciais e estabelecem toda uma psicológica própria de relações sociais nas coletividades regionais.

Para Scott (2003), o desenvolvimento regional enquanto processo tem causalidade bidiretiva, ou seja, o fortalecimento da aglomeração (e dos agentes econômicos) contribui para o desenvolvimento econômico da região e este serve de estímulo à expansão da aglomeração, num processo circular e cumulativo. Consequentemente, o processo também produz um fenômeno inverso em termos de subdesenvolvimento regional.

Além dessa casualidade bidiretiva, Forbes (1989) sustenta que as relações sociais e espaciais de produção são interdependentes e interreativas. Nessas relações o espaço se torna um depositário de força de trabalho e de excedente econômico apropriado, entre quem produzo o excedente e pouco participa da sua apropriação. $\mathrm{O}$ processo de desenvolvimento regional reflete então a dialética socio-espacial das relações entre os indivíduos e a estrutura de produção para manter uma dinâmica que se reflete na ampliação da acumulação de capital e no fortalecimento da polarização. As regiões desenvolvidas são mais hábeis nessa dinâmica. Já as regiões subdesenvolvidas são menos dinâmicas e dependentes da acumulação de capital que ocorre nas regiões desenvolvidas. Ou seja, o fenômeno regional que conduz processo de desenvolvimento das regiões também pode gerar um processo obscuro: as regiões subdesenvolvidas e o fortalecimento do subdesenvolvimento regional.

A explicação para a natureza das regiões subdesenvolvidas, a forma como se dinamizam e retroalimentam seu empobrecimento também deve ser procurado nas características territoriais. A resiliência à 
transformação social, humana e produtiva cada vez demanda o conhecimento do perfil territorial e a forma como poder é exercido e influencia na gestão da base produtiva e nas relações sociais. Ou seja, a forma como as comunidades se apropriam do processo de desenvolvimento reflete $\mathrm{o}$ resultado de um conjunto de ações em prol de projeto de auto-transformação dessa comunidade.

Em suma, a construção de uma ciência da região implica em construir agendas de pesquisa, abordagens metodológicas e perspectivas de intervenção regional que possam levar regiões subdesenvolvidas a desenvolvidas ou a fortalecer o processo de desenvolvimento regional sem incorrer no fortalecimento de polarizações.

\section{Considerações finais}

As Ciências Sociais Aplicadas possuem toda uma gama de modelos teóricos que respondem e fornecem pistas claras dos elementos mais importantes para o desenvolvimento regional, a partir de uma série de estudos de caso. Esses modelos são ferramentas que fornecem elementos para criar políticas públicas de intervenção regional e estratégias de desenvolvimento. Mesmo assim, a concentração da riqueza entre as regiões e territórios permanece se fortalecendo ao longo do tempo, o que demonstra a necessidade de se conhecer a natureza da convergência entre as regiões, e, em especial, as características locais de comunidades e seu papel na promoção do desenvolvimento.

Apesar das cadeias produtivas serem consideradas o motor do crescimento econômico regional, o dinamismo comunitário, a liderança e a resiliência vêm se impondo como categorias para se compreender como as decisões inerentes ao indivíduo e a coletividade regional conseguem transformar espaços pouco atrativos ao capital e à logica das cadeias de valor. Em outros espaços regionais é a criação de certas oportunidades sociais, tais como: saúde, educação, equipamentos comunitários, que fazem a diferença na formação de um capital humano pleno para estimular o processo de desenvolvimento.

No mundo moderno, com novas facilidades de locomoção, com a transmissão rápida da informação e condições mais facilitada de acesso e bens e serviços, urge se produzir novos modelos teóricos e metodológicos para se avançar na compreensão do fenômeno do desenvolvimento regional. Para isso, se faz essencial identificar, analisar e propor políticas de intervenção regional bem consubstanciada por analises com rigor 
metodológico. Nesse sentido, as pesquisas em desenvolvimento regional e mesmo planejamento regional demandam uma nova orientação, no sentido de tornar a interdisciplinaridade a principal característica da Ciência Regional em construção.

Além da interdisciplinaridade, a compreensão do fenômeno regional também exige a abordagem holística multidisciplinar. Os princípios e postulados de algumas ciências humanas e sociais aplicadas devem se ajustar ao aspecto regional a partir da sistematização de dados e da percepção e ações das lideranças locais. Assim, os procedimentos metodológicos são ferramentas, mas não são princípios ou leis, apenas instrumentais que podem ser usados de acordo com as características do objeto e do problema de pesquisa. Nesse sentido, seria preferível que a pesquisa e os pesquisadores (as) estivessem descolados de ideologias pessoais.

Portanto, os estudos científicos aplicados ao fenômeno regional, respeitando as regras do método científico, são capazes de conduzir a área de desenvolvimento regional em direção a orientações mais precisas em termos de análises sobre o processo de desenvolvimento ou subdesenvolvimento. Mais ainda, direções válidas para se construir um novo campo do saber e fomentar a Ciência Regional brasileira.

\section{Bibliografia}

CAPES. Documento da área Planejamento Urbano e Regional/ Demografia. Brasília : CAPES, 2016.

CLAVAL, P. Comment s'organise l'espace régional? Revue Sciences Humaines, no o8, p.6-8, 1995.

FERRERA DE LIMA, J. Les institutions et la concertation territoriale. Organisations et Territoires. Québec, vol.19, nº 01, p.05-10, 2010.

FIJALKOW, Yankel. Sociologie de la ville. Paris : PUF, 2002.

LACOUR, C.; GACHET, F. Métropolisation, centre et centralité. Revue d'Économie Régionale et Urbaine (RERU), noo 01, p.49-72, 2002.

FORBES, D. K. Uma visão critica da geografia do subdesenvolvimento. São Paulo: Bertrand Brasil, 1989.

MYRDAL, G. Procès de la croissance. Paris : PUF, 1978. 
PERROUX, F. Filosofia do novo desenvolvimento. Lisboa: Fundação Calouste Gubenkian, 1979.

PROULX, M-U. (sous la direction). Le phénomène régional au Québec. Québec: PUQ, 1996.

SCHULTZ, T. W. Investment in human capital. New-York : Harper and Hall, 1971.

SCOTT, A. La poussée régionale : vers une géographie de la croissance dans les pays en développement. Géographie, Économie et Société, vol. 05, no 01 p.31-57, 2003. 



\section{A dimensão regional do desenvolvimento: contribuições teóricas e experiências sul-americanas ${ }^{1}$}

Virginia Elisabeta Etges ${ }^{2}$

\section{Introdução}

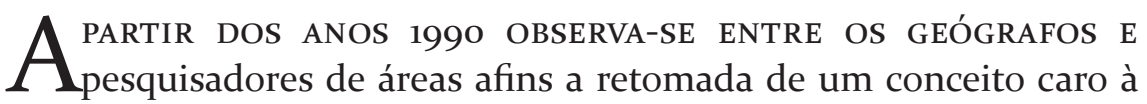
Geografia, o território. A retomada do conceito acontece num contexto de importantes reflexões e ações voltadas ao desenvolvimento regional, principalmente no âmbito latino-americano.

Expressão da materialidade que lhe é dada pelo seu uso, o território, mais do que simples base física, traz a marca de gerações que lhe deram forma através de seu trabalho e dos embates políticos, econômicos e sociais; é expressão do nível tecnológico que os seus habitantes alcançaram; mas, acima de tudo, é resultante do tipo de organização social ali criada.

Quanto mais próxima esta organização for da perspectiva territorial, mais estreita será a relação com a natureza, no sentido de conhecer e respeitar os seus limites e mais solidária ela será, uma vez que estará voltada ao respeito e à integridade de todas as formas de vida, inclusive a humana.

Compreender, pois, o significado da concepção de território, implícito nessa reflexão, se faz indispensável. É o que abordamos na primeira parte do artigo. A seguir, discutimos o significado das dimensões local e regional no contexto do desenvolvimento territorial e sua repercussão na experiência da IIRSA, em âmbito sulamericano, e nas experiências dos Coredes e de Consórcios Intermunicipais no sul do Brasil.

1 Versão revisada e atualizada de artigo originalmente publicado em Etges (2014).

2 Geógrafa, doutora em Geografia pela Universidade de São Paulo - USP, docente do Programa de Pós-Graduação em Desenvolvimento Regional na Universidade de Santa Cruz do Sul - UNISC, líder do Grupo de Pesquisa em Desenvolvimento Regional e Bolsista de Produtividade em Pesquisa do CNPq (etges@unisc.br) 


\section{Território e Globalização}

Segundo Milton Santos (1996), nas atuais condições, os arranjos territoriais não se dão apenas através de figuras formadas de pontos contínuos e contíguos. Hoje, ao lado dessas manchas, ou por sobre essas manchas, há, também, constelações de pontos descontínuos, mas interligados, que definem um território de fluxos reguladores. As segmentações e partições presentes no território sugerem que se admitam, pelo menos, dois recortes. De um lado, há extensões formadas de pontos que se agregam sem descontinuidade, como na definição tradicional de região. São as horizontalidades. De outro lado, há pontos no território que, separados uns dos outros, asseguram o funcionamento global da sociedade e da economia. São as verticalidades. O território se compõe de uns e de outros desses recortes, inseparavelmente. É a partir dessas novas subdivisões que devemos pensar novas categorias analíticas.

Estudando a diferença entre lugares modernizados e lugares letárgicos no norte da Patagônia argentina, Silveira (apud SANTOS, 1996) examina o funcionamento da produção e da circulação, e mostra como essas lógicas cruzam as cidades e produzem um arranjo territorial em que superpõem vinculações horizontais e verticais. As verticalidades são vetores de uma racionalidade superior e do discurso pragmático dos setores hegemônicos, criando um cotidiano obediente e disciplinado. As horizontalidades são tanto o lugar da finalidade imposta de fora, de longe e de cima, quanto o da contrafinalidade, localmente gerada. Elas são o teatro de um cotidiano conforme, mas não obrigatoriamente conformista e, simultaneamente, o lugar da cegueira e da descoberta, da complacência e da revolta.

Santos (1996) acrescenta ainda que, paralelamente, forças centrípedas e forças centrífugas atravessam o território, como tendências ao mesmo tempo contrastantes e confluentes, agindo em diversos níveis e escalas.

As forças centrípedas resultam do processo econômico e do progresso social, e tanto podem estar subordinados às regularidade do processo de produção, quanto às surpresas da intersubjetividade. Essas forças centrípedas, forças de agregação, são fatores de convergência. Elas agem no campo, na cidade e entre cidade e campo. No campo e na cidade, elas são, respectivamente, fatores de homogeneização e de aglomeração. E entre o campo e a cidade, elas são fatores de coesão.

As forças centrífugas, por sua vez, podem ser consideradas um fator de desagregação, quando retiram à região os elementos do seu próprio 
comando, a ser buscado fora e longe dali. Pode-se falar numa desestruturação, se nos colocamos em relação ao passado, isto é, ao equilíbrio anterior; e de uma reestruturação, se vemos a coisa do ponto de vista do processo que está se dando. Entre os fatores longínquos, causadores de uma tensão local, contamos o comércio internacional, as demandas da grande indústria, as necessidades do abastecimento metropolitano, o fornecimento de capitais, as políticas públicas ditadas nas metrópoles nacionais ou estrangeiras.

Assim, forças centrípedas conduzem a um processo de horizontalização, forças centrífugas conduzem a um processo de verticalização. Mas, em todos os casos, sobre as forças centrípedas, vão agir forças centrífugas. Essas forças centrífugas se dão em diversas escalas, a maior delas sendo o planeta tomado como um todo, os chamados fluxos universias. Entre o lugar e o mundo, as outras escalas são regionais, nacionais e continentais. Tal superposição faz com que a explicação do que se passa dentro de cada área deva obrigatoriamente incluir as escalas superiores. A solidariedade interna ao subespaço, providenciada pelas forças centrípedas, está permanentemente perturbada pelas forças centrífugas e deve permanentemente ser refeita.

Neste contexto estamos hoje longe daquela solidariedade orgânica, que era o próprio cerne da definição do fenômeno regional, complementa Santos (1996, p. 226). O que temos hoje são solidariedades organizacionais, criadoras de uma coesão organizacional baseada em racionalidades de origens distantes, mas que se tornam um dos fundamentos da sua existência e definição.

Portanto, o território é processo, uma forma-conteúdo, traço de união entre o passado e o futuro imediato. Ele tem que ser visto como um campo de forças, como um lugar de exercício de contradições entre o vertical e o horizontal, entre o Estado e o mercado, entre o uso econômico e o uso social dos recursos.

É nesse sentido que o território hoje é nervoso, instável, afirma Santos (1999). E é por isso que, a partir do território, se verifica no Brasil a crise da Nação. Não há melhor indicador da crise por que passa a Nação que o território, afirma o autor; pela sua nervosidade, pela sua instabilidade, pela sua ingovernabilidade, enquanto território produzido. Isto tudo é resultado das mudanças rápidas de normas que reconhecemos como luta global pela mais-valia maior, essa competitividade que está na raiz mesma da posição ocupada na economia global e exige uma adaptabilidade permanente das normas das grandes empresas, o que aumenta a 
instabilidade do território „de cima“ para „baixo“. Isto é, a produção da ordem para as empresas e da desordem para todos os outros agentes, e para o próprio território, incapaz de se ordenar porque ideologicamente está decidido que estas grandes empresas são indispensáveis. Assim aceitamos a idéia de que o território tem que ser desorganizado. É o que nós estamos fazendo, complementa o autor. Tudo isto se coloca num contexto em que o poder maior sobre o território deixa de ser do Estado e passa a ser das grandes empresas, explica Santos. A gestão do território, a regulação do território são cada vez menos possíveis pelas instâncias ditas políticas e passam a ser exercidas pelas instâncias econômicas. $\mathrm{O}$ que acontece é que hoje a economia se realiza pela política. Não é a economia que ocupa hoje a posição central; é a política exercida pelos agentes econômicos hegemônicos. E, o que é grave, conclui o autor, é que as necessidades das empresas globais, e isso o território mostra, arrastam os governos - nacional, estaduais, no caso do Brasil, e locais.

Nesse sentido, uma importante iniciativa, no âmbito sul-americano, evidencia a constatação de Santos. Trata-se da Iniciativa para a Integração da Infraestrutura Regional Sul-Americana - IIRSA, criada por ocasião da I Reunião de Presidentes da América do Sul, realizada em 200o, que propõe a "integração" do continente a partir de verdadeiros "rasgos" no território, também chamados de "eixos de integração", atendendo a segmentos econômicos interessados, basicamente, na aceleração do escoamento de commodities para os grandes centros de consumo mundiais.

\section{O significado da dimensão local e regional no território}

Observa-se, nos dias atuais, que vários autores entendem o local e o regional como sinônimos. No nosso entender isso tem levado a sérios equívocos na interpretação da realidade, uma vez que se trata de duas dimensões de abordagem que devem ser devidamente esclarecidas.

Ao longo dos anos 1990, de acordo com Brandão et al (2006), as temáticas atinentes à dimensão territorial do desenvolvimento readquirem relevância ao mesmo tempo em que ocorre certa banalização e vulgarização da problemática, principalmente quando se trata de escalas de abordagem. Essa questão foi deslocada, muitas vezes, para o lugar comum do voluntarismo, cristalizando um grande consenso, que por vezes exagera no endogenismo, levando a literatura e as muitas políticas públicas, em todo o mundo, a acreditar que a escala local é a mais adequada, de onde 
se poderia estruturar a força sinérgica comunitária, capaz de promover o verdadeiro desenvolvimento sustentável.

Esta abordagem teórica sugere que estaríamos vivendo a possibilidade de consolidar um novo padrão de desenvolvimento, construído totalmente no âmbito local, dependente apenas da força de vontade dos agentes empreendedores, que mobilizariam as potências endógenas (ocultas e/ou reveladas) de qualquer localidade. Essas concepções afirmam que todas as escalas intermediárias entre o local e o global estariam perdendo sentido. (BRANDÃO et al, 2006, p.196)

É óbvio, reafirma o autor, que no âmbito local muitas ações importantes podem ser articuladas e promovidas. Mas a escala local encontra uma série de limites que devem ser levados em conta nas políticas de desenvolvimento. A realidade, em todo o mundo, tem mostrado que as políticas de desenvolvimento com maiores e melhores resultados são justamente as que não discriminam nenhuma escala de per se, mas reforçam a dimensão multiescalar inerente aos problemas a serem enfrentados.

Essa constatação reafirma a perspectiva de análise proposta por Lacoste (1988), que privilegia a abordagem da espacialidade diferencial dos fenômenos a serem analisados, como caminho mais eficaz de compreensão da realidade.

Em uma perspectiva crítica, observa-se que a organização das forças produtivas na atual fase do capitalismo, coloca em evidência a tensão entre as "forças globalizantes" e as "forças regionalizantes".

Trabalhos recentes discutem a persistência da região enquanto categoria de análise. Nas palavras de Limonad (2004, p. 57)

devemos recordar que a região, a despeito de todas as adjetivações que a acompanham e perseguem, é antes de qualquer coisa uma construção social que atende interesses políticos precisos, mesmo em se tratando de uma região funcional, ou da região natural. Muito embora, não haja meios de definirmos de forma categórica uma linha divisória precisa, um marco delimitador que permita o cientista afirmar aqui termina uma região $\mathrm{A}$ e ali começa uma região $B$, pois o espaço é uma expressão de continuidades e descontinuidades físicas e sociais. Então ressurge o aspecto que assombrou durante décadas o pensamento social na geografia, no planejamento, na gestão territorial: como definir a região, como regionalizar? 
Segundo Corrêa (1997, p. 191), é a diferenciação de áreas, resultante tanto de processos da natureza como sociais, que constitui as bases da possibilidade de se poder falar em regiões.

A diferenciação de áreas não está, no nosso entender, associada à ideia de singularidade, que entendemos vincular-se ao conceito de lugar, mas sim à ideia de particularidade, isto é, uma mediação entre o universal (processos gerais advindos da globalização) e o singular (a especificação máxima do universal).

A região constrói-se, portanto, a partir de distintos agentes em múltiplas escalas articuladas que, de certa forma, encontram um rebatimento em práticas e processos sócio espaciais, histórica e geograficamente localizados, o que permite a Silveira (1999, p. 386) salientar que o "local e o global se afirmam e se negam dialeticamente na região".

Uma regionalização pode fundamentar uma reflexão teórica ou atender a necessidades impostas por uma política setorial, uma prática de planejamento ou propostas de desenvolvimento regional. As regionalizações possíveis para um mesmo território, espaço social, podem apresentar variações em função da finalidade a que se propõem.

Neste contexto, a região, enquanto particularidade territorializada do processo geral de acumulação capitalista, adquire novo sentido. Ao mesmo tempo que expressa formações sócio econômicas, ou sócio espaciais, nas palavras de Milton Santos (1996), enquanto particularidades, ela expressa também o contra movimento à globalização, enquanto uma das extremidades do movimento que atualmente, mais do que em qualquer outro período da história, tensiona a realidade: a tensão entre o particular e o todo, entre o regional e o global.

O processo de globalização, que vem configurando os territórios mundo afora, teria pelo menos duas faces: a da perversidade do processo em si, expresso na territorialização dos interesses dos segmentos hegemônicos, e a face da oportunidade, que se apresentaria aos atores regionais quando se apropriassem de conhecimentos que lhes permitissem reagir, superar a passividade. Assim, segundo Santos (1996), é na dimensão regional que se encontraria a possibilidade da resistência ao processo perverso da globalização.

Os atores regionais, entendidos como sociedade civil organizada, nas suas mais diversas formas de expressão (Prefeituras, Associações, Pequenas Empresas, ONGS, etc), encontram-se na dimensão da horizontalidade do processo, na dimensão da contiguidade territorial, no 
chamado espaço banal, o espaço de todos, das pessoas que vivem, trabalham, buscam atividades de lazer e têm endereço. E é este o contexto potencial para o surgimento das regiões, enquanto expressões da horizontalidade, tendo como cenário, como arena, o território.

Santos (1996) complementa que a tendência atual é de que os lugares se unam verticalmente, e tudo é feito para isso, em toda parte. Créditos internacionais são postos à disposição dos países mais pobres para permitir que as redes modernas se estabeleçam a serviço do grande capital. Mas os lugares também podem se unir horizontalmente, reconstruindo aquela base de vida comum, suscetível de criar normas locais, normas regionais, que acabam por afetar as normas nacionais e globais. A região - não importando sua dimensão - seria, espontaneamente, a sede da resistência da sociedade civil. Para isso, seria indispensável insistir na necessidade de um conhecimento sistemático da realidade, mediante tratamento analítico do território, interrogando-o a propósito de sua própria constituição no momento histórico atual.

A partir do exposto, evidencia-se que a escala regional é a mais adequada para a promoção do desenvolvimento na perspectiva da sustentabilidade. A escala local (comumente entendida como o município) é restrita e frágil demais, quando se trata de enfrentar desafios que representam altos investimentos (por exemplo, em saúde: infraestrutura hospitalar; ou em transportes: construção/manutenção de estradas), ou quando se trata de enfrentar o embate com as forças globais, no sentido de garantir qualidade de vida a segmentos de trabalhadores.

Estas constatações nos permitem entender, em grande medida, o surgimento dos novos arranjos territoriais, expressos em novas regionalizações, como é o caso dos Conselhos Regionais de Desenvolvimento COREDES e dos Consórcios Intermunicipais no sul do Brasil.

A partir do exposto coloca-se o seguinte questionamento: $O$ desaparecimento de uma região acontece quando ela deixa de ser „nó“ de alguma rede (verticalidade) ou quando ela não consegue organizar-se, articularse internamente (horizontalidade)?

Cabe aqui voltar ao questionamento sobre o que é, afinal, uma região. Não há dúvida que, do ponto de vista político-administrativo, regiões podem ser definidas e mapeadas sem grandes problemas. No entanto, uma região, para que exista de fato, segundo Boisier (1999), tem que ser construída socialmente, a partir de laços comuns, de traços de identidade que se expressam no âmbito do cultural, do econômico e do político, que permitam vislumbrar desafios comuns à comunidade envolvida. 
Construir socialmente uma região significa potencializar sua capacidade de auto-organização, transformando uma sociedade inanimada, segmentada por interesses setoriais, pouco perceptiva de sua identidade territorial e definitivamente passiva, em outra, organizada, coesa, consciente de sua identidade, capaz de mobilizar-se em torno de projetos políticos comuns, ou seja, capaz de transformar-se em sujeito de seu próprio desenvolvimento.

Neste contexto, reafirma-se o papel do Estado, não enquanto agente centralizador de decisões, mas enquanto viabilizador do debate, facilitador da capacidade de organização das regiões e, principalmente, enquanto promotor de inserção das regiões no mercado global. Em outras palavras, é fazer o caminho inverso do que historicamente se fez: ao invés de apresentar o território como peça rara e valiosa em grandes leilões internacionais, o Estado deve voltar-se para dentro do seu território, visualizar suas potencialidades e promovê-las, enquanto expressões de conteúdo histórico e cultural de gerações que, de forma multicultural e interétnica, construíram um território único, e por isso, extremamente valioso.

\section{Experiências Sulamericanas e Sulbrasileiras}

\section{A IIRSA no território Sulamericano}

A Iniciativa para a Integração da Infraestrutura Regional SulAmericana - IIRSA resulta de um movimento que vem desde o início da década de 1990, quando se processava uma mudança na referência regional da identidade internacional do Brasil. Assumia-se e incentivavase uma "sul-americanidade" que vinha substituir o conceito de América Latina, que perdia o sentido no cenário internacional do pós-Guerra Fria. No contexto de formação de um espaço sul-americano visando à construção de um bloco coeso, vislumbrava-se o processo de integração das infraestruturas como motor de um projeto integracionista de maiores ambições, liderado pelo Brasil. (COUTO, 2006)

A IIRSA tem como propósito prover a região de uma infraestrutura básica, nas áreas de transporte, comunicações e energia, disponibilizando as bases para uma maior integração comercial e social do subcontinente sul-americano, a ser desenvolvida no período de dez anos. 
AAméricadoSul foi divididaem Eixos deIntegraçãoe Desenvolvimento, dentro dos quais seriam discutidos e avaliados os projetos de infraestrutura de integração.

O conceito de Eixos de Integração e Desenvolvimento, fundamentado nas ideias de Eliezer Batista, ex-presidente da Companhia Vale do rio Doce e ex-ministro de Minas e Energia do Governo de João Goulart, já tinha sido usado como subsídio à elaboração do Plano Plurianual do Governo Federal brasileiro, sob a presidência de Fernando Henrique Cardoso, para o período 2000-2003.

Figura 1 - Eixos de Integração Sul Americana - IIRSA

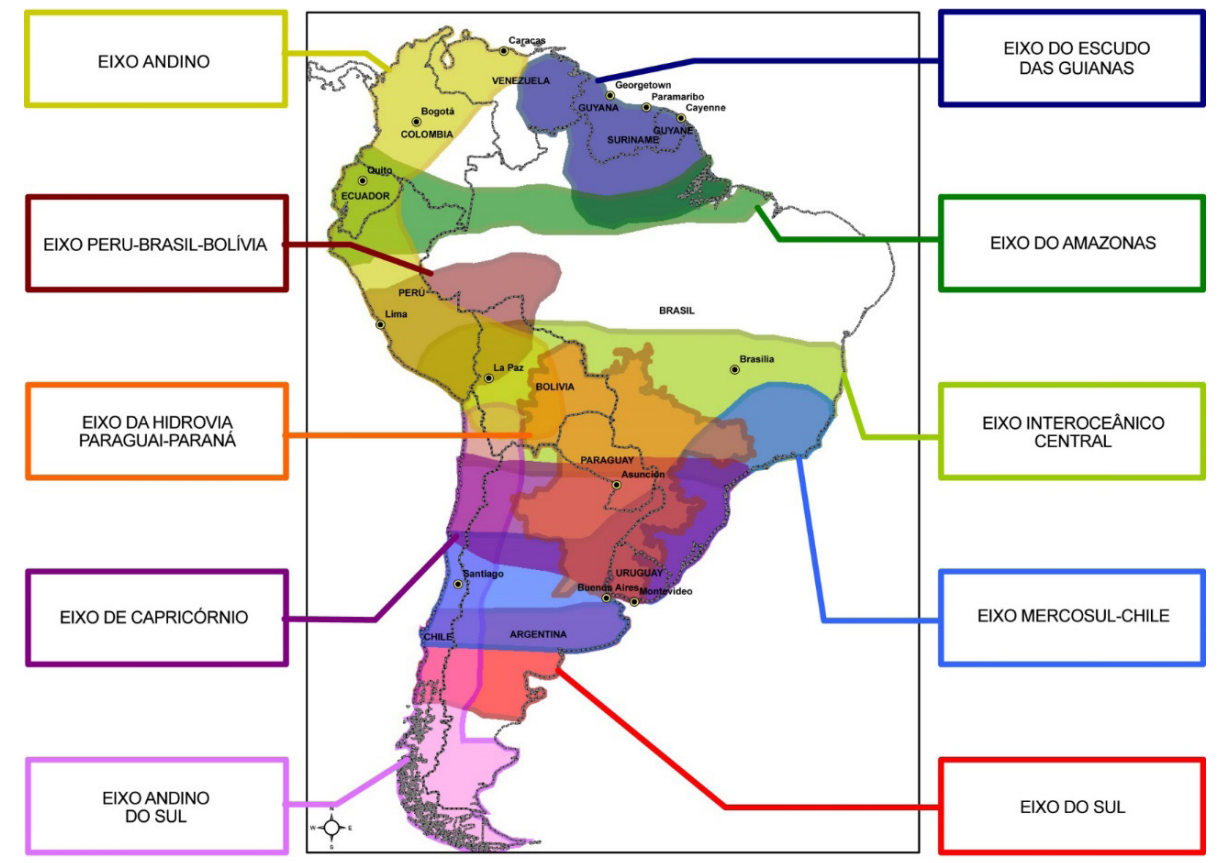

Fonte: IIRSA 
Com a IIRSA, o Brasil propõe a expansão dessa metodologia de planejamento territorial para o espaço sul-americano, com a qual se chegaria a um portfólio hierarquizado de projetos de infraestrutura, como se observa na Figura 2.

\section{Figura 2 - Agenda de Implementação Consensuada 2005-2010}

\section{IIRSA - AGENDA DE IMPLEMENTACION CONSENSUADA 2005-2010}

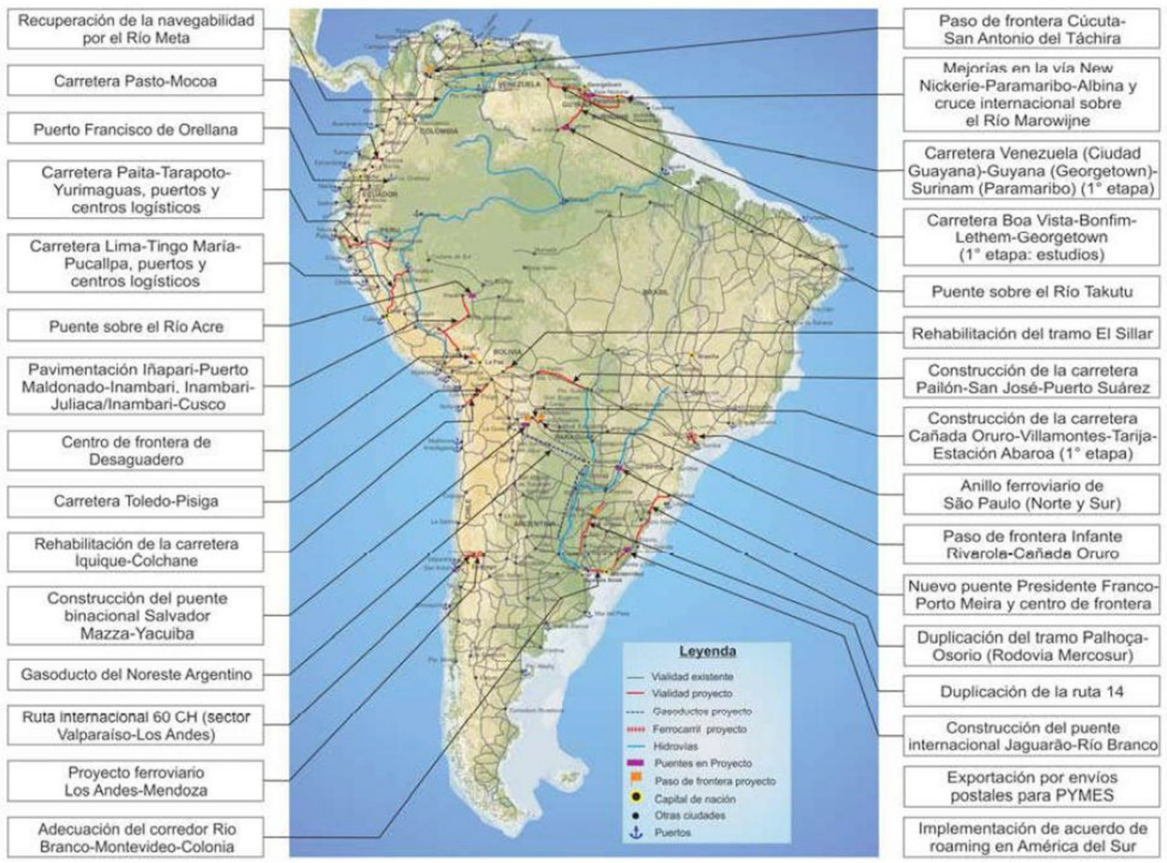

Fonte: wnw.iirsa.org

Quando se observa os valores envolvidos na implementação dos projetos dos respectivos eixos tem-se a dimensão mais clara do poder dos agentes globais, interessados na sua concretização. 
Figura 3 - Portfólio de Projetos IIRSA 2010, por EID

(Em unidades e bilhões de US\$ correntes)

\begin{tabular}{|c|c|c|c|}
\hline $\begin{array}{l}\text { Eixo de Integração } \\
\text { e Desenvolvimento }\end{array}$ & $\begin{array}{l}\text { Número de } \\
\text { grupos }\end{array}$ & $\begin{array}{l}\text { Número de } \\
\text { Projetos }^{(a)}\end{array}$ & $\begin{array}{l}\text { Investimento } \\
\text { Estimado }^{(\mathbf{b})}\end{array}$ \\
\hline Eixo do Amazonas & 7 & 58 & 5,4009 \\
\hline Eixo Andino & 10 & 64 & 7,4780 \\
\hline Eixo Capricórnio & 5 & 72 & 9,4214 \\
\hline Eixo do Escudo Guianês & 4 & 25 & 1,6949 \\
\hline Eixo Hidrovia Paraguai - Paraná & 5 & 95 & 6,6774 \\
\hline Eixo Interoceânico Central & 5 & 55 & 5,5251 \\
\hline Eixo Mercosul - Chile & 6 & 107 & 35,8362 \\
\hline Eixo Peru - Bolívia & 3 & 23 & 21,4023 \\
\hline Eixo do Sul & 2 & 27 & 2,7130 \\
\hline TOTAIS & 47 & 524 & 96,1192 \\
\hline
\end{tabular}

a) Os totais de "Número de projetos" e de "investimento estimado" mencionados não se relacionam com a soma aritmética dos totais por EID por existirem dois projetos rótula: (l) Passo de Fronteira Pircas Negras, pertencente aos Eixos de Capricórnio e Mercosul - Chile; (1l) Construção da Ferrovia Cascavel - Foz do Iguaçu, pertencente aos Eixos de Capricórnio e da Hidrovia Paraguai - Paraná (ver definição de Projeto Rótula na Seção 111 a).

b) Não são considerados os investimentos de dois projetos existentes cujos investimentos foram principalmente realizados antes do início da Iniciativa IRSA. Estes projetos são o Corredor rodoviário Santa Marta - Paraguachon - Maracibo - Barquisimeto - Acarigua, do Eixo Andino e o Sistema de Itaipu, do Eixo Mercosul - Chile.

Fonte: IIRSA, Portfolio de Projetos 2010.

Nesse contexto, segundo Couto (2006), a formação do Mercosul foi deliberadamente desviada para questões meramente comerciais. E, a integração física sul-americana com Cardoso admitia um papel reduzido aos Estados, delegando às agências regionais de desenvolvimento eà iniciativa privada o papel de incentivadores e executores do processo. Isso, segundo o autor gerava, à primeira vista, algumas ambiguidades. A primeira delas diz respeito à delegação da secretaria-executiva às agências multilaterais Corporação Andina de Fomento - CAF, ao Banco Interamericano de Desenvolvimento - BID e o Fundo para o Desenvolvimento da Bacia do Prata - FONPLATA. Na mesma linha, chama a atenção a ausência do Banco Nacional de Desenvolvimento Econômico e Social - BNDES, segundo maior banco de investimento do mundo e ator-chave para a promoção da indústria brasileira, nos trabalhos da iniciativa. Por outro lado, permitiu-se a presença do BID, no qual a influência norte-americana tende a ser muito forte. 
A partir de 2004, já no Governo Lula, passa a haver um envolvimento mais ativo da diplomacia brasileira, na tentativa de retomar a IIRSA como um instrumento da estratégia brasileira para a América do Sul.

Na realidade, o propósito passa por assegurar que os projetos não se convertam em grandes corredores de exportação, mas que possam gerar desenvolvimento nas suas áreas de influência. Antes mesmo de se concretizar uma ligação interoceânica por meio da integração das infraestruturas na América do Sul, passou-se a focalizar a importância que esses projetos podem ter no estímulo ao desenvolvimento do interior do continente que, longe da costa, está pouco conectado aos fluxos regionais. Isso porque, de acordo com Padula (2008, p. 199),

um plano de infraestrutura de transportes pode trabalhar basicamente para duas formas de integração: (a) para integrar a região no comércio global, reafirmando e acentuando nossa tendência primário-exportadora (ou exportadora de commodities), com uma boa infraestrutura voltada para fora, com conexões entre centros produtores e consumidores voltados apenas para o litoral, sem ligações adequadas e eficientes entre si; (b) para realizar a integração regional, ligando centros produtores e urbanos da própria região, encurtando as distâncias com transportes multimodais eficientes e baratos, fomentando a produção industrial dos países da região e acelerando uma integração dinâmica, com vantagens competitivas na produção e comercialização de bens industriais de alta intensidade tecnológica e valor agregado, além de ligar os países ao comércio internacional, garantindo, porém, uma inserção soberana. A primeira forma geralmente vem associada ao Estado neoliberal: privilegia a participação do setor privado nos investimentos e sustenta o Estado mínimo.

E é esta a perspectiva que vem orientando a implementação da IIRSA desde o início, bem evidenciada nos argumentos de Padula (2008, p. 192) quando afirma que

O potencial de comércio entre as principais áreas econômicas da região, especialmente entre as áreas do Atlântico e do Pacífico, não é devidamente explorado. O centro da região, área dotada de importantes recursos e ricos ecossistemas, não está devidamente ocupado e interligado ao restante do continente e ao mundo. O interior é praticamente despovoado. Exemplo disso é a região amazônica.

Na realidade, há por parte da sociedade sul-americana um grande desconhecimento a respeito do tema, decorrente da pouca disseminação de informações a respeito da iniciativa até os dias atuais. 
Cabe ressaltar, entretanto, que a partir de 2007, com a implementação do Programa de Aceleração do Desenvolvimento - PAC, financiado com recursos do BNDES, o Brasil passou a fortalecer sua posição no âmbito sul americano, uma vez que grande parte dos investimentos também estavam sendo direcionados à infraestrutura de transportes e de geração de energia, ao mesmo tempo em que a sustentabilidade social e ambiental dos empreendimentos, bem como a sua dimensão regional, estariam sendo negligenciadas.

Em 2009, a IIRSA é incorporada como secretaria técnica ao Conselho Sul-Americano de Infraestrutura e Planejamento (COSIPLAN) da União das Nações Sulamericanas (UNASUl). A incorporação da IIRSA ao Conselho pode ser entendida como resultado da cobrança dos países da região em torno de uma maior coordenação política no tema da infraestrutura, com o desenvolvimento de mecanismos que garantissem os financiamentos dos projetos, além de buscar superar a falta de conexão da iniciativa com os mecanismos de integração regional existentes, munindo-a de um "guarda-chuva" institucional ampliado. No COSIPLAN, em 2011, a Agenda de Implementação Consensuada 2005-2010 (AIC) foi reformulada e renomeada como Agenda de Projetos Prioritários de Integração (API) reunindo os mesmos 31 projetos, com prazo de conclusão das obras em 2022. (HONÓRIO, 2017).

\section{Conselhos Regionais de Desenvolvimento - COREDES}

Criados a partir de 1991 através de iniciativa articulada do governo do Estado do RS, os Coredes foram instituídos legalmente por meio da Lei no 10.283 , de 17 de outubro de 1994, e regulamentados através do Decreto no 35.764 , de 28 de dezembro de 1994. São definidos como espaço plural e aberto de construção de parcerias sociais e econômicas, em nível regional, através da articulação política dos interesses locais e setoriais em torno de estratégias próprias e específicas de desenvolvimento para as regiões (COREDES, 2010).

A atuação dos COREDES se dá em várias frentes relevantes, dentre as quais destacamos a elaboração de planos estratégicos de desenvolvimento regional, atividade realizada ao longo do ano de 2010, com apoio do ILPES/CEPAL através do oferecimento de um curso de formação, e com apoio do Ministério da Integração, que subsidiou a atividade com recursos financeiros. Os Conselhos também têm a incumbência de coordenar o processo de realização da Consulta Popular em suas respectivas 
regiões, realizada anualmente, através da qual a população define prioridades para investimentos de recursos públicos.

Dessa forma, valoriza-se a participação como elemento estrutural dessa nova concepção de planejamento. Para Brose (2001), mais importante que o resultado em si que o planejamento participativo possa trazer, é o processo de exercitá-lo. A dimensão participativa dessa concepção de planejamento, além de permitir a valorização da amplitude social e cultural, bem como a representatividade política dos sujeitos sociais envolvidos, possibilita também uma interação interdisciplinar e multissetorial, facilitando o surgimento de soluções mais criativas, duradouras e ajustadas a cada realidade social.

Assim, os Conselhos constituem-se em fóruns de discussão, orientados ao desenvolvimento regional, cujas atribuições incluem a promoção da participação social no diagnóstico das necessidades e potencialidades regionais para a formulação e implementação de políticas públicas; a elaboração de planos estratégicos de desenvolvimento regional; a manutenção de espaço permanente para a participação democrática e a cidadania; a regionalização do orçamento estadual; o acompanhamento sistemático das ações dos governos Estadual e Federal na região definida por cada COREDE; e o respaldo às ações do Governo do Estado objetivando maior participação nas decisões nacionais. (COREDEs, 2010)

A criação dos COREDEs ocorreu no contexto de afirmação da redemocratização do País e de valorização da descentralização das políticas públicas e de estímulo à participação da sociedade civil, marcas características da Constituição Federal de 1988 e reiteradas no Estado, com a Constituição Estadual de 1989.

Assim, a aproximação entre governo e instituições da sociedade civil em cada região, em especial as universidades, possibilitou a partir de 1991, as condições para a constituição e estruturação iniciais dos COREDEs que, já em 1994, se consolidavam de forma efetiva em 21 regiões do território do Rio Grande do Sul.

Atualmente o Rio Grande do Sul conta com 28 COREDEs que, embora apresentem dificuldades para seu melhor funcionamento, constituemse em importantes instâncias que reúnem distintos representantes da sociedade civil, organizando a participação junto ao processo de planejamento governamental e promovendo debates acerca do desenvolvimento das regiões. 
Figura 4: Os 28 COREDESs e suas regiões de abrangência

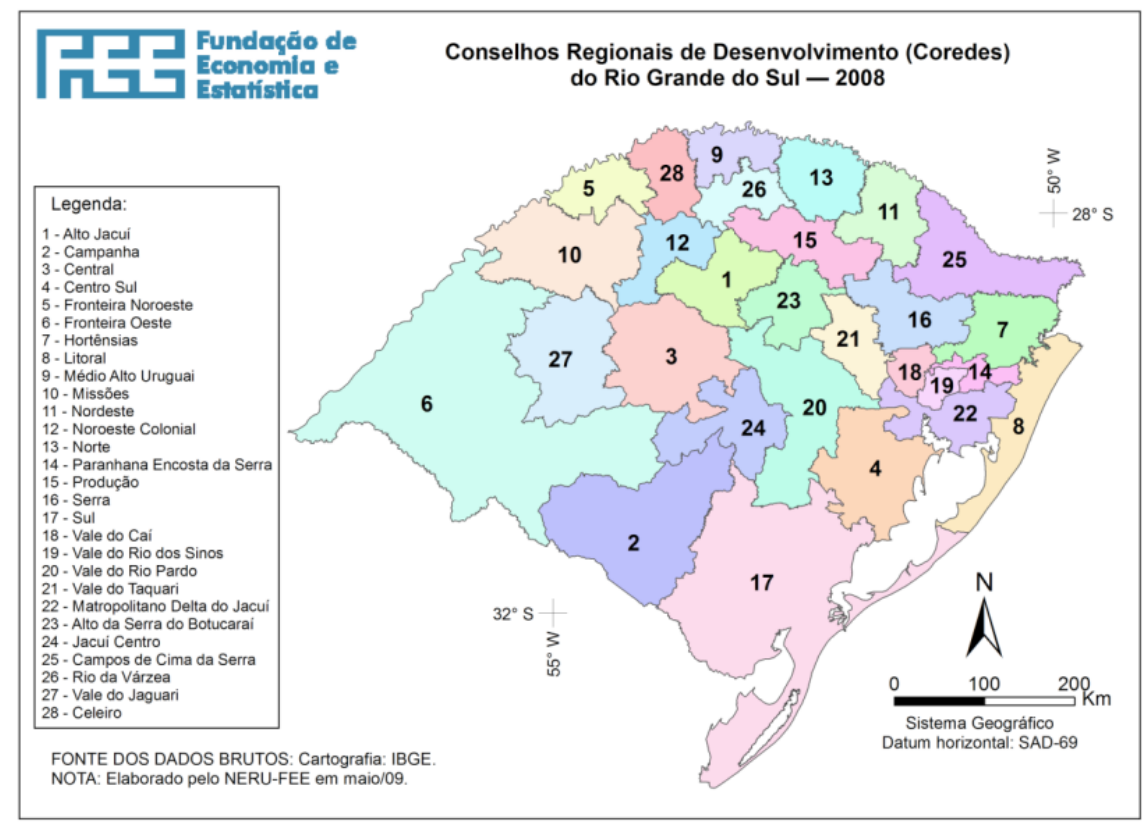

Fonte: FEE, 2018

\section{Consórcios Intermunicipais}

Atualmente o Brasil vive significativas inovações na institucionalidade associativa municipal. Vários arranjos, como os consórcios intermunicipais e articulações de municipalidades em torno de bacias hidrográficas, vêm conhecendo grande aprendizagem institucional. Esse tema tende a adquirir maior destaque com a lei que criou a normatização de contratos para a institucionalização de consórcios públicos e de contratos de programas que incentivam a gestão associada de serviços públicos. Tais atuações conjuntas - buscando a solução de problemas "entrelaçados", que extrapolam limites territoriais, competências e âmbitos restritos de poder, a fim de realizar obras, serviços, atividades etc, que são de interesse supralocal, congregando forças políticas, recursos financeiros e de gestão, os quais superam a dispersão dos esforços - podem se constituir em importante ação capaz de ampliar a interlocução interinstitucional e interescalar. (BRANDÃO, 2008) 
Brandão (2008) afirma ainda que novas categorias territoriais potencializam o surgimento de processos associativos locais, permitindo a viabilização de projetos nas mais diversas áreas. Como muitos desses lugares não apresentam porte ou densidade para a provisão de serviços públicos, o consorciamento possibilita ganhos de escala, representando alternativa importante para o enfrentamento de variados problemas, tais como disposição de lixo e abastecimento de água. Na maioria das vezes, tais formas cooperativadas em associações intermunicipais impuseram-se pela necessidade e por problemas concretos.

\begin{abstract}
Considerando apenas os arranjos horizontais no Brasil, observamos que estes ganham relevância ainda maior se considerarmos as transformações recentes, como o fortalecimento dos municípios enquanto entes federados, após a Constituição de 1988. Com a proliferação do número de municípios - muitos dos quais apresentando grande fragilidade administrativa, com quadros técnicos insuficientes e/ou pouco qualificados e, sobretudo, situação financeira bastante debilitada -, a associação intermunicipal se apresenta enquanto alternativa para a superação de dificuldades de várias naturezas relacionadas à oferta de bens e serviços coletivos. (BRANDÃO, 2008, p. 148)
\end{abstract}

Segundo Cruz (2006), os municípios de pequeno porte não possuem recursos suficientes para a implantação de serviços com uma maior complexidade ou não possuem condições financeiras de serem suportados. Da mesma forma, muitos municípios transcendem o território municipal, tornando necessário que a sua atuação seja discutida com os municípios vizinhos.

Nesse contexto, inúmeros municípios buscam inovar ao criar novas formas de prestação de serviços e de organização, assim como de articulação. Iniciou-se então uma grande discussão sobre a possibilidade de parcerias entre municípios, em que os mesmos passam a discutir problemas e soluções de forma conjunta.

Conforme destaca Amorim (2009, p.2),

Os consórcios públicos são parcerias formadas por dois ou mais entes da federação, para a realização de objetivos de interesse comum, em qualquer área. Os consócios podem discutir formas de promover o desenvolvimento regional, gerir o tratamento de lixo, saneamento básico da região, saúde, abastecimento e alimentação ou ainda execução de projetos urbanos. Eles têm origem nas associações dos municípios, que já eram previstas na Constituição de 1937. Hoje, centenas de consórcios já funcionam no País. Só na área de saúde, 1969 municípios fazem ações por meio destas associações. Porém, faltava a regulamentação da 
legislação dos consórcios para garantir regras claras e segurança jurídica para aqueles que já estão em funcionamento e estimular a formação de novas parcerias. É esta a inovação da lei atual. Ela busca, sobretudo, estimular a qualidade dos serviços públicos prestados à população.

Amorim (2009) ainda refere que existem amplas possibilidades de atuação conjunta de municípios através de consórcios, desde pequenas ações pontuais a programas de longo prazo e intensa influência sobre o destino dos municípios. Os consórcios podem se constituir com menor ou maior pretensão de durabilidade e impacto.

O significado de Consórcio, do ponto de vista jurídico e etimológico é a união ou associação de dois ou mais de dois entes da mesma natureza. O consórcio não é um fim em si mesmo; constitui, sim, um instrumento, um meio, uma forma para a resolução de problemas ou para alcançar objetivos comuns.

Expressando um acordo firmado entre municípios, possibilita aos prefeitos municipais assegurar ações e serviços, mediante a utilização dos recursos materiais e humanos disponíveis. A união desses recursos produzirá os resultados desejados, o que não ocorreria se os municípios atuassem isoladamente.

A base do consórcio é a relação de igualdade entre os municípios envolvidos, preservando, assim, a decisão e a autonomia dos governos locais, não admitindo subordinação hierárquica a um dos parceiros ou à entidade administradora. Cada consórcio tem características próprias, decorrentes das peculiaridades e dificuldades, tanto da região, quanto do município consorciado (ZANELLA FILHO, 2010)

É utilizado, predominantemente, nas áreas de saúde, educação, transporte, meio ambiente, agricultura e outras, onde os problemas envolvem vários municípios e os seus governos podem usar o consórcio como instrumento operacional, de grande valia, para maior rendimento de seus esforços, evitando a dispersão de recursos financeiros, humanos e materiais e maximizando o aproveitamento dos recursos municipais.

No RS existem atualmente 34 Consórcios Públicos institucionalizados (AGCONP, 2020), atuando em diversas áreas, ao lado de um grande número de iniciativas que se encontram em processo de institucionalização. Dentre essas, várias surgem da necessidade de reagrupamento dos pequenos municípios, como forma de fazerem frente às inúmeras demandas impostas pela realidade atual e aos limites impostos pela extrema fragmentação, não somente a territorial, mas também a extrema fragmentação dos interesses políticos, econômicos e sociais, que passam 
a colocar em risco as promessas que haviam garantido o apoio da maioria à emancipação das novas municipalidades.

Evidencia-se então uma aparente contradição: toda a mobilização feita em torno da necessidade da emancipação como único caminho para desenvolver o lugar passa a confrontar-se com os limites impostos pela extrema fragmentação, não somente a territorial, mas também a extrema fragmentação dos interesses políticos, econômicos e sociais, que passam a colocar em risco as promessas que haviam garantido o apoio da maioria à emancipação das novas municipalidades. De alguma forma, a necessidade de um redesenho da base territorial passa a impor-se, o que leva as lideranças dos pequenos municípios, em muitos casos as mesmas que haviam liderado a emancipação, a proporem um movimento de reagrupamento, no sentido de formar uma nova base territorial e política, suficientemente forte para sustentar enfrentamentos políticos, principalmente no tocante ao planejamento de ações conjuntas (intermunicipais) em áreas estratégicas, como infraestrutura viária, saúde, educação, entre outras, e à busca dos recursos necessários para a sua execução.

Esta constatação leva os pequenos municípios, aqui entendidos como dimensão local, a articularem-se entre si, em torno de anseios e desafios comuns, dando forma a regiões, para fazer frente às inúmeras demandas provenientes dos anseios e necessidades da população.

Em síntese, os Consórcios Intermunicipais surgem da necessidade de formar uma nova base territorial e política, suficientemente forte para sustentar enfrentamentos políticos, principalmente no tocante ao planejamento de ações conjuntas entre municípios, para viabilizar o desenvolvimento de suas respetivas regiões. Nessa perspectiva, a dimensão do local regionalmente articulado, adquire novo significado.

\section{Considerações finais}

Para finalizar esta reflexão, fazemos nossas as palavras de Milton Santos (1996, p. 272), quando afirma que "a ordem global busca impor, a todos os lugares, uma única racionalidade. E as regiões respondem ao mundo segundo diversos modos de sua própria racionalidade."

A ordem global serve-se de uma população esparsa de objetos regidos por essa lei única que os constitui em sistema. A ordem local/regional é associada a uma população contígua de objetos, reunidos pelo território e como território, regidos pela interação. 
No primeiro caso, a solidariedade é produto da organização. No segundo caso, é a organização que é produto da solidariedade. A ordem global e a ordem local/regional constituem duas situações geneticamente opostas, ainda que em cada uma se verifiquem aspectos da outra. A razão universal é organizacional, a razão local/regional é orgânica. No primeiro caso, prima a informação que, aliás, é sinônimo de organização. No segundo caso, prima a comunicação.

A ordem global funda as escalas superiores ou externas à escala do cotidiano. Seus parâmetros são a razão técnica e operacional, o cálculo de função, a linguagem matemática. A ordem local/regional funda a escala do cotidiano, e seus parâmetros são a co-presença, a vizinhança, a intimidade, a emoção, a cooperação e a socialização com base na contiguidade.

Dito em outras palavras, para promover o desenvolvimento regional no contexto da realidade atual é preciso estar atento à dimensão horizontal do processo, conhecer, em profundidade a região em questão, identificar suas potencialidades e construir instrumentos de coesão social em torno de propósitos comuns à população envolvida. Além disso, é preciso criar formas de representação da vontade da maioria, identificada a partir participação de todos, para permitir que uma nova forma de gestão do território possa ser gestada. Mas, acima de tudo, é necessário criar políticas de Estado e eleger governos comprometidos, não com a dimensão vertical do processo, expressa no famigerado „leilão do território“, cuja manifestação mais conhecida no país é a chamada „guerra fiscal“, e sim com a dimensão horizontal do processo, com o olhar voltado para dentro do território, identificando e fomentando as reais potencialidades do mesmo, e a partir daí projetá-lo para fora, para o contexto do mundo globalizado. (ETGES, 2001).

As experiências analisadas, ainda que brevemente, são lições para (re) pensar o desenvolvimento regional no Brasil e na América do Sul, por meio do comprometimento da sociedade como um todo, e as diversas regiões em particular, na tomada de decisões referentes à gestão do território. 


\section{Referências}

AMORIM, Maria Raquel Machado de Aguiar Jardim de. Consórcios Públicos: O poder de diálogo das prefeituras junto aos governos estadual e federal. Disponível em: <http://wwwold.imb.go.gov.br/pub/conj/ conj8/10.htm>. Acesso em 17 mai. 2020.

Associação Gaúcha de Consórcios Públicos - AGCONP. Disponível em http://agconp.org.br/noticia/index/64 Acesso em 18 mai 2020.

BOISIER, Sergio. El desarollo territorial a partir de la construccion de capital sinergetico. In: Revista REDES, Universidade de Santa Cruz do Sul, vol.4, n.1, jan/abr de 1999.

BRANDÂO, Carlos A., COSTA, E.J.M., ALVES Maria A. da Silva. Construir o espaço supralocal de articulação socioprodutiva e das estratégias de desenvolvimento: os novos arranjos institucionais. Economia regional e urbana: contribuições teóricas recentes. Belo Horizonte: Editora UFMG, 2006.

BRANDÂO, Carlos A. Pactos em Territórios: escalas de abordagem e ações pelo desenvolvimento. Organizações \& Sociedade - v.15 - n.45 - Abril/ Junho - 2008 .

BROSE, Markus. Metodologia participativa: uma introdução a 29 instrumentos. Porto Alegre: Tomo Editorial, 2001.

COREDES. FÓRUM DOS COREDES DO RIO GRANDE DO SUL. Pró-RS IV. Propostas estratégicas para o desenvolvimento regional do Estado do Rio Grande do Sul. Passo Fundo: Passografic, 2010.

CORRÊA, Roberto Lobato. Trajetórias Geográficas. Rio de Janeiro: Bertrand Brasil, 1997.

COUTO, Leandro F. A Iniciativa para a Integração da Infraestrutura Regional Sul-Americana - IIRSA como instrumento da política exterior do Brasil para a América do Sul. OIKOS (Revista de Economia Heterodoxa), no 5, Ano V. Edição temática América Latina. Rio de Janeiro: Oikos, 2006.

CRUZ, Maria do Carmo M. T. Cooperação Intermunicipal: arranjos institucionais como instrumento para o Desenvolvimento Local e a experiência paulista. São Paulo: SEBRAE e Instituto de Cidadania, 2006. 
DINIS, Clelio Campolina; CROCCO, Marco. Economia Regional e Urbana - contribuições teóricas recentes. Belo Horizonte: Editora da UFMG, 2006.

ETGES, Virginia Elisabeta. Länderkunde und Erdkunde: a região no contexto geográfico. In: HELFER, Inácio (org.). Pensadores alemães dos séculos XIX e XX. Santa Cruz do Sul: Edunisc. 2000.

A região no contexto da globalização: o caso do Vale do Rio Pardo. In: VOGT, Olgário e SILVEIRA, Rogério. Vale do Rio Pardo: (re)conhecendo a região. Santa Cruz do Sul: Edunisc. 2001.

Desenvolvimento Regional sustentável: o território como paradigma. REDES, Santa Cruz do Sul, v.10, n.3, p.47-55, set/dez. 2005.

The regional dimension: theoretical considerations and practical experience in Southern Brazil. In: GRABHER, Gudrun M.; MATHISMOSER, Ursula (Org.) Regionalism(s): a variety of perspectives from Europe and the Americas. Viena: New Academic Press, 2014.

HONÓRIO, Karen. IIRSA - Iniciativa para a Integração da Infraestrutura Regional Sulamericana. Disponível em http://observatorio.repri.org/ artigos/glossary/iniciativa-para-a-integracao-da-infraestrutura-regional-sulamericana-iirsa/. Acesso em 17 mai 2020.

INICIATIVA DE INTEGRAÇÃO REGIONAL SUL AMERICANA - IIRSA. Disponível em: http://www.iirsa.org/. Acesso em 16 mai 2020.

FUNDAÇÃO DE ECONOMIA E ESTATÍSTICA. Disponível em http:// www.fee.tche.br/sitefee/pt/content/resumo/pg_coredes_detalhe.php?corede=Vale+do+Rio+Pardo. Acesso em o6 nov 2018.

LACOSTE, Yves. A Geografia - isso serve, em primeiro lugar, para fazer a guerra. Campinas, SP: Papirus. 1988.

LENCIONI, Sandra. Região e Geografia. São Paulo: Edusp, 1999.

LIMONAD, Ester. Brasil século XXI, regionalizar para que? Para quem? In: LIMONAD, E; HAESBART, R.; MOREIRA, R. Brasil Século XXI - por uma nova regionalização - Agentes, processos e escala. São Paulo: Max Limonad, 2004. 
OLIVEIRA, Francisco. Elegia para uma re(li)gião. Sudene, Nordeste e conflito de classe. Rio de Janeiro: Paz e Terra, 1975.

PADULA, Raphael. Transportes - Fundamentos e propostas para o Brasil. Brasília: Confea, 2008.

SANTOS, Milton. A natureza do espaço - técnica e tempo, razão e emoção. São Paulo: Hucitec, 1996.

SILVEIRA, Maria Laura. Um país, uma região. Fim de século e modernidades na Argentina. São Paulo: FAPESP/LABOPLAN, 1999.

ZANELLA Filho, Renato A. Intermunicpal Consortiums and Regional Development - the case of Vale do Taquari/RS/Brazil. Disponível em http://www.rkk.hu/en/leading_news/annual_conference_of_the_regional_studies_association_in_pecs.html. Acesso em 21 abr 2014. 


\section{Parte II \\ Políticas, Escalas, \\ Territórios}

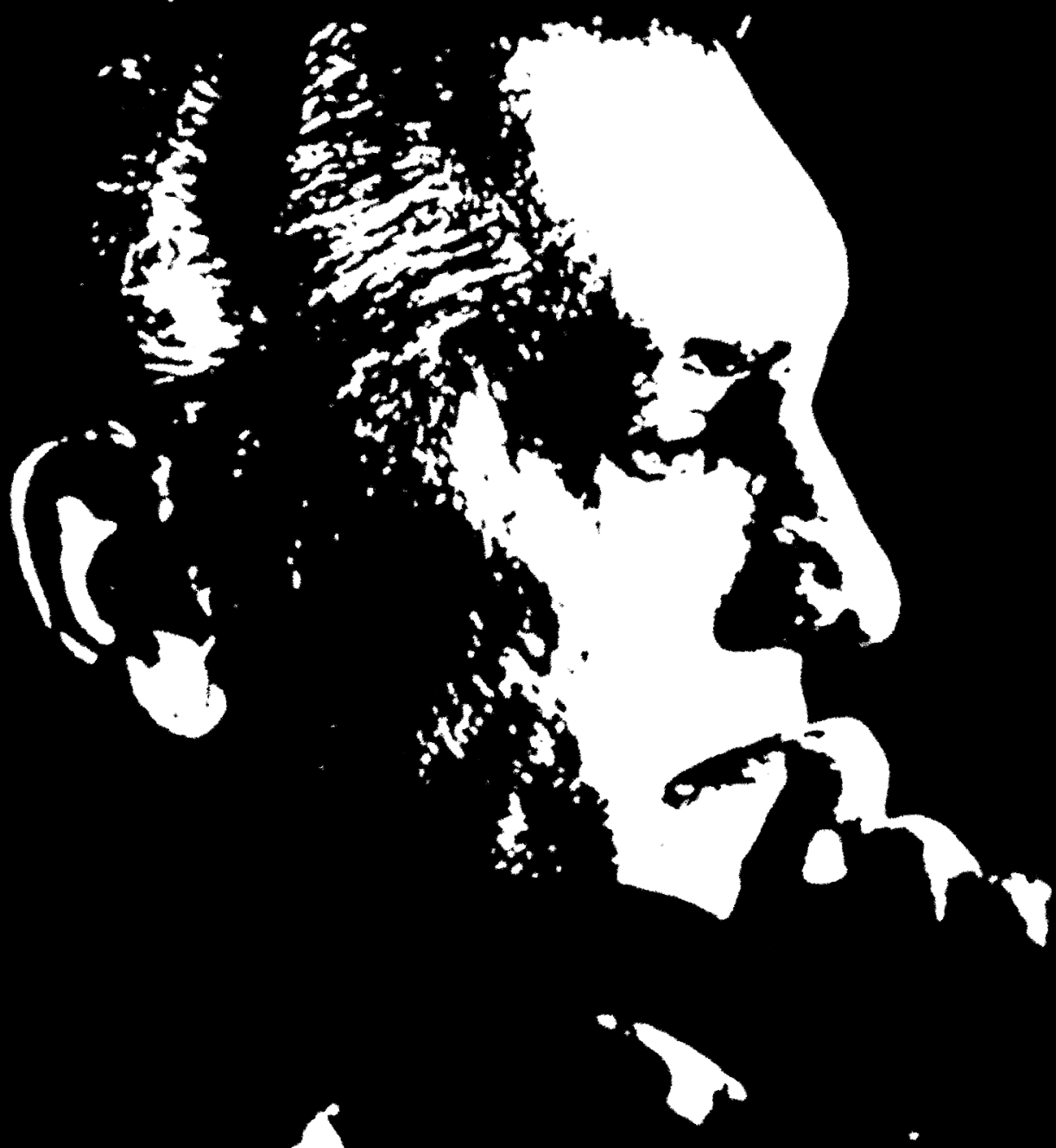





\section{Política Nacional de \\ Desenvolvimento Regional no Brasil - Incapacidade ou Não-Acontecimento? \\ Uma Interrogação Pendente}

Rainer Randolph ${ }^{1}$

\section{Introdução}

"Captar a natureza do subdesenvolvimento não é tarefa fácil; muitas são as dimensões e as que são facilmente visíveis nem sempre são as mais significativas" (FURTADO 1974, p. 22). Apesar do presente trabalho não estar voltado às mencionadas dimensões, essa expressão pode ser seu lema; ou seja, ao invés de ter como objeto o subdesenvolvimento, procura-se identificar a "natureza" daqueles que estão "envolvidos" no "des"-envolvimento. Aí vale a frase quase ipsis litteris: identificar a natureza daqueles que são responsáveis pelo desenvolvimento (e, por tabela, o não-desenvolvimento) não é tarefa fácil porque muitas das dimensões facilmente visíveis nem sempre - ou, talvez, raras vezes - são as mais significativas.

Talvez não seja tão difícil encontrar as muitas "dimensões" que permitiriam identificar a natureza daqueles que contribuem para o desenvolvimento. Na literatura encontram-se indicações de diferentes dimensões a partir de diversas abordagens (démarches) que não serão citadas aqui. O próprio Furtado é considerado um dos mais importantes autores, não apenas por sua produção intelectual, mas também como "envolvido" por causa da sua atuação como planejador em vários órgãos governamentais durante muitos anos.

1 Professor Titular aposentado da UFRJ; Prof. Colaborador Voluntário e docente permanente do Programa de Pós-Graduação em Planejamento Urbano e Regional do Instituto de Pesquisa e Planejamento Urbano e Regional (IPPUR/UFRJ, e-mail: rainer. randolph@gmail.com. 
No âmbito do espaço limitado de presente capítulo, deve-se ter, primeiro, uma resposta ao desafio de Furtado de não eliminar, de antemão, dimensões significativas da exposição. Eis uma questão "dialética", à medida que o julgamento sobre importância ou significado de uma dimensão exigiria o conhecimento da totalidade das dimensões da qual as mais significativas constituem um grupo particular. Este o dilema metodológico de qualquer processo de produção de conhecimento, que tem a pretensão de revelar algo que não seja apenas a "aparência" relativamente pouco significativa de um fenômeno

De alguma forma como expressão dessa dialética - post factum -, adota-se os seguintes procedimentos e providências:

1. inicialmente, no primeiro item, será indicada a política de desenvolvimento regional em nível federal como assunto da investigação, delimitando seu horizonte histórico e os recortes regionais contemplados. Assim, o estudo se refere a manifestações políticas pelo Estado brasileiro e diferentes governos mais ou menos facilmente visíveis de (des) envolvimento dos anos 1950/6o até o presente. Especificamente, interessam características de políticas de desenvolvimento regional formuladas e/ ou implementadas pelos diferentes governos federais dos anos de 1950 a 1963 e do período de 2003 a 2019, como referencia empírica do presente trabalho. Numa breve apreciação da literatura sobre estes assuntos será identificada a dimensão dos resultados obtidos por essas políticas como a mais significativa para sua apreciação. À medida que esta parte visa apontar a referência empírica do estudo e contribuir para uma primeira problematização, a análise das referidas políticas não será aprofundada;

2. a finalidade da parte seguinte será mostrar as limitações de julgar sucesso ou fracasso dessas políticas de desenvolvimento regional apenas a partir de seus (aparentes) resultados. É necessário, para identificar possíveis dimensões mais "ocultas", contemplar, também, além da execução de políticas - alcance ou não de metas, objetivos etc, - as formas de sua articulação/ formulação e instituição/ institucionalização. Assim, como forma de afastar-se de um víeis positivista, "resultados" precisam ser compreendidos, também, como uma forma de exclusão de outras possibilidades. Aquilo que chamamos de "não-acontecimentos" são tão "resultados" como os próprios; sua "produção" antecede, em muitos casos, a própria instalação da política ou mesmo ocorre concomitantemente a caminho do alcance de determinados resultados. São expressão de "potencialidades" de uma política não realizadas por determinadas 
"razões" que, muitas vezes, são apenas mencionadas genericamente sem maior investigação enquanto forças que impedem "outros resultados". Será mostrado que a identificação e qualificação dessa dimensão como "significativa" é possível e necessária. Assim, aqui será introduzida uma dimensão institucional e estrutural da produção desses "resultados" - do "não-acontecido" - onde se dará ênfase à produção dessa sua "natureza", variável com o tempo;

3. no próximo item, essa discussão será continuada por meio da apresentação de uma outra dimensão ligada a processo de ação e atuação governamental, que dirige a atenção à "dialética" entre estrutura institucional e dinâmicas de atuação, numa perspectiva da execução de políticas. Articulação dialética, diga-se de passagem, que não se revela sob a observação de falta de sucesso ou de possíveis fracassos das políticas; precisam ser contemplados os processos de atuação dos governos.

4. finalmente, a breve conclusão retoma a pergunta do título do presente trabalho a respeito da caracterização das políticas de desenvolvimento regional que serviam aqui como ilustração. Não há como adiantar respostas definitivas se suas "falhas" tem sua origem em certas incompetências; ou que apontam para sua compreensão como "não-acontecimento" na medida que uma boa parte das apreciações por especialistas e estudiosos questiona até se devam ser consideradas como de desenvolvimento regional. De alguma forma, até Celso Furtado (2002, p.36) vai propor, numa publicação de 2002 , que um processo de reconstrução de políticas regionais deve considerar uma maior participação popular no sistema das decisões. As dificuldades de seguir neste caminho são brevemente apontadas no final da argumentação do presente texto.

\section{Políticas de desenvolvimento regional desde a década de 1950}

Na literatura há certa diversidade e discordância entre as abordagens sobre as principais características de diferentes períodos históricos na trajetória de políticas brasileiras de desenvolvimento regional. Além de diferentes caracterizações, há divergências mesmo em relação à abrangência histórica e territorial das suas periodizações. Apenas para ilustrar, Pitanga (2014) aponta cinco etapas históricas da política regional 
brasileira de 1877 a $2002^{2}$; uma sexta de 2003 adiante não é mencionada. Já Carvalho (2014, p. 298-305) observa, ao abordar a experiência passada do desenvolvimento regional no Brasil, que "planejamento e desenvolvimento regional no Brasil nasceu no Nordeste" cuja experiência abrange os 30 anos que vão de 1950 ao final dos anos 1980. Gumiero (2017), também em relação à política regional para o Nordeste, diferencia quatro fases desde a década de 1950 até ao governo Lula e Dilma Rousseff, de 2003 a 2014. As periodizações estão vinculadas, também, a cada vez mais específicas regionalizações das políticas de desenvolvimento.

Dentro do foco do atual trabalho, não é preciso entrar numa discussão a este respeito. Pode-se constatar um certo consenso dos analistas - e senso comum na sociedade - que as desigualdades econômicos e sociais entre estados e suas aglomerações em (macro) regiões constituem o principal problema e dão origem a propostas e intervenções regionais do governo federal. Como é sabido, a região Nordeste se destaca como principal alvo destes esforços durante um longo período da história brasileira.

Esse enfoque da política da União pode se verificar - diferenciadamente - em dois momentos históricos, que servem para a atual discussão como referencial e ilustração desses períodos. Não será necessário aprofundar alcance ou não das proposições e objetivos de suas políticas à medida que se pretende apenas apresentar apreciações de autores a respeito de seus supostos "sucessos" ou "fracassos". São contextos importantes para o presente estudo, porque essas "realidades" vão justificar a perspectiva aqui adotada

Começando pelo momento mais recente, este se inicia em 2003 quando o recém-empossado presidente Luiz Inácio Lula da Silva começa a cumprir um compromisso assumido durante a campanha eleitoral, e atribui prioridade ao problema das desigualdades regionais na sua agenda política, com a formulação de uma Política Nacional de Desenvolvimento Regional (PNDR). Resultado de uma série de esforços prévios de analises e diagnósticos 3 , só em 2007 no início da segunda gestão do governo Lula será institucionalizada por Decreto Presidencial № 6.047, de 22 de fevereiro daquele ano. A emergência dessa política foi, conforme Macedo e

2 O autor indica que essa periodização da intervenção do governo na questão regional é uma adaptação do documento de referência da Conferência Nacional de Desenvolvimento Regional (BRASIL 2012) e do relatório "Fundos Constitucionais de Financiamento", ambos disponíveis no site do MI.

3 Vide a sistematização em Costa (2016) e sua indicação de um trabalho de Araújo de 1999, considerado da maior influência para a formulação da política; 
Porto (2018, p. 611), "considerada um marco na retomada da questão do desenvolvimento regional, após mais de duas décadas de esvaziamento das políticas anteriores e dos instrumentos para combater as iniquidades regionais no país" 4 .

Em termos de seus resultados essa PNDR não foi considerada uma história de sucessos porque, naquele momento, sua proposta, apesar de levantar "pontos da maior importância para a questão regional brasileira ... não chegou a ser concretizada em termos institucionais e no tocante aos meios e instrumentos necessários para sua implantação" (GUIMARÃES NETO 2012, p. 206). Alegou-se que possíveis avanços de redução de desigualdades regionais durante os anos do então governo devam ser creditados a resultados regionalmente diferenciados de políticas setoriais. $\mathrm{Ou}$ seja, a redução (relativa) de tais desigualdades (BRANDÃO 2014, p. 340) se deveu às características das políticas setoriais implementadas, e não a uma atuação regional deliberada5.

A respeito de um renovado esforço, a partir de 2012, de criar uma nova Política Nacional de Desenvolvimento Regional (PNDR II) enquanto lei, Brandão (2014, p. 339) já chamou atenção, em 2014, para o perigo de a nova PNDR II ter o mesmo destino da versão anterior, apesar de ter considerado seu resultado bastante coerente. Nem tanto pelas razões alinhadas por Guimarães Neto, mas por causa da escassez "de atores políticos de peso que sustentam uma política de tal complexidade" (BRANDÃO, 2014, p. 342). E mesmo a formulação de uma proposta da PNDR II por meio de um amplo processo de consulta e participação não consolidou, como segue o autor, "a legitimação e força política suficientes para romper o impasse da implementação de políticas nacionais e regionais de desenvolvimento .... Ou seja, atribuiu a responsabilidade pela, então, possível não aprovação do projeto de lei da PNDR II e de sua subsequente não implantação, a determinadas circunstâncias (forças) políticas e sociais. E além de poder faltar sustentação, Brandão (2014, p. 342) vê, mais

4 Vide também Silva (2016, p. 373) que considerou que a principal novidade expressa pela PNDR, além de trazer de volta a temática do desenvolvimento regional à agenda pública, foi o fato de ser a primeira experiência verdadeiramente nacional de desenvolvimento regional, isto é, com foco de atuação diferenciada de acordo com as realidades inter-regionais e intrarregionais em todo o território brasileiro."

5 Conforme relata Coelho (2015, p. 280) Guimarães Neto diferencia políticas e ações explicitamente voltadas para o desenvolvimento regional e políticas e ações implicitamente regionais; vide também a definição em Silva (2015, p.22) que "políticas regionais implícitas" são aquelas políticas setoriais com abordagem territorial; para isto também Brandão (2019) 
radicalmente, a possibilidade de ser ativamente combatido e interditado por "forças arcaicas e conservadoras" da sociedade brasileira.

Os receios de Brandão vão se tornar realidade em 2019. Em 30 de maio daquele ano, sem ter sido anunciado no programa do candidato vitorioso à presidência nas eleições de $2018^{6}$, o Governo recém-empossado em janeiro institui pelo Decreto № 9.810 da Presidência da República uma nova Política Nacional de Desenvolvimento Regional (PNDR). Revoga o supramencionado decreto de 2017 a respeito do mesmo assunto e determina como sua finalidade "reduzir as desigualdades econômicas e sociais, intra e inter-regionais, por meio da criação de oportunidades de desenvolvimento que resultem em crescimento econômico, geração de renda e melhoria da qualidade de vida da população" (BRASIL 2019).

Desta forma, a não institucionalização da PNDR II desde 20137, confirmam as conjecturas de Brandão a respeito de seu "destino", pois ela foi implicitamente "enterrada" pelo decreto de 2019, que revogou a política anterior (PNDR I), em vigor até aquele momento, e ignorou a tramitação do respectivo projeto de lei da PNDR II no Congresso. Diante das mudanças no quadro político-governamental do país ocorridas após o fim do primeiro mandato da Presidente Dilma, já manifestamos (RANDOLPH 2017) nosso ceticismo em relação à aprovação e implantação do projeto de Política Nacional de Planejamento Regional de 2012/2013, ou mesmo de iniciativas semelhantes em nível federal.

Em 2007 deu-se a institucionalização da PNDR. Neste mesmo ano foram refundadas, por Lei Complementar, duas superintendências de desenvolvimento: a do Nordeste (Sudene) - a primeira experiência de política regional formulada e implementada no Brasil - e a da Amazônia (SUDAM), a primeira tendo sido criada em 1959, a segunda em 1967. Ambas haviam sido extintas em 2001.

A divergência que surgiu por ocasião da recriação dessas duas superintendências parece confirmar a impressão de que a dimensão mais significativa neste debate foi algum tipo de resultado que se esperava em vista das metas dessas políticas. Com o argumento de precisar conter as desigualdades dessas duas regiões em relação às demais, alguns autores ${ }^{8}$ apoiaram essa medida, quando outros argumentaram contra ao considerar a recriação desnecessária, uma vez que mesmo durante a fase do início

6 Vide RANDOLPH 2018.

7 A proposta visava que a PNDR não seria apenas aprovada como uma política de governo, mas se tornaria uma política de Estado.

8 Vide as indicações em Horsth et ali (2017, p. 549). 
de seu funcionamento até sua extinção não tinham conseguido modificar, substancialmente, a estrutura de desenvolvimento regional brasileiro" Uma posição mais ponderada defendeu Costa (2016, p.9), à medida que chama a atenção que, ao julgar as realizações do planejamento regional efetuadas pela Sudene, se considere as condições nas quais foram "constritas nas possibilidades históricas concretas, que constroem caminhos mais ou menos obstaculizados para que o Estado exerça sua 'autonomia relativa'",

Caracterização e apreciação da elaboração e realização de medidas de desenvolvimento regional para a região Nordeste do país, nos anos 1950 e início de 1960 por parte da Sudene, já foram amplamente discutidas nos meios acadêmicos e político-social. Atribui-se ao economista Celso Furtado um protagonismo (CABRAL, 2011) em sua participação na formulação da Política Nacional de Desenvolvimento Regional do Nordeste no âmbito do Grupo de Trabalho para o Desenvolvimento do Nordeste $(\text { GTDN })^{10}$ e na criação da Sudene.

Contra a oposição das oligarquias nordestinas" ${ }^{11}$, com o apoio dos deputados do Centro Sul ao relatório do GTDN a Sudene foi criada

em dezembro de 1959, pela lei no 3.692 , com a finalidade de executar a política de desenvolvimento proposta para a região nordestina. Junto à lei que criou esse órgão, instituirram-se, inicialmente, dois mecanismos de incentivo (artigos 18 e 19, respectivamente) no sentido de atrair investimentos para o Nordeste (ALMEIDA, ARAÚJO 2004, p. 104).

Conforme Costa (2016, p. 69) foi objetivo da Sudene não apenas a modernização econômica, mas também a "modernização política" da região. Foi convicção de Celso Furtado que o fortalecimento da burguesia

9 Como observam Pessoa e Milani (2013), mesmo em 2017, que os problemas regionais relacionados ao crescimento econômico, emprego e renda, pobreza extrema e saúde ainda estão presentes.

10 O GTDN, criado pelo presidente Juscelino Kubitschek em 1958 (GTDN 1967).

11 Um dos principais argumentos contra a aprovação da Sudene era o temor de que haveria um controle excessivo do Governo Federal na região e a priorização da industrialização em detrimento de problemas regionais - como por exemplo, a seca. "Mas, por trás das críticas, estava o receio de que a criação do novo órgão interferisse significativamente no padrão usual de direcionamento e apropriação de recursos federais pela oligarquia agrária nordestina, com o agravante de que o novo órgão também teria o importante papel de fiscalizar o uso das mesmas" (COSTA, 2015, p. 70). 
industrial do Nordeste seria capaz de enfrentar a tradicional elite agrária (COSTA 2016, 73).

O originalmente planejado sistema de captação de recursos para o empresariado regional ("sistema 34/12) acabou sendo desvirtuado ao permitir que empresários de outras regiões (Centro-Sul) abrissem filial na área da Sudene, o que incentivou a transferência de frações do capital industrial dessas regiões (e seus interesses) para o Nordeste. Mas, como afirma Costa (2016, p. 73), "não foi apenas no sistema de captação de recursos que a instituição teve que se reajustar ou viu parte de seu planejamento inicial frustrado".

Diferente da formulação das propostas de diferenciação regional das PNDR I e II no século XXI, a Sudene, por meio da aparência de neutralidade do planejamento, surge

\begin{abstract}
como desfecho de um processo agudo de transformações e conflitos sociais, políticos e econômicos, com suas respectivas implicações, tornando o Estado produtor também no Nordeste, à exemplo do que já ocorria no Sudeste. No plano do discurso, a problemática era traduzida como "questão regional", "região problema", "conflitos interregionais" e "ameaça à unidade nacional".. (COSTA 2016, p. 86)
\end{abstract}

De outro lado, no plano político-prático, a questão a ser resolvida pela atuação regional do governo federal foi a integração nacional num momento mais intenso do debate, à segurança nacional. Essas observações levam a duvidar da "natureza" das políticas de desenvolvimento para o Nordeste - ou seja, questionar, pelos seus resultados, sua falta de sucesso ou mesmo fracasso.

Não se trata de evitar apreciar as diversas iniciativas de política nacional de desenvolvimento regional entre os anos 1950 e as duas primeiras décadas do século XXI. Compreende-se aqui que a política de desenvolvimento da Sudene e as formulações da PNDR constituem dois momentos significativos numa sequência de esforços cujos resultados podem ser questionados, embora se reconheçam certos méritos e conquistas logradas.

Seria até mesmo possível duvidar se houve em algum momento da história brasileira realmente, em nível federal, uma sistemática e coerente atuação governamental para elaborar e implementar políticas que pudessem ou mesmo quisessem contribuir para soluções dos problemas de desigualdades regionais no país. Apesar de ter apresentado poucas 
indicações a respeito das políticas aqui mencionadas, é possível concordar com a afirmação de Brandão (2010, p. 102)

.. o Brasil nunca conheceu verdadeiro processo de desenvolvimento, posto que, malgrado dispor de mecanismos dinâmicos de crescimento econômico cíclico, convive com poderosas e permanentes estruturas de reprodução de desigualdades que ampliam suas heterogeneidades estruturais e perenizam sua situação de subdesenvolvimento.

Ou seja, a dimensão na qual as políticas são julgadas diz respeito a sua incapacidade de romper "com poderosas e permanentes estruturas de reprodução de desigualdades”, enquanto um resultado necessário para permitir um verdadeiro processo de desenvolvimento. Como já mencionado antes, implicitamente, possíveis políticas de desenvolvimento regional são desta forma consideradas ou como fracassadas, valendo para aquelas antes mencionadas; ou como até inexistentes, o que se aplicaria ao período das últimas décadas do século XX.

Uma dimensão significativa para compreender uma política certamente são os resultados visíveis e sua relação, ou mesmo o confronto, com as intenções (discurso de metas, objetivos, projeto etc.) previamente declaradas e seu potencial instrumental ${ }^{12}$. Mas, ao priorizar essa dimensão corre-se o risco de se deixar de perceber que há outras dimensões que, assim, podem, de certo modo, se tornar "invisíveis". E, a julgar pela sua dimensão territorial pouco esclarecida, iniciativas de formular políticas regionais são consideradas inexistentes - não reconhecidas enquanto tais - ou fracassadas.

Como já anunciado antes, o presente trabalho procura mostrar como uma outra dimensão, que já foi chamada de "potencialidades" de formulação ou mesmo implantação de políticas, pode contribuir para sua melhor compreensão ${ }^{13}$.

12 A respeito da avaliação dos instrumentos das políticas regionais, o objetivo de Portugal (2017) "é identificar quais caminhos os atuais instrumentos da Política de Desenvolvimento Regional (PDR) brasileira (Fundos Constitucionais de Financiamento, Fundos de Desenvolvimento Regional e Incentivos Fiscais) estão trilhando e os seus desdobramentos sobre a sociedade".

13 Vide a tese de doutorado de Costa (2016), que aborda tanto criação e recriação da Sudene, não apenas em termos dos seus (magros) resultados, mas também busca sistematizar os condicionantes sociais e políticos de sua trajetória. 


\section{A institucionalização de seletividades e a produção política de não-acontecimentos no Estado capitalista ${ }^{14}$}

Como se viu no item anterior, ao avaliar superficialmente a experiência brasileira de formulação e implantação de políticas de desenvolvimento regional em nível federal é difícil julgá-las, definitivamente, em relação à sua inexistência, inviabilidade ou mesmo fracasso. Sua realidade é complexa demais para ser resumido a um juízo tão simples. Longe de querer dar por terminada a discussão sobre resultados ou mesmo abandonar essa "dimensão de sua natureza", a presente investigação procura mostrar que uma avaliação pelos resultados - "fracassos" - não será suficiente para compreender essas políticas.

Como já anunciado acima, para superar um víeis possível positivista na apreciação de políticas "resultados" precisam ser compreendidos, também, como uma forma de exclusão de outras possibilidades. "Nãoacontecimentos" ${ }^{15}$ são tão "resultados" como os próprios; sua produção ocorre concomitantemente à afirmação de determinados resultados. São expressão de "potencialidades" de uma política, que, geralmente, são apenas mencionadas marginalmente como "vencidas", "eliminadas". A identificação e qualificação dessa dimensão como "significativa” não será 'possível pela mera observação dos fenômenos aparentes, mas exigirá uma compreensão de processo responsáveis pela sua "produção". Neste sentido, defende-se aqui que há outras "dimensões" cujo caráter de serem "significativas" precisa ser mais bem compreendido. Apesar de serem apontadas, de vez em quando, em uma parte das apreciações das políticas, o significado dessas dimensões geralmente é pouco reconhecido.

Ao interpretar fenômenos como "não-acontecimentos" - e não como simples inexistências - atribui-se, a esse, seu "verdadeiro" caráter de resultado de processos sócio-políticos de inclusões/exclusões e não como falta de um objeto do mundo físico-natural, que simplesmente não está presente. Um aprofundamento da discussão sobre a diferença entre ausência e não-acontecimento levantaria, em última instância, questões metodológicas e até epistemológicos (vide RANDOLPH 2015) que não serão abordadas aqui ${ }^{16}$.

14 Os dois itens seguintes retomam, ao ampliar e aperfeiçoar uma reflexão sobre seletividade e governança, um estudo anterior (RANDOLPH 2017).

15 Vide Randolph (2017).

16 Essa não é nenhuma questão "esotérica" porque qualquer esforço de planejamento, projeção e prospecção e, como o presente caso, desenho de políticas enfrenta o desafio 
A compreensão destes processos passa pela identificação dos (complexos) mecanismos que produzem tanto seu não-acontecimento como de processos (geralmente concomitante) que o "naturalizam", ou seja, que tornam "invisíveis" seu caráter de produto social. Algo que, talvez, em analogia ao fetichismo da mercadoria, possa ser denominado um "fetichismo" da decisão.

Tendencialmente, se colocaria, então, o enorme desafio em identificar tanto aqueles agentes sociais, sujeitos das ações, que lutaram, possuindo uma certa potencialidade virtual para tal, a favor de que um fenômeno aconteça, como aqueles que se opuseram e conseguiram impedir que essa virtualidade se tornasse "real" ${ }^{17}$. Ou seja, em relação à temática atual de políticas regionais, ao invés de ficar analisando os elementos de uma proposta que não se reconhece como política regional, é necessário desvendar os mecanismos - as "seletividades", como será argumentado adiante - que impediram seu "acontecimento" e mesmo o reconhecimento de seu caráter sócio-político.

Esse trabalho se tornaria uma tarefa quase impossível se não tivesse certos "lugares" nas sociedades capitalistas que, com relação à formulação e implementação de políticas públicas, são privilegiados e responsáveis tanto para sua execução e seus resultados, como, concomitantemente, para a "produção" sistemática de seus não-acontecimentos. O desafio se desloca, então, para a tarefa de encontrar esses mecanismos (sociais, políticas, econômicos) que são responsáveis, sistematicamente, por esta produção.

No nosso caso, adiantamos, são as dimensões institucional e da ação política que precisam ser consideradas para compreender o "verdadeiro"

de trabalhar com "virtualidades"; falando genericamente, a identificação de "não-acontecimentos" exigirá a investigação dos agentes envolvidos nesta "produção", suas agências, lugares e dinâmicas responsáveis para este (não) resultado - tanto daqueles que contribuíram para a virtualidade do acontecimento (LEFEBVRE, 1999, p.16), como daqueles que acabaram por impedir que essa virtualidade se realizasse. $\mathrm{Ou}$ seja, não-acontecimentos pressupõem a "virtualidade" de acontecimentos. Em outras palavras, a ausência de algum fenômeno social, ao ser produzida deliberadamente, significa um não-acontecimento (RANDOLPH 2015).

17 Em princípios, "não-acontecimentos" fazem parte da própria vida cotidiana porque, na maioria das vezes, qualquer passo ou ação realizada pressupõe (conscientemente ou não) alguma escolha de "inclusão/exclusão": excluem possibilidades que poderiam ter sido realizadas; e mesmo quando algo parece "impossível" o pode ser porque a falta de possibilidades é social e politicamente produzida; sem mencionar aqui aqueles "não-acontecimentos" que resultam das relações sociais de produção numa sociedade, mas podem aparecer como "naturais. 
significado de uma política regional. Apenas assim será possível encontrar algo que o simples "resultado" de uma política não mostra (cumprimento ou não dos objetivos de sua ação instrumental); resultado que é apenas uma expressão aparente, um mero fenômeno que não representa a totalidade de uma política.

À medida em que a problemática do "não-acontecimento" de uma politica regional está situada no contexto da formulação de políticas, ela deve ser situada em relação às relações entre sociedade e Estado ${ }^{18}$. Não obstante de ser necessário contemplar "não-acontecimentos" dentro do espectro dessas relações, acredita-se ser possível se restringir a levar em conta um certo protagonismo do Estado, que seria o "lugar" que concentra certas "condições estruturais" de sua produção"19.

Sem entrar em maiores detalhes, para as seguintes breves observações sobre o Estado, optou-se pela apropriação de ideias de dois autores: Nicos Poulantzas e Claus Offe.

Como sintetizado por Miguel (2014, p. 150), Offe nem recorre a relacionamentos especiais entre os detentores do poder e a burguesia (elite) e não precisa apelar a "estruturas" ou outros mecanismos externos para o Estado atender à racionalidade dos interesses do capital, o que vai lhe assegurar seu financiamento ${ }^{20}$ Há uma dependência estrutural do Estado democrático organizado que impede, objetivamente, a tomada de medidas que afetam os níveis de remuneração aceitáveis pelo capital. Seu desrespeito provocaria retração da atividade econômica e risco para o

18 Na presente discussão as relações se referem a sociedades capitalistas democráticas e respectivos Estados capitalistas; torna-se necessário dedicar-se, minimamente, à investigação do Estado, o que permitirá, também, compreender a sistemática e intencionalidade dessa produção como referência conceitual para a reflexão no atual texto.

19 Em outro lugar (RANDOLPH 2019), ao discutir a formulação de agendas políticas, apoiamos na concepção das três arenas de Offe (1981, p. 128s), que não são hierárquicas, mas circulares. Para ele, o processo de influenciar a formulação de políticas (e conquistar posições hegemônicas) pode "ser melhor compreendido, se o imaginamos composto de três níveis ou três arenas de conflitos, dispostas uma sobre a outra" (OFFE, 1981, p. 128). "Embora o espaço de ação do primeiro nível ('política formal') seja, em grande parte, determinado pela matriz do poder social ('segundo nível'), é ele próprio, capaz de facilitar e promover uma revisão das bases normativas e das interpretações da distribuição do poder social ('terceiro nível')" (OFFE, 1981, p. 131).

20 Com isto Offe (1984, p.144) se distancia de abordagens de outros autores a respeito do Estado capitalista que o entendem ou meramente como instrumento neutro (estruturalistas) ou como unicamente determinado pelos interesses da burguesia (participação direta dos membros da classe dominante no aparelho do Estado (Miliband). 
financiamento do Estado - processos que foram de fácil identificação no Brasil dos últimos anos.

Dessa dependência, Offe deriva aquilo que chama a "seletividade sistêmica" que se origina na "seletividade das instituições" e é imposta "pelas estruturas e processos organizacionais do sistema político", que serve tanto para decantar um interesse global da classe capitalista ${ }^{21}$, quanto para bloquear manifestações anticapitalistas (OFFE 1984, pp. 148-50; MIGUEL 2014, p. 150).

Para Offe, a sistematicidade de diferentes formas de seletividade é uma das características fundamentais do Estado capitalista e, assim, "chave-mestre" para abrir seus "segredos". Em nossa opinião, sua forma e expressão - até, no caso extremo, "ausência" ou não-acontecimento - poderia servir para caracterizar a particularidade de um Estado e sua relação com a sociedade ${ }^{22}$. Ainda mais, o autor argumenta que essa seleção sistemática permite a preservação de uma aparente neutralidade de classe, fundamento para a dominação de uma classe ${ }^{23}$. É assegurada, pelos processos de seletividade, a restrição sistemática de um espaço de virtualidades ou possibilidades - através dos quais a dominação política (classista) é exercida ${ }^{24}$.

21 Seria interessante desvelar as particularidades desses processos de "seletividade" na história das relações entre Estado e sociedade no Brasil - objeto de futura investigação.

22 Offe argumenta que o Estado é classista à medida que privilegia sistematicamente determinados interesses de classes em detrimentos aos de outras. Ou como diz o próprio autor: "O problema estrutural do Estado capitalista é que ele precisa simultaneamente praticar e tornar invisível o seu caráter de classe. As operações de seleção e direcionamento de caráter coordenador e repressor, que constituem conteúdo de seu caráter classista, precisam ser desmentidas por uma terceira categoria de operações seletivas de caráter ocultador: as operações divergentes, isto é, as que seguem direções opostas" (OFFE 1984, p. 163, destaque nosso). A falta dessa "sistematicidade" da seletividade, no caso brasileiro, torna aparente, muitas vezes, seu caráter não apenas classista, mas autoritário, patrimonialista e oligárquico.

23 Se poderia aqui discutir a contribuição do planejamento tecnocrata ou racional para construir e/ou apoiar essa aparência de neutralidade do Estado por meio de seu "cientificismo";

24 "Essa seletividade se constitui por meio de um processo dialético (circular): sua institucionalização em determinados aparelhos estatais é tanto resultado como condição da disputa pelo poder entre forças sociais e políticas. Em outras palavras, as próprias instituições são resultado das disputas entre diferentes interesses políticos e sua distribuição manifesta aquela seletividade sistemática. ... (Determinam) quais as "demandas" submetidas ao atendimento que serão acatadas e apoiadas e quais aquelas que nem entram nas agendas políticas - ou seja que tem o destino do "não-acontecimento" (RANDOLPH 2015). 
A corriqueira falta da "sistematicidade" dessa seletividade institucional no caso brasileiro torna aparente, muitas vezes, seu caráter não apenas classista, mas autoritário, patrimonialista, oligárquico e precariamente democrático. Nestas condições os não-acontecimentos não apenas expressam uma seletividade repressiva ${ }^{25}$, mas o Estado, por seus aparelhos repressivos, lança mão de seletividades divergentes - ou seja perde uma coerência racional do seu discurso e sistematicidade da sua atuação quando privilegia, pontual e aleatoriamente, determinados interesses e demandas. Ou seja, pode prejudicar a necessidade de o Estado contar com uma determinada lealdade mesmo dos membros de classes subalternas que obriga governos, quando pressionados, a atender, ao menos parcialmente, a determinadas reinvindicações.

Assim, "instituições definem as regras do jogo político e, enquanto tais, definem quem pode jogar e como pode jogar. Instituições podem determinar quem ganha e quem perde; ... o termo instituição pode ser facilmente substituído por 'poder ou 'detentores de poder social'" (OFFE 2006, p. 9).

Como se pode deduzir da abordagem de Offe de uma forma genérica, um não-acontecimento poderia ser expressão da conjunção de seletividades divergentes, que resultam em uma atuação de aparente incoerência de um governo, mas tem sua "coerência" no fato que é expressão (dialeticamente) "coerente" das dependências estruturais do governo que o limitam (e o Estado através das suas instituições) a lidar, sistematicamente, com as contradições que o atravessam.

Portanto, para propostas tecnicamente competentes e pertinentes de desenvolvimento regional - vide aquelas das políticas acima discutidas - serem realmente aprovadas e implementadas, elas terão que satisfazer os critérios definidos por determinados "filtros" institucionais ${ }^{26}$ estabelecidas no Estado. Ou, à medida que tem, em princípio, um potencial de

25 A regulação (seletividade) exercida pelo Estado tem três formas, expressando-se a sistematicidade por: (a) uma atuação de afirmação; mas também por (b) uma atuação de repressão, à medida que, de maneira quase imperceptível, reprime certas demandas que podem ser tanto de segmentos do capital como oriundas de reivindicações por parte das classes subalternas (trabalhistas, forças anticapitalistas); e, finalmente, por (c) uma atuação divergente, que revela as limitações do Estado capitalista em lidar com os antagonismos de uma sociedade capitalista, mesmo em regimes democráticos.

26 Como mencionado, exigências de remuneração aceitável para compromissos e investimentos por parte do capital podem ser "filtros" numa sociedade capitalista. Ou seja, políticas podem ser "coerentemente" implementadas apenas se respeitarem essas exigências, se não ameaçarem os níveis aceitáveis de remuneração. Ou, então, a 
dar origem a novas institucionalidades, realizar este potencial e alterar seletividades existentes (institucionalizadas) através de um excepcional apoio político e administrativo. Tanto a trajetória da Sudene (e da política regional para o Nordeste) como a trajetória recente das PNDRs são dois exemplos diferentes de "enfrentamento" de diferentes formas de seletividades ${ }^{27}$.

Na hora da sua formulação e implementação, a política regional para o Nordeste e a Sudene estavam conceituadas para ajudar superar velhas "estruturas" e apoiar novas hegemonias (burguesia industrial). Exigia, para tanto, a institucionalização por meio de um órgão que pudesse estabelecer "seletividades" neste sentido (apenas atender determinadas demandas). Obteve apoio, incialmente, para este projeto porque a questão nordestina foi interpretada (em certos discursos) como questão nacional.

Já no caso da PNDR, ela se iniciou por uma formulação em 2003 que apenas foi institucionalizada em 2007 - até então não superou os obstáculos que diferentes formas de seletividades criaram. Sua formalização precisava da força política por ocasião da reeleição do então presidente, mas mesmo assim só a foi por decreto presidencial e sua execução foi atribuída a um ministério sem uma força político-administrativa muito grande.

No entanto, o caso da Sudene mostra claramente como a criação de "filtros seletivos", num primeiro momento, não foi nenhuma garantia que, durante a execução da política, estes não podem ser alterados de uma forma a colocar em risco ou quase inviabilizar a realização do projeto que lhe deu origem ${ }^{28}$. Ou seja, durante um certo período, podem ter

"potencialidade" (virtualidade) de implantação das políticas aumenta caso manifestações anticapitalistas consigam levar os investidores a reverem suas taxas de lucro.

27 Não será possível explorar aqui este aspecto que, na verdade, iria aprofundar a questão da "existência" de potencialidades. Em relação tanto à Sudene como às primeiras duas formulações de políticas regionais em nível nacional no novo século, há fortes indícios (em formas de grupos de trabalho, documentos programáticos, relatórios, livros), da preparação e mesmo da formulação e sua institucionalização das políticas, que já foram amplamente discutidas na literatura, mas que poderiam ser reinterpretados na perspectiva do atual trabalho. Vide Furtado (1962) e, também, Bernardes e Lima (2010).

28 Há uma literatura extensa sobre este projeto; mas, parece-nos que seria necessário retomar essa discussão a partir da recuperação do texto fundamental de Celso Furtado de 1962 que, infelizmente, ainda não foi possível, no atual texto, incorporar aqui essa discussão. 
existido condições (uma "potencialidade") para formulação, aprovação e, até, implementação das políticas de desenvolvimento regional. Mas, as forças de sua sustentação inicial não foram capazes de manter seu projeto na (primeira) agenda das prioridades ou podem até ser expressão de uma seletividade divergente, que apenas satisfaz interesses muito particulares e de limitado apoio político.

Outro exemplo interessante seria a mobilização em torno da formulação da segunda PNDR, que desembocou até na organização de uma Conferência Nacional de Desenvolvimento Regional e na redação de um projeto de lei com amplo envolvimento de órgãos governamentais em nível federal e estadual, de segmentos profissionais e de comunidades de diferentes estados, um processo de indicação para representação e articulação de agendas etc ${ }^{29}$.

Neste sentido, defende-se aqui, que, em ambos os casos, podem ser encontrados argumentos que apontam para certas possibilidades (probabilidade) de sua realização, seu "acontecimento" - o que aliás se verificou parcialmente ${ }^{30}$. Conforme já discutido antes, nestes casos valeria a pena realizar investigações com maior detalhe e profundidade para além das mencionadas razões (sociedade arcaica e conservadora; falta de apoio político etc.) a fim de identificar e caracterizar aquele processo da produção sócio-político do seu "não-acontecimento".

Em relação à proposta de 2019 de uma política de desenvolvimento regional em nível federal, há de se ter cuidado em tirar conclusões por causa das circunstâncias da publicação do referido Decreto da Presidência, logo após a instauração de um governo cuja plataforma eleitoral não contemplava nem a questão do desenvolvimento regional. A rápida aprovação da proposta poderia, neste caso, ser expressão de uma forma de seletividade divergente.

Apesar de não ser possível entrar em maiores detalhes a respeito das mencionadas políticas regionais ${ }^{31}$, esperamos ter mostrado que as

29 Uma ideia da discussão na fase da articulação da proposta para a PNDR II pode ser encontrada em Randolph e Tavares (2018).

30 E, como acabamos de afirmar, sua possibilidade/potencialidade se manifesta concretamente em propostas, ações ou mesmo na sua (parcial) institucionalização; ou seja, as tentativas não foram "sufocadas" sem ter possibilidade de "aparecer" por uma seletividade repressiva; como discute Offe, muitas potencialidades (prorrogativas, demandas, reivindicações etc.), tem esse destino.

31 Há investigações e análises a seu respeito que não usam a referência conceitual aqui proposta, mas que podem fornecer elementos importantes para um detalhamento das apreciações aqui só provisoriamente detalhada. 
instituições do Estado representam uma "dimensão significativa" para compreender as políticas regionais na sua complexidade.

\section{Estruturas e processos, governança e contradições sócio-políticas}

A institucionalização de seletividades representa o lado estrutural do Estado e cria disponibilidades, mas também certas amarras para um governo. Como dito antes, a atuação de um governo depende, em certa medida, das formas institucionais que encontra, mantêm e/ou altera quando assume o poder e reproduz ou adapta ao seu projeto durante o período da sua gestão ${ }^{32}$.

Para um entendimento melhor da complexidade do "encontro" entre estruturas do Estado e contradições na sociedade e das suas consequências para as politicas se recorre aqui a Poulantzas. Como diz Miguel (2014, p. 154), apesar das trajetórias e bagagens intelectuais diversas de Poulantzas e Offe, as contribuições do último podem ser agregadas à teorização do Poulantzas "pós-estruturalista" sobre a relação entre Estado e luta de classes. As instituições do Estado, para Poulantzas, "não podem ser entendidas como mero instrumento a serviço da classe dominante, nem como um espaço neutro de resolução dos conflitos, mas como a resultante da correlação de forças de determinada formação social em determinado momento de sua história" (MIGUEL 2014, p 154-155)33.

Reconhece-se, especialmente, a proximidade entre as duas perspectivas, de Poulantzas e Offe, por ocasião da ênfase do último ao poder, porque qualquer instituição envolve, de alguma forma, poder social ${ }^{34}$. Para ele, instituições não podem ser analisadas e compreendidas sem a

32 Isto é um processo que é capaz de alterar as agendas dos governos à medida em que as forças políticas e sociais da sociedade se alteram - vide para isto a concepção de Offe das três arenas.

33 Complementarmente ao acima apresentado, Poulantzas aponta para contradições e lutas de classe - o que não permite que o Estado seja considerado uma entidade intrínseca, mas uma relação, ou "condensação material de uma relação de forças entre classes e frações de classe", com instituições próprias, no seio do Estado. "As contradições de classe constituem o Estado, presentes na sua ossatura material, e fabricam assim sua organização" (POULANTZAS, 1981, p. 197). Essa abordagem "materialista" do Estado se aproxima bastante da de Claus Offe.

34 Para Offe (2006, p. 20 ), o poder social se manifesta em um modo de ação que tem o efeito de definir parâmetros para a ação de outros atores sociais, seja em maneiras desfavoráveis ou favoráveis, como visto por aqueles outros. Em ambos os casos, o exercício do poder é conflituoso, controverso e contestado. 
observação do poder social, que tem uma relação complexa com as próprias instituições e cuja dinâmica, por sua vez, é constituinte para aquela do Estado.

Esse formato estrutural/institucional do Estado "moldura", por assim dizer, as ações do governo. "Governar" significa realizar uma série de ações (que estão inscritos nesse quadro institucional), mas precisam responder (em princípio, conforme formas seletivas estabelecidas) a necessidades e demandas varáveis do próprio governo e da sociedade. Como observado acima, há uma "dialética" entre esses aspectos estruturais e dinâmicas: à medida que as estruturas orientam (restringem) o universo das possibilidades de governar, as ações governamentais são capazes de reproduzir ou alterar essas estruturas 35 .

É dentro deste contexto que existem abordagens do conceito de "governança" que se tomam importantes para a atual investigação. Quando observa que as capacidades "governativas" são determinadas por forças e poderes que operam para além das limitações do Estado, Jessop (2004/2014), encaminha essa discussão sobre as seletividades para o termo de governança ${ }^{36}$ - Suas realizações - gestão ou governo que ultrapassa as limitações expressas nas instituições do Estado - interferem no mecanismo de seletividades estruturais/sistêmicas que determinam, como já foi discutido anteriormente, o acesso e suas formas das diferentes classes ou segmentos sociais a Estado e governo.

Vale reter a identificação do autor de uma "seletividade estratégica" que obriga analistas olhar

para além do Estado para examinar a sua incorporação dentro de um sistema político mais amplo, sua relação com outras ordens institucionais e sistemas funcionais, e ao mundo da vida (ou da sociedade civil). Por sua vez, a tentativa de exercício do poder estatal (ou, melhor, os poderes do

35 Eis a expressão simplificada de uma reflexão de Jessop (2004/2014), que vê o Estado embutido em contextos espaço-temporais específicos, onde as instituições produzem consequências específicas e diferenciais (seletividades específicas). Semelhante à discussão antes travada, vê que, conforme a capacidade de diferentes forças políticas e interesses particulares e estratégicas que se expressam através do Estado, têm acesso a ou controle sobre determinadas capacidades dele e de suas instituições.

36 Para Jessop (2004/2014), "em termos gerais, a governança se refere aos mecanismos e estratégias de coordenação adotadas em face da interdependência recíproca complexa entre os atores operacionalmente autónomos, organizações e sistemas funcionais. Assim, governança ocorre em todos os campos sociais e seus estudiosos examinaram uma ampla gama de tais mecanismos e estratégias, incluindo mercados, clãs, redes, alianças, parcerias, cartéis, associações e Estados". 
Estado, no plural) irá refletir algum equilíbrio existente de forças como este é institucionalmente mediada através do aparelho do Estado com a sua seletividade estratégica estruturalmente inscrita (Jessop 2004/2014, tradução nossa).

Essa compreensão torna-se crucial para o debate anterior na medida em que desloca a discussão institucional das seletividades (e de não-acontecimentos) para outras esferas da vida social (organizações fora da esfera estatal) e dos sistemas econômicos (setor privado, mercado etc.). A governança como ação política (e não apensa como conceito) permitiria e mesmo exigiria pensar e compreender as seletividades fora do contexto limitado do Estado, porque "institucionaliza" determinadas formas de responsabilidades da sociedade civil 37 .

Essa "exigência" vai ao encontro com as perspectivas ampliadas sobre o Estado dos autores acima referidos. Abordagens puramente centradas no Estado em termos de gestão ou governo seriam inconsistentes dentro dessa perspectiva "gramsciana/ poulantziana/offeana" - aqui adotada porque pressuporiam que o Estado pode ser examinado isoladamente e tratado como uma variável independente. Foi discutido que tanto Offe (1984, 2006), Poulantzas (1981) e Jessop (2004/2014) propõem abordagens que não pretendem cometer esse equívoco ${ }^{38}$.

Essa discussão da governança precisa ser realizada dentro da perspectiva que estrutura institucional e dinâmica gerencial constituem uma dialética de consolidação e modificação do Estado. Como se viu antes, além da formulação e implementação de políticas governamentais, a própria execução passa por determinados "filtros seletivos", onde se expressa a institucionalidade do Estado, mas que é suscetível a ser modificada por forças políticas envolvidas na sua execução. Se determinam quais as ações os governos podem ou devem tomar, determinam, também, quais não "cabem" no âmbito de determinada política. Assim, a própria dinâmica entre estrutura e processo pode se tornar um círculo vicioso - reproduzir ou reforçar problemas - ou virtuoso - romper gradualmente com o que se reforça.

37 Obviamente, o próprio processo das seletividades leva em conta que havia sempre um "fluxo" de reivindicações , demandas etc. para o governo/Estado, que foram submetidos aos processo de seletividade. E também sempre teve formas de influenciar essas seletividades por mecanismos fora dos governos; talvez a corrupção seja o exemplo mais óbvio; mas havia formas de influenciação legítimas por lobbys etc.

38 Uma apresentação mais detalhada das abordagens destes autores, especialmente Offe e Jessop, mostraria seus posicionamentos em relação à circulação do poder, à institucionalização de seletividades e à articulação entre sociedade política e sociedade civil. 
Foi argumentado, em relação à estrutura do Estado, Offe (2006, p. $10 \mathrm{~s})$, que sua criação precisa ser compreendida como resultado de uma luta entre poderes sociais que, reclama, ao menos rudimentarmente, a reinvindicação de validade, na medida em que não é intencional, instrumental ou orientado para determinados objetivos e possui "ideias de animação", ou alguma teoria implícita que fornece certas razões para seu suporte ou defesa ${ }^{39}$. Ou seja, a formação das instituições é sempre um processo dinâmico dentro do qual a atuação do próprio governo tem sua própria influência.

A nosso ver, entre as diferentes perspectivas ${ }^{40}$ discutidas na literatura, apenas uma, ainda em desenvolvimento, se refere a uma perspectiva de governança, que possibilitaria compreender essa dialética entre estrutura e processo da gestão no sentido que acabamos de anunciar: está voltada para questões de descentralização, diversificação da política (politics and policy) e de regulação. Pode ser interpretada, assim, como um conceito que expande o conceito de governança e procura compreender as relações dinâmicas entre organização, regulação, envolvimento e o papel fundamental de conflitos e contradições sociais.

Permitiria, assim, colocar a discussão sobre a seletividade e produção de não-acontecimento num âmbito mais amplo - como já mostrou o modelo das arenas de Offe - do atravessamento entre sociedade política e sociedade civil; ou mesmo do conceito ampliado de Gramsci (1999).

Uma perspectiva da governança de fundo gramsciana poderia abrir um novo horizonte para a discussão da execução de políticas. Poderia permitir uma perspectiva mais complexa e aprofundada a respeito da questão acima introduzida dos "resultados" da execução de políticas e, assim, avançar para além de uma mera avaliação em falhas, fracassos, inexistências etc.

39 Em particular, instituições aumentam a eficiência de transações na medida em que ajudam a economizar custos na procura, negociação e execução de interações em mercados ou não-mercados. Permitem uma auto-coordenação sem atritos ao oferecerem oportunidades e incentivos. Fornecem continuidade na medida em que a inovação fica mais cara. Finalmente, só em caso de mudanças acidentais e repentinas de condições no mundo externo (crise), perda de plausibilidade moral (conflito) etc., colapso ou falhas institucionais podem acontecer, conforme Offe (2006, p. 14 s).

40 Na sua sistematização das ramificações do debate sobre governança Levi-Faur (2011/2012), identificou quatro vertentes: (i) uma neoliberal ; (ii) uma por este autor chamada "degoverncing"; (iii) uma governança centrada na resiliência do Estado; e (iv) uma que se encontrava ainda em fase de gestação que explora as relações entre "governo" e "governança" de um ponto de vista regulatório que pavimenta um caminho para algo que pode ser chamado de capitalismo regulado ou regulatório (RANDOLPH 2017). 
Em articulação com as seletividades institucionais, poderia se constituir como uma verdadeira "dimensão" que mereceria maior atenção na discussão das políticas regionais que fornecem o horizonte político-histórico do atual estudo. Pois, a produção de não-acontecimentos não é limitada ao Estado, mas ocorre também nas estruturas políticas e sociais (classes, segmentos, grupos etc.) da sociedade ${ }^{41}$.

Uma interpretação das experiências de execução (e dos resultados) da política regional do nordeste - enquanto política nacional - e da primeira PNDR poderia, certamente, exemplificar melhor e dar maior concretudo a essa discussão da governança. Por limitações de espço e tempo, isto vai ter que ser postergado para um outro momento.

O que se pode dizer é, como mostra a referência deste estudo às políticas de desenvolvimento regional, a produção de "não-acontecimentos" remete a questões da exclusão de classes subalternos na sua formulação e da manutenção de velhas hegemonias, cuja "superação" - um dos objetivos da Sudene - (exclusão e reprodução de hegemonia) foi ao menos não como um dos objetivos cujo "acontecimento" não pode ser.

Para identificar possibilidades da superação de "exclusão" e "velha hegemonia" ter "acontecido", seria necessário reconhecer respectivas potencialidades na sociedade brasileira nos diferentes períodos históri$\cos ^{42}$. Seria, provavelmente, fortalecer a "presença" de interesses de classes subalternas nos fóruns ou arenas de circulação do poder (contra as acima mencionadas "forças arcaicas e conservadoras").

\section{Incapacidade ou "não-acontecimento"? À guisa de uma conclusão}

O que se queria salientar aqui ao final do presente estudo é que as duas experiências mostram dois formatos bem diferentes, refletindo as possibilidades dos espaços e tempos históricos de sua formulação e execução. Mesmo ao procurar ter o maior cuidado para não desqualificar os esforços envolvidos e, também, resultados obtidos, parece-nos pertinente levantar aquela interrogação que consta no título deste capítulo.

41 Vide, mais uma vez, a concepção das arenas de Offe como uma aproximação a esta problemática;

42 Parece tentador, elaborar uma "história virtual" a respeito de oportunidades perdidas para a sociedade brasileira; e acompanhar, no tempo, os momentos e características destes não-acontecimentos"; não muda a história, mas pode permitir um melhor aprendizado do passado para projetar o futuro. 
Uma certa descrença em relação à utilidade, para o debate, do julgamento de "fracasso" (ou mesmo "sucesso") das políticas nacionais de desenvolvimento regional no Brasil a partir do resultado de sua execução ou institucionalização perde, neste sentido, uma parte de sua relevância. Não obstante parecem mais interessantes aquelas apreciações que não julgaram as políticas dentro dos parâmetros dos resultados de sua formulação e/ou execução. Apresentam argumentos a respeito da competência das propostas e da sua competência ao propor medidas e instrumentos com alguma (discutida) potencialidade de contribuir para que o objetivo central das políticas - a redução das desigualdades inter-regionais no Brasil - pudesse ser cumprido.

Neste sentido, a pergunta em relação à responsabilidade de uma "incompetência" (técnica/instrumental) na formulação e/ou execução das políticas pela sua falha pode ser negada - desconsiderando eventuais menores problemas. Seria interessante observar mais de perto esta questão em relação à política para o desenvolvimento do Nordeste e as duas versões da PNDR, o que vai ter que ser deixado para ouro momento.

Uma identificação das características e das eventuais causas ou razões das políticas não lograrem reduzir as desigualdades regionais - parece este "fato" ser mais ou menos consensual - se tornou necessário, então, procurar outras "variáveis" ou, ao seguir o conselho de Celso Furtado, "dimensões" que permitiriam perceber a complexidade dos fenômenos.

Pressupondo tratar no universo do nosso estudo de fenômenos com um certo grau de complexidade, procuramos dimensões que pudessem ter uma influência no "fracasso/sucesso" de uma política de desenvolvimento regional. E, ao invés, de atribuir às políticas um status de simples "não-existência", procuramos compreender essa "inexistência" como produto ou "resultado" de processos sociais e políticos.

Se não se quer simplesmente excluir sua existência, pode-se admitir que processos sociais e políticos que foram mobilizados para sua produção não conseguiram assegurar seu "acontecimento". Um potencial "acontecimento" não se realizou e deu lugar a um "não-acontecimento" - ou seja há, nesta produção social e política, uma relação dialética entre acontecimento/não-acontecimento, porque sem um potencial/virtual acontecimento, não haveria um não-acontecimento ${ }^{43}$.

43 Usamos, em outro lugar, o exemplo da "inexistência" do sol durante a noite em um determinado lugar. Não se trata aqui de um "não-acontecimento" por ser resultado de um processo natural que excluí qualquer possibilidade do sol aparecer na noite. 
Em outras palavras, é o processo de produção do acontecimento/não -acontecimento que vai poder confirmar se um "não-acontecimento" está acontecendo. Foi mostrado, nos itens anteriores, qual a dinâmica e os mecanismos que estão envolvidos na produção destes acontecimentos/ não-acontecimentos.

Para redimir a dúvida, expressa no título do texto a respeito da "existência" de uma política nacional de desenvolvimento regional no Brasil, seria necessário seguir, particularmente, os processos de seletividade nas suas formas mais gerais. Obviamente, a breve apresentação acima dos dois momentos da formulação e/ou execução de políticas que se propuseram contribuir ao desenvolvimento regional não permite chegar a uma conclusão a respeito de seu status. Em nível de certa plausibilidade e sem emitir nenhum juízo definitivo poderia se identificar elementos que descartam tanto sua avaliação como simples fracasso, bem como propostas incompetentes, mas, talvez, por causa de uma certa potencialidade, como "não-acontecimentos".

Enfim, ao vincular a atual discussão das políticas a questões do Estado - como muitos outros autores também fazem; menos, talvez os economistas que estão muito presentes no campo do desenvolvimento regional - entram em cena outras temáticas que poderiam ser importantes para pensar no "futuro" em políticas de desenvolvimento regional.

Vale lembrar de uma afirmação de Celso Furtado que já foi mencionada antes. Fala o autor da necessidade de uma reconstrução da temática:

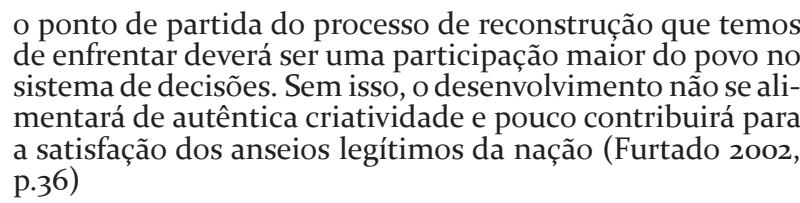

Acredita-se que Furtado, como já o fizeram outros, toca aqui num ponto de maior importância. E, implicitamente, temos a esperança que a discussão apresentada neste texto pode dar alguma, ainda que limitada, contribuição para esta reconstrução - que ainda há de ser feita, mesmo que fosse apenas para compreender a profundidade do desafio que Celso Furtado nos faz.

Pois, como mencionado acima, a análise de um fenômeno como "não-acontecimento" vai dirigir a atenção, no caso de políticas públicas, aos mecanismos de seletividade que são os principais responsáveis por sua produção. Remete a questões de poder e da inclusão/exclusão por 
determinadas estruturas, instituições e dinâmicas: classes, segmentos, grupos sociais e especialmente aqueles que, estruturalmente, não são envolvidos e contemplados pelas políticas. E vai mostrar limites que essas estruturas e dinâmicas colocam para transformar em futuras propostas um "acontecimento" que contemple aqueles que hoje são sistematicamente excluídos.

Em seu debate sobre um aprofundamento da democracia, Miguel (2014) trava essa mesma discussão em relação aos limites que o atual quadro de instituições impõe. A abordagem dos "não-acontecimentos" pode, em analogia ao caso discutido pelo autor,

evidenciar os limites tanto da mera incorporação de integrantes de grupos subalternos aos espaços decisórios já constituídos (a "política de presença" propugnada pelo movimento feminista a partir dos anos 1990) quanto da abertura de arenas marginais na estrutura do Estado, que seriam mais permeáveis às demandas dos grupos dominados (os novos espaços participativos, como conferências, conselhos de políticas públicas ou orçamentos abertos à manifestação popular, para citar exemplos em voga na ciência social brasileira)" (MIGUEL 2014, p. 158).

Sem poder aprofundar aqui, o debate trazido por Miguel dá uma impressão de como os mecanismos de seletividade e as estruturas políticas são capazes de neutralizar a eventual presença de membros de grupos subalternos ${ }^{44}$. O conhecimento da força e da resiliência dos mecanismos de reprodução da dominação social mostra a necessidade de se resistir a mecanismos "imunes" de cooptação através de recompensas simbólicas e materiais para aqueles que aceitam "jogar o jogo" da política normalizada (MIGUEL 2014, p. 160).

\section{Referências}

ALMEIDA, J.E., ARAÚJO, J.B. Um modelo exaurido: a experiência da Sudene. Teor. e Evid. Econ. Passo Fundo v. 12 n. 23, 2004, p. 97-128

BERNARDES, D., LIMA, M.C. Celso Furtado e a pré-revolução brasileira. maio 2010 https://www.acessa.com/gramsci/?page=visualizar\&id=1235; acesso em 15.04.2020

44 Há uma literatura sobre este assunto que traz diferentes abordagens de resistência, insurgência até de subversão como formas de reação para escapar deste risco, vide p.ex. Randolph 2014 . 
BRANDÃO, C. Desenvolvimento nacional, políticas regionais e o poder de decisão segundo Celso Furtado. Cadernos do Desenvolvimento, vol. 5 (7), 2010, p. 101- 115

BRANDÃO, C. Avançamos na PNDR II, mas falta transformá-la em uma estratégia de Estado. Revista Política e Planejamento Regional (RPPR), Rio de Janeiro, v. 1, n. 2, julho/dezembro 2014, p. 339-344

BRASIL PRESIDÊNCIA DA REPÚBLICA, Decreto № 6.047 , de 22.02.2005, Brasília 2007

BRASIL PRESIDÊNCIA DA REPÚBLICA, Decreto № 9.810 de 30.05.2019, Brasília, 2019

CARVALHO, O. Perspectivas do desenvolvimento regional no Brasil. Revista Política e Planejamento Regional (RPPR), Rio de Janeiro, v. 1, n. 2, 2014, p. 295 a 310

COELHO, V.L.P. A política regional do governo Lula (2003-2010) Revista Política e Planejamento Regional (RPPR), Rio de Janeiro, v. 2, n. 2, 2015, p. 265-286

COSTA, M.R. O Estado e a Sudene: Trajetória do planejamento regional no Brasil. Campinas, SP: UNICAMP, 2016, (tese de doutorado)

FURTADO, C. A pré-revolução brasileira. Rio de Janeiro: Editora Fundo da Cultura, 1962

FURTADO, C. Em busca de novo modelo: reflexões sobre a crise contemporânea. São Paulo: Paz e Terra, 2002.

FURTADO, C. O mito do desenvolvimento econômico. Rio de Janeiro: Paz e Terra, 1974

GRAMSCI, A. Cadernos do cárcere. Rio de Janeiro: Civilização Brasileira 1999

GTDN. Uma política de desenvolvimento econômico para o Nordeste. 2.ed. Recife: Sudene, 1967.

GUIMARÃES NETO, L. Desafios para uma Política Nacional de Desenvolvimento Regional no Brasil. Entrevista especial com Leonardo Guimarães Neto. Entrevistadores: J. Natal e H. Siqueira (realizada em março de 2011), R. Pol. Públ., São Luís, v.16, n.1, jan./jun. 2012, p. 203-207 
GUMIERO, R.G. A trajetória das politicas de desenvolvimento regional do Nordeste: balanço entre a Operação Nordeste e a PNDR. Revista Politica e Planejamento Regional (RPPR), Rio de Janeiro, v. 4, n. 2, 2017, p. 189 a 210

HORSTH, T.A., ALMEIDA, F.M., MENDES, W.A. Efeitos das recriações da SUDAM e da Sudene no desenvolvimento socioeconômico municipal. Trabalho publica nos anais do IV Encontro Brasileiro de Administarção Pública, João Pessoa, maio 2017

JESSOP, B. Multi-level governance and multi-level meta-governance. Changes in the EU as Integral Moments in the Transformation and Reorientation of Contemporary Statehood, in I. Bache and M. Flinders, eds, Multi-Level Governance, Oxford: OUP, 49-74, 2004. - on-line version is the pre-copyedited, preprint version 2014: http://bobjessop. org/2014/o1/10/multilevel-governance-and-multilevel-metagovernance/

LEFEBVRE, H. A revolução urbana. Belo Horizonte: Editora UFMG, 1999

LEVI-FAUR, D. From big government to big governance? Jerusalem Papers in Regulation \& Governance, Working Paper No. 35, July $2011 / 12$

MACEDO, F.C., PORTO, L. Existe uma Política Nacional de desenvolvimento Regional no Brasil? G\&DR - Taubaté, SP, v. 14, n. 2, 2018, p. 605-631 MIGUEL, L. F. Mecanismos de exclusão política e os limites da democracia liberal. Uma conversa com Poulantzas, Offe e Bourdieu. Novos Estudos CEBRAP, no 98, março 2014, p. 145-161

OFFE, C. Algumas contradições do Estado social moderno. In: Offe, C. Trabalho e sociedade. Perspectivas. Rio de Janeiro: Tempo Brasileiro 1981, p. 113-131

OFFE, C. Dominação de classe e sistema político. In: Offe, C., Problemas estruturais do Estado capitalista. Rio de Janeiro: Tempo Brasileiro, 1984, p. 140-179

OFFE, C. Governance: An "Empty Signifier"? Constellations 16, 2009, p. $55^{-}-562$ 
OFFE, C. Political institutions and social power: conceptual explorations. In: I. Shapiro; S. Skowronek; D. Galvin (Eds). Retinking political institutions. The art of the state. New York, London: New York Ubiversity Press 2006, p. 9-31

PESSOA, S.R.N., MILANI, A.M.R. A invenção criadora da GTDN e o desenvolvimento econômico sob a ótica de Schumpeter: o empresário inovador como elemento de convergência. Revista Economia Política do Desenvolvimento, v.6, n. 16, 2013, p.123-144

PITANGA, P.A. Os desafios a uma Política Nacional de Desenvolvimento Regional no Brasil. INTERAÇÕES, Campo Grande, v. 15, n. 1, 2014, p. 175-192

PORTUGAL, R. O que dizem as avaliações da política de desenvolvimento regional np Brasil? Rev. Econ. NE, Fortaleza, v. 48, n. 3, 2017, p. 157-170,

POULANTZAS, N. O Estado, o poder, o socialismo. Rio de Janeiro: Graal 1981 (publicado originalmente em francês em 1978).

RANDOLPH, R. Subversão e planejamento como "práxis", uma reflexão sobre uma aparente impossibilidade. In: LIMONAD, E.; CASTRO, R. E. (Orgs.) Um novo planejamento para um novo Brasil? Rio de Janeiro: LetraCapital 2014, p. 40-57

RANDOLPH, R. Arenas de formulação de políticas regionais: uma proposição metodológica. Revista Brasileira de Desenvolvimento Regional, v. 3, 2015, p. 5-26.

RANDOLPH, R. Política, planejamento e governança do desenvolvimento regional - quo vadis? Redes - Santa Cruz do Sul: Universidade de Santa Cruz do Sul, v. 22, n. 1, 2017. p. 218-239

RANDOLPH, R. Quo vadis, planejamento e desenvolvimento regional? Apresentação na Mesa Redonda VI: Perspectivas e Avaliação da Área de PUR no Brasil no IV SEDRES. Palmas-TO: UFT, 2018

RANDOLPH, R. Fóruns Políticos, Exercício do Poder e Agendas Regionais: contextos para a formulação de políticas regionais de desenvolvimento no Brasil In: RANDOLPH, R. BARBOSA, G.S., ANTUNES, L. PEIXOTO, D.F. (Orgs) Consórcios Intermunicipais e Comitês de Bacia Hidrográfica - Suas potencialidades e limitações para formular agendas de 
desenvolvimento regional no Brasil, Rio de Janeiro: Hexis Ed. 2019, p. $31-47$

RANDOLPH, R., TAVARES, H.M. (Orgs.) Política e planejamento regional - uma coletânea. Brasília-DF: Gráfica Movimento, 2013

SILVA, L.P. Análise da trajetória institucional de implementação da Política Nacional de Desenvolvimento Regional no Brasil. Rev. Serv. Público, Brasília vol. 67 (3) 2016, p. 351-376

SILVA, S.A. A PNDR e o planeamento regional brasileiro no início do século XXI. Texto para discussão no. 2150, IPEA - Brasília: Ipea 2015 


\section{Escalas Espaciais, Território \\ e Desenvolvimento Regional: \\ Notas para discussão teórica e metodológica}

Rogério Leandro Lima da Silveira ${ }^{1}$

"Cada lugar é, ao mesmo tempo, objeto de uma razão global e de uma razão local convivendo dialeticamente”.

Milton Santos

\section{Introdução}

s escalas EsPaciais ESTÃo PRESENTES EM nOSSA VIDA, EM NOSSAS
representações da realidade, em nossas ações, relações e lutas sociais. Também estão presentes nos processos sociais e econômicos e na construção e implementação das políticas públicas de planejamento e desenvolvimento regional.

Entretanto, o significado etimológico do termo escala ainda é de difícil compreensão, dada a polissemia que o vocábulo expressa, como veremos adiante, na próxima seção.

Para o senso comum, a temática da escala, de um modo geral, também passa despercebida ou quando é considerada, a mesma é relacionada em sua dimensão quantitativa. Ou seja, a proporção entre as medidas e distâncias existentes em uma dada planta arquitetônica, carta ou mapa cartográfico e as medidas, dimensões e distâncias reais dos objetos eáreas territoriais, correspondentes. No meio acadêmico, sobretudo em algumas de suas áreas disciplinares como as engenharias, a arquitetura e a

1 Doutor em Geografia. Pesquisador do CNPq. Professor do Programa de Pós-graduação em Desenvolvimento Regional e do Departamento de Ciências, Humanidades e Educação, da Universidade de Santa Cruz do Sul. Coordenador do Observatório do Desenvolvimento Regional e Líder do Grupo de Pesquisa Estudos Urbanos e Regionais (GEPEUR-CNPq).E-mail: rlls@unisc.br. 
cartografia, essa concepção e uso da escala, pode-se dizer, são também predominantes na análise espacial e nos projetos de intervenção.

Entendemos que a escala cartográfica é, e continuará sendo, um importante instrumento de análise e representação espacial dos objetos, fluxos, formas construídas e territórios. Entretanto, essa concepção de escala não é única, e diante dos complexos, cambiantes e desiguais processos socioespaciais de desenvolvimento que experimentamos no presente, em diferentes regiões do mundo, através da atuação de sujeitos e instituições concretas que se relacionam, se enfrentam, se aliam no território, se torna imprescindível valorizar e utilizar a escala, em sua dimensão geográfica ou espacial. Ou seja, é preciso que valorizemos a escala espacial nos estudos sobre os processos, as políticas, as ações e relações sociais presentes na produção social dos territórios.

Nas duas últimas décadas tem ocorrido um importante debate acadêmico no âmbito das ciências humanas e sociais, especialmente entre geógrafos, economistas políticos e sociólogos, sobre o conceito de escala espacial, enquanto produto social e estratégia política e de poder para a compreensão dos processos sociais e econômicos e das dinâmicas territoriais de desenvolvimento atualmente existentes (MARSTON, 200o; SMITH, 2000; SANTOS, 2001; BRANDÃO, 2007; SWYNGEDOUW, 2004; e BRENNER, 2009).

Além disso, observa-se também que as escalas espaciais também têm despertado relativo interesse dos formuladores e gestores das políticas públicas territoriais, ainda que muitas vezes fiquem limitadas ao discurso e a escrita das políticas e dos planos. (CARGNIN, 2014; CORREA, 2018)

Nesse ensaio, contribuímos com esse debate sobre a importância das escalas espaciais ou geográficas na análise do território e dos processos de desenvolvimento e planejamento regional. Nossa contribuição se dá a partir da nossa formação acadêmica no campo da Geografia, mas também pela nossa atuação no ensino, na pesquisa e na extensão da pósgraduação em desenvolvimento regional. Algumas das reflexões aqui apresentadas surgiram da nossa participação nas discussões e debates realizados com meus alunos e colegas no Grupo de Pesquisa Estudos Urbanos e Regionais (GEPEUR) e no Programa de Pós-Graduação em Desenvolvimento regional, da UNISC.

As notas que aqui apresentamos iniciam com apresentação do conceito de escala espacial e a necessária distinção em relação ao conceito de escala cartográfica. Também refletimos sobre a especificidade e a relação entre escala dos fenômenos, escala de análise e escala de ação. No 
segundo tópico abordamos a ideia chave que fundamenta nossa compreensão e reflexão sobre a escala espacial, que é justamente a de que as escalas são constructos sociais, ou seja, são produzidas socialmente por agentes concretos em suas relações e estratégias políticas nos territórios. No terceiro e último tópico, tratamos da relação entre escala espacial e a dinâmica territorial, com a intenção de contribuir teórica e metodologicamente para a compreensão, análise dos processos e políticas de desenvolvimento regional.

\section{O conceito de escala espacial}

A escala, como bem nos lembra Castro (2003, p.118), "É uma estratégia de aproximação do 'mundo real', um mecanismo de compreensão da realidade, por causa impossibilidade de apreendê-la na sua totalidade".

Todavia é preciso também considerar que a escala é um termo polissêmico. Etimologicamente essa polissemia se expressa através dos vários significados atribuídos a este vocábulo. Consultando o dicionário, vamos encontrar diversos sentidos e aplicações que essa palavra suscita. Dentre outros, destacam-se: a escada ou conjunto de degraus para passar de um nível mais baixo a outro mais alto, ou vice-versa; a sequência de notas musicais ordenadas de modo ascendente ou descendente que constituem a escala musical; o registro indicando a ordem de serviço para cada trabalhador, configurando a escala de trabalho; a série de divisões traçadas num instrumento de medição de temperatura, ou seja, a escala termométrica; um ponto de parada intermediária em uma dada viagem realizada por meios de transporte como aviões, trens ou ônibus, como escala para recebimento de carga ou passageiros ou para reabastecimento, ou ainda como a relação entre as dimensões e tamanho de um desenho, um mapa e os do objeto ou área representados (MICHAELIS, 2015).

A polissemia da escala também se expressa epistemologicamente entre as ciências. Na química contemporânea o campo de estudo da nanociência e da nanotecnologia tem buscado compreender e controlar a matéria em nanoescala, ou seja, em escala atômica e molecular, visando o desenvolvimento de novos materiais e componentes para diversas áreas e setores como a medicina, a eletrônica, e a engenharia de materiais. A escala aqui se apresenta como condição absolutamente necessária para a análise estrutural e produção de novos materiais (FERNANDES E FILGUEIRAS, 2008). Por sua vez, Castro (1992, p.23) com base no pensamento de Merleau-Ponty sobre a escala, nos lembra que na Filosofia, 
mais especificamente na fenomenologia, "quando se trata das escalas de percepção do real: não há escala mais ou menos válida; não há hierarquização de grandezas escalares; a escala da percepção é sempre ao nível do micro fenômeno, o real está presente em toda a escala”. Na Arquitetura, o significado predominante de escala é aquele de medida de redução ou ampliação de uma dada área para sua representação, usualmente gráfica. A produção de projetos e maquetes arquitetônicas, dependendo das necessidades e objetivos de representação gráfica dos objetos e dos espaços reais, faz uso, então, de escalas de redução ou de escalas de ampliação (FONTENELLE, 2018).

As noções de escala presentes na Cartografia e na Geografia também têm participado na produção dessa polissemia epistemológica da noção de escala, e a distinção entre elas é de fundamental importância para que possamos avançar na compreensão do conceito de escala espacial.

Na Cartografia a escala é uma fração que indica a relação matemática entre as medidas do real (na superfície terrestre) e aquelas da sua representação gráfica (no mapa ou numa planta). Ela indica a relação entre o valor de uma distância medida no mapa e sua correspondente no terreno. Ou seja, ela é usada para representar a relação de proporção entre a área real e a sua representação cartográfica no mapa. Como didaticamente já demonstrou Souza (2013, p.180):

A escala cartográfica pode ser apresentada sob a forma de uma escala numérica, em que a proporção é expressa como uma fração, sendo que o denominador representa a distância no terreno, e o numerador, o seu equivalente no mapa (carta ou planta). Por exemplo, 1:1.ooo.ooo significa que um centímetro no mapa equivale a um milhão de centímetros no terreno (isto é, 1.ooo quilômetros). [...]Ela pode também ser apresentada sob a forma de uma escala gráfica, em que a proporcionalidade é expressa com a ajuda de uma barra numerada.

No âmbito da Geografia o termo escala significa um indicador de tamanho do espaço considerado, ou do recorte escolhido para a análise espacial. Para Souza (2013, p.181) a escala geográfica "tem a ver não com a fração da divisão de uma superfície representada em um documento cartográfico, mas sim com a própria extensão ou magnitude do espaço, que se está levando em conta".

Ou seja, enquanto a escala cartográfica expressa a representação espacial de uma dada parcela da superfície terrestre como "forma geométrica", a escala geográfica expressa a representação da relação que a sociedade através dos agentes sociais, das suas instituições, mantêm com essa 
“forma geométrica", em realidade com essa parcela do espaço geográfico. (RACINE, RAFFESTIN E RUFFY, 1983).

Na Geografia essa compreensão sobre o significado e uso da escala geográfica está sobretudo presente na Geografia Humana, onde desde o movimento de sua renovação epistemológica crítica, a partir do final dos anos setenta do século passado, tem ocorrido importantes avanços na investigação sobre a teorização e a representação da escala. Busca-se compreender a espacialidade do processo de globalização capitalista, de sua dinâmica e das particularidades de sua reprodução ou resistência nos diferentes lugares e regiões do mundo. Entre tais estudos, destacam-se o trabalho de Taylor propondo uma economia política de escala que se fundamente na especificação das escalas características de operação dos processos econômicos e sociais essenciais e da exploração das formas pelas quais as diferentes escalas geográficas (local, nacional e global) se articulam, nesses processos, umas com as outras (TAYLOR (1985) apud GREGORY, 2000, p.186). Destaca-se também as contribuições seminais de Smith (1982) em sua obra Gentrification and Uneven Development onde ele introduz três escalas nas quais pode-se observar um desenvolvimento geográfico desigual: o urbano, o regional e o nacional. Em cada escala, ele aborda as relações especificamente capitalistas que conectam áreas desenvolvidas e subdesenvolvidas através dos movimentos espaciais do capital. Esses movimentos têm velocidades e concentrações diferentes, à medida que o capital responde e produz seu cenário contraditório de equalização e diferenciação espacial. (SMITH, 1982 e 1988).

Para uma melhor compreensão do que seja a escala geográfica ou espacial, como aqui estamos a definindo, Souza nos orienta a levar também em consideração as suas três subdivisões, ou dimensões constitutivas: as escalas do fenômeno, de análise e de ação.

A escala do fenômeno se refere a escala do tamanho ou de abrangência de um dado objeto ou fenômeno natural, ou social, existente no espaço geográfico e presente na realidade. Como exemplo, podemos aqui mencionar a extensão da urbanização de um município, de uma microbacia, de uma dada aglomeração urbana, de uma região econômica, ou ainda de uma pandemia como a do Covid-19 ou a escala de abrangência do agronegócio ou da agricultura familiar num dado território. Cada fenômeno vai se apresentar em uma dada escala de tamanho ou abrangência: local, regional, nacional, internacional ou global. 
Souza assinala que quando nos referimos a escala de fenômenos sociais precisamos considerar algumas especificidades pois

\begin{abstract}
"podemos estar nos referindo à abrangência de processos referentes a dinâmicas essencialmente "impessoais" (como a globalização) e a resultantes de desdobramentos não premeditados, ainda que muitas vezes previsíveis ( a exemplo de uma catástrofe nuclear), ou ainda à abrangência de dinâmicas de ação coletiva programática ou consciente, como resistências, lutas e movimentos sociais; e podemos estar lidando com fenômenos que, ao menos à primeira vista, se deixam apreender como áreas e territórios contínuos por exemplo, a escala de um país) ou diversamente. Com fenômenos que demandam uma compreensão de sua estruturação em rede (como as redes do crime organizado)" (SOUZA, 2013, p. 181-182).
\end{abstract}

A relação entre escala do fenômeno e escala de análise se vincula diretamente com a relação entre realidade e conhecimento, sendo este último resultado da apreensão e compreensão do objeto real, através das percepções, da experiência, da vivência e de uso dos conceitos pelos sujeitos.

Do mesmo modo, a escala de análise é definida e construída intelectualmente pelo pesquisador como um nível analítico do fenômeno da realidade a ser investigado, que permita apreender as suas características e particularidades relevantes, em sintonia com as questões norteadoras e/ ou com o problema de pesquisa (SOUZA, 2013).

Por outro lado, é preciso também considerar que diante da complexidade atual dos processos políticos e econômicos e da dinâmica socio espacial, envolvendo distintos agentes sociais, diferentes instituições e com desiguais reflexos nos territórios, não há como lançar mão de ou se privilegiar apenas uma escala de análise, mas sobretudo valorizar abordagens multiescalares. Pois, como assinalou Lacoste (1988), no processo de conhecimento

\footnotetext{
“não há um nível [escalar] de análise privilegiado", [já que] "nenhum deles é suficiente, pois o fato de se considerar tal espaço [a partir de uma dada escala] como campo de observação irá permitir apreender certos fenômenos e certas estruturas, mas vai acarretar a deformação ou a ocultação de outros fenômenos e de outras estruturas, das quais não se pode, a priori, prejulgar o papel e, portanto, não se pode negligenciar"(Lacoste, 1988, p.81)
}

As escalas de análise, em seus diferentes níveis de abrangência espacial como a local, regional, nacional e global, não existem ou são dadas a priori. Como lembra bem Souza (2013, p.188), "elas são antes "arrancadas" 
da realidade no processo de construção do objeto de conhecimento por parte do pesquisador". As escalas de análise "variam em número e natureza, da mesma maneira como variam os objetos de conhecimento, os modos de construí-los e as questões (os problemas) que orientam essa construção".

Além disso, como veremos adiante, as escalas espaciais são construídas socialmente, o que implica que em nossa análise devemos primeiro focar nos fenômenos e processos socioespaciais e depois identificar as formas contingentes e dimensão escalar que manifestam. Tão pouco os diferentes níveis escalares do local ao global, devem ser vistos como resultantes de uma ordem hierárquica, mas sim numa perspectiva interrelacional. (PECK,2010).

Já a escala de ação se refere a um dado aspecto ou fato específico em sua dimensão política relacionada estrategicamente "à reflexão acerca do alcance espacial das práticas dos agentes. É, portanto, um tipo de escala que se refere a determinados fenômenos sociais, concernentes às ações (em geral coletivas) e ao papel de agentes/sujeitos" (SOUZA, 2013, p.182).

As práticas e as estratégias de ação dos agentes sociais nos processos de desenvolvimento territorial e regional e nas relações políticas existentes, ocorrem na maior parte das vezes, em diversas escalas espaciais. Os atores hegemônicos, por exemplo, como as grandes corporações multinacionais, buscam viabilizar seus interesses setoriais e políticos, definindo estratégias de ação e explicitando relações de poder, em múltiplas escalas. Para tanto atuam simultaneamente tanto nas escalas local e nacional, quanto na escala global. Ou ainda, possuem a capacidade de saltar escalas, de acordo com a lógica de suas ações políticas hegemônicas globais, ignorando muitas vezes os condicionantes nacionais ou regionais, e realizando seus projetos e interesses diretamente nos espaços locais. Também os atores sociais ligados ao mundo do trabalho quando conseguem articular ações e estratégias políticas em distintos níveis escalares, do local, ao regional e mesmo ao nacional, conseguem melhores condições políticas para garantir o atendimento de suas reivindicações sociais ou trabalhistas junto ao Estado e às empresas.

Nesta linha de abordagem da escala espacial, enquanto escala de ação, as relações de poder adquirem importância fundamental. Smith (2000, p.142) reforça essa compreensão quando assinala que a "produção e reprodução da escala expressa tanto a disputa social quanto a geográfica para estabelecer fronteiras entre diferentes lugares, localizações e sítios de experiência". 
Na construção do conceito de escala espacial com esse mesmo sentido e perspectiva outros autores a nomeiam como escala geográfica de poder (RAMBO e RÜCKERT, 2008), escala territorial (DINIZ, 2001), escalas de poder (VAINER, 2001) ou ainda como escala geográfica (GRANDI, 2012 e SOUZA,2013).

Assim, entendemos que as escalas espaciais são níveis de análise do raciocínio espacial que permitem explicar, de modo ordenado, as complexas relações entre sociedade e natureza. A diferenciação e a articulação simultâneas das escalas geográficas constituem uma maneira eficaz para compreender as transformações que se processam no mundo atual.

\section{A construção social e política das escalas}

A escala não é uma categoria criada naturalmente, ou seja, cuja existência ontológica seja dada a priori. Tão pouco a escala deve ser pensada como uma variável ou fator externo já constituído e disponível, e que precisa ser descoberto e aplicado para compreendermos a realidade.

Como bem destaca Souza (2013, p.187) muitos ainda são os pesquisadores e planejadores que tomam "os níveis [escalares] de análise da realidade como "dados", quase da mesma maneira como observamos uma porção da superfície terrestre expressa em uma (...) imagem de satélite”. Ou seja, é como se as escalas local, regional, nacional e global existissem por si próprias, independentemente do processo de construção, pelo analista, do objeto em análise, ou a despeito dos processos sociais. É como se as escalas espaciais dos fenômenos, de análise e de ação, "fossem uma espécie de realidade anistórica ou quase material, à maneira de "camadas de contextualização" nas quais os homens e mulheres concretos "se inscreveriam" para serem por elas condicionados, mas, de resto, sem exercerem, eles próprios, maior influência sobre tais "camadas"”(SOUZA, 2013, p.187)..

Neil Smith (1993), nos ajuda a lembrar que as escalas espaciais não são quadros ou molduras dadas a priori dentro dos quais vivemos nossa vida. Vivemos nossa vida cotidiana em diferentes e simultâneas dimensões escalares, desde a escala do nosso corpo, da nossa comunidade ou bairro, da nossa cidade, da nossa região, do nosso país, do mundo.

Muitas vezes também identificamos por parte dos pesquisadores e planejadores a identificação da escala espacial como sendo ela própria o sujeito da ação. Nesse aspecto, não é incomum nos depararmos com expressões como "o global se apropria e domina o regional e o local" ou "relações de poder entre o local e o global". 
Estas perspectivas de pensamento e compreensão sobre a escala espacial acabam contribuindo ora para sua coisificação ou reificação, ora para sua subjetivação.

Pensamos diferentemente, com Vainer (2002), que em realidade, os processos econômicos, políticos, sociais, culturais que ocorrem historicamente possuem diferentes dimensões escalares, e na maioria das vezes, também, tais processos apresentam uma dimensão multi ou transescalar. "As próprias escalas são produzidas em processos profundamente heterogêneos, conflituosos e contestados" (VAINER, 2002, p.24).

Essa compreensão nos chama atenção para a importância de superarmos a visão, ainda corrente, de que os processos ocorrem e/ou estão contidos em uma estrutura escalar ordenada e pré-existente que agrupa hierarquicamente desde o nível escalar local, passando pelos níveis escalares intermediários regional e nacional, até se alcançar o nível escalar global, ou em movimento inverso, mas também hierárquico, do global pra o local.

As metáforas comumente utilizadas para representar as escalas ou para buscar explicar o seu significado tem reforçado essa estrutura hierárquica. Nos livros escolares de Geografia é comum, por exemplo, o uso da metáfora da escada para representar a estrutura hierárquica das escalas ao mostrar que se "sobe" do degrau "local" para o "regional", depois para o "nacional "até alcançar o degrau "global", ou então que se "desce" do degrau global para o nacional, e assim sucessivamente até o local. O uso de tal metáfora ao associar o degrau mais alto da escada ao global parece indicar que ela está acima de todas as demais escalas, ao mesmo tempo em que mostra que cada escala é diferente da outra. Essa representação metafórica revela uma maneira particular de conceituar as relações escalares entre lugares, caracterizada pela ideia de ordem e hierarquia como as mesmas se relacionam (HEROD, 2008).

Uma outra metáfora frequentemente utilizada para a representação das escalas é a da Matryoshka, bonecas russas idênticas e de tamanhos diferentes que se encaixam umas dentro das outras, demostrando a ideia de uma "hierarquia aninhada" Nessa metáfora, cada boneca (ou seja, cada escala) é separada e distinta e pode ser considerada sozinha. De acordo com Herod (2008, p.228)

Se pensarmos em escala dessa maneira, teremos uma situação em que não há escala 'acima' de qualquer outra no sentido vertical que a metáfora da escada sugere. Da mesma forma, a escala global (a boneca externa) é vista como 'maior' do que todas as outras escalas 'menores', de 
modo que o global possa conter outras escalas, mas isso não funciona ao contrário (ou seja, o local não pode conter o global). Por outro lado, a metáfora da boneca Matryoshka implica com muito mais força do que a metáfora (...) da escada que existe uma hierarquia aninhada de escalas, com cada escala se encaixando perfeitamente para fornecer um todo coerente ${ }^{2}$.

A complexidade dos processos cada vez mais interdependentes, interrelacionados nos demandam a pensar as escalas socialmente construídas e vivenciadas em uma perspectiva relacional, ou seja, em sua dimensão multiescalar.

Nesse sentido, concordamos com Peck (2010, p.86), quando afirma: "Os processos sociais e regulatórios não podem estar categoricamente atribuídos a escalas específicas, e tão pouco a constituição escalar desses processos teóricos se outorgou com anterioridade ou se fixou historicamente. Melhor dito, a relação entre uma escala em particular e um processo social específico (...) é histórica e geograficamente contingente3".

Outro aspecto a considerar na construção social da escala e em sua dimensão política é a necessidade, no contexto contemporâneo de aceleração dos fluxos no território, como assevera Milton Santos (1996) de distinção entre escala das ações operacionais e a escala do seu comando, pois o espaço geográfico é um hibrido, produzido por um conjunto indissociável de objetos e de ações e uma conjunção singular de processos materiais e culturais.

Nessa mesma direção, Endlich (2012, p.02) destaca ainda que as escalas geográficas "são produzidas e estão profundamente vinculadas aos alcances do poder em cada momento histórico [acompanhando] o modo de produção capitalista. Se, atualmente, existe a escala global, é porque existem agentes que podem operar nesta escala, ao passo que,

2 No original: "If we think about scale in this way, then we have a situation in which there is no scale which is 'above' any other in the vertical sense that the ladder metaphor suggests. Likewise, the global scale (the outside doll) is viewed as being 'larger' than all the other 'smaller' scales, such that the global can contain other scales but this does not work the other way round (i.e. the local cannot contain the global). On the other hand, the Matryoshka doll metaphor implies much more forcefully than does (...) the ladder metaphor that there is a nested hierarchy of scales, with each scale fitting neatly together to provide a coherent whole" (HEROD, 2008, p.228).

3 No original: "Los processos sociales y regulatórios no puden estar categórigamente assignados a escalas especificas, y tampoco la cpnstituición escalar de estos processos teóricos se otorgó com anterioridade o se fijó historicamente. Mejor dito, la relación entre uma escala em particular y um processo social específico (...) es histórica y geográficamente contingente" (PECK, 2020, p.86). 
contraditoriamente, significativa parte da sociedade não pode se apropriar nem da escala local". Harvey, nesse sentido, complementa que "as escalas são produtos de mudanças tecnológicas, são modos de organização humana e da luta política" (HARVEY, 2000, p.108).

Entendemos também que a escala é construída socialmente numa perspectiva relacional resultante das "tensões contingentes que existem entre as forças estruturais e as práticas dos agentes” (MARSTON, 2000, p. 220), dos "processos sociais contraditórios de competição e cooperação4" (SMITH, 200o, p. 142), ou através da "dinâmica socio-espacial (...) e do conflito social e da luta político-econômicas" (SWYNGEDOUW, 2010, p. 56).

Nos últimos tempos, o conceito de escala espacial e sua compreensão e uso metodológico a partir da noção de que a escala é produzida socialmente, tem recebido atenção não apenas de geógrafos, mas também de outros pesquisadores, sobretudo no campo das Ciências Sociais, que criticamente tem abordado e debatido o significado e o papel da escala na análise social e estrutural, e na luta política.

Muitos tem sido os autores que, desde diferentes perspectivas, têm participado do debate sobre o que são as escalas espaciais e como as mesmas podem ser empregadas na análise dos processos sociais e econômicos. Entre esses autores se destacam os aportes de Brenner (2009 e 2013) sobre os limites e possibilidades das interpretações escalares sobre os padrões de reestruturação urbana e regional existentes nos períodos do pós-fordismo e do início do século XXI e as contribuições de Peck (2010) sobre as economias políticas da escala e as relações interescalares, e o reescalonamento do Estado no contexto neoliberal. Por fim, destacamos também as contribuições de Swyngedouw (2010) sobre a importância de valorizar a perspectiva escalar na análise da vida política e econômica atual para uma compreensão crítica do processo de globalização de modo a melhor entender a sua espacialidade, as relações de poder e a centralidade do poder político, e as contradições estruturais, nele existentes.

Um dos aspectos importantes no debate sobre a construção social da escala, presente na obra desses autores, se refere a dimensão política das escalas, ou a política de escala(s). Smith (1990) propõe aprofundar a pesquisa em torno de questões sobre como a construção de escala também

4 No original: "contradictory social processes of competition and cooperation" (MARSTON, 2000, p.220).

5 No original: "y el conflicto social y la lucha político-económica" (SWYNGEDOUW, 2010, p. 56). 
é tentada ou realizada por um conjunto diversificado de atores envolvidos em transformações políticas, configurando o que ele denominou de a prática de uma política de escala. As análises de tais práticas chamam a atenção para as relações desiguais entre espaço e poder, mas também para concepções e ideologias que orientam atores sociais que se esforçam para mudar a ordem social e econômica estabelecida, mas também atores sociais que buscam resistir às mudanças sociais.

Nessa mesma perspectiva, Souza de modo mais detalhado, complementa que a política de escala também pode ser definida como

\begin{abstract}
a articulação de ações e agentes operando em níveis escalares diferentes (isto é, que possuem magnitudes e alcances distintos) com a finalidade de potencializar efeitos, neutralizar ou diminuir o impacto de ações adversas ou tirar maiores vantagens de situações favoráveis; por exemplo, ampliando esferas de influência (ao expandir audiências, sensibilizar atores que sejam possíveis aliados, etc.) e propiciando sinergias políticas (ao recrutar novos apoios, costurar alianças etc.). (SOUZA, 2010, p.42; Grifado no original).
\end{abstract}

A política de escala evidencia que para a efetividade e eficácia política das ações no território, é de fundamental importância que estas possam ser realizadas através da articulação, em diferentes escalas, de um maior número e de distintos atores sociais, bem como da ampliação dos níveis escalares desse apoio político. Tal processo é identificado por Smith (2000) como "jumping scales" ou saltar escalas, e caracterizado por Tarrow (2008) como "scale shift" ou deslocamento escalar.

Ao considerarem a produção social da escala como um âmbito privilegiado da luta política, Smith (2000) e Marston (2000) concentram suas análises nas possibilidades e potencialidades que os agentes e grupos sociais, que se opõem ou lutam contra o poder estabelecido, têm de se organizarem e lutarem em diferentes e cada vez mais amplas escalas. A esse respeito, destaca Smith: "saltar escalas permite aos expulsos dissolver as fronteiras espaciais que são em larga medida impostas de cima e que detêm, em vez de facilitar, sua produção e a reprodução da vida cotidiana" (SMITH, 2000, p. 137).

O saltar escalas (jumping scales) ou o deslocamento escalar (scale shift) são também estratégias escalares dos movimentos sociais e ativismos visando superar as limitações locais e melhor promover e divulgar suas causas e lutas. Para tanto saltam escalas transformando seus movimentos locais em regionais, nacionais e globais, escapando assim dos obstáculos do localismo, do paroquialismo e do particularismo através da 
expansão do alcance geográfico e político de novos apoios para suas pautas e reivindicações (SMITH, 2000 e MARSTON, 200o). Muitos tem sido os movimentos sociais que têm utilizado essa estratégia de saltar escalas, como são os casos dos Zapatistas, no México; dos povos indígenas como os do Xingu, no Brasil, liderados pelo cacique Raoni, ou como os Mapuches, no Sul do Chile; o Movimento dos Trabalhadores Sem Terra, no Brasil, ou ainda como os movimentos feministas e ativismos ambientais atuantes em diferentes lugares do mundo.

Essa perspectiva crítica de compreensão das escalas espaciais como constructos sociais e políticos, que se efetivam no território através de uma dinâmica multiescalar e relacional dos fenômenos e processos ambientais, culturais, sociais, econômicos e políticos oferece novas possibilidades teóricas e metodológicas para se pensar e analisar o desenvolvimento regional.

\section{Escalas espaciais, Território e Desenvolvimento Regional}

No campo mais específico dos estudos sobre planejamento e desenvolvimento regional, também tem havido um crescente interesse sobre o tema das escalas espaciais, com a produção de importantes aportes sobre seu significado, sua compreensão e seu uso teórico e metodológico na análise dos territórios e dos processos de planejamento e desenvolvimento territorial.

Dentre algumas dessas obras de referência destacam-se: os estudos de Fernández (2010) sobre a importância de se pensar e analisar desde a periferia latino-americana o desenvolvimento regional através de uma perspectiva transescalar que considere as regiões não apenas desde seus territórios, mas também como nós de redes de fluxos e atores, e de decisões e recursos externos que as atravessam redefinindo-as e condicionando suas possibilidades de desenvolvimento; as contribuições de Brandão (2010, 2015) sobre a necessidade de aprofundarmos a reflexão teórica e metodológica sobre a dimensão territorial do desenvolvimento em suas distintas escalas espaciais, problematizando a questão das decisões e das relações de poder entre os sujeitos concretos envolvidos na construção social dos espaços; os aporte de Vainer (2002) sobre o papel das escalas de poder e as escalas de ação na análise dos processos de planejamento e desenvolvimento territorial; e as contribuições de Ramírez (2010) sobre como o uso e manejo da escala nos processos de produção do 
espaço tem sido um elemento fundamental na promoção do desenvolvimento regional.

Buscando contribuir com esse profícuo debate teórico e metodológico sobre a importância da valorização das escalas espaciais nos estudos urbanos e regionais, apresentamos a seguir alguns pontos para a reflexão que nos parecem fundamentais para a compreensão e análise dos processos e políticas de desenvolvimento regional.

Iniciamos pelo território, ou mais exatamente do que estamos entendendo por território, pois é nele que os processos e políticas de desenvolvimento regional ocorrem e são socialmente produzidos, desde distintas, mas também relacionais, escalas espaciais.

Entendemos o território desde uma perspectiva geográfica, na qual é preciso considerar de antemão, que o espaço geográfico antecede o território. Ao se apropriarem de um espaço, concreta ou abstratamente (por exemplo, pela representação), os atores sociais "territorializam" o espaço. "O território, nessa perspectiva, é um espaço onde se projetou um trabalho, seja energia e informação, e que, por consequência, revela relações marcadas pelo poder" (RAFFESTIN,1993, p.143-144).

Nossa compreensão é complementada com a proposição de Souza (1995, p.78-79) de que o território deve ser apreendido como "um espaço definido e delimitado por e a partir de relações de poder". Ou seja, ele é "essencialmente um instrumento de exercício de poder: quem domina ou influência quem nesse espaço, e como?”

Em que pese tal concepção esteja mais vinculada à sua dimensão política, ligada à instituição e consolidação histórica do Estado-Nação (ELDEN, 2013), a mesma não se restringe apenas à escala nacional, associada com o Estado enquanto instância política de controle, regulação e gestão, ou por derivação aos territórios dos municípios e dos estados da federação brasileira. Territórios existem e podem ser demarcados, delimitados, apropriados, constituídos e reconstituídos nas mais diversas escalas espaciais.

Além disso, na medida em que as noções de controle, de ordenamento e de gestão espacial, fundamentais no debate sobre o território, não se restringem apenas ao Estado, mas igualmente se vinculam às estratégias de distintos grupos sociais e das grandes corporações econômicas e financeiras, o território deve ser apreendido como resultado da interação entre múltiplas dimensões sociais, econômicas, políticas e culturais (SILVEIRA, 2018). 
Nesse sentido concordamos com Milton Santos (2002, p.10) de que:

O território não é apenas o conjunto dos sistemas naturais e
de sistemas de coisas superpostas. O território tem que ser
entendido como o território usado, não o território em
si. O território usado é o chão mais a identidade. A identi-
dade é o sentimento de pertencer àquilo que nos pertence.
O território é o fundamento do trabalho, o lugar da residên-
cia, das trocas materiais e espirituais e do exercício da vida
(Grifo nosso).

A importância dessa dimensão relacional (que também deve estar presente nas escala espaciais) na análise e compreensão do território é também assinalada por Reis (2005, p.53) ao destacar que para se interpretar o território é preciso considerar em sua leitura "a natureza das estruturas e das dinâmicas da sociedade e da economia, um entendimento sobre o modo como se alcança a coordenação dos processos coletivos, sobre o papel desempenhado pelos atores neles intervenientes, e sobre as relações (hierárquicas ou não) entre atores e processos de diferentes escalas espaciais".

Esse sentido relacional presente na definição do território traduz a incorporação, simultânea, do conjunto das relações sociais e de poder, e da relação complexa entre processos sociais e espaço geográfico, este entendido como ambiente natural e ambiente socialmente produzido. Além disso, esse sentido relacional implica também que consideremos que o significado do território não apenas se vincula as ideias de enraizamento, estabilidade, limite, fronteira, fixidez, mas também as ideias de movimento, de fluidez, de conexão (SILVEIRA, 2018 e HAESBAERT, 2002).

A coexistência de fenômenos e processos globais, regionais e locais revela o conteúdo histórico e a complexidade dos usos do território e requer tanto para a análise dos fenômenos e dos processos sociais, culturais e econômicos quanto para a formulação de políticas de desenvolvimento, que se valorize a importância das escalas espaciais para uma melhor compreensão da dinâmica territorial do desenvolvimento regional.

Metodologicamente, precisamos identificar as escalas nas quais os fenômenos e os processos se originam, ocorrem e alcançam no território. Precisamos, também, definir as escalas de análise necessárias à compreensão da dinâmica dos fenômenos e processos presentes no território ou que nele incidem. E, igualmente devemos pensar e compreender as escalas de ação, envolvendo as ações práticas e políticas, em sua dimensão narrativa e como objeto e instrumento de políticas, planos e projetos de desenvolvimento em disputa em relação a um dado território. 
Nesse sentido, como nos lembra Brandão (2015, p.o8) o desafio científico e político posto é o de justamente "procurar definir o que cada escala poderá revelar cientificamente e com que meios, mecanismos e instrumentos políticos cada escala pode contar para mobilizar, contestar, acionar, regular, comandar ou controlar."

A qualificação da análise e da formulação das políticas de desenvolvimento regional impõe a necessidade de se superar a costumeira adoção de uma única escala de análise e/ou intervenção e de se buscar a articulação e a seleção de escalas espaciais adequadas para análise dos processos ou para se buscar alcançar os objetivos dessas políticas.

Para uma adequada compreensão dos processos e das políticas de desenvolvimento regional nos territórios há que se buscar superar a ideia de que a escala regional está dada a priori, assim como a de que o território usado da região é uma espécie de contentor ou de espaço palco, fechado e passivo, onde o que importa analisar são os agentes, as instituições, suas ações e relações, e os processos e políticas, existentes e circunscritos ao território e à escala regionais.

Como já mencionamos acima, vivemos um tempo de crescente complexidade, mudança, interrelação e interdependência dos fenômenos ambientais, dos processos socioespaciais de desenvolvimento. Na etapa contemporânea da economia capitalista observamos uma crescente, ainda que desigual, circulação e ampliação de fluxos de diferentes tipos: pessoas, capitais, matérias primas, recursos, produtos, ideias, informações e ordens entre os lugares e regiões do mundo.

Tais fluxos, expressam e resultam de relações geopolíticas, econômicas, sociais, políticas, culturais e de poder, na maioria das vezes assimétricas, estabelecidas entre distintos e numerosos agentes sociais e instituições, e que são mediadas e reguladas pelo mercado e pelo Estado, em diferentes níveis de abrangência e graus de intensidade, de acordo com as especificidades e condicionantes de cada formação socioespacial e da conjuntura existente.

A dinâmica de produção e de circulação desses fluxos no espaço geográfico das regiões ora é organizada e condicionada por redes pré-existentes, ora resulta na criação de novas redes, não apenas circunscritas ao território regional.

Os fluxos que organizam e definem essas redes são produzidos por relações sociais e articulações econômicas e políticas engendradas no território, simultânea, mas também desigualmente, em distintos níveis escalares, desde o local, o regional, o nacional, e o global. Cada um dos 
agentes sociais, das organizações e instituições que se apropriam e usam e transformam o território regional se relacionam, interagem, se articulam em uma ou mais escalas espaciais.

Assim, além de considerarmos as distintas escalas (e sua interrelação) das ações e processos em rede que são engendrados ou que repercutem nos territórios usados das regiões, precisamos igualmente levar em conta na análise do desenvolvimento regional e buscar identificar e compreender como se apresentam as escalas de ação dos seguintes agentes e instituições:

- as escalas espaciais de elaboração e de efetivação da política pública, em suas instâncias nacional, estadual e municipal, como no caso do Brasil, e o modo como se combinam ou se contradizem, assumindo particularidades nos territórios regionais;

- as diferentes escalas de ação dos grupos empresariais nacionais e transnacionais que comandam as cadeias produtivas regionais, mas também das empresas locais e regionais, em suas estratégias de jumping scales nos usos e apropriação dos territórios regionais;

- as distintas escalas de ação prática e política dos atores sociais que vivem e atuam nas regiões (como os sindicatos de trabalhadores urbanos e rurais, os ativismos e os movimentos sociais e ambientalistas, as associações empresariais urbanas e rurais), seus usos do território e suas estratégias de scale shift;

- as escalas de atuação das instituições regionais como as universidades, associações de municípios, consórcios intermunicipais, conselhos regionais, cooperativas, etc. e suas ações, articulações em relação aos demais agentes sociais e organismos estatais existentes no território;

- as escalas de ação dos órgãos estatais de diferentes níveis (federal, estadual, regional) que atuam nos territórios regionais, buscando também identificar as estratégias de scale shift que adotam, por exemplo através da descentralização, as diferentes regionalizações que apresentam e as interações espaciais que promovem nos territórios, através dos fluxos de serviços; $\mathrm{e}$

- as escalas e as estratégias de ação das redes de organizações e de cooperação no âmbito da sociedade civil. Redes essas, que não sem conflitos e através de relações de poder, buscam implementar projetos e políticas de desenvolvimento endógenos, menos assimétricos e mais autônomos, valorizando as particularidades, a identidade, os atributos, as contingências, e as oportunidades existentes no território regional. 
Certamente, diante da complexidade dos processos de desenvolvimento regional, inúmeras outras variáveis e dimensões igualmente precisam ser consideradas na sua análise. Portanto, esse conjunto de atores e instituições para as quais propomos acima identificar e compreender suas escalas de ação no território regional, não se faz suficiente para tamanho desafio analítico. A despeito disso, ele nos parece um bom caminho para iniciar essa empreitada científica.

\section{À guisa de conclusão}

A polissemia do vocábulo escala enseja distintos significados e aplicações pelas ciências e pelo senso comum. A complexidade do espaço geográfico e as diferentes dimensões e medidas dos fenômenos socioespaciais, exigem maior nível de abstração. Portanto é preciso então pensar a escala não só como medida matemática de proporção da representação gráfica do território, mas também como representação de diferentes modos de percepção e de concepção do real, e como produto social das relações estabelecidas no território.

As escalas não são neutras por serem produzidas por processos heterogêneos e de conflito. Elas não estão dadas a priori nem são geometricamente definidas. Precisamos criticar os usos da escala que produzem sua reificação e subjetivação, e valorizar a compreensão de que as escalas são frutos de processos de apropriação e de dominação do espaço e, por isso, carregam consigo todo um conteúdo estratégico e político.

As escalas são, portanto, produtos das ações sociais ao longo de processos históricos envolvendo disputas que perpassam por todas as escalas espaciais, na maioria das vezes acontecendo simultaneamente.

Não há, assim, uma escala mais importante do que a outra. O que importa é a perspectiva que interrelacione as escalas envolvidas nos processos políticos, sociais, econômicos e culturais em foco, para buscar melhor compreender sua complexidade.

Na prática, estamos acostumados com hierarquizações muito simples, como a da microescala (local) para a macroescala (global), ou vice-versa, sendo pensadas com ou sem a metáfora cartográfica. Mas essas hierarquizações, muito influenciadas pela representação espacial euclidiana, nos prendem ao plano geométrico e à dimensão espacial bidimensional. Em geral, somos levados a esquecer a perspectiva dinâmica e multifacetada e relacional que as escalas espaciais nos trazem. Essa perspectiva nos oferece melhores condições metodológicas para compreender os processos 
de desenvolvimento territorial através da identificação no território das escalas dos fenômenos, de análise e das ações.

Pensamos que nesse contexto de crescente interdependência e de desigual interação de diferentes aspectos e níveis de relação entre os atores sociais e econômicos e entre eles e as instituições públicas e estatais, em diferentes territórios, soa importante valorizar as escalas espaciais na análise dos processos de desenvolvimento regional e de formulação e implementação das políticas de desenvolvimento regional.

Por fim, essa perspectiva crítica de compreensão das escalas espaciais como constructos sociais e políticos, que se efetivam no território através de uma dinâmica multiescalar e relacional dos fenômenos e processos ambientais, culturais, sociais, econômicos e políticos, oferece também novas possibilidades teóricas e metodológicas para se avançar a produção do conhecimento no campo do desenvolvimento regional.

\section{Referências}

BRANDÃO, Carlos A./ FERNÁNDEZ, Victor Ramiro/ RIBEIRO, Luiz Cesar de Queiroz. (Org.). Escalas espaciais, reescalonamentos e estatalidades: lições e desafios para América Latina. 1. ed. - Rio de Janeiro: Letra Capital: Observatório das Metrópoles, 2018. Disponível: http://docplayer.com.br/86178729-Escalas-espaciais-reescalonamentos -e-estatalidades-licoes-e-desafios-para-america-latina.html Acessado em março, 2020.

BRANDÃO, Carlos Antônio. Produción social del ambiente construído y sus escalas espaciales: notas para uma teoria acerca de las acciones y decisiones de sujeitos concretos. In:Fernández, Victor R. y Brandão, Carlos (Org.). Escalas y Politicas del Desarrollo Regional - Desafios para América Latina. Buenos Aires: Ed. Mino y D’ávila. 2010. P.241-272

. Transformar a provisão de bens e serviços públicos e coletivos nos espaços urbanos e regionais do Brasil. In: e-metropolis. N.23, Ano 06. Dezembro, 2015. P. o6-14.

. Visões teóricas sobre desenvolvimento regional e a questão das escalas (mundial, nacional, subnacional e local) nas políticas regionais contemporâneas. In: Curso Territorialidade e Políticas Públicas no Brasil. ENAP, Brasília, 2 de maio de 2011. 
BRENNER, Neil. Reestruturação, reescalonamento e a questão urbana. In: GEOUSP - espaço e tempo, São Paulo, $\mathrm{N}^{\circ} 33$, 2013. pp. 198-220.

. Restructuring, rescaling and the urban question. In: Critical Planning, 10, 2009. Disponível em: http://citeseerx.ist.psu.edu/viewdoc/download?doi=10.1.1.485.9921\&rep=rep1\&type=pdf. Acessado abril, 2020 .

CARGNIN, Antônio P. Escalas de poder e gestão e a implementação de políticas de desenvolvimento regional no estado do Rio Grande do Sul. In: Revista Política e Planejamento Regional (PPR), Rio de Janeiro, v. 1, n. 1, p. 57-80, jan./jun. 2014. P.57-80.

CASTRO, I. E. O problema da escala. In: CASTRO, I.E.; GOMES, P.C.C.; CORRÊA, R.L (Org.).Geografia: conceitos e temas. $5^{\text {a }}$ ed. Rio de Janeiro: Bertrand Brasil. 2003. p.117-140.

Análise geográfica e o problema epistemológico da escala.

In: Anuário do Instituto de Geociências da UFRJ. Vol.15. 1992. Disponível em: http://www.ppegeo.igc.usp.br/index.php/anigeo/article/ view/1505/1394 Acessado em: março, 2020.

CORREA, José Carlos Severo. O planejamento regional no Corede Fronteira Oeste: uma análise da articulação das políticas territoriais numa perspectiva multiescalar. Tese de Doutorado. Programa de Pós-Graduaçäo em Desenvolvimento Regional. UNISC. 2018.

DINIZ, Clélio Campolina. Globalização, escalas territoriais e política tecnológica regionalizada no Brasil. Texto para Discussão 168. Belo Horizonte: UFMG/Cedeplar, 2001.Disponível: <http://cedeplar.face. ufmg.br/pesquisas/td/TD\%20168.pdf>. Acesso em 20 fev. 2015

ELDEN, Stuart. The birth of territory. Chicago: The University of Chicago Press. 2013.

ENDLICH, Ângela Maria. Escala e território: a perspectiva do município no Brasil. Scripta Nova. Revista Electrónica de Geografía y Ciencias Sociales. [En línea]. Barcelona: Universidad de Barcelona, 1 de noviembre de 2012, vol. XVI, no 418 (54). <http://www.ub.es/geocrit/sn/sn-418/ sn-418-54.htm>. Acessado em: março, 2020.

FERNANDES, Maria Fernanda Marques; FILGUEIRAS, Carlos A. L.. Um panorama da nanotecnologia no Brasil (e seus macro-desafios). 
Quím. Nova, São Paulo , v. 31, n. 8, p. 2205-2213, 2008 . Disponível em:<http://www.scielo.br/scielo.php?script=sci_arttext\&pi$\mathrm{d}=\mathrm{S} 0100-40422008000800050 \& \operatorname{lng}=\mathrm{en} \& \mathrm{nrm}=\mathrm{iso}>$. Acessado em 14 Mai 2020. https://doi.org/10.1590/So100-40422008000800050.

FERNÁNDEZ, Victor Ramiro.Desarrollo Reginal bajo transformaciones trasns-escalares. Porqué y cómo recuperar la escala nacional? In:Fernández, Victor R. y Brandão, Carlos (Org.). Escalas y Politicas del Desarrollo Regional - Desafios para América Latina. Buenos Aires: Ed. Mino y D’ávila. 2010. P.301-341.

FONTENELLE, Carlos Eduardo Costa e Silva. Escala gráfica: contribuições paraa representaçãodoprojeto arquitetônico. Dissertação (mestrado) - Universidade Estadual de Campinas, Faculdade de Engenharia Civil, Arquitetura e Urbanismo, Campinas, SP. 2018. Disponível em: <http://www.repositorio.unicamp.br/handle/REPOSIP/331803>. Acesso 03 mar. 2020.

GREGORY, Derek. Escala. In. JOHNSTON, R.J.; GREGORY, D. e SMITH, David M. (Org). Diccionário Akal de Geografía Humana. Madrid: Ediciones Akal, 2000.

HARVEY, David. Espaços da esperança. São Paulo: Ed. Loyola. SP. 2000.

HAESBAERT, Rogério. Concepções de território para entender a desterritorialização. In: Território, territórios. Programa de Pós-Graduação em Geografia. Niterói: UFF/AGB, 2002. p.17-38.

HEROD, Andrew. Scale: The local and the global. In.: Clifford, N.; Holloway, Sarah; Rice, Stephen and Valentine, Gill (Editores). Key Concepts in Geography. SAGE Publications. Second edition. p.217-235. 2008.

LACOSTE, Yves. A geografia - Isso serve, em primeiro lugar, para fazer a guerra. Campinas: Ed. Papirus, SP. 1988.

MARSTON, SallieA. The social construction of scale. Progress in Human Geography, London, Volume 24, n.2. June, 2000. p. 219-242. Disponível em: https://journals.sagepub.com/doi/10.1191/030913200674086272 Acessado em abril, 2020. 
MICHAELIS. Dicionário Brasileiro da Língua Portuguesa. Editora Melhoramentos Ltda. 2015. Disponível em: https://michaelis.uol.com. br/moderno-portugues/ Acessado em abril, 2020.

PECK, J. Economías políticas de escala: políticas rápidas, relaciones interescalares y workfare neoliberal. In: Fernández, Victor R. y Brandão, Carlos (Org.). Escalas y Politicas del Desarrollo Regional - Desafios para América Latina. Buenos Aires: Ed. Mino y D’ávila. P.77-120, 2010.

RACINE, J.B. RAFFESTIN, C. e RUFFY, V. Revista Brasileira de Geografia. IBGE: Rio de Janeiro. Vol. 45, n.1. jan./mar,1983. P.123-135.

RAFFESTIN, Claude. Por uma geopolítica do poder. São Paulo: Ed. Ática, SP. 1993.

RAMBO, Anelise Graciele; RÜCKERT, AldomarArnaldo. Desenvolvimento territorial e escalas geográficas de poder e gestão - o caso da Cooperacana, Porto Xavier - RS. Geosul, Florianópolis, v. 23, n. 46, p 95-114, jul./dez. 2008. Disponível: <https://periodicos.ufsc.br/index.php/geosul/issue/ view/1256>. Acesso em 20 fev. 2020.

RAMIREZ, Blanca. De la escala al espacio em la construción del desarrollo regional. In: In:Fernández, Victor R. y Brandão, Carlos (Org.). Escalas y Politicas del Desarrollo Regional - Desafios para América Latina. Buenos Aires: Ed. Mino y D’ávila. 2010. P.217-237.

REIS, José. Uma epistemologia do Território. In: Estudos Sociedade e Agricultura, Rio de Janeiro, vol. 13, no. 1, 2005, p. 51-74.

SANTOS, Milton. Território e Dinheiro. In: Programa de Pós-Graduação em Geografia da UFF. Território, Territórios. Niterói: PPGEO-UFF/AGBNiterói, RJ. 2002. p.17- 38

SANTOS, Milton. A natureza do espaço. São Paulo: Ed. Hucitec, SP. 1996.

SILVEIRA, Rogério Leandro Lima da. Território, Rede e Desenvolvimento Regional: Notas para discussão. In: SILVEIRA, R.L.L. e FELIPPI, A.C.T. (Org). Territórios, Redes e Desenvolvimento Regional: Perspectivas e Desafios. Florianópolis: Ed. Insular, SC. 2018. P.232-252. 
SMITH, Neil. Contornos de uma política espacializada: veículos dos semteto e a produção de escala geográfica. In: ARANTES, Antônio A. (org.) O espaço da diferença. Campinas: Papirus, 2000. p. 132-159.

Homeless/global: scaling places. In: BIRD, John et al. (Ed.). Mapping the futures: local cultures, global change. London/New York: Routledge, 1993. p. 87-119

. Desenvolvimento Desigual: natureza, capital e a produção do espaço. Trad. Eduardo de Almeida Navarro. Rio de Janeiro: Bertrand Brasil, 1988.

. Gentrification and uneven development. Economic Geography 58:39-155. 1982.

SOUZA, Marcelo Lopes de. Os conceitos fundamentais da pesquisa sócio-espacial. Rio de Janeiro: Ed. Bertrand Brasil, 2013.

. Com o Estado, apesar do Estado, contra o Estado: Os movimentos urbanos e suas práticas espaciais, entre a luta institucional e a ação direta. Cidades. Volume 7, Número 11, 2010. P.13-47. Disponível em: https://revista.fct.unesp.br/index.php/revistacidades/article/ view/523/554 Acessado, março, 2020.

SWYNGEDOUW, Erik. Globalización o glocalización? Redes, territórios y reescalamiento. In: Fernández, Victor R. y Brandão, Carlos (Org.). Escalas y Politicas del Desarrollo Regional - Desafios para América Latina. Buenos Aires: Ed. Mino y D’ávila. P.47-75. 2010 [2004].

Neither global nor local: 'glocalization' and the politics of scale. In: COX, Kewin R. Spaces of globalization: reasserting the power of the local. New York/London: The Guilford Press, 1997. p. 137-66.

TARROW, Sidney. Power in Movement. Social Movements and Contetious Politics. Cambridge: Cambridge University Press.2008.

VAINER, Carlos. As escalas do poder e o poder das escalas: o que pode o poder local? Cadernos IPPUR, Rio de Janeiro, v. 15, n. 2, p. 13-32, dez. 2002. 



\section{Para pensar as espacialidades e as temporalidades dos processos sociais regionalizados em conjuntura de crise disruptiva}

Carlos Antônio Brandão ${ }^{1}$

Toda decisão envolve uma forma de exercício de uma forma de poder". [Seria preciso] "identificar a natureza do sistema de dominação: seu relacionamento com a estratificação social, seus meios de legitimação, sua organização no espaço, seus meios de reprodução etc. (FURTADO, 1980, p. 33).

\section{Introdução}

Ceguindo as pistas de Stuart Hall e Doreen Massey (2010, P.

57), quando afirmam que "uma conjuntura é um período durante o qual diferentes contradições sociais, políticas, econômicas e ideológicas, que estão em ação, vêm se juntar em uma específica e distintiva forma”, procuramos pensar a presente condensação de contradições em 2020 e propor um conjunto de questões ligadas aos processos sociais regionalizados nesta conjuntura de crise disruptiva.

Há momentos históricos cruciais, em que a confluência de determinações e circunstâncias potenciais ou pendentes acabam se desenrolando em uma situação de rompimento abrupto da trajetória pregressa, engendrando um novo regime pósnormal. Ziauddin Sardar (2010), discutindo os tempos pósnormais, afirma que nesses contextos problemáticos, de incerteza e ignorância para a tomada de decisões políticas, seria preciso ter imaginação e criatividade na nova era marcada por complexidades, contradições e o caos.

1 Professor Titular do IPPUR/UFRJ. Doutor, Livre Docente e Professor Titular pelo Instituto de Economia da Unicamp. Pós-doutor pela Universidade British Columbia e pelo Centro de Estudos Sociais da Universidade de Coimbra. Bolsista do CNPq. Coordenador do site www.interpretesdobrasil.org. Coordenador do Observatório Celso Furtado para o Desenvolvimento Regional do Centro Internacional Celso Furtado. E-mail: brandaoufrj@gmail.com. 
Estamos perplexos diante da conjuntura de condensação de contradições, conflitos, caos e crise. Talvez precisemos de uma outra pedagogia da crise econômica, política e social, como propõem Bob Jessop e Karim Knio (2019). Eles buscam discutir a natureza e os horizontes espaço-temporais das crises vistas não como eventos acidentais ou excepcionais, anomalias ou distúrbios momentâneos, mas enquanto processos sistêmicos e multideterminados, em multifacetado mosaico, que desorientam e desestabilizam a sabedoria convencional e os contextos estruturais anteriores. $\mathrm{Na}$ conjuntura atual estamos atormentados por uma crise pandêmica e uma crise estrutural resultante do avanço neoliberal.

Melhor do que falar em era do neoliberalismo, seria caracterizar as últimas décadas como um processo de neoliberalização, que vai ocorrendo em distintas rodadas cíclicas: um processo dinâmico, plástico e resiliente, com repercussões variadas nos âmbitos sociais e espaciais e que lança mão de dispositivos, mecanismos e instrumentos bastante diferenciados de experimentações rerregulatórias pró-mercado e de mercantilização parametrizada. Imersos na mercadejação ou marquetização radical e na voracidade caótica da crise multidimensional contemporânea, não temos, no momento, forças acumuladas para o contraponto. O Estado, que poderia coordenar decisões transformadoras, foi "incapacitado para responder a emergências" (SOUSA SANTOS, 2020) e a sociedade parece perplexa, amorfa ou anestesiada. Pior, o processo de neoliberalização, metamorfoseando-se continuamente, sendo flexível e adaptando-se a cada tempo-espaço concreto, ingressa em uma conjuntura de pós-verdade, autocrática e pós-democrática novo-normal.

Mesmo nesta conjuntura desfavorável, poderia existir uma abertura para gerar fissuras e brechas a ocupar ou oportunidades emancipatórias a explorar? Talvez fosse o tempo de quebrar o senso comum de todos os fundamentalismos, inclusive o de mercado. Tempo de buscar engendrar outras condições de existência social, que não a econômica ou a individualista. Perseguir o enriquecimento cultural além do material, alargando os horizontes de possibilidades, segundo o conceito furtadiano. Recolher e enfeixar condições objetivas e subjetivas que lograssem se contrapor à constelação de injustiças que nos são impostas e nos constrangem, estruturando e legitimando decisões alternativas.

Como nos ensina Celso Furtado (1967), decisão pode ser vista, ora como uma unidade, um elemento ao longo de uma cadeia de decisões, ora como um centro de irradiação e de influência das decisões de outros agentes. Na primeira, como um elemento ao longo de uma cadeia, está-se 
colocando ênfase no fato de a decisão constituir, até certo ponto, resposta "passiva" a uma situação social posta; na segunda, como um núcleo de irradiação de decisões, põe-se o acento no fato de que uma decisão é capaz de modificar "ativamente" dada situação ou contexto social.

Neste contexto geral, elaboro neste ensaio exploratório alguns apontamentos acerca da necessidade da área do desenvolvimento regional avançar em uma teorização do papel fundante das decisões cruciais dos agentes dominantes e seus contrapoderes. Defendo a necessidade da realização de atividades de ensino, pesquisa e extensão que não negligenciem as estruturas constitutivas mais gerais, mas que, ao mesmo tempo, não percam as lógicas das conjunturas mais particulares. É essencial buscar apreender as estruturas constituintes das relações sociais em suas articulações com o todo, mas, simultaneamente, acompanhar os movimentos da conjuntura, os elementos contingenciais e circunstanciais das temporalidades mais curtas e das espacialidades mais imediatas.

O momento poderia ser de tomada de decisões com ousadia e inventividade. Ou seja, requereria decisões de outra natureza do que aquelas características do status-quo.

Defendo aqui que a questão regional hoje deveria se expressar, antes de tudo, na forma de decisões ousadas nucleadas na provisão de direitos e bens e serviços coletivos. Proponho a discussão de uma estratégia territorializada de um adequado padrão de oferta de bens, equipamentos e serviços públicos e coletivos para enfrentar a destituição de direitos e as desigualdades variadas nas escalas microrregional, supralocal e do lugar no Brasil.

Destaco que a escala regional apresenta virtualidades e potencialidades a serem melhor exploradas. Ao mesmo tempo, as escalas subregionais também não podem ser perdidas de perspectiva quando se pretende empreender lutas contra o desenvolvimento desigual e enfrentar decisivamente as destituições e as injustiças.

A escala regional só pode ser vista de forma relacional, em sua coerência estruturada, na posicionalidade de seu específico ambiente e no contexto histórico com suas particulares e específicas capacidades de decisão, relações de propriedade e poder etc., mas também em seus nexos, acionamentos e articulações interescalares no todo da divisão inter-regional do trabalho. Nas escalas subregionais, as práticas espaciais de sujeitos sociopolíticos em seus loci de pragmatismo, no acontecer do imediato e do vivenciado concretamente em cada espaço e cada conjuntura também requerem análise. 
Assim, avalio que as pesquisas e os cursos de pós-graduação em desenvolvimento regional deveriam continuar a mergulhar nas suas especificidades geográficas, históricas, estruturais e conjunturais dos seus respectivos mundos micro e mesorregionais, buscando captar toda a riqueza da diversidade e da complexidade de seus contextos e posicionalidades frente ao todo. Seus estudos bem situados, geográfica e historicamente, são fundamentais para suas singulares regiões e para o Brasil. Entretanto, não deveriam flertar com concepções teórico-metodológicas conservadoras, pois estas já demonstraram que não tem nada a ver com as nossas formações e realidades socioeconômicas, territoriais, culturais e espaciais.

\section{Os variados Cs: conjuntura complexa de condensação de contradições e conflitos na caótica crise}

Analisar nosso atual e desafiante tempo histórico como conjuntura, vista como um complexo processo de condensação de contradições, ajuda a arguir sobre as temporalidades e espacialidades desse momento radical de rupturas em que estamos agora mergulhados. Mais do que nunca, é indispensável buscar a imaginação e a criatividade nesta conjuntura atravessada por complexidades, contradições e o caos.

Entretanto, a conjuntura não é favorável a nenhuma ousadia. Desde o final dos anos 1970, ingressamos em um mundo parametrizado, normalizado, marquetizado e perplexamente dominado pelo mercado e pelo neoliberalismo (CAHILL et al., 2019; BERNDT et al., 2020). O acelerado e disruptivo tempo conjuntural em que estamos vivendo (que expressa inédita condensação do tempo estrutural) revela a tentativa radical (vencedora pelo menos na atual quadra histórica) de desestabelecer do mercado em relação às forças sociais. Trata-se de conjuntura de conexões contraditórias, no sentido de Doreen Massey e Stuart Hall, que parece confirmar a vitória do "moinho satânico" da mercantilização extrema, no sentido apontado por Karl Polanyi (1980). O processo de neoliberalização ingressa em uma fase de pós-verdade, autocrática e pós-democrática. Para complicar a crise econômica, política e social em que estamos mergulhados, temos também as crises ambiental, energética e sanitária irrompidas a partir da pandemia de 2020.

Nesta conjuntura adversa, somos convidados a ousar pensar com radicalidade e com especificidade, como diria Francisco de Oliveira (2001). 
Por um lado, é crucial buscar apreender as estruturas. Olhar para a totalidade do "orgânico", para a coerência estruturada, tentando capturar o conjunto das interconexões sociais, com suas racionalidades e regularidades e com os movimentos históricos de longa duração. Por outro, é preciso cultivar, em aproximações sucessivas, uma perspectiva teórica que lembra o que Doreen Massey chamou de procura por um enquadramento teórico metodológico mais flexível, capaz de apreender os movimentos, dinâmicas e mudanças. Ou seja, é necessário examinar minuciosamente os processos e as transformações estruturais, porém as estruturas devem ser analisados sem direção predeterminada.

Porém, ao mesmo tempo, torna-se necessário não negligenciar os movimentos da conjuntura, o "inorgânico", a conjunção e condensação de contingências, que engendram e põem em ação táticas e estratégias sociopolíticas circunstanciadas. São articulações mais imediatas, situadas e contingenciais, sujeitas a temporalidades mais curtas, possibilitando a coexistência conflitiva, contestada, relacional e contraditória do real-concreto mais imediato e mundano.

Essa adequada e melhor percepção dos movimentos dos espaços e tempos estruturais e conjunturais pode nos auxiliar na interpretação dos específicos processos socioespaciais, que devem ser analisados em seu movimento histórico, contraditório e dinâmico. Devem, também, percorrer teórica e empiricamente as interconexões entre práticas conjunturais e as estruturas, observando as variadas escalas desses processos de combinação das formas variadas existentes, neste momento em que a América Latina e o mundo passam por transformações radicalizadas.

Infelizmente, vivemos, mais uma vez, uma daquelas rodadas do predomínio dos modelos importados para pensar concretamente nossa realidade. Há clara colonização do pensamento e perda de criatividade intelectual para refletir a partir de uma perspectiva de conjunto. A fragmentação do campo de conhecimento territorial-espacial, a hegemonia dos paradigmas conservadores, os desvios promovidos pelo debate da "pós-modernidade" e sua proposta de "derrocada das grandes narrativas", o avanço da razão neoliberal, dentre outros fatores, têm dificultado o avanço para trajetórias mais substantivas de entendimento da realidade concreta em sua dinâmica contraditória de transformação.

Há pouco espaço teórico para as análises sustentadas na dinâmica das relações sociais contraditórias. Predomina uma perspectiva de harmonia social em parte das pesquisas da área. Não há espaço para a oposição ou interdependência dos agentes e suas práticas. Elabora-se um discurso 
sofisticado de estabilização social, sem a discussão das bases materiais, como se houvessem práticas (harmoniosas) sem estruturas (em movimento contraditório e tenso). De análises que tinham uma concepção de estruturas sem sujeitos, corremos o risco de termos caído em representações de atores sem estruturas.

Como a dimensão espacial em si já é interface de múltiplas dimensões, é certo que nenhum campo disciplinar isoladamente dará conta da riqueza de determinações deste complexo processo. Entretanto, apesar do discurso sofisticado sobre trans-, multi- e inter-disciplinaridade, pouco respeito há entre os campos disciplinares e muito menos sua devida articulação para estruturar objetos de conhecimento relevantes e pertinentes.

Para se ter uma visão melhor determinada, mediada e qualificada sobre o espaço, que possam apresentar potencial de apreensão e transformação teórica e política de nossa realidade. Amplas potencialidades se encontram disponíveis hoje de reconstrução teórico-metodológica crítica, que poderiam informar e estruturar disputas políticas em torno das ações sociais no ambiente construído, informando movimentos contestatórios e/ou a orientação de políticas públicas democráticas.

Se concebermos o desenvolvimento como um processo complexo de decisões que logram estruturar o pleno exercício de opções alternativas que alargam os horizontes civilizatórios, inexoravelmente construídas em tensão sociopolítica, então ele é só trajetórias abertas, sujeitas ao embate estratégico em contexto de incontornável diferenciação de poder (de comando sobre o destino de determinada sociedade). Assim, desenvolvimento é distorcer a correlação de forças, importunar diuturnamente as estruturas e coalizões tradicionais de dominação e reprodução do poder. É exercer em todas as arenas políticas e esferas de poder uma pressão tão potente quanto o é a pressão das forças sociais que perenizam o subdesenvolvimento. Neste sentido, carecemos de melhor identificação e qualificação dos limites e das potencialidades de construção de estratégias de desenvolvimento que possam avançar maiores níveis de integração e coesão social, físico-territorial e econômica do país nos próximos anos, valorizando o trunfo de nossa diversidade e criatividade, enfrentado o encadeamento das ações de veto dos projetos hegemônicos que buscam perenizar o atraso e a falta de democracia.

Celso Furtado (1967, p. 92) bem sintetizou que

o estudo do desenvolvimento tende a concentrar-se na caracterização das estruturas, na identificação dos agentes significativos e nas interações entre determinadas 
categorias de decisões e as estruturas. Estas condicionam o processo de irradiação e a eficácia no espaço e no tempo das decisões, mas ao mesmo tempo são por elas determinados.

Albert Hirschman identificou nas situações do subdesenvolvimento da "falta de capacidade para tomar decisões". Nestes contextos, seria necessário, segundo Sunkel e Paz (1971, p. 38), elaborar "uma estratégia de desenvolvimento desequilibrada para forçar decisões que, de outro modo, não seriam tomadas".

Inspirado por estas concepções críticas latino-americanas, seria importante avançar em estudos regionais que lograssem depurar, discriminar e hierarquizar os fatores endógenos e exógenos determinantes, condicionantes ou coadjuvantes dos processos sociais, econômicos, políticos etc. em cada território sob análise. Esses estudos devem procurar construir mediações históricas, teóricas (e por que não dizer institucionais, territoriais, políticas etc.) devidas e pertinentes, cultivando para se uma abordagem teórica e metodológica da produção social do espaço, dos conflitos que se estruturam e das lutas (das frações de classe e das facções sociais) que se travam e tramam em torno deste ambiente construído.

Dever-se-ia ter sempre presente que o espaço é uma unidade dinâmica de reprodução social, por ser encarnação de processos e projetos diversos e manifestação concreta de conflitualidades de projetos políticos em disputa. Seu tratamento, portanto, requer o abandono dos tratamentos tecnicistas que pensam estruturas sem decisões de sujeitos reais ou atores atomizados sem contexto estrutural. Os espaços são construções (sociais, discursivas e materiais) e sua análise exige que nos baseemos na interação entre decisões e estruturas, nas articulações entre microprocessos, microiniciativas versus macrodecisões, nas múltiplas escalas espaciais e nas várias conjunturas em que se organizam e se enfrentam os interesses em cena e em disputa.

Proponho aqui que o refinamento analítico requerido passa pela centralidade das decisões e do poder de comando de sujeitos concretos, situados e envolvidos nas disputas diversas (com variados instrumentos) em torno da construção social de determinado espaço, investigando as hierarquias e hegemonias de poder de comando, as ações e as cadeias de reações das decisões tomadas (por variados agentes e sujeitos sociais que operam em variadas escalas espaciais). 


\section{Decisões cruciais de agentes dominantes com poder, envoltos em estruturas-conjunturas geohistóricas e contextos sociopolíticos específicos}

Procuro desenvolver aqui uma argumentação que defende que os estudos regionais deveriam colocar no centro de suas metodologias a análise do sistema decisional (público e privado) e seus poderes.

Coloco no centro desta abordagem metodológica a problemática das decisões concebidas como elemento de uma cadeia de ações e reações de algumas unidades de poder com recursos assimétricos e capazes de comando e dominação.

Entendo que a constituição e o exercício concreto de poder de comando de agentes e sujeitos reais, que operam em variadas escalas espaciais, nas disputas em torno da produção social de determinado espaço precisam ser investigadas detalhadamente.

Como já afirmava Max Weber (1922), os processos de desenvolvimento econômico são lutas de dominação. O desenvolvimento desigual, envolvendo processos de dominação e irreversibilidades diferenciais, impõe hierarquias, relações de força assimetricamente constituídas e exercidas por variados veículos e escaninhos de poder. Há a imposição de hierarquias, relações de força desigualmente constituídas e exercidas. São erguidas estruturas com complexidade díspar, com potência assimétrica e heterogênea, configurando lógicas hierarquizadas. A discussão destes processos e forças desemboca na questão terminal do poder diferencial de capacidade de decisão, fruto de uma correlação de forças que está sintetizada no processo de hegemonia. Como processo síntese, o poder de comando, de dominação de classe, é exercido e legitimado tendo por base determinada equação política, que se configura em um arco de alianças, um pacto de poder, assentado em certa correlação de forças políticas, que dá direção e domínio das condições sociais em determinado território.

Celso Furtado afirmava que

os processos sociais tendem a apresentar-se sob a forma de reações causais em cadeia, ou seja, cumulativamente (...) Analisando as cadeias de reações provocadas por decisões autônomas, será possível identificar fatores que aumentam ou reduzem sua capacidade de decisão (FURTADO, 1967, p. 90).

A capacidade promissora de uma metodologia que possa investigar a força motora de uma decisão, sua capacidade de propagação e de gerar 
tensão nas estruturas deveria estar no centro de uma abordagem que possa orientar, direcionar e reordenar processos complexos.

Incluem-se aí processos como aqueles atinentes à produção social do espaço e às outras formas de conceber estratégias regionais que possam acumular capacidade de decisão para a transformação política. Mudança que alargue os horizontes de decisões e de possibilidades, que seria o verdadeiro desenvolvimento,

que é principalmente um processo de ativação e canalização de forças sociais, de avanço na capacidade associativa, de exercício da iniciativa e da inventiva. Portanto, se trata de um processo social e cultural, e só secundariamente econômico (FURTADO, 1982, p. 149).

Ou seja, produz-se o desenvolvimento com intencionalidade, pois "o desenvolvimento significa a gênese de formas sociais efetivamente novas”.

A experimentação teórico-metodológica proposta aqui busca colocar no centro da análise a problemática das decisões. O refinamento analítico e categorial requerido passa pela centralidade das decisões e do poder de comando de sujeitos concretos, situados e envolvidos nas disputas diversas (com variados instrumentos) em torno da construção social de determinado espaço, investigando as hierarquias (divisão social do trabalho) e hegemonias de poder de comando.

É preciso conferir atenção às ações e às cadeias de reação das decisões tomadas por agentes e sujeitos sociais que se situam e operam em variadas escalas espaciais e que se encontram em interação. Essa interação entre atores, agentes e sujeitos forja e transforma estruturas, estratégias e determinados campos espaciais e arenas de luta e de conflituosidade.

É imperioso concentrar atenção na análise dos agentes cruciais e seus efeitos de dominação, examinar as estruturas decisórias e a natureza da atuação dos agentes, procurando entender como vão se redefinindo, no processo histórico e conjuntural, o modo de ação e o relacionamento entre os heterogêneos espaços urbano-regionais.

É preciso elaborar instrumentos analíticos de uma economia política da manifestação dos processos sociais no espaço, problematizando estruturas e sujeitos produtores dos espaços, elegendo as problemáticas do poder e dos processos decisórios dos agentes dominantes (Estado e grande empresa) como as nucleares para a análise e a ação consequentes e comprometidas com a justiça socioespacial.

Neste contexto, os estudos urbano-regionais devem assumir a conflitualidade inerente e a contenda perene de interesses múltiplos e seus 
variados loci de possibilidade de concertação, ou não, de projetos em disputa e das coalizões e arco de alianças que vão se armando em cada conjuntura histórica e territorial.

A assunção da conflitualidade, a dinâmica de ação das facções das classes sociais e a identificação dos sujeitos sociopolíticos portadores de decisão transformadora devem ser uma constante nos estudos regionais.

Se a reprodução social da vida necessita ocupar papel central na análise, por outro lado, os atores, agentes e sujeitos não são autômatos (ou unidades atomísticas racionais) que obedecem imediatamente leis gerais de movimento que lhes determinem suas ações.

Ação dotada de sentido, finalidade e intencionalidade tem

um movimento que necessariamente se realiza através de sujeitos, individuais e/ou coletivos, que, ao agirem, desencadeiam séries causais. As formas espaciais produzidas pela sociedade manifestam projetos, interesses, necessidades, utopias. A práxis humana é alimentada por pré-ideações que têm o espaço vivenciado como estímulo (MORAES, 2002, p. 22).

Discutindo a posição de Marx nesta questão, Sereni (1973, p. 63) afirma que este atribui ações a "agentes que não são apenas econômicos e estruturais, senão também superestruturais. É precisamente da multiplicidade e entrecruzamento de agentes e ações, internos e externos, de onde se faz derivar a não unilinearidade da sucessão de formações sociais ou da evolução de suas instituições, em relação às quais, portanto, ficam abertas diversas alternativas".

As análises concretas requerem a investigação criteriosa dos interesses (não só das identidades!) regionais, a concentração no estudo das estruturas espaciais, escalares e políticas, da estruturação do place, do habitat, da vida cotidiana, e dos projetos e das práticas dos sujeitos, tanto dos sujeitos constituídos e em constituição, quanto dos a constituir, articulando contextos e lógicas situadas, hierárquica e espacialmente, e ações.

Pierre Bourdieu, em "O singular e o plural", sustenta que:

As lógicas das práticas inscritas na história e no tempo são imanentes às práticas porque estas são ações, e não comportamentos (...) Suas determinações devem ser consideradas como estritamente sociais, por serem contestadas e insistentes, inteiramente imanentes às situações. [Nada nos pode] desviar de uma interrogação sobre as práticas compreendidas como ações, ou seja, como atos intencionais, inscritos na temporalidade para agir sobre o mundo (BOURDIEU, 2005, p. 152). 
Estes e outros autores nos proporcionam importantes insights sobre a centralidade das decisões, da premência em se analisarem os resultados e as consequências das decisões tomadas por agentes e sujeitos com poder heterogêneo e assimétrico.

Precisamos analisar as decisões cruciais, e questionar em quais atores, agentes e sujeitos se apoiam e qual o estatuto decisional destes. Alcouffe (2009), citando Furtado, fala da premência em se construir uma nova coerência teórica que leve em conta a desigualdade dos agentes, mas sublinhando a força da organização que a dominação traz. Bourdieu (1998) nos fala das cadeias de autoridade que expressam as articulações de força que se estruturam na sociedade.

É fundante "analisar a noção de poder e suas relações com a de espaço e delinear um marco teórico-interpretativo que aborde o acionar dos sujeitos sociais" (GARCÍA; ROFMAN, 2013, p. 103). Esses autores buscam uma análise da espacialidade do poder e realizam uma arguta sistematização dos principais autores desta temática (Claval, Rafestin, Massey, dentre outros), que entendem por poder tanto a capacidade de atuar como de fazer com que outros atuem, demonstrando a capacidade diferencial de dominação das diversas geometrias de poder temporalmente variáveis.

Relações sociais apresentam sempre vinculações espaciais e temporais, envolvendo alguma forma de controle de recursos materiais e simbólicos (GARCÍA; ROFMAN, 2013). Todas as relações sociais apresentam alguma dimensão ou são relações de dominação, condicionando de algum modo práticas de outros.

Já em 1974, Alejandro Rofman havia apresentado importante contribuição ao discutir os efeitos espaciais gerados pela ação dos tomadores de decisão no sistema capitalista dependente periférico. Defendeu a necessidade de se analisar simultaneamente

\begin{abstract}
a identificação dos agentes decisionais que operam no marco do poder econômico e político de cada uma das formações sociais e o efeito espacial gerado pelos agentes que se concretiza em uma específica estrutura urbano-regional em cada sistema social estudado (ROFMAN, 1974, p. 42).
\end{abstract}

Quanto aos agentes dominantes, é preciso distinguir a tomada de decisão pública da tomada de decisão privada. Examinar minuciosamente a tomada de decisão privada da classe proprietária, que tem poder de definir as unidades de decisão que operacionalizam o funcionamento econômico, com destaque para as decisões sobre o processo de inversão 
de capital. Esquadriar os instrumentos e as formas do exercício do poder estatal, posto que

a ação do Estado é configurada como um processo ininterrupto de decisões (...) no particular e de acordo com cada conjuntura histórica e é a resultante da luta de interesses setoriais do bloco dominante que se desenvolve em seu seio (ROFMAN, 1974, p. 27).

A capacidade de transformação do espaço social é desproporcionalmente realizada pelas classes proprietárias, por um lado. Por outro, o Estado, enquanto condensação de uma relação de forças também desempenha papel fundamental, também detém poder assimétrico de produção do meio ambiente construído.

Analisar o papel do Estado, dos grupos empresariais e corporações deve estar no centro dos estudos regionais. A análise da lógica e dos interesses ao longo das cadeias de decisões e reações a decisões tomadas pelo "mundo privado" é essencial, pois

\begin{abstract}
as decisões empresariais sobre compra, venda, desenvolvimento de ativos e estratégias competitivas desempenham, todas elas, papéis num cenário geográfico" (...) "Por que é importante estudar o comportamento das empresas nas economias regionais? As decisões empresariais conformam tanto a distribuição inter-regionais da atividade econômica quanto a qualidade e natureza do trabalho dentro das regiôes" (MARKUSEN, 2005, p. 64).
\end{abstract}

Assim, o estudo pormenorizado, em cada espaço-tempo, dos projetos hegemônicos, segundo Jessop (2007), torna-se central a fim de se analisar os compromissos instáveis, as estruturas, forças e estratégias políticas e ideológicas que dão forma ao Estado e suas bases sociais de apoio e oposição. Os projetos hegemônicos buscam angariar o apoio das forças sociais relevantes, pelo menos momentaneamente, em cada conjuntura histórica (JESSOP, 2007).

Em síntese, os processos de estruturação do espaço apresentam conflitos de interesses entre agentes e sujeitos que forjam e transformam estruturas, estratégias e campos e arenas de luta e de conflitualidade entre projetos sociopolíticos distintos. Assim, o resgate da problemática da reprodução das classes sociais, das estruturas e das decisões, tornase questão inarredável para se entender a produção social do espaço e a dimensão urbano-regional do processo de desenvolvimento capitalista em cada contexto escalar específico. 
Além de investigar qual o poder do poder público, qual o poder do poder privado, é também fundamental examinar qual o poder das forças contra-hegemônicas. Contra toda sorte de espoliações socioterritoriais que as forças privadas promovem (que na maior parte das vezes induzem ou se legitimam nas forças estatais), é preciso que analisemos também as contra-re-ações das forças emancipatórias e reivindicativas, que buscam se contrapor às diversas modalidades de injustiças sociais e espaciais.

\section{Prover um adequado padrão de oferta de bens, serviços e equipamentos coletivos para enfrentar a destituição de direitos e as desigualdades nas escalas meso e microrregionais, supralocais e do lugar da vida cotidiana no Brasil}

Defendo aqui que as estratégias territorializadas de desenvolvimento deveriam estar orientadas por uma visão abrangente de um sistema de provisão de bens, infraestruturas, serviços e equipamentos coletivos de utilidade pública, sobretudo, nos espaços regionais mais carentes e desiguais.

Em países enormes, desiguais e heterogêneos como o Brasil é crucial promover o suporte infraestrutural da provisão de bens e serviços públicos essenciais e de uso coletivo para a consolidação de uma sociedade de direitos de massas, que busque ofertar de forma adequada, e a mais espraiada territorialmente possível, o acesso aos direitos sociais da reprodução cidadã (acesso à saúde, educação, seguridade social, transporte urbano de alta densidade, moradia, saneamento, ensino-aprendizagem etc.).

O desafio de transformar pelo imenso território o padrão de oferta de bens e serviços e a provisão de infraestruturas de utilidade pública e inovativas é tarefa hercúlea. A ação pública deveria, em uma nova geometria de poder, executar estratégias coletivas no sítio-lugar, instilando no espaço-tempo da (con)vivência cotidiana, uma cultura permanente de transformação pedagógica e politizante no sentido de crescente autoconsciência de seus direitos.

É necessário promover políticas redistributivas (não apenas focalizadas e compensatórias), que tenham capacidade de engendrar assimetrias virtuosas, de forma difusa e pervasiva, geradoras de combates frontais às heterogeneidades estruturais e aos variados e recalcitrantes lógicas e mecanismos socioeconômicos, culturais e políticos de destituição, exploração e marginalização. 
O Estado, em sua ação espacial (um Estado espacializado!), deve provocar, enfeixar, congregar e dar impulso a ações concretas que busquem o abandono de atitudes acomodatícias e alienantes por parte da população local-regional. Com isso, é possível construir uma verdadeira cidadania regionalista, ou melhor, um regionalismo cidadão, que promova e institucionalize o envolvimento, o diálogo e a concertação contratualizada de interesses, a fim de criar elementos políticos redutores de incertezas e neutralizadores de fatores de instabilidade, oportunismos e ciclos políticos. E, além disso, capazes de engendrar novos instrumentos de geração de escolhas públicas e coletivas para a solução de problemas específicos, impulsionando a criatividade social, com aderência, plasticidade e pragmatismo com lugares específicos.

Estas ações espaciais do Estado devem apoiar segmentos prioritários de grande capilaridade espacial ligados aos complexos de saúde e educação, habitação, saneamento, transporte urbano, recursos hídricos, energias renováveis, agricultura e processos produtivos de baixa intensidade de uso de recursos naturais e energia. Este Estado espacial tem a tarefa, premente nos países periféricos, de realizar redobrado esforço de inversão em serviços públicos de natureza social e coletiva, de utilidade pública, isto é, em Capital Básico Social e em atividades indiretamente produtivas. Ele deve fomentar tecnologias sociais que atendam demandas dos setores sociais mais necessitados, especialmente em temas como segurança alimentar e nutricional, energia, habitação, saúde, saneamento, meio ambiente, agricultura familiar, geração de emprego e renda, inserção de jovens.

Assim, é decisivo identificar e qualificar os limites e as potencialidades de construção de estratégias de desenvolvimento que possam avançar maiores níveis de integração e coesão social, físico-territorial e econômica do país nos próximos anos, valorizando o trunfo de nossa diversidade e criatividade e a complexidade do nosso processo de urbanização.

É urgente transformar profundamente o padrão de oferta de bens e serviços e de provisão de infraestruturas sociais de utilidade pública, sobretudo em seu segmento infraestrutura social e urbana (saneamento, habitação, metrôs, trens urbanos, universalização da eletricidade e pleno acesso aos recursos hídricos). Dever-se-ia, com grande diálogo e coordenação de políticas públicas, avançar na consistência e articulação das múltiplas interfaces dos variados sistemas: o Sistema Nacional de Fomento (BNDES, Caixa Econômica Federal, Banco do Brasil, Banco do Nordeste do Brasil etc.), o Sistema de Proteção e Provisão de Bem-Estar 
Social, o Sistema de Aprendizado/Educação/CTI e o Sistema Nacional de Políticas Urbanas, Rurais e Regionais.

O certo é que a mudança no Padrão de Oferta de Bens e Serviços tem potencialmente a possibilidade de reforçar os efeitos dinâmicos e sinérgicos entre estes sistemas (alguns deles ainda precários em sua estruturação). Como simples exemplos, dentre muitos outros de caráter sistêmico que poderiam ser lembrados: existia a possibilidade de se articular melhor as políticas de CTI e industriais em torno de equipamentos de água, mobilidade urbana de massa, saúde, lazer e cultura; era para ter se dado maior impulso às ações educativas, artísticas, de prevenção de doenças, pedagógicas-politizadoras; elas requereriam melhor articulação, através de postos e pontos de atendimento, eventos, utilização de espaços físicos como escolas, arenas e estádios de futebol, rádios comunitárias, emissoras públicas, clubes etc., em uma ação pública de indução massiva, catalisadora e integrada no terreno da vida cotidiana, a começar pelas áreas mais carentes dos espaços urbanos e rurais de cada região brasileira. $\mathrm{Na}$ verdade, esses exemplos e outros visam demonstrar que não deveria haver contradição, mas antes complementaridade, entre ações exigentes de tecnologias avançadas e de ponta e ações que reclamam antes tecnologias sociais e mobilização, ativismo e agitação sociocultural.

Propõe-se aqui formas emergenciais, um verdadeiro "tratamento de choque" na provisão de direitos, com adequadas quantidade e qualidade, que promovam a habilitação cidadã, com base na oferta incisiva, concentrada e enfeixada de bens e serviços de utilidade pública, enquanto meios de reprodução da vida social; e infraestruturas sociais e meios de consumo-direitos coletivos, ou seja, instrumentos auxiliares na formação ampliada das forças e capacidades produtivas e criativas-emancipatórias humanas, que possam desatar e mobilizar ações universalizantes e de criação de patamar adequado de homogeneidade social, pela via da construção da habilitação e das inovações sociais e institucionais. As ações de indução pública e coletiva precisam ultrapassar a simples lógica fragmentária, "setorialista" e compartimentada, promovendo a capacidade articuladora do tecido sócio-produtivo-territorial, ao lado de impulsionar os adequados engate e conexão de aparelhos produtivos localizados e a distribuição de riqueza e renda, habilitando e distribuindo territorialmente direitos sociais aos cidadãos. Essa ação de conjunto do Estado brasileiro deveria partir de uma visão de "não inventar a roda" (não propor, de início, nem novas políticas públicas, nem novas instituições), mas partir do que já se tem disponível (alguns ativos, capacitações e recursos ociosos ou 
latentes) em cada território: equipamentos, ações e iniciativas já existentes, identificação de lideranças, agentes de transformação e novas lógicas de participação. Seria importante utilizar institucionalidades já disponíveis, capacitando-as para a nova tarefa, por exemplo, os CRAS - Centro de Referência da Assistência Social. Antes de tudo, cabe construir um "efeito demonstração" da presença robusta e benfazeja do Estado no território. A população precisa sentir "de que lado estão os aparelhos estatais".

Em suma, é urgente prover o suporte adequado de bens e serviços públicos básicos, essenciais e coletivos, transformando o formato e as modalidades de chegada (com solidez, estabilidade e consistência) do Estado no território, com plasticidade e resiliência, no chão das práticas cotidianas e do imediato sensível, das experiências localizadas, no lócus específico de reprodução social das "pessoas de carne e osso". Urge realizar a provisão desses bens e serviços para a consolidação de uma sociedade de consumo e de direitos de massa, que logre acessar (territorialmente) plenamente direitos sociais e cidadania (saúde, educação, seguridade social, transporte urbano de alta densidade, moradia, saneamento, etc.). Do mesmo modo, é fundamental prover infraestruturas sociais que aperfeiçoem habilidades e propiciem habilitações. É preciso construir a atuação com alta efetividade do Estado brasileiro, por meio de institucionalidades, instrumentos e mecanismos que, capilarmente, difundam, concretizem e enraízem suas ações em todo o vasto território nacional.

O travamento da oferta e o não acesso à educação, propriedade e serviços públicos de qualidade destitui a maior parte da população brasileira dos direitos fundamentais da vida cidadã. Uma provisão com qualidade, que instale a habilitação cidadã deveria ter por base os serviços de utilidade pública enquanto meios de reprodução, de consumo coletivo, ou seja, instrumentos auxiliares na formação ampliada das forças e capacidades produtivas e inovativas humanas, que promovessem ações universalizantes e de criação de patamar adequado de homogeneidade social, pela via da construção de habilitação e das inovações sociais e institucionais.

O esforço de grande transformação da situação socioespacial brasileira deve ser articulado simultaneamente em variadas dimensões (tecnológica, produtiva, social etc.), em várias escalas espaciais (no lugar, na micro, meso e macro região, e nos espaços nacional, continental e internacional), coordenando diferentes níveis de governo (união, estados e municípios) e tendo por base múltiplas institucionalidades e diversificados sujeitos sociopolíticos. 
Deve-se pretender, com tais políticas, a "recomposição territorial" através da ação planejada, a reconstrução de espaços públicos e dos canais institucionalizados de participação e a criação de variadas arenas que possam aglutinar e dar vazão aos diferentes interesses.

Em suma, o Brasil necessita construir estratégias e instituições capazes de conectar os canais de interação entre crescimento econômico, integração territorial, construção de cidadania social, ciência, tecnologia e inovação e aprimoramento de capacidades humanas emancipadoras. Obviamente, estas estratégias ficam para um momento democrático de reconstrução do país, mas podem ir sendo implementadas de baixo para cima nas escalas locais e regionais.

\section{Restabelecer outros Ps: o poder participativo do povo. Cadeias de reação a decisões hegemônicas e luta pela democracia}

Desde o início do século XXI, um importante debate está em andamento sobre o momento pós-democrático, autoritário, autocrático e de pós-verdade. O processo de neoliberalização parece ter se consolidado de forma definitiva e brutal. Os seus métodos para fazer avançar as lógicas da mercantilização extremada, reposicionando de poder, já não importam.

A partir de 2020, tudo indica que os desdobramentos estruturais e conjunturais do regime pós-normal da pandemia do coronavírus poderão, por contraditório que possa parecer, acelerar, desatar e exacerbar diversas tendências que vinham se desenhando e confirmando de aumento desregrado da concentração e centralização da renda, da riqueza, da propriedade privada e do poder em todas as escalas espaciais, em grande parte, passando ao largo dos direitos individuais e coletivos e das regras democráticas.

O termo pós-democracia foi cunhado por Jacques Rancière (NASH, 1996) e desenvolvido e disseminado através do trabalho de Colin Crouch (2004). Esses autores mostram como os poderosos interesses das minorias se tornaram mais ativos e as elites políticas aprenderam a gerenciar e manipular cada conjuntura, multiplicando cada vez mais o poder de seus negócios e combatendo quaisquer alternativas para a redistribuição de poder e riqueza. Jessop (2019) fala de uma nova ordem, com a consolidação do neoliberalismo autoritário e seu regime de acumulação inevitavelmente propenso a crises, predatório e dominado pelas finanças e sua associação com um estado de austeridade duradoura, como um estado 
conjuntural de emergência ou um novo normal, realizado continuamente de maneira não democrática. Na América Latina, com sua longa tradição de ciclos autoritários e ditatoriais, o debate sobre pós-democracia pode oferecer um terreno fértil para a pesquisa de suas formas concretas.

Neste ambiente inóspito para o avanço das forças progressistas e da promoção de estratégias de combate às desigualdades e destituições, seria fundamental discutir e levar à frente formas de ampliar as decisões e torná-las mais permeáveis à ampla participação democrática, alargando e aperfeiçoando renovadas formas de controle do exercício de poder. Será preciso desafiar a imaginação para engendrar uma nova formação sociopolítica geohistórica, abrindo para o desenvolvimento de um novo cidadão sujeito e agente do processo decisório.

É necessário uma nova gramática, uma nova pedagogia e uma nova ontologia, a fim de promover o "exercício real da capacidade consciente de optar e escolher por finalidade e caminhos" (...) "Só o ser social pode ser assim livre" (MONTAÑO; DURIGUETTO, 2013, p. 8o). Ou seguindo Boaventura de Sousa Santos,

\begin{abstract}
Como as democracias são cada vez mais vulneráveis às fake news, teremos que imaginar soluções democráticas baseadas na democracia participativa a nível de bairros e comunidades, e na educação cidadã orientada à solidariedade e à cooperação, e não ao empreendedorismo e à competitividade a todo custo" (...) "A política, que deveria mediar as ideologias e as necessidades e aspirações dos cidadãos, tem renunciado a esta função. (SOUSA SANTOS, 2020, p. 25)
\end{abstract}

Estudos bem contextualizados e comparativos das mudanças estruturais-conjunturais dos variados espaços regionais são sempre muito bem-vindos neste contexto, buscando analisar as hierarquias das decisões informadas por sua posição de classe social. Seria necessário, neste contexto, investigar os contornos histórico-institucionais concretos em que se processam as ações sociais e as decisões de sujeitos e agentes de transformação.

Por exemplo, na escala regional, que pode ser desdobrada em outros sub-recortes, é possível elucidar as articulações das estruturas e dinâmicas mais localizadas com os outros níveis escalares, se constituindo em fundamental plano intermediário de observação.

Esta escala possui geralmente alguma autoridade e força política, controlando alguma base tributária e influenciando ou regulando algumas decisões extra-regionais. Deve aglutinar forças, articular a complementaridade produtiva e a solidariedade de interesses cruciais, e desenvolver 
capacidade mínima de modular sua inserção externa segundo sua posição relativa em uma divisão inter-regional do trabalho.

É crucial nas ações regionalizadas ter um Estado legitimado, potencializado e capacitado para tomar decisões que transformem a realidade, sobretudo, naqueles territórios mais destituídos de direitos, riqueza e poder, ter um Estado democrático que promova e amplie o poder participativo do povo. É preciso que haja pressão de baixo para cima para potencializar cadeias de reação a decisões hegemônicas e aglutinar forças para novas impulsões à radicalização da democracia.

Assim, requer-se ter presente nas pesquisas regionais a dinâmica de ação das diferenciadas facções das classes sociais, analisando a precária constituição de sujeitos sociopolíticos desalienados e portadores de decisões transformadoras. Essa precariedade coloca impasses estruturais à constituição de processos de desenvolvimento duradouros, inclusive em sua dimensão territorial.

Neste contexto inóspito, um olhar plural para as escalas subregionais e mesmo nas microescalas espaciais é fundamental. Como Massey e Rustin bem apontam:

É preciso haver respeito pela diversidade, pelas especificidades de cada esfera da vida e reconhecimento do que deveriam ser concepções orientadoras fundamentais de justiça, igualdade e 'democracia profunda'. A tarefa seria criar e sustentar um novo consenso em torno desses valores. (MASSEY: RUSTIN, 2015, p. 220)

Até por isso, é importante dimensionar o poder das facções subalternas nas lutas reivindicatórias de mobilização, protesto e de resistência, avaliando a real capacidade das forças contestatórias e insurgentes avançarem na catalisação e unificação de lutas democráticas e emancipatórias. As análises das suas formas renovadas de lutas, suas opções táticas e estratégicas, as disputas por maior justiça social e ambiental avançaram sobremaneira nas últimas décadas.

A canalização das energias de insatisfação e de inconformismo se expressa em formatos variados, em contra-re-ações protetoras da sociedade atingida, sem direitos e sem voz, e lógicas organizativas portadoras de ações e reações de resistência e de encadeamentos de vetos, que são passíveis ou não de se constituírem em coalizões insurgentes e alternativas. A potência das relações de força das múltiplas formas de indignação, mobilização. Inconformados, destituídos de direitos, de fala e de meios de consumo coletivo travam no dia-a-dia lutas contra opressões de toda 
espécie, trazendo a nova energia da insatisfação para variados espaços de contestação.

Alguma noção mundana de compartilhamento de experiências particulares vividas, de cotidianidade, de sentidos e sentimentos de referência, pertencimento, identidade ou significante, um ponto singular no espaço, também está presente em quase todas as definições de lugar que ainda apresentam algum diálogo com a reprodução social das práticas da vida cotidiana e a interação humana.

São lutas por justiça socioespacial, conflitos promotores de contra-re -ações protetoras da sociedade atingida e lógicas organizativas portadoras de ações e reações de resistência (em múltiplas formas) e de encadeamentos de vetos, que são passíveis ou não de se constituírem em coalizões insurgentes e alternativas.

\section{(In)conclusões}

Neste ensaio, mesmo quando não explicitado, estamos colocando ênfase na escala regional. A escala regional pode melhor demarcar o campo das lutas sociais, dar concretude a bandeiras, clivagens e orientações de lutas e ações políticas, delimitar e criar a ancoragem identitária, a partir da qual se pode lograr erguer um contencioso em relação a imposições de decisões (por vezes ameaçadoras) provenientes de outras regiões, na mesma ou em outras escalas.

O estudo das decisões em uma escala regional, com repercussões e manifestações em uma intricada cadeia de ações e reações em outras escalas, requer uma abordagem metodológica estrutural-conjuntural e relacional. Uma escala pode ser definida e determinada e qualificada apenas em relação às outras. Parte das dinâmicas e lógicas escalares repousa nos nexos, acionamentos e coerências interescalares, nas interregionalidades e interdependências. Nesse sentido, as decisões ao longo da divisão inter-regional do trabalho, o específico ambiente e o contexto histórico regionais, suas particulares relações e coalizões de poder e suas estratégias político-reprodutivas devem ser o objeto primordial da pesquisa regional.

Certas lutas sociais podem se manifestar na forma de narrativas escalares regionais democrático-populares. Assim, é decisivo analisar espaços-tempos variados nas escalas de observação e ação: mesorregional, microrregional, da cidade, do bairro, da comunidade etc. Tais espaços tempos podem sustentar uma cadeia potente de contrarreações, que, por 
sua vez, podem lograr alargar, pulverizar e democratizar os mecanismos de decisão. Eles podem engendrar mecanismos mais descentralizados e democráticos de decisão, potencializando ou antepondo cadeias de reação a decisões hegemônicas antipopulares e antidemocráticas.

A escala do lugar, fundante para se analisar as práticas espaciais de sujeitos sociopolíticos que tem a intenção de objetivar e concretizar seus projetos singulares de reprodução da vida, requer análises apuradas. $\mathrm{O}$ ambiente construído e suas estruturas espaciais envolvem os projetos individuais do terreno da vida cotidiana. Mas, o mesmo ambiente construído e suas estruturas espaciais também são envolvidos e elaborados pelos projetos da vida cotidiana. No nível de análise fundamental da imediaticidade, ou seja, da teia fina do tecido social, é crucial se atentar para as práticas espaciais no contexto da esfera essencial imediata e pragmática da reprodução da vida cotidiana e intrínseca a cada um(a). Assim, o lugar é o lócus do pragmatismo, da reprodução imediata, da convivência, do vivenciado, do circunstanciado e das espacialidades e temporalidades específicas, porção espacial das práticas da vida cotidiana e manifestação menos mediada, portanto mais imediata, das relações sociais, logo, espaço do acontecer e das singularidades. Nesta escala espacial, capacidades de respostas mais imediatas e conjunturais a situações reais e particulares são formuladas e implementadas.

Em suma, o aparato crítico-conceitual a ser construído e acionado requer melhor análise e qualificação das novas e das velhas formas de disputa em torno do ambiente construído, colocando as questões do poder e dos processos decisórios dos agentes dominantes (Estado e grande empresa) no centro da análise e da ação, reposicionando as cadeias de reação a decisões hegemônicas, que deveriam ser contrapostas e colocadas em xeque.

Para pensar as espacialidades e as temporalidades diferenciais dos processos sociais regionalizados, sobretudo, em conjuntura de aguda crise disruptiva, é preciso examinar o encadeamento concreto das decisões em cada território sob análise. E pensar as interregionalidades, interescalaridades e os interesses e as contradições inter-classes, em presença, in loco, ao longo dos tempos e nos variados espaços. E procurar vencer a ideia de decisões racionais individualizadas, de forma a construir e coordenar decisões ousadas, que verdadeiramente possam enfrentar as multidimensionais destituições, desigualdades e injustiças e promovam uma outra produção social do espaço. 


\section{Referências Bibliográficas}

ALCOUFFE, Alain (2009). Furtado, o Brasil e os economistas franceses: influências cruzadas. In: COELHO, Francisco S. e GRANZIERA, Rui G. Celso Furtado e a Formação Econômica do Brasil. São Paulo, Atlas/ OEB, pp. 34-46.

BERNDT, C.; PECK, J.; RANTISI, N. (eds.) (2020). Market/place: exploring spaces of exchange. Newcastle upon Tyne: Agenda Publishing, 2020.

BOURDIEU, Pierre (2005). O singular e o plural. In: ENCREVÉ, Pierre; LAGRAVE, Rose-Marie (coord.). Trabalhar com Bourdieu. Rio de Janeiro, Bertrand Brasil.

CAHILL, Damien et al. (eds.) (2019). The Sage Handbook of Neoliberalism. Los Angeles, Sage.

MONTAÑO, Carlos e DURIGUETTO, Maria Lúcia (2013). Estado, classe e movimento social. São Paulo, Cortez.

FURTADO, Celso (1982). Nova Dependência. São Paulo, Paz e Terra.

GARCÍA, Ariel y ROFMAN, Alejandro (2013). Poder y espacio. Hacia una revisión teórica de la cuestión regional en Argentina. Revista Problemas del Desarrollo, 175 (44): 101-124.

MASSEY, Doreen and RUSTIN, Michael (2015). Displacing neoliberalism. In: Hall, Stuart, Massey Doreen and Rustin Michael (2015). After neoliberalism: Kilburn Manifesto London: Lawrence \& Wishart.

HALL, Stuart and MASSEY, Doreen (2010). Interpreting the crisis, Soundings, (44): 57-71.

JESSOP Bob (2019) Authoritarian neoliberalism: periodization and critique South Atlantic Quarterly. 118(2): 343-361.

JESSOP Bob and KNIO Karim (2019). The pedagogy of economic, political and social crises: dynamics, construals and lessons. London, Routledge.

JESSOP, Bob (2007). Estratégias de acumulação, formas estatais e projetos hegemônicos. Ideias, Campinas, 14(1-2): 101-135. 
MARKUSEN, Ann (2005). Mudança econômica regional segundo o enfoque centrado no ator. In: DINIZ, Clélio Campolina; LEMOS, Mauro Borges (orgs.). Economia e território. Belo Horizonte, Editora UFMG.

MORAIS, Antônio Carlos R. (2002). Ideologias geográficas: espaço, cultura e política no Brasil. São Paulo, Hucitec.

NASH, Kate. Post-democracy, politics and philosophy: An interview with Jacques Rancière. Angelaki: Journal of the Theoretical Humanities, s.l., v. 1, n. 3, p. 171-178, 1996.

OLIVEIRA, Francisco de (2001). Pensar com radicalidade e com especificidade. Lua Nova, São Paulo, (54): 89-95.

POLANYI, Karl [1944]. A grande transformação: as origens da nossa época. Rio de Janeiro: Campus, 1980.

RANCIÈRE, Jacques (1996). Post-democracy, politics and philosophy: an interview with Jacques Rancière. Angelaki 1(3):171-78.

ROFMAN, Alejandro B. (1974). Dependencia, estructura de poder y formación regional en América Latina. Buenos Aires, Siglo Veintiuno.

SARDAR, Ziauddin (2010). Welcome to postnormal times. Futures, (42): 435-444.

SERENI, Emilio (1973). La categoria de formación económico-social. In: LUPORINI, Cesare et al. El concepto de formación económico-social. Buenos Aires, Siglo Veintiuno.

SOUSA SANTOS, Boaventura (2020). La cruel pedagogía do virus. Ciudad Autónoma de Buenos Aires, CLACSO.

SUNKEL, Oswaldo e PAZ, Otávio (1971). Teoria do desenvolvimento econômico. São Paulo, Difel.

WEBER [1922]. Economia e sociedade. Brasília, Editora da UnB, 1994. 



\title{
Processos de apropriação espacial: contribuições para estudos futuros
}

\author{
Thiago José Arruda de Oliveira ${ }^{1}$ \\ Waldecy Rodrigues ${ }^{2}$
}

\section{Introdução}

$\mathrm{O}$

HOMO SAPIENS, DE UM ANIMAL INSIGNIFICANTE QUE SURGIU HÁ 70 mil anos em algum lugar da África, transformou-se no senhor do planeta e agora, por intermédio da tecnologia, está próximo de obter capacidades divinas (HARARI, 2019). No entanto, o seu domínio na Terra está longe de alcançar um convívio harmonioso com os seus entes e a natureza. Em vista disso, o capítulo analisou os processos de ocupação espacial ao longo da história e por que esse desequilíbrio ainda persiste na sociedade mesmo com as facilidades existentes. A partir daí, propôs a aplicação de tais reflexões em pesquisas científicas direcionadas ao campo do Desenvolvimento Econômico, Regional, Local e áreas afins.

Para tanto, evitou-se discussões acerca dos conceitos básicos da Geografia, uma vez que essa temática possui um longo tempo de debate. Ademais, esquivou-se de uma revisão sistemática de artigos correlatos a fim de que este trabalho obtenha um certo nível de originalidade. Desse modo, adotou-se uma concepção simplificada, porém, tendo como referência o conceito de meio técnico-científico-informacional de Milton Santos (1926-2001), de que o espaço é apenas a materialização das ações humanas em um determinado local. Como esse meio passou por seguidas

1 Economista. Doutor em Desenvolvimento Regional e Agronegócio (Unioeste). Bolsista nível pós-doutorado do Programa de Pós-Graduação em Desenvolvimento Regional da Universidade Federal do Tocantins (UFT). thiago.arruda85@gmail.com.

2 Economista. Doutor em Ciências Sociais (UnB). Professor associado do curso de graduação em Ciências Econômicas e do Programa de Pós-Graduação em Desenvolvimento Regional da UFT. waldecy@terra.com.br. 
modificações, tornou-se uma necessidade a realização de uma revisão histórica concentrando os esforços nos principais acontecimentos da humanidade.

Além desta introdução, o capítulo dividiu-se em mais oito partes, sendo que as primeiras tratam sobre o caráter que o espaço adquiriu com o passar dos séculos. No sexto, "Não há mais tanto espaço", iniciou-se uma discussão contemporânea sobre os processos de apropriação espacial. No seguinte, “Qual é o nosso espaço?”, realizou-se uma reflexão no que concerne aos próximos passos do Homo sapiens no mundo, e como os pesquisadores se enquadram nessa perspectiva. Adiante, concluiu-se o estudo apontando quais são as possibilidades de trabalhos futuros no Brasil que tratam sobre o desenvolvimento. Por último, as referências bibliográficas expuseram quais foram os livros consultados ao longo da análise.

\section{O espaço como objeto de dominação}

Os ancestrais dos humanos, os Australopithecus, surgiram na África Oriental há cerca de 2,5 milhões de anos e 500 mil anos depois se assentaram em áreas do norte desse continente, Europa e Ásia. Em relação a nossa espécie, Homo sapiens, apareceu na Terra em 150.00o a.C. e iniciou o processo de apropriação das terras dos seus antepassados por volta do século 70.00o a.C. A dominação plena aconteceu em 13.000 a.C. após a extinção do Homo floresiensis e a ocupação completa da América. Esse sucesso se deveu a sua capacidade de planejar e realizar ações múltiplas e complexas em regime de cooperação, habilidades inexistentes em outros vertebrados.

Durante a primeira Revolução Agrícola (9.500 a.C. até 3.500 a.C.), a humanidade abandonou a sua ligação simbiótica com a natureza na medida que passou a manipulá-la por meio da domesticação de plantas e animais. Em consequência disso, houve uma superoferta de alimentos, contribuindo para a sua explosão demográfica. A relação pessoas em demasia confinadas em vales férteis gerou conflitos sociais. Tornou-se uma necessidade estabelecer um conjunto de normas a fim de evitar tais distúrbios. As elites locais pensaram em um modo de controlar os ímpetos da massa e, assim, surgiram organizações políticas, ideológicas e religiosas, todas baseadas na mente criativa do Homo sapiens ${ }^{3}$.

3 Informações adicionais sobre a evolução do poder da imaginação humana ver Harari (2019). 
Neste sentido, através de um ordenamento imaginado, a partir de 3 mil a.C. apareceram os impérios, que são sociedades complexas, extensas, hierárquicas e dominadoras ${ }^{4}$. Os líderes, por intermédio da cooperação forçada com os seus súditos, encravavam os seus ideais (mitos, ficções, modo de pensar e agir) em outros povos. Dentre os que apareceram na África e Ásia nesse período, o egípcio é aquele que despertou maior fascinação por causa de sua estrutura social, representada pelas suas suntuosas pirâmides. Durou de 3.200 a.C., quando o faraó Menes unificou as tribos do delta e do estuário do rio Nilo, até 30 a.C., após o falecimento da rainha Cleópatra VII.

A sua ascensão apenas ocorreu porque os camponeses souberam, cooptados pela figura mística do faraó, utilizar o solo lamacento, encharcado pelo Nilo depois do transbordamento natural entre os meses de julho e outubro, para a produção de alimentos. Isto posto, surgiram inovações como a construção de diques e adutores para reter, distribuir e dispersar o volume hídrico adquirido no ano. Assegurada a quantidade de umidade na terra, plantavam cereais, linhos, leguminosas e forrageiras no sistema bienal de rotação. Esse revezamento alimentava 300 habitantes por quilômetro de área cultivado, servindo, também, para a nutrição de bovinos, ruminantes e porcos, e empregavam os seus excrementos na fixação de nitrogênio no solo.

Tal qual o reino dos faraós, os incas na América do Sul também unificaram assentamentos agrícolas com base no mito da figura divina. Todavia, díspar dos egípcios antigos, a sua área de controle estabeleceuse em vales profundos, florestas tropicais e terras áridas. Aproveitando-se disso, essa tribo, que posteriormente tomou formas imperiais, preservou os sistemas desenvolvidos pelos povos conquistados, e assim, surgiram especializações produtivas. Nas elevadas altitudes dos Andes, difundiase a criação de alpacas e lhamas, e entre 4.200 e 3.600 metros, prevalecia o plantio de batatas e quinoa. Nas baixadas, a irrigação garantia o cultivo de milho, feijão e outros vegetais ao longo do ano 5 .

No nível do mar, o algodão e as leguminosas forrageiras eram os produtos diferenciados, enquanto na faixa tropical prevalecia a mandioca e o extrativismo vegetal, especialmente o da coca e de frutas amazônicas. Essas singularidades permitiram a formação de uma rede comercial

4 A noção de império e as suas formas de dominar outros povos é amplamente debatido em Burbank; Cooper (2019).

5 Maiores informações sobre as civilizações hidráulicas antigas ver Mazoyer; Roudart (2010). 
interligada pelas estradas reais, uma estrutura inexistente no Egito Antigo. Quando os soldados espanhóis de Francisco Pizarro apareceram nas terras incaicas no ano de 1532, esse império sul-americano estendia-se por 4 mil quilômetros e abrigava 70 etnias. Embora o poder advindo do DeusSol restringisse a liberdade do campesinato, viviam em melhores condições do que com a introdução das crenças espanholas, alicerçadas na fé católica.

Os exemplos apresentados mostraram que as apropriações sucederam com auxílio de um poder supremo, proveniente da imaginação humana. Sem isso, locais como o rio Nilo, a Cordilheira dos Andes, área litorâneas e a Amazônia nunca produziriam bens agrícolas e fluxos comerciais. Veja o caso dos papuas, nativos da Nova Guiné, ilha onde uma parte compõe o arquipélago indonésio. Lar do ancestral silvestre da cana-de-açúcar e de certos tipos de banana, é uma das áreas do mundo onde houve uma Revolução Agrícola pré-histórica. O seu solo, fertilizado por meio das atividades vulcânicas, a abundância de chuvas e rios permanentes colaboraram para esse processo. Em compensação, nenhum império surgiu nessas terras.

A princípio, os vales da Nova Guiné são estreitos, o que aumenta a vazão d'água e consequentemente, o seu uso para a irrigação por transbordamento. A carne ainda emanava da caça, especialmente de porcos selvagens e pequenos pássaros, propiciando restrito valor calórico comparando-se com a do boi ou da lhama. Acima de tudo, o fator limitante para a formação de uma ordem compartilhada entre os seus habitantes é o isolamento espacial. Das 6.000 línguas registradas no mundo, 1.000 encontram-se nessa ilha, sendo que a metade possui menos do que 500 falantes ${ }^{6}$. As doenças típicas dos biomas tropicais, assim como a dificuldade de se locomover entre as árvores, são outros relevantes empecilhos.

\section{O espaço como fonte de riqueza individual}

Havia desde a Idade Antiga, ou mesmo antes, no norte da África, Oriente Médio, vale do rio Indo, do rio Amarelo, na Mesoamericana e nos Andes, rotas e cidades onde fluíam intensas trocas comerciais. No entanto, em nenhum outro lugar essa relação se tornou tão avassaladora como no continente europeu. Trata-se de um notável acontecimento, dado que a maior parte de suas terras possuem baixa fertilidade. Sem

6 Diamond (2018) discorre sobre as sociedades presentes na Nova Guiné. 
excedentes de alimentos, restava para os seus habitantes uma vida miserável no campo ou de servidão. Todavia, civilizações como a da Grécia Arcaica estavam próximas de reinos abundantes de riquezas como a do Egito Antigo e da Pérsia. Diante disso, o comércio se tornou um caminho natural.

Primeiramente, enviaram para a África e Ásia produtos feitos à base de bronze, vinho e toras de madeira, e em troca, recebiam o trigo. Ao conhecer essa gramínea, os gregos desenvolveram espécies adaptadas para o seu solo e clima. Dessa maneira, a agricultura floresceu nesta parte da Europa, porém acentuaram as disputas agrárias. Para cessar tais conflitos, legisladores atenienses como Sólon, Psístrato e Clísteno no século VI a.C. deram início à primeira reforma agrária da história. Além disso, asseguraram a participação do campesinato e demais cidadãos no processo decisório. Assim, surgiu a democracia, apesar dos escravos, estrangeiros e mulheres continuarem à margem da vida política em Atenas.

De igual modo, o Senado romano ao longo do período republicano (509 a.C. - 30 a.C.) aplicou medidas para distribuir as terras conquistadas à plebe. $\mathrm{O}$ assassinato dos irmãos políticos Tibério e Caio Graco minaram qualquer chance de ampliar a reforma. Durante o período ditatorial de Júlio César (48 a.C. - 44 a.C.) ocorreu uma tímida reformulação no ordenamento agrícola, medida suficiente para desagradar os conservadores. A sua eliminação foi uma questão de tempo, e após a sua morte e posteriormente a do seu protegido, Marco Antônio, Roma emergiria como o império dos Césares, concepção que remete ao Deus-Faraó dos egípcios antigos e a do Deus-Sol dos Incas.

Consequentemente, a união entre os povos através do comércio na orla do Mediterrâneo cedeu lugar para a inserção forçada dos costumes romanos nessas sociedades. Antes disso, Alexandre III da Macedônia realizou essa tarefa, porém teve como meta a dominação calcada na fusão entre os ideais do Ocidente com o Oriente. Embora o seu reinado tenha se mantido por apenas 13 anos, preservou a estrutura produtiva, religiosa e cultural dos conquistados. Após a sua morte, os egípcios continuaram sob o regime faraônico, desta vez comandado por um dos seus generais, Ptolomeu. A dinastia ptolomaica durou quase 300 anos, tendo o seu fim com o suicídio da rainha Cleópatra VII e a ascensão do primeiro imperador de Roma: Otávio Augusto. 
O sistema imperial romano consistia em retirar o máximo de riqueza das suas 45 províncias ${ }^{7}$. As trocas comerciais entre as regiões eram praticamente inexistentes e toda a produção destinava-se para a população de Roma e o seu exército. Sem incentivos, os campesinos migraram para as cidades e o campo passou para o poder da aristocracia. Como a necessidade por alimentos aumentava com o tempo, a escravidão foi a solução encontrada pela elite para suprir essa demanda. Em detrimento disso, a produção agrícola se tornou cada vez mais dependente dessa mãode-obra. Quando o catolicismo ganhou força e conquistou devotos dessa classe, o império encaminhava-se para o seu desfecho.

Posteriormente à queda de Roma, iniciou-se a Idade Média, marcada pelo domínio da Igreja Católica na Europa ${ }^{8}$. Aos poucos, substituiu-se a escravidão pela servidão, nada mudando na prática. A maior parte da riqueza gerada pela agricultura tinha como destino o senhor feudal e o corpo clerical. As sobras dificilmente sustentavam os servos, e se obtivessem uma colheita farta, a nobreza proibia a sua comercialização. Diante de uma estrutura fragmentada, os europeus se tornaram alvo de invasores como os árabes, os otomanos e os vikings. Os reinos cristãos repeliram ou negociaram com os forasteiros, situação que impactou positivamente em seu crescimento populacional a partir do século X.

Neste contexto, a solução encontrada para aumentar a oferta de alimentos remete-se às iniciativas adotadas pelos egípcios antigos e incas. Em primeiro lugar, beneficiando-se da disponibilidade de terras sem ocupação efetiva no norte da Europa, construíram edificações direcionadas para controlar o regime das águas. Dentre as obras, destacam-se os diques, barreiras que impossibilitavam a entrada do mar nas planícies costeiras. Com o tempo, essa faixa se transformou em uma área seca com solo bastante salgado. Por isso, no primeiro momento, eram utilizados apenas para a pastagem de caprinos e bovinos. Posteriormente, dessalinizado e adubado com excremento dos animais, o solo tinha condições para a agricultura.

Ademais, reativaram o cultivo rotativo bienal desenvolvido pelos egípcios antigos, e introduziram equipamentos de tração pesada (o arado charrua conduzido pela força de um cavalo), substituindo os de tração leve (o arado simples impulsionado pelo boi ou pelo próprio camponês). Os outros avanços foram a estabulação do gado durante o inverno,

7 Número alcançado no ano de 117 d.C. Para maiores informações sobre Roma ver Woolf (2017).

8 O poder do papa é discorrido em Brown (2013). 
alimentado com feno. Como resultado, a produtividade duplicou mesmo em solos arenosos 9 . Gradualmente, o excedente de alimentos incentivou a volta das trocas comerciais. Essas interações ocorriam nos burgos, locais onde se pagavam para adquirir bens e serviços. A remuneração do trabalho em moedas resultou na formação de uma classe social intitulada de burguesia.

Antes do renascimento agrícola e comercial na Europa medieval, repúblicas como a de Veneza e Gênova, na península Itálica, estavam na frente em relação aos demais ${ }^{10}$. De posições geográficas privilegiadas, estabeleceram rotas mercantis com a Ásia, de onde vinham especiarias, artigos de luxos e escravos, e as revendiam por todo o continente europeu. Nesse tocante, surgiu um grupo de empreendedores, que além da influência econômica, tinha participação política, uma condição semelhante à dos cidadãos atenienses. Entretanto, o aumento sucessivo de impostos, sobrecarregando os mercadores, somado com a queda de Constantinopla, onde viviam 10 mil venezianos, impediram o surgimento de um novo império.

Por outro lado, os muçulmanos, ou mouros, conseguiram efetivamente fundar um reino duradouro na Europa. Existiu do século XVIII até 1491, ano que a última cidade sob dominação islâmica, Granada, sucumbiu aos reis católicos Fernando de Aragão e Isabel de Castela. Esse processo, denominado de "a reconquista", é um termo enganador ${ }^{11}$. Antes dos árabes, a Ibéria era turbulenta e miseravelmente habitada por visigodos, um povo germânico que vivia nas margens da cristandade. Após a ascensão dos Califas, tornou-se um lugar próspero, cuja população era alfabetizada e o governo promovia estudos na área do direito, ciência, arquitetura, engenharia, astronomia, matemática, filosofia e literatura.

Embora tenha se submetido ao controle do cristianismo por séculos, aos poucos os europeus romperam com a mentalidade afincada em concepções divinas. Essa mudança de pensamento adveio dos textos clássicos elaborados pelos gregos, da crescente burguesia, dos desesperados mercadores italianos e dos árabes instalados na península Ibérica. Nessa parte da Europa, emergiram dois impérios que difundiriam esses novos

9 As inovações agrícolas desenvolvidas na Europa medieval ver Mazoyer; Roudart (2010).

10 A ascensão da burguesia e o apogeu e declínio de Veneza ver Acemoglu; Robinson (2012).

11 Os conhecimentos científicos dos povos devotos do Islã são apresentados em Grandin (2014). 
ideais para o mundo: Portugal e Espanha. Contudo, os seus reis, por serem cristãos fervorosos, ainda apoiariam essa fé e a conduziriam para as terras recém descobertas pelo genovês Cristóvão Colombo em 1492 ${ }^{12}$. Nos séculos seguintes, todavia, essa associação seria dissolvida pela Inglaterra e Países Baixos ${ }^{13}$.

\section{O espaço capitalista}

A hegemonia do controle português e espanhol sobre os continentes americano, africano e asiático durou menos do que dois séculos. Esses impérios se enraizaram em uma concepção arcaica, proveniente da Idade Média e Antiga, enquanto os ingleses e neerlandeses, as suas principais ameaças, ignoravam as ordens do Vaticano e implementavam iniciativas que atacavam os ideais dos ibérios. No lado da Inglaterra, a Coroa apoiava explicitamente a pirataria e a pilhagem no Atlântico e Caribe. Nesse contexto, surgiram personagens emblemáticos como o corsário sir Francis Drake, admirado pela sua rainha, Elisabeth I. Todavia, foi sir John Hawkins o primeiro a espoliar o ouro e a prata extraídos na América espanhola.

Ao mesmo tempo, os Países Baixos, aproveitando da sua experiência no comércio internacional, diplomacia e direito à propriedade privada, optaram por iniciativas levemente sutis para apropriarem-se das riquezas do então novo mundo. Primeiramente, assim como os ingleses abandonaram o catolicismo em detrimento do anglicanismo, adotaram o calvinismo como religião oficial. Adiante, formaram a VOC, uma companhia mercantil cujo financiamento provinha de participação acionária. Anterior a isso, o único modo de conseguir fundos para as viagens transoceânicas consistia em convencer o rei ou a rainha ${ }^{14}$. Dessa forma, surgiu o crédito, a promessa de que o investimento terá um retorno algum dia.

Novamente, a imaginação humana foi capaz de mudar as relações sociais na Europa e difundir-se, paulatinamente, ao redor do mundo. Sem a ideia do crédito, os neerlandeses nunca pagariam exércitos para

12 A aliança entre o papa e os reis da Espanha e Portugal é amplamente debatido em Brown (2014).

13 Informalmente referido como Holanda, que por sua vez relaciona-se as suas duas principais províncias, Noord-Holland e Zuid-Holland, o governo neerlandês emprega oficialmente o nome Países Baixos em seus registros.

14 Brown (2014) discorre como a Inglaterra e os Países Baixos destronaram Portugal e Espanha em menos de dois séculos. 
combater as tropas da Espanha e Portugal. Logo após as vitórias, quitavam-se as dívidas na data agendada como forma de aumentar o nível de confiança do seu sistema frente aos demais países. Além do que, o seu corpo jurídico protegia os indivíduos que se sentissem lesados, garantindo o direito à defesa. Com isso, cada vez mais pessoas aplicavam as suas riquezas nesse mercado para dilatar o seu patrimônio. A partir disso, surgiu o credo do capitalismo, a ideia de que os lucros precisam constantemente serem reinvestidos.

A Inglaterra reproduziu sem retoques o sistema financeiro neerlandês, inclusive convidando o regente das províncias ao norte dos Países Baixos, Guilherme de Orange, e a sua esposa, Maria, filha protestante do rei inglês Jaime II, a assumir o trono, episódio conhecido como Revolução Gloriosa. Na prática, o Parlamento é que ditava as regras, transformando a Coroa em um mero personagem decorativo. Nesse tocante, o monarca perdeu o monopólio na exploração do comércio ultramarino, canais e estradas, dando espaço para que os nobres investissem nessas atividades. A Casa também aprovou leis que asseguravam o direito de propriedade, a defesa e a penhora em situação de não-pagamento de dívidas ${ }^{15}$.

Por conseguinte, as inovações impostas pelo Parlamento inglês no século XVIII deram as bases para o surgimento da primeira Revolução Industrial. Em suma, esse período marcou o início da produção em larga escala, especialmente de manufaturas têxteis. Surgiram fábricas em todo o Reino Unido que atraíram pessoas oriundas da zona rural. Cidades como Manchester, Liverpool, Leeds, Sheffield, Newcastle e Birmingham cresceram em um ritmo exponencial. A capital, Londres, destronou Amsterdam do título de principal centro financeiro mundial. Desse modo, os Países Baixos, endividados pelas guerras travadas nos mares e o declínio do comércio de especiarias, a sua base econômica, perdeu a condição de potência hegemônica.

Em contrapartida, a França emergiu como a grande rival dos ingleses ao estabelecer colônias na América, África e Ásia. De fato, essa rixa existia desde o final da Idade Média, precisamente após a vitória francesa na Guerra dos 100 anos. Nesse período, Paris era uma cidade bem mais importante do que Madri, Lisboa, Londres ou Amsterdam. As suas igrejas góticas, monastérios, universidades e feiras que vendiam os produtos agrícolas advindos da região de Champagne eram pontos obrigatórios de

15 A adoção do sistema financeiro neerlandês e os impactos da Revolução Gloriosa e Industrial são analisados em Ferguson (2017). 
permanência para qualquer viajante. Além disso, a Igreja Católica detinha uma forte influência nesse reino, sendo que alguns dos seus bispos se tornariam papas como Urbano IV, João XXII e Clemente VI.

No entanto, os franceses se envolviam constantemente em guerras ou distúrbios internos. As revoltas camponesas da era medieval, a queda da Bastilha e o período napoleônico são exemplos de eventos calamitosos. Além disso, até o final da Idade Moderna, diferente da Inglaterra, as decisões políticas concentravam no rei e as entidades católicas ainda ditavam as regras sociais. No que tange à mudança de mentalidade na Europa, a França era uma retardatária. Para se recuperar, desvencilhou-se do Vaticano e criou empresas constituídas por sociedades anônimas, porém os seus resultados foram um completo desastre ${ }^{16}$.

Neste contexto, o domínio inglês alinhado no credo capitalista obteve todas as condições necessárias para se expandir ao redor do planeta. Se antes os lusos e espanhóis se contaminaram com a "febre do ouro", os ingleses promoveram a "febre do lucro". Para tanto, os seus produtos manufaturados adentraram nos impérios milenares como o da China, e também nas suas colônias americanas, africanas, asiáticas e da Oceania, ou até em possessões portuguesas como o Brasil. Em troca, recebiam bens de baixo valor agregado como a seda chinesa, o chá indiano, o açúcar caribenho e peles de animais da América do Norte. Na África, o comércio de escravos empregados nas plantations era a sua principal fonte de receita ${ }^{17}$.

Consequentemente, o mundo se transformou em um gigantesco império, onde todas as suas regiões se especializaram em alguma produção. A diferença é que a partir do século XIX a representatividade divina se transfigurou no livre mercado. Quanto menos interferirem em sua dinâmica, maiores serão as chances de as pessoas prosperarem no futuro. Nesse sentido, o governo teria a única função de impedir as perturbações nesse meio. Assim, a riqueza gerada pelos vultuosos lucros se transformaria em capital e seria continuamente investida em qualquer atividade, mesmo que seja o tráfico negreiro. Esse é o principal fundamento do pensamento econômico liberal.

Apesar disto, houve uma nacionalização do colonialismo, uma vez que a Inglaterra apoderou das terras pertencentes à Companhia Britânica na Índia, e os Países Baixos da VOC na Indonésia. Nitidamente, essa iniciativa era uma espécie de seguro para os investidores ingleses ou

16 O atraso dos franceses em relação aos ingleses é explicado em Acemoglu; Robinson (2012).

17 Maiores informações sobre o comércio de escravos africanos ver Grandin (2014). 
neerlandeses. Como resultado, surgiu um conluio entre políticos e capitalistas a fim de satisfazer os seus anseios, e geralmente agiam sem limites, indiferentes no tratamento aos povos subjugados. Essas lideranças se baseavam em ideias racistas para justificar suas atitudes degradantes, porém a verdadeira motivação para isso era somente a obtenção do lucro. A valer, o capitalismo promoveu mais assassinatos do que a Roma Antiga ou a Inquisição Medieval ${ }^{18}$.

Para se ter uma noção, no intuito de suprir a crescente demanda internacional por látex, entre 1885 e 1908 o governo da Bélgica massacrou 6 milhões de indivíduos no Congo, a sua única colônia africana. As mortes cessaram em razão de denúncias, e assim, o mundo tomou conhecimento das falhas de mercado. Isto posto, da mesma forma que a primeira Revolução Agrícola forçou o surgimento de leis a fim de conter os distúrbios sociais, e a partir daí despontaram os impérios e as religiões, e o capitalismo demandava um conjunto de aparelhos para corrigir os problemas apresentados. Com isso, a mente humana idealizou as instituições, mecanismos que estabelecem as práticas de convívio entre os agentes econômicos ${ }^{19}$.

\section{O espaço institucionalizado}

As diferenças de êxito econômico entre os países, ou até na esfera inter-regional, são frequentemente atribuídas ao desempenho das suas instituições. Por exemplo, nas nações ou regiões prósperas, crianças e adolescentes têm acesso a institutos de ensino de qualidade, e na fase adulta encontram um ambiente que os estimulam a empenhar-se em alguma atividade de interesse. Na outra via, em partes do mundo que estão imersos na pobreza, nem ao menos há mecanismos que garantam os direitos básicos para os seus cidadãos. Desse modo, as chances de eles acumularem riqueza e formarem capital são mínimas. Para reverter esse cenário, o governo elabora leis, projetos e programas que tendem a favorecer a sociedade como um todo.

Nesta situação, surgem os seguintes questionamentos: por que alguns espaços capitalistas possuem instituições eficazes, e outros não? Qual é a origem dessas diferenças? De antemão, afirma-se que a hipótese geográfica, cultural e da ignorância são argumentos inválidos para responder

18 Harari (2019) trata o capitalismo como a pior invenção da imaginação humana.

19 Para adentrar no conceito e origem das instituições ver North (1966 e 1998). 
tais questões ${ }^{20}$. Por isso, a análise retorna para a primeira Revolução Agrícola a fim de compreender a natureza dessas indagações. Como se denotou anteriormente, o excedente de alimentos consolidou as organizações complexas como os impérios e as religiões na Ásia e África. A Europa entrou nesse processo tardiamente, contudo, logo gerou riquezas através das trocas comerciais no Mediterrâneo.

Por lógica, lugares onde não existiam estrutura social complexa, como a Nova Guiné dos papuas, tornam-se improváveis o advento imediato de instituições progressistas. Assim, a ocupação espacial para fins agrícolas é um dos requisitos para o estabelecimento de uma sociedade moderna. A outra exigência concerne ao sentimento de comunidade que os seus moradores adquiriram com o tempo. Ao passo que a Grécia e a China possuem 4 mil anos de história, o Peru, onde os espanhóis destruíram as grandes cidades Incas, tem menos de 200 anos de independência. Dessa forma, gregos e chineses estão a gerações aperfeiçoando os seus sistemas organizacionais, enquanto os peruanos encontram-se no começo do processo $^{21}$.

Observe o caso dos Estados Unidos da América, a nação que superou o poderio do Império inglês, o seu colonizador, após a I Guerra Mundial (1914 - 1918). No começo, o seu projeto de ocupação espacial seguia o modelo de exploração da América portuguesa e espanhola. Entretanto, os diretores da empresa privada encarregada, a Companhia da Virgínia, depois de seguidas tentativas fracassadas, compreendeu que seria impossível utilizar essa estratégia de apropriação na baía de Chesapeake. Além disso, nenhum nativo sabia onde estava o ouro e a prata ou outros metais preciosos, e tampouco se havia pau-brasil ao norte do continente americano.

Neste tocante, a única opção viável seria a efetivação de uma colonização de base comunitária. Para tanto, incentivaram os puritanos (protestantes radicais) a migrarem e a cultivarem em fazendas de 20 hectares pertencentes à Companhia da Virgínia. Além disso, doaram ferramentas, sementes, residência e garantiram o voto das famílias assentadas na Assembleia Geral. Trata-se dos primeiros movimentos da democracia americana, um processo semelhante ao ocorrido na Atenas do século VI a.C. Em compensação, domínios ingleses ao sul como Geórgia, Belize e

20 Acemoglu; Robinson (2012) detalha as razões.

21 Diamond (2018) trata sobre a origem das instituições. 
Jamaica teriam uma ocupação igual à da colônias luso-espanholas, e herdariam os mesmos problemas pós-independência.

Quando as 13 colônias inglesas se tornaram Estados Unidos em 1776, de imediato, os seus fundadores expandiram o seu território rumo ao Pacífico. Os países que tinham possessões nas adjacências acharam vantajoso comercializá-los. Dessa maneira, os americanos compraram a Louisiana dos franceses, a Flórida dos espanhóis, o Pacífico Noroeste dos ingleses, o Alasca dos russos, o Texas dos mexicanos e posteriormente, pelo uso da força, a região da Alta Califórnia. Nenhum deles se preocuparam com as tribos que ali residiam, sendo impiedosamente massacrados pelos novos donos. Esse acontecimento demonstrou que as instituições democráticas originadas na América do Norte excluíam sem remorso os nativos ${ }^{22}$.

Diante de tais acontecimentos, apesar de os Estados Unidos terem menos de 300 anos de existência, desde o começo, por uma mera obra do acaso, aprenderam os princípios do capitalismo e da participação popular, legado dos ingleses. Por outro lado, quando prosseguiram com a ampliação dos seus domínios no ultramar, houve frustrações. Nas Filipinas, as elites locais resistiram a tais investidas. O resultado da ofensiva em Porto Rico foi a criação de um país que era ao mesmo tempo autônomo e submisso aos americanos. O único caso de absorção completa aconteceu no Havaí porque os produtores de açúcar da ilha, constituídos por japoneses e filipinos, enxergaram o potencial do mercado consumidor americano.

Os experimentos americanos reforçam a ideia de que o implemento de instituições democráticas em prol do capitalismo é um processo árduo. Desse modo, a efetivação de um espaço institucionalizado demanda uma certa quantidade de persistência. Observe o exemplo da Colônia do Cabo, atualmente o oeste da África do Sul. Antes da chegada dos neerlandeses, era habitado pelos khoikhois e xhosas. Depois, se tornou um entreposto para os navegantes da VOC que seguiam rumo ao Índico. Nesse contexto, os nativos vendiam seus alimentos para os transeuntes, e com o dinheiro das vendas, aprenderam a construir casas de tijolos e implementaram modernas técnicas agrícolas, como os canais de irrigação.

Sob o domínio inglês, iniciado em 1806, o Parlamento aprovou leis emancipando escravos aprisionados pelos agricultores neerlandeses, e garantiu a propriedade privada tanto para os brancos como a favor dos negros e o livre comércio. Em 1853, a Colônia do Cabo obteve uma

22 Para compreender o período de expansão do território americano ver Ferguson (2011). 
instituição democrática subordinada ao Reino Unido cuja participação estava em aberto a qualquer representante das etnias, desde que tivesse algum imóvel ou uma renda estável. De todas as possessões europeias da África meridional, essa era a única onde os seus habitantes avistavam a prosperidade. Com a descoberta das minas de diamantes, cresceram os investimentos em ferrovias, portos e estradas, melhorando a infraestrutura da possessão.

Em compensação, a mineração atiçou o sentimento imperialistacapitalista da Inglaterra, que avançou sobre os territórios dos bôeres ${ }^{23}$, gerando conflitos armados. O resultado das guerras foi a criação de uma confederação, a União Sul-Africana. Nesse episódio, a grande prejudicada foi a população nativa, que tiveram as suas terras tomadas, foram proibidos de comprarem propriedades rurais e até de votarem, inclusive no Cabo, onde esse direito existiu por mais de oitenta anos. Na década de 1940, os anglófonos foram substituídos no poder pelos descendentes dos neerlandeses, e a então África do Sul se transformou numa república racial sedimentada no pensamento do apartheid $^{24}$.

Se as instituições democráticas implementadas na África meridional pelos ingleses tivessem logrado um maior tempo, qual seria o resultado? A resposta está na Bechuanalândia, atualmente Botsuana, que se tornou um protetorado inglês devido a sua posição geográfica, localizada entre uma colônia portuguesa (Moçambique), uma alemã (agora Namíbia) e as possessões do magnata da mineração Cecil J. Rhodes (hoje Zâmbia e Zimbábue). Desse modo, funcionava como uma barreira de contenção às ameaças externas sobre o Cabo. Os missionários e as lideranças locais tiveram uma função primordial nesse processo ao sensibilizar o primeiro-ministro inglês sobre a importância estratégica de preservar o território dos tswanas ${ }^{25}$.

Sobaégideda Coroa, os ingleses pouco interferiram na Bechuanalândia, somente construíram uma estrada de ferro. Com isso, os chefes tribais se sentiram confiantes para tomarem decisões em conjunto. Assim, surgiu uma espécie de Assembleia Geral da mesma forma ao ocorrido nas terras

23 Embora tenham perdido a Colônia do Cabo, os neerlandeses e seus descendentes, os bôeres ou africânderes, tomaram dos zulus e demais tribos as suas terras, originando a República de Transvaal, a Colônia de Natal e o Estado Livre de Orange (MEREDITH, 2017).

24 Para saber mais sobre as origens e consequências do apartheid ver Meredith (2017).

25 Para saber como os tswanas e os missionários convenceram os ingleses ver Acemoglu; Robinson (2012). 
da Companhia da Virgínia. Quando se tornou independente, em 1966, o novo país tinha poucas estradas pavimentadas e irrisórias pessoas com diploma de nível superior. Atualmente, é uma das raras nações africanas democráticas e multipartidárias, e que nunca passaram por uma ditadura ou guerra civil. Ademais, a sua renda per capita é maior do que a Hungria e Estônia, um feito raro que se relaciona à robustez das suas instituições.

\section{Não há mais tanto espaço}

Se as instituições democráticas no Cabo possuíssem um tempo maior de existência, os khoikhois e xhosas teriam um padrão de vida semelhante ao dos vizinhos tswanas? Caso os incas ganhassem tempo e conseguissem maiores informações sobre os espanhóis, resistiria ao avanço hispânico na América do Sul, dado que Francisco Pizarro contava com poucos soldados e o reforço próximo estava no Panamá, a dois mil quilômetros de distância? Como ninguém inventou uma metodologia fidedigna para testar tais hipóteses, essas indagações com elevada dose de imaginação, se tornam retóricas. Na prática, resta aos pesquisadores simplesmente analisar os eventos históricos e procurar soluções aos problemas contemporâneos.

Por outro lado, o capitalismo e as suas instituições infiltraram de tal maneira no mundo que há poucos lugares propícios para executarem novos processos de ocupação espacial. Na Nova Guiné, por exemplo, logo que se anexou à Indonésia, na década de 1960, se usurpou de administradores públicos javaneses e comerciantes chineses. Além do que, sucedeu uma revolução agrícola graças ao cultivo em larga escala de batatasdoces desenvolvidas nas Filipinas. Em síntese, a outrora ilha selvagem dos papuas atualmente obtém uma produção excedente de alimentos. Através disso, transformou-se em mais uma integrante do complexo sistema mercantil vigente.

Nem ao menos o Ártico, uma das últimas áreas desbravadas pelo ser humano, está a salvo da apropriação institucionalizada. O aquecimento global derreteu uma parte das calotas polares, possibilitando a sua navegabilidade na maior parte do ano. Um navio partindo de Xangai-China até Nova York via canal do Panamá gasta uma semana a mais do que indo pelo norte do Canadá. Ademais, o degelo converteu terras improdutivas em áreas de exploração agrícola ou mineral. Nesse contexto, a Rússia sobressai em relação aos demais ao possuir cidades, ao invés de vilas como ocorre em sua vizinhança, dentro do círculo polar. Destaca-se 
Murmansk, próximo da Finlândia, com 300 mil habitantes e sede de petroleiras offshore.

A influência dos russos no Ártico se estende até onde um dos seus 32 navios quebra-gelos, a maior frota do mundo, alcança. Enquanto isso, os Estados Unidos têm somente um e sem planos para construir outro. Essa supremacia reacendeu os tempos da Guerra Fria e o perigo de que a região se transforme em um campo de batalha. Se acontecer, provavelmente as ilhas Svalbard, Noruega, o ponto mais setentrional do planeta com assentamento urbano, será o primeiro local de batalha. Lá, existe uma crescente população de migrantes da Rússia que trabalham nas minas de carvão. Com isso, gerou-se uma tensão em vista que ultimamente Moscou tomou áreas na Geórgia e Ucrânia onde seus cidadãos têm bastante representatividade.

Agrava-se a situação diante do fato que os noruegueses são membros da Organização do Tratado do Atlântico Norte (OTAN). Isto posto, caso sejam ameaçados, os Estados Unidos e a Inglaterra são obrigados a participarem do embate. Em vista disso, o atual presidente dos EUA, Donald Trump, demonstrou interesse em adquirir a Groenlândia dos dinamarqueses como forma de contrabalancear o poderio russo no Ártico. Essa proposta remonta os dias em que os americanos compraram o Alasca da Rússia e as Ilhas Virgens, no Caribe, da própria Dinamarca ${ }^{26}$. Desse modo, práticas antigas de apropriação espacial ainda possuem condições de retornarem à contemporaneidade.

No outro extremo do globo, os tratados internacionais preservaram o continente antártico contra as investidas externas. No entanto, países como a Argentina, dona de seis bases científicas na região, ao passo que o Brasil tem apenas uma, possui interesse em explorá-las quando revisarem os acordos. Até esse tempo, extrai petróleo e gás offshore na costa da Patagônia, atividades que acirram a rivalidade com os ingleses devido aos resquícios da Guerra das Malvinas. Mesmo que aumente a sua influência nas adjacências da Antártica, os argentinos enfrentarão questões geopolíticas com relação a nações tecnologicamente avançadas, e desafios naturais similares a do Ártico: ventos gelados, noites intermináveis e o isolamento.

Nesta perspectiva, ainda que o Homo sapiens tenha o domínio dos desertos, dos mares e das selvas, aparenta-se que as áreas polares demandarão uma quantidade maior de tecnologia para se obter o total controle.

26 Para aprofundar sobre a geopolítica no Ártico e na Antártica ver Marshall (2018). 
Dessa forma, apenas as nações que possuem tais conhecimentos como os Estados Unidos e a Rússia se apropriarão dos recursos naturais provenientes dos continentes gelados. Nada obstante, devido à ganância humana transfigurada em doutrina capitalista, provavelmente tais riquezas acarretarão parcos benefícios para os demais habitantes da Terra. Em consequência disso, se dilatarão as desigualdades socioeconômicas no mundo, exigindo cada vez mais arranjos institucionais para amenizar tais desníveis.

\section{Qual é o nosso espaço?}

O capitalismo é frequentemente criticado sob contundentes motivos, principalmente no que concerne à geração de desigualdades de renda. A única tentativa decente de destitui-lo, o comunismo, mostrou-se danoso em todos os aspectos. Desse modo, são raros os experimentos alternativos, e tampouco há espaços para servirem como tubos de ensaio. Por isso, nesse momento da história, nenhum país, região ou comunidade possui condições de desenvolver um modo de produção capaz de substitui-lo. Assim, embora haja diferenças de fisionomias, costumes, crenças e identidades, as pessoas desse planeta se tornaram meros pontos de um sistema de produção massificado.

O Google Earth, popular programa online lançado em 2005, demonstra como as relações espaciais são resumidas a pixels. De qualquer computador no mundo conectado à internet, basta clicar no mouse para que o usuário obtenha informações sobre um lugar, inclusive das partes remotas. Se almeja a efetivação de negócios lucrativos no exterior, estudar em uma universidade de renome ou passar as férias em uma ilha paradisíaca, o indivíduo os conhece antes da viagem. Com a difusão dos smartphones, toda a Geografia passou, literalmente, a caber no bolso da calça, da saia ou da bermuda. O capitalismo, além de homogeneizar o gosto dos humanos, comprimiu o planeta em petabytes ${ }^{27}$.

Em compensação, governos estão descontentes com o Google por expor dados e informações sigilosas. Além do que, como a privacidade se transformou em produto comercializável, ninguém sabe ao certo a quantidade de dólares que a empresa fatura vendendo tais sigilos, e tampouco os impactos no longo prazo dessa atividade no cotidiano, uma vez que o lançamento do programa ocorreu a menos de 20 anos. Efetivamente, o

27 Para saber mais sobre o Google Earth ver Brotton (2014). 
número de tecnologias disponibilizadas no mercado se tornou tão vertiginoso que beira o impossível avaliar as suas consequências na sociedade. Por exemplo, antes de se popularizar a inteligência artificial, prontamente haverá um substituto: a inteligência emocional ${ }^{28}$.

Na tentativa de prever como o excesso de inovação afetará as relações sociais presentes em um determinado espaço, pesquisadores se empenham incessantemente na elaboração de robustos modelos computacionais. São ferramentas primordiais na análise de dados, porém de alcance restrito. Essa limitação deve-se à constatação de que a história da humanidade, conforme denotou-se ao longo deste estudo, é caótica. São tantas forças em ação com diferentes intensidades que se tornou inviável construir um software capaz de prever os próximos acontecimentos. Com isso, ninguém tem informações confiáveis para determinar quando ocorrerá a próxima revolução, dado que essa palavra, por definição, significa ação imprevista.

Neste panorama, apesar da profusão de tecnologias que asseguram o modelo de ocupação espacial via capitalismo, o futuro ainda é nebuloso. As instituições criadas para corrigir o lado negativo desse sistema, como o Banco Mundial, sugeriram equivocadas políticas a serem adotadas nos países em desenvolvimento, resultando no aprofundamento das diferenças sociais no mundo. Por outro lado, o fracasso de tais iniciativas geralmente vincula-se aos seus governantes desonestos, que aplicaram os recursos para fins particulares ao invés de promover o bem-estar comum. Dessa forma, inicialmente criado para se tornar a salvação da humanidade, os institutos passaram à condição de vilões.

Uma das razões é a ausência de um sistema econômico alternativo, questão amplamente discutida anteriormente. Outra, de igual forma debatida, relaciona-se ao tempo que um país ou região delonga para criar instituições benéficas. Essas duas constatações resumem-se a uma questão biológica, de que no geral o Homo sapiens é um ser incapaz de viver como uma comunidade globalizada. Essa habilidade, de acordo com a evolução das espécies, demorará milênios para que aconteça por completo. Até esse tempo, é questionável se a humanidade continuará presente neste planeta. Portanto, se incorrerá melhorias no longo prazo, tem sentido persistir com o atual modelo?

A resposta é sim, pois a história mostrou que nem todas as substituições transfiguraram em melhorias para a população. A primeira

28 As afirmações a partir daqui tem como base Harari (2019). 
Revolução Agrícola viabilizou a construção de impérios que subjugaram uma parte da humanidade. Aqueles que sobreviveram as guerras passaram os últimos anos na escravidão. Em outra situação, a evolução no uso da água para a agricultura no Egito faraônico acarretou parcos benefícios para os camponeses. Assim como a tecnologia dos espanhóis, um desastre para os incas, e de modo similar, para os papuas da Nova Guiné. Sobre a África do Sul, extinguiu-se o apartheid através da democracia, e mesmo assim, a maioria dos negros continuam à margem da sociedade.

Prossegue a análise questionando se os índios e o descendentes de escravos beneficiaram com a migração dos puritanos junto com a sua Assembleia Geral na América do Norte. Outro caso, a democracia ateniense não trouxe mudança na relação marido e esposa, e com isso, as mulheres continuaram numa existência amargurada. Na Revolução Industrial, os trabalhadores ingleses da indústria têxtil de Londres ou Manchester tinham uma expectativa de vida menor que os miseráveis campesinos. Por fim, na Idade Média, a Igreja Católica auferia um profundo desinteresse em melhorar as condições de trabalho dos servos em terras feudais.

Em razão disto, o sistema capitalista resiste, com todas as suas mazelas constatadas neste estudo, pelo motivo de que os processos de apropriação espacial anteriores obtiveram um desempenho pior no que tange ao bem-estar geral. Por outro lado, ao sintetizar a humanidade em bancos de dados acessíveis remotamente, nenhum dos problemas testemunhados desapareceram por completo neste século. Ao contrário, as doenças como a AIDS e o câncer, a pobreza, a exploração do trabalho, o feminicídio e a exclusão social continuam presentes no mundo, em menor ou maior frequência, a depender do país. Desse modo, por que é tão difícil promover a integração entre os povos?

Harari (2019) aponta que os pesquisadores consideraram demasiadamente em suas análises as variáveis econômicas como renda, patrimônio e acesso a serviços, para determinar o nível de desenvolvimento da nação ou região. De fato, riqueza, saúde e participação política explicam uma parte desse processo. Em compensação, recentes estudos empíricos demonstraram que fatores sociais, éticos e espirituais tem tanta influência no progresso de um lugar quanto as condições materiais. Sintetizaram essas constatações em um parâmetro denominado de "felicidade humana". Em resumo, versa sobre a sensação que descreve o prazer imediato ou contentamento no longo prazo com o espaço no qual participa ativamente. 
Ao entender que o atual sistema produtivo se propagará por longos períodos, trata-se de uma nova maneira de aprender sobre o processo de ocupação espacial e a sua relação com o desenvolvimento. No momento, o desafio consiste em criar um robusto método de análise a partir de uma melhor definição sobre a felicidade humana. Esse trabalho encontra-se nos primeiros passos e de imediato se demonstrou promissor. Nos próximos anos, será possível colocar essa variável em modelos econométricos ou analisá-la por meio de questionários e entrevistas. Previamente, entende-se que isso não resolverá os problemas que padecem na humanidade. Apesar disso, a iniciativa traz um sentido para a existência dos Homo sapiens.

\section{Conclusão}

Os processos de ocupação espacial são geralmente caracterizados pelos conflitos entre invasores e invadidos, e o desequilíbrio nas relações dos humanos com a natureza. Essa situação decorre em vista da necessidade de explorar as terras para obter riquezas que sustentarão o imperador e os seus subordinados, ou um poder imaginário, no atual contexto, o capitalismo baseado no livre mercado. A partir disso, surgiram inovações na área da agricultura, indústria e informática como medidas para assegurar tais domínios. Em consequência, elevou-se a quantidade de alimentos, de bens manufaturados e facilitou a comunicação entre as pessoas, porém, as dificuldades que afligem a sociedade ainda persistem no século XXI.

No que concerne à mudança no sistema produtivo em questão, as chances de acontecer são improváveis. A tecnologia fez com que todos os seres humanos se integrassem à conjuntura vigente. Com isso, é inimaginável que alguém queira renunciar aos confortos da vida contemporânea. Caso contrário, nem mesmo o Ártico é mais uma opção. Dessa forma, o capitalismo continuará triunfante, e ao mesmo tempo, os problemas da humanidade persistirão, embora as instituições atuem para corrigir as falhas de mercado. A valer, o ambiente institucional colabora para o bem-estar das pessoas, contudo, esses dispositivos exigem um certo tempo de maturação, às vezes séculos, para satisfazer os envolvidos.

Diante de tais averiguações, a atitude apropriada do pesquisador é primeiramente aceitar as condicionantes impostas pelo atual contexto. Se entrar em rota de coalização, aumentará ainda mais a sua frustração diante das injustiças geradas pelo sistema. A comunidade científica 
percebeu essa situação e propõe novos métodos de análise. Um deles é averiguar o nível de felicidade humana presente em um determinado espaço. Questiona-se se as pessoas que sobrevivem ali têm ou não uma elevada empatia sobre as limitações existentes. Talvez, esse sentimento seja apenas mais um produto da imaginação do Homo sapiens. Isto posto, existe a chance de que a nossa existência se resume a criar ilusões.

Independentemente disto, torna-se necessário que os próximos estudos sobre desenvolvimento elevem a variável felicidade humana em um nível de importância similar à da renda, patrimônio e serviços. No entanto, essa iniciativa se tornará viável somente nos próximos anos, quando se obterá uma maior confiança nos procedimentos metodológicos que avaliem esse parâmetro. Em relação à sua aplicabilidade no Brasil, em vista da infiltração do agronegócio na zona rural, do avanço das igrejas pentecostais e neopentecostais na sociedade e do tráfico de drogas nas cidades, esse tipo de análise possui um vasto campo de estudo. Destarte, inseri-lo será o principal e maior desafio, especialmente nos trabalhos que tratam sobre desenvolvimento.

\section{Referências bibliográficas}

ACEMOGLU, D.; ROBINSON, J. Por que as nações fracassam: as origens do poder, da prosperidade e da pobreza. Rio de Janeiro: Elsevier, 2012.

BROTTON, J. Uma história do mundo em doze mapas. Rio de Janeiro: Zahar, 2014 .

BROWN, S. R. 1492. São Paulo: Globo, 2013.

BUBANK, J.; COOPER, F. Impérios: uma nova visão da história universal. São Paulo: Planeta, 2019.

DIAMOND, J. Armas, germes e aço: o destino das sociedades humanas. Rio de Janeiro: Record, 2018.

FERGUNSON, N. Colosso: a ascensão e queda do império americano. São Paulo: Planeta do Brasil, 2011.

Império: como os britânicos fizeram o mundo moderno. São

Paulo: Crítica, $2^{\circ}$ ed., 2017. 
GRANDIN, G. O império da necessidade: escravatura, liberdade e ilusão no Novo Mundo. Rio de Janeiro: Rocco, 2014.

HARARI, Y. N. Sapiens - Uma breve história da humanidade. Porto Alegre: L\&PM, 2019.

MARSHAL, T. Prisioneiros da geografia: 10 mapas que explicam o que você precisa saber sobre a política global. Rio de Janeiro: Zahar, 2018.

MAZOYER, M.; ROUDART, L, Histórias das agriculturas no mundo: do neolítico da crise contemporânea. Brasília: NEAD, 2010.

MEREDITH, M. O destino da África: cinco mil anos de riquezas, ganância e desafios. Rio de Janeiro: Zahar, 2017.

NORTH, D. C. Growth and welfare in the American past: a new history. Englewood Cliffs, NJ, EUA: Prentice-Hall, 1966.

. Custos de transação, instituições e desempenho econômico. Rio de Janeiro: Instituto Liberal/Instituto Millenium, 1998.

WOOLF, G. Roma: a história de um império. São Paulo: Cultrix, 2017. 


\section{Ordenamento territorial e desenvolvimento regional: aproximações conceituais ${ }^{1}$}

Lívia Gabriela Damião de Lima²

Larissa da Silva Ferreira Alves ${ }^{3}$

\section{Introdução}

Necessidade de compreansão do PAPEl EXERCido Pelo Estado
perante as nuances das práticas econômicas, políticas, sociais e ideológicas vem ganhando espaço desde o final do século XX até os dias atuais. Mencionadas práticas ocasionam alterações na organização espacial e nas ações estatais em diferentes espaços, o que se torna premente pensar no redirecionamento das ações do Estado dadas ao território. Dentro dessa perspectiva, torna-se cada vez mais latente a proeminência da análise nas escalas locais e regionais para que se compreenda como o Estado (re) pensa e ordena o seu território.

O ordenamento territorial (OT), enquanto prática estatal de organização do território, a partir do planejamento e alocação de recursos infraestruturas etc., é constituído de intenções que buscam racionalizar o uso do território e o resguardo dos atores de maior poder econômico e político na sociedade. Esse entendimento aplica-se ainda ao planejamento setorial dado em esferas como, educação, saúde, esporte, dentre outros instrumentos entendidos nesse trabalho como partes de uma totalidade que, sistematizados, constituem a concepção de uma política de ordenamento do território.

1 O presente trabalho possui uma versão anterior à aqui apresentada, tendo sido publicada na Revista Política e Planejamento Regional, v. 5, p. 142-156, 2018.

2 Geógrafa e Mestra em Planejamento e Dinâmicas Territoriais no Semiárido (PLANDITES/UERN). E-mail: livia.gabrieladl@hotmail.com.

3 Profa. Dra. do Departamento de Geografia e do Programa de Pós-Graduação em Planejamento e Dinâmicas Territoriais no Semiárido (PLANDITES), Campus de Pau dos Ferros (CAPF), da Universidade do Estado do Rio Grande do Norte (UERN). E-mail: larissaferreira@uern.br. 
A partir da compreensão de que ordenamento do território é uma ferramenta fundamental a ser utilizada pelo Estado no que tange a organização espacial do território, o desenvolvimento regional (DR) não pode ser negligenciado, uma vez que as questões regionais devem ser compreendidas dentro da totalidade do processo de desenvolvimento, constituindose como um importante instrumento para o ordenamento do território.

Assim sendo, "os estudos sobre o desenvolvimento são caros ao OT, uma vez que estão imbuídos nas articulações políticas e inserem-se na perspectiva de um planejamento em múltiplas escalas. Portanto, o ordenamento territorial compreende não só as disparidades socioespaciais como mecanismo de desenvolvimento, este por sua vez assegura o crescimento econômico, a competitividade e gere os conflitos no uso e na apropriação do território." (LIMA, 2017, p. 15)

Nesse sentido, o trabalho busca abordar o conceito de desenvolvimento regional, atrelado aos pressupostos teóricos do OT enquanto conceitos que se interligam no âmbito do planejamento, na tentativa de minimizar as disparidades do desenvolvimento desigual dos espaços, sendo preciso repensar a dimensão da intervenção estatal, por meio de políticas de integração nacional, na perspectiva do desenvolvimento em suas múltiplas escalas. O papel do Estado é enfatizado como um agente regulador, modificador e produtor do território através das ações efetivadas que refletem diretamente na ordenação deste. E é nesse bojo sobre a responsabilidade do Estado que nos aportamos também sobre as ideias de desenvolvimento de Celso Furtado, enquanto importante entusiasta da corrente keynesiana.

Tal aproximação entre DR e OT está na origem da própria noção desse último, pois segundo Moraes (2005), referido conceito remonta à geografia regional francesa da década de 1960, mais especificamente a escola do aménagement du territoire, que buscava a articulação de diferentes políticas públicas no território através da análise regional. Nessa perspectiva, a questão regional ganha nova acepção por determinar relações naturais e sociais sobre o território, compreendendo dessa forma, a região como uma importante escala para a organização e planejamento territorial.

Didaticamente, o trabalho encontra-se divido em duas seções. A primeira aborda a concepção do ordenamento territorial, enquanto elemento fundamental na organização espacial do território, tendo o Estado como principal ator nesse cenário.

Na segunda, apresenta-se o conceito de desenvolvimento regional, entendendo este como elemento necessário no processo de ordenação do 
território, haja vista as aproximações existentes entre a proposta ideológica de ambas as discussões, no que tange a importância da efetivação de políticas descentralizadoras para o desenvolvimento.

\section{Pressupostos teóricos do ordenamento do território}

A partir da compreensão de que o território antecede ao conceito de ordenamento territorial (OT), cabe aqui expor a percepção de território, na tentativa de facilitar o entendimento no contexto do OT. Sendo assim, Saquet (2003) percebe o território como uma expressão concreta/ abstrata do espaço produzido a partir das relações de poder, sejam elas econômicas, culturais, políticas e/ou sociais.

Nessa mesma perspectiva, Souza (2001) compreende o território como "espaço das relações de poder", onde as relações sociais são projetadas no espaço. Nesse sentido, o território é caracterizado pelo domínio político de um determinado espaço, que por sua vez, é compreendido por Iná Elias de Castro como espaço político, e pode ser caracterizado como um

espaço delimitado pelas regras do poder político, é um espaço dos interesses dos conflitos, das normas, do controle. É um espaço que demarca um território onde interesses se organizam e, onde as ações possuem efeitos necessariamente abrangentes para todo o conjunto da sociedade. (CASTRO, 2014, s/p).

Assim sendo, os acontecimentos políticos surgem a partir de problemas que não são inatos, mas construídos, e que, na maioria das vezes, são expostos como elementos intrínsecos à sociedade. O domínio político atribuído ao território traz coadunada a necessidade de políticas públicas que o ordenem no sentido de qualificá-lo.

O território é, portanto, aqui entendido como espaço de exercício de um poder essencialmente concentrado no Estado, sendo este, um agente regulador, modificador e produtor do território.

A relação entre Estado e território assinala para a necessidade de implantação de infraestruturas através do poder do Estado, considerando que o território ao adquirir novos significados a partir da multiplicidade de seu uso - ênfase no uso político -, conduz ao Estado a inevitabilidade de planejar a partir de políticas que promovam a ordenação do território na perspectiva do desenvolvimento. 
Desse modo, a compreensão do termo território, enquanto um espaço de controle e de poder do Estado, servirá com alicerce para a estruturação do conceito de ordenamento territorial a ser delineado nesse estudo.

A princípio, é importante destacar que existem diferenças conceituais entre "ordenamento territorial" e "regulamentação do uso do solo". Moraes (2005) aponta que se tratam de propostas e competências executivas distintas. No que se refere ao último termo, Ferreira (2008, p.36) destaca que,

o regime de uso do solo define-se pela classificação do solo em urbano e rural, conforme o destino básico dos terrenos, e pela qualificação do solo, que regula, segundo a classificação básica, o aproveitamento dos terrenos em função da atividade dominante que neles possa ser efetuada ou desenvolvida, estabelecendo o respectivo uso e edificabilidade.

Em contraponto, o OT abrange uma composição formal e funcional, que objetiva a organização do uso e funções no espaço, para o desenvolvimento integrado do território em suas múltiplas escalas. Agrega e ordena políticas urbanas, regionais e setoriais.

Ao corroborar com Cabeza (2002), quando afirma que a ordenação do território tem sido objeto de diversas interpretações no mundo, faz-se necessário a construção do conceito de ordenamento territorial, tendo em vista que este constitui-se como uma ferramenta de planejamento a ser utilizado pelo Estado por e a partir de ações públicas, logo, é posto em pauta a relevância da compreensão do OT enquanto um instrumento de organização espacial.

Na perspectiva da geografia política, os estudos sobre o ordenamento do território, enquanto uma ferramenta administrativa de gestão do território, vêm se alargando no decorrer do tempo devido sua capacidade de criar espaços e tendências territoriais. Porém, o estudo e a compreensão sobre OT torna-se complexo, devido o território ser um espaço de definição de forças e de representações de poder. A priori nas definições, usamos o Dicionário de Geografia ao ponderar que

o ordenamento do território corresponde, na maior parte dos casos à vontade de corrigir os desequilíbrios de um espaço nacional ou regional e constitui um dos principais campos de intervenção da Geografia aplicada. Pressupõe por um lado, uma percepção e uma concepção de conjunto de um território e, por outro lado, uma análise prospectiva. (BAUD, BOURGEAT: BRAS, 1999, p.262). 
O conceito exposto apresenta uma compreensão inicial da necessidade de ordenar o território. No entanto, esta acepção não comtempla a abrangência do ordenamento do território, logo, as vertentes do OT são inúmeras, correspondendo principalmente ao planejamento estratégico do Estado.

Embora constituindo-se como um tema relativamente novo, o conceito de OT sofre mudanças de acordo com as alterações nas ações do Estado, diante as transformações emblemáticas de um mundo dinâmico. Moraes (2005, p. 45) afirma que

\begin{abstract}
o ordenamento territorial diz respeito a uma visão macro do espaço, enfocando grandes conjuntos espaciais (biomas, macrorregiões, redes de cidades, etc.) e espaços de interesse estratégico ou usos especiais (zona de fronteira, unidades de conservação, reservas indígenas, instalações militares, etc.). Trata-se de uma escala de planejamento que aborda o território nacional em sua integridade, atentando para a densidade da ocupação, as redes instaladas e os sistemas de engenharia existentes (de transporte, comunicações, energia, etc.). Interessam a ele as grandes aglomerações populacionais (com suas demandas e impactos) e os fundos territoriais (com suas potencialidades e vulnerabilidades), numa visão de contiguidade que se sobrepõe a qualquer manifestação pontual no território.
\end{abstract}

É importante considerar que, mesmo sendo um tema recente na academia, o OT, essencialmente não é novo, pois, a necessidade de pensar o território existe há muito tempo, em uma perspectiva de organização espacial interna e externa. O ordenamento enquanto política pública e ferramenta de planejamento, remonta a como Estado percebe o território. Para Moraes (2005), o Estado é o principal agente na produção do espaço, agindo a partir de ações públicas.

Logo, compreende-se que o OT funciona como elemento de organização espacial do território a partir das ações do Estado, caracterizando-se como um conjunto de ações setoriais sistematizadas que visam promover o desenvolvimento do espaço. Contudo, Ferrão (2011) ao discutir o ordenamento territorial, afirma que a existência de um sistema de ordenamento do território jovem, mas precocemente descredibilizado e de uma comunidade técnico-profissional e científica disciplinarmente fragmentada, contribui para fragilizar a política de ordenamento do território.

Mesmo com tais fragilidades, vários são os autores em âmbito nacional e internacional que se propõem ao debate sobre OT. Todavia, é preciso considerar a existência de um documento que delineia noções gerais para a compreensão do tema, a Carta Europeia de Ordenação do Território 
- CEOT, de 1983 (CEMAT, 2011), que caracteriza o OT a partir de três eixos fundamentais que precisam ser entendidos de maneira simultânea. Assim, o ordenamento territorial é: a) um ramo acadêmico-científico; b) uma política pública e c) uma ferramenta do planejamento.

Em seus estudos, a venezuelana Estaba (1999) apresenta elementos importantes na construção conceitual e no debate sobre OT. A autora parte da premissa da descentralização espacial, sendo esta, um elemento fundamental na ordenação do território, e o conceitua como sendo

a ordenação do território ou a sistematização do desenvolvimento no espaço geográfico constituem-se em outra estratégia rumo à modernidade e atada à ideia de descentralização, já que parte do reconhecimento do desenvolvimento desigual das regiões de um país, tal como resultante do desmesurado centralismo na Venezuela. Referem-se àquelas ações do Estado concertadas e dirigidas a buscar uma organização do uso da terra, com base na redistribuição de oportunidades de expansão e na detecção de necessidades, potencialidades, limitações e vantagens comparativas e competitivas. Sua consecução supõe propiciar um sistema de cidades harmônico e eficiente integrado à globalização, meta comprometedora porque significa salvar as desvantagens das forças de integração da globalização e aproveitar as forças da fragmentação ou diferenciação espacial com fins de fortalecer centros com capacidade de competir com os dominantes; estimular o desenvolvimento de atividades que permitam reduzir e reorientar as migrações; garantir a qualidade da infraestrutura requerida e criar âmbitos dotados de equipamentos e mecanismos que permitam um gênero de vida comparável com os das cidades dominantes. [...] (tradução nossa) ${ }^{4}$ (ESTABA, 1999, p. 6)

A autora apresenta a necessidade de medidas descentralizadoras, bem como a efetivação de ações públicas em todas as escalas do planejamento,

4 La ordenación del territorio y la sistematización del desarrollo en el espacio geográfico constituyen en otra estrategia hacia la modernidad y atados a la idea de la descentralización, como parte del reconocimiento del desarrollo desigual de las regiones de un país como consecuencia del centralismo no medida en Venezuela. Se refieren a aquellas acciones concertadas del Estado y dirigida a buscar una organización del uso de la tierra, basado en la redistribución de las posibilidades de expansión y la detección de las necesidades, capacidades, limitaciones y ventajas comparativas y competitivas. Su logro supone proporcionar un sistema armónico y eficiente de las ciudades integradas en la globalización, poniendo en peligro objetivo, ya que significa ahorro de las desventajas de las fuerzas de la globalización de la integración y aprovechar las fuerzas de fragmentación y diferenciación espacial con fines de fortalecimiento de los centros con la capacidad para competir con el dominante; fomentar el desarrollo de las actividades para reducir y reorientar la migración; asegurar la calidad de la infraestructura necesaria y crear áreas con equipos y mecanismos que permitan una vida comparable a la de género de las ciudades dominantes. ESTABA, 1999, p. 6). 
nacional, regional e local, para que existam praticas mais consistentes de ordenação do território, contudo, evidencia a escala nacional enquanto delineadora do território em um contexto amplo. Dentro desse contexto geopolítico, Becker (2005) em seus estudos define o OT como "o conjunto de decisões que afetam o território e que são da competência do setor público". Nesse panorama, o Estado deve efetivar ações sob a ótica da totalidade, sendo o ordenamento do território um instrumento fundamental no que tange ao planejamento estatal.

Cabe então, evidenciar o pensamento de Moraes, (2005, p. 45), ao declarar que

o ordenamento territorial busca, portanto, captar os grandes padrões de ocupação, as formas predominantes de valorização do espaço, os eixos de penetração do povoamento e das inovações técnicas e econômicas e a direção prioritária dos fluxos (demográficos e de produtos). Enfim, ele visa estabelecer um diagnóstico geográfico do território, indicando tendências e aferindo demandas e potencialidades, de modo a compor o quadro no qual devem operar de forma articulada as políticas públicas setoriais, com vistas a realizar os objetivos estratégicos do governo.

Assim, entende-se que o OT deve estar no topo das políticas territoriais, devendo se embasar em vetores que permitam identificar os espaços fragilizados, e a apreensão de suas potencialidades a fim de subsidiar uma gestão integrada do território nacional, contribuindo para a formulação de políticas de desenvolvimento regional. Todavia, é preciso compreender que o OT é um instrumento de organização territorial que não necessariamente repara as desigualdades, podendo até mesmo colaborar para a ampliação destas, como historicamente ocorreu no Brasil.

Dito isso, lembramos aqui de Ruckert (2007) ao afirmar que é possível inferir que o OT deve estar presente nos planos urbano-regionais, tendo o desígnio de delinear um modelo de ordenamento territorial para os espaços urbanos, focado em sugestões de desconcentração populacional, redução das desigualdades sociais, reestruturação e diversificação do espaço urbano, estimulação e conservação da estrutura urbana multicêntrica e estimulação da sustentabilidade ambiental. Também é salutar destacar a relevância de uma desconcentração econômica, pois esse é um componente essencial para a construção de uma política de OT.

Costa (2005, p.55) afirma que "o tema do ordenamento territorial inspira uma reflexão sobre a relevância, os limites e a eficácia das políticas públicas formuladas e operadas a partir de estratégias e objetivos especificamente nacionais." O ordenamento territorial é uma forma de gestão do 
território, que apresenta um conjunto de elementos sociais, naturais e culturais historicamente estabelecidos. Nesse contexto, o OT pode ser uma ferramenta responsável pela minimização das desigualdades espaciais em todas as escalas do planejamento, haja vista a tendência à fragmentação das políticas públicas territoriais na escala nacional. Logo, compreendese que as diretrizes do OT devem nortear as ações nos níveis federativos em busca de um desenvolvimento integrado e equilibrado dos espaços.

Sob uma outra perspectiva, Pujadas; Font (1998) apontam o foco interdisciplinar nos estudos sobre ordenamento do território. De acordo com os autores,

ordenar consistirá em atribuir usos específicos e diferenciados num mosaico de subdivisões [...] para o território fragmentado, objeto da ordenação $[\ldots . .$.$] impulsionar o$ desenvolvimento econômico, para melhorar a qualidade, para proteger o meio natural, pois um critério a ser sempre considerado é o caráter limitado do território. O território deve ser visto como um bem escasso, tanto em termos absolutos, especialmente em termos de territórios que tenham alguma qualidade adicional [...] está se enfatizando o caráter limitado e a escassez definitiva do território" (Pujadas \& Font,1998, p.12). (Tradução nossa). 5

Sob a perspectiva dos autores, a interdisciplinaridade do conceito é um elemento importante para a transformação dos espaços e a coesão territorial. Evidenciam, ainda, a necessidade de pensar o território de modo racional, uma vez que este apresenta-se com um bem escasso, sendo necessário avaliar o direcionamento das ações mediante aos interesses políticos.

Dada a importância de se produzir o território de forma consciente, Farinós (2004) destaca que uma condição basilar para o planejamento e o desenvolvimento territorial é a existência de políticas públicas que tenham uma abordagem holística e integrada, apropriada para a regulação dos impactos no território. Nesse cenário, a ordenação do território

5 Ordenar consistirá en asignar usos específicos y diferenciados al mosaico de subdivisiones [...] en que se ha desagregado el territorio objeto de la ordenación [...] impulsar el desarrollo económico, para mejorar la calidad, para proteger el medio natural, pos un criterio a tener siempre en cuenta es el carácter limitado del territorio. El territorio ha de verse como un bien escaso, tanto en términos absolutos como, sobre todo, en términos de territorios que tengan alguna cualidad adicional [...] está poniendo de manifiesto el carácter limitado, la escasez en definitiva, del territorio. (PUJADAS; FONT, 1998, p. 12). 
passa a ser estratégica, uma vez que pode dirimir problemas existentes no território, culminando na coesão territorial.

A partir das premissas da coesão territorial, o OT passa a ser um dispositivo para a articulação setorial e institucional, que tem como objetivo a redução das desigualdades territoriais, por meio de um planejamento espacializado das ações do poder público. Para Rocha Neto (2016, p. 22) "há, ainda, um componente difícil a ser superado quando se fala de politicas intersetoriais: o apoio interno e a convivência com as resistências inter e intraorganizacionais, muitas vezes manifestadas de forma sectária [...]”. $\mathrm{O}$ autor aponta que isso ocorre divido a baixa capacidade de se governar de forma horizontal e integralizada, uma vez que cada instituição governamental tende a se isolar durante todo o processo de planejamento.

Nesse contexto, o OT possui uma finalidade política que busca o desenvolvimento proporcional das regiões, por intermédio da organização física dos espaços a partir da implementação de ações estatais que compõem o planejamento territorial. Assim, compreende-se o OT como um agregado de ações que, articuladas entre si, propõem o desenvolvimento espacial.

As diferenciadas concepções e interpretações acadêmicas de OT são reflexos das culturas de territórios, que vão definir diferentes sistemas e políticas públicas de OT. Esses sistemas, segundo Ferrão (2011), geram processos de interação e influência, que devem ser compreendidos dentro dos modelos particulares de determinado território.

Nessa perspectiva, cita-se Lima (2017, p. 32) ao ponderar que,

\begin{abstract}
portanto, ordenar exige considerar as opções possíveis e eleger os usos adequados dos espaços através dos agentes públicos e privados que atuam no território e de seus interesses e processos de ocupação. Dessa forma, compreendese o OT como um agregado de ações que, articuladas entre si, proponham o desenvolvimento espacial, que perpassa pela necessidade de uma gestão territorial competente no que tange a ordenação e uso dos recursos no território em uma perspectiva de desenvolvimento e respeito futuro.
\end{abstract}

A complexa conceituação do ordenamento territorial se dá devido a existência de diversos elementos e características peculiares para o seu implemento. Logo, as conceituações aqui apresentadas, mostram que elas não são estagnadas, sendo difícil um consenso entre elas.

A partir da definição de OT apresentada, coloca-se em pauta o conceito de desenvolvimento regional, integrado aos pressupostos teóricos do OT enquanto conceitos que se imbricam na esfera do planejamento, 
na tentativa de minimizar as disparidades do desenvolvimento desigual dos espaços, sendo necessário repensar a intervenção estatal, por meio de políticas de integração nacional, na perspectiva do desenvolvimento em suas múltiplas escalas.

\section{O OT na perspectiva do desenvolvimento regional}

O debate regional apresenta um relativo esvaziamento no âmbito do planejamento nas décadas de 1990 até meados dos anos 200o. Contudo, a discussão tem ganhado corpo não só nos debates acadêmicos, mas, também, no âmbito da gestão pública, que apresentou interesse crescente nas demandas do desenvolvimento regional. Tal debate ganha nova conotação por determinar relações naturais e sociais sobre o território, compreendendo assim, a região como uma importante escala para a organização territorial. Deste modo, é pertinente concordar com Castro (1992), quando afirma que, para entender a região em sua plenitude, fazse necessário compreender a construção de suas dimensões territoriais.

Dito isso, é salutar destacar as palavras de Gorenstein (2014, p. 23), ao afirmar que "no restante da América Latina ${ }^{6}$, o discurso teórico sobre a "questão regional" abandonou a noção de região e absorveu, de maneira mais frequente, o termo território". Para a autora, a alusão ao território transporta uma intensa ambiguidade e envolve novos conceitos e categorias analíticas desenvolvidas e imbricadas no vasto campo das ciências sociais, da geografia e economia. Assim, é possível realizar análise de uma região, esta enquanto unidade de planejamento, sob a interpretação conceitual do território, uma vez que a região já estará definida a partir das diferentes regionalizações a serem adotadas pelos pesquisadores.

Ao abordar a questão regional, é importante considerar a dimensão histórica do desenvolvimento nacional, tendo em vista que a grande heterogeneidade espacial é resultado das relações sociais capitalistas que se difundiram no território brasileiro. Cabe ponderar então as palavras de Furtado (2009, p.147) ao nos dizer que

[...] a teoria do desenvolvimento que se limite a reconstruir, em um modelo abstrato - derivado de uma experiência histórica limitada -, as articulações de determinada estrutura não podem pretender elevado grau de generalidade. [...]

6 Comparando com o posicionamento da Argentina. 
Assim sendo, é fundamental entender que o desenvolvimento socioeconômico brasileiro não é um fenômeno autônomo, todavia, é reflexo de um conjunto de elementos, tais como, concentração fundiária, e o advento da economia industrial concentrada, por exemplo, que consagram o desenvolvimento desigual e, afetam qualitativamente o territorio nacional.

Pacheco (1998, p. 32) afirma que "a discussão sobre regiões, é desde logo uma problemática afeita ao desenvolvimento do capitalismo”. Dentro desse contexto de desenvolvimento capitalista, Brandão (2012) aponta as regiões como uma plataforma de atração de investimentos, pautadas essencialmente nas guerras ficais. $\mathrm{O}$ autor assinala, ainda, a necessidade da intervenção estatal a partir de políticas eminentemente territoriais, no que diz respeito ao controle dessas desigualdades regionais.

O economista Wilson Cano (2007), em seu trabalho dedicado à compreensão dos desequilíbrios regionais e concentração industrial no Brasil, aponta que "persistem no trato da questão regional alguns equívocos que não permeiam o trabalho acadêmico voltado para o tema, como também o campo político da questão" (CANO, 2007, p.26). Na obra, o autor afirma que o problema central da questão regional vai além da "menor densidade demográfica, industrial ou bancária”, e passa a atingir camadas mais pobres da população. Mediante a tal colocação, entende-se necessária a elaboração de estratégias para um planejamento regional coerente com a realidade de cada espaço, porém de maneira articulada para que haja uma totalidade no processo de desenvolvimento nacional, discussão que se aproxima com a perspectiva de política pública do OT em que propõe que o território seja pensado a partir da articulação das múltiplas escalas de planejamento.

Harvey (1992) assinala que o debate regional é posto na ordem do dia a partir das mudanças produtivas e do trabalho das últimas décadas, de modo que estes elementos fomentaram as nuances regionais no contexto mundial. Desse modo, compreende-se que novas e reiteradas desigualdades se lançam no território e incidem na necessidade de emersão de práticas políticas que (re)organizem estes espaços de modo adequado.

Logo, é fundamental a concepção do conceito de desenvolvimento regional, na perspectiva de entender a relevância das políticas governamentais para minimização das disparidades regionais construídas ao longo dos anos.

Com o passar do tempo, a teoria do desenvolvimento regional sofreu grandes modificações, estas ocasionadas pela decadência de regiões 
historicamente caracterizadas pela presença marcante da indústria, bem como pelo surgimento de novos protótipos direcionados à industrialização, à globalização e ao desenvolvimento local, fazendo com que a economia regional deixasse de ocupar espaço primário no desenvolvimento das regiões. É salutar atentar que não existe um modelo pronto do conceito de desenvolvimento regional, assim, este apresenta-se de maneira polissêmica, sendo passível de diversas interpretações.

O Ministério da Integração Nacional (2012) caracteriza o desenvolvimento regional como um conjunto de ações para promover processos socioeconômicos em áreas definidas do território, com uma visão integradora e sustentável que induzam ao bem-estar social e à redução de desigualdades regionais. Pautando-se nessa linha de pensamento, é possível aferir que o grande foco do desenvolvimento regional se dá a partir de uma visão integradora do território, reportando-nos aos postulados do OT, uma vez que níveis de integração elevados podem apontar um planejamento feito sob uma perspectiva macro para o desenvolvimento dos espaços.

Nesse interim, lembramos Furtado ao destacar que

a teoria da integração constitui uma etapa superior da teoria do desenvolvimento e a política de integração, uma forma avançada de política de desenvolvimento. Ỏ planejamento da integração surge, pois, como a forma mais complexa dessa técnica de coordenação das decisões econômicas. (FURTADO, 2000, p. 331)

Na concepção furtadiana, o processo de integração é uma ferramenta de destaque na superação do subdesenvolvimento. Dessa forma, entende-se que um planejamento estatal que não se baseie na lógica da integração regional poderá ocasionar problemas na superação das disparidades regionais. A exemplo, Furtado aponta em sua obra intitulada "Desenvolvimento e subdesenvolvimento", que o processo de desenvolvimento europeu aconteceu pautado na integração política.

Ao discutir desenvolvimento, Clemente (1994) afirma que o desenvolvimento regional corresponde aos valores dos PIB's regionais. A partir da percepção do autor, percebe-se uma definição um tanto restrita se consideramos o termo desenvolvimento a partir da visão de autores como Vasconcellos e Garcia (1998), que afirmam que desenvolvimento em qualquer concepção deve resultar do crescimento econômico acompanhado de melhoria na qualidade de vida, ou seja, deve incluir "as alterações da 
composição do produto e a alocação de recursos pelos diferentes setores da economia, de forma a melhorar os indicadores socioeconômicos.

Em contrapartida, Polése (1998) argumenta que o desenvolvimento regional acontece quando há uma descentralização de políticas, proporcionando um desenvolvimento endógeno da região. O pensamento do autor se assemelha ao do Ministério da Integração em uma perspectiva de efetivação de políticas estatais que reflitam nos espaços regionais. Contudo, para que se compreenda a ideia do autor, deve-se inicialmente entender a essência dos conceitos de descentralização e de desenvolvimento endógeno.

Como referência nos estudos sobre descentralização, pautamo-nos em Estaba (1999), que parte dos pensamento de que um Estado centralizador compromete o desenvolvimento territorial. A autora aponta que a ideia de descentralização se associa ao ordenamento territorial, ao afirmar que

comprometer o país num projeto de transformação global, gradual, progressiva e que reforce a autonomia regional das autoridades locais e participação pública. É uma estratégia para a modernidade que reconhece as desigualdades territoriais e se destina a aumentar o autodesenvolvimento. (ESTABA, 1999, p.o2). (Tradução nossa).7

Pensar o espaço regional a partir da descentralização territorial é de grande importância para o desenvolvimento territorial, reafirmando a ideia da autora que o ordenamento territorial se torna uma importante ferramenta no processo de concretização de políticas públicas.

Para Brandão (2012, p. 36), "o debate regional foi homogeneizado pelas teorias do desenvolvimento endógeno. Mediante a esse debate, o desenvolvimento endógeno pode ser compreendido como o processo de crescimento econômico que alude na ampliação da capacidade de agregação de valores sobre a produção e absorção de determinada região. Assim, a ideia explanada por Polése caracteriza o desenvolvimento regional como um conjunto de ações que promovem a organização espacial do território regional por meio da intervenção do Estado, reafirmando a importância do OT para a efetivação do desenvolvimento regional.

7 Comprometer al país con un provecto de transformación global, gradual, progresivo y dirigido al fortalecimiento de los poderes locales y la participación ciudadana. Es una estrategia hacia la modernidad que reconoce las desigualdades territoriales y está dirigida al auto-impulso del desarrollo (ESTABA, 1999, p.o2). 
Autores como Brandão (2012) posicionam-se criticamente à perspectiva do desenvolvimento endógeno, uma vez que considera que o localismo (endogenia) não é capaz de assegurar por si só, um desenvolvimento sem uma base de planejamento nacional que coordene e articule esse processo. Para o autor, caso isto aconteça, o território estará propenso à "guerra dos lugares". Brandão afirma que,

[...] essa luta dos lugares para realizar a melhor "venda da região ou da cidade", com a busca desenfreada de atratividade a novos investimentos, melhorando o "clima local dos negócios", subsidiando os custos tributários, logísticos, fundiários e salariais dos empreendimentos, tem conduzido a um preocupante comprometimento, a longo prazo, das finanças locais e embotado o debate das verdadeiras questões estruturais do desenvolvimento. (BRANDÃO, 2012, p.39)

Para o autor, a dinâmica endógena é questionável, pois são aniquiladas as possibilidades de heterogeneidade dos territórios. Brandão ainda aponta a necessidade de considerar o regime capitalista que leva a divisão social do trabalho em todas as escalas espaciais. Um planejamento multiescalar é o termo utilizado pelo autor para um desenvolvimento territorial e não setorial e localista, grande contributo para as reflexões sobre a temática do DR e totalmente coadunadas ao que acreditamos para uma política de OT.

Nesse mesmo contexto, Gaspar (1995) diz que o grande desígnio do desenvolvimento regional é a coesão social, econômica e política do território, logo,

o desenvolvimento regional nunca poderá ser medido através de indicadores como densidade demográfica ou maximização do aproveitamento dos recursos endógenos, mas sim através de índices compostos que tenham em conta a qualidade de vida das populações, a produtividade, a robustez do tecido econômico [...] (GASPAR, 1995, p.5).

De tal modo, compreende-se que o desenvolvimento em escala regional depende do ajuste de políticas públicas que adequem os recursos de acordo com as necessidades conferidas para a maximização de um desenvolvimento não localizado e concentrador, como feito historicamente no país. 
Siqueira e Siffert Filho (2001) apontam a necessidade de entender o desenvolvimento regional como uma política, assim sendo, os autores consideram que

se entendermos desenvolvimento regional como uma política para melhorar as condições sociais da população e reduzir as diferenças entre as regiões, pode-se inferir o grau de desenvolvimento de determinada região a partir da avaliação do estoque de capital fixo - relacionado às empresas e à infraestrutura física e social - disponível em determinada região, pelo nível educacional da população e pelos índices sociais e de renda. (SIQUEIRA; SIFFERT FILHO 2001, p.83)

Para os autores, quando se trata do desenvolvimento regional é importante se distanciar de um planejamento meramente setorial, para uma compreensão de uma política integracionista, que prime pelo desenvolvimento espacial. Nessa mesma perspectiva, Hilhorst (1973, p.18) afirma que "o processo de desenvolvimento regional culmina quando as atividades espacialmente distribuídas e especializadas estejam internamente integradas e formam parte integral de um todo [...]." Para o autor, o desenvolvimento regional resulta de um conjunto de decisões que ocorrem dentro e fora dela, sendo distribuídas espacialmente através das inter-relações.

Planejar o espaço regional a partir de políticas públicas de DR e pela ótica da descentralização territorial é de suma importância para o desenvolvimento territorial, reafirmando a ideia de que o ordenamento territorial se torna uma ferramenta de destaque no processo de concretização de políticas públicas. Porquanto, descentralização das ações não significa a ausência de um ente coordenador e regulador, o que prima o pressuposto teórico-conceituais de ambos os conceitos trabalhados aqui: OT e DR. É justamente o enfraquecimento do ente coordenador de ações de organização espacial, no caso o Estado-nação, que há grave processo de desregulação territorial, guerra dos lugares e demais efeitos perversos da presença do capital dada de modo ilimitado.

O desenvolvimento regional surge já no primeiro Plano Nacional de Desenvolvimento (PND), como uma estratégia para a integração nacional, pautando-se essencialmente no desenvolvimento socioeconômico, de modo que tal integração deveria ocorrer através dos polos regionais.

Nessa conjuntura, o olhar dos diversos interessados (inclusive do poder público) deve estar atento para várias dimensões (econômica, social, ambiental, cultural etc.) que compõem a diversidade e a complexidade regional, no intuito de construir uma maior coesão interna dentro de um contexto efetivo de desenvolvimento (BRANDÃO, 2007). Esse 
cenário evidencia a dimensão do ordenamento à medida que, cabe ao Estado concretizar essa coesão através de suas políticas e ações. Sobre esse papel do Estado, Bezzi (2001, p. 145) destaca que

\begin{abstract}
o Estado deve ser considerado como sujeito do planejamento do desenvolvimento regional. Ele estabelece, com os agentes econômicos e sociais, o estilo de desenvolvimento regional a ser executado. Assim, é necessário que o desenvolvimento regional crie condições para intervenção nacional.
\end{abstract}

De acordo com a fala da autora, o planejamento por intermédio do Estado corresponde à definição e aplicação de medidas políticas que permitam diminuir as disparidades regionais. Nesse mesmo contexto, lembramos Celso Furtado em obras como a "Formação Econômica do Brasil" (1959), ao apontar o dever do Estado em procurar equacionar as contradições e as demandas sociais para assegurar sua autonomia e sustentabilidade.

Promover o desenvolvimento regional é, portanto, viabilizar as regiões como copartícipes do desenvolvimento nacional. Está embutida a articulação com a política macroeconômica e as políticas setoriais, o que permite buscar a convergência entre interesses nacionais e regionais. (STEINBERGER, 1988) A autora mostra que o desenvolvimento regional deve estar embutido nas articulações políticas, o que permitirá um maior nível de integração das escalas nacional e regional contribuindo para o processo de desenvolvimento em uma escala totalitária. Sob esta ótica, a diminuição das desigualdades regionais insere-se na agenda nacional como uma questão relevante à medida que se busca um crescimento que colabore para a atenuação das desigualdades, sejam elas interpessoais ou inter-regionais.

Becker (2005) pondera que as políticas relacionadas ao planejamento regional teriam como prioridade a atuação em áreas com menor renda e baixo dinamismo econômico, correspondendo a um dos instrumentos do ordenamento territorial. De acordo com a autora, o OT deve gerir os conflitos regionais, bem como a sua ordenação como reflexos diretos no território nacional. Isto pois, segundo a autora supracitada, o desenvolvimento regional encontra-se embutido no ordenamento territorial, por este último possuir uma abrangência escalar mais abrangente.

Nesse contexto, o ordenamento territorial atenta não só para as desigualdades socioespaciais; este por sua vez assegura o crescimento 
econômico e a competitividade, bem como administra conflitos no uso e na apropriação do território.

É evidente que existe uma série de problemas que precisam ser considerados na formulação de uma de uma política de desenvolvimento regional. Nesse sentido, a tomada de decisões no processo de planejamento constitui uma implicação não apenas econômica, mas, política e social. É importante raciocinar que essas implicações irão refletir nas as estratégias de promoção e continuidade do desenvolvimento e, consequentemente, da ordenação do território, de acordo com os interesses dos grupos políticos que estão no poder.

Para Brandão (2011) o atual processo de desenvolvimento regional tem o desafio de contestar e melhorar o estilo do período anterior a $2003 \mathrm{com}$ o atual crescimento econômico. Indubitavelmente, a questão da dimensão territorial no que tange ao desenvolvimento é estratégico no contexto da construção de uma nova política de conteúdo desenvolvimentista, sendo o ordenamento territorial uma ferramenta para a construção dessa nova política.

Logo, o desenvolvimento regional é resultado não apenas de uma construção teórica ou acadêmica do conceito de desenvolvimento, mas de uma necessidade de conduzir eficientemente os fatores do desenvolvimento no que se refere ao uso dos recursos, assegurando uma maior participação dos diferentes atores na busca de solucionar os problemas ocasionados pela dinâmica econômica, sobretudo no que se refere à atenuação dos desequilíbrios espaciais.

\section{Conclusão}

O trabalho fez um preâmbulo sobre os conceitos de ordenamento territorial e de desenvolvimento regional, partindo da premissa de aproximação teórica entre ambos, entendendo que estes se interligam visando sanar a problemática do desenvolvimento desigual do território em suas múltiplas escalas do planejamento.

Percebe-se uma intersecção constante das ideias propostas pelo ordenamento do territorio e pelo desenvolvimento regional, enquanto ferramenta e escala de planejamento respectivamente. Referida aproximação se torna ainda mais peculiar ao considerar o Estado como principal agente interventor no processo de efetivação de políticas que promovem o desenvolvimento regional, a partir dos pressupostos teóricos do OT, uma vez que este busca o desenvolvimento equilibrado das regiões. 
Considera-se, ainda, a indissociabilidade das discussões, a medida em que ambos estão embasados sobre as mesmas perspectivas de desenvolvimento, dentre elas, a de descentralização das políticas como forma de obter o desenvolvimento em sua totalidade, pautado em visão macro do espaço para a organização espacial do território.

É possível, pois, aferir que o ordenamento do território é uma ferramenta salutar para o planejamento regional, buscando a integração dos espaços nacionais a partir da descentralização das políticas estatais.

\section{Referências}

BAUD, P.; BOURGEAT, S.; BRAS, C. Dicionário de Geografia. Lisboa: Plátano, 1999.

BRANDÃO, C.A. Território e Desenvolvimento: as múltiplas escalas entre o local e o global. $2^{\underline{a}}$ ed. Campinas, SP. Editora da Unicamp,2012.

A Busca da Utopia do Planejamento regional. In: Revista Paranaense de Desenvolvimento. Curitiba, n.120, p.17-37, jan. /jun. 2011. Disponível em: < http://www.ipardes.pr.gov.br/ojs/index.php/ revistaparanaense/article/view/263/667> Acesso em: 09.abr.2016.

Território e Desenvolvimento: as múltiplas escalas entre o local e o global. 1.ed. Campinas: Editora da Unicamp, 2007.

BECKER, B. Síntese das contribuições da oficina da Política Nacional de Ordenamento Territorial. IN: Para pensar uma Política Nacional de Ordenamento Territorial. Brasília, 2005.

BRASIL - MI - Ministério da Integração - A Sudene na I CNDR. Julho de 2012 Disponível em: < http://www.integracao.gov.br/c/document_ library/get_file?uuid=a56bd6a2-c1ce-44a8-a366-9b34c973c5c5\&groupId=63635 > Acesso em: o6 de novembro de 2016.

CABEZA, Á. M. Ordenación del território en America Latina. Scripta Nova. Revista electrónica de geografia y ciencias sociales, Universidad de Barcelona, vol. VI, núm. 125, 1 de octubre de 2002. Disponível em: < http://www.ub.es/geocrit/nova-ig.htm> Acesso em :23 de abr. de 2016.

CANO, W. Desequilíbrios regionais e concentração industrial no Brasil 1930-1970. $3^{\mathrm{a}}$ ed. São Paulo: Editora UNESP, 2007. 
CASTRO, Iná E. de. A Geografia e a Política. IN: $3^{\mathbf{0}}$ Simpósio Nacional de Geografia Política. Palestra de Abertura. UFRJ, 2014. Disponível em: $<$ https://www.youtube.com/watch?v=4F-qB4XnFfE > Acesso em: 18.jan. 2017.

. O Mito da Necessidade: discurso e prática do regionalismo nordestino. Rio de Janeiro: Bertrand Brasil, 1992.

CEMAT - Conferência Européia dos Ministros Responsáveis pelo Ordenamento do Território. Carta Européia de Ordenação do Território - CEOT. Secretaria-Geral do Ministério do Planejamento e da Administração do Território: Lisboa, 1988. Disponível em:<http://www. estig.ipbeja.pt/ sirb/carta\%2oeuropeia\%2ode\%2oordenamento\%20 do\%2oterritorio.pdf >. Acesso em: 12.abr. 2016.

CLEMENTE, A. Economia regional e urbana, São Paulo: Atlas, 1994.

COSTA, W.M. Subsídios para uma Política Nacional de Ordenamento Territorial. IN: Para pensar uma Política Nacional de Ordenamento Territorial. Brasília, 2005.

ESTABA, R. M. La descentralización y la ordenación del territorio de Venezuela: estratégias hacialamodernidad. In: Scripta Nova. Revista eletrônica de geografia y cienciassociales, Universidad de Barcelona, núm. 54, 15 de diciembre de 1999. Disponível em: http://www.ub.es/geocrit/ sn-54.htm. Acesso em: 10/04/2016.

FERRAO, João. O ordenamento do território como política pública. Maio, 2011.

FERREIRA, C.C.G. Degradação do Solo no Conselho De Gondomar: Uma Perspectiva Geográfica. Contribuição para A Definição De Estratégias de Planeamento E Ordenamento do Território. Tese de Doutorado Universidade do Porto, Faculdade de Letras, Porto, 2008.

FURTADO, C. Desenvolvimento e subdesenvolvimento. $5^{\mathrm{a}} \mathrm{ed}$. Rio de Janeiro: Contraponto. Centro internacional Celso Furtado, 2009.

. Formação econômica do Brasil. São Paulo: Nacional, 1964.

. Teoria e Política do Desenvolvimento Econômico. Paz e Terra. 200o. 
GASPAR, G. O Novo Ordenamento do Território - Geografia e Valores. Centro de Estudos Geográficos. Universidade de Lisboa, 1995.

GORENSTEIN, S. Da Região ao Território: uma análise estilizada sobre abordagens, debates e novos desafios do desenvolvimento urbano-regional. IN: Revista Política e Planejamento Regional (PPR), Rio de Janeiro, v. 1, n. 1, p. 22-38, jan./jun. 2014.

HILHORST, J.G.M. Planejamento Regional, enfoques e sistemas. Biblioteca de ciências sociais. Zahaar editores. Rio de Janeiro, 1973.

LIMA, Lívia G. Damião de. O Financiamento e a Política Nacional de Desenvolvimento Regional no Ordenamento Territorial do Semiárido nos estados do Rio Grande Do Norte, Ceará e Paraíba (20032017). Dissertação de mestrado. Programa de Pós-Graduação em Planejamento e Dinâmicas Territoriais no Semiárido. Universidade do Estado do Rio Grande do Norte. 2017, 178p. Disponível em: https:// sucupira.capes.gov.br/sucupira/public/consultas/coleta/trabalhoConclusao/viewTrabalhoConclusao.jsf?popup=true\&id_trabalho=5402641\# Acessado em 10/04/2020.

LIMA, Lívia G. Damião de; ALVES, Larissa da S. Ferreira. Aproximações teóricas-conceituais entre ordenamento do território e desenvolvimento regional. In: Revista Política e Planejamento Regional, v. 5, p. 142-156, 2018. Disponível em: http://www.revistappr.com.br/artigos/publicados/ Aproximacoes-teoricas-conceituais-entre-ordenamento-do-territorioe-desenvolvimento-regional.pdf Acessado em 10/04/2020.

Desenvolvimento regional no Brasil: um contexto histórico e atual. In: Revista Brasileira de Desenvolvimento Regional, v. 6, p. 05-30, 2018. Disponível em: https://proxy.furb.br/ojs/index.php/rbdr/ article/view/6022 Acessado em 10/04/2020.

MORAES, Antônio C. R. Ordenamento territorial: uma conceituação para o planejamento estratégico. In: Para pensar uma Política Nacional de Ordenamento Territorial. Brasília, 2005.

PACHECO, C. A. Fragmentação da Nação. Campinas, Unicamp.IE, 1998.

POLÉSE, M. Economía urbana y regional. Cartago: Libro Universitario Regional. 1998. 
PUJADAS, R. FONT, J. Ordenación y Planificación Territorial. Madrid: España: Sintesis, 1998.

ROCHA NETO, J.M. Cooperação e competição entre políticas públicas no Brasil: Os custos da governabilidade no presidencialismo de coalisão. Jundiaí: Paco Editorial, 2016.

RUCKERT, A. A Política Nacional De Ordenamento Territorial - Brasil: uma política territorial contemporânea em construção. In: Scripta Nova Revista electrónica de geografía y ciencias sociales. Vol. XI, núm. 245 (66), 1 de agosto de 2007.

SAQUET, M. Os tempos e os territórios da colonização italiana. Porto Alegre. EST Edições, 2003.

SIQUEIRA, T. V.; SIFFERT FILHO, N. Desenvolvimento Regional no Brasil: Tendências e Novas Perspectivas. IN: Revista do BNDES. Rio de Janeiro, V. 8, N. 16, P. 79-118, dez. 2001. Disponível em: < http://www. bndes.gov.br/SiteBNDES/export/sites/default/bndes_pt/Galerias/ Arquivos/conhecimento/revista/rev1603.pdf > Acesso em: 10. Abr.2016.

SOUZA, M. J. L. de. O território: sobre espaço e poder, autonomia e desenvolvimento. In: CASTRO, Iná Elias de, CORRÊA, Roberto Lobato \& GOMES, Paulo Cesar da Costa (Orgs.) Geografia: conceitos e temas. 3 ed. Rio de Janeiro, Bertrand. Brasil, 2001. p. 77-116.

STEINBERGER, M. Política de desenvolvimento regional: Uma proposta para debates. IN: Revista de administração Pública. Vol. 22 (2). Abril/ Junho de 1988. p. 117- 129.

VASCONCELOS, M. A.; GARCIA, M. E. Fundamentos de economia. São Paulo: Saraiva, 1998. 



\title{
Diferenciais produtivos no espaço Semiárido brasileiro: o caso do Ceará
}

\author{
Maria Daniele Cruz dos Santos ${ }^{2}$ \\ Francisco do O' de Lima Júnior ${ }^{3}$
}

\section{Introdução}

$\mathrm{D}$ ESDE A FORMAÇÃO DO TERRITÓRIO CEARENSE TEM-SE OBSERVADO a distribuição desigual da estrutura produtiva no Estado. Com a incorporação econômica inicial através da pecuária se dando pelo interior, a configuração da dinâmica nas microrregiões responde a diversos fatores, entre eles a maneira como fora ocupado o estado, as particularidades físicas de cada microterritório, as forças políticas regionais, dentre outros. Essas forças políticas contribuíram, inclusive, com a ampliação da delimitação do espaço Semiárido, que é foco de ação da Superintendência de Desenvolvimento do Nordeste (Sudene), saltando de 150 para 164 municípios, representando este espaço quase 90\% do território estadual. Com fins de atrair políticas públicas capitaneadas não somente por este órgão mas por outras instituições e esferas governamentais, tal delimitação pode, em alguns casos, não cumprir efetivamente seu propósito, ao observar-se gradativamente que as transformações regionais são muito mais fruto de articulação da política do Estado do que derivadas diretamente desses novos arranjos institucionais.

1 Este trabalho é derivado de reflexões feitas a partir do trabalho de dissertação de mestrado intitulado "A Reconfiguração das Atividades Econômicas do subespaço Semiárido dos Estados do Ceará, Rio Grande do Norte, Paraíba e Pernambuco nos anos de 2000 a 2015.", defendido junto ao programa de Pós-graduação em Planejamento e Dinâmicas Territoriais do Semiárido (PLANDITES-UERN), Campus Pau dos Ferros/ RN, de autoria de Maria Daniele Cruz dos Santos.

2 Professora do Curso de Ciências Econômicas da Universidade Regional do Cariri (URCA), Campus Iguatu/CE. E-mail: danielecruzeconomia@gmail.com.

3 Professor do Departamento de Economia da URCA, Campus Crato/CE. Professor do Programa de Pós-graduação em Planejamento e Dinâmicas Territoriais do Semiárido (PLANDITES-UERN). E-mail: lima.junior@urca.br. 
Os fenômenos percebidos na economia e no sistema urbano cearense que acompanharam a tendência da urbanização nacional e internacional de modo geral foram: a) a modernização, dinamização e inserção de atividades produtivas; b) as políticas institucionais do estado voltadas para o desenvolvimento do tripé indústria-lazer/turismo-agronegócios; c) o avanço econômico e populacional da Região Metropolitana de Fortaleza (RMF); d) alguns centros médios urbanos que polarizam o interior do estado; e) expansão das fronteiras da especulação imobiliária em todo o território do estado e; f) as tendências do processo de metropolização. Essas alterações casam significativamente com as mutações temporais ocorridas na estrutura produtiva como um todo do Ceará, mais especificamente no litoral e nos polos de desenvolvimento, como será percebido.

Os anos 2000 a 2015 foram marcados por ser um período em que as políticas macroeconômicas adotadas no Brasil assumiram um perfil desenvolvimentista, com destaque para ação governamental nos moldes defendidos pelo pensamento furtadiano com sua atualização, após um longo período de hegemonia neoliberal carimbando os governos anteriores (FURTADO, 2002). Em outras palavras, é um período de transição de um paradigma de intervenção mínima do Estado para outro em que ele volta a assumir protagonismo no desenvolvimento de políticas, afora com orientação para inserção competitiva externa.

Este artigo visa descrever a estrutura produtiva assentada no Semiárido cearense nos anos 2000, nas microrregiões que detém relevante dinamismo para o estado. A nova delimitação do Semiárido Brasileiro (2017) sob jurisdição da Sudene é composta por 1.262 municípios e o Ceará detém 13\% deles, presente em quase todas as 33 microrregiões. Dada a proposta e o percurso metodológico deste estudo, o critério utilizado para selecionar as microrregiões foi o quantitativo de estabelecimentos: selecionou-se aquelas que apresentaram no período estudado, no mínimo, 500 estabelecimentos de acordo com a Relação Anual de Informações Sociais (RAIS). Isso se deu por uma motivação orgânica a esta elaboração: ao longo da formação do território, esses espaços foram (e são) aqueles que se tornaram mais dinâmicos em relação aos outros, permanecendo como polos de atração econômicos. Os dados sobre vendas externas, foram extraídos por município da base AliceWeb e agregados por microrregião. Esta base constitui o Sistema de Análise das Informações de Comércio Exterior, da Secretaria de Comércio Exterior, pertencente ao extinto Ministério do Desenvolvimento, Indústria e Comércio Exterior e hoje abrigado no Ministério da Economia. As análises estatísticas acerca 
dos estabelecimentos e do emprego tiveram como fonte de dados a RAIS (2018) e as informações sobre Produto Interno Bruto (PIB) são de origem do Instituto Brasileiro de Geografia e Estatística (IBGE).

O texto está estruturado em três partes além desta Introdução. Na seção seguinte, serão traçadas notas mais gerais sobre a estrutura produtiva do território do Semiárido cearense para, na seção seguinte, serem analisadas de forma mais detalhada as atividades produtivas por microrregiões, seguindo o corte metodológico acima apresentado. Seguem alguns Apontamentos Finais, com reflexões feitas vis a vis ao resgate de um breve conjunto de contribuições do pensamento furtadiano.

\section{A Estrutura Produtiva no Semiárido Cearense}

O Ceará é um dos estados do Nordeste brasileiro que mais se destaca em termos de diversificação da atividade produtiva. Assim como a maioria dos estados nordestinos, a formação econômica cearense é originada de atividades como a pecuária, o algodão, a agricultura de subsistência, cujos produtos eram comercializados nas típicas feiras, mas principalmente, a inserção desse território no contexto regional se deu pela expansão da atividade subsidiária da cana, a pecuária.

A fase inicial de sua ocupação territorial é caracterizada por uma inexpressiva atividade canaveira, ficando restrita a pequenos subespaços na produção de rapadura e aguardente e, também, pela ocupação que partiu, inicialmente, do interior para o litoral, graças à atividade pecuária. Os sentidos da ocupação do território cearense é tema de debate entre correntes de historiadores se alternando entre i) os que afirmam que a ocupação se dá do litoral para o interior, partindo especificamente da foz do Rio Jaguaribe alcançando os sertões e; ii) outro grupo indicando que esta ocupação se dá pelas correntes dos caminhos do gado advindas das zonas canavieiras baianas e/ou pernambucanas. O importante a se considerar é que de fato a incorporação econômica com geração de algum excedente veio da hinterlândia interiorana, incialmente, da atividade pecuária e, posteriormente, do algodão. Lima Júnior (2014) descreve de forma mais aprofundada este debate sobre a formação da estrutura de ocupação territorial cearenses sob a perspectiva produtiva.

Assim, apesar de a incorporação econômica do território ter-se iniciado a partir do interior, existe uma concentração significativa de capitais no litoral para fins de investimento, tanto os que são oriundos da acumulação mercantil inicial, passando por aqueles provenientes dos 
incentivos fiscais da Sudene, chegando aos de financiamento dos bancos de desenvolvimento e políticas direcionadas a fomentar a estrutura produtiva do Estado. Pode-se atribuir à política estadual de estímulo à industrialização, através do Fundo de Desenvolvimento Industrial (FDI), a tentativa de interiorizar as empresas industriais com descontos tributários regressivos, maior a concessão destes descontos à medida que se distanciam do litoral. No entanto, poucos foram os empreendimentos atraídos com essa intenção. Ao compasso da instalação de investimentos subvencionados em áreas próximas à RMF, a melhoria de infraestrutura como a instalação do porto do Pecém para escoamento da produção do complexo industrial de São Gonçalo do Amarante e de todo o sistema produtivo regional, contribuiu ainda mais com essa concentração.

Como anteriormente tratado e será visto no decorrer deste texto, os condicionantes da reconfiguração da estrutura produtiva do Semiárido foram a combinação de diversos elementos e grupos de medidas que integraram o rol de políticas públicas, juntamente à ação das estruturas de poder local que atuaram em todo o período de formação e conformação das atividades econômicas no subespaço. No Semiárido cearense, observa-se um quantitativo maior de microrregiões que possuem mais de um nó (município) dinâmico e produtivo. No entanto, o estado como um todo ainda contempla lugares que não apenas dependem financeiramente de outras instâncias federativas como também fomentam grande parte da geração de emprego local, o que revela uma insipiente estrutura produtiva de bens e serviços fora da esfera pública. O setor de serviços é destaque em quase todo estado e alocado em um contingente expressivo de empresas pequenas, com até nove funcionários. Conforme aponta Santos (2018), naqueles territórios em que predomina a indústria, o setor de serviços está adjacente e complementar na promoção do desenvolvimento regional.

Ainda assim, os pequenos núcleos produtivos no interior do estado, consolidados desde a ocupação do território apresentam uma dinâmica diferenciada. Percebe-se a manutenção desses espaços como centros de atração de estabelecimentos, mão de obra, investimentos e instalações públicas. Na Figura 1, é possível observar como está distribuído o quantitativo dos estabelecimentos nas microrregiões do estado. Apesar de assumir somente em meados da primeira metade do século XIX o seu protagonismo econômico na história do Ceará, a microrregião de Fortaleza detém o maior número de estabelecimentos e o setor que mais concentra empresas é o Comércio Varejista, que gera mais de 18 mil empregos. 
Apenas Fortaleza, a capital do Estado, registrou mais de 51 mil estabelecimentos em 2016, 83\% do total da microrregião segundo a RAIS. Caucaia e Maracanaú são respectivamente o 20 e 30 lugar na microrregião com 3.090 e 2.998 empresas ( $5 \%$ e 4,8\% das empresas nessa ordem). O setor de Construção Civil é um dos que tem maior número de empresas em Fortaleza: 1.876 estabelecimentos.

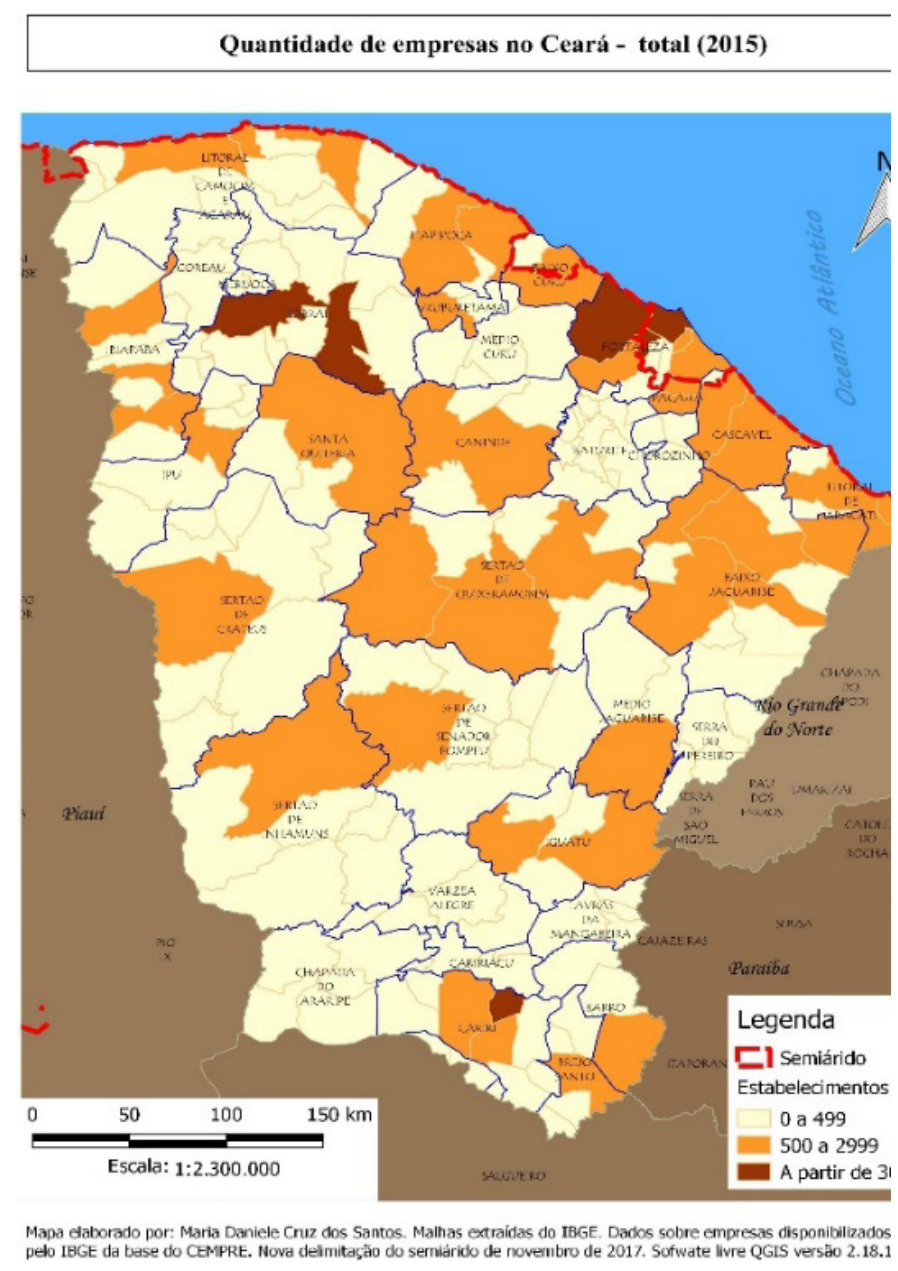

Figura 1 - Mapa de localização espacial dos estabelecimentos do Semiárido cearense

Fonte: Elaboração própria com dados extraídos da RAIS/MTE. Mapa construído com malhas disponibilizadas pelo IBGE e com a utilização do software livre QGIS versão 2.18.15. 
No estado, observando-se o tamanho do estabelecimento em número de empregados, predominam as empresas de pequeno e médio porte em todos os setores da economia (de o até 9 funcionários), totalizando $82,65 \%$ de todas as empresas, e 54,01\% estão na categoria de 1 a 4 funcionários. Apenas 1,19\% das empresas são de grande porte e empregam a partir de 100 empregados. Nos centros considerados polos regionais médios esta realidade se reforça. Entretanto, cidades pequenas e médias, a exemplo de Acopiara, Icó e Iguatu, no Centro Sul do estado, Milagres e Missão Velha na Mesorregião Sul Cearense, o predomínio de empregadores desse porte (com mais de mil empregados) é o setor de Administração Pública.

Tabela 1 - Quantitativo de empresas cearenses por número de empregados - 2016

\begin{tabular}{l|c|c}
\hline \multicolumn{1}{c|}{$\begin{array}{c}\text { Tamanho do } \\
\text { estabelecimento }\end{array}$} & $\begin{array}{c}\text { Quantidade de } \\
\text { empresas }\end{array}$ & $\begin{array}{c}\text { Participação no } \\
\text { total \% }\end{array}$ \\
\hline o empregados & 529 & $11,44 \%$ \\
\hline De 1 a 4 & 2497 & $54,01 \%$ \\
\hline De 5 a 9 & 795 & $17,20 \%$ \\
\hline De 10 a 19 & 435 & $9,41 \%$ \\
\hline De 20 a 49 & 240 & $5,19 \%$ \\
\hline De 50 a 99 & 72 & $1,56 \%$ \\
\hline De 100 a 249 & 39 & $0,84 \%$ \\
\hline De 250 a 499 & 11 & $0,24 \%$ \\
\hline De 500 a 999 & $\mathbf{2}$ & $0,04 \%$ \\
\hline A partir de 1000 & 3 & $0,06 \%$ \\
\hline Total & 4623 & $100 \%$ \\
\hline
\end{tabular}

Fonte: Elaboração própria com dados extraídos da RAIS/MTE

Apesar de toda uma estrutura preestabelecida para o recebimento de novas atividades produtivas, com o aumento da capacidade de geração de energia elétrica através de termoelétricas, com a ampliação de rodovias estaduais para facilitação do escoamento da produção, como exemplo a Rodovia Padre Cicero, os investimentos, conforme concebia a Sudene em sua concepção original, foram pouco direcionados ao Estado. 
Acompanhando os indicadores de projetos da Sudene de 2014 e 2015, percebe-se que não houve uma diferença significativa que direcionasse os esforços das políticas de incentivos fiscais para interiorizar empresas ao Semiárido do estado (ou não foram suficientes para alterar significativamente a estrutura produtiva). Nesse sentido, para além da atuação estatal com a Superintendência, ocorreram iniciativas através das linhas de financiamento geridas por bancos de desenvolvimento nacionais e regionais (BNDES e BNB, respectivamente).

\section{Atividades produtivas no semiárido cearense - por microrregiões}

\section{Microrregião do Litoral de Camocim e Acaraú}

Esta é umas das regiões mais turísticas do Estado, onde os serviços de alojamento e alimentação tem forte participação na economia local, mas em baixo valor adicionado. É composta por 12 municípios (todos no semiárido) com uma população em 2010 de 360 mil. Apresentando 28.302 vínculos ativos (em 31 de dezembro de 2016), a maioria (30,4\%) em regime estatutário (8.599 empregados), essa microrregião ocupa a $5^{\text {a }}$. colocação no ranking do PIB, a preços correntes do estado em 2015, com três bilhões de reais. A exportação não é o foco econômico da microrregião. No entanto, a evolução do valor exportando segue a tendência de crescimento do estado na primeira década e declínio nos cinco últimos anos de análise. Seu crescimento médio anual foi de $18,83 \%$ no período de 2000-2015, como pode ser visto na Tabela 2.

Tabela 2 - Exportações da microrregião de Litoral de Camocim e Acaraú no período de 2000-2015

\begin{tabular}{c|c|c|c}
\hline \multicolumn{1}{c|}{ Período } & US\$ FOB & Peso Líquido $(\mathbf{k g})$ & Quantidade \\
\hline o1/2000 até $12 / 2000$ & 8.447 .666 & 938.273 & 9.581 \\
\hline o1/2010 até 12/2010 & 39.530 .401 & 3.816 .126 & 2.403 \\
\hline o1/2015 até 12/2015 & 32.312 .673 & 3.628 .866 & 209.346 \\
\hline
\end{tabular}

Fonte: Elaboração própria com dados extraídos de AliceWeb (2018)

Nessa microrregião, o município em destaque é o de Camocim. Com 557 estabelecimentos, e acompanhando a tendência do estado em ter a maioria das empresas no setor de Comércio Varejista. Destaca-se que em 
todos os setores, por tamanho de estabelecimento, quase $60 \%$ deles tem de 1 a 4 empregados e $13 \%$ não possuem nenhum. Os setores de Comércio e Serviços, juntos, representam $85 \%$ dos estabelecimentos locais. Neste contexto, 10,4\% da população estava ocupada em 2015, segundo o IBGE (2018), e os maiores PIBs per capita da microrregião foram os de Jijoca de Jericoacoara (mais de R 11 mil), Acaraú (R\$mil), Itarema (R99,7mil) e Marco $(\mathrm{R} \$ 9,8 \mathrm{mil})$. Esta é uma região conhecida pela sua extensa faixa praiana, de atrativos turísticos de destaque, cujo último investimento estadual recente em infraestrutura se deu na construção do Aeroporto de Jericoacoara, localizado na cidade de Cruz, com vista a atendimento a voos chat, outros de pequeno porte, e pouso de jatos particulares, helicópteros.

O setor turístico pode ter crescido nessa região em consequência da forte política de valorização do sol e mar impetrados pelos governos do Ceará, aprofundando as ações de promoção do já mencionado tripé do desenvolvimento. Essa opção definiu o ordenamento do território desde o princípio e explica esforços mais concentrados em suas zonas costeiras. Em termos de fundos de financiamento governamental, os recursos do Fundo Constitucional do Nordeste (FNE), em 2016, somavam R\$ 3,4 milhões no município de Camocim, onde deliberou $\mathrm{R} \$ 1,7$ milhão somente para a agropecuária ou agroindústria local. O direcionamento específico para o setor de turismo foi na monta de 312 mil reais.

\section{Microrregião de Itapipoca}

A microrregião de Itapipoca fica localizada na região Norte do estado, compreendida pelos municípios de Amontada, Itapipoca e Trairí, que são banhados pelo litoral com população de 206 mil habitantes. Esses municípios têm uma população reduzia se comparada ao restante do estado, mas é concentradora de altos valores de renda e PIB per capita. A maior parte das empresas é de Comércio Varejista, com predominância de minimercados, mercearias e armazéns, com 4,79\% das empresas nesse subsetor, Construção de edifícios com 4,5\%, artigos de vestuário com 4,1\%.

Pode-se verificar o aumento da quantidade de estabelecimentos na microrregião em apenas cinco anos (2010-2015) em relação aos oito anos anteriores (2002-2010), alavancada principalmente pelo setor de Comércio e Serviços. Há uma reconfiguração dos setores, aumentando a participação do setor de Construção Civil nos anos analisados, mas ainda o deixa na penúltima posição em número de estabelecimentos. 
Tabela 3 - Crescimento do número de estabelecimentos na microrregião de Itapipoca 2002-2015

\begin{tabular}{l|c|c|c|c|c|c}
\hline $\begin{array}{c}\text { IBGE Grande } \\
\text { Setor }\end{array}$ & $\mathbf{2 0 0 2}$ & $\mathbf{2 0 1 0}$ & $\begin{array}{c}\Delta \text { 2002-2010 } \\
\%\end{array}$ & $\mathbf{2 0 1 5}$ & $\begin{array}{c}\Delta \text { 2010-2015 } \\
\%\end{array}$ & $\begin{array}{c}\Delta \text { 2002-2015 } \\
\%\end{array}$ \\
\hline 1- Indústria & 27 & 37 & $37 \%$ & 78 & $111 \%$ & $189 \%$ \\
\hline $\begin{array}{l}\text { 2- Construção } \\
\text { Civil }\end{array}$ & 5 & 20 & $300 \%$ & 36 & $80 \%$ & $620 \%$ \\
\hline 3- Comércio & 172 & 356 & $107 \%$ & 542 & $52 \%$ & $215 \%$ \\
\hline $4-$ Serviços & 92 & 170 & $85 \%$ & 294 & $73 \%$ & $220 \%$ \\
\hline $5-$ Agropecuária & 12 & 21 & $75 \%$ & 28 & $33 \%$ & $133 \%$ \\
\hline Total & 308 & 604 & $96 \%$ & 978 & $62 \%$ & $218 \%$ \\
\hline
\end{tabular}

Fonte: elaboração própria com dados extraídos da RAIS/TEM

O município de Itapipoca, em sua microrregião de mesmo nome, é destaque entre os municípios do sistema urbano cearense. Com base no censo de 2010, sua população era de 116 mil habitantes, seu PIB per capita era algo em torno de 9,5 mil reais, sendo o $2^{\circ}$ na microrregião, atrás de Trairi (R\$10,6mil). A economia local é basicamente do setor de serviços e abriga duas grandes empresas instaladas a partir da política de atração de investimentos: a DASS, fabricante dos produtos de calçados Fila, e a Ducoco, fabricante de gêneros alimentícios, além de um turismo que explora atrações naturais da região, da arqueologia e da arquitetura. $\mathrm{O}$ FNE destinou ao município cerca de 9,2 milhões de reais em 2016, com maior destaque para agricultura, pecuária e agroindústria (4 milhões de reais). O setor de comércio e serviços (90\%) e o de turismo (10\%) receberam aporte de 4,9 milhões do Fundo.

Em se tratando de exportações, o município tem a 8a. posição no ranking estadual com 51,2 milhões de dólares em 2017, 14,93\% a mais que em 2016, e uma balança superavitária de US\$ 40,66 milhões. Houve uma efetiva evolução na sua participação nas exportações do estado desde 2007, quando tinha apenas US\$3,67 milhões. Esse bom resultado do ano foi garantido em boa parte pelo setor de produtos alimentares e bebidas, que representam $70 \%$ da pauta exportadora municipal e de partes de calçados, que representa os outros 30\%. Em 2016, os EUA foi o maior comprador desse município (55\%). Tal estratégia faz parte do amplo conjunto de reestruturação da economia cearense, seguindo o bojo da inserção competitiva internacional, padrão adotado na atual rodada da acumulação capitalista, que dispõe à lógica internacional seu portfólio propício 
à atração super lucrativa de investimentos forasteiros, conforme aponta Macedo (2010).

Tabela 4 - Exportações da microrregião de Itapipoca no período 2000-2015

\begin{tabular}{c|c|c|c}
\hline Período & US\$ FOB & Peso Líquido $(\mathbf{k g})$ & Quantidade \\
\hline o1/2000 até 12/2000 & 132.889 & 12.570 & 12.795 \\
\hline o1/2010 até 12/2010 & 9.180 .572 & 3.844 .424 & 228.458 \\
\hline o1/2015 até 12/2015 & 24.921 .037 & 16.704 .210 & 448.717 \\
\hline
\end{tabular}

Fonte: Elaboração própria com dados extraídos de AliceWeb (2018)

Para o período analisado, percebe-se um vultoso crescimento das exportações da microrregião: a cada um dólar exportado em 2000, houve um aumento de US\$ 186 dólares no período até 2015, o que significa um crescimento médio de $1.243 \%$ ao ano. Nota-se que a inversão dos investimentos regionais, tanto de capitais públicos como por via de financiamento, são uma expressão literal de que as políticas desenvolvimentistas, quando não bem pensadas para um todo, acabam se concentrando em pequeno número de núcleos, favorecendo-os, mas esquecendo as demais regiões, provocando e permitindo o aumento das disparidades regionais.

A economia regional está polarizada em duas frentes: uma que abrange um grande número de estabelecimentos menores mantenedores da região com o suprimento de bens básicos, enquanto que, na outra extremidade, poucas empresas são as alavancas regionais de crescimento econômico, dinamizadoras de grande fluxo produtivo e econômico, que geram impactos significativos no desenvolvimento local. Nesta nova acepção de ações consideradas desenvolvimentistas, a expressa concentração setorial e espacial vão na contramão da transformação econômica mais equilibrada e diversificada do ponto de vista da estrutura produtiva, defendida desde os diagnósticos originais de uma política para desenvolvimento da região, já expressa no GTDN (FURTADO, 2005).

\section{Microrregião do Baixo Curu}

Composta pelos municípios de Paracuru, Paraipaba e São Gonçalo do Amarante com 106 mil habitantes e apenas São Gonçalo do Amarante pertencendo à região semiárida, a microrregião do Baixo Curu vem desenvolvendo um papel importante no reordenamento da produção 
industrial e de gerenciamento de portos para escoamento da produção se constituindo no caso mais destacado de políticas sistematizadas no território do Ceará dotando-o de equipamentos e infraestruturas modernas e competitivas, sendo um caso clássico de planejamento e atuação do Estado furtadiano em prol do desenvolvimento regional. No período de 2010 a 2016 houve um aumento expressivo no número de estabelecimentos dessa microrregião, considerando o aporte na implementação de um parque industrial produtivo na cidade de São Gonçalo do Amarante, tendo em vista a zona portuária do Pecém.

Ali se destaca o polo industrial do Complexo Industrial e Portuário do Pecém (CIPP), na cidade de São Gonçalo do Amarante. Esse complexo, idealizado pelo Programa Nacional de Desenvolvimento de Zonas Portuárias no Brasil, que criou 31 deles, veio como alternativa local de escoamento da produção industrial para outras regiões, do país e do mundo, bem como fortalecer a atratividade de indústrias para o estado do Ceará (ADECE, 2015).

O CIPP tem como objetivo viabilizar a operação de atividades portuárias e industriais integradas, imprescindíveis ao desenvolvimento de um complexo com características de Porto Industrial. Constituído de dois píeres marítimos (um para insumos e produtos siderúrgicos e carga geral e outro para granéis líquidos, em especial óleo cru e derivados de petróleo), iniciou as operações comerciais em novembro de 2001 e foi inaugurado em março de 2002.

$\mathrm{O}$ foco em desenvolvimento de um parque industrial tem aumentado significativamente o PIB per capita desta microrregião, atraindo investimentos para todos os seus municípios a partir das externalidades geradas pelo Pecém: em São Gonçalo do Amarante, esse valor chega a ser R \$ 39 mil reais, Paracuru R\$12 mil e Paraipaba $\mathrm{R} \$ 11$ mil. Aqui, a dinamização produtiva advinda com o CIPP sinaliza para uma transformação estrutural já que "a implantação da indústria de base representada pelo CIPP e por sua ZPE, ainda que predominantemente nas fases de processamento, inaugura outro momento da industrialização do Ceará. Até então, a atividade industrial do estado volta-se quase que exclusivamente para a indústria de bens de consumo não duráveis." (LIMA JÚNIOR; MACEDO; ALVES, 2019, p. 8).

São Gonçalo do Amarante apresenta indicadores de destaque: o primeiro no ranking estadual e microrregional de maior PIB per capita em 2015, melhor salário médio nacional, com 3,6 salários-mínimos por pessoa, 31,58\% da população ocupada, seu IDHM de 2010 fora de o,664. Tal 
realidade decorre da concretização de projetos e programas de investimentos que vieram com o CIPP, dentre eles a Zona de Processamento de Exportações (ZPE) conforme já apontado. Entretanto, quase 50\% da população em 2010 detinha rendimento nominal mensal de até 1/2 salário-mínimo, o que implica dizer que existe uma altíssima concentração de renda e geração do PIB que não atende a toda a população de pouco mais de 40 mil pessoas. Ademais, grande parte da população empregada no CIPP é oriunda de outros municípios da RMF.

Ocupando a $7^{\text {à }}$. posição nos maiores PIBs do estado, o valor adicionado industrial deixa o município sede do CIPP na 6a posição, com uma produção a preços correntes de 772 milhões de reais em 2015. Essa região fora recentemente adicionada ao Semiárido o que, de certa forma e devido seus bons indicadores econômicos, contribuíram na melhoria dos indicadores médios do Semiárido cearense.

Apenas em 2016, o FNE destinou R 5 bilhões em financiamentos para empresas em São Gonçalo do Amarante, R\$2 milhões somente para uma empresa de comércio e serviços. A agricultura e pecuária receberam $\mathrm{R} \$ 1,1$ milhão, todos para pessoas físicas do programa PRONAF "B".

Tabela 5 - Exportações da microrregião do Baixo Curu no período 2000-2015

\begin{tabular}{c|c|c|c}
\hline Período & US\$ FOB & Peso Líquido $(\mathbf{k g})$ & Quantidade \\
\hline 01/2000 até 12/2000 & 283.707 & 101.151 & 167.620 \\
\hline 01/2010 até $12 / 2010$ & 16.517 .454 & 10.554 .533 & 5.041 .533 \\
\hline 01/2015 até $12 / 2015$ & 19.745 .223 & 21.729 .464 & 5.288 .878 \\
\hline
\end{tabular}

Fonte: Elaboração própria com dados extraídos de AliceWeb (2018)

Já as exportações do período 2000-2015 tiveram influência de dois movimentos: o primeiro, ascendente que vai do primeiro ano da década de 2000 até 2010 em um ritmo crescente, acompanhando as tendências de crescimento nacional e o cenário externo demandante dos países latino-americanos e da intensificação com o mercado chinês. O segundo, é a criação da ZPE, em 2002, que aumentou significativamente o número de estabelecimentos locais e de empresas com a finalidade exclusiva de exportar. Esses dois momentos alavancaram os indicadores econômicos regionais de modo que não se pode entendê-los separadamente. Um salto sem precedentes de $5.722 \%$ em 10 anos mostra o quanto políticas focadas em desenvolvimento regional são capazes de transformar, pelo menos 
economicamente, uma região com tão pouco desempenho antes dessas medidas. Nos cinco anos seguintes, a expansão da exportação da região continuou, mas desta feita com $19,54 \%$, ou seja, taxas bem inferiores que acompanham a tendência nacional. $\mathrm{O}$ efeito estatístico também se apresenta considerando que, anteriormente, o município de São Gonçalo do Amarante não possuía participação na atividade industrial.

\section{Microrregião de Fortaleza}

Composta por nove municípios, mas somente três no semiárido (Caucaia, Maranguape e Guaiúba), devido ao recorte espacial proposto neste estudo, o município com maior representatividade regional é Caucaia, que tem limites com a capital Fortaleza e possui população censitária de aproximadamente 325 mil pessoas (IBGE, 2010). O rendimento médio dos trabalhadores formais é em torno de 2,2 salários-mínimos e $13,2 \%$ da população tinha ocupação em 2015, além de $43 \%$ dos habitantes terem rendimento nominal per capita de 1/2 salário-mínimo em 2010. Esse município tem o $9^{\circ}$ PIB per capita do estado ( $\mathrm{R} \$ 16 \mathrm{mil}$ ) e um IDHM de o,682. Ocupava, em 2015, a 3ª - posição no ranking do valor adicionado industrial do estado, com 1,4 bilhão de reais, e o $4^{\circ}$. no setor de serviços, com 2,2 bilhões no mesmo ano.

O município de Caucaia recebeu do FNE aportes no valor total de R\$92,7 milhões só em 2016, $\mathrm{R} \$ 4,8$ milhões destinados para o setor agropecuário e agroindustrial, R\$69,3 milhões para a indústria, $\mathrm{R} \$ 16,7$ milhões para o comércio e R\$1,8 milhão para o turismo. Em 2016, dos 2.998 estabelecimentos no município, o maior número de empresas estava concentrado nas firmas individuais (47\%) e nas sociedades limitadas (39\%). As empresas com maior número de empregados (acima de 1.00o) são de natureza Sociedade Anônima Fechada (1), Sociedade Limitada (1) e do poder executivo Municipal (1). A Seção CNAE com maior concentração de empresas fica o Comércio e Reparação de Veículos Automotores e Motocicletas (42,5\%), seguida da Indústria de Transformação (15,3\%).

Essa microrregião, apesar da crise vivenciada em 2008 em todo o cenário internacional e os anos seguintes a ela, foi afetada de maneira distinta e a trajetória do valor das exportações é ascendente, apesar de ser a taxas decrescentes. A variação entre 2000-2010 é de $216 \%$, como se pode verificar na Tabela 6, e no período $2010-2015$ foi de $34 \%$. 
Tabela 6 - Exportações totais no período 2000-2010-2015 na microrregião de Fortaleza

\begin{tabular}{c|c|c|c}
\hline Período & US\$ FOB & Peso Líquido $(\mathrm{kg})$ & Quantidade \\
\hline o1/2000 até 12/2000 & 12.662 .941 & 4.494 .498 & 202.747 \\
\hline o1/2010 até 12/2010 & 40.067 .192 & 9.468 .419 & 357.077 \\
\hline o1/2015 até 12/2015 & 53.992 .355 & 17.212 .132 & 376.127 \\
\hline
\end{tabular}

Fonte: Elaboração própria com dados extraídos de AliceWeb (2018)

Caucaia, assim como os municípios da Microrregião de Itapipoca e do Vale do Curu que se beneficiaram das externalidades positivas pela proximidade territorial do CIPP, foi favorecida pela facilidade de escoamento dos produtos destinados ao mercado externo. O município se destacou também nas exportações com a produção e comercialização de Máquinas e Aparelhos, Material Elétrico e suas partes (55\% das exportações em 2017 e $76 \%$ das de 2016) e Obras de Pedra, Gesso e cimento (31\% das exportações em 2017 e $13 \%$ em 2016) com valor total de US\$ 46 milhões. A Tabela 7 a seguir apresenta os exportadores em 2016 com a devida faixa de valor exportado:

Tabela 7 - Quantidade de empresas exportadoras da microrregião semiárida de Fortaleza por faixa de valor exportado - 2016

\begin{tabular}{l|c}
\hline Faixa de valor exportado & Quantidade de empresas \\
\hline Entre US\$ 50 e US\$ 100 milhões & 1 \\
\hline Entre US\$ 5 e US\$ 10 milhões & 1 \\
\hline Entre US\$ 1 e US\$ 5 milhões & 3 \\
\hline Até US\$ 1 milhão & 8 \\
\hline Total & 13 \\
\hline
\end{tabular}

Fonte: Elaboração própria com dados extraídos do MDIC (2018)

Conforme vem sendo observado, é notório que os municípios e regiões mais próximos ao litoral metropolitano são concentradores de renda e riqueza e, apesar das tentativas de desconcentração a partir de programas e políticas, este ainda é um longo processo em curso, que sofre suas restrições setoriais e também locacionais, conforme observa Pereira Júnior (2012). 


\section{Microrregião de Sobral}

Essa microrregião pertence totalmente ao semiárido cearense e os municípios, além de Sobral que dá nome e polariza esta microrregião, são Senador Sá, Massapê, Santana do Acaraú, Miraíma, Irauçuba, Forquilha, Mucambo, Graça, Pacujá, Cariré e Groaíras e concentra uma população no censo de 2010 de 381 mil. Essa microrregião está circunscrita na mesorregião Noroeste Cearense e possui 3.322 estabelecimentos no total dos municípios. A maior concentração das empresas são firmas individuais (53\%). O registro CNAE mais concentrador de empresas é a de Comércio e Reparação de Veículos Automotores e Motocicletas (48\% da microrregião). Os grandes empregadores (com mais de 1.000 funcionários) são do setor de Serviços (3 companhias), da Administração Pública (2 empresas) e da Indústria de Transformação (1 empresa). Na categoria de pequenos empreendimentos (de o até 9 funcionários) são 83\% dos estabelecimentos. O município mais evidente em termos econômicos é Sobral, responsável por $81 \%$ dos estabelecimentos da microrregião.

Os indicadores de Sobral são bastante peculiares: dentro da sua microrregião, o município é o único com mais de 1.000 estabelecimentos registrados, sendo que os outros municípios têm até 499; 81\% dos estabelecimentos da microrregião estão nessa cidade e o Comércio Varejista é o mais representado em termos de empresas registradas no setor. Apesar dos maiores volumes de PIB serem destacados no setor de calçados, a maior concentração de empresas no município está nos setores de Alimentação (205), Atividades de Atenção à Saúde Humana (172), Comércio e Reparação de Veículos Automotores e Motocicletas (148) e Construção Civil que, juntos, respondem por $63 \%$ das empresas locais. A maioria é de pequeno porte, como boa parte das empresas do Semiárido, que tem até 4 funcionários. Somente as Indústrias de Calçados registram um número significante de empregados por estabelecimento.

As exportações sobralenses estão mais fortemente concentradas no setor calçadista, com 95\% das exportações do município, e é o $2^{\circ}$. município de maior exportação no estado em 2017. A unidade da Grendene S.A., em 2017, foi a empresa que mais exportou, classificada na faixa de valor exportado acima de US\$ 100 milhões.

No total, a microrregião teve um bom desempenho nas exportações estaduais, mas é totalmente dependente dos números da indústria de calçados. Houve um crescimento expressivo na década 2000-2010, de um total de $465 \%$, uma média de crescimento anual de $46,58 \%$. No período 
2010-2015, ocorreu baixo o crescimento: cerca de 2,52\% no quinquênio com média de meio por cento ao ano. Essa foi uma das microrregiões que mais sofreu com a crise internacional, por se tratar de um setor que depende de cenários favoráveis externos para se expandir. No total, a média de crescimento anual fica em torno de $32 \%$, mostrando um crescimento a taxas decrescentes muito mais intenso nos últimos cinco anos do período analisado.

Tabela 8 - Exportações da microrregião de Sobral no período 2000-2015

\begin{tabular}{c|c|c|c}
\hline Período & US\$ FOB & Peso Líquido $(\mathbf{k g})$ & Quantidade \\
\hline o1/2000 até 12/2000 & 31.795 .414 & 6.743 .525 & 12.113 .337 \\
\hline o1/2010 até 12/2010 & 179.929 .163 & 93.058 .255 & 53.772 .527 \\
\hline o1/2015 até 12/2015 & 184.470 .942 & 19.030 .742 & 46.268 .318 \\
\hline
\end{tabular}

Fonte: Elaboração própria com dados extraídos de AliceWeb (2018)

Esse declínio nas exportações de bens de consumo não duráveis, como é o caso dos calçados, é o comportamento natural de produtos exportados com essas características. Quando há um clima favorável externo, há sempre um expressivo crescimento, como ocorreu na década 20002010, ao passo que no primeiro sinal de crise e retração do consumo, sua demanda internacional decresce e ele sofre as consequências.

\section{Microrregião de Iguatu}

Esta microrregião é parte da Mesorregião Centro-sul Cearense e abriga em seu território 2.175 empreendimentos, dos quais estão no município de Iguatu, na maioria, firmas individuais $(63 \%)$ e sociedades limitadas (26\%) com até 9 funcionários. Está totalmente na região semiárida do estado e é composta pelos municípios de Cedro, Iguatu, Icó, Quixelô e Orós, com aproximadamente 222 mil habitantes em 2010.

$\mathrm{Na}$ microrregião, Iguatu é o município polo que registra mais de 1.000 estabelecimentos. O setor que tem mais empresas é o de Comércio Varejista (711), Comércio e Reparação de Veículos (93), Atividades de Atenção à Saúde Humana (75), Alimentação (63), Construção Civil (39), Educação (38) responsáveis por $69 \%$ dos estabelecimentos do município. O poder público municipal é um dos dois empregadores com mais de 1000 funcionários registrados e $85 \%$ das firmas tem entre o e 9 funcionários. 
Iguatu, que polariza não só essa microrregião mas toda a parte CentroSul cearense, não é um município de perfil exportador: em 2017, exportou pouco mais de US\$ o,3 milhões e teve um déficit na Balança Comercial de US\$ 0,1 milhões. Todas as exportações, em 2016 e 2017, foram de móveis. Dos anos analisados (2000, 2010 e 2015), apenas em 2000 teve exportação (US\$ 34.775).

Em termos de financiamento, o FNE destinou para o município, em $2016, \mathrm{R} \$ 27$ milhões de reais, $66 \%$ para o setor de comércio e serviços, $\mathrm{R} \$$ 6,7 milhões para agropecuária e agroindústria, $\mathrm{R} \$ 2$ milhões para a indústria e R\$ 0,3 milhões para o turismo.

O que sustenta a economia da microrregião são os empregos públicos gerados pelos entes federativos e as políticas de transferência de renda. São ao todo 8.935 empregados só em 2016, com a prefeitura dos municípios contando na folha de pagamentos do poder executivo, 8.662 funcionários. Os demais eram do legislativo e de esfera estadual. Só de primeiro emprego nessa microrregião foram contratados 1.071 funcionários. A maioria dos funcionários $(73,52 \%)$ recebem renda salarial de 0,5 até 3 salários-mínimos.

Embora o perfil produtivo seja pouco diversificado, conforme apontado, a dinâmica microrregional é dada pelo forte papel polarizador exercido pelo município de Iguatu, que é $5^{\circ}$. maior núcleo urbano do Ceará, excluindo os municípios da RMF. Seu tamanho e o fornecimento da rede de Comercio Varejista para toda a Mesorregião Centro-Sul Cearense, bem como o atendimento de instituições de serviços educacionais e de saúde, dão notabilidade a este centro regional.

\section{Microrregião do Cariri}

A Microrregião do Cariri assumiu historicamente importante papel nas conexões do território cearense às demais regiões do Nordeste pela sua localização mais interiorizada e, principalmente, pelas suas condições físicas e naturais particulares. A dotação de recursos hídricos e naturais de um bioma misto, permitiu que a ocupação neste espaço fosse mais adensada desde a etapa da incorporação econômica. A presença da Chapada do Araripe e sua geomorfologia possibilitou uma agricultura mais diversificada que deu ao Cariri a alcunha de seleiro. A comercialização dos produtos agrícolas deu origem a feiras e permitiram diferenciações econômicas decorrentes da acumulação mercantil inicial, trazendo mais dinamismo. 
Atualmente, o aglomerado da conurbação formada pelas cidades de Crato, Juazeiro do Norte e Barbalha é o núcleo de maior população no Ceará depois da RMF (SILVA E QUEIROZ, 2017). Possui uma população de aproximadamente 534 mil habitantes e está totalmente no semiárido. A microrregião do Cariri se destaca com maior número de estabelecimentos pelos municípios de Juazeiro do Norte (1.694), Crato (572) e Barbalha (122), os quais formam o núcleo duro do desenvolvimento regional. Ali estão situados ícones do turismo religioso, como a Estátua do Padre Cícero, grande patriarca da cidade e dos nordestinos, esculpida no topo da Colina do Horto. Há, também, a localização de balneários de fonte de água natural, que jorram intermitentemente nos municípios de Crato e Barbalha.

Juazeiro do Norte tem o maior número de empregos absolutos e relativos na microrregião do Cariri, com 4.623 estabelecimentos, dos quais 1.874 estão registrados no setor de Comércio Varejista, mais de $40 \%$. Crato se destaca com o Comércio Varejista (741), Alimentação (114), Atenção à Saúde Humana (111), Comércio e Varejo de Veículos Automotores e Motocicletas (75), Educação (69) e Construção Civil (65), compondo, juntos, $69 \%$ dos empreendimentos do município. Barbalha possui no total pouco mais de $1 / 8$ de todos os empregos de Juazeiro do Norte e 2/3 do emprego total do Crato. No município também é destaque o Comércio Varejista como setor que concentra o maior número de empresas.

As exportações são modestas em relação às outras regiões do estado, como apresentado anteriormente. No entanto, o Cariri tem um dinamismo que se conecta com outras regiões e é bastante pertinente: as interconexões estaduais facilitam o tráfego de mercadorias adquiridas nesse corredor, principalmente de gênero alimentícios.

Tabela 9 - Exportações da microrregião do Cariri no período 2000-2015

\begin{tabular}{c|c|c|c}
\hline Período & US\$ FOB & Peso Líquido $(\mathbf{k g})$ & Quantidade \\
\hline o1/2000 até 12/2000 & 5.823 .520 & 1.266 .839 & 1.102 .037 \\
\hline o1/2010 até 12/2010 & 16.918 .734 & 2.163 .691 & 1.584 .802 \\
\hline o1/2015 até 12/2015 & 2.487 .656 & 490.963 & 534.236 \\
\hline
\end{tabular}

Fonte: Elaboração própria com dados extraídos de AliceWeb (2018

As exportações nessa microrregião vêm declinando: em 2015, teve-se uma perda relativa ao ano de 2000 de $57 \%$ do volume daquele ano. Assim como Sobral, boa parte das exportações são do setor calçadista, já que 
a economia cratense possui outra unidade da empresa Grendene S.A., instalada em território cearense. Até 2019 operou em Juazeiro do Norte uma unidade da Indústria de Máquinas de Costura, a Singer Brasil, que reduziu seu dinamismo durante o período analisado bem como sua participação caindo de forma significativa nos totais regionais. Esta empresa era uma das grandes beneficiárias de diversos programas de incentivos e operava na cidade há 22 anos (O POVO, 2019). Apesar disso, essa microrregião segue crescendo, a taxas decrescentes, mas é uma das atuantes na participação e formação do PIB estadual, bem como foi a que obteve a maior abertura de empresas no período 2010-2016.

\section{Microrregião do Baixo Jaguaribe}

A microrregião do Baixo Jaguaribe possuía aproximadamente 313 mil habitantes em 2010 e segue um ciclo de programas e políticas ativas de desenvolvimento de um polo produtivo agroindustrial, com foco na fruticultura irrigada, um dos tripés de promoção do dinamismo econômico estadual e intensificado ao logo dos anos, sendo seu foco principal a produção direcionada ao mercado externo. Composta pelos municípios de Alto Santo, Ibicuitinga, Jaguaruana, Limoeiro do Norte, Morada Nova, Palhano, Quixeré, Russas, São João do Jaguaribe e Tabuleiro do Norte, a microrregião do Jaguaribe foi responsável, em 2015, por $\mathrm{R} \$ 3,8$ bilhões de reais a preços correntes. Acompanhando a tendência regional, apresenta concentração de empresas no setor de comércio com 1.517 estabelecimentos. Havia, nesse ano, 2.995 estabelecimentos.

O município de Russas é um importante polo do Vale do Jaguaribe e está a aproximadamente $165 \mathrm{~km}$ da capital Fortaleza, conhecida como a capital do vale do Jaguaribe ou terra da laranja doce. Com um PIB per capita de R\$12.043,00, Russas também possui o maior número populacional da microrregião.

Tabela 10 - Exportações da microrregião do Cariri no período 2000-2015

\begin{tabular}{c|c|c}
\hline Período & US\$ FOB & Peso Líquido $(\mathbf{k g})$ \\
\hline o1/2000 até $12 / 2000$ & 9.204 .630 & 6.360 .039 \\
\hline 01/2010 até $12 / 2010$ & 16.746 .485 & 3.379 .063 \\
\hline 01/2015 até $12 / 2015$ & 19.881 .806 & 14.538 .245 \\
\hline
\end{tabular}

Fonte: Aliceweb (2018) 
Percebe-se o crescimento das exportações na microrregião no período, com a duplicação do seu valor. As exportações de Russas são de produtos do agronegócio, tais como Cera Vegetal, Melão e Banana e representam aproximadamente $70 \%$ do valor total exportado da região em 2015. O caráter heterogêneo das microrregiões do Estado do Ceará revela que os centros dinâmicos tendem a concentrar atividades produtivas e ampliar sua capacidade ao longo do tempo ao se observar que nestas territorialidades econômicas, principalmente com a análise da microrregião Jaguaribe, o tripé norteador das políticas de desenvolvimento das últimas três décadas se complementa. O agronegócio que define o dinamismo jaguaribano, definiu um dos suportes de inserção competitiva desta parte do Ceará sem que estrangulamentos como as questões estruturais de porte fundiário fossem atenuadas, conforme propunha as recomendações de Furtado desde o clássico estudo do GTDN.

\section{Apontamentos finais}

Os condicionantes da reconfiguração da estrutura produtiva do Semiárido cearense se deram a partir da combinação de diversos elementos e de medidas que integraram o rol de políticas públicas, juntamente à atuação das estruturas de poder local que se fizeram presentes em todo o período de formação e conformação das atividades econômicas no subespaço. A expressão do planejamento ainda se faz necessária. Percebe-se que no Ceará, existe um número maior de microrregiões com mais de uma cidade que se destaca e que aponta a germinação de polos produtivos, mas a sua maior parte ainda contempla lugares que não só são dependentes de instituições públicas como agentes de geração de emprego com uma fraca participação na geração de valor adicionado produtivo. O setor de Serviços predomina em diversos espaços, mas nos locais em que a indústria assume o papel principal, esses dois setores estão bem mais correlacionados, mantendo assim uma cadeia de relacionamentos produtivos.

No período de 2000 a 2015, grande parte das empresas com mais de 1.000 funcionários são de natureza jurídica vinculada ao poder público, federal, municipal ou estadual, onde há uma maior concentração desse tipo em municípios com menor grau de dinamismo sendo, muitas vezes, a fonte principal de renda da população. Naqueles polos urbanos que se destacam como centros regionais de médio porte, percebe-se que, além desse quadro, há também empresas da iniciativa privada, mas a maioria 
delas não são originalmente brasileiras ou nordestinas, tampouco regionais. Esse modelo resultou da nova política de atração industrial já que, dentre as intenções originais das proposições da Sudene, o de criar uma classe empresarial burguesa local, alcançou na economia cearense forte ancoragem expressa nos seus grupos econômicos até os anos 1990 (LIMA JÚNIOR, 2014; ARAÚJO, 2001).

O que prevalece em termos de estrutura empresarial é o pequeno negócio, que tem de o até 9 funcionários. Esse tipo de empreendimento chega a ocupar 9o\% de todos os estabelecimentos, mostrando que a base de sustentação econômica está naqueles de pequeno porte. Uma das razões para esse quadro seria não só a falta de oportunidade de empregos, que forçosamente obriga as pessoas se tornarem autônomas, ou ainda, a insatisfação dessas pessoas com o mercado de trabalho, que faz com que procurem o ramo do microempreendedoríssimo para se esquivarem de remunerações salariais tão baixas. Para captar melhor esta dinâmica, fazse necessário novo estudo para verificação da conexão existente entre esse fato e a mortalidade de pequenos empreendimentos, tanto no Semiárido quando no Brasil.

Os polos já consolidados como as capitais regionais, cada vez mais vem aumentando sua participação no cenário econômico regional, tornandose mais atrativos para empresas de um porte mais elevado. É possível admitir que a história econômica vivenciada no período da intervenção planejada através da Sudene, ou mesmo da recente reestruturação da política de atração de investimentos subvencionados nesse território, foi mais aflorada gerando as ilhas de dinamismo (ARAÚJO, 1999) e validando em alguns signos o papel do planejamento pública e da ação desenvolvimentista furtadiana expressa na Sudene.

Mesmo saindo de uma estrutura eminentemente agrícola e pecuária no início de sua ocupação e, atualmente, quase que totalmente dependente da estrutura do setor de serviços, é fácil de observar como os vultosos investimentos dos Fundos Constitucionais e das políticas de incentivos fiscais ainda são direcionados a agropecuária, principalmente aos grandes produtores agroindustriais. No caso particular da economia cearense, isso se observa no estímulo à fruticultura irrigada, que reproduz padrões já implantados em outras partes do Brasil, no próprio Nordeste.

O Ceará desponta como um dos estados que mais investe em turismo e dá suporte aos empreendedores desse lado da oferta de serviços, garantindo a reprodução em longo prazo dessas práticas, pois embora neste setor estejam grandes investimentos como os modernos luxuosos resorts 
litorâneos, observam-se inúmeros pequenos produtores que conseguem gerar maior quantidade de empregos. É um modo de aproveitar positivamente a alta temperatura e as escassas chuvas.

A indústria do turismo, como é denominada, aproveita os potenciais regionais de clima quente e menos chuvoso para se estabelecer como promissora e um conjunto de reflexões são importantes para o aproveitamento de seus desdobramentos transformadores. A necessidade de potencializar e desenvolver uma estrutura produtiva interconectada e clusterizada, com características regionais para captação e fixação de recursos no território capaz de contribuir efetivamente com o desenvolvimento da região, é um dos caminhos em pauta na atual condução das políticas.

O desenvolvimento de estudos acerca da implementação de iniciativas coletivas regionais se faz necessário para que no futuro se possa ter uma estrutura produtiva no estado distribuída mais homogeneamente entre as microrregiões, além de um olhar ativo para os pequenos e microempreendedores. Negócios dessa natureza vêm mostrando significado expressivo na região, como as cooperativas de transporte alternativo no Ceará, que fazem contratos licitatórios do Governo do Estado para os trechos de viagem. No concernente aos pequenos empreendedores, são esses negócios que movimentam o comércio do bairro, da vizinhança e abriga grande parte dos desempregados e dos informais.

Ademais, muito contribuiu o impacto da expansão dos serviços públicos através da disseminação da Educação Superior e do crescimento da rede de atendimento básico em saúde. Tal fato estimulou a interiorização de profissionais especializados por todo o território Semiárido, não somente no Ceará. Neste campo, a colaboração efetiva das Instituições de Ensino Superior, discentes e docentes, junto à Administração Pública na elaboração de Políticas Regionais, também é uma alternativa viável na busca por melhoria ou criação de propostas de Programas de Desenvolvimento Regional. 


\section{Referências}

ADECE, A. DE D. DO E. DO C. S. A. Complexo Industrial e Portuário do Pecém (CIPP). Disponível em: <http://www.adece.ce.gov.br/index. php/porto-do-pecem>. Acesso em: 12 fev. 2018.

AliceWeb. Disponível em: http://www.mdic.gov.br/comercio-exterior/estatisticas-de-comercio-exterior/comex-vis/frame-ppe?ppe=1051 Acesso em 12 de agosto de 2017.

ARAÚJO, T. B. de. A "questão regional" e a "questão nordestina”. In: TAVARES, Maria da Conceição (org.). Celso Furtado e o Brasil. São Paulo: Editora Fundação Perseu Abramo, 2001.

- Por uma política nacional de desenvolvimento regional. Revista Econômica do Nordeste, Fortaleza, Banco do Nordeste, V.30, n.2, abr-jun 1999.

IBGE, Instituto Brasileiro de Geografia e estatística. Disponível em: $<$ https://sidra.ibge.gov.brl>. Acesso em 23 de Abril de 2020.

FURTADO. C. A constatação do GTDN e as exigências da atualidade. In: ALENCAR JUNIOR, J. S.et. al. (Org.) Celso Furtado e o Desenvolvimento Regional. Fortaleza/CE: Banco do Nordeste, 2005.

. Uma política de desenvolvimento econômico para o Nordeste. GRUPO DE TRABALHO PARA O DESENVOLVIMENTO DO NORDESTE (GTDN). In: ALENCAR JÚNIOR, J. S. de. et al (org.). Celso Furtado e o desenvolvimento regional. Fortaleza: BNB, 2005 .

Em busca de novo modelo: reflexões sobre a crise contemporânea. São Paulo: Paz e Terra, 2002.

LIMA JUNIOR, F. do O' de. Estrutura produtiva e rede urbana no estado do Ceará durante o período de 1980-2010. Campinas/SP: Universidade de Campinas, 2014.

. Sudene e forças sociais nordestinas: papel institucional face ao novo marco regulatório de intervenção estatal e de desenvolvimento nos anos 2000. Fortaleza/CE: RDS Editora, 2004. 
LIMA JÚNIOR. F. do O'. MACEDO, F. C. e ALVES, D. F. Infraestrutura, economia e território no Ceará: as conexões dadas pelo Complexo Industrial e Portuário do Pecém. XVIII Encontro da ANPUR. Disponível em: http://anpur.org.br/xviiienanpur/anaisadmin/capapdf.php?reqid=152 27 a 31 de maio de 2019. Natal, RN: ANAIS XVIII ENANPUR,

MACEDO. F. C de. Inserção externa e território: impactos do comercio exterior na dinâmica regional e urbana do Brasil (1980-2008). Campinas, SP: Instituto de Economia - IE, Universidade Estadual de Campinas - UNICAMP, 2010 (Tese de Livre Docência).

RAIS, Relação Anual de Informações Sociais. Disponível em: <http:// bi.mte.gov.br/bgcaged/login.php>. Acesso em 23 de Abril de 2020.

O POVO. Fábrica da empresa Singer têxtil fecha em Juazeiro do Norte. https://www.opovo.com.br/noticias/economia/2019/o4/o6/fabricada-empresa-textil-singer-fecha-em-juazeiro-do-norte-apos-22-anos-defuncionamento.html Acessado em 22 de janeiro de 2020.

SANTOS, M. D. C. dos. A reconfiguração das atividades econômicas do subespaço semiárido dos Estados do Ceará, Rio Grande do Norte, Paraíba e Pernambuco nos anos 2000 a 2015. 2018. Dissertação (Mestrado em Planejamento e Dinâmicas Territoriais do Semiárido). Universidade do Estado do Rio Grande do Norte, Pau dos Ferros, 2018. 168p.

SILVA, J. G. da, QUEIROZ, S. N. Migração interestadual para a Região Metropolitana do Cariri (RMC). VII Congresso de la Asociación Latinoamericana de Población; XX Encontro Nacional de Estudos Populacionais ABEP. Disponível em: https://www.researchgate.net/profile/Joao_Silva3o6/publication/329531529_MIGRACAO_ INTERESTADUAL_PARA_A_REGIAO_METROPOLITANA_ DO_CARIRI_RMC/links/5coe 5742 a 6 fd c c 494 fe 9 od 57 / MIGRACAO-INTERESTADUAL-PARA-A-REGIAO-METROPOLITANADO-CARIRI-RMC.pdf 17 a 22 de outubro de 2016. Foz do Iguaçu, PR: ANAIS VII ALAP; XX Encontro ABEP. 


\section{Parte III \\ Federalismo}

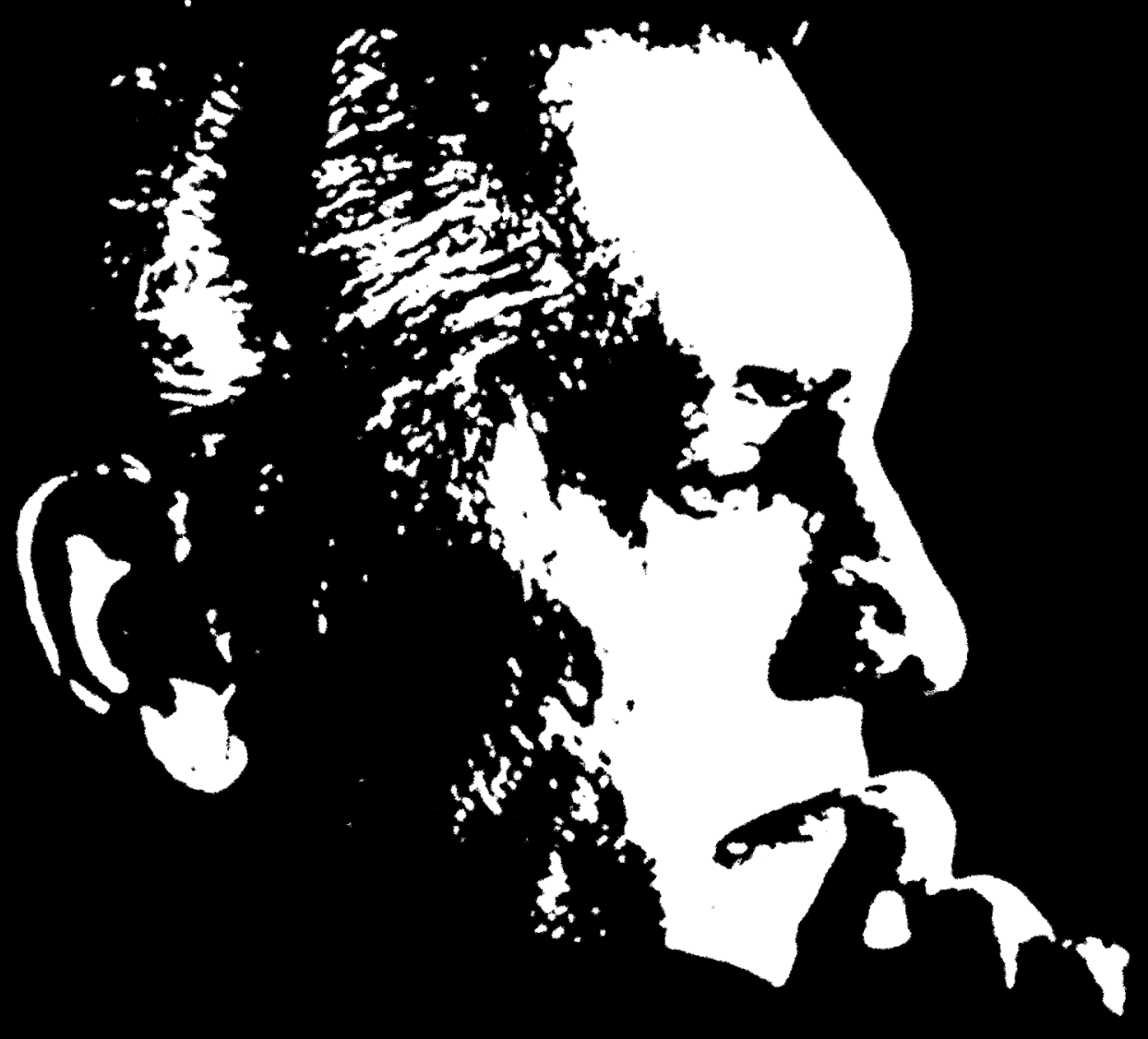





\title{
O desenvolvimento regional em Celso Furtado: a coordenação federativa e as implicações institucionais
}

\author{
Luciléia Aparecida Colombo \\ Thales Haddad Novaes de Andrade \\ Aristides Monteiro Neto ${ }^{3}$
}

\section{Introdução}

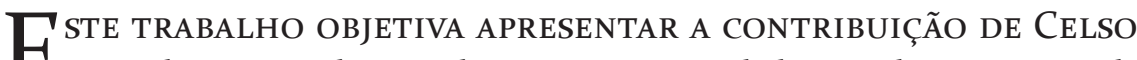

¿ Furtado para o desenvolvimento regional do Nordeste, especialmente o seu esforço em articular centros dispersos do poder para a formação da Superintendência do Desenvolvimento do Nordeste (Sudene). Para realizar esta tarefa, nos amparamos nas Atas das reuniões ocorridas na Sudene no período de 1959 a 1964, disponibilizadas no site do Procondel, que é um projeto de preservação do material produzido pelo Conselho Deliberativo da Sudene - Condel (http://procondel.sudene. gov.br/). Nosso esforço é, tendo como pano de fundo o tema do federalismo, compreender em quais condições houve o surgimento da Sudene e o esforço de Furtado para tal.

1 Professora Adjunta de Ciência Política da Universidade Federal de Alagoas (UFAL); pesquisadora-visitante da Diretoria de Estudos e Políticas Regionais, Urbanas e Ambientais do Instituto de Pesquisa Econômica Aplicada (IPEA); Doutora em Ciência Política pela Universidade Federal de São Carlos (UFSCAR).

2 Professor associado do Departamento de Ciências Sociais da Universidade Federal de São Carlos. Doutor em Ciências Sociais pela Universidade Estadual de Campinas (UNICAMP).

3 Economista com Doutorado em Economia Aplicada pelo IE/UNICAMP (2005) e Mestrado em Economia pelo PIMES/UFPE (1995). É Técnico em Planejamento e Pesquisa do IPEA desde 1997. Foi Chefe da Assessoria de Planejamento e Articulação Institucional do IPEA (2011-2012). Foi Secretário de Estado da Ciência, Tecnologia e Meio Ambiente de Pernambuco (jan/2007-jul2009) e Assessor Especial do Governo de PE (ago/2009-mar/2010). É especialista em Desenvolvimento Econômico, Economia Regional e Políticas Públicas. Professor do Mestrado Profissional em Políticas Públicas e Desenvolvimento do IPEA. 
Acreditamos que o federalismo brasileiro possui particularidades que devem ser ressaltadas. Originalmente, o sistema federativo tem o objetivo de resolver conflitos inerentes a ele, pois é um sistema no qual há uma abdicação da liberdade e da autonomia dos entes subnacionais, que o fazem para alcançarem um bem coletivo, o pacto federativo, através do qual estarão fidelizadas as demais esferas subnacionais. O Brasil não apresenta grandes diferenças de origem cultural, étnica, religiosa, mas possui regiões com um grau de desenvolvimento desigual. Por sua grande extensão territorial, o país convive com um bloco de regiões consideradas desenvolvidas, como o Sul e o Sudeste, antagonicamente dispostas em outro bloco de regiões com frágeis graus de desenvolvimento econômico, como o Nordeste e o Norte.

O Nordeste apresenta, historicamente, um esforço no sentido de imprimir uma identidade nos planos de desenvolvimento, pois se projetou no cenário federativo com algumas inovações institucionais importantes, como foi a experiência da Sudene. Os desníveis de renda entre esta região e as demais foram observadas por vários intelectuais, entre eles, Furtado (1981, 1984). Entre muitas medidas governamentais de intervenção na região, para tentar reverter o quadro de desigualdade, a Sudene foi a que mais aproximou a ideia de uma intervenção planejada e organizada.

Uma segunda característica do federalismo brasileiro é o pêndulo através do qual ele gravita, podendo ser mais ou menos centralizado, mais ou menos descentralizado. Podemos apontar que os momentos de centralização federativa foram os períodos ditatoriais e, em contrapartida, os períodos de ampla descentralização foi foram os períodos democráticos. Tais oscilações tiveram impacto no desenho das políticas públicas adotadas ao longo dos anos, especialmente porque podem apontar para uma maior participação das unidades subnacionais. Como também podem barrar a influência de policy makers determinados, uma vez que estados e municípios - a depender de seu protagonismo - podem estar alijados do processo decisório de políticas, ou podem determinar a sua formulação e implementação.

Por fim, um terceiro ponto que merece destaque em relação ao federalismo brasileiro é a sua diferença em relação ao federalismo americano. Para Stepan (1999), o federalismo americano encaixa-se em seu modelo come together, ou seja, federações que nascem intuindo promover a união das partes de um determinado território. O pacto federativo americano demonstra bem este modelo, na medida em que as unidades federadas possuem ampla autonomia e fidelidade ao pacto. O Brasil, 
contrariamente ao modelo americano, possui uma formação de tipo hold together, segundo o modelo de Stepan (1999), pois não houve um acordo cooperativo entre as partes da federação, tampouco um programa de descentralização. O que aconteceu, em nosso caso, foi um desenho imposto pelo governo central às unidades subnacionais, as quais não compreenderam, em grande medida, quais as suas devidas competências neste sistema.

Neste sentido, há sempre a dualidade de quem tem mais ou menos poder: se o Governo Federal ou se Estados e Municípios, pois o federalismo nasceu sob os auspícios de manter uma união já existente, com alguns vícios sociais e políticos também presentes de antemão. Além disso, com este desenho de fundo delineado, temos diferenças regionais significativas entre as regiões brasileiras, que sempre necessitaram de um olhar do governo federal mais detido.

Feitas tais considerações, este estudo debruça-se especificamente sobre uma experiência de planejamento para conter tais assimetrias, especialmente relacionada à região Nordeste, que foi a Sudene. À sua frente, com um fiel representante e defensor, temos a atuação de Celso Furtado, que desenhou, implementou e executou a proposta da instituição de maneira fervorosa.

Para uma melhor localização do leitor, este estudo está dividido da seguinte maneira: esta introdução, precedida de um item posterior que aponta a agenda governamental que antecedeu a formação da Sudene; um outro item salientando as disputas políticas em torno da formação da instituição; um item analisando a atuação de Celso Furtado entre os anos da fundação da instituição até as suas alterações no período militar e, finalmente, uma conclusão.

\section{A agenda governamental antecessora das instituições de desenvolvimento regional}

O momento que antecedeu a criação da Sudene foi marcado por alguns fatores que merecem ser mencionados: em primeiro lugar, de 1945 a 1964, o Brasil viveu um período de intensa agitação, caracterizado como a Segunda República, com experiências federativas inovadoras, especialmente verificadas a partir da cooperação entre os estados. Outros fenômenos também passaram a coexistir, ao lado de tais experiências, como por exemplo, o afloramento do populismo, das relações clientelísticas e do paternalismo, gramáticas políticas fortemente enraizadas nas 
representações dos interesses localistas. Mesmo com a existência de relações cooperativas travadas entre os entes federados, o Brasil ainda apresentava uma agenda política pautada nos vínculos regionalistas e dos mandos de seus interlocutores locais.

Havia também naquele momento uma preocupação latente com as desigualdades regionais, tanto que a Constituição de 1946 dedicou a prerrogativa do artigo 58 para o dispositivo sobre representação na Câmara dos Deputados. Esta prerrogativa garantia benefícios às regiões mais vulneráveis, como é o caso do Nordeste, para elegerem seus representantes políticos no legislativo federal. A elites nordestinas passaram a apoiar o fim do princípio "um cidadão, um voto", e, em contrapartida, a bancada nordestina, então em formação, começou a ganhar força e protagonismo no parlamento. A robustez dos pactos destas elites parlamentares garantiu, ainda, a destinação de parte da renda tributária da União para as áreas acometidas pelas secas em algumas regiões.

Neste sentido, a partir de uma nova configuração política, o Nordeste também presenciava a possibilidade de competir efetivamente para a concretização de políticas públicas até então desenvolvidas pelo eixo Sul e Sudeste. Além destas modificações de cunho da representatividade, a região Nordeste também beneficiava-se, em um cenário mais amplo, da ideologia imperante do momento, denominada por Bielschowsky (1988) como "reaparelhamento econômico", impulsionada pela campanha do petróleo, com a facilidade observada para a modernização do Estado, em princípios burocratizantes.

Alguns desafios ainda permeavam o pleno desenvolvimento da região Nordeste, como a permanência das secas. Apesar do relativo amparo institucional, com instituições como o Departamento Nacional de Obras Contra as Secas (DNOCS), alguns momentos desafiadores ameaçavam decisivamente a concretização de políticas mais consistentes para a região. Tais momentos podem ser delineados com as secas de 1951, 1953 e a de 1958 , as quais propiciaram um aumento das migrações, cujo objetivo era a busca por melhores condições de vida e de trabalho especialmente em São Paulo. Estas migrações foram, também, fatores essenciais para as decisões políticas tomadas a partir de então no que se refere à questão regional. Era preciso conter o fluxo migratório, evitando um esvaziamento populacional no Nordeste.

Diante de tal cenário, com a projeção de dados negativos da região Nordeste em relação às condições de vida e de fixação da população no território, novas instituições foram criadas, como por exemplo, o Banco 
do Nordeste do Brasil (BNB), em 1952, cujos objetivos previam ações intervencionistas e desenvolvimentistas. $\mathrm{O}$ banco representava uma nova fase de intervenção do Estado na região, criando um espaço de articulação das elites nordestinas para a promoção de políticas destinadas objetivamente ao crescimento. Além disso, o banco possuía um espaço privilegiado de pesquisa das condições regionais, personificado em seu Escritório de Estudos Técnicos sobre a Economia do Nordeste (ETENE), cujos estudos foram decisivos para a compreensão da região, com a criação de uma expertise técnica adequada para a promoção do desenvolvimento que se aventava. Além disso, ao mapear as áreas mais vulneráveis dentro da região, os estudos do ETENE permitiam uma compreensão adequada do modelo de política a ser formulado para elas.

Todas estas novidades institucionais eram propiciadas pela cooperação vertical que passava a ser observada entre o governo federal, os governadores dos estados nordestinos e os representantes do legislativo federal. A necessidade de repensar a região Nordeste também assentavase na ideia da criação de uma instituição capacitada para tal. Assim, a Sudene, juntamente com a criação de Brasília, passava a fazer parte do arcabouço institucional indispensável para que a agenda governamental incorporasse as demandas das regiões menos desenvolvidas. Os desequilíbrios regionais eram o pano de fundo e a grande justificativa para a necessidade, imperiosa, de tratá-los de maneira mais articulada, a partir da intervenção do governo federal. Neste sentido, cabe uma análise mais detalhada sobre a criação da Sudene e da atuação de Celso Furtado para a implementação da instituição.

\section{A criação da Sudene e a atuação de Celso Furtado: uma atuação militante e ativa}

A partir do cenário anteriormente descrito, que favoreceu o surgimento de instituições responsáveis pelo planejamento regional e com o agravamento da situação da região Nordeste causada pelos efeitos constantes das secas, o então Presidente Juscelino Kubitscheck convocou Celso Furtado para auxiliar na busca de soluções. Na época, Furtado atuava no então Banco Nacional de Desenvolvimento Econômico (BNDE) e possuía uma quantidade razoável de material e dados sobre a região Nordeste. Estes dados foram sistematizados e se transformaram na chamada Operação Nordeste, que posteriormente foi denominada de 
Conselho de Desenvolvimento do Nordeste (CODENO), o qual forneceu as bases para o surgimento da Sudene.

Além disso, cabe destacar a atuação do Grupo de Trabalho para o Desenvolvimento do Nordeste (GTDN), com a liderança novamente de Furtado. Em 1959, o autor elaborou Uma Política de Desenvolvimento Econômico para o Nordeste, ou como é conhecido, O Relatório do GTDN. Os estudos deste grupo foram fundamentais para o estabelecimento de um planejamento específico para o desenvolvimento do Brasil a partir do conceito das desigualdades regionais. A questão do Nordeste foi transformada em problema federativo, no qual somente uma instituição com amplos poderes seria capaz de suplantar práticas desarticuladas e de instituir mecanismos de cooperação para as unidades federadas. Nas palavras de Furtado (1959):

\begin{abstract}
Se esse processo chegasse a persistir por muito tempo, observaríamos, seguramente, no Brasil, profundos desequilíbrios regionais, que provocariam conflitos de natureza econômica e política capazes de retardar nosso desenvolvimento econômico e social. Não podem coexistir, no mesmo país, um sistema industrial de base regional e um conjunto de economias primárias dependentes e subordinadas, por uma razão muito simples: as relações econômicas entre uma economia industrial e economias primárias tendem sempre a formas de exploração (FURTADO, 1959, p. 13).
\end{abstract}

A implantação da Sudene nasceu vinculada a tensões sociais e políticas e dependeu de uma série de articulações para ser implantada. $\mathrm{O}$ GTDN foi transformado em Conselho de Desenvolvimento do Nordeste (CODENO), cujo Conselheiro era Celso Furtado. O que se buscava era desmontar e desarticular o poderio das oligarquias rurais, ao mesmo tempo em que se tentava uma identificação da instituição com o apoio popular. Desta forma, a Sudene nascia sobre as condições da Lei no 3.692, de 1959, enviada por Juscelino Kubitscheck ao Congresso, sendo definida sua subordinação direta à Presidência da República. A tramitação do Congresso Nacional também encontrou uma série de resistências, inclusive com o veto de parlamentares nordestinos contrários ao governo federal (COHN, 1973).

Como ressalta Carvalho (1979), o receio da elite nordestina e dos parlamentares era o temor de que a Sudene se transformasse em um superministério, controlando as outras pastas existentes. Além disso, outros políticos locais acreditavam que os objetivos da instituição eram muito amplos, deixando em aberto a questão se a sua competência era formular ou também implementar políticas para o desenvolvimento da região. A 
partir de tais questionamentos, o Artigo 2을 da Lei n. 3.692 de 15 de dezembro de 1959 assim descrevia as competências da instituição:

Estudar e propor diretrizes para o desenvolvimento do Nordeste. Supervisionar, coordenar e controlar a elaboração e execução de projetos a cargo de órgãos federais na região e que se relacionem especificamente com o seu desenvolvimento. Executar, diretamente ou mediante convênio, acordo ou contrato, os projetos relativos ao desenvolvimento do Nordeste que lhe foram atribuídos, nos termos da legislação em vigor. Coordenar programas de assistência técnica, nacional ou estrangeira, ao Nordeste (BRASIL. CÂMARA DOS DEPUTADOS. Lei de criação da Sudene, 1959, art. $2^{\circ}$ ).

O receio em torno da figura de Celso Furtado também era grande, tanto que convencionou-se que o Conselho Deliberativo seria formado por vinte e dois membros entre governadores de estado, representantes dos Ministérios e dos bancos federais, além obviamente do Superintendente, Celso Furtado (CARVALHO, 1979). Apesar das contrariedades do período, Furtado foi um grande articulador e conseguiu promover o consenso entre os atores políticos para o nascimento da instituição. Em seu discurso de posse, reconhecia, de forma sutil, os interesses oligárquicos presentes na sociedade e que deveriam ser transpostos:

Sabemos todos que a liberdade de ação do Governo Federal em uma região pobre como o Nordeste está profundamente comprometida pela pressão de grupos locais, cuja perspectiva se projeta no plano da política estadual. Muitos que observam de fora esses problemas supõem que o Governo Federal é todo-poderoso no Nordeste. Mas a vera realidade é que a faculdade de manobra dos dirigentes dos órgãos federais e sua capacidade de agir em conjunto estão comprometidas por composições de interesses locais de perspectiva necessariamente limitada. A Lei da Sudene, ao integrar em um órgão federal responsável pelas diretrizes da política econômica os dirigentes dos executivos estaduais, criou um mecanismo de entendimento à base da discussão aberta e do confronto de critérios (FURTADO, 1959, p. 16).

Ressaltava, ainda, a sua responsabilidade como superintendente da Sudene, diante dos graves problemas nordestinos:

Ao assumir a Superintendência da Sudene faço-o consciente do peso da responsabilidade que recai sobre meus ombros. Essa consciência, adquiri-a não agora, mas em todo esse ano de luta pela vitória da Operação Nordeste. Nessa luta, entre outras coisas aprendi a admirar mais os homens públicos de meu país. Afirmo, com júbilo, que o presidente Kubitscheck, desde o primeiro momento, teve consciência de que não era esta obra para ser acabada em 
seu governo. A este período governamental caberia, na Operação Nordeste, antes obra de desgaste e sacrifício do que a fruição dos empreendimentos concluídos. E porque não se afastou, em nenhum momento, desta concepção da obra que iniciávamos, o Sr. Presidente despertou em mim, simples técnico, essa fé que transfigura todos os sacrifícios em momentos de esperança (FURTADO, 1959, p. 17).

Ao vincular-se diretamente à Presidência da República, a Sudene tinha a capacidade de reunir em torno das reuniões de seu Conselho Deliberativo os governadores de estado, que passariam a atuar a partir de pautas coletivas, e não mais individuais. Além de suas prerrogativas formais, a Sudene representou uma maneira de repensar o desenvolvimento regional a partir do próprio federalismo, uma inovação institucional capaz de impulsionar tanto as agendas governamentais federais quanto as estaduais. Era, portanto, um elo de ligação entre o governo federal e os governos estaduais nordestinos. Neste sentido, cabe apontar algumas das passagens mais importantes da atuação de Furtado verificadas a partir da análise das Atas do Condel.

\title{
As Atas do Condel e a atuação de Furtado
}

As Atas do Conselho Deliberativo de Desenvolvimento do Nordeste foram recolhidas através do site do Procondel, que foi um projeto de preservação e disponibilização do acervo do Conselho Deliberativo da Sudene - Condel, no período que corresponde aos anos de 1959 até 2000. Todos os documentos, atas, pareceres, relatórios e resoluções deste período estão disponíveis no site. ${ }^{4}$

Neste sentido, a reunião realizada em 26 de abril de 1959, que também foi responsável por aprovar o regimento interno da Sudene, expõe claramente a liderança de Celso Furtado para organizar a instituição, bem como a articulação entre as instituições externas e os estados nordestinos, conforme podemos perceber nesta passagem:

\begin{abstract}
O conselheiro Celso Furtado deu a conhecer o importante auxílio financeiro oferecido pelo governo de Pernambuco à Cepal, propondo a realização nesta cidade do próximo curso de Treinamento em Problemas de Desenvolvimento, colocado à disposição do órgão coordenador a importância de um milhão de cruzeiros, oferecendo, ainda, local para as aulas, o custeio de duas bolsas de estudos para os governos dos demais estados da região, bem como os funcionários burocráticos necessários à Secretaria do curso (BRASIL. ATA do CONDEL, 1959).
\end{abstract}

4 Disponível em: http://procondel.Sudene.gov.br/sobre.aspx. 
Além dos treinamentos previstos, buscando-se criar no Nordeste um corpo técnico com expertise no desenvolvimento regional, Furtado vislumbrava três setores a serem atendidos pelo Governo Federal: 1 - Infraestrutura de transporte; 2 - Suprimento de energia elétrica; 3 Economia de resistência às secas. Além disso, ficava evidente a preocupação em subsidiar os empreendimentos dos pequenos proprietários através de créditos do BNB e de utilizar instituições como a Codevasf para implantar projetos de irrigação na região Nordeste.

A análise das atas do conselho deliberativo deixa claro a dificuldade para obtenção do consenso, com alguns governadores com sentimentos pessimistas em torno das propostas de Furtado. Entretanto, se instituir a Sudene fora um movimento difícil, aprovar o plano diretor também envolveu debates acalorados, repletos de dissensos. As manifestações especialmente de Cid Sampaio, então governador de Pernambuco, giravam em torno da preocupação para que o Congresso fosse impedido de modificar o Plano Diretor, em votação. Rômulo de Almeida, também Conselheiro, contrariando Cid Sampaio, destacava a atuação da Sudene nos seguintes termos:

Quero chamar a atenção para um fato politicamente fundamental: poderá a Sudene suceder bem se contrariar frontalmente o Congresso, os governos, a opinião pública? Evidentemente não. $\mathrm{O}$ próprio mérito de um programa bem apresentado constitui um fator de convencimento. É preciso notar que um grande número de congressistas precisam resolver o problema (BRASIL. ATA DO CONDEL, 1959).

O resultado destas discordâncias políticas acabaram gerando um atraso na aprovação do Plano Diretor da Sudene, comprometendo, ademais, a receita para o tratamento dos problemas nordestinos, conforme expresso na Ata do Condel de 2 de dezembro de 1959:

O conselheiro Celso Furtado fez uma explanação dos trabalhos da Secretaria Executiva durante o último mês, registrando que os mesmos foram perturbados pelo atraso do andamento do projeto de criação da Sudene, pois os planos iniciais, estabelecidos por este órgão, tinham em vista a aprovação da Lei da Sudene em tempo útil ainda para que o orçamento de 1960 se beneficiasse já dos dispositivos desta lei que favorece o Nordeste com uma cota de $2 \%$ adicional da receita tributária (BRASIL. ATA DO CONDEL, 1959). 
Além disso, os debates verificados no ano de 196o também evidenciam o esforço de Furtado para a aprovação do Plano Diretor:

Referindo-se à elaboração do Plano Diretor, diz que o mesmo deverá ser apresentado ao Congresso Nacional, antes da entrada do orçamento para o ano de 1961, frisando que enquanto as equipes da Sudene trabalham arduamente para ultimar o plano, defrontou-se o órgão com dois contratempos de importância: o primeiro deles, a perspectiva de uma nova seca, que forçou a interrupção parcial dos trabalhos para constituir grupos de emergência com a missão de acompanharem o inverno na fase decisiva e, posteriormente, o inverno se apresentou com o caráter de calamidade, com múltiplas enchentes em todo o Nordeste (BRASIL. ATA DO CONDEL, 1960).

Em maio de 1960 iniciaram-se as discussões sobre o Plano que posteriormente seria enviado ao Congresso Nacional para aprovação. As propostas contidas no Plano Diretor tramitaram por um ano e sete meses, passando pelas comissões da Câmara dos Deputados e do Senado Federal, com diversas emendas recebidas, o que poderia distorcer o projeto original, temor que se manifestava entre os conselheiros do Condel, registrados nas Atas. Outro ponto de desacordo era relacionado a partilha dos recursos financeiros, que acabaram polarizando o apoio dos governadores dos estados, contribuindo para o atraso na aprovação do Plano Diretor, conforme aponta Lima (2009).

A regra do dissenso era a tônica nas reuniões do Conselho Deliberativo da Sudene, especialmente pela morosidade em torno da aprovação do Plano Diretor. Furtado, com sua perspicácia política, buscou apoio nos governadores e dirigia-se a eles da seguinte maneira:

O nosso pobre Nordeste não pode se dar ao luxo de perder uma eleição presidencial. Por que não colocar a política de desenvolvimento da região acima da confrontação partidária? O Plano Diretor foi elaborado com a colaboração entusiasta de governadores dos dois partidos que disputam a presidência. É natural que, seguindo os partidos respectivos, os governadores se dividam em torno dos candidatos à Presidência da República. Mas por que não obter dos dois candidatos um compromisso de levar adiante o Plano Diretor? Eles poderiam assumi-lo de público em uma das visitas que necessariamente fariam à região. $\mathrm{O}$ novo superintendente seria escolhido no quadro desse compromisso de continuidade da política de desenvolvimento regional (FURTADO, 1989, p. 87). 
O primeiro plano Diretor foi aprovado pela Lei no 3.995, em 1961. Suas diretrizes, após diversos debates, previam:

O objetivo principal deste primeiro Plano Diretor da Sudene é apresentar um conjunto orgânico de diretrizes de política econômica que possam servir de base a um esforço progressivo de ordenação dos investimentos do Governo Federal no Nordeste. Á análise esboçada nas seções anteriores indicou, claramente, que o Poder Público desempenha o principal papel no processo de formação de capital, cabendo-lhe a liderança do desenvolvimento econômico regional. Este fato leva a reconhecer a importância que tem, para o Nordeste, a formulação precisa de uma política de desenvolvimento que norteie e dê continuidade à atuação do Poder Público (BRASIL. ATA DO CONDEL, resolução n. 34,1961$)$.

E ainda:

\begin{abstract}
A Sudene tem a responsabilidade de propor as diretrizes de uma política de desenvolvimento regional, as quais deverão subordinar-se todos os investimentos federais no Nordeste. Além de definir essas diretrizes, cabe à Sudene atuar como órgão centralizador do planejamento dos investimentos federais na região. Ao exigir a formulação de uma política de desenvolvimento e no unificar a direção das atividades de planejamento dos investimentos, realizou a Lei 3692 uma reforma administrativa de grande alcance (ATA DO CONDEL, Resolução n. 34, 1961).
\end{abstract}

Mesmo após a aprovação do Plano Diretor, algumas problemáticas vieram à tona, especialmente em 1963, quando entrou em discussão o II Plano Diretor, previsto para os anos de 1963-1965, cuja grande iniciativa foi a propositura de um Fundo de Emergência, para que os efeitos adversos do clima do Nordeste fossem contornados. Além disso, era explícito no II Plano Diretor a necessidade de aumento dos investimentos da iniciativa privada na região, tornando-a competitiva frente aos outros centros industriais. Além disso, o plano previa algumas mudanças relacionada a estrutura fundiária da região Nordeste, com a redistribuição de terras e este ponto promoveu discordâncias e restrições por parte de alguns governadores, especialmente que se identificavam com as propriedades rurais em questão.

Tais atores acabaram tornando-se veto players para as proposituras futuras da Sudene, boicotando e esvaziando o Condel. Além disso, a partir de 1964, novas alterações foram realizadas de maneira decisiva na Superintendência, a partir do golpe militar, que marcou um período de centralização política e de autoritarismo. Na reunião de 6 de maio de 
1964, já era registrado como superintendente da Sudene o General Manoel Expedito Sampaio. Celso Furtado relata a sua saída da Superintendência da seguinte maneira:

Despedi-me das pessoas presentes, acompanhado do oficial superior que me substituía e que se esforçava para dar a impressão de que tudo se passava 'entre amigos'. Atravessava pela última vez a porta daquela instituição que surgira e adquirira fama mundial sob a minha direção. Era muito mais do que uma agência administrativa. Graças a ela, emergira o Nordeste como entidade política. Tudo tivera de ser disputado palmo a palmo. Aquele mesmo edifício do IAPI, em parte ocupado pelo comando da Sudene, fora por nós invadido na calada da noite, forma a que tivemos de apelar para fazer prevalecer decisões superiores contra manobras escusas da baixa burocracia (FURTADO, 1989, P. 197).

A partir de então, a Sudene passou a ter uma atuação de coordenadora e de supervisora das ações governamentais, relegando um papel marginalizado no processo decisório de políticas. Os chamados Programas Especiais $^{5}$ passaram a pautar a agenda dos militares, especialmente no tocante às chamadas questões regionais. Tais programas tinham o objetivo de promover a integração das regiões brasileiras através, principalmente, da retomada de antigos programas já desenvolvidos, como os de irrigação. As desigualdades federativas foram mantidas, com o agravamento de algumas regiões, pois havia, a partir de então, concentração de renda e de investimentos em alguns estados nordestinos em detrimento de outros.

\section{Conclusão}

Este estudo buscou analisar qual a influência de Celso Furtado para a concretização da Sudene e, portanto, para uma agenda governamental que assimilou as políticas de desenvolvimento regional. Além disso, como pano de fundo, delimitamos as assimetrias federativas, que necessitaram, historicamente, de intervenções governamentais na região Nordeste. Entretanto, a concepção da Sudene e a sua implementação foram pautadas por um complexo jogo político, com uma série de conflitos que permearam todos os debates, inclusive aqueles referentes a aprovação do I Plano Diretor. Ao ser vinculada diretamente à Presidência da

5 Alguns dos Programas Especiais foram: Polonordeste, Projeto Sertanejo e o Programa de Irrigação. 
República, a Sudene representava uma arena de resolução de conflitos federativos, estabelecendo pontes entre o governo federal e os governos estaduais, e destes entre si. Foi uma experiência institucional que priorizou experiências cooperativas, apesar da grande oposição formada em torno da aprovação tanto da lei que a instituiu formalmente, como da aprovação de seus planos diretores. É possível defender a assertiva de que a Sudene conseguiu romper as resistências das elites nordestinas locais daquele momento.

A agenda governamental que antecedeu a inauguração da Sudene também propiciou a formação de um aparato burocrático e institucional que favoreceu a tomada de decisão por uma instituição nos moldes da superintendência. Parte desta assertiva reside no fato de que os anos 1950 e início dos anos 1960 permitiram a formação de instituições como BNB, o BNDES e a demais instituições de desenvolvimento, como a Superintendência do Desenvolvimento da Amazônia (SUDAM) e a Superintendência de Desenvolvimento do Centro-Oeste (SUDECO). Além disso, as elites locais interessavam-se por fomentar novos processos de industrialização, que utilizasse capital nacional e de experiências que pudessem consolidar ainda mais o seu poderio. Neste sentido, podemos considerar uma grande articulação política tanto de Juscelino Kubitschek como de Celso Furtado para transpor tais relações localistas pautadas pelo conservadorismo político.

A análise das Atas do Conselho Deliberativo da Sudene demonstra a influência de Furtado para a concretização da Sudene. Entretanto, com o golpe militar, houve alterações significativas em seu desenho, que funcionou nos moldes furtadianos até a aprovação de seu I Plano Diretor, em 1961, sofrendo as consequências do regime centralizador que o sucedeu posteriormente em 1964. A aprovação do I Plano Diretor aconteceu em meio a conturbados enfrentamentos políticos e, posteriormente, sob a égide dos militares, os programas da Sudene foram substituídos pelos chamados Programas Especiais, cujos objetivos eram a modernização da agricultura, o aperfeiçoamento da agropecuária e o financiamento de programas de irrigação.

O papel desempenhado pela Sudene passa a ser residual a partir de então, cuja característica foi a de apenas servir como uma instituição orientadora das ordens do governo central, com a restrição da capacidade de formular e de implementar políticas. Se antes a Sudene permitia a formulação de políticas de tipo bottom-up, favorecendo as necessidades regionais, com o regime militar observamos as políticas de modelo 
top-down, ou seja, formuladas unicamente pelo governo central, sem uma identificação mais sensível com os problemas locais e regionais.

Após o afastamento de Celso Furtado da liderança da instituição, a interlocução com as elites locais também comprometeu-se, pois passava a ser realizada pela alta cúpula do regime militar. Contudo, os interesses divergentes da região mantinham-se mesmo com a mudança de governo, conforme delineado pelo próprio Furtado (1989, p. 198): "No mundo moderno, o Estado é uma arena onde se confrontam os interesses mais diversos. As circunstâncias podem favorecer estes ou aqueles grupos, mas nem sempre são alheias à vontade dos atores, como havíamos comprovado com frequência”.

Neste sentido, consideramos que repensar a postura de Celso Furtado como um grande intelectual mas, sobretudo, como um militante do planejamento regional é essencial também nestes dias atuais. A atualidade de sua obra é, de fato, um respiro em meio a indefinição recorrente de planos de desenvolvimento regional que requerem a cooperação e a interlocução constante entre os entes federados para a obtenção de efetividade.

\section{Referências}

BIELSCHOWSKY, R. Pensamento econômico brasileiro - o ciclo Ideológico do Desenvolvimentismo. 5. Ed. Rio de Janeiro: Contraponto, 1988.

BRASIL. ATA DO CONSELHO DELIBERATIVO DA SUDENE. Recife, 1959.

BRASIL. ATA DO CONSELHO DELIBERATIVO DA SUDENE. Recife, 1960.

BRASIL. ATA DO CONSELHO DELIBERATIVO DA SUDENE. Recife: Resolução n. 34, 1961.

BRASIL. CÂMARA DOS DEPUTADOS. Lei de Criação da Sudene. Brasília, 1959.

BRASIL. Procondel. Recife: Sudene, 2020. Disponível em: http://procondel.Sudene.gov.br/sobre.aspx

CARVALHO, O. A economia política do Nordeste: secas, irrigação e desenvolvimento. Rio de Janeiro: Campus, 1988. 
Desenvolvimento regional: um problema político. Rio de Janeiro: Campus, 1979.

COHN, A. Crise regional e planejamento. O processo de criação da Sudene. São Paulo: Editora Perspectiva, 1973.170 p.

FURTADO, C. A fantasia desfeita. Rio de Janeiro: Paz e Terra, 1989.

A luta pelo Nordeste e a estratégia da Sudene. São Paulo. Digesto Econômico. Ano XX, n.․ 168, 1962.

A operação Nordeste. Textos brasileiros de Economia. Rio de Janeiro, 1959.

. A Pré-Revolução Brasileira. Rio de Janeiro: Fundo de Cultura, 1962. 1992, 2 ed.

. Brasil: a construção interrompida. Rio de Janeiro: Paz e Terra, Celso Furtado entrevistado por Aspásia Camargo e Maria Andréa Loyola. Rio de Janeiro: EdUERJ, 2002.

. Dialética do desenvolvimento. Rio de Janeiro: Fundo de Cultura, 1964.

. Discurso comemorativo aos 40 anos de atuação da Sudene. In: FORMIGA, M.; SACHS, I. Celso Furtado, a Sudene e o Futuro do Nordeste. Recife: Sudene, 2000.

. Entrevista a Maria da Conceição Tavares. Celso Furtado e o Brasil. São Paulo: Editora Fundação Perseu Abramo, 2002.

. Formação Econômica do Brasil. São Paulo: Editora Nacional, 1987.

. O Brasil Pós-Milagre. Rio de Janeiro: Paz e Terra, 1981.

O Nordeste: reflexões sobre uma política alternativa de desenvolvimento. São Paulo: Revista de Economia e Política, vol. 4, n. 3, 1984 . 
- Uma política de desenvolvimento econômico para o Nordeste. Grupo de Trabalho para o Desenvolvimento do Nordeste. Rio de Janeiro: Departamento de Imprensa Nacional, 1959.

FURTADO, R. F. D'Aguiar. A batalha da Sudene. In: Arquivos Celso Furtado. Rio de Janeiro: Contraponto, 2009.

LIMA, M. C. O Conselho Deliberativo da Sudene (1959-1964). In: Furtado, C. (1920-2004). O Nordeste e a saga da Sudene - 1958 a 1964. Rio de Janeiro: Contraponto: Arquivos Celso Furtado, 2009.

STEPAN, A. Authoritarian Brazil: origins, policies, and future. New Haven: Yale University Press, 1973. Second hardcover printing, 1975. Yale paperback, sixth printing, 1985. 1988.

(Ed.). Democratizando o Brasil. Rio de Janeiro, Paz e Terra,

Modern multi-national democracies: transcending a Gellnerian Oxymoron. In: HALL, J. A. (org.). The state of the nation: Ernest Gellner and the Theory of Nationalism. Cambridge: Cambridge University Press, 1998.

. Para uma nova análise comparativa do federalismo e da democracia: federações que restringem ou ampliam o poder do Demos. Dados, vol. 42, n. 2, 1999, p. 197-251.

STEPAN, A.; LINZ, J.J. (Eds.). The Breakdown of Democratic Regimes. Baltimore: The John's Hopkins University Press, 1978. Second hardcover printing, 1980.

Political identities and electoral sequences: Spain, Soviet Union and Yugoslavia. Daedalus, vol. 21, no 2, 1992. p. 512-522. 


\section{Federalismo Brasileiro: uma revisitação das contribuições de Celso Furtado}

Rosangela dos Santos Alves Pequeno ${ }^{1}$

Fernando Cézar de Macedo ${ }^{2}$

\section{Introdução}

S TRANSFORMAÇÕes Do CAPITALISMO GLOBAL, INTENSIFICADAS
la partir da década de 1980, tornaram imperativo o reexame dos papéis e funções dos governos em diferentes níveis, sobretudo devido ao aspecto multiescalar da globalização. Macroeconomicamente, o que se tem constatado é o aprisionamento dos Estados-nações, reféns da volatilidade dos fluxos financeiros internacionais. Reduz-se, assim, a autonomia de suas políticas econômicas e a capacidade de superação das desigualdades socioeconômicas.

No caso do Brasil, país continental, federativo e com desigualdades regionais históricas, não foi diferente. As mudanças na economia mundial redefiniram seu papel na divisão internacional do trabalho e sua atratividade para com os ciclos de liquidez internacional. Esta reinserção de sua economia no mundo globalizado criou dificuldades para a construção de um regime federativo que se adaptasse às novas formas de integração à economia mundial e garantisse, simultaneamente, laços de solidariedade e cooperação.

Sob este prisma, a questão do "pacto federativo" brasileiro também assumiu novo desenho. Observa-se, sob pressão dos mercados, crescente dificuldade regulatória do Governo Central e de sua capacidade de coordenação dos entes subnacionais. Enfraqueceram-se os mecanismos

1 Doutoranda em Desenvolvimento Econômico do Instituto de Economia da UNICAMP/Campinas-SP. Docente do Departamento de Economia da UFRN. E-mail: rosangelapequeno@gmail.com.

2 Professor do Instituto de Economia da Unicamp. Pesquisador do Centro de Estudos de Desenvolvimento Econômico - CEDE. E-mail: fcmacedo@unicamp.br. 
de soldagem da base federativa, extremamente heterogênea, do mesmo modo que são minados pelas forças de mercado à medida que o sistema econômico nacional perde força.

Entender a complexidade do federalismo exige olhá-lo sob diferentes enfoques, a partir de uma perspectiva que leve em conta a compreensão do processo histórico, econômico, político e jurídico de formação do país. Isto significa que se faz necessário um estudo abrangente que envolva o conhecimento em diversas áreas da ciência, pois uma estrutura federativa incorpora diferentes atributos que devem ser analisados multidisciplinarmente.

Nesses termos, a vasta e profícua obra de Celso Furtado se torna o fio condutor deste artigo, por possibilitar discussões abrangentes sobre a natureza, as características e as especificidades da estrutura federativa brasileira à luz de sua dinâmica econômica. A escolha se deve graças ao fato de o pensamento furtadiano percorrer as mais diversas áreas do conhecimento - da teoria econômica à história; da teoria do desenvolvimento à política e à cultura. $\mathrm{O}$ autor nos mostra o quão multidisciplinar é o seu legado intelectual.

Na obra de Furtado é notória sua contribuição para captar as tendências estruturais da História brasileira, a qual abarca as interpretações do desenho institucional do federalismo. O autor oferece contribuições teóricas para compreensão dos padrões de relacionamento entre os entes federados e para o entendimento de suas capacidades de formular políticas públicas capazes de diminuir as assimetrias regionais.

A contribuição de Celso Furtado para o tratamento da problemática do federalismo brasileiro inicia-se na década de 1950, quando a reflexão do desenvolvimento econômico assumiu o norte de sua atuação intelectual e política. Obstinado pela superação do subdesenvolvimento brasileiro, empreendeu esforços teóricos e práticos para a urgente necessidade de reconstrução do "pacto federativo". Àquele momento, o agravamento das disparidades regionais se apresentava como grande obstáculo ao processo de construção da nação.

Com ampla bibliografia, Furtado analisou o processo de transformação econômica do país, inclusive em sua dimensão federativa, bem como a persistência de seu subdesenvolvimento. Tomava como referência a necessidade de construção de um sistema econômico nacional que internalizasse os centros de decisão e articulasse as diversas economias regionais num mesmo movimento sincrônico. 
A partir da década de 1990, o posicionamento de Furtado se torna mais enfático com a consolidação do neoliberalismo no Brasil. Acreditava que a construção da nação fora interrompida sem conseguir redução das disparidades sociais e regionais - sem garantir, portanto, a superação de suas históricas mazelas sociais. A capacidade reguladora do Estado sucumbiu ante a força das empresas transnacionais que lhe restringem o poder político e a capacidade de garantir a formação econômica nacional soberana e autodeterminada.

Em sua obra "O longo amanhecer", Furtado apresenta a problemática do federalismo (e sua crise). Reconhece que sua adoção se justificava pela "dependência econômica de certas regiões com respeito a outras, de dissimetria nas relações entre regiões, de transferências unilaterais de recursos encobertas em políticas de preços administrados." (FURTADO, 1999a, p. 46). Esta ideia estava na base do documento do GTDN que originou a Sudene, a mais conhecida experiência de planejamento regional do país.

Partindo da concepção de que o federalismo deve se basear na cooperação e na solidariedade, ele observa que a diversidade de situações que marca o extenso território brasileiro impõe dificuldades que se agravaram com a transnacionalização da economia e com o neoliberalismo. Afinal, os governos Central e subnacionais encontram sérios problemas para desempenhar ações que reduzam os conflitos federativos e que sejam capazes, coordenadamente, de garantir uma eficiente prestação de serviços públicos.

Se a Federação é baseada na cooperação e na solidariedade, como afirmou o autor, também o é pela competição entre os entes, o que reforça o papel desempenhado pelo Estado nacional e indica os limites colocados pelo seu enfraquecimento no cenário pós-199o. Por isso, nos termos apresentados por Furtado, este quadro exige novos entendimentos que sejam formalizados e voltados para aperfeiçoar os mecanismos institucionais que atuam como moderadores dos conflitos federativos.

Deste modo, este artigo parte de uma estrutura concreta analisada sob uma abordagem histórica do processo de formação federativa do Brasil, tendo como substrato teórico o pensamento de Celso Furtado. O objetivo é revisitar as contribuições desse autor centradas nas questões do federalismo brasileiro, com base em seu método histórico-estrutural.

Este capítulo está dividido em mais três seções, além desta introdução e das considerações finais. Na primeira, são explicitadas as principais contribuições teóricas de Furtado voltadas aos aspectos considerados 
fundamentais na trajetória do federalismo brasileiro. Na seção seguinte, é apresentada uma síntese sobre a relevância da questão regional na estrutura federativa do país, em que prevalece a abordagem de Furtado no processo de desenvolvimento nacional. Na última, é discutido o federalismo brasileiro na contemporaneidade, a partir dos anos 1990, apresentando uma abordagem dos aspectos centrais enfatizados pelos mecanismos institucionais de cooperação presentes no debate mais recente, em contraponto com a discussão original de Furtado.

\section{Uma breve reflexão do pensamento furtadiano sobre o federalismo}

A concepção de Celso Furtado para a estrutura federativa brasileira abrange o debate econômico sobre os rumos do desenvolvimento nacional e regional. A partir de seus primeiros escritos nos anos 1950, o autor menciona que o projeto de país desde a origem da República foi sedimentado pelos interesses sediados no moderno polo cafeicultor paulista, com reflexos na formação da estrutura federativa. Como exemplo, o autor cita que para atender aos interesses do baronato do café, o Governo Central se subordinou e instituiu uma política cambial sobrevalorizada, em detrimento das consequências negativas para as demais regiões do país. (FURTADO, 1999a).

Na década de 1980, como integrante da Comissão Preparatória do Projeto de Constituição, Furtado viu as forças políticas discutirem amplamente os múltiplos aspectos que moldariam a estrutura federativa do Brasil na Constituição Federal de 1988. Ele pensava a questão a partir da concepção de que "Federalismo é o conceito mais amplo que tem sido utilizado para expressar a ideia de que a organização política deve basearse na solidariedade e na cooperação, e não na compulsão." (FURTADO, 1999a, p. 45). A nova Constituição representava, portanto, a possibilidade de fortalecimento dos laços federativos nos termos colocados pelo autor.

Esta compreensão de Furtado estava fundamentada pelas ideias de Proudhon (2001) que, em 1858, levantava duras críticas ao Estado centralizado e acenava para o federalismo como um sistema socioeconômico no qual os múltiplos grupos seriam os livres criadores das suas relações econômicas e políticas. Isto significa que se deveria reconstituir uma verdadeira vida coletiva, o que implicaria que os problemas fossem debatidos, que os interesses se pronunciassem e que os regulamentos internos fossem discutidos e escolhidos 
O autor reconhece que a partir da década de 1990 a lógica econômica neoliberal no país impossibilitaria o projeto de construção político-econômica do Brasil. Em sua obra "Brasil: a construção interrompida" esta convicção fica bem clara ao dizer:

\begin{abstract}
Na lógica da ordem econômica internacional emergente, parece ser relativamente modesta a taxa de crescimento que corresponde ao Brasil. Sendo assim, o processo de formação de um sistema econômico nacional já não se inscreve naturalmente em nosso destino nacional. [...] num país ainda em formação, como é o Brasil, a predominância da lógica das empresas transnacionais, na ordenação das atividades econômicas, conduzirá quase necessariamente a tensões inter-regionais, à exacerbação de rivalidades corporativas e à formação de bolsões de miséria, tudo apontando para a inviabilização do país como projeto nacional”. (FURTADO, 1992, p. 13/35).
\end{abstract}

Segundo Fiori (2001, p. 35-36), a desesperança de Furtado não é surpresa em um contexto de enfraquecimento do sistema econômico nacional, fator decisivo para a construção e a preservação de sua unidade e do seu próprio pacto federativo. Para Fiori, isto se torna visível pelos conflitos verticais e horizontais que desmancham os laços de solidariedade inter-regional, indispensáveis ao funcionamento de qualquer república federativa; laços necessários, também, para superação do subdesenvolvimento nos termos furtadianos.

Furtado (1999a) menciona que a luta pelo federalismo na Europa foi reflexo da aspiração profunda da preservação da identidade de grupos étnicos e culturais com história própria. Isto era diferente da situação brasileira que, ao instituir o regime federativo, não apresentava problemas de choques de nacionalidade, nem conflitos étnicos e/ou religiosos separatistas, mas uma dependência econômica de certas regiões no imenso território que o formava. Vale salientar que a concepção teórica de não neutralidade do espaço é reforçada por Furtado, tendo em vista que seu conceito de região é necessariamente dinâmico. Em suas palavras: "Mas essa consciência de unidade nacional, dentro de um espaço que se expande, coexiste com o senso de identidade que se definiu historicamente em cada região particular. A identidade do brasileiro tem raízes em sua inserção regional [...]." (FURTADO, 1999a, p. 47).

A trajetória histórica do federalismo brasileiro seguiu um movimento pendular que, segundo Furtado (1999a), gerou alternância de poder político, quando, em determinados períodos, o poder central era reforçado e, em outros, se reivindicavam os poderes regionais e locais. Ele recomenda 
situar a análise desse movimento na História de modo coerente com seu método.

Desta forma, cronologicamente, identificam-se cinco períodos distintos, marcados por profundas transformações, ao longo da trajetória histórica da federação brasileira: o da Primeira República (1889/1930), caracterizado pela descentralização; o do Estado Novo (1930/1945), assumindo uma tendência nitidamente centralizadora; o da restauração democrática (1945/1964), etapa favorável à descentralização; o do regime militar (1964/1985), de intensa centralização; e o da Nova República (1985/aos nossos dias), no qual, inicialmente, predominam as tendências descentralizadoras. ${ }^{3}$

Para cada um desses períodos, Furtado (1999a) examinou o quadro federativo do país por meio de dois traços fundamentais: a consciência de unidade nacional e a identidade regional. Deste modo, a expansão da economia cafeeira é tida como fator explicativo para a atuação mais descentralizada do sistema federativo ao longo da Primeira República. Isto se deve à subordinação do Governo Central aos interesses da região cafeeira. Já no período do Estado Novo, o centralismo foi a marca do Governo Vargas que possibilitou a formação de um mercado interno integrado e capaz de autogerar o crescimento econômico do país por meio da atividade industrial que passou a ser o motor da economia.

No entanto, a industrialização veio acompanhada do aumento dos desequilíbrios regionais, pois se concentrou na região Sudeste, principalmente na cidade de São Paulo e em seu entorno. Como solução, Furtado liderou os estudos que resultaram na criação de órgãos de desenvolvimento regional, a fim de introduzir elementos compensatórios para as perdas das demais regiões. Há que se destacar que as Constituições Federais de 1934 e 1946 previam recursos de 4\% (a de 1934) e 3\% (a de 1946) de toda receita da União para o combate às secas e promoção da ocupação da Amazônia. Estabeleciam-se, também, contrapartidas estaduais e municipais.

3 Vale destacar que o arranjo federativo brasileiro, posto pela Constituição Federal de 1988 acabou apresentando caráter contraditório, por conta das alterações que envolveram ampla recentralização fiscal na esfera da União. Deste modo, em um primeiro momento, ampliou-se fortemente os recursos dos governos subnacionais, por meio dos fundos de participação, mas, em meados de 1990, concedeu-se ao Governo Central a capacidade de ampliar seus recursos, de forma exclusiva, via contribuições e aumento de alíquotas de impostos. 
O golpe militar em 1964 instaurou no país mais um período centralizador baseado na ideologia da "segurança nacional". Com uma política de "integração nacional", os projetos governamentais enfrentaram inúmeros obstáculos diante da dimensão continental que possui o território brasileiro.

Por fim, para o período da chamada Nova República, a concepção de Furtado (1999a) sobre o federalismo é vista pela continuidade do centralismo político que acompanha o centralismo econômico, no qual se produzem distintos níveis de desenvolvimento no território brasileiro. Neste cenário, segundo o autor, não basta apenas restaurar as tendências descentralizadoras fiscais da estrutura federativa do país para conter o aprofundamento das desigualdades regionais. Na verdade, para ele:

\begin{abstract}
Em uma economia de mercado só é possível deter as tendências estruturais ao centralismo econômico mediante ação política, a qual requer uma visão ampla do processo social. Somente a vontade política pode evitar que a difusão da racionalidade econômica venha transformar um tecido social diversificado num amálgama de consumidores passivos. E essa vontade política entre nós é inseparável do federalismo. (FURTADO, 1999a, p. 53).
\end{abstract}

Furtado é enfático ao dizer que a estrutura federativa do país se tornou insuficiente neste último período, haja vista que "as desigualdades demográficas e territoriais entre estados não são alheias às crescentes disparidades na qualidade de serviços essenciais prestados às populações." (FURTADO, 1999a, p. 54).

O autor menciona, ainda, que "os pequenos estados não alcançam a densidade mínima de recursos requerida para prestar adequadamente muitos desses serviços. E muito menos para exercer uma ação promocional efetiva no campo do desenvolvimento econômico." (FURTADO, 1999a, p. 54). Fica claro que, para ele, o federalismo brasileiro desaguava na mais grave crise, refletida no colapso econômico-financeiro das instâncias estaduais ou municipais.

Muitos são os fatores que têm servido para explicar tais problemas, entre eles, os mais recorrentes na literatura dizem respeito à vasta extensão territorial do país e à visível desproporcionalidade das condições socioeconômicas dos entes subnacionais que os levam à dependência em relação aos recursos fiscais intergovernamentais e à execução das políticas públicas.

Francisco de Oliveira destacou o posicionamento de Furtado sobre a federação brasileira em artigo intitulado "Um republicano exemplar", em 
homenagem ao economista. Naquela ocasião, Oliveira ressaltou a importância do pensamento furtadiano para o federalismo ao dizer que ele foi o:

\begin{abstract}
único clássico do pensamento social brasileiro que colocou a questão da federação no centro de suas preocupações teórico-práticas, propondo, no fim dos anos cinquenta a refundação do pacto federativo, mudando-lhe a escala e os recortes, para uma espécie de federação regionalizada. Esta era a natureza da Sudene, de que foi seu criador e primeiro dirigente. [...] ousou propor a mudança na forma da articulação federativa e uma gestão compartilhada dos recursos nacionais entre a união e os estados, propondo, também, uma nova representação que não substituía aquela inspirada nos princípios democráticos, mas acrescentava-lhe a dimensão regional, para remar contra a tendência de desfiguração da federação pelas enormes pressões do próprio desenvolvimento. (ÓLIVEIRA, 2003, p. 117-122).
\end{abstract}

Esta passagem evidencia que o problema federativo brasileiro é antigo, complexo e persistente. Na verdade, centro e trinta anos depois da Proclamação da República, não se conseguiu implantar uma estrutura que desempenhe de modo efetivo as propostas de solidariedade e cooperação entre os entes federados, a fim de minimizar as desigualdades regionais.

A vasta literatura publicada sobre o federalismo tem exposto que o principal mecanismo para a garantia da articulação entre as três esferas de governo são os fundos públicos. Estes assumem papel crucial, pois devem servir para mitigar as desigualdades locais e regionais quanto à disponibilidade de recursos a serem aplicados pelos entes federativos no oferecimento de serviços públicos. Seguindo esta linha de raciocínio, para Affonso (1995), o pacto federativo consiste em:

[...] intrincado sistema de trocas, na maioria das vezes implícito, centrado em grande parte nos fundos públicos e responsável pela soldagem dos interesses regionais e pela constituição de um espaço nacional de poder. Nos últimos anos, forças centrífugas desagregadoras, tanto internas quanto externas ao espaço nacional, têm atuado no sentido de problematizar esse pacto federativo e dificultar a sua recomposição em novas bases. A isso chamamos de "crise do federalismo" ou "crise da federação", a qual é uma dimensão fundamental da crise do Estado. A referência à dimensão espacial da crise impõe-se, principalmente, em um país marcado por tão grandes disparidades regionais. (AFFONSO, 1995, p. 71-72).

Neste cenário, para além dos fundos públicos, a solução proposta por Furtado (1999a) para a crise do federalismo brasileiro passa pela busca 
de novas formas de articulação entre os entes (União, estados e municípios) e lança a ideia de debater a possibilidade de uma esfera regional de poder. Em suas palavras: "A fórmula a ser encontrada deveria preservar os estados atuais e, mediante a inserção do poder regional, buscar corrigir os aspectos mais negativos das desigualdades demográficas e territoriais existentes." (FURTADO, 1999a, p. 55). Para tal, o planejamento se torna fundamental para o revigoramento do federalismo, tendo em vista que pode corrigir a tendência de aglomeração espacial das atividades produtivas.

Estas desigualdades, em âmbito territorial, decorrem das diferentes estruturas produtivas de cada região e do processo pelo qual elas foram integradas ao mercado nacional. Portanto, para melhor entender este contexto que vem se processando, é preciso considerar as profundas disparidades econômicas, sociais, políticas e mesmo culturais, que serão discutidas a seguir.

\section{A relevância da questão regional na estrutura federativa}

Celso Furtado apresenta seu interesse pelas questões regionais na obra "Formação econômica do Brasil", publicada em 1959. Através do método histórico-estrutural, apresenta a formação das economias regionais, sua estrutura interna, as formas de organização do trabalho e a formação e circulação dos fluxos de produto e renda. Analisou, por este método, o complexo econômico nordestino dos séculos XVI e XVII (capítulos VIII a XI), a economia mineira escravista do século XVIII (capítulos XIII ao XV), a economia algodoeira do Maranhão no início do XIX (capítulo XVI), as economias do café paulista e da borracha amazônica do século XIX (capítulos XVIII a XXIX) e a transição para um sistema industrial e o deslocamento do centro dinâmico econômico para o Sudeste (capítulos XXX a XXXVI). Diz o autor:

[...] o desenvolvimento da primeira metade do século XX apresenta-se basicamente como um processo de articulação das distintas regiões do país em um sistema com um mínimo de integração. Se, por um lado, o rápido crescimento da economia cafeeira entre 1880 e 1930 criou fortes discrepâncias regionais de níveis de renda per capita, por outro dotou o Brasil de um sólido núcleo em torno do qual as demais regiões tiveram necessariamente de articular-se. (FURTADO, 2005, p. 232-233). 
Evidenciam-se, na obra de Furtado, as diferentes dinâmicas das regiões ao longo da história que ajudam na explicação de como se deu a concentração espacial da produção no país. Essa interpretação seria decisiva para sua ação de planejamento regional, a qual ele tentaria executar por meio da criação da Sudene. A origens dessa concentração também são mencionadas por Cano (2007a) quando em sua obra "Raízes da concentração industrial em São Paulo" relata:

Fica portanto muito claro que o processo de concentração industrial de São Paulo já fora desencadeado entre 1907 e 1919, e, graças à dinâmica da economia paulista que mantém altas taxas de crescimento na década de 1920 , a indústria do resto do país não conseguiria jamais alcançá -la. [...] Café, agricultura, transportes, indústria, comércio e finanças cresciam, assim, dinâmica e integradamente, ampliando consideravelmente o potencial de acumulação do complexo paulista. Dessa forma, a economia paulista contou com amplas condições para o seu desenvolvimento, ao contrário do que ocorria no restante do país [...]. (CANO, 2007a, p. 260-263).

Este quadro suscitou amplo debate sobre o problema dos desequilíbrios regionais da economia brasileira a partir da década de 1950. Os dados das Contas Nacionais do Brasil ampliaram a discussão sobre a desigualdade regional decorrente da estrutura econômica. Deste modo, um arcabouço institucional, a Superintendência do Plano de Valorização Econômica da Amazônia (1953), transformada em 1966 na Sudam, foi criado como forma de tentar minimizar desigualdades; do mesmo modo, a Superintendência do Plano de Valorização Econômica da Região da Fronteira Sudoeste do País (1956), transformada em 1967 na Sudesul; a Superintendência do Desenvolvimento do Nordeste (Sudene) em 1959; a Comissão de Desenvolvimento do Centro-Oeste (1961), transformada na Sudeco em 1967; e, neste mesmo ano, a Suframa, que instituiu a Zona Franca de Manaus. (CANO, 2007b)

O GTDN apontou a regressividade do sistema tributário como prejudicial para o Nordeste, pois fazia com que a carga sobre a região se tornasse maior do que seria de se esperar, dado o seu menor nível de renda quando comparado com as demais regiões do país. (GTDN, 1967). Este era um dos pontos que reforçavam as disparidades regionais. 
Reconhecendo os desequilíbrios regionais, a Constituição Federal de 1988, em Artigo 159, assegurou o repasse de 3\% das receitas do Imposto sobre Produtos Industrializados (IPI) e do Imposto de Renda (IR) para as regiões Norte, Nordeste e Centro-Oeste. Os Fundos Constitucionais destinam-se ao financiamento do setor produtivo dessas regiões, com o objetivo de estimular a redução das desigualdades regionais.

Vale reforçar que sob a ótica do federalismo, a questão regional é vista por Furtado da seguinte maneira:

\begin{abstract}
No Brasil, a luta pelo federalismo está ligada às aspirações de desenvolvimento das distintas áreas do imenso território que o forma. Não se coloca entre nós o problema de choque de nacionalidades, de agressões culturais ligadas a disparidades étnicas ou religiosas. Mas sim o da dependência econômica de certas regiões com respeito às outras, de dissimetria nas relações entre as regiões, de transferências unilaterais de recursos encobertas em políticas de preços administrados. (FURTADO, 2013 p. 378).
\end{abstract}

A proposta de Celso Furtado era fortalecer o federalismo cooperativo, com descentralização parcial na aplicação dos recursos públicos federais nos estados-membros, o que seria feito pelas instituições regionais federais. Para ele, o desenvolvimento econômico dependia muito mais das iniciativas da União do que das unidades subnacionais. Neste caso, o debate em torno da redefinição do pacto federativo em bases cooperativas ficaria concentrado no Congresso Nacional, que ganharia maior relevância, tornando-se assim protagonista maior na tentativa de redução dos desequilíbrios regionais existentes no país.

Os indicadores selecionados e apresentados na Tabela 1 ilustram como os contrastes regionais ainda são evidentes e continuam como um problema nacional e um desafio para o sistema federativo. Não por acaso, Furtado (1999a) advertiu que qualquer estratégia requereria ação planificada com macrodecisões do Estado para se contrapor à lógica de mercado cujas ações tendem a ampliar as desigualdades. 
Tabela 1 - Brasil e as Grandes Regiões: indicadores de desigualdade regional

\begin{tabular}{|c|c|c|c|c|c|c|}
\hline \multirow[b]{2}{*}{ Indicadores } & \multirow[b]{2}{*}{ Brasil } & \multicolumn{5}{|c|}{ Grandes Regiões } \\
\hline & & Norte & Nordeste & Sudeste & Sul & $\begin{array}{l}\text { Centro- } \\
\text { Oeste }\end{array}$ \\
\hline $\begin{array}{l}\text { População' (\%) } \\
\text { (Estimativa em 2018) }\end{array}$ & 100,0 & 8,7 & 27,2 & 42,1 & 14,3 & 7,7 \\
\hline $\begin{array}{l}\text { - Pop. Rural (\%)* } \\
(\text { Censo 2010) }\end{array}$ & 15,6 & 26,5 & 26,9 & 7,0 & 15,1 & 11,2 \\
\hline $\begin{array}{l}\text { - Pop. Urbana }(\%) * \\
(\text { Censo 2010) })^{2}\end{array}$ & 84,4 & 73,5 & 73,1 & 93,0 & 84,9 & 88,8 \\
\hline PIB33 Total (\%) - ano 2016 & 100,0 & 5,4 & 14,3 & 53,2 & 17,0 & 10,1 \\
\hline - PIB³ Agrícola (\%) & 100,0 & 11,1 & 15,9 & 24,9 & 28,0 & 20,1 \\
\hline - PIB33 Industrial (\%) & 100,0 & 6,2 & 13,4 & 53,0 & 20,1 & 7,3 \\
\hline $\begin{array}{l}\text { PIB per capita } 3(\%)- \\
\text { ano } 2016\end{array}$ & 100,0 & 64,9 & 50,8 & 113,0 & 119,6 & 146,3 \\
\hline $\begin{array}{l}\text { Esperança de vida }{ }^{4} \text { ao } \\
\text { nascer (anos), em } 2016\end{array}$ & 75,7 & 72,2 & 73,1 & 77,5 & 77,8 & 75,1 \\
\hline $\begin{array}{l}\text { Taxa de Mortalidade Infan- } \\
\text { til }^{4} \text {, em } 2016\end{array}$ & 13,3 & 17,6 & 16,7 & 10,4 & 9,4 & 14,4 \\
\hline $\begin{array}{l}\text { Pessoas }=\mathrm{e}>10 \text { anos sem } \\
\text { Instrução ou menos de } \\
1 \text { ano de Instrução }(\%) \\
\text { *(PNAD, 2015) }\end{array}$ & 8,5 & 9,3 & 14,3 & 5,8 & 5,8 & 7,3 \\
\hline $\begin{array}{l}\text { Pop. Ocupada }=\text { e > } 15 \text { anos } \\
\text { que não contribui para } \\
\text { Previdência Social }(\%) \\
\text { *(PNAD, 2015) }\end{array}$ & 38,0 & 55,9 & 56,1 & 29,1 & 26,0 & 34,8 \\
\hline $\begin{array}{l}\text { Pop. Rendimento = 1SM (\%) } \\
*(\text { PNAD, 2015) }\end{array}$ & 21,2 & 30,7 & 45,8 & 13,1 & 10,6 & 15,5 \\
\hline $\begin{array}{l}\text { Taxa de Pobreza (\%) } \\
\text { *(IPEA, 2014) }\end{array}$ & 12,8 & 22,3 & 25,1 & 6,6 & 5,7 & 4,7 \\
\hline $\begin{array}{l}\text { Taxa de Extrema Pobreza (\%) } \\
*(\text { IPEA, 2014) }\end{array}$ & 4,0 & 6,2 & 8,7 & 1,9 & 1,5 & 1,1 \\
\hline
\end{tabular}

Fonte: IBGE/SIDRA, vários anos. Em parceria com os Órgãos Estaduais de

Estatística, Secretarias Estaduais de Governo e Superintendência da Zona

Franca de Manaus - SUFRAMA. (Elaboração própria)

${ }^{1}$ IBGE, População estimada em 2018. Coordenação de População e Indicadores Sociais,

Estimativas da população residente com data de referência ıo de julho de 2018 .

${ }^{2}$ IBGE, Censo Demográfico 2010.

3 IBGE, Contas Nacionais Anuais, Contas Regionais do Brasil, 2016.

${ }^{4}$ IBGE, Projeção da População das Unidades da Federação, por Sexo e Idade, para o Período 2000/2030, Revisão 2013.

5 IBGE, Pesquisa Nacional por Amostra de Domicílios, 2015.

${ }^{6}$ IPEA - Banco de Dados do Ipeadata, 2014. 
O sistema federativo brasileiro também apresenta forte desequilíbrio fiscal em termos regionais. Nesse sentido, é preciso levar em conta que a participação das esferas de governo na arrecadação tributária está determinada não só pela atribuição de competência, mas também pela composição da carga tributária e pela distribuição regional de bases de tributação. Assim, a estrutura federativa do país tem sido marcada pelos ciclos de centralização e de descentralização fiscal, bem como pela localização regional das atividades produtivas.

Nos movimentos centralizadores observa-se um aumento da arrecadação das receitas tributárias na esfera federal, paralelamente ao aumento do grau de dependência de estados e municípios em relação ao poder central, reduzindo-se, portanto, sua autonomia em relação à política tributária e fiscal. Além disso, as relações de dependência e autonomia envolvem também a possibilidade da vinculação das receitas a despesas determinadas, o que reduz o grau de autonomia dos governos locais para definirem suas prioridades.

Ao contrário, nos movimentos descentralizadores, não somente se verifica aumento do grau de autonomia dos governos subnacionais, como também se observa maior grau de responsabilidade dessas esferas para com a gestão pública, correspondente a um maior número de encargos repassados, o que faz com que haja necessidade de maior transferência de recursos por parte do governo central.

Este quadro do federalismo brasileiro está presente de forma ampliada na obra de Furtado, tendo em vista que seus argumentos estão para além da ótica exclusivamente econômica. Sua especial atenção a esse tema, possivelmente decorrente de sua experiência na direção da Sudene, levou-o à formulação de projetos para agir contra as desigualdades regionais. Este legado furtadiano se tornou relevante para o entendimento da crise do federalismo brasileiro e pode contribuir para a formulação de estratégias, diante da inserção do país na economia mundial. O próximo item evidencia este novo marco histórico e os seus dilemas federativos.

\section{O federalismo brasileiro na contemporaneidade}

As novas condições econômicas, políticas e sociais determinadas pela globalização têm levado os governos nacionais e subnacionais a buscarem adaptações do sistema federativo. Isto se tornou mais evidente à medida que as atividades econômicas passaram a buscar as localidades mais lucrativas, transcendendo as fronteiras nacionais e diminuindo o 
controle dos Estados-nações sobre seus territórios, colocando em risco a unidade federativa.

Esta nova ordem mundial levou Celso Furtado a pensar qual lugar caberia ao Brasil na lógica capitalista emergente, haja vista que o projeto de desenvolvimento com base na expansão do mercado interno entrou em crise. Em "Brasil: a construção interrompida", lançado em 1992, ele discorreu sobre o futuro incerto dos países subdesenvolvidos e mostrou a precoce interrupção do processo de formação do Estado nacional. $\mathrm{O}$ resultado disso, no caso brasileiro, foi a interrupção de um projeto nacional cuja força coesiva estava na expansão do mercado interno e na construção de um sistema econômico nacional. Para ele:

[...] a partir do momento em que o motor do crescimento deixa de ser a formação do mercado interno para ser a integração com a economia internacional, os efeitos de sinergia gerados pela interdependência das distintas regiões do país desaparecem, enfraquecendo consideravelmente os vínculos de solidariedade entre elas. [...] Na lógica das empresas transnacionais, as relações externas, comerciais ou financeiras, são vistas, de preferência, como operações internas da empresa, e cerca de metade das transações do comércio internacional já são atualmente operações realizadas no âmbito interno de empresas. As decisões sobre o que importar e o que produzir localmente, onde completar o processo produtivo, a que mercados internos e externos se dirigir são tomadas no âmbito da empresa, que tem sua própria balança de pagamentos externos e se financia onde melhor lhe convém. (FURTADO, 1992, p. 32-33).

Essa força disruptiva da globalização também foi percebida por Fiori (1995), para quem os Estados nacionais estariam diante de três desafios: o primeiro dizia respeito aos impactos das políticas macroeconômicas quanto ao movimento da internacionalização do capital; o segundo referia-se aos investimentos diretos externos que buscavam as localidades mais lucrativas, resultado de maior fluidez e mobilidade do capital; e o terceiro concernia à homogeneização das políticas econômicas, a partir da qual os países periféricos seriam a porta de entrada para programas de estabilização que prometiam trazer de volta o crescimento econômico junto com os benefícios da terceira revolução industrial e tecnológica.

É diante deste quadro que a vigente estrutura federativa brasileira completa três décadas. Muito se discute, ainda hoje, sobre como efetivar o princípio constitucional de cooperação entre os entes federativos frente a um contexto de globalização. Este impõe restrições e limites aos instrumentos de política econômica do governo nacional e, aos entes subnacionais, políticas competitivas de atração do investimento. No Brasil, 
a guerra fiscal é uma manifestação deste processo de federalismo predatório praticado pelos estados e municípios. Mas não é o único exemplo.

O sistema fiscal rígido - com repartição das competências tributárias, distribuição do produto e das fontes da arrecadação fiscal com a incumbência aos entes federados da prestação dos serviços públicos e cooperação intergovernamental - também coloca dificuldades para a pactuação federativa. Furtado (1999b) reconhecia que a cooperação entre os estados-membros, sem envolver o governo federal, nunca foi natural e espontânea, sendo marcada mais fortemente por lacunas, descontinuidades e iniciativas episódicas.

Partindo desta concepção, observa-se que a questão do federalismo brasileiro não foi resolvida com as reformas instituídas pela Constituição Federal de 1988. Ao contrário, o que se viu foi que o aumento das transferências intergovernamentais, apesar de minimizar o desequilíbrio vertical na partilha de receitas, ampliou os graves desequilíbrios horizontais, em decorrência das dificuldades para modificar as regras de partilha.

É oportuno refletir sobre o posicionamento de Furtado quanto à defesa do federalismo cooperativo. Para o autor, diante das desigualdades sociais e econômicas existentes entre as regiões brasileiras, a saída é buscar, por meio de mecanismos cooperativos, a melhor distribuição das atividades econômicas no país e o maior equilíbrio político entre os participantes da federação.

Desse modo, o papel do governo federal seria decisivo para o desenvolvimento econômico. Isto porque a articulação dos interesses dos governos subnacionais deveria ser negociada com o governo federal, por meio da institucionalização de órgãos regionais. Furtado (2000) via a Sudene, por exemplo, como um instrumento cooperativo entre os governadores nordestinos, que facilitava o caminho para as intervenções federais. Isto permitia ao Nordeste participar das negociações em melhores condições, sobretudo nas questões concernentes aos estados economicamente mais fortes da federação.

Entretanto, ao longo da década de 1990, a função articuladora da Sudene, em âmbitos nacional e regional, foi progressivamente esvaziada. Nota-se que a ação cooperativa entre os governos estaduais deixou de ser estimulada por instituições federais regionais, tornando-se mais dependente de iniciativas dos próprios estados e municípios envolvidos.

Neste contexto, ganha importância o papel dos governos subnacionais na promoção do desenvolvimento, devendo reunir recursos financeiros, 
humanos e de gestão para avançar nos planos de desenvolvimento econômico, social e político, ainda que não tenham condição para isso.

As teorias localistas de desenvolvimento regional fortaleceram as forças fragmentadoras da unidade nacional. A problemática federalista passa a ser tratada sob uma abordagem mais microespacial em contraponto à visão macroespacial de Celso Furtado e dos principais teóricos latino-americanos do desenvolvimento desde a contribuição da CEPAL. No entanto, entre uma visão e outra, o certo é a necessidade de se estabelecer arranjos institucionais que possibilitem a cooperação dos três entes federativos, a fim de superar as limitações dos recursos financeiros. Nem tanto a velha concepção prevalecente de que tudo se define a partir do Estado nacional, tampouco a descentralização atomística de que o poder local pode tudo.

A concretização para uma ação mais cooperativa, apesar do art. 23 da Constituição Federal de 1988 já prever ações cooperativas entre a União, os estados e os municípios, somente se deu com a construção de um arcabouço legal. Este foi instituído em 2005 como a Lei Federal dos Consórcios Públicos (Lei $\mathrm{n}^{\circ}$ 11.107, de 06 de abril de 2005), sendo regulamentada pelo Decreto $\mathrm{n}^{\circ} 6.017$ de 17 de janeiro de 2007, representando um importante avanço institucional, para além da organização federativa dos três entes (União, estados e municípios). Mesmo assim, não tem sido fácil o desafio do financiamento e da gestão a serem compartilhados de forma que os governos sobreponham os interesses coletivos aos individuais quando se trata de ultrapassar os limites da espacialidade territorial dos entes subnacionais.

Na verdade, o modelo de federalismo que busca fortalecer a coesão dos entes subnacionais precisa ser aprimorado para ampliar as ações consorciadas - previstas na legislação acima - que potencializem a capacidade de investimentos, gerem maior cooperação e estimulem o desenvolvimento regional. Embora se tenham intensificado os esforços de análise sobre o federalismo brasileiro, alguns autores ${ }^{4}$ apontam que o processo de consorciação é ainda pouco explorado, principalmente quando o objeto de estudo se volta para analisar os mecanismos de coordenação e cooperação em redes federativas horizontais.

Isto se deve ao fato de que a formação de consórcios intermunicipais e interestaduais é uma experiência recente no país, mas que pode se tornar

4 Para um exame acurado ver: Monteiro Neto (2013; 2017), Prado (2007; 2014) e Rezende $(2006 ; 2013 ; 2016)$. 
um dos traços característicos do federalismo brasileiro e um importante instrumento de política de desenvolvimento regional. Sobretudo em decorrência dos limites impostos ao Estado nacional a que se fez referência anteriormente, os consórcios públicos possivelmente ganhariam maior destaque na estrutura federativa brasileira. Neste caso, seriam importantes mecanismos de cooperação horizontal que oportunizariam o planejamento, a implementação e a gestão compartilhada de políticas públicas, visando ao desenvolvimento não apenas dos entes consorciados, mas de todo o entorno regional.

Para seus defensores, as experiências consorciadas são capazes de resgatar os conceitos de cooperação, dado que potencializam as ações de articulação intergovernamental. Neste sentido, em geral, a função dos consórcios tem sido a de possibilitar ganhos de escala de produção, racionalizando o uso dos recursos financeiros, humanos e tecnológicos por meio da cooperação entre os entes que dividem a responsabilidade da prestação de serviços públicos. Na visão de Trevas:

\begin{abstract}
Os consórcios públicos estão criando grandes expectativas. São percebidos como uma saída, para superar as limitações e insuficiências dos municípios em implementar e gerenciar serviços públicos. Para as regiões metropolitanas começam a ser visualizados como um complemento importante, ou contraponto aos arranjos de governança instituídos. Os estados tendem a considerar os consórcios públicos nos seus relacionamentos com os municípios. O governo federal vem incorporando-os em suas diferentes estratégias e programas. (TREVAS, 2013, p. 21).
\end{abstract}

Em termos conceituais, Dieguez (2011) chama atenção ao dizer que os consórcios públicos podem ser considerados uma instituição, dado que o consórcio intermunicipal, por exemplo, pode ser entendido como "uma relação contratual entre dois e mais municípios, já que sua formação altera o comportamento dos atores políticos envolvidos nessa associação e também torna mais previsível e estável a relação entre eles." (DIEGUES, 2011, p. 296). Assim, o conceito central que se destaca na definição dos consórcios públicos é justamente o de gestão associada, que está relacionado ao estabelecimento de mecanismos de vinculação entre entes federativos de acordo com um objetivo comum.

Além disso, a dimensão analítica da escala territorial sob quais os consórcios públicos atuam são questionadas, tendo em vista que as decisões tomadas refletem sobre o território. Esta é uma questão citada por Dieguez (2011), que amplia a discussão para o campo de conhecimento da geografia, posto que, quando os municípios atuam através dos consórcios, 
transforma-se a escala em que são desenvolvidas suas decisões, passando da escala local para a escala regional.

Neste sentido, o atual modelo do federalismo brasileiro abrange o desenvolvimento de ações consorciadas entre os entes federados, de forma a facilitar: a produção de infraestrutura; a regulação e a gestão dos serviços públicos; a gestão compartilhada do desenvolvimento local-regional; e a gestão das regiões metropolitanas que se tornaram áreas para as quais os consórcios públicos passaram a ter um importante desempenho no Estado brasileiro. Vale destacar que coexistem diferentes arranjos consorciados entre os entes federados que podem assumir diversos formatos, de acordo com as necessidades das partes envolvidas.

Fonseca (2013) afirma que se um determinado consórcio tiver por objetivo o "desenvolvimento regional", ele poderá estabelecer convênios de cooperação em diversas áreas (com entes federativos distintos, integrantes do consórcio). Igualmente, um mesmo ente federativo poderá integrar diversos consórcios, pactuando objetivos distintos com cada um deles. A normatização possibilitou uma variedade de formatos quanto à área de atuação, podendo sua totalidade corresponder a soma dos territórios, nos termos expostos por Fonseca:

a) aos municípios, quando formada somente por municípios, ou por um estado e municípios pertencentes a esse estado; b) aos estados ou aos estados e ao Distrito Federal, quando formado por mais de um estado, ou por um ou mais estados e o Distrito Federal; c) aos municípios e ao Distrito Federal, quando constituído por municípios e o Distrito Federal. (FONSECA, 2013, p. 38).

Os governos subnacionais, com o objetivo de ampliar sua capacidade de ação e otimizar seus recursos, aderem aos consórcios públicos por serem um instrumento de amplo alcance que abrange desde simples ações pontuais até programas de longo prazo com influência direta sobre os seus territórios. Segundo a legislação, a atuação dos consórcios com personalidade jurídica de direito público é bem extensa. Em se tratando de ações que possam transbordar os limites do território de um ente federativo, podem-se citar os exemplos: a) exercício de polícia administrativa (vigilância sanitária, inspeção agropecuária, polícia ambiental, controle de divisas etc.); b) arrecadação e fiscalização de tributos; c) atividades de fomento; d) realização de obras públicas em conjunto (investimento em construção e conservação de rodovias, ferrovias, redes de saneamento, de águas pluviais etc.); e) gestão de grandes empreendimentos (hospitais de emergência, universidades, penitenciárias etc.). 
Assim, a normatização e a regulação dos consórcios públicos incorporam maior flexibilidade e proporcionam aos entes federados a associação como, por exemplo, entre municípios não limítrofes, ou mesmo entre aqueles pertencentes a diferentes estados da federação. É notória a importância do instrumento legal, posto que, se dá caráter mais seguro à pessoa jurídica criada, legitima o compromisso firmado, já que a adesão ao consórcio possui caráter voluntário. Além disso, garante um fluxo de recursos por meio do contrato de rateio com penalização para o ente consorciado inadimplente, além, de, sob regime jurídico de direito público, possibilitar que o consórcio possa ser destinatário de recursos do orçamento da União.

Deste modo, vários estudos têm assinalado que os consórcios públicos podem ser vistos como instrumentos de cooperação com protagonismo para (re)orientar as relações intergovernamentais, sendo necessárias formas peculiares de articulação de interesses locais em torno de determinados problemas que requerem uma capacidade de gestão, definição de setores prioritários e fluxo contínuo e suficiente de recursos financeiros. Entretanto, cabe ressaltar que se nos aspectos jurídicos os consórcios públicos receberam incentivos para o aprimoramento de suas experiências, no plano institucional como "inovação" federativa torna-se importante examinar como este processo vem se manifestando.

Neste processo, o desafio implica na necessidade de se criarem espaços institucionais que, na visão de Dallabrida (2011), referem-se à concertação social' , pois o que está em jogo é a negociação, regulação de conflitos e construção de interesses coletivos. No entanto, por ser um método complexo, precisam-se considerar seus diferentes condicionantes, a fim de evitar que a cooperação seja vista como uma panaceia, já que a trajetória histórica do federalismo brasileiro retrata em grande parte uma prática centralista, dada a cultura individualista e personalista fortemente enraizada e ainda presente na atual estrutura federativa do país.

Acima de tudo, deve-se salientar que, ao privilegiar a atuação em âmbito local e/ou regional, o tratamento dado aos consórcios públicos deve estar ancorado na dinâmica do processo fundamentado em escala nacional. Isto se deve ao entendimento de que determinadas políticas só podem ser exercidas pelo Estado nacional. Como bem expõe Cano (2008,

5 Na concepção de Dallabrida (2011, p. 100), refere-se a "um processo em que membros das diferentes representações sociais, corporativas e institucionais de uma sociedade, através de procedimentos voluntários de conciliação e mediação, assumem a prática da gestão territorial de forma descentralizada." 
p. 17-18), ao dizer: "Esse culto ao poder local parece não se dar conta, por um lado, de que ele coopera ativamente para enfraquecer ainda mais o Estado nacional, [...] e, por outro [...] o poder local não faz câmbio, nem moeda, nem juros, e só administra tributos locais.”

\section{Considerações finais}

A partir das reflexões aqui realizadas, é possível extrair algumas considerações finais do objetivo inicialmente aduzido neste artigo. Em linhas gerais, pode-se afirmar que as lições históricas centradas ao longo da trajetória do federalismo brasileiro analisadas por Furtado nos ajudam a repensar os aspectos estruturais do regime federativo e a persistência da disparidade socioeconômica entre as regiões.

Assim, tomando o modelo atual da estrutura federativa do Brasil, é possível visualizar a presença simultânea de elementos competitivos e cooperativos. O processo de descentralização político-financeira da Constituição Federal de 1988 evidenciou as disputas entre as unidades subnacionais pelos fundos públicos e pelos incentivos fiscais. Ao mesmo tempo, as transferências e os fundos constitucionais como mecanismos de cooperação contribuíram para minimizar as desigualdades regionais.

No entanto, os problemas econômicos de curto prazo, como o combate à inflação e o controle dos gastos públicos, prevaleceram na agenda governamental, enquanto a elaboração de planos nacionais e regionais voltados para o desenvolvimento tiveram caráter secundário. Como resultado, tem-se o agravamento das tensões federativas com o acirramento das disputas por mais recursos e por uma redefinição de responsabilidades para os entes da federação.

Vale destacar que no ideário de Celso Furtado, a solução para os conflitos federativos viria com adoção do planejamento, pois a distribuição espacial da atividade econômica tenderia a ser menos concentrada. Furtado também deixa claro que o revigoramento do federalismo brasileiro requer o fortalecimento da instituição parlamentar. Em suas palavras: "Isso porque somente o poder que reúne os representantes do povo de todas as regiões pode dar origem a um consenso capaz de traduzir as aspirações dessas mesmas regiões em uma vontade nacional." (FURTADO, 1999a, p. 56)

A partir dessa perspectiva, coloca-se no centro do desenho da atual estrutura federativa brasileira a necessidade de barganha, de negociação e de coalizões. É principalmente no âmbito municipal que essas atitudes 
precisam ser tomadas com o objetivo de possibilitar ganhos de escala de produção, racionalizando o uso dos recursos financeiros, humanos e tecnológicos, e que alguns avanços podem ser observados pela formação e atuação dos consórcios públicos em busca de soluções de problemas comuns.

De acordo com os dados disponibilizados pela Plataforma on-line "Observatório Municipalista de Consórcios Públicos", torna-se evidente uma participação expressiva nas regiões Sudeste e Sul, onde estavam concentrados 43,6\% e 30,8\%, respectivamente, do total de 491 consórcios ativos em 2018. As demais regiões apresentavam uma menor tendência para a execução de ações compartilhadas, tendo em vista que o Nordeste respondia por $13,2 \%$, o Centro-Oeste por $10,4 \%$ e o Norte por $2,0 \%$ da quantidade de consórcios estabelecidos em seus territórios.

Os dados também permitem verificar as principais áreas de atuação dos consórcios públicos onde se sobressaíram os setores de saúde, meio ambiente, resíduos sólidos e saneamento. É possível que esta tendência esteja relacionada com a instituição de Políticas Públicas de cunho nacional, que inseriram em seu marco regulatório a prestação desses serviços públicos de forma compartilhada.

Deste ponto de vista, de certo modo, a "questão nacional" tem sido inserida no contexto dos consórcios públicos, apesar das controvérsias acadêmicas que dispõem para a escala territorial uma dimensão analítica que potencializa apenas ações de articulação microrregional. Conforme foi visto, o pensamento furtadiano representa um resgate da importância da escala nacional no planejamento, na articulação e na condução do processo de desenvolvimento da nação e suas regiões.

Nesse ponto, por ser um processo em curso, os estudos referentes a essas transformações no federalismo brasileiro ainda são incipientes, sendo necessário ampliar e aprofundar as análises da formação e do desenvolvimento dos consórcios públicos. Não cabe aqui, por ora, definir o impasse entre o macro e o micro, mas levantar a possibilidade de examinar novos paradigmas que possam ser expressos regionalmente. Talvez essa nova realidade seja mais uma das situações em que, "como deus Jano, tanto olha para frente como para trás”, como diria Furtado (1992).

Em síntese, no conjunto da obra de Celso Furtado prevalece a abordagem macroespacial do "poder regional", tendo como elemento organizador uma identidade econômico-cultural em dar estabilidade ao sistema federativo brasileiro. Já o Brasil convive com o esgarçamento de seu pacto federativo, no qual a falta de um "planejamento nacional" revela os 
impasses estruturais para a construção de um "Projeto de Nação". Tendo em vista esta realidade, finaliza-se este artigo com a célebre frase de Furtado (1999a, p. 26): "Em nenhum momento da nossa história foi tão grande a distância entre o que somos e o que esperávamos ser."

\section{Referências}

AFFONSO, R. B. A. A federação no Brasil: impasses e perspectivas. In: AFFONSO, R. B. A.; SILVA, P. L. B. (org.). A federação em perspectiva: ensaios selecionados. São Paulo: FUNDAP, 1995. p. 57-75.

BRASIL. [Constituição (1988)]. Constituição da República Federativa do Brasil: texto constitucional promulgado em 5 de outubro de 1988 , com as alterações adotadas pelas emendas constitucionais nos 1/1992 a 99/2017, pelo Decreto legislativo ํo $186 / 2008$ e pelas emendas constitucionais de revisão nos 1 a 6/1994. 53. ed. Brasília: Câmara dos Deputados, Edições Câmara, 2018. Disponível em: http://bd.camara.gov.br/bd/handle/bdcamara/15261. Acesso em: 14 abril 2020.

. Decreto no 6.017, de 17 de janeiro de 2007. Regulamenta a Lei no 11.107, de 6 de abril de 2005, que dispõe sobre normas gerais de contratação de consórcios públicos. Disponível em: http://www.planalto.gov.br/ ccivil_03/_Ato2007-2010/2007/Decreto/D6o17.htm. Acesso em: 14 abril 2020 .

Lei no 11.107, de 6 de abril de 2005. Dispõe sobre normas gerais de contratação de consórcios públicos e dá outras providências. Disponível em: http://www.planalto.gov.br/ccivil_03/_ato2004-2006/2005/lei/ l11107.htm. Acesso em: 14 abril 2020.

CANO, W. Raízes da concentração industrial em São Paulo. 5. ed. Campinas, SP: Unicamp. IE, 2007a.

- Desequilíbrios regionais e concentração industrial no Brasil 1930-1970. 3. ed. São Paulo: UNESP, 2007b.

. Desconcentração produtiva regional do Brasil 1970-2005. São Paulo: UNESP, 2008.

CONFEDERAÇÃO NACIONAL DE MUNICÍPIOS (CNM). Observatório municipalista de consórcios públicos. Plataforma On-line. Disponível 
em: http://www.consorcios.cnm.org.br/\#mapa-dos-consorcios. Acesso em: 27 abril 2020.

DALLABRIDA, V. R. (org.); ROSSETO, A. M. et al. Governança territorial e desenvolvimento: descentralização político-administrativa, estruturas subnacionais de gestão do desenvolvimento e capacidade estatais. Rio de Janeiro: Garamond, 2011.

DIEGUEZ, R. C. Consórcios intermunicipais em foco: debate conceitual e construção de quadro metodológico para análise política e institucional. In: Cadernos do desenvolvimento, Rio de Janeiro, v. 6, n. 9, p. 291-319, jul./dez. 2011.

FIORI, J. L. O federalismo diante do desafio da globalização. In: AFFONSO, R. B. A.; SILVA, P. L. B. (org.). A federação em perspectiva: ensaios selecionados. São Paulo: FUNDAP, 1995. p. 19-38.

. A propósito de uma "construção interrompida". In: TAVARES, M. C. et al. (org.). Celso Furtado e o Brasil. São Paulo: Editora Fundação Perseu Abramo, 2001. p. 33-57.

FONSECA, F. Consórcios públicos: possibilidades e desafios. In: CHERUBINE, M.; TREVAS, V. (org.). Consórcios públicos e as agendas do Estado brasileiro. Projetos para o Brasil. São Paulo: Editora Fundação Perseu Abramo, 2013. p. 29-40.

FURTADO, C. Brasil: a construção interrompida. 2. ed. Rio de Janeiro: Paz e Terra, 1992.

. O longo amanhecer: reflexões sobre a formação do Brasil. Rio de Janeiro: Paz e Terra, 1999a.

Depoimento concedido a Ricardo Ismael. Rio de Janeiro, Duração: 1 hora e 30 minutos, 9 nov. 1999b.

. Discurso na homenagem do estado da Paraíba aos seus 80 anos de idade. In: FORMIGA, M.; SACHS, I. (coord.). Seminário Internacional: Celso Furtado, a Sudene e o futuro do Nordeste. Recife: Sudene, 200o. p. 351-354.

. Formação econômica do Brasil. 32. ed. São Paulo: Companhia Editora Nacional, 2005. 
Essencial Celso Furtado. São Paulo: Penguin Classics Companhia das Letras, 2013.

GTDN (Grupo de Trabalho para o Desenvolvimento do Nordeste). Uma política de desenvolvimento econômico para o Nordeste. 2 . ed. Recife: Sudene, 1967.

INSTITUTO BRASILEIRO DE GEOGRAFIA E ESTATÍSTICA (IBGE). Censo demográfico 2010: características da população e dos domicílios. Resultados do universo. Rio de Janeiro: IBGE, 2011. Disponível em: https:// biblioteca.ibge.gov.br/visualizacao/periodicos/93/cd_2010_caracteristicas_populacao_domicilios.pdf. Acesso em: 15 abril 2020.

- Projeção da população das unidades da federação por sexo e idade para o período 200o/2030. Coordenação de População e Indicadores Sociais. Rio de Janeiro: IBGE, 2013. Disponível em: ftp.ibge. gov.br/Projecao_da_Populacao_2013/nota_metodologica_2013. Acesso em: 15 abril 2020.

Pesquisa Nacional por Amostra de Domicílios (PNAD). Síntese de Indicadores 2015. Coordenação de Trabalho e Rendimento. Rio de Janeiro: IBGE, 2016. Disponível em: https://biblioteca.ibge.gov.br/ visualizacao/livros/liv98887.pdf. Acesso em: 15 abril 2020.

. Sistema de Contas Regionais: Brasil 2016. Contas Nacionais no64. Disponível em: https://biblioteca.ibge.gov.br/visualizacao/livros/ livio1619_informativo.pdf. Acesso em: 15 abril 2020.

Estimativas da população residente para os municípios e para as unidades da federação com data de referência em $1^{\circ}$ de julho de 2018. Coordenação de População e Indicadores Sociais. Rio de Janeiro: IBGE, 2018. Disponível em: https://biblioteca.ibge.gov.br/visualizacao/livros/liv101609.pdf. Acesso em: 15 abril 2020.

INSTITUTO DE PESQUISA ECONÔMICA APLICADA (IPEA). Ipeadata, Banco de dados macroeconômicos, financeiros, sociais e regionais do Brasil. Disponível em: http://www.ipeadata.gov.br. Acesso em: 20 abril 2020.

MONTEIRO NETO, A.. Política de desenvolvimento regional: questão periférica no pacto federativo brasileiro. In: BRANDÃO, C.; SIQUEIRA, H. (org.). Pacto federativo, integração nacional e desenvolvimento 
regional. Projetos para o Brasil. São Paulo: Editora Fundação Perseu Abramo, 2013. p. 121-144.

. Federalismo e redistribuição intergovernamental de recursos no Brasil: um mapa do padrão de atuação federal no território no período recente (2000-2015) - Região Nordeste em perspectiva. In: MONTEIRO NETO, A.; CASTRO, C. N.; BRANDÃO, C. A. (org.). Desenvolvimento regional no Brasil: políticas, estratégicas e perspectivas. Rio de Janeiro: Ipea, 2017. p. 197-219.

OLIVEIRA, F. Um republicano exemplar. In: OLIVEIRA, F. A navegação venturosa: ensaios sobre Celso Furtado. São Paulo: Boitempo Editorial, 2003. p. 117-122.

PRADO, S. A questão fiscal na federação brasileira: diagnóstico e alternativas. Documento elaborado no âmbito do Convênio CEPAL/IPEA (Projeto - Brasil: o estado de uma nação). Rio de Janeiro, mar. 2007.

. Transferências intergovernamentais na federação brasileira: avaliação e alternativas de reforma. Fórum Fiscal dos Estados Brasileiros. Caderno Fórum Fiscal n. 6, 2014.

PROUDHON, Pierre-Joseph. Do princípio federativo. São Paulo: Nu-Sol: Imaginário, 2001.

REZENDE, F. Desafios do federalismo fiscal. Rio de Janeiro: Editora FGV, 2006.

O federalismo brasileiro em seu labirinto: crise e necessidade de reformas. Rio de Janeiro: Editora FGV, 2013.

Conflitos federativos: esperanças e frustações - Em busca de novos caminhos para a solução. Belo Horizonte: Fórum, 2016. (Coleção Fórum IRB).

TREVAS, V. C. Y P. Consórcios públicos e o federalismo brasileiro. In: CHERUBINE, M.; TREVAS, V. (org.). Consórcios públicos e as agendas do Estado brasileiro. Projetos para o Brasil. São Paulo: Editora Fundação Perseu Abramo, 2013. p. 15-28. 



\section{Parte IV \\ Comunicação, \\ Educação \\ e Cultura}

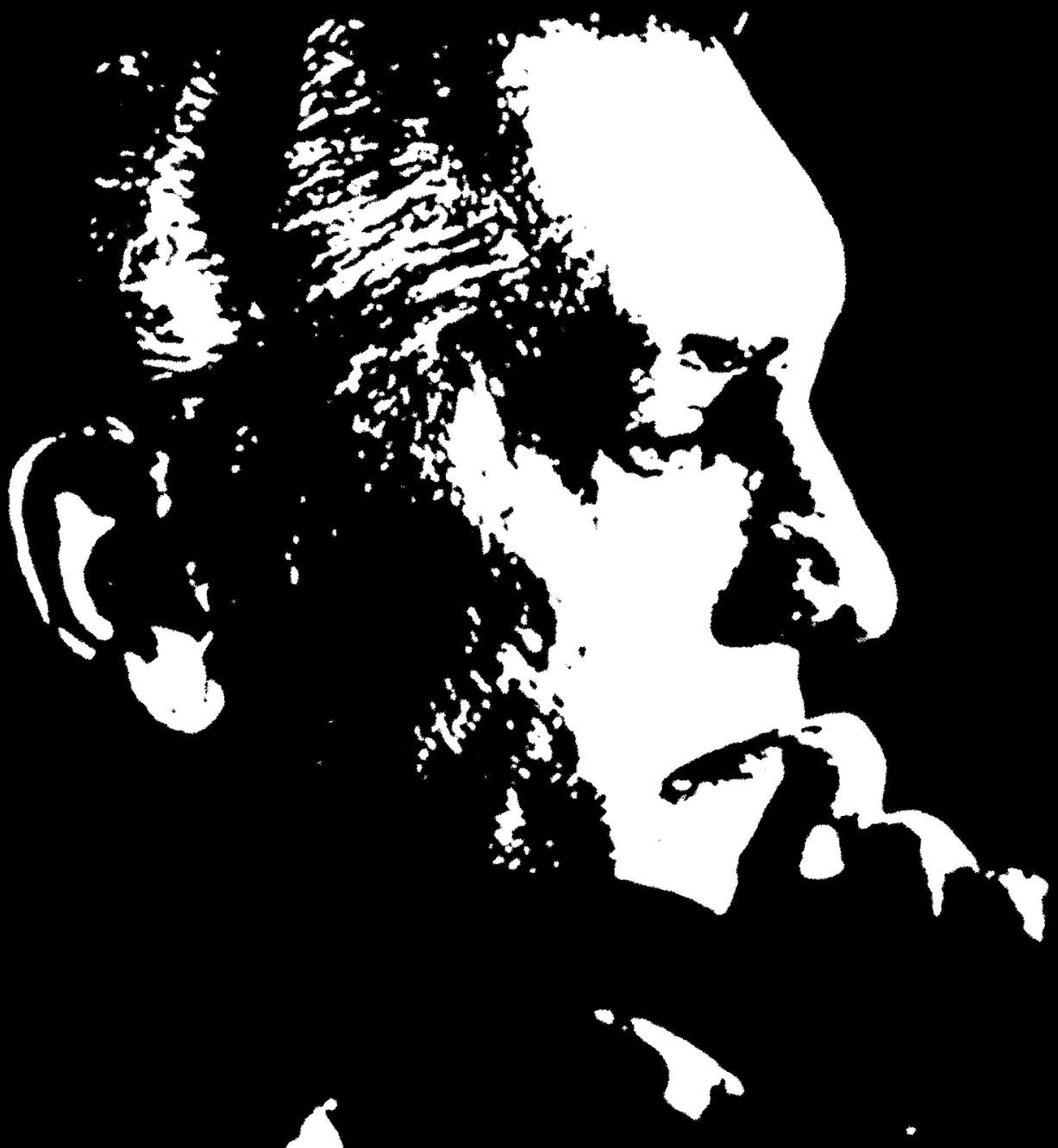





\title{
Aproximações entre estudos culturais e desenvolvimento regional: uma proposta teórico-metodológica para estudar a comunicação na interdisciplinaridade ${ }^{1}$
}

\author{
Ângela Cristina Trevisan Felippi ${ }^{2}$ \\ Grazielle Betina Brandt ${ }^{3}$
}

\section{Introdução}

Aimensão cultural no desenvolvimento regional toma do saber. Ao refletirmos sobre a relação entre cultura e desenvolvimento

1 O texto deste capítulo foi originalmente publicado na edição de volume 12, número 4, de 2016, da Revista Brasileira de Gestão e Desenvolvimento Regional, da Universidade de Taubaté/SP. Algumas atualizações foram realizadas pelas autoras. A republicação foi autorizada pela Revista e pelas autoras.

2 Graduada em Comunicação Social/Jornalismo (UFSM, 1990), Doutora em Comunicação Social (PUCRS, 2006), com pós-doutorado em Comunicação Recepção e Cultura (UCU/Uruguai, 2019). Professora dos cursos de Comunicação Social e do Programa de Pós-Graduação em Desenvolvimento Regional da Universidade de Santa Cruz do Sul. Líder do Grupo de Pesquisa do CNPq Desenvolvimento Regional e Processos Socioculturais. Tem interesse nos temas de Comunicação e Desenvolvimento, cultura e desenvolvimento, identidade cultural e territorial, políticas de cultura e de comunicação, análise do discurso, jornalismo, assessoria de comunicação e Comunicação e Política. E-mail: angelafe@unisc.br.

Relações Públicas pela Universidade de Santa Cruz do Sul (2001) e Mestre em Desenvolvimento Regional pela Universidade de Santa Cruz do Sul (2004). É doutora em Desenvolvimento Regional pela Université du Quebéc à Rimouski -UQAR (2010), Canadá. Pós-doutora no Programa de Pós-Graduação em Planejamento Urbano e Regional da Universidade Federal do Rio Grande do Sul PROPUR/UFRGS (2018). Docente e pesquisadora do Departamento de Comunicação Social e do Programa de Pós-Graduação em Desenvolvimento Regional da Universidade de Santa Cruz do Sul. Foi bolsista Fulbright no Multinational Institut of American Studies na New York University (2018). Professora visitante da New York University (2018-2019), NYU/ Steinhardt, no Programa de Educação, Cultura e Desenvolvimento. Possui experiência nas áreas do planejamento urbano e regional e temáticas ligadas a comunicação social, atuando principalmente nos seguintes temas de pesquisa: migrações, deslocamentos, desenvolvimento territorial e desenvolvimento urbano. E-mail: grazielle@unisc.br. 
regional, por exemplo, observamos que a cultura pode ser pensada enquanto produção e prática social, sendo essas expressas por meio de representações simbólicas que impregnam o espaço geográfico. A relação entre cultura e desenvolvimento regional, ainda que por demasiada complexa, pode ser entendida a partir dos esforços dos estudos culturais, assim como da geografia cultural e da chamada nova geografia cultural (CORREA, 2003), entre outras possibilidades. Mas, ao refletir sobre a perspectiva comunicacional, onde exatamente poderia se encaixar o esforço interdisciplinar que busca, na sua essência, articular a dimensão cultural dos processos sociais e o desenvolvimento regional?

É sabido que a área da Comunicação não desfruta ainda do prestígio que outras áreas possuem no campo interdisciplinar do desenvolvimento regional. Isso porque o próprio conceito de comunicação não chega a ser bem compreendido nesse campo. As oportunidades para trabalhar a relação comunicação e desenvolvimento estiveram, durante décadas, ligadas à corrente norte-americana do mass communication research, essencialmente vinculadas a estratégias desenvolvimentistas, com o intuito de interpretar a função social dos meios de comunicação na sociedade. Foi o momento em que a comunicação atuou na estruturação, implantação e controle de uma diversidade de planos desenvolvimentistas.

Com o colapso de muitos planos de desenvolvimento em diferentes regiões do mundo, especialmente as subdesenvolvidas, a perspectiva comunicacional começa a ser (re)pensada frente aos novos paradigmas vigentes. Especialmente, ao buscar entender que a comunicação se dá em um determinado contexto, ou seja, em um espaço onde o valor simbólico da cultura se expressa.

A proposta que aqui tratamos, portanto, refere-se a um esforço de inserir a perspectiva comunicacional no campo do Desenvolvimento Regional, a partir de um viés orientado para a sua dimensão cultural, que vá além da sua função orgânica, especialmente, levando em conta que a comunicação se constitui na relação entre a cultura e o espaço.

\section{Estudos culturais e sua relação com o Desenvolvimento Regional}

Os estudos culturais podem ser definidos enquanto um campo de investigação interdisciplinar, tendo como base a análise da cultura, que se consolidou na área acadêmica a partir de trabalhos que articularam pensadores em diferentes departamentos e universidades. Ao traçar uma 
cartografia dos estudos culturais, Escosteguy (2010, p. 17) observa que "existem diversos movimentos de apropriação da perspectiva dos estudos culturais, para não mencionar a anfibiedade das definições que circulam sobre os mesmos e, também, a existência de uma extensa bibliografia, sobretudo em língua inglesa, sobre o tema”.

Os precursores dos estudos culturais foram Richard Hoggart, com seu estudo do cotidiano da working class, Raymond Williams e E. P. Thompson, com estudos centrados na história material da cultura, ambientados no contexto da Inglaterra pós Segunda-Guerra mundial. Esses autores buscaram considerar a cultura num sentido mais amplo, a identidade nacional britânica passou a ser confrontada com a cultura de grupos sociais, especialmente da middle class. Sobre os "pais fundadores", Escosteguy (2010, p. 31) evidencia que, "embora não tenham uma intervenção coordenada entre si, revelam um leque comum de preocupações que abrangem as relações entre cultura, história e sociedade”.

No campo acadêmico, os estudos desses precursores foram marcados por marginalidades e fragilidades, o que fez com que esses autores se tornassem personalidades deslocadas no mundo universitário britânico (MATTELART E NEVEAU, 2004). A primavera dos estudos culturais nasce com a Escola de Birmingham, na segunda metade do século passado, marcada por estudos de intelectuais que intervém na sensibilidade das diferenças culturais, utilizando o pensamento crítico que se circunscrevia em aportes que transitavam do marxismo althusseriano à semiologia. A influência de pensadores como Antonio Gramsci, Mikhail Bakhtin, Jean-Paul Sartre e Michel Foucault é fundamental para a construção da teoria da cultura. Nesse momento, a alteridade passa a ser incorporada aos estudos com a perspectiva da identidade, etnicidade e questões raciais, com ênfase nos trabalhos de comunidades de imigrantes ou de filhos de imigrados desenvolvidos por Stuart Hall, bem como dos estudos feministas, desenvolvidos pelo grupo de estudiosas de Birmingham. Os estudos de mídia e das práticas de comunicação surgem na pauta dos estudos culturais por volta dos anos 80 , não por coincidência, associados à temática das alteridades e na emergência das indústrias culturais em meio à globalização.

A irradiação dos estudos culturais no cenário internacional se deve, especialmente, à difusão de pesquisas anglofônicas, obtendo êxito no Canadá, Estados Unidos, assim como na Austrália, sendo estas associadas aos estudos de língua e de civilização britânicas e anglo-saxônicas (MATTELART E NEVEAU, 2004). Com sua expansão, os estudos culturais 
foram se caracterizando por uma multiplicidade de objetos de investigação, numa análise cultural que necessariamente leva em consideração as relações de poder e as estratégias de mudança social (ESCOSTEGUY, 2001).

No contexto latino-americano, a penetração dos estudos culturais ocorreu a partir das escolas de comunicação e foi nomeada de American Latin Cultural Studies. Mas, se no Reino Unido ele adveio de uma "nova esquerda" repleta de questionamentos existenciais e desafios científicos, na América Latina ele se desenvolveu a partir dos anos de chumbo dos regimes militares. (MATTELART E NEVEAU, 2004).

Entre os principais estudiosos destacam-se Jesús-Martín Barbero, Nestor Garcia Canclini e Renato Ortiz. Esses autores buscaram construir seus próprios quadros conceituais apropriando-se de teóricos da cultura, provenientes da tradição europeia, não necessariamente vinculados à escola britânica, alguns deles atrelados ao pensamento franco-belga, por exemplo. De acordo com Ronsini (2011) a perspectiva das mediações de Jesús-Martín Barbero, por exemplo, buscou construir sua formação intelectual confrontando-a com os processos políticos e culturais globais para pensar a especificidade latino-americana.

Ao contextualizar os estudos culturais, nosso interesse aqui é o de melhor explorar uma aproximação com o desenvolvimento regional. Cabe evidenciar que a questão cultural no âmbito do desenvolvimento regional pode ser interpretada de acordo com as diferentes perspectivas temáticas que caracterizam essas áreas. De certa forma, reconhece-se que a cultura e o desenvolvimento regional são termos profundamente relacionados. A cidade, a região e o estado-nação constituem-se a partir de expressões e condições culturais, entendendo-se cultura como práticas de significação, permeadas por relações de poder. As questões que dizem respeito à dimensão cultural do desenvolvimento regional são complexas e manifestam-se de diferentes formas nos territórios.

Cabe mencionar que as relações entre cultura e desenvolvimento regional, não foram, até o início dos anos 9o, objeto intenso e sistemático de debate entre os pesquisadores do desenvolvimento regional. A dimensão cultural ganha espaço na área do Desenvolvimento Regional com o ressurgimento da geografia cultural nosanos8o. ParaCorrea(1999, p.51), "o ressurgimentoda geografia cultural se faz num contexto pós-positivista e vem da consciência de que a cultura reflete e condiciona a diversidade da organização espacial e suadinâmica”. Naárea dosestudosculturais, os anos 8 o foram igualmente o ponto de partida para uma expansão dos objetos 
empíricos e das referências teóricas (MATTELART e NEVEAU, 2004), assim como das possibilidades de estratégias metodológicas dos muitos objetos possíveis para a teoria da cultura, com predominância de pesquisas de natureza qualitativa.

Nesse sentido, ao levar em conta o "espaço vivido" busca-se, nos estudos da geografia cultural e humanística, levar em conta práticas, percepções, afetividades e ainda, significados distintos, segundo grupos culturais face à natureza e ao espaço social. (CORREA, 2003).

Com Haesbaert (1997) há uma confluência entre a geografia cultural e a geografia regional. Ao se dedicar a compreender o oeste baiano, esse pesquisador interpreta e analisa as profundas transformações regionais decorrentes de mudanças culturais com a imigração, discutindo características da mobilidade, da construção e da vivência dos indivíduos. No seu olhar o território territorializa-se entre significância e subjetividade.

No nosso caso, a perspectiva cultural no Desenvolvimento Regional demanda um entendimento de uma determinada prática na área dos estudos culturais. Esse entendimento pressupõe, ainda, uma vinculação entre sistemas simbólicos e relações de poder e, por sua vez, privilegia uma versão de estudos culturais que dá preferência à materialidade social da cultura e a sua dimensão simbólico-política, ao contrário de outras versões que enfatizam sua materialidade estética. (ESCOSTEGUY E FELIPPI, 2013, p. 10)

Convém ressaltar que é nos territórios onde ocorre a materialização das especificidades culturais de um determinado grupo. A partir de uma delimitação escalar é possível identificar a relação dos sujeitos com seus ambientes, visualizando identidades que se constroem na escala regional, por exemplo, até a escala do Estado- Nação.

A proposta que se segue com três protocolos metodológicos denota entradas possíveis dos estudos culturais ao campo do Desenvolvimento Regional, aqui aproximadas como sugestões para o tratamento de objetos oriundos das manifestações comunicacionais e midiáticas. Nesse sentido, diversos temas podem ser enfrentados no campo do Desenvolvimento Regional com o referencial teórico-metodológico dos estudos culturais, tais como pesquisas sobre o processo migratório, abordadas a partir da (re)construção identitária dos migrantes, observando os hibridismos, as resistências, as dominações. Pesquisas sobre as culturas tradicionais e suas identidades territoriais ou culturais (entendidas também como manifestações de comunicação) e as articulações para o desenvolvimento são outras entradas possíveis. Movimentos de resistência ou de resiliência 
a partir do enfoque cultural são, ainda, outros exemplos. Assim como o estudo das produções midiáticas das indústrias culturais sobre/para/nos territórios, observando as relações entre as institucionalidades, as tecnicidades, o consumo e suas implicações, as relações entre o massivo e o popular.

\section{Protocolos metodológicos para a comunicação no Desenvolvimento Regional}

Os estudos culturais têm permitido pensar a cultura e nela a comunicação em sua processualidade e como práticas sociais, levando em conta a integralidade do processo produtivo dos bens culturais/comunicacionais, bem como as intercessões de ordem econômica, política, social etc. Alguns protocolos metodológicos foram desenvolvidos para dar conta das relações entre produção e consumo, considerando o texto e a sua leitura, na produção cultural. Entre eles, destacamos neste artigo o circuito da cultura desenvolvido por Richard Johnson (1999), o circuito da cultura elaborado por Paul Du Gay e Stuart Hall et al (1997) e o mapa noturno/ das mediações de Jesús Martín-Barbero (2009). Vale lembrar que no campo da Comunicação, esses protocolos já têm sido utilizados.

Os protocolos mencionados são apresentados nesta reflexão com o propósito de se constituírem em possibilidades analíticas das produções culturais/comunicacionais estudadas no campo do Desenvolvimento Regional. Isso porque a perspectiva teórica que as sustenta pode ser aproximada das reflexões que têm sido desenvolvidas no Desenvolvimento Regional, não só, mas muito por conta da visão integral e complexa que propõem ao abordarem um objeto de pesquisa de natureza simbólica. Esses protocolos permitem análises que vão desde as condições de produção do bem simbólico, os seus modos de recepção e consumo ou as questões específicas de circulação dos mesmos, sempre observando as relações de poder que permeiam os circuitos produtivos. O que se oferece é uma análise cultural da comunicação no Desenvolvimento Regional.

Neste sentido, Richard Johnson elabora um diagrama, uma representação gráfica de uma proposição analítica para a cultura/comunicação, denominada de circuito da cultura (FIGURA 1). O diagrama, assim como os demais protocolos expostos neste artigo, baseia-se na descrição de Karl Marx sobre o circuito do capital e suas metamorfoses (JOHNSON, 1999). Johnson representa os momentos do processo produtivo, entendidos como sendo de produção, circulação e consumo, em que "Cada 
momento depende dos outros e é indispensável para o todo" (1999, p. 33). A visão integral e interligada que o circuito permite pretende burlar duas armadilhas da pesquisa comunicacional feita até então: a visão focada num momento do processo produtivo, que, segundo o autor, não permite olhar adequadamente os demais ou o conjunto; e o processo escondido nos produtos, ou seja, as condições de produção não visíveis ou apreensíveis nas análises que se focam no texto (no produto), por exemplo.

Figura 1: Circuito da cultura

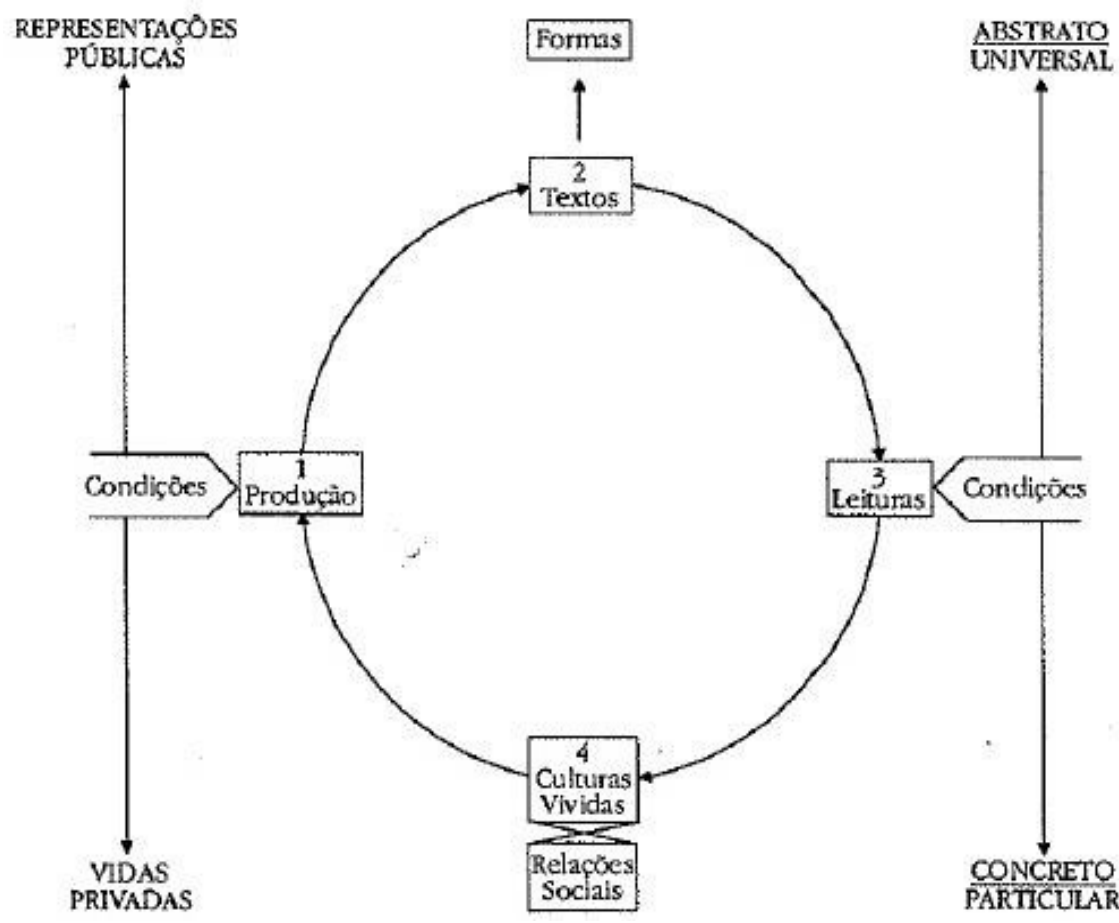

Fonte: JOHNSON (1999, p.35).

O diagrama de Johnson (1999) ${ }^{4}$ coloca o processo produtivo cultural num círculo composto de quatro momentos, Produção (1), Texto (2), Leituras (3) e Culturas Vividas (4), observando que os Textos estão sujeitos aos Formatos históricos, assim como a novas propostas de organização dos mesmos; e as Culturas Vividas estão em conexão com as Relações Sociais. Produção (entendido como o momento do fazer) e Leituras

4 Johnson analisa o lançamento do carro Mini-Metro, no final do século XX, na Inglaterra, tomado como uma mercadoria rica de significados. 
(momento da audiência, consumo ou recepção) têm condições específicas num dado tempo e espaço.

\begin{abstract}
O circuito envolve movimentos entre o público e o privado, mas também movimentos entre formas mais abstratas e mais concretas. Estes dois polos estão relacionados de forma bastante estreita: as formas privadas são mais concretas e particulares em seu escopo de referência; as formas públicas são mais abstratas, mas também têm uma abrangência maior. (JOHNSON, 1999, p. 38)
\end{abstract}

Embora o diagrama de Johnson pareça se colocar para a análise de produtos eminentemente culturais, o próprio autor o explica por meio de um exemplo do lançamento de um carro ${ }^{3}$, tomado pelo seu simbolismo e sua dimensão cultural. O que reforça nosso argumento desses, assim como os que seguem, serem protocolos analíticos bastante plausíveis para o campo do Desenvolvimento Regional, que extrapolariam inclusive o estudo dos bens comunicacionais, podendo ser tomados para outros processos vistos em sua dimensão cultural.

Assim como o autor anterior, Paul Du Gay e Stuart Hall e outros (1987) pensaram seu circuito da cultura (FIGURA 2), cujo diagrama traz semelhanças com o de Johnson, porém insere outros elementos. Du Gay et al propõe um circuito produtivo que considera a produção na relação com o consumo, intermediada pela representação, identidade e regulação. A inserção da identidade e da representação considera o fato de a produção gerar artefatos culturais carregados de sentidos, de representação sobre o mundo e as coisas, que tendem a promover processos de identificação junto aos consumidores e gerar novas ou reforçar identidades, ocasionando a regulação do social, o ordenamento das práticas sociais. O esquema salienta a subjetivação dos sujeitos presente nos atos de consumo de bens culturais, bem como a constituição de identidades.

O circuito de Du Gay et al expõe a produção como não sendo o único momento de elaboração de sentidos; como a recepção/consumo sendo também responsável pela produção de sentidos. A interligação do processo cultural/comunicativo se mostra também nesta espécie de troca ou confusão dos papeis tradicionalmente atribuídos aos momentos da produção cultural. E, ao inserir a inserção da regulação, traz uma contribuição rica ao propor pensar as normatizações na vida social decorrentes da produção e do consumo cultural, bem como da regulação que essa produção sofre do mercado, Estado e outros agentes. 
A proposta se mostra pertinente num tempo de centralidade da cultura e da comunicação, de grande produção e circulação de bens culturais e de identidades em crise. Permite estudar a construção de representações e de identidades propostas pelo mercado de bens culturais/comunicacionais para os consumidores e as implicações na prática social, assim como as políticas públicas reguladoras da cultura, incluindo as políticas para migrantes, as telecomunicações, a produção cultural, entre outras, questões pertinentes e possíveis de serem abordadas no Desenvolvimento Regional.

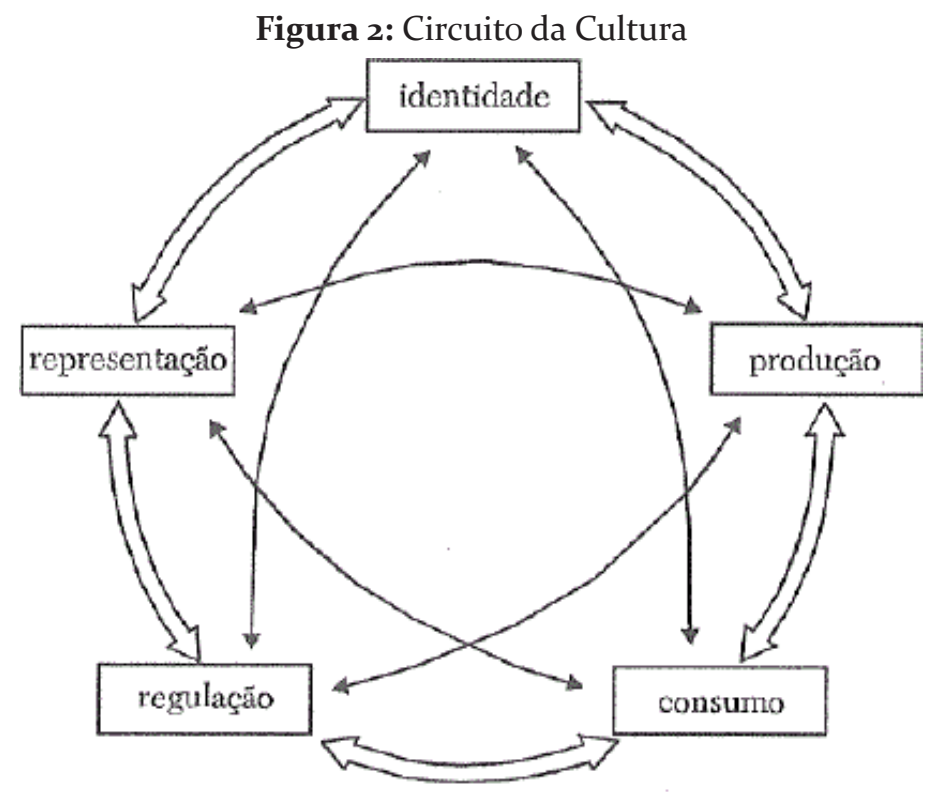

Fonte: DU GAY et al (1997, p. 3).

O terceiro protocolo metodológico proposto vem de Jesús MartínBarbero. O "mapa noturno" (Figura 3) representa graficamente uma das elaborações do autor sobre a teoria das mediações, pensada nos anos 80 e revista nas décadas seguintes. O mapa comunga com os esquemas anteriormente apresentados neste artigo na visão ampla e circular do processo cultural/comunicativo e tem sido apropriado especialmente pelo campo da Comunicação, muito embora o destaque vá para o caráter interdisciplinar da proposta das mediações, que desloca o olhar dos meios e o leva ao que o circunda, as mediações. 


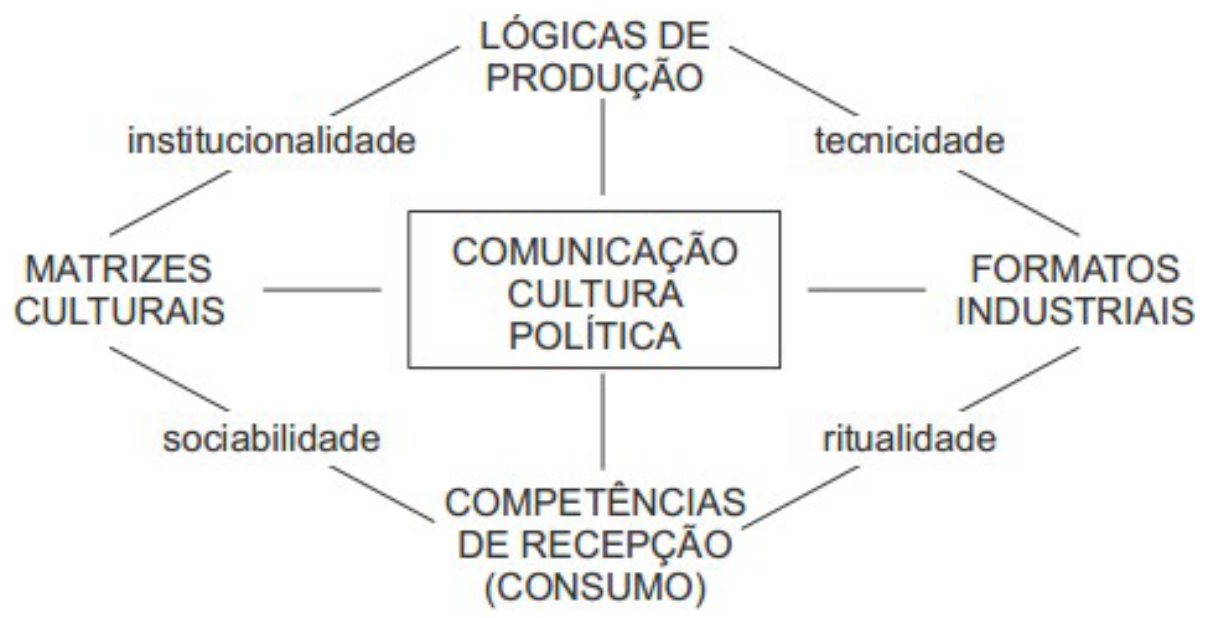

Figura 3: Mapa das Mediações

Fonte: Martín-Barbero (2009, p. 16).

Agregar a perspectiva das mediações ao processo comunicativo contribuiu para se perceber as relações entre o massivo e o popular, ou de como o popular se forjou na formação da sociedade de massa dos séculos XVIII, XIX e XX. Permite observar certa cumplicidade entre os discursos hegemônicos e subalternos, ver "[...] a constituição - ao longo dos processos históricos - de gramáticas discursivas originadas de formatos de sedimentação de saberes narrativos, hábitos e técnicas expressivas"s. (MARTÍN-BARBERO, 2009, p. 17).

Ao dar à comunicação um lugar estratégico na sociedade contemporânea, inclusive com a "hegemonia comunicacional do mercado sobre a sociedade" (2009, p. 13), o autor propõe estudar a comunicação na interdisciplinaridade com as ciências sociais, observando as "novas complexidades nas relações constitutivas entre comunicação, cultura e sociedade" (2009, p. 15). Portanto, por meio do mapa das mediações, Martín-Barbero articula os momentos do processo cultural/comunicativo e desafia a pensar que a construção de sentido na comunicação não se dá somente na produção e na recepção, mas também nas interações que o processo requer.

O mapa das mediações dispõe o processo produtivo da comunicação em: Lógicas de Produção, Formatos Industriais, Competências de Recepção (consumo) e Matrizes Culturais. E como mediações oferece a

5 Grifos nas citações da obra de Jesús Martín-Barbero são deste autor. 
Tecnicidade, a Ritualidade, a Socialidade e a Institucionalidade. O mapa sugere relações diacrônica e sincrônicas entre os eixos.

O momento das Lógicas de Produção refere-se ao fazer cultural/ comunicacional propriamente dito, quando a produção prepara os formatos. Sua compreensão articula a "estrutura empresarial, suas competências comunicativa e tecnológica”. O Formatos Industriais trazem os textos e seus gêneros correspondentes, as sugestões de leitura propostas pela produção aos receptores e atravessadas pelas mediações da Institucionalidade e da Tecnicidade, assim como ao serem propostos, têm incorporadas as Matrizes Produtivas e pensado o seu consumo. Por Institucionalidade, Martín- Barbero se refere a "uma mediação densa de interesses e poderes contrapostos, que tem afetado, e continua afetando, especialmente a regulação dos discursos (...)" (2009, p. 18), afeta a regulação dos discursos, expõe relações de poder dos grupos sociais, políticos e econômicos e suas tentativas, sucessos e fracassos na instância da produção dos meios. Vem especialmente do Estado, garante a ordem instituída e, segundo Martín-Barbero, da parte dos cidadãos, busca defender seus direitos e fazer-se reconhecer. A mediação da Tecnicidade carrega a preocupação com o "novo estatuto da técnica" (2009, p. 19) que a globalização e o desenvolvimento das tecnologias comunicacionais digitais causaram. A Tecnicidade está ligada à capacidade dos meios de inovarem tecnicamente seus formatos, à sua competitividade tecnológica ou industrial.

As Competências de Recepção são mediadas pela Ritualidade, que "remete-nos ao nexo simbólico que sustenta toda comunicação: à sua ancoragem na memória, aos seus ritos e formas, seus cenários de interação e repetição" (2009, p. 19). A Ritualidade fornece à recepção as gramáticas para a "leitura" dos Formatos Industriais. E a Ritualidade leva "aos usos sociais dos meios" (2009, p. 19).

A Sociabilidade ou Sociabilidade, situada entre as Competências de Recepção e as Matrizes Culturais, é o local em que os receptores se firmam como sujeitos, é “(...) gerada na trama das relações cotidianas que tecem os homens ao juntarem-se, é por sua vez lugar de ancoragem da práxis comunicativa e resulta nos modos e usos coletivos de comunicação, isto é, de interpelação/constituição dos atores sociais e de suas relações (hegemonia/contra-hegemonia) com o poder" (2009, p. 17). As Matrizes Culturais são o lugar do residual, do que permanece da cultura, mas que é afetado pelos movimentos sociais e discursos públicos (2009, p. 17), é onde se pode ver a relação entre os discursos hegemônicos e os 
subalternos, entre o massivo, o popular e o erudito, como os sentidos vão agindo na cultura.

A descrição dos protocolos mencionados nos permite refletir sobre o potencial de utilização dos estudos culturais no campo do Desenvolvimento Regional. Os estudos culturais, nessa perspectiva, têm a capacidade de atribuir dinamismo aos estudos que privilegiam a dimensão cultural do desenvolvimento regional. Nesse sentido, ao valerse dos protocolos metodológicos descritos, pesquisadores podem contribuir para uma melhor compreensão/conhecimento das culturas locais/ regionais/globais contemporâneas e as manifestações comunicacionais, além de questionar as formas e os efeitos da globalização sobre as culturas em campos de análise que perpassam os deslocamentos, o hibridismo cultural, bem como os refúgios identitários que se constituem. A cultura torna-se um filão que permite articular espaço e identidade, como meio de abordar os desafios sociais e políticos dos territórios.

\section{Aplicações dos estudos culturais no Desenvolvimento Regional}

Em estudos recentes envolvendo temáticas relacionadas à comunicação pesquisadas no campo do Desenvolvimento Regional, os estudos culturais vêm adquirindo relevância metodológica a partir de quadros e categorias que referenciam a cultura. Nesta seção, trazemos alguns estudos cujas abordagens foram convergentes à proposta do artigo e realizadas por professores, mestrandos e doutorandos no contexto do Programa de Pós-Graduação em Desenvolvimento Regional da Universidade de Santa Cruz do Sul (PPGDR/UNISC).

Nesta perspectiva são abordadas algumas investigações acadêmicas que centram foco nas identidades culturais ou territoriais, subjetividades, hibridismos, processos de significação, representações sociais, consumo e relações de poder que permeiam os contextos históricos, políticos e econômicos como fatores essenciais para a compreensão da cultura. Nesse sentido a comunicação expressa novas formas de ver, perceber e entrar em contato com a dimensão cultural. Para que os territórios sejam entendidos como espaços de produção e negociação de sentidos, é necessária a compreensão dos diferentes modos de comunicação, sem menosprezar os diferentes produtores e receptores desses meios.

OprotocolodeRichardJohnson (1999) foiaplicadono Desenvolvimento Regional pela dissertação de Weber (2011), intitulada $O$ relacionamento 
dos jornais impressos hegemônicos das regiões Central e do Vale do Rio Pardo/RS com os leitores e com o território. Ancorado nos estudos culturais e num diálogo com autores do Desenvolvimento Regional e do Jornalismo, buscou compreender as relações que dois impressos mantinham desde sua produção e circulação até seu consumo com seus respectivos territórios.

Nicolini (2013) teve nos estudos culturais o lastro teórico para pesquisar uma identidade territorial marcante na região do Vale do Rio Taquari, no Rio Grande do Sul, na dissertação A construção da identidade territorial a partir das manifestações culturais no Vale do Taquari: etnografia dos grupos de danças folclóricas alemãs de Estrela e do $47^{\circ}$ Festival do Chucrute. A análise de Nicolini foi direcionada para a compreensão do território e dos atores regionais na dinâmica que existe entre a dimensão global e local/regional. Em sua análise, o desenvolvimento regional, dentro da perspectiva territorial, tem como fator indissociável a questão da cultura e, consequentemente, da identidade cultural.

Freitas (2014) privilegiou as dimensões da cultura e da economia e sua relação com as indústrias culturais, especificamente a da publicidade. Sua pesquisa - A reação do regional diante do global: análise das campanhas publicitárias do Supermercado Miller e do Hipermercado Big na Região de Santa Cruz do Sul - RS, tratou do conflito estabelecido na região em estudo quando da chegada de uma rede internacional de supermercados.

Em 2015 tem-se a dissertação de Almeida, A identidade territorial gaúcha no branding das marcas regionais : caso da marca da cerveja Polar. Assim como os demais mestrandos citados, Almeida aproximou a literatura sobre território, região e desenvolvimento empregada nos estudos de Desenvolvimento Regional aos estudos culturais, dedicando-se a desvelar os processos escondidos nos produtos. No caso, conhecer a gestão da marca Polar para compreender a apropriação de uma identidade territorial por uma empresa transnacional (AMBEV) como recurso para construção de uma imagem que associa uma marca e seu produto correspondente (cerveja) a um território.

Johann (2016) associa autores do Desenvolvimento Regional aos dos estudos culturais na dissertação Fotografia e identidade territorial a partir dos jovens do Vale do Rio Pardo/RS. O propósito desta dissertação foi conhecer como os jovens da referida região constroem suas referências sobre a mesma. A produção científica dos estudos culturais sobre cultura e identidade juvenil foram fundamentais para a compreensão deste grupo social na relação com seu território. A pesquisa orignal em termos 
metodológicos pelo uso do celular e da fotografia como recurso metodológico no campo. Dois grupos de jovens foram desafiados a participar da pesquisa e fotografar por meio de seus aparelhos celulares as marcas do seu território, obviamente, a partir dos seus olhares. $\mathrm{O}$ material foi analisado juntamente com a realização de uma entrevista com questões abertas e fechadas.

Ainda, outros trabalhos no PPGDR se valeram dos estudos culturais na compreensão de fenômenos comunicacionais a partir do Desenvolvimento Regional. Um deles aciona o protocolo de Jesús MartínBarbero (2009) no estudo dos complexos processos da comunicação na saúde, tomando o caso da comunicação externa dos hospitais da região do Vale do Rio Pardo/RS. A dissertaçãode Hoss (2017) pretendeu atestar se a comunicação com a sociedade feita pelas instituições hospitalares se caracterizada como comunicação pública. A teoria das mediações, associada aos estudos sobre território, regionalização da saúde e políticas públicas na saúde e comunicação possibilita o olhar integral que se quer para compreender a comunicação hospitalar.

Outra pesquisa tomou o circuito da cultura de Richard Johnson no estudo da inovadora experiência da agência nacional de notícias Pública, valendo-se dos estudos culturais, associados ao conceito de desenvolvimento como liberdades, proposto por Amartya Sen. A autora, Oliveira (2017) se deteve nos momentos da Produção e do Texto (JOHNSON, 1999) compreendendo se o processo produtivo da Pública e as reportagens frutos desse possibilitam um jornalismo denominado de independente que potencialize as liberdades necessárias ao desenvolvimento. $\mathrm{O}$ estudo segue no doutorado, ainda em curso, com a ambição de compreender o fenômeno na sua escala latino-americana.

A dissertação de Bortoluzzi, Do Barro de A Caverna ao cobertor mostardeiro: o artesanato a partir de uma perspectiva territorial (2017) tem no "mapa noturno" de Martín-Babero seu roteiro metodológico, tomado para compreender como os capitais territoriais repercutem no processo produtivo do artesanato tradicional entendido enquanto produto da cultura popular.

Em nível de doutorado, uma pesquisa se dedicou a compreender a territorialização de uma política pública de cultura, o Vale Cultura, numa dada região do Rio Grande do Sul, tomando o protocolo de Jesús MartínBarbero. A tese focou o olhar no consumo dos bens culturais/comunicacionais viabilizados a partir da política pública que no período da produção da tese oscilou entre a fase da implantação e sua suspensão, 
com a saída da presidente Dilma Rousseff (2011-2016) da gestão federal. Foram observados os momentos do processo cultural nas suas relações sincrônica e diacrônica.

Já a tese de Almeida (2018) foi original na área ao analisar a construção de marca lugar (place branding) como potência para o desenvolvimento urbano, desconstruindo o processo produtivo de uma marca de Porto Alegre/RS, criada por ocasião da realização da Copa do Mundo no Brasil, em 2015. A originalidade se deu especialmente no aspecto metodológico, com a adoção do protocolo de Du Gay et al (1997), percorrendo o circuito produtivo da marca - produção, identidade, representação, regulação e consumo- e resultando na sua compreensão, bem como na elaboração de uma proposta metodológica de análise de marcas para a área do Desenvolvimento Regional, bem como de um conceito de marca territorial.

Ainda, a relação da juventude rural com seu território foi o tema da tese de Guerin (2017), calcada na teoria das mediações de Martín-Barbero articulada com a teoria das representações sociais. Guerin constroi também uma proposta metodológica para a compreensão das representações do rural a partir das mediações sociais e culturais, com foco no desenvolvimento rural.

E o estudo do hibridismo cultural gerado a partir da presença e do aprendizado da língua inglesa numa região com suas particularidades é tema de outra tese (PACHECO, 2017), que não chega a acionar os protocolos analíticos supracitados, no entanto enfrenta a temática com o cotejamento dos estudos culturais e as produções sobre território e desenvolvimento regional.

Por fim, destaca-se pesquisa que envolveu dois programas de pós-graduação ${ }^{6}$, com equipe interdisciplinar, que explorou as interfaces entre os estudos da Comunicação e do Desenvolvimento Regional. A investigação relatada no livro As tecnologias da comunicação no cotidiano de famílias rurais: (Re)configurações de uma ruralidade (EDUNISC, 2019) teve caráter socioantropológico e dedicou-se ao estudo do consumo das tecnologias de comunicação e informação, com ênfase no celular, no computador e na internet, por famílias da agricultura familiar da Microrregião de Santa Cruz do Sul. A pesquisa se apropriou dos diferentes mapas de

6 Um programa de Comunicação Social, da Pontifícia Universidade Católica do Rio Grande do Sul, e outro, o PPGDR/UNISC. A pesquisa teve a coordenação geral de Ana Carolina Escosteguy (PPGCOM/PUCRS) e a coordenação local de Ângela C. T. Felippi. É financiada pelos editais Universal 14/2014, MCTI/CNPq. 
Jesús Martín-Barbero como recursos analíticos e construiu um mapa na articulação desses, por dentro das duas áreas acadêmicas envolvidas na investigação. A análise associou as mediações da sociabilidade, ritualidade, mobilidade e institucionalidade às mediações do espaço, tempo e tecnologia, consideradas centrais para a compreensão da ação ativa dos sujeitos na realidade.

\section{Considerações finais}

Com base no que foi tratado percebemos que há muitos desafios para inserir a perspectiva comunicacional no campo interdisciplinar do Desenvolvimento Regional. A proposição do artigo buscou elencar os estudos culturais como possibilidade teórica e metodológica de registro da comunicação enquanto componente presente nas discussões contemporâneas sobre o Desenvolvimento Regional.

Com o intuito de evidenciar essa possibilidade, buscamos destacar alguns trabalhos de pesquisa desenvolvidos no âmbito do PPGDR/ UNISC e que se valeram dos estudos culturais para inserir a comunicação no contexto interdisciplinar do desenvolvimento regional. Nesse sentido, nos parece apropriado mencionar que os estudos selecionados e que transitam pelo desenvolvimento regional, detalham trajetórias, processos e articulações entre cultura e comunicação construídas no cotidiano de uma sociedade que se globaliza, evidenciando, sobretudo, as distintas texturas na forma de experimentar o tempo e o espaço.

Esses estudos sinalizam uma investida da comunicação, a partir de um percurso teórico-metodológico (os estudos culturais) com potencialidades de adquirir visibilidade acadêmica no campo do Desenvolvimento Regional.

Inevitavelmente, ao escolhermos um caminho, estamos expostos a determinados riscos. Contudo, nosso interesse é o de utilizar os estudos culturais, sem a intenção de abandonar as referências territoriais, atentando, por meio de sua abordagem para os fenômenos da cultura que ocorrem em determinados contextos geográficos, bem como seus desdobramentos, que podem ser traduzidos de acordo com as opções de análise privilegiadas.

Nossa atenção se foca na importância dos lugares e dos territórios. Nesse sentido, estamos nos reportando aos significados que adquire o espaço a partir da experiência pessoal de seus indivíduos. Ao considerarmos que as experiências pessoais acontecem a partir de um contexto 
espacial e temporal, evidenciamos que as identidades individuais e coletivas estão fortemente atreladas ao desenvolvimento de uma consciência territorial.

Assim, nos parece oportuna à reivindicação desse olhar cultural pelo desenvolvimento regional. A atenção à dimensão cultural nos estudos em Desenvolvimento Regional nos sugere formas da valorizar a comunicação nas discussões sobre essa área para além de uma fronteira disciplinar que a delimite, além de incentivar o debate interdisciplinar no campo do Desenvolvimento Regional.

\section{Referências}

ALMEIDA, Giovana Goretti Feijó de. Marca territorial como produto cultural no âmbito do Desenvolvimento Regional: o caso de Porto Alegre, RS, Brasil. 2018. Tese (Doutorado em Desenvolvimento Regional) - Universidade de Santa Cruz do Sul, 2018.

A identidade territorial gaúcha no branding das marcas regionais: caso da marca da cerveja Polar. 2015. Dissertação (Mestrado) - Universidade de Santa Cruz do Sul, 2015.

BORTOLUZZI, Cristiane Greiwe. Do Barro de A Caverna ao Cobertor Mostardeiro: o artesanato a partir de uma perspectiva territorial. 2017. Dissertação (Mestrado em Desenvolvimento Regional) Universidade de Santa Cruz do Sul, 2017.

CORRÊA, Roberto Lobato; ROSENDAHL, Zeny. Geografia Cultural: Introduzindo a Temática, os Textos e uma Agenda. In: CORRÊA, R. L.; ROSENDAHL, Zeny (Orgs.). Introdução à Geografia Cultural. Rio de Janeiro:BertrandBrasil,2003.p.9-18.

http://ihgrgs.org.br/artigos/contibuicoes/Roberto\%2oLobato\%2oCorr\% C3\%AAa\%20-\%2oSobre\%2oa\%2oGeografia\%2oCultural.pdf

DU GAY, Paul, HALL, Stuart et al. Doing Cultural Studies: the story of the Sony Walkman. London: Sage Publication, 1997.

ESCOSTEGUY, Ana Carolina et al. As tecnologias da comunicação no cotidiano de famílias rurais: $(\mathbf{R e})$ configurações de uma ruralidade. Santa Cruz do Sul: EDUNISC, 2019, p. 15-31. Disponível em: https://www. unisc.br/pt/home/editora/e-books?id_livro=485 Acessado em 12 set. 2019. 
ESCOSTEGUY, Ana Carolina D.. Cartografias dos Estudos Culturais: uma versão latino-americana. Belo Horizonte: Autêntica, 2010. Disponível em: http://www.autenticaeditora.com.br/autentica/cartografias_dos_ estudo s_culturais_-_uma_versao_latino-americana/41. Acessado em: 30 set. 2016.

Circuitos de cultura/circuitos de comunicação: Um protocolo analítico de integração da produção e da recepção. Revista Comunicação, Mídia e Consumo / Escola Superior de Propaganda e Marketing. V.4, n.11. São Paulo: ESPM, 2007. Disponível em: http://revistacmc.espm.br/index. $\mathrm{php} / \mathrm{revistacmc/article/view/111.} \mathrm{Acessado} \mathrm{em:} 30$ set. 2016.

Os estudos culturais. HOHLFELDT, Antonio; MARTINO, Luiz C.; FRANÇA, Vera Veiga (org.). Teorias da Comunicação: conceitos, escolas e tendências. Petrópolis, RJ: Vozes, 2001, p.151-17o. Disponível em: http://www.pucrs.br/famecos/pos/cartografias/artigos/estudos_cultura is_ana.pdf . Capturado em: 10 out. 2016.

FELIPPI, Ângela Cristina Trevisan. Jornalismo e identidade cultural: construção da identidade gaúcha em Zero Hora. Santa Cruz do Sul: Edunisc, 2008 (SérieConhecimento,46). Disponívelem: http://www. unisc.br/portal/pt/editora/e-books/61/jornalismo-e- identidade-culturalconstrucao-da-identidade-gaucha-em-zero- hora.html. Acessado em: 30 set. 2016.

FREITAS, Elísio Rodrigues de. A reação do regional diante do global: análise das campanhas publicitárias do Supermercado Miller e do Hipermercado Big na região de Santa Cruz do Sul - RS. Dissertação (Mestrado em Desenvolvimento Regional) - Universidade de Santa Cruz do Sul, 2014.

GUERIN, Yhevelin Serrano. Múltiplos olhares, múltiplas mediações: as representações sociais da ruralidade entre os jovens rurais da Microrregião de Santa Cruz do Sul. 2017. Tese (Doutorado em Desenvolvimento Regional) - Universidade de Santa Cruz do Sul, 2017.

HAESBAERT, Rogério. Des-territorialização e Identidade: a rede "gaúcha” no Nordeste. Niterói: EdUFF, 1997.

HALL, Stuart. A centralidade da cultura: notas sobre as revoluções culturais do nosso tempo. Cultura, Mídia e Educação - Educação \& Realidade. Porto Alegre, v. 22, n 2, p 15-46, jul./dez. 1997a. 
Da diáspora: identidades e mediações culturais. Belo Horizonte: UFMG, 2003.

HOSS, Lídia Schwantes. Comunicação Pública e Saúde: o processo produtivo e suas mediações na comunicação hospitalar na $13^{\circ}$ Coordenadoria Regional de Saúde do Rio Grande do Sul. 2017. Dissertação (Mestrado em Desenvolvimento Regional) - Universidade de Santa Cruz do Sul, 2017.

JOHANN, Elisângela Rüdiger. Fotografia e identidade territorial a partir dos jovens no Vale do Rio Pardo - RS. Dissertação (Mestrado) Universidade de Santa Cruz do Sul, 2016.

JOHNSON, Richard. O que é, afinal, Estudos Culturais? Belo Horizonte: Autêntica, 1999.

MARTÍN-BARBERO, Jesús. Dos meios às mediações: comunicação, cultura e hegemonia. Rio de Janeiro: UFRJ, 2009.

MATTELART, Armand; NEVEU, Érik. Introdução aos estudos culturais. São Paulo: Parábola Editorial, 2004.

NICOLINI, Cristiano. A construção da identidade territorial a partir das manifestações culturais no Vale do Taquari: etnografia dos grupos de danças folclóricas alemãs de Estrela e do $47^{\circ}$ Festival do Chucrute . 2013. Dissertação (Mestrado) - Universidade de Santa Cruz do Sul, 2013.

OLIVEIRA, Vanessa Costa. Desenvolvimento e jornalismo: a estratégia produtiva da Agência Pública na perspectiva da informação como fator de expansão das liberdades. 2017. Dissertação (Mestrado em Desenvolvimento Regional) - Universidade de Santa Cruz do Sul, 2017.

OLIVEIRA, Vinícios Gonchoroski. Democracia digital e participação cidadã: o Sistema Estadual de Participação Popular e Cidadã da Gestão do Governo Tarso Genro/RS (2011-2014). 2019. Tese (Doutorado em Programa de Pós-graduação Desenvolvimento Regional) - Universidade de Santa Cruz do Sul, 2019.

RONSINI, Veneza. A perspectiva das mediações de Jesús Martín- Barbero (ou como sujar as mãos na cozinha da pesquisa empírica de recepção). In: JANOTTI Junior, Jeder; GOMES, Itânia. (orgs). Comunicação e estudos culturais. Salvador: EDUFBA, 2011. 
WEBER, Carina Hörbe. O relacionamento dos jornais impressos hegemônicos das Regiões Central e do Vale do Rio Pardo/RS com os leitores e com o território. 2011. Dissertação (Mestrado) - Universidade de Santa Cruz do Sul, 2011.

WILLIAMS, Raymond. Culture is ordinary. In: GRAY, Ann; MCGUIGAN, Jim. (orgs). Studyine culture. London: Arnold, 1993, p. 5- 14. 


\title{
Comunicação para o desenvolvimento regional ${ }^{1}$
}

\author{
Monica Franchi Carniello ${ }^{2}$ \\ Moacir José dos Santos ${ }^{3}$
}

\section{Introdução}

$\mathrm{O}$ S ESTUDOS DE DESENVOLVIMENTO REGIONAL DEMANDAM, NECESsariamente, uma perspectiva interdisciplinar. A contribuição das distintas áreas do conhecimento foi se delineando paulatinamente, consolidando conceitualmente os paradigmas que pautam os estudos de desenvolvimento regional contemporâneos, superando a inicial disciplinaridade da Economia, área de gênese das discussões sobre o desenvolvimento em âmbito acadêmico, somada às contribuições seminais da Geografia na abordagem da regionalização. Sem minimizar a representatividade dessas áreas, reconhecendo até mesmo a impossibilidade de se pensar desenvolvimento regional sem a perspectiva econômica e espacial, os ângulos de reflexão foram se ampliando com o extrapolar dos limites dos campos do conhecimento. Para exemplificar, Dallabrida (2011) aponta como a questão cultural foi incorporada gradativamente nas discussões sobre desenvolvimento, atentando, no entanto, para a superação de uma perspectiva determinista ao apresentar escolas de pensamento distintas que validam a variável cultura como interveniente nos processos de desenvolvimento.

1 Uma versão anterior foi publicada na Revista Brasileira de Gestão e Desenvolvimento Regional, v.9, n. 2 (2013). Esta versão foi revisada e modificada pelos autores.

2 Doutora em Comunicação e Semiótica (PUC SP), professora-pesquisadora do Programa de Mestrado em Planejamento e Desenvolvimento Regional da Universidade de Taubaté, Taubaté, SP, Brasil; profesora da FATEC Pindamonhangaba. E-mail: monicafcarniello@gmail.com.

3 Doutor em História (UNESP), professor-pesquisador do Programa de Mestrado em Planejamento e Desenvolvimento Regional da Universidade de Taubaté, Rua Expedicionário Ernesto Pereira, Centro,Taubaté, SP, Brasil; professor do Centro Universitário Módulo, Caraguatatuba, SP, Brasil. E-mail: professormoacirsantos@ gmail.com. 
Observa-se uma significativa ampliação do debate sobre o desenvolvimento sob o caleidoscópio proporcionado com a interdisciplinaridade. Tal deslocamento propiciou a percepção do desenvolvimento como um processo complexo, sujeito a variáveis históricas relacionadas à cultura, a economia, ao território e às relações sociais. A compreensão do desenvolvimento como correspondente a organização da sociedade implica a necessidade de conceituá-lo como complexo, múltiplo e dinâmico. A sua investigação corresponde à compreensão das implicações conceituais e metodológicas do desenvolvimento enquanto processo histórico, pois se trata de mensurar e significar os vínculos entre economia, história, cultura, território e sociedade. Deste modo, torna-se plausível a investigação dos aspectos interdisciplinares que caracterizam a complexidade do desenvolvimento enquanto processo histórico sem negligenciar as contribuições particulares a cada área do conhecimento a ele vinculada. Enfatiza-se que a abordagem do desenvolvimento regional pauta-se na abordagem da complexidade (MORIN, 2005), por superar a abordagem simplificadora de que uma somatória de estudos de cada área do conhecimento permitiria compreender o todo, e sim ao compreender que o todo imprime dinâmicas relacionais que resultam em uma abordagem sistêmica do território.

O cenário acadêmico contemporâneo, no que tange ao desenvolvimento, constitui um mosaico que exige dos pesquisadores relacionados à sua investigação uma compreensão aguda da sua complexidade, limites e clivagens. Assim, o desenvolvimento é conceituado como desenvolvimento econômico, desenvolvimento sustentável, desenvolvimento econômico sustentável, desenvolvimento econômico regional, desenvolvimento econômico regional sustentável, desenvolvimento local, desenvolvimento local sustentável, desenvolvimento territorial e outras denominações produzidas com a especialização do debate sobre o tema com a ampliação da interdisciplinaridade e, até mesmo, embora não constitua o espoco do presente trabalho, da transdisciplinaridade.

Não se propõe a discussão da pertinência das designações destacadas - neste texto será adotada doravante o termo desenvolvimento regional -, e sim observar que o campo epistemológico relacionado ao desenvolvimento está em construção, o que exige dos pesquisadores relacionados à temática o esforço em contribuir com sua conceituação que considera a formação disciplinar para chegar em uma visão sistêmica. Essa constatação justifica a realização da reflexão quanto a relação entre a área de Comunicação Social, um foco mais específico ainda do escopo 
sociocultural de uma sociedade, e os estudos acerca do Desenvolvimento Regional. Aparentemente, e sob a perspectiva do senso comum, as interfaces podem parecer frágeis, no entanto há uma estreita relação entre as áreas. Cabe ressaltar que uma das marcas que caracteriza a revolução tecnológica do século XX é o desenvolvimento das tecnologias de informação e comunicação (TIC), que impactaram sobre os processos sociais, as formas de sociabilidade, a organização dos sistemas produtivos, as formas de se ler e registrar informação, e consequentemente, de comunicar e, sob a concepção conceitual e a prática da organização da sociedade, do que se entende por desenvolvimento.

Tal observação foi apontada em obra original de 1964 por Wilbur Schramm, que publicou um livro, com apoio da Unesco, intitulado Comunicação de Massa e Desenvolvimento. As relações entre comunicação e desenvolvimento regional foram prenunciadas por Leber (apud SCHRAMM, 1970), no entanto, Schramm pode ser considerado um marco acadêmico por explorar de maneira categórica o assunto. A persperctiva de Schramm sobre a comunicação para o desenvolvimento é difusionista, situda em um ambiente midiático caracterizado pela comunicação de massa. Conforme Servaes (2016), o modelo difusionista é verticalizado e não gera envolvimento ativo nos processos de desenvolvimento. Difusão de inovações e divulgação de projetos de desenvolvimento é o papel atribuído à comunicação nesta abordagem.

O cenário midiático contemporâneo estruturado em rede (CASTELLS, 1999) permite outras abordagens sobre a comunicação para o desenvolvimento, e fenômenos contemporâneos como as fake news e, consequentemete a pós-verdade - escolha e aceitação de narrativas que trazem segurança emocional (D’ANCONA, 2018) - demonstram que a presença intensa de meios de comunicação na sociedade não resulta, mecanicamente, em incrementos nos processos rumo ao desenvolvimento de uma sociedade.

Com base no pensamento seminal de Schramm (1970), são desenvolvidos os argumentos, de maneira a refletir sobre as relações entre Comunicação e Desenvolvimento, incluindo as abordagens de pesquisadores que voltaram o olhar para esta questão, apresentando outras abordagens para o que foi denominado de $\mathrm{C}_{4} \mathrm{D}$ (Communication for Development) e $\mathrm{ICT}_{4} \mathrm{D}$ (Information and Communication Technologies for Development). Esse aporte relaciona-se a necessidade de se contribuir conceitualmente para a caracterização epistemológica do desenvolvimento, ao distinguir entre contribuições disciplinares, 
interdisciplinaridade e a complexidade da sua historicidade. Apesar dos evidentes avanços na construção do conhecimento deste campo de investigação, depois da reflexão inicial de Schramm (1970), Heeks (2006) alerta para a necessidade de superação de adordagens descritivas para uma necessidade de teorização sobre $\mathrm{ICT}_{4} \mathrm{D}$, ao identificar que "estamos mudando o mundo sem interpretá-lo ou compreende-lo. A maioria das pesquisas de $\mathrm{ICT}_{4} \mathrm{D}$ produzidas são prioritariamente descritivas e não analíticas" [tradução dos autpres] (HEEKS, 2006, p.1).

Dines (1970), ao prefaciar o livro de Schramm (1970, p.19), exalta "o manancial inesgotável que a comunicação oferece para o desenvolvimento de um país a partir do momento em que ela for posta a serviço da motivação de uma comunidade para o progresso". Destaca-se uma potencialidade, marcada pela visão da época, entre comunicação e desenvolvimento. Cabe, com base nessa afirmação, situar como o conceito de desenvolvimentoganhou novos contornos, superando a ideia de progresso e crescimento, bem como autores que se debruçaram sobre a relação comunicação e desenvolvimento estabeleceram as conexões e aproximaram os conceitos, em uma sociedade marcada pela complexidade.

Urbanização, industrialização e a reorganização da vida
econômica, entre outros aspectos, evidenciam como a
modernidade é dinâmica, complexa e densa. O modelo
urbano como local de acolhimento à industrialização; o
adensamento da rede de transportes em escala global; o
desenvolvimento tecnológico dos meios de comunicação
e a estruturação de uma rede mundial de computadores,
ao mesmo que potencializaram a ação humana, tornaram
a sociedade mais complexa (SANTOS; CARNIELLO, 2011,
p. 287).

O pensamento de Schramm (1970) se contextualiza em um ambiente marcado pela comunicação de massa. Nas últimas décadas do século XX, o cenário midiático global foi radicalmente alterado com a emergência e difusão da tecnologia digital, que possibilitou uma transição da comunicação de massa para a comunicação estruturada em rede. Tal contexto demanda uma atualização do pensamento sobre a relação entre comunicação e desenvolvimento situado em um cenário midiático completamente reconfigurado. $\mathrm{O}$ objetivo deste texto é apresentar posibilidades de abordagens do campo da comunicação para o desenvolvimento no contexto contemporâneo.

Para tal, adotou-se uma abordagem qualitativa e natureza exploratória, fundamentada em produções bilbiográficas, e uma estrutura de subseções baseada a partir da divisão capitular do livro de Schramm, 
adaptando-a para delinear as seguintes seções: do significado humano do subdesenvolvimento ao desenvolvimento sustentável; o papel da informação no desenvolvimento.

\section{Do significado humano do subdesenvolvimento ao desenvolvimento sustentável}

Para estabelecer a relação entre comunicação e desenvolvimento no contexto contemporêneo, faz-se necessária a compreensão do constructo conceitual de desenvolvimento. O conceito de desenvolvimento é historicamente recente e adquire visibilidade no campo acadêmico após a Segunda Guerra Mundial. O debate sobre o desenvolvimento insere-se na conjuntura do pós guerra como tema fundamental para a compreensão da ordem política internacional do período e sua associação à divisão internacional do trabalho, especificamente no campo capitalista. A instituição da CEPAL pela ONU em 1948 possibilitou ampliar a investigação e a reflexão acerca das condições delineadoras do desenvolvimento econômico e social na América Latina.

Pensar historicamente o subdesenvolvimento e suas relações como derivadas da trajetória econômica e política da América Latina instigava a elaboração da crítica à ilusão da possibilidade de mimetizar com sucesso o modelo dos países hegemonicos na relação centro periferia

A CEPAL desenvolveu-se como uma escola de pensamento
especializada no exame das tendências econômicas e
sociais de médio e longo prazos nos países latinoameri-
canos. A teoria estruturalista constitui um corpo analí-
tico dedicado à análise do subdesenvolvimento da região
em três níveis: (i) condicionantes estruturais do cresci-
mento, do emprego e da distribuição da renda (as "res-
trições ao crescimento" e a dificuldade da "convergência"
aos padrões de renda e riqueza dos países avançados); (ii)
modo de inserção internacional (enfoque centro-perife-
ria); e (iii) ação estatal para promover a industrialização
e o desenvolvimento mediante programas e políticas
adequadas ao enfrentamento das dificuldades impostas
pelo quadro estrutural socioeconômico herdado da for-
mação histórica latino-americana (BIESLCHOWSKY, p.
$5-6,2020$ ).

O debate promovido pela CEPAL e que no Brasil tem em Celso Furtado (2009) o seu expoente nas décadas, evidencia que o subdesenvolvimento não é uma etapa do desenvolvimento econômico e sim uma condição histórica delineada no ambito das relações internacionais de produção e organização política. E sua superação, como sintetiza Bieslchowsky, 
implica na elaboração e aplicação de políticas aptas a promover a superação dos bloqueios derivados da formação histórica da América Latina.

A repercussão do debate sobre o subdesenvolvimento alcançou diversas área do conhecimento e se tornou um parâmetro para o debate sobre a trajetória latinoamericana em diversas áreas do conhecimento. O pioneiro na área da Comunicação Social, por buscar associá-la ao desenvolvimento, foi Schramm (1970, p.33). “[...] 'subdesenvolvido' não é um termo pejorativo. Significa apenas que o crescimento econômico (e as mudanças sociais que devem acompanhar o crescimento econômico) ainda não ultrapassou determinado ponto" (SCHRAMM, 1970, p.33).

A observação de Schramm ressalta a tensão resultante da ambiguidade do termo desenvolvimento. Sob o prisma das políticas públicas, especialmente quanto à promoção da qualidade de vida, ao acesso à educação, a saúde, a moradia e ao bem estar de maneira geral, o termo desenvolvimento é plenamente justificado. Entretanto, limitar o debate sobre o desenvolvimento a tais premissas é insuficiente em razão de que os próprios critérios que definem qualidade de vida são historicamente definidos. Tal dificuldade implica a constante alteração dos parâmetros relacionados à mensuração da qualidade de vida e não obstante faz-se necessário reconhecer que a esses termos tem comprometimento ideológico em razão do contexto histórico em que são elaborados. Outro aspecto ignorado por Schramm (1970) é o papel das economias latinoamericanas na relação centro perifieria (FURTADO, 2009) e as consequências estruturais que definem o subdesenvolvimento como resultado da divisão internacional do trabalho (MARX, 2013).

O primeiro momento de debate explícito acerca do desenvolvimento, entendido como a extensão das conquistas materiais ao conjunto da população, ocorreu no pós Segunda Guerra Mundial. A realização de políticas públicas relacionadas à efetivação do desenvolvimento corresponde a dois fatores distintos naquele contexto histórico. O primeiro derivou do sucesso da política econômica anti- crise, adotada após 1929, em âmbito internacional e baseada em ideias heterodoxas cuja principal expressão intelectual foi o economista britânico John Maynard Keynes (SILVA, 1995). No cenário econômico recessivo do início da década de 1930, as tradicionais soluções de corte liberal não alcançaram eficiência. A intervenção do Estado como agente regulador e planejador da atividade econômica, impensável antes de 1929, constituiu a estratégia mais eficaz para a superação da crise econômica. O sucesso da abordagem heterodoxa afirmou uma nova perspectiva quanto à efetivação da política 
econômica, entendida a partir daquele momento, como voltada a garantir simultaneamente o crescimento econômico e o combate aos desequilíbrios capitalistas que provocam as crises econômicas. A experiência de planejamento econômico durante a Segunda Guerra Mundial preparou toda uma geração de economistas, administradores e políticos para a aplicação eficiente dos mecanismos de regulação econômica necessária à preservação da economia capitalista.

A experiência adquirida quanto ao planejamento econômico correspondente ao combate aos efeitos da crise econômica de 1929 e as lides da Segunda Guerra Mundial alcançou relevo com a política norte- americana efetivada no pós-guerra em relação à Europa Ocidental (HOBSBAWM, 1995). Com a derrota da Alemanha, os territórios liberados por Estados Unidos e União Soviética tornaram-se áreas de influência das respectivas superpotências. Deste modo, o leste europeu constitui zona de exercício do poder e liderança soviética, enquanto o oeste europeu experimentou a liderança norte-americana. Essa divisão respeitava os acordos firmados na Conferência de Teerã, em 1943, que estabeleciam as áreas de influência das superpotências no futuro pós-guerra. Entretanto, o papel relevante do Exército Vermelho na guerra de desgaste que destruiu os exércitos nazistas no leste europeu, possibilitando a vitória de modo mais rápido na frente ocidental e também a liderança dos comunistas na resistência à ocupação nazista, como na França e na Grécia, tornaram os partidos comunistas populares na área de influência americana. O prestígio dos comunistas, no início da Guerra Fria, preocupava os norte-americanos. O cenário de crise econômica, resultante da destruição material e de vidas humanas, efetivado durante o conflito, provocava temor quanto à vitória em eleições ou mesmo revoluções lideradas pelos comunistas. A memória quanto à contribuição da crise internacional de 1929 para a ascensão de regimes autoritários e totalitários em escala mundial ainda era recente, particularmente quanto a Adolf Hitler. Urgia, sob a perspectiva norte-americana, agir para evitar a repetição do cenário, especialmente quanto à perda de regimes aliados na Europa Ocidental.

O Plano Marshall consistiu na resposta norte-americana as ameaças que esse cenário apresentava. Durante vários anos foram disponibilizados recursos para os países da Europa Ocidental que integraram o plano. Ao todo o governo norte-americano disponibilizou para os Estados participantes 13 bilhões de dólares, que em valor atualizado supera 130 bilhões de dólares (JUDT, 2008). O Plano Marshall favoreceu a recuperação econômica dos principais países europeus, favorecendo um longo ciclo 
de crescimento econômico, que durou até o inicio da década de 1970, quando a crise do petróleo e as mudanças cambiais promovidas com o rompimento do acordo de BrettonWoods por parte dos Estados Unidos provocou uma nova crise econômica em escala mundial.

A associação entre as medidas heterodoxas aplicadas a política econômica pós 1929 e também no espectro da Segunda Guerra Mundial com o Plano Marshall, provocou a constituição do debate sobre o desenvolvimento enquanto elevação da qualidade de vida da população. O Estado de bem estar social tornou-se um modelo mundial em razão do sucesso que vários países europeus lograram em simultaneamente promover o crescimento econômico e a distribuição da riqueza produzida entre a população, elevando o nível de vida mediante a melhora dos indicadores relacionados à educação, saúde, moradia, acesso ao trabalho digno e lazer. O modelo da Europa ocidental tornou-se parâmetro de desenvolvimento. Mundialmente estruturou-se um debate sobre como se alcançar o desenvolvimento. Políticos e pesquisadores de diversas áreas, bem como as respectivas populações passaram a entender o desenvolvimento como uma premissa social, política e econômica.

Porém, esse debate suscita duas questões. Primeiro como alcançar o desenvolvimento. A resposta a essa indagação, que no período imediatamente posterior à Segunda Guerra Mundial, parecia repousar na efetivação da industrialização e do correspondente crescimento econômico se fez rapidamente quando o modo de industrialização da América Latina efetivou-se.

Furtado (1961) formulou a tese da tendência à continuidade do subemprego - e, consequentemente, do subdesenvolvimento - ao longo do processo de industrialização. Às interpretações cepalinas prévias sobre tendências ao desequilíbrio estrutural na balança de pagamentos e à inflação, somava-se agora a evidência da instalação de uma nova modalidade de pobreza e desequilíbrio social, crescentemente urbana, e simultânea à modernização promovida pela industrialização. (...) Esse é o momento em que se inaugura a tradição cepalina de vincular pobreza e distribuição de renda à evolução das disparidades na produtividade e na remuneração do trabalho entre pessoas, setores e regiões - a heterogeneidade estrutural, interpretada como resultantes das condições históricas herdadas e da evolução corrente do mercado de trabalho (BIESLCHOWSKY, p. 13, 2020).

A observação acima exposta torna evidente a necessidade de se evitar a confusão entre os conceitos desenvolvimento econômico, crescimento 
econômico e desenvolvimento enquanto processo social global. No contexto histórico do pós Segunda Guerra Mundial essas distinções não eram evidentes, mas o avanço do Estado de bem estar social popularizava a expectativa sobre a possibilidade real de se distribuir melhor a riqueza, o que obliterava as condições estruturais da América Latina e a divisão internacional do trabalho.

A segunda questão remete exatamente ao que se define como desenvolvimento, afinal, as conquistas atribuídas ao Estado de bem estar social situam-se em relação a um modelo político e econômico inserido em uma ordem mundial capitalista cuja característica fundamental é desigualdade espacial na produção e distribuição da riqueza. O sucesso dos países da Europa Ocidental, dos Estados Unidos e do Japão remete à centralidade destas economias em relação às demais e ao acesso desigual aos recursos tecnológicos, econômicos e bélicos que fundamentam a ordem política internacional. E subjacente ao que se define como desenvolvimento está o questionamento da possibilidade de se replicar o modelo do Estado de bem estar social por meio de um sistema econômico que se reproduz a partir da divisão desigual no acesso aos recursos econômicos.

Em relação a esse questionamento, Arrighi (1997) evidencia que o modelo de desenvolvimento predominante remete ao desempenho econômico alcançado por países que estão na vanguarda capitalista, tradicionalmente percebidos no escopo das ciências sociais como centrais na dinâmica econômica e política internacional, notadamente os Estados Unidos, os países da Europa Ocidental que lideram a União Europeia e o Japão. $\mathrm{O}$ fosso econômico entre tais nações e os demais Estados nacionais implica, para Arrighi, em uma condição praticamente intransponível, uma vez que a inovação tecnológica que caracteriza perenemente a modernidade capitalista é controlada de maneira exclusiva por aqueles que concentram não apenas a riqueza material, mas a própria produção de conhecimento, tecnologia e inovação, que de fato possibilitam o predomínio das economias capitalistas avançadas.

Arrighi (1997) retoma a reflexão de Marx acerca do impulso tecnológico e econômico pautado na inovação constante que atinge a composição das relações de produção e o próprio ordenamento das forças produtivas. Schumpeter (1982) atribuiu exclusivamente à inovação tecnológica a capacidade de romper a tendência à estagnação econômica do sistema capitalista, pois negligenciou, no afã de compreender os mecanismos que estimulam o crescimento econômico, a constituição das relações de produção e das forças produtivas relacionadas ao sistema econômico. Marx 
(2013), assertivamente, percebeu que o espectro ideológico tem papel preponderante na aplicação da inovação tecnológica, historicamente inserida e cujos efeitos correspondem a sua inserção na ordem social e política.

Deste modo, a produção do espaço capitalista é histórica e geograficamente localizada, com a respectiva concentração da riqueza no que tange as dimensões espacial, social e funcional. Harvey (2011) observa que a circulação do capital constitui o mecanismo principal de reprodução do capitalismo e sua ampliação corresponde aos desequilíbrios do sistema, especialmente as crises econômicas. Para Harvey (2011) a reprodução do capital decorre de uma ambiguidade intimamente relacionada ao caráter cíclico das crises econômicas no capitalismo. A expansão do capital depende de sua concentração espacial em determinada região ou país quanto à disponibilização dos recursos financeiros, materiais e tecnológicos necessários à elevação da riqueza, o que potencialmente dificulta sua circulação e o aumento do consumo. Deste modo, os períodos de bonança econômica correspondem ao crescimento da riqueza e a elevação do consumo em virtude da bem sucedida incorporação de mercados consumidores e trabalhadores submetidos à hierarquia espacial e funcional da atividade econômica, porém na medida em que cada ciclo atinge seus limites técnicos e econômicos advém a crise em função da redução da circulação do capital correspondente a obtenção do lucro almejado com o ciclo de produção e consumo.

As contribuições promovidas por Marx, Arrighi e Harvey acerca das nuances do desenvolvimento capitalista indicam a superficialidade da oposição entre desenvolvimento e subdesenvolvimento. Percebe-se que a adoção desta oposição redunda em uma interpretação marcada por uma perspectiva linear, vinculada a um empirismo incapaz de perceber que esses termos vinculam-se uma dinâmica histórica que supera a mera distribuição dos recursos materiais. A adoção de um posicionamento que compreenda o desenvolvimento como um processo global permite situá-lo nos limites das contradições estruturais e históricas do próprio capitalismo. Atingir o que se considera o desenvolvimento implica transcender a miragem que o estágio de organização social e política que as economias centrais alcançaram. Não se trata de negar as efetivas conquistas que beneficiaram as populações dos países considerados desenvolvidos, ameaçadas nas últimas décadas com adoção do neoliberalismo por diversos Estados, especialmente na Inglaterra e nos Estados Unidos, mas de se contextualizar historicamente e socialmente essa conquista. 
Tal percepção é essencial para se construir formas de desenvolvimento não associadas à reprodução global das disparidades capitalistas, uma vez que o Estado de bem estar social pautava-se na concentração social, espacial e funcional da renda e da riqueza típica da divisão internacional do trabalho no pós-guerra.

O rompimento gradual com essa perspectiva, dado à extrapolação do pensamento acadêmico para a sociedade e a fatos como intensificação das estruturas comunicacionais e sociais em redes, diagnosticadas e analisadas por Castells (1999), tornou o termo subdesenvolvimento superado. O cenário contemporâneo caracteriza- se por uma maior fluidez das informações e dos processos de comunicação, tanto no que tange a comunicação interpessoal e no acesso ao lazer quanto no que concerne a difusão do conhecimento. É necessário reconhecer que em comparação ao período imediato do pós-guerra, quando se iniciaram os debates relativos ao desenvolvimento, ainda confundido com crescimento econômico, ocorreram avanços importantes, especialmente na problematização do desenvolvimento. Torna-se necessário mediar o avanço do debate acadêmico relativo ao desenvolvimento em sua acepção global para o conjunto da sociedade e também direcionar as estruturas comunicacionais e em rede como vetores da implantação de processos de desenvolvimento que rompam com o modelo gerador de assimetrias espaciais e sociais que caracteriza o capitalismo.

Apesar das limitações inerentes ao contexto histórico de elaboração de sua obra, Schramm (1970) percebeu que a variável que incide diretamente sobre o desenvolvimento é a industrialização. A reprodução espacial e histórica das assimetrias relativas ao capitalismo vincula-se ao processo de industrialização, cuja pujança, por sua vez, depende da liderança no que concerne aos processos de inovação necessários ao rompimento da tendência a estagnação econômica que o processo de acumulação capitalista possui. A distinção aplicável universalmente quanto à forma de efetivação daquilo que se entende por desenvolvimento, conforme Schramm (1970), não é racial, geográfica ou temporal, e sim está diretamente ligada ao processo de industrialização. Tal afirmação torna necessária a compreensão de como se delimitaram, na segunda metade do século XX, os conceitos de crescimento econômico e desenvolvimento econômico, necessários para permitir uma melhor leitura sobre os efeitos da industrialização em determinada região. Para Perroux (1981) o crescimento é o aumento de uma unidade, mensurada geralmente em escala país, e medido pelo produto nacional bruto em referência ao número de 
habitantes. Tal equação não revela os efeitos do setor produtivo no país ou qualquer outra escala regional, pois um país pode ter um representativo aumento do Produto Interno Bruto sem que haja melhorias nos indicadores sociais, diretamente relacionados à melhoria da qualidade de vida. Sen (2000) corrobora tal perspectiva ao relacionar desenvolvimento com liberdade do indivíduo, e para que este esteja apto ao exercício da liberdade, deve ter as condições socioeconômicas equacionadas.

\begin{abstract}
Para Amartya Sen (1999), desenvolvimento econômico significa aquilo que os agentes econômicos usufruem a partir de suas posses, e não necessariamente ter mais posses. Uma região desenvolvida é aquela em que os indivíduos podem desfrutar das liberdades individuais, para atender a seus desejos, associada ao comprometimento social institucional. Uma atuação mais direta dos indivíduos contribui para a formação de um capital social, resultante do clima de confiança estabelecido entre os membros de uma comunidade. Os contatos sociais entre os membros de uma determinada sociedade facilitam, além das questões econômicas, a disponibilidade dos sujeitos para atender às necessidades da coletividade (VIEIRA; SANTOS, 2012, p. 349).
\end{abstract}

Schramm (1970), no entanto, expressa a representatividade da questão social, que compõe os objetivos do desenvolvimento atualmente. "Se quisermos promover o desenvolvimento econômico, deverá haver uma transformação social, e, para que isso ocorra, devemos mobilizar os recursos humanos, e os problemas difíceis de ordem humana deverão ser resolvidos" (SCHRAMM, 1970, p.32). Ora, a sociedade se organiza mediante o uso do instrumental e da carga ideológica inerente aos processos de comunicação. Se houve mudanças representativas nos recursos e fluxos comunicacionais, isso vai incidir diretamente na maneira como a sociedade se organiza.

Exposto esse cenário conceitual, parte-se para a discussão sobre as relações entre Comunicação e Desenvolvimento.

\title{
O papel da informação no desenvolvimento
}

Schramm (1970) utiliza o termo informação para estabelecer seus argumentos. Apesar de o acesso à informação não garantir que o processo de comunicação seja eficaz, é fato que a disponibilização de informação para a sociedade é elemento fundamental em sociedades democráticas, estas consideradas por Sen (2000) como contexto necessário para o desenvolvimento. Sen compreende o acesso a informação e garantias de 
trasparência como uma das liberdades constitutivas para minimizar as barreiras que impedem o exercício das capacidades dos indívíduos.

\begin{abstract}
Com a reformulação do conceito de desenvolvimento no final do século 20 , uma vez que conceitos estão sujeitos à historicidade, a relação entre cultura e desenvolvimento se delineia de maneira mais explícita em distintas escolas de pensamento, das quais se destaca a abordagem sobre capital social [...]. A premissa dessa concepção baseia-se na existência de redes de relações formais e informais que, pautadas na cooperação e reciprocidade, são elementos de fomento ao desenvolvimento. Os estudos contemporâneos sobre desenvolvimento indicam as práticas participativas como elementos constitutivos dos processos de desenvolvimento regional. (CARNIELLO; SANTOS, p. 171, 2011)
\end{abstract}

A perspectiva difusionista não é suficiente para situar a comunicação como elemento relacional na sociedade. Autores posteriores a Schramm desenharam abordagens participativas da comunicação para o desenvolvimento, que enfatizam a democratização e participação no diversos níveis (SERVAES, 2016).

Os fluxos de comunicação não se realizam de modo abstrato, pois estão vinculados aos processos sociais que os definem. A comunicação é uma variável fundamental para se investigar se o desenvolvimento em uma conjuntura regional ou nacional supera o espectro econômico e abrange aspectos relacionados às demais varáveis que caracterizam o desenvolvimento global. Para se investigar o desenvolvimento é necessário situá-lo de modo permanente na conjuntura da dinâmica capitalista para se entender as características de sua consecução em um determinado momento histórico e espacialidade. Essa atenção é fundamental se observar se as políticas públicas relacionadas à efetivação do desenvolvimento correlacionam-se a medidas contrárias a tendência de reprodução da desigualdade presente no capitalismoou se de fato a combatem.

Tal abordagem se reflete na estrutura de mídia nacional, que com base na proposta de categorização de Hallin e Mancini (2004) classificase como modelo Mediterrâneo ou pluralista polarizado, caracterizado por: baixos níveis de circulação de jornais; protagonismo da mídia privada; politização da radiodifusão pública e da regulamentação da radiodifusão. O protagonismo das empresas comerciais no cenário nacional resultam em uma distribuição dos veículos de comunicação nas regiões que se constituem como bons mercados, o que gera condições de acesso que reproduzem as desigualdades econômicas, na cobertura jornalística desigual, gerando desertos de notícias. A pesquisa Atlas da Notícia 

demonstra revela que $62 \%$ dos municípios não têm cobertura noticiosa e $18 \%$ da população carece de acesso a jornalismo local.

Segundo a pesquisa TIC domicílios (CGI, 2018), a internet está presente nos lares de $99 \%$ de pessoas da classe econômica A, enquanto apenas $40 \%$ dos lares das classes $\mathrm{D}$ e E estão conectados à Internet.

A questão estrutural aparece nos modelos de análise de Heeks (2010), que apresenta uma cadeia de valor da ICT4 $\mathrm{D}$, que passa pelas etapas de prontidão (readiness), disponibilidade (availability), captação (uptake) e impacto (impact). Considera-se, neste modelo, pré-requisitos tais como infraestrutura, habilidades, políticas públicas, os processos de implantação, bem como os impactos tanto na escala local quanto na ampliação dos processos de desenvolvimento. Nota-se, na perspectiva de Heeks (2010), uma nítida superação da pesrpectiva difusionista e um olhar que privilegia não apenas a presença ou ausência de processos mediados de comunicação, mas de uma visão processual de abordagem qualitativa, que busca compreender como ocorre determinato processo.

A abordagem sistêmica também se revela no framework de análise proposto por Kleine (2013), que aproxima o debate da comunicação a abordagem de desenvolvimento proposto por Sen (2010), ao buscar compreender em quais condições a presença de tecnologias de informação e comunicação podem contribuir para a ampliação das liberdades humanas. Tal perspectiva se afasta tanto do modelo difusionista quanto do participativo, aproximado a comunicação como um possível vetor para o alcance do bem-estar social, finalidade última do desenvolvimento.

A configuração midiática contemporânea acrescenta elementos ao processo de comunicação, não previstos por Schramm (1970) e que, portanto, constituem uma importante oportunidade para se refletir acerca do papel das novas formas de comunicação quanto ao entendimento do desenvolvimento e das contradições históricas, sociais e espaciais que permeiam sua efetivação. Com a difusão do sistema de comunicação digital em rede - Internet - um dos aspectos que adquire evidência é a acessibilidade à informação. A característica da rede é que seus usuários, potencialmente podem divulgar e acessar informações e participar de grupos formais e informais por meio da ferramenta comunicacional, caracterizando o que foi denominado por Castells (1999) de sociedade em rede, ou também chamada de sociedade da informação.

Alguns efeitos podem ser discutidos a partir dessa nova configuração midiática, que supera a sociedade de massa vivenciada e observada por 
Schramm. Serão destacados os seguintes efeitos ou aspectos: a exposição da regionalidade; a funcionalidade do acesso à informação para tomada de decisão e promoção da transparência; a potencial aproximação da sociedade com o governo por meio do acesso à informação rumo a governança; e a formação de espaços de diálogos públicos da sociedade nas mídias como possível vetor de ampliação das capacidades de indivíduos e grupos. Tais aspectos não são únicos nem excluem outras possibilidades de relações entre comunicação e desenvolvimento, mas são opções devido sua representatividade nos processos de desenvolvimento. Ressalta-se que as potencialidades dos meios de comunicação para o desenvolvimento nem sempre se efetivam, pois esse processo não é indissociado das relações de poder nem dos projetos políticos vigentes. Menciona-se o uso perverso da mídia no fenômeno contemporâneo das fake news, que deixa explícito que a mera disponibilidade e o acesso a meios de comunicação necessariamente não resulta movimentos rumo ao desenvolvimento, que não é um processo linear.

Quanto a exposição da regionalidade, em um contexto de globalização também dos processos comunicacionais, ou de mundialização, conforme aponta Augée (1994), ao mesmo tempo em que processos econômicos e financeiros ganham dimensões globais, as regiões tornam-se mais visíveis para o mundo, exatamente pelo fato de as informações de cada localidade do planeta estarem acessíveis a todos. O mundo está inteiro mapeado, mensurado e explicitado (mas não necessariamente analisado). Além disso, uma localidade tem um potencial de projeção e divulgação de sua imagem ou características pelas mídias sociais digitais, se deparando com uma possibilidade inexistente em um contexto comunicacional anterior. A visibilidade potencial é um fator de grande relevância, viabilizado por meio dos meios de comunicação. Também se estabelece a relação entre mídia na própria configuração dos territórios, que demarcam ou omitem aspectos identitários. Melo, Sousa e Gobbi (2006) exploram a questão da mídia regional e suas relações com o desenvolvimento, com detaque a abordagem feita por Melo (2006) ao propor a formulação de um conceito midiático de região, que evidencia a relação entre comunicação e desenvolvimento.

A facilidade de distribuição e, consequentemente, acesso a informação, é um dos elementos fundamentais para o desenvolvimento, sob diversas perspectivas. A primeira delas diz respeito à oferta de dados para tomada de decisão por parte de gestores públicos, para a função fiscalizatória da sociedade, bem como para o diagnóstico das regiões. Gerar 
dados, ainda que com todos os limites inerentes aos indicadores sociais (GUIMARÃES; JANUZZI, 2005), é fundamental para a compreensão e diagnóstico das lacunas de uma localidade, região ou país, constituindo elemento fundamental para a gestão pública, nos processos decisórios e na elaboração de políticas públicas. Essa disponibilização de informação cabe esclarecer, não necessariamente fomenta a participação da sociedade ou traz soluções imediatas, mas é um direito do cidadão e uma condição para o desenvolvimento, conforme afirma Sen (2000), ao relacionar o desenvolvimento aos ambientes políticos democráticos.

Observa-se o esforço de acadêmicos e setor público na
busca de gerar informações, manifestadas por indicadores,
que sejam capazes de aferir o desenvolvimento de regiões
em suas várias dimensões. É o caso da iniciativa do governo
de Sarkozy, França, ao formar e incumbir uma comissão
para estabelecer discussão e diretrizes sobre o que deve ser
aferido em uma região para avaliar seu desenvolvimento
(STIGLITZ; SEN; FITOUSSI, 2010).

Um terceiro aspecto que diz respeito à geração e disponibilização de informações à sociedade

[...] vê-se que a tecnologia da informação pode constituir-se em instrumento de apoio à administração pública, ao permitir o oferecimento de novos serviços aos cidadãos, ao oferecer condições para ampliação da eficiência e da eficácia dos serviços públicos, ao melhorar a qualidade dos serviços prestados e ao permitir acesso à informação e à constituição de novos padrões de relacionamento com cidadãos e novos espaços para promoção da cidadania. (CUNHA, FREY, DUARTE, 2009, p.197).

Mais do que a disponibilização de informação que instrumentalizam o cidadão para a função fiscalizatória, o que foi chamado por Schramm (1970) de função de vigilância da Comunicação, as mídias sociais digitais podem estreitar um possível diálogo entre sociedade e governo, o que converge com a função política também apontada pelo autor. Tal função política encontra dois obstáculos potenciais. O primeiro diz respeito à própria alienação da sociedade dos processos participativos. $\mathrm{O}$ não empoderamento dos espaços e canais de participação política dificulta a democratização do desenvolvimento e os meios de comunicação, especialmente os digitais constituem meios de empoderamento, mas somente o serão mediante a ação social.

O segundo diz respeito a possibilidade constante e historicamente efetivada, de uso não democrático dos meios de comunicação, com o 
propósito de alienação política da população. Schramm (1970) não nega essa possibilidade, admitindo não apenas o potencial, mas os precedentes históricos que justificam essa percepção. Mais uma vez observa-se que os processos de comunicação e os meios de comunição não estão descontextualizados do contexto político e histórico de sua inserção. Trata-se de perceber que há o potencial para contribuição com políticas relacionadas ao desenvolvimento em sua acepção mais global e não apenas econômica. Esse potencial é ampliado no cenário contemporâneo com a amplitude de acesso e debate que os meios de comunicação digital possibilitam. As barreiras relacionadas à efetivação deste potencial relacionam-se a própria desigualdade no acesso aos recursos de comunicação, especialmente os digitais. Cabe ao poder público, mas também a organizações civis e partidárias atuar no sentido de democratizar o acesso aos meios de comunicação, especialmente em um momento de facilitação do acesso a comunicação digital.

No ambiente midiático contemporâneo, apesar de os meios de comunicação de massa exercerem grande influência sobre a opinião pública e, no caso do Brasil, se organizarem em grandes conglomerados de mídia privados articulados com grupos políticos (ALBUQUERQUE, 2008) as mídias sociais digitais se apresentam como um espaço de discussão pública, na qual os contrapontos e contradições da sociedade tornam-se visíveis, pois permitem tanto que a empresas de mídia estendam ampliem sua comunicação, mas permitem também que grupos da sociedade, mais ou menos organizados e/ou institucionalizados, apresentem suas manifestações, configurando-se potencialmente como, no mínimo, grupos de pressão. Partindo da informação que "todo estágio da sociedade possui seu estágio próprio de comunicação" (SCHRAMM, 1970, p.74), cabe destacar que no estágio atual da comunicação midiática o cidadão, de maneira formalizada ou não, possui voz ampliada pela mídia, mesmo que em meio a uma guerra de discursos não isenta de manipulações, como o caso das fake news anteriormente mencionadas.

Foram sistematizadas algumas perspectivas atuais a partir das funções da comunicação apontadas por Schramm, que indicam a representatividade da geração de informações e dos fluxos de informação para disseminar essas informações para os processos de desenvolvimento. Para Schramm (1970), a quantidade de informação disponível e a amplitude de sua distribuição constituem fatores-chave do desenvolvimento. Entende-se que esta etapa avançou de forma significativa em relação ao cenário midiático analisado por Schramm (a despeito das desigualdade 
de acesso que persistem conforme anteriormente mencionado). O que se descortina, em um contexto de conexão em rede, são ou usos e apropriações possíveis que possam fomentar processos de desenvolvimento.

Quando Schramm refletiu sobre o fluxo de informações no mundo, a realidade se referia a um sistema midiático pautado na comunicação de massa. "Quando uma sociedade começa a se modernizar, um dos primeiros sinais do desenvolvimento é a dilatação dos canais de comunicação" (SCHRAMM, 1970, p.129).

No contexto da comunicação digital, os fluxos de informação se intensificam e passam a operar sob a perspectiva de rede. Em relação a dilatação dos canais de comunicação, apesar de haver ainda controvérsias sobre o sistema de regulação das telecomunicações no Brasil, principalmente no que tange às concessões e aos grandes conglomerados de mídia, é inegável que alguns avanços gradativos tem ocorrido. A Lei de Acesso à Informação (BRASIL, 2012) representa um desses avanços. Ainda que seja difícil mensurar seus resultados, o marco legal é fundamental por ser o balizador para as reivindicações e pressões da sociedade pelo direito de se manter informada, condição fundamental para o seu desenvolvimento.

Do pensamento seminal de Schramm (1970), notam-se avanços significativos na compreensão das relações entre comunicação e desenvolvimento, manifesta, de forma mais direta ou indireta, nas obras de Heeks (2006,2010), Servaes (2016), Sen (2010), Kleine (2013), Melo, Sousa e Gobbi (2006).

\section{Considerações finais}

A reflexão sobre a relação entre Comunicação e Desenvolvimento, localizada em um contexto midiático fundamentado na comunicação digital, remete a uma discussão epistemológica, fundamental para delimitar os paradigmas dos estudos sobre desenvolvimento.

Seria ingênuo recortar o objeto demasiadamente, sem antes pontuar as explícitas relações, e também contradições, entre a formação do conceito de desenvolvimento em um sistema capitalista. Tal caminho, escolhido nesse texto, visa superar, ou reflexionar, sobre o conjunto de estudos produzidos, em sua maioria metodologicamente suportados por estudos de caso, com o objetivo de teorizar sobre a comunicação para o desenvolvimento. Tais investigações são fundamentais para a caracterização e formação de um acervo sobre estudos regionais que, em sua totalidade, permitem a análise e constituem-se base para obras que sistematizem os 
casos estudados, originando obras de síntese, tal qual o livro de Schramm, na década de 1960, que serviu de base para a reflexão aqui proposta.

Elaborada essa necessária exposição da historicidade à qual está sujeita a concepção conceitual de desenvolvimento, pontuaram-se algumas possíveis interfaces entre Comunicação e Desenvolvimento, que ampliam as ou reconfiguram as funções da comunicação para o desenvolvimento observadas por Schramm no final da década de 1960.

No percurso dos estudos de comunicação para o desenvolvimento, observam-se três abordagens que se desenharam: a difusionista, a participativa e a do bem-estar social. Evidências históricas demonstraram também que a mera presença de um sistema de mídia em uma região não garante seu uso em prol do desenvolvimento regional, mas constituiu uma etapa estutural que precisa ser associada a outros fatores, estes indissociados das estruturas e processos sociais vigentes.

Espera-se que a reflexão aqui apresentada estimule a continuidade da construção da delimitação do campo de pesquisas na área, posto que a visão multidimensional do desenvolvimento insere definitivamente a comunicação como um elemento constitutivo dos processos de desenvolvimento de uma sociedade.

\section{Referências}

ALBUQUERQUE, Afonso de. A mídia como "poder moderador": uma perspectiva comparada. Compós. 2008. Disponível em: http://www. compos.org.br/data/biblioteca_305.pdf Acesso em: 17 fev. 2020.

ARRIGHI, G. A ilusão do desenvolvimento. São Paulo: Vozes, 1997.

AUGÉ, Marc. Não-lugares: introdução a uma antropologia da supermodernidade. Campinas: Papirus, 1994.

BIESLCHOWSKY, Ricardo.DO“MANIFESTOLATINO-AMERICANO”DE RAUL PREBISCH AOS DIAS DE HOJE: 70 ANOS DE ESTRUTURALISMO NA CEPAL. Rev. econ. contemp., Rio de Janeiro , v. 24, n. 1, e202411, 2020 . Available from <http://www.scielo.br/scielo.php?script=sci_arttext\&pi$\mathrm{d}=\mathrm{S} 1415-98482020000100200 \& \operatorname{lng}=\mathrm{en} \& \mathrm{nrm}=\mathrm{iso}>$. access on 8 May 2020. Epub Apr 27, 2020. http://dx.doi.org/10.1590/198055272411. 
BRASIL. Lei de Acesso à Informação - Lei n ${ }^{\circ}$ 12.527/11. 18 nov. 2011. Disponívelem:http://www.planalto.gov.br/ccivil_03/_ato2011-2014/2011/ lei/l12527.htm> Acesso em: 21 out. 2012.

CARNIELLO, M.F.; SANTOS, M.J. Predisposiçãopara Formaçãode Capital Social entre Comerciantes dos Corredores Comerciais da Região Central do Município de São José dos Campos - SP. Revista Desenvolvimento em Questão, ano 9・n. 18・jul./dez. • 2011 p. 169- 195.

CASTELLS, Manuel. A sociedade em rede. São Paulo: Paz e Terra, 1999.

CGI. Pesquisa TIC Domicílios 2018. Disponível em: https://www.cetic.br/ pesquisa/domicilios/ Acesso em: 15 maio 2020.

CUNHA, Maria Alexandra. DUARTE, Fábio. FREY, Klaus. (Org.). Governança Local e as Tecnologias de Informação e Comunicação. Curitiba: Champagnat, 2009.

DALLABRIDA, V.R. Economia, Cultura e Desenvolvimento: uma primeira aproximação sobre as origens teóricas da abordagem do tema. Revista Brasileira de Gestão e Desenvolvimento Regional. v. 7, n.2,2011. Disponívelem:< http://www.rbgdr.net/revista/index.php/rbgdr/article/ view/432> Acesso em: 28 maio 2013.

D’ANCONA, Mathew. Pós-verdade. Barueri: Faro editorial, 2018.

DINES, A. Prefácio. In: SCHRAMM, W. Comunicação de massa e desenvolvimento. Rio de Janeiro: Bloch, 1970.

FURTADO, Celso. Desenvolvimento e subdesenvolvimento. Rio de Janeiro: Centro Celso Furtado / Contraponto, 2009.

GUIMARÃES, J. R.S.; JANUZZI, P de M. IDH, indicadores sintéticos e suas aplicações em políticas públicas. Revista Brasileira de Estudos Urbanos e Regionais. V. 7 , N. 1, maio 2 o o 5 Disponível em: < http:// www.anipes.org.br/cursos/pdf/fontes_indicadores/ind_idh_pot_li mites.pdf> Acesso em: 15 jun 2009.

HALLIN, Daniel C.; MANCINI, Paolo. Comparing Media Systems: Three Models of Media and Politics. Cambridge: Cambridge University Press, 2004.

HARVEY, D. O enigma do capital. São Paulo: Boitempo, 2011. 
HEEKS, Richard. Doinformation and communication technologies (ICTs) contribute to development? Journal of International Development, 22(5), 625640, 2010. Disponível em: http://onlinelibrary.wiley.com/doi/10.1002/ jid.1716/abstract Acesso em: 18 maio 2020.

HEEKS, Richard. Theorizing ICT4D Research. The Massachusetts Institute of Technology Information Technologies and International Development. Volume 3, Number 3, Spring 2006, 1-4.

HOBSBAWM, E. A era dos extremos. São Paulo: Companhia das Letras, 1995 .

INSTITUTO PARA O DESENVOLVIMENTO DO JORNALISMO. Atlas da notícia. 2019. Disponível em: $<$ https://www.atlas.jor.br/> Acesso em: 19 dez.2019.

JUDT, T. Pós-guerra: uma história da Europa desde 1945. Rio de Janeiro: Objetiva, 2008.

KLEINE, Dorothea. Technologies of Choice? ICTs, development, and the capabilities approach. Cambridge/ London: MIT Press, 2013.

MARX, Karl. O capital. São Paulo: Boitempo, 2013.

MELO, José Marques de; SOUSA, Cidoval Moraes de; GOBBI, Maria Cristina. Regionalização midiática: estudos sobre comunicação e desenvolvimento regional. Rio de Janeiro: Sotese, 2006.

MELO, José Marques de. Por um conceito midiático de região. In: MELO, José Marques de; SOUSA, Cidoval Moraes de; GOBBI, Maria Cristina. Regionalização midiática: estudos sobre comunicação e desenvolvimento regional. Rio de Janeiro: Sotese, 2006

MORIN. Edgar. O Método 1, 2, 3, 4, 5,6 (Coleção). Editora Sulina, 2005.

PERROUX, F. Ensaio sobre a filosofia do novo desenvolvimento. Lisboa: Fundação Calouste Gulbenkian, 1981.

SANTOS, M. J.; CARNIELLO, M. F.;, E. A. A. Q. O. Comunicação digital na gestão pública dos municípios da RMVP: acesso à informação, transparência e mecanismos de participação. REVISTA BRASILEIRA DE DESENVOLVIMENTO REGIONAL, BLUMENAU, 1 (1), P. 167-184, 2013. 
SANTOS, M. J.; CARNIELLO, M. F. Por uma história do desenvolvimento. Revista Brasileira de Desenvolvimento Regional. v. 7, n. 3, p. 279295, set-dez/2011, Taubaté, SP, Brasil. Disponível em: <v. 7, n. 3, p. 279295, set-dez/2011, Taubaté, SP, Brasil > Acesso em: o1 nov. 2011.

SCHRAMM, W. Comunicação de massa e desenvolvimento. Rio de Janeiro: Bloch, 1970.

SCHUMPETER, Joseph A. (1911). A teoria do desenvolvimento econômico. São Paulo: Abril Cultural, 1982.

SEN, A. Desenvolvimento como liberdade. São Paulo: Companhia das Letras, 2000.

SERVAES, Jan. Communication for Development and Social Change. New Delhi: SAGE, 2007.

SILVA, Antonio Carlos Macedo e. A economia de Keynes, a busca de uma nova teoria econômica e a "armadilha do equilíbrio". Economia e Sociedade, Campinas, (5):111-58, dez.1995. Disponível em: http://www. eco.unicamp.br/images/arquivos/artigos/434/o5-ACARLOS5.pdf Acesso em: 19 maio 2020.

STIGLITZ, J.E.; SEN, A.; FITOUSSI.J.-P. Mis-measuring our lives. New York, USA: The New Press, 2010.

VIEIRA, E. T.; SANTOS, M. J. Desenvolvimento econômico regional - uma revisão histórica e teórica. Revista Brasileira de Gestão e Desenvolvimento Regional. v. 8, n. 2, p. 344-369, mai-ago/2012, Taubaté,SP,Brasil.Disponívelem:< http://www.rbgdr.net/revista/index. php/rbgdr/article/view/679> Acesso em o1 set. 2012. 


\title{
A Educação como fator de desenvolvimento regional ${ }^{1}$
}

\author{
Flávio Eliziário de Sousa ${ }^{2}$ \\ Mariane Freiesleben ${ }^{3}$
}

\section{Introdução}

TEMA QUE NORTEIA ESTE TEXTO RELACIONA EDUCAÇÃO E DESEN-
volvimento regional que, a nosso ver, agrega a homenagem prestada ao cientista social Celso Furtado. A sua vasta produção intelectual abarca tanto questões teóricas sobre os obstáculos ao desenvolvimento das economias periféricas, como também as interpretações históricas sobre a formação econômica latinoamericana e do Brasil. Um autor que ao longo de suas pesquisas associou economia, com desenvolvimento e educação.

Estando a frente de seu tempo, compreendia que os problemas econômicos não podem ser separados dos condicionantes socioculturais e

1 Este texto foi publicado no formato de artigo em 2018 pela revista da FAE, com o mesmo nome.

2 Doutorando em Economia - Universidade do Vale do Rio do Sinos (Unisinos - RS). Mestrado-profissionalizante em Gestão de Políticas Públicas pela Universidade Federal do Tocantins (UFT). Especialista em Gestão Pública e Sociedade pela UFT. Graduado em Administração pela mesma instituição. Docente do Instituto Federal de Educação, Ciência e Tecnologia do Tocantins. Atualmente é Diretor do IFTO-Campus Paraíso do Tocantins. E-mail: flavioeliziario@ifto.edu.br.

3 Doutoranda em Desenvolvimento Regional - pela Universidade Federal do Tocantins. Mestre em Ciências do Ambiente - pela UFT (2015); Pós-Graduada em Educação a Distância com Habilitação em Tecnologias Educacionais - Instituto Federal de Educação, Ciência e Tecnologia do Paraná, IFPR (2016), e em METODOLOGIA. DO ENSINO DA GEOGRAFIA APLICADA AO PLANEJAMENTO AMBIENTAL pela Universidade Estadual do Maranhão, UEMA (2005); Graduada em Geografia pela Universidade Estadual do Maranhão (2004). Autora do livro POR UMA GEOPOÉTICA DA PAISAGEM NA PRÁTICA DIDÁTICA. 1. ed. Curitiba: Appris, 2019. v. 1. 124p.; entre outros. Docente no IFTO - Instituto Federal de Educação, Ciência e Tecnologia do Tocantins - Campus Paraíso do Tocantins. E-mail: mariane@ifto.edu.br. 
políticos que sobredeterminam, rejeitando o enfoque cosmopolita dos problemas econômicos. Para Celso Furtado, o Estado nacional ancora a unidade de referência de sua teoria do desenvolvimento econômico. E neste contexto coloca a educação como sendo um fator preponderante para o desenvolvimento local, regional e/ou mundial. Sendo o objetivo central deste, propiciar elementos para uma análise bibliográfica de vários autores, destacando os desvios que viabilizam conclusões acerca do assunto.

Entende-se que o planejamento regional deve basear-se em estudos científicos com metodologia adequada, até porque dentro das finalidades da administração científica conforme Taylor (1995), baseado na pirâmide social, é dado o enfoque onde os trabalhadores por meio da sua renda poderão melhorar seu padrão de vida, e que além da possibilidade do trabalhador por meio de seu trabalho e renda desfrutar de uma vida familiar e social mais feliz, também usufruir de condições de trabalho salutares, tanto social como individualmente satisfatórias.

Este mesmo enfoque também constitui o índice que mede o desenvolvimento Humano o IDH, que é facilmente calculado, sintético e de simples aplicação, formado por 3 elementos essenciais como a longevidade, grau de escolaridade e renda per capta, e que mesmo apesar de críticas continua sendo o principal instrumento de aferição para o desenvolvimento econômico de um país (MACHADO e PAMPLONA, 2008).

Pensando no contexto do desenvolvimento regional e nas possibilidades de sua realização acredita-se ser o Estado e a educação os principais potencializadores desta ação. O presente artigo é resultado de pesquisa qualitativa, de natureza exploratória, apoiada, fortemente, em revisão de literatura (livros, artigos em periódicos), com ênfase temática concentrada na relação educação e desenvolvimento regional.

\section{O Estado como principal agente do desenvolvimento}

Cavalcante (2007) em seu artigo: Desenvolvimento regional: principais teorias, aborda que entre as teorias estudadas a industrialização é colocada como um dos principais meios para se alcançar o desenvolvimento, pois suas relações em cadeia impulsionam as principais atividades econômicas da região atingida. Mas Durkhein (1999) alerta que essas relações também contribuem para o enfraquecimento da consciência coletiva e das crenças comuns manifestadas nas similitudes, nos costumes e nos hábitos que ocorreram na solidariedade contratual, aumentando, também, o 
desenvolvimento em volume e densidade da divisão do trabalho, o que propicia a necessidade de agentes na construção deste desenvolvimento.

Como a organização da sociedade vem da divisão social do trabalho, tem-se uma solidariedade orgânica, uma socialização, um grau de consenso produzido entre os indivíduos, o cimento que une os indivíduos, decorrente da evolução humana e da diferença dos papeis sociais (DURKHEIN, 1999). Fato este, que coloca o Estado como o "cérebro-espinhal" do organismo social, cujo poder regulador ramifica-se numa difusão constante e crescente por toda extensão da vida social, por meio dos códigos, regras jurídicas e instituições. Posteriormente, com o poder da "tutela", passa a representar o instrumento real do mecanismo da sociedade industrial (DURKHEIN, 1999).

Para Polany (200o), foi o Estado que criou o comercio interno na Europa Ocidental, sendo chamado de comércio municipal que funcionava como um comércio de vizinhança, de forma que o comércio a longa distância não podia infiltrar-se de qualquer forma, devido às barreiras criadas pelo Estado que impedia a competitividade, mas favorecia o mercado nacional. Deixando claro que sem a intervenção estatal no comércio não haveria desenvolvimento do mesmo. Em Fligstein e Dauter (2012) é possível encontrar a afirmação, que de acordo com a teoria institucional ${ }^{4}$, a troca mercantil contratual depende do Estado, para definir, sancionar as regras e também os produtos que são apropriados para troca.

De acordo com Fligstein (2003), os mercados e o Estado estão fortemente ligados, pois a legitimidade dos mercados é dada pelos Estados, que por meio das políticas implantadas intervém nos mercados (formação, estabilização e transformação), assim também como o próprio desenvolvimento mundial, que ao longo do tempo sempre adotou instituições como por exemplo a $\mathrm{ONU}^{5}$, o $\mathrm{BIRD}^{6}$ e o $\mathrm{FMI}^{7}$, que atuam como organismos maiores de controle e organização de desenvolvimento para o mundo, fomentando por meio de relatórios alternativas para os países mais pobres (MADUREIRA, 2015).

Assim, é possível concluir, em tese, que o Estado é uma organização de natureza política, constituído por leis que regulamentam a vida em

4 Segundo esta teoria as organizações são levadas a incorporar as práticas e procedimentos definidos pelos conceitos que predominam no ambiente organizacional e que estejam institucionalizados na sociedade (FLIGSTEIN e DAUTER, 2012).

5 Organização da Nações Unidas.

6 Banco Internacional para Reconstrução e Desenvolvimento

7 Fundo Monetário Internacional. 
sociedade, e tem como um dos objetivos principais realizar fins de forma a sanar as necessidades da vida do homem, na busca pelo bem estar comum.

\section{O que se entende por desenvolvimento regional}

As implicações e o alcance do desenvolvimento regional variam de acordo com a definição de uma região, e de como a região e seus limites são percebidos internamente e externamente. Por isso pensar em desenvolvimento regional é alocar a participação da sociedade local no planejamento continuo da distribuição dos frutos e ocupação do espaço neste processo de crescimento (OLIVEIRA e LIMA, 2003).

Entre as teorias que discorrem sobre o desenvolvimento regional temos: a teoria da localização, que baseada nos baixos custos com transportes, impulsiona o crescimento econômico; e a teoria dos lugares centrais fundamentada nos fatores de aglomeração, que se justifica por meio da indústria como impulsionadora de polos de crescimento heterogêneos no espaço geográfico, onde o crescimento possui intensidades variáveis, diversificando os canais e efeitos finais sobre a economia (CAVALCANTE, 2007; CIMA e AMORIM, 2007). E são justamente estas teorias do desenvolvimento regional que viabilizam o suporte às políticas econômicas que impulsionam a sociedade regional.

Assim também como os objetivos do desenvolvimento regional que ao longo do tempo foram modelados, de forma a atingirem atualmente fundamentações nos seguintes aspectos: 1) combater as assimetrias regionais; 2) aproveitar os recursos e potencialidades endógenos das regiões; 3) promover o ordenamento do território; 4) garantir a participação dos cidadãos na resolução dos problemas regionais (DINIZ, 2009). Tais objetivos se fundamentam na condição de que a aplicação do desenvolvimento regional deve atentar-se a melhorias que facilitem a elaboração de um conjunto de medidas de incentivo e suporte necessário ao crescimento econômico da região.

O ramo da ciência que se dedica ao estudo do Desenvolvimento Regional, juntamente com suas teorias apresenta o Estado como um importante fomentador desse processo. E para Cavalcante (2007):

(...) Em que pese a redefinição do seu papel no período recente, o Estado dispõe ainda de instrumentos de intervenção que vão da provisão de infra-estrutura à concessão de benefícios fiscais e financeiros, e não parece haver ainda 
indicações claras quanto ao efetivo papel que poderia ser desempenhado por cada um desses instrumentos nos esforços para a promoção do desenvolvimento regional. Por essa razão, uma estratégia voltada para a promoção do desenvolvimento econômico e social de espaços subnacionais terá que ser necessariamente individualizada, não havendo uma diretriz única aplicável a todas as regiões (p.29).

Entende-se assim que o desenvolvimento regional é uma necessidade de gerir eficazmente os fatores de desenvolvimento, seja no melhor uso dos recursos como na garantia de uma maior participação dos diferentes atores, como também na busca de soluções para os problemas criados pela dinâmica da economia global, principalmente no tocante aos desequilíbrios espaciais.

Nesse sentido para um melhor entendimento conclui-se que o grande protagonista deste processo são os atores locais, na formulação de estratégias, na tomada de decisões econômicas e sua implementação, pois o desenvolvimento regional é o conjunto dos diferentes desenvolvimentos locais, não se resumindo a um processo de estímulos nacionais em uma dada localidade. E o Estado por sua vez utiliza as teorias do desenvolvimento regional para dar suporte às políticas que aplicam na sociedade (MADUREIRA, 2015). E para que os atores locais possam agir adequadamente, é preciso conhecimento, para buscar entendimento, garantindo assim escolhas eficientes para a gestão local e ou regional.

\section{A Educação como influência para o desenvolvimento regional}

Entende-se que as normas que orientam a vida dos indivíduos na sociedade, e que passam de geração a geração são denominadas fatos sociais, e é essa consciência coletiva que rege uma comunidade, assim compreende-se que um conjunto de costumes, que por sua vez resultam na forma de solidariedade de um ser com o outro. Por isso nossa sociedade é marcada por uma altíssima divisão do trabalho social, onde a interdependência entre os indivíduos é resultante da especialização, podendo assim ser denominada solidariedade orgânica (DURKHEIN, 1999).

Vivemos em sociedades complexas, que possuem diferentes interesses e conflitos. Desta forma, nossa convivência é administrada por meio de interesses públicos. E que a política surgiu com o intuito de propiciar o bem comum dos cidadãos integrando à sociedade. Os fatos sociais estão na sociedade e caso não sejam seguidos existirão sanções. Até mesmo dentro do contexto da educação observa-se o papel de produção 
e reprodução do ser social, seja no contexto da família ou social (amigos e escola): consiste num esforço continuo de imposição à criança de maneiras de ver, sentir, ideias a seguir e formas de agir às quais ela não teria chegado espontaneamente (DURKHEIM, 1999).

Pensando na política como um conjunto de procedimentos formais e informais que expressam as relações de poder, buscando a resolução pacífica dos conflitos relacionados aos bens públicos, para Nazzari et al (2004 P.3) "O capital social apresenta-se como uma alternativa para superar os valores sociais e culturais que impedem a adaptação de políticas sociais que visem o bem comum".

Atualmente, tem-se na educação uma das dimensões mais importantes para o desenvolvimento do país. Ela atua como valorização e empoderamento dos cidadãos, permitindo o fortalecimento e a eficácia das redes de capital social priorizando o desenvolvimento regional (NAZZARI et al, 2004), por meio da aquisição de conhecimentos o indivíduo aumenta sua renda, sua qualidade de vida e consequentemente ocorre o crescimento da nação, ainda que seja um processo lento e necessite de constantes ajustes.

Pensando em educação encontramos em Adam Smith (2012) que:

Considera-se como algo de grande importância que um número adequado de jovens seja educado em certas profissões, propósito para o qual foi criada, as vezes pelo Estado, às vezes pela caridade de entidades privadas, uma quantidade de pensões, bolsas de estudo etc., que atiram nessas carreiras muito mais gente do que as que pretendiam segui -las em condições normais. [...] Os que seguem tal carreira nem sempre, então, conseguem uma recompensa proporcional a uma educação que leva tanto tempo, estudo e despesa, pois a igreja se vê abarrotada de gente que, para obter emprego, está disposta a aceitar uma remuneração muito inferior a que poderia de outro modo aspirar, com uma educação análoga; e assim a concorrência dos pobres arrebata a remuneração dos ricos (p. 167).

Neste caso aborda-se a preocupação educacional pela via da qualificação, cujo papel central é aumentar a produtividade, uma vez que a maioria da população se presta a exercer atividades rotineiras. De acordo com Smith (2012, p. 127) "Numa sociedade civilizada, são apenas os extremamente pobres que fazem por ofício o que outra sorte de pessoas procura por passatempo".

O mesmo autor deixa claro que a educação também beneficia a economia de maneira indireta, pois as pessoas instruídas são mais conscientes 
na cadeia produtiva, os trabalhadores são ordenados e colaboram com a hierarquia das posições econômicas. Isso porque:

\begin{abstract}
Na Inglaterra e em todos os países católico-romanos, a loteria da igreja é na realidade muito mais vantajosa do que seria necessário. Bastam os exemplos da Igrejas da Escócia, de Genebra, e muitas outras igrejas protestantes, para nos convencer de que, numa profissão tão prestigiosa, na qual a educação é de tão fácil acesso, a perspectiva de benefícios muito mais módicos lançará nas ordens sacras um número suficiente de homens cultos, decentes e respeitáveis (SMITH, 2012, p.169).
\end{abstract}

Ainda considerando "que o homem se constrói homem no e pelo trabalho” (SANTOS, 2010, p. 59) insere-se que a educação dá acesso à ciência e à tecnologia, fornecendo às pessoas meios para entender o mundo e seu papel nele. De acordo com os autores Silva e Amorim (2012), que escreveram um artigo sobre o Pensamento Sociológico de Max Weber e a Educação, deixam claro que "A Educação é, segundo Weber, o instrumento que propicia ao homem a preparação necessária para o exercício de atividades funcionais adequadas as exigências das mudanças ocasionadas pela racionalização que o homem irá se deparar socialmente" (2012, p.1).

Para Santos (2010) o que determina o modo de viver do homem é como ele atua para produzir sua existência. $\mathrm{O}$ homem que não domina o processo produtivo, não é o proprietário do produto de seu trabalho, e não seria a relação entre educação e trabalho, uma condição fundamental para o desenvolvimento econômico, até porque em suas pesquisas nos anos de 1970/80 o Brasil chegou ao patamar de oitava economia mundial, e não tínha índices de educação e trabalho animadores na Amazônia. $\mathrm{Ou}$ seja, o Brasil cresceu economicamente, porem não evoluíu no grau de escolaridade, na produção de conhecimentos.

Para o autor, mesmo nos anos seguintes existindo políticas focalizadas para a educação e o trabalho, que eram e ainda são incipientes, fragmentadas e descontínuas, isso não propiciou o desenvolvimento econômico para a Amazônia, e em 2009 novamente o Brasil atingiu o patamar de oitava economia do mundo, agora com mais prestígio no mundo desenvolvido (SANTOS, 2010). Isso porque embora a economia do Brasil como um todo estivesse crescendo, grandes lacunas no sentido educacional ficaram e ainda estão abertas.

É importante destacar que "Enquanto prática desveladora, gnosiológica, a educação sozinha, porém, não faz a transformação do mundo, mas esta a implica" (FREIRE, 1997. p.16), como matriz principal do 
desenvolvimento regional, pois conscientiza o ser de sua realidade social, funcionando como uma espécie de motivador psicológico de sua transformação. Quando empoderados os indivíduos dotados de conhecimento tem seu comportamento transformado, beneficiando não somente o desenvolvimento pessoal, mas também o de sua comunidade, sua região.

Rolim e Serra (2010), que realizaram um estudo sobre as Instituições de Ensino Superior, nos lembram que transformar conhecimento em produtos inovadores, é um desafio constante e que requer uma rede de relações entre instituições, cidades, regiões e atores sociais. Justamente por isso entende-se que estas instituições são as portadoras da transformação e organização do espaço, mobilizando recursos humanos, financeiros, e assim dinamizando as economias locais e regionais.

\section{Em que medida a educação propicia desenvolvimento regional}

Os países desenvolvidos possuem elevado Índice de Desenvolvimento Humano (IDH) - que utilizam como critérios de analise a educação (alfabetização e taxa de matricula), longevidade (esperança de vida ao nascer) e renda (PIB per capta). São países que detêm considerável qualidade na educação, respeito, defendem o cumprimento das leis, punem a corrupção, impedem regalias e praticam a cidadania, em decorrência, desenvolvem-se (SALLES, 2006).

A própria "revolução industrial, que é nada mais nada menos do que o resultado de um investimento no conhecimento para a produção de técnicas com base no conhecimento científico" (OLIVEIRA JR, 2014, p.1348) ocorreu primeiramente nos países desenvolvidos.

Desde os anos 1950 os países subdesenvolvidos em geral pensam na educação como o grande propulsor do desenvolvimento econômicosocial, criando expectativas otimistas relacionadas aos impactos que seriam advindos da adoção de políticas pública de educação. Para isso, universalizaram o atendimento escolar, melhorando também a qualidade dos serviços prestados (SALLES, 2006).

No Brasil, as primeiras ações foram influenciadas pelo pensamento enciclopedista, em que a educação esteve articulada ao desenvolvimento econômico, lembrando que este período foi marcado pelo contexto da Guerra-Fria e o conceito de crescimento econômico da época. Buscava a integração dos países subdesenvolvidos ao sistema mundial capitalista, além de tentar responder a problemas como desigualdade social, 
pobreza e indigência cultural, utilizando a precariedade da educação como explicação para as condições socioeconômicas adversas desses países (SALLES, 2006).

Após um balanço da ONU sobre a situação econômica dos países subdesenvolvidos na década de 1990, articulou-se uma nova proposta de desenvolvimento econômico-social onde a CEPAL $^{8}$ e a OREALC ${ }^{9}$ elaboram em conjunto a ideia que serviu de base para a reforma da educação para a maior parte dos países da região. Nesta nova abordagem "o progresso técnico" constitui o elemento central dos esforços de desenvolvimento econômico-social dos países da região, especialmente o Brasil, numa tentativa de reduzir as desigualdades sociais e os bolsões de pobreza do país (SALLES, 2006).

Era necessário aumentar a produtividade, melhorar a economia e por meio da educação seria possível alcançar os qualificadores e as disposições, já que o crescimento econômico só é alcançado quando o trabalhador entende e transforma ideias em produtos, tecnologias em recurso, ou seja, quando ele produz.

É neste período também que no Brasil a ideia de desenvolvimento a partir do conhecimento científico ganha novos aliados em vários campos da sociedade, sendo possível observar nos discursos o papel da ciência como atividade estratégica para o desenvolvimento. (GOMES et al, 2014).

Ferreira (2007) alerta que:

Partimos do pressuposto de que para a realização de todas as funções e tarefas, que estão articuladas com os procedimentos Técnicos e funcionais das novas tecnologias (nos domínios da programação, concepção, planejamento, gestão, controle e manutenção), são exigidos novos conhecimentos, novos comportamentos de carácter físico e cognitivo, que se consubstancia num efetivo aumento qualitativo e quantitativo das qualificações e competências do fator de produção trabalho (p.10).

A produtividade, portanto, é o resultado do conhecimento, eficiência e transformação das técnicas e tecnologias. Não é possível esperar aumento da produtividade sem levar em conta os aspectos estruturais e institucionais que moldam uma sociedade, seja em economias basicamente agrícolas ou altamente industrializadas, até porque é o arranjo da

8 Comissão Econômica para a América Latina e o Caribe (CEPAL), uma das cinco comissões regionais das Nações Unidas, foi criada em 25 de fevereiro de 1948, para contribuir com o desenvolvimento econômico da América Latina e reforçar as relações econômicas dos países da Região, entre si e com as demais nações do mundo.

9 Oficina Regional de Educação para a América Latina e Caribe. 
atividade econômica, seja no nível organizacional do trabalho ou no simples aumento de entrada de fomentadores do crescimento econômico que vai propiciar o aumento da produtividade. Desta forma, observamos que pela educação e qualificação, obtem-se o arranjo institucional necessário para o bom desenvolvimento, seja local, regional e até mesmo mundial.

\section{Que tipo de educação propicia desenvolvimento regional?}

Pesquisar e compreender que tipo de educação desenvolve uma consciência crítica e atuante é uma tarefa árdua, haja vista termos tantas concepções de consciência quanto ao número de pesquisadores, pois fazse necessário saber como, para que e que tipo de educação e sociedade queremos. E aqui no Brasil esta tem sido uma discussão constante, onde o Estado por meio de programas busca resgatar o sentido da educação. Como iniciativas temos o Programa Mais Educação criado pela Portaria Interministerial no 17/2007 e regulamentado pelo Decreto 7.083/10, e agora o Novo Mais Educação, criado pela Portaria MEC no 1.144/2016 e regido pela Resolução FNDE no 5/2016, que funciona como uma alternativa indutora do aumento da jornada escolar e desenvolvimento sustentável da educação através da formação do sujeito integral. Programas que são importantes, já que trabalham a base da educação (BRASIL, 2017).

Por meio deste programa é problematizado, em seu processo de execução a organização da escola em relação à estrutura física e sua articulação com outros espaços, já que se amplia o tempo, o território e as oportunidades educativas (LECLERC e MOLL, 2012). E se queremos formar um sujeito de forma integral, como ser político, histórico e social, faz-se necessário levar em consideração esta condição, principalmente porque a comunidade na qual a escola está inserida será a mantenedora do projeto.

Pensando na questão produtividade/trabalho é possível encontrar programas como: o Programa Universidade para Todos - PROUNI, que foi criado e institucionalizado pelo governo, por meio da Lei no 11.096, de 13 de janeiro de 2005 , que tem por finalidade a concessão de bolsas de estudo integrais e parciais em cursos de graduação e sequenciais de formação específica, em instituições de ensino superior privadas, em contrapartida àquelas instituições que aderem ao Programa recebem isenção de tributos. Para Oliveira JR (2014)

(...) as Universidades, como instituições de ensino, pesquisa, extensão e promoção social, assumem importância estratégica no processo de desenvolvimento. O conjunto de 
suas atividades passa a dar origem a uma força de atração de consumidores e empresas, contribuindo para gerar um crescimento econômico-social local/regional (p.1338).

Mas de acordo com Catani, Hey e Gilioli (2006), o princípio do PROUNI é promover o acesso à educação superior com baixo custo para o governo, sem necessariamente preocupar-se com a finalização do curso por parte dos estudantes. Essa medida, na prática, atende às demandas do setor privado, pois regula as contas do Estado, que por meio do aumento das isenções fiscais para as IES privadas, sustenta a imagem de um país que não daria calote aos seus investidores externos, garantindo que sua dívida é sustentável, já que as IES não possuem transparência na concessão das bolsas e maquiam os balanços.

Em 2008, numa tentativa integradora e expansionista, o então presidente do período, sancionou a Lei que criava 38 institutos federais de educação, ciência e tecnologia, transferindo para esses Institutos, os centros federais de educação tecnológica (Cefets), escolas agrotécnicas federais e escolas técnicas vinculadas a universidades. Sendo assim, os Institutos

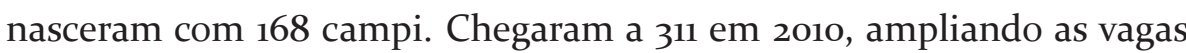
de 215 mil para 500 mil. Atualmente, são 644 campi, alcançando, assim, todos os Estados, e aumentando o número de vagas em cursos técnicos de nível médio, licenciaturas e cursos superiores de tecnologia (BRASIL, 2017). As universidades impulsionam o crescimento, desenvolvendo os lugares onde estão instaladas e novos campi podem vir a ser polos de produção econômica (OLIVEIRA JR, 2014).

Durante os últimos trinta anos, o reconhecimento da tecnologia como o motor do crescimento econômico tem provocado medidas de incentivo e suporte necessárias ao desenvolvimento tecnológico (GIRON e AMORIM, 2007). E de acordo com os autores do projeto, como os Institutos se inserem na área de pesquisa e extensão, o desenvolvimento seria estimulado, pois estaria se buscando soluções técnicas e tecnológicas que estenderiam seus benefícios à comunidade, aproveitando assim o potencial da rede já existente. Desta forma estariam respondendo de forma ágil e eficaz às demandas crescentes por recursos humanos, difundindo o conhecimento científico e propiciando suporte aos arranjos produtivos locais (BRASIL, 2017).

Utilizando a teoria dos polos de desenvolvimento e considerando o espaço geográfico como noção de polarização, os polos passam a ser geradores de regiões, onde a apropriação da terra passa a ser o fundamento principal do planejamento territorial. Por meio das estratégias 
de desenvolvimento local, as novas aglomerações econômicas levarão a novos espaços de produção (OLIVEIRA JR, 2014)

E de acordo com a própria Lei no 11.892 , de 29 de dezembro de 2008, na seção II das finalidades dos Institutos Federais no artigo 6º, inciso IV uma das finalidades e característica dos IFs são:

Orientar sua oferta formativa em benefício da consolidação e fortalecimento dos arranjos produtivos, sociais e culturais locais, identificados com base no mapeamento das potencialidades de desenvolvimento socioeconômico e cultural no âmbito de atuação do Instituto Federal (BRASIL, 2008).

Acredita-se que com essas instituições a oferta de ensino técnico profissionalizante e superior alcancem as cidades mais distantes, interagindo com a área regional, promovendo a capacitação e articulando competências, e assumindo seu papel de liderança no desenvolvimento regional (ROLIM e SERRA, 2009). De acordo com esses autores, as regiões desenvolvidas são as que estabelecem um projeto político congregando diferentes atores, aumentando a competitividade e utilizando, de forma intensiva e coordenada, os conhecimentos existentes.

Desta forma, as atividades dos campi passam a atrair consumidores e empresas, assumindo importância estratégica no processo de desenvolvimento, gerando um crescimento econômico-social local/regional (OLIVERIA JR, 2014). Gobel e Miura (2004), que realizaram um trabalho de análise do papel da Universidade no Município de Toledo - Paraná, destacam a importância da mesma como geradora de emprego e renda, mas também recursos humanos locais e regionais, disseminando o desenvolvimento tecnológico e liberando ao mercado de trabalho mão-de-obra qualificada.

Já em 2011, por meio da Lei 12.513/2011, o Governo Federal criou o Programa Nacional de Acesso ao Ensino Técnico e Emprego (PRONATEC), cujo objetivo é expandir, interiorizar e democratizar a oferta de cursos de educação profissional e tecnológica no país (BRASIL, 2017). Para as autoras Martins e Cavaignac (2016), foi por meio da criação do lema: "Brasil: país rico é sem pobreza”, e posteriormente com o Plano Brasil Sem Miséria (BSM), que agregou-se distribuição de renda, acesso a serviços sociais e inclusão produtiva. E é justamente neste último eixo que o plano se vincula ao PRONATEC, pois diz respeito à qualificação do profissional para inserção ou reinserção no mercado de trabalho.

Porem, Rota Junior e Ide (2016), que realizaram um estudo sobre o desenvolvimento regional no Norte de Minas Gerais na década de 1960, 
alertam que o Norte de Minas recebeu investimento em educação de nível superior, mas também ação industrializadora da Sudene e SUDEMINAS, com isenções fiscais, incremento das redes de energia e de estradas na época.

Rolim e Serra (2010) alertam para o fato de que algumas Universidades apesar de estarem nas regiões não, trabalham, especificamente, para elas, mas produzem conhecimentos universais, que capacitam os alunos para o mercado de trabalho mais amplo. Já Mina, Ramos e Rezende (2012) destacam que alimentação, lazer e saúde são os gastos mais significativos dos estudantes nas localidades em que essas instituições estão instaladas, independente da área de formação.

\section{Conclusão}

Ao final deste texto, faz-se necessário recapitular quatro de suas principais implicações. Em primeiro lugar, o papel do Estado enquanto organização política, que por meio das leis regulamenta a vida da sociedade em busca de bem estar comum a todos. Em segundo, o que se entende por desenvolvimento regional, que necessariamente envolve inversões e políticas por parte do Estado às regiões menos desenvolvidas. Em terceiro lugar, como a educação contribui para o desenvolvimento da sociedade, confrontando interesses públicos e interesses particulares, e projetandose como multiplicadora do empoderamento e eficácia da produção de um ser humano melhor.

Em quarto lugar colocamos como a educação empodera o individuo, já que a mesma propicia o progresso tecnológico e por meio dele é possível obter eficiência na produção. E finalmente em quinto lugar quando por meio de vários autores foi possível expor que a educação universitária aperfeiçoa e qualifica cientificamente o individuo de acordo com as necessidades regionais e locais interagindo com os problemas em busca de soluções.

$\mathrm{O}$ artigo teve a finalidade de evidenciar, por meio de levantamento bibliográfico, que o desenvolvimento regional depende da ação do Estado, da educação e da população local, conforme visto nas citações. Ficou também evidente, que o Brasil tem investido nesta área por meio de seus programas e Leis, cujo objetivo central é integrar o território, levar educação as áreas mais distantes e qualificar nossa mão-de-obra para o mercado de trabalho. 


\section{Bibliografia}

BAZZO, W. A.; SILVEIRA, R. M. F.. Ciência e Tecnologia: transformando o homem e sua relação com o mundo. Revista Gestão Industrial (Online), Ponta Grossa, v. 2, n.2, p. 01-12, 2006.

BRASIL. Lei no 11.892, de 29 de dezembro de 2008. Disponível em:< http://www.planalto.gov.br/ccivil_03/_ato2007-2010/2008/lei/l11892. htm>Acessado em: 01/02/2017.

. MINISTÉRIO DA EDUCAÇÃO - MEC. Disponível em:<http:// portal.mec.gov.br/programa-mais-educacao $>$ Acessado em: 01/02/2017.

. MINISTÉRIO DA EDUCAÇÃO - MEC. Disponível em:<http:// prouniportal.mec.gov.br/o-programa>Acessado em: 01/02/2017.

MINISTÉRIO DA EDUCAÇÃO - MEC. Disponível em:<http:// portal.mec.gov.br/pronatec $>$ Acessado em: 01/o2/2017.

MINISTÉRIO DA EDUCAÇÃO - MEC. Disponível em:<http://portal.mec.gov.br/ultimas-noticias/212-educacao-superior -1690610854/11864-sp-103278730>Acessado em: 01/o2/2017.

MINISTÉRIO DA EDUCAÇÃO - MEC. Disponível em:<http:// redefederal.mec.gov.br/expansao-da-rede-federal>Acessado em: 01/02/2017. CATANI, A. M.; HEY, A. P. ; GILIOLI, Renato . Prouni: democratização do acesso às instituições de ensino superior?. Educar em Revista, v. 28, p. 125-140, 2006.

CAVAlCANTE, L. R. M. T.. Produção Teórica em Economia Regional: uma proposta de sistematização. Revista Brasileira de Estudos Regionais e Urbanos. São Paulo, vol. 02, № 1, p. 09-32, 2007.

CIMA, E. G.; AMORIM, L. S. B.. Desenvolvimento Regional e Organização do Espaço: uma análise do desenvolvimento local e regional através do processo de difusão de inovação. Revista FAE. Curitiba, v. 10, n. 2, p. 73-87, jul/dez, 2007.

DINIZ, C. C. . Celso Furtado e o Desenvolvimento Regional. Revista Nova Economia. Belo Horizonte, v. 19, n. 2, p. 227-249, mai/ago, 2009.

DURKHEIM, E.. Da Divisão do Trabalho Social. $2^{\underline{a}}$ ed. São Paulo: Martins Fontes, 1999. 
FERREIRA, J. M. C.. Atualidade da Construção do Objeto Científico da Sociologia Económica. RAE Eletrônica, São Paulo, v. 6, n.1, p. 1-22, 2007.

FLIGSTEIN, N.; DAUTER, L.. A Sociologia dos Mercados. Caderno CRH, Salvador, v. 25, no 66, p. 481-504, 2012.

FLIGSTEIN, N. O MERCADO ENQUANTO POLÍTICA: Uma abordagem político-cultural às instituições de mercado. In: Rafael Marques e João Peixoto (Org.) A Nova Sociologia Econômica: Uma antologia. $\mathbf{1}^{\underline{a}}$ ed. Oeiras - Portugal: Celta Editora, 2003.

FREIRE, P. Pedagogia da Esperança: Um reencontro com a Pedagogia do Oprimido. Rio de Janeiro: Paz e Terra, 1997, 127 p.

GIRON, E,; AMORIN, L. S. B. . Desenvolvimento Regional e Organização do Espaço: Uma Análise do desenvolvimento Local e Regional Através do Processo de Difusão de Inovação. Revista da FAE, v. 10, p. 73 / no 2-87, 2007.

GOEBEL, M. A. ; MIURA, M. N. . A Universidade como fator de Desenvolvimento: o caso do município de Toledo-PR. Revista Expectativa, Cascavel, v. 3, n.3, p. 35-47, 2004.

GOMES, O. C ; GOMES, S. R. ; BARBOSA, I. ; AGUIAR, J. V. S. . CTS e alfabetização científica: possibilidades para uma educação mais compromissada através do programa ciência na escola. In: IV Simpósio Nacional de Ensino de Ciências e Tecnologias, 2014, Ponta Grossa. Educação Científica e Tecnológica e Estudos CTS, 2014. v. o1. p. 01-12.

LECLERC, G. F. E. ; MOLL, J. . Programa Mais Educação: avanços e desafios para uma estratégia indutora da educação integral e em tempo integral. Educar em Revista (Impresso), v. 45, p. 91-110, 2012.

MACHADO, J. G. R.; PAMPLONA, J. B. . A ONU e o Desenvolvimento Econômico: Uma Interpretação das Bases Teóricas do PNUD. Economia e Sociedade (UNICAMP. Impresso), v. 17, p. 53-84, 2008.

MADUREIRA, E. M. P.. Desenvolvimento Regional: principais teoria. Revista Thêma et Scientia, v. 5, p. 8-23, 2015. 
MARTInS, A. A. ; CAVAIGNAC, M. D. . A Política de Assistência Social e a promoção ao trabalho: uma análise do PRONATEC BSM com base em um estudo com egressos em Fortaleza-CE. Revista Brasileira de Politicas Publicas, v. 6, p. 139-154, 2016.

MINA, R. V.; RAMOS, P. S. ; REZENDE, M. L. . Estudo dos Impactos Econômicos da Expansão da Universidade Federal de Alfenas no Município de Alfenas, Minas Gerais. In: XV Seminário sobre a Economia Mineira, 2012, Diamantina. XV Seminário sobre a Economia Mineira. Belo Horizonte: UFMG, 2012.

NAZZARI, R. K.; CAMINATI, J. G. de O. ; ANTUNES, E. R.; SILVA, D. A. C. da ; TEODORO JUNIOR, A. ; TEODORO, P. A. V. B.; RAIZEL, T.. Desenvolvimento, Capital Social e Educação no Brasil. In: III Seminário do Centro de Ciências Sociais Aplicadas, 2004, Cascavel. Anais do III Seminário do Centro de Ciências Sociais Aplicadas, 2004. v. 1. p. 1-7.

OLIVEIRA, G. B.; LIMA, J. E. S.. Elementos Endógenos do Desenvolvimento Regional: considerações sobre o papel da sociedade local no processo de desenvolvimento sustentável. Revista FAE. Curitiba, v. 6, n. 2, p. 29-37, mai/dez, 2003.

OLIVEIRA JR, A de.. A Universidade como polo de desenvolvimento local \regional. In: Simpósio Mineiro de Geografia, 2014, Alfenas, MG. Anais do I Simpósio Mineiro de Geografia. Alfenas: UNIFAL, 2014. v. 1. p. 1337-1349.

POLANYI, K.. A grande transformação: as origens da nossa época. $2^{2}$ ed. São Paulo: Campus, 2000.

ROLIM, C. F. C.; SERRA, M.. Instituições de Ensino Superior e Desenvolvimento Regional: O Caso da Região Norte do Paraná. Revista de Economia (Curitiba), v. 35, n. 3, p. 87-102, set./dez. 2009.

Universidade e Desenvolvimento: ser da região x estar na região. In: $7^{\text {}}$ Congresso ibérico de estudos africanos (CIEA 7), 2010, Lisboa. Livro do $7^{\circ}$ Congresso ibérico de estudos africanos (CIEA 7). Lisboa: Centro de Estudos Africanos - Instituto Universitário de Lisboa, 2010. Disponível em:< http://www.portaldoconhecimento.gov.c > Acessado em: 15/02/2017. 
ROTA JUNIOR, C.; IDE, M. H. de S. . Ensino superior e desenvolvimento regional: o Norte de Minas Gerais na década de 1960. Revista Brasileira de Educação, v. 21, p. 143-164, 2016.

SALLES, F. C.. Breve histórico do pensamento econômico na educação brasileira. In: VII Seminário Nacional de Estudos e Pesquisas 'História, Sociedade e Educação no Brasil, 2006.

SANTOS, T. F. A, M.. Trabalho, Educação e o Desenvolvimento Regional da Amazônia. UNOPAR Científica, Ciências Humanas e Educação. Londrina, v. 11, n. 1, p. 59-67, jun. 2010.

SILVA, J.A.M.; AMORIM, W. L. . O pensamento sociológico de Max Weber e a Educação. RIC@. Revista Interdisciplinar Científica Aplicada, v. 6, p. 100-110, 2012.

SMITH, A. . A Riqueza das Nações. Tradução Alexandre Amaral Rodrigues, Eunice Ostrensky. $2^{\underline{a}}$ ed. São Paulo: WMF Martins Fontes, 2012.

TAYLOR, F. W.. Principios da Administração Científica. Tradução de Arlindo Vieira Ramos. 8a ed. São Paulo: Atlas, 1995. 



\section{Um olhar teórico-metodológico sobre processos de intervenção e de extensão para o desenvolvimento regional}

Cidonea Machado Deponti ${ }^{1}$

\section{Introdução}

— STE ENSAIO OBJETIVA APRESENTAR E DISCUTIR ALGUMAS QUESTÕES

$\amalg$ relacionadas ao processos de intervenção e de extensão em contextos de desenvolvimento regional. Esta temática ainda é pouco tratada na área do Planejamento Urbano Regional e Demografia. No último Enanpur, em 2019, foi concedido um espaço específico para esta discussão, situação que podemos considerar um avanço e uma ação positiva no sentido de permitir a construção da troca de informações entre os pesquisadores que atuam com este tema. Em função disso, este ensaio, embora não pretenda ser conclusivo, procura ser reflexivo apostando na experiência de mais de dez anos em processos de intervenção e de extensão². Assim, pretendemos trazer para análise algumas aproximações teóricas do que entendemos sobre desenvolvimento regional e algumas experiências de extensão que poderão contribuir com a construção de passos metodológicos para ações de intervenção e de extensão.

\section{Desenvolvimento regional: em busca de uma definição}

Inicialmente, tomamos por base uma breve revisão dos principais autores que discutem o tema na área do desenvolvimento regional. De

1 Economista (UFSM-RS); Especialista em Desenvolvimento Rural e Agroecologia (UFRGS-RS); Mestre em Integração Latino-Americana (UFSM-RS); Doutora em Desenvolvimento Rural (UFRGS-RS); Pós-Doutora em sociologia do Desenvolvimento (PPGS/UFRGS). Pesquisadora e Professora Adjunta do Programa em Desenvolvimento Regional (UNISC-RS). Editora da Revista Redes. Diretora Sul da RETE. E-mail: cidonea@unisc.br.

2 Destacamos que para construção deste ensaio foram mobilizadas várias discussões já produzidas e publicadas por mim em outras oportunidades, como tese, artigos, aulas. 
acordo com Theis (2019), desenvolvimento regional é algo que se situa entre a hipótese e a teoria, constituindo-se em uma teoria de médio alcance, uma espécie de guia para investigações empíricas. Para o autor, desenvolvimento regional é algo bom com que se procura combater algo ruim (desigualdades - sociais, econômicas e políticas). Estas só poderão ser extintas quando os membros das comunidades regionais recuperarem sua autonomia. Dessa forma, o autor sugere que o desenvolvimento regional busque aproximar-se da realidade sociocultural brasileira, dando visibilidade ao passado colonial, ao sofrimento dos povos originários, às mulheres e à diversidade da natureza.

Já Silveira (2020) destaca oito observações que devem ser levadas em consideração quando se trata de desenvolvimento regional, tais como: os significados de desenvolvimento e de desenvolvimento regional; a natureza do espaço geográfico onde os processos de desenvolvimento ocorrem historicamente; os conceitos de território, de territorialização e de territorialidade e sua importância para análise do desenvolvimento regional; a renovada importância da região nos estudos territoriais e nos processos de desenvolvimento; a escala espacial como produto social; a presença e o papel das redes em sua relação com o território e no desenvolvimento regional; a nova Divisão Territorial do Trabalho (DTT), com suas repartições espaciais e seu funcionamento no território regional; o papel das normas no processo de desenvolvimento regional. Para o autor este esquema de oito observações não é fechado, existindo outras categorias e conceitos que podem e devem ser acionados para auxiliar no desafio da compreensão da complexidade dos processos de desenvolvimento regional. Ainda destaca que "tão pouco as compreensões e significações das categorias e conceitos aqui apresentados são absolutas, ou se pretendem verdadeiras". Para Silveira (2020) as observações buscam lançar luzes para o pensar e o fazer científico sobre a temática do desenvolvimento regional.

De acordo com Boisier (2000), o desenvolvimento regional é um processo de mudança estrutural que combina três dimensões: espacial, social e individual. Tal mudança estaria associada a um constante progresso da região, da comunidade ou da sociedade nela existente. Assim, para pensar o regional lança-se da perspectiva territorial, a fim de entender de forma mais endógena como esses processos ocorrem no espaço local.

Ainda para Etges e Degrandi (2013, p. 2), a compreensão de desenvolvimento regional no Brasil poderia ser explicada sob a base de dois enfoques principais. O primeiro - enfoque hegemônico que pauta muitos trabalhos científicos e documentos norteadores de políticas públicas - destaca que 
“à medida em que as relações de produção tipicamente capitalistas vão tornando-se hegemônicas, as regiões tenderiam a desaparecer, uma vez que as especificidades que as teriam originado também desapareceriam".

O segundo - evidenciado a partir da década de 1990, período em que o conceito de região é retomado sob um novo enfoque - enfatiza que as desigualdades fazem parte da própria lógica econômica do modo de produção capitalista, expressando-se pela concentração de capitais e de rendas, da qual deriva a exclusão econômica, social e, também, geográfica.

Enquanto para o primeiro enfoque as desigualdades regionais e a própria região são tomadas como obstáculos a serem superados ou descartados, para o segundo, são tidas como particularidades que podem e devem ser potencializadas, como forma alternativa e endógena de desenvolvimento regional (ETGES; DEGRANDI, 2013, p. 2).

Deste modo, pode-se concluir que a ideia de desenvolvimento regional, de acordo com os autores estudados acima, engloba conceitos como: região, território, mudança, atores, instituições, especificidades, particularidades, escalas, dinâmicas, endógeno, desigualdades, complexidade, capitais, recursos, entre outros. No nosso entendimento, desenvolvimento regional pode ser compreendido como um processo complexo e dinâmico de mudança social e espacial que depende da visão de mundo dos atores envolvidos. Assim, concordamos com Favareto (2006) e entendemos que não há uma teoria de desenvolvimento regional, que o regional pode ser encarado como uma categoria, sob o ângulo analítico, e um domínio da realidade, sob o ângulo empírico. O regional é uma escala (móvel) e um conceito, sendo um conceito carece de uma teoria, pois conceitos não existem sem teorias. Nestes termos, o desenvolvimento precisa ser operado por meio de uma teoria ou de alguma teoria que dê conta desta complexidade.

\section{Desenvolvimento regional como intervenção, extensão e mediação}

Nesse sentido, desenvolvimento é um processo de mudança social, complexo, multiator, multiescalar, multidimensional, carregado de heterogeneidades de práticas, de processos e de políticas, sem limites definidos no tempo e no espaço, que avança e retrocede. Considerando assim a ideia de desenvolvimento, para definirmos o conceito de desenvolvimento regional tomaremos por base teórica alguns conceitos advindos 
da sociologia, da antropologia e da ciência política como a mediação, a alteridade e a agência.

O termo mediação é de fundamentação intervencionista e constituído por múltiplos processos de negociação. Este processo é de interface entre as partes envolvidas, nem de cima para baixo (top-down), nem de baixo para cima (buttom-up), mas de encontro, de interface, em que os diferentes conhecimentos se entrelaçam, tornando-se um híbrido, que valoriza tanto o conhecimento técnico quanto o saber-fazer. A mediação leva ao sentimento de pertencimento, ao fazer parte do processo. Quando se é parte, torna-se legítimo e legitimado, representado.

De acordo com Sardan (1995), a capacidade de conhecer e de compreender outros conhecimentos está no centro de sua função de mediador. No entanto, os mediadores, na maioria das vezes, não são formados para a competência da mediação e, assim, sua função de porta-vozes é posta em evidência, desenvolvendo uma mediação de maneira "imprópria e unilateral”. As citações do discurso técnico-científico passadas aos mediados serão reinterpretadas no interior do seu próprio sistema de conhecimentos e de sentidos.

O porta-voz realiza a atividade de tradução; “[...] transladar interesses significa, ao mesmo tempo, oferecer novas interpretações desses interesses e canalizar as pessoas para direções diferentes" (LATOUR, 2000, p. 194). Por isso, a noção de tradução incorpora uma ideia de poder. Quando um porta-voz fala em nome dos representados e de seus interesses, ele está se engrandecendo, tornando-se um ator coletivo que é capaz de falar através de uma só voz e representar o interesse de todos os silenciados a partir da representação. Portanto, tradução pode ser expressa por mediação. Traduzir é estabelecer-se como um porta-voz, exprimindo em sua própria linguagem o que os outros dizem e querem, como agem e como se associam uns aos outros.

Os porta-vozes são todos os agentes envolvidos nos diferentes estágios dos processos de representação. Falar pelos outros é em primeiro lugar silenciar aqueles em cujo nome se fala. Sendo assim, no exercício da mediação nem todos os agentes falam, porque existem os porta-vozes que representam, indiretamente pela mediação, o interesse dos outros. Essa ideia de porta-voz permeia as atividades de extensão tradicional em que o modelo, na maioria das vezes, é baseado na ideia de uma comunicação linear, em que o saber é adaptado e traduzido pelos mediadores aos mediados aos agricultores que são vistos, simplesmente, como destinatários passivos. 
Um dos problemas dessa relação é o fato de a maioria dos projetos pré-definirem metas e resultados esperados, além de aporte de recursos financeiros. A mediação é um trabalho de longo prazo, de resultados pequenos no curto prazo, de muitas negociações de conflitos, de características contraditórias, de difícil assimilação e prática, de exigências de novas posturas de abertura e de flexibilidade. Os projetos de desenvolvimento não são desenvolvidos levando em consideração todas essas peculiaridades, e os mediadores em linha de frente têm a árdua tarefa de lidar com a complexidade do processo de mediação social/intervenção para o desenvolvimento regional.

A qualidade da mediação está justamente no desenvolvimento da capacidade de reflexão, de análise e de decisão dos mediados, considerando que as escolhas por estes últimos definidas poderão ser diferentes e diversas daquelas inicialmente propostas. A capacidade de transformar os mediados em sujeitos do processo de desenvolvimento coloca ao mediador a necessidade de um perfil flexível, maleável, diplomático. A dificuldade é essa transformação, a busca por um fazer diferente, a prática de novos saberes e, sobretudo, a aceitação da necessidade desse novo perfil.

A alteridade é outra característica relevante em processos de intervenção/extensão para o desenvolvimento, é a compreensão do outro a partir dele mesmo, não da nossa trajetória, mas dentro do sistema de sentido do outro, do seu conjunto de significado, de crenças e de costumes, do seu próprio pensar-agir-sentir. A alteridade discursiva se apoia, está claro, em um pressuposto de semelhança. $\mathrm{O}$ discurso do primeiro não se acha situado no mesmo plano que o discurso do segundo: o sentido que o mediador estabelece depende do sentido do mediado, mas é ele quem detém o sentido desse sentido - o mediador é quem explica e interpreta, traduz e introduz, textualiza e contextualiza, justifica e significa esse sentido (VIVEIROS DE CASTRO, 2002). A alteridade exige sensibilidade que é a capacidade de observar, compreender, se deixar entender, se permitir conhecer e ser conhecido.

A agência seria o terceiro elemento, aqui entendida com base em Weber que compreende os processos de desenvolvimento partindo da análise do comportamento dos indivíduos. No entanto, aprofundada em Antony Giddens que vislumbra a agência como:

Os agentes ou atores humanos [...] têm, como aspecto inerente do que fazem, a capacidade para entender o que fazem enquanto o fazem. As capacidades reflexivas do ator humano estão caracteristicamente envolvidas, de um modo contínuo, no fluxo da conduta cotidiana, nos contextos da 
atividade social. Mas a reflexividade opera apenas parcialmente num nível discursivo. $\mathrm{O}$ que os agentes sabem acerca do que fazem e de por que o fazem - sua cognoscitividade como agentes - está largamente contido na consciência prática. Esta consiste em todas as coisas que os atores conhecem tacitamente sobre como "continuar" nos contextos da vida social sem serem capazes de lhes dar uma expressão discursiva direta (GIDDENS, 2009, p.25).

Nesses termos, agência é a capacidade de interferir em eventos, não necessariamente de modo intencional. Agir, mais do que pretender algo, é ser significativo na sua ocorrência, na medida em que a "ação depende da capacidade do indivíduo de 'fazer uma diferença' em um estado pré -existente de coisas ou curso de eventos" (GIDDENS, 1984, p. 14).

A agência humana não se refere às intenções que as pessoas têm ao fazer as coisas, mas à capacidade de elas realizarem essas coisas. Os agentes humanos têm capacidade de entender o que fazem enquanto fazem, eles sabem tacitamente como continuar, mas sem a capacidade de dar uma explicação discursiva direta. A noção de agência, portanto, apresenta importância estratégica para compreender o significado das redes sociais, garantir informações, formar opiniões, legitimar pontos de vista e, assim, gerar diferentes relações de poder. A incorporação de novas ideias e modos de comportamento carrega, simultaneamente, processos de transformação.

Ser capaz de "atuar de outro modo" significa ser capaz de intervir no mundo, ou abster-se de tal intervenção, com o efeito de influenciar um processo ou estado específico de coisas. Isso pressupõe que ser um agente é ser capaz de exibir (cronicamente, no fluxo da vida cotidiana) uma gama de poderes causais, incluindo o de influenciar os manifestados por outros. A ação depende da capacidade do indivíduo de "criar uma diferença" em relação ao estado de coisas ou curso de eventos preexistente. Um agente deixa de o ser se perde a capacidade para "criar uma diferença", isto é, para exercer alguma espécie de poder (GIDDENS, 2009, p. 17).

Com isso, Long e Ploeg (2011, p. 27) lembram que a capacidade de agência, apesar de estar no indivíduo, depende também de um contexto social e de associações entre atores, ou seja, "as estratégias e construções culturais aplicadas pelos indivíduos não surgem do nada, mas são sim retiradas de um estoque de discursos disponíveis (verbais e não verbais)".

O desenvolvimento regional expressa-se em termos diversos, nas particularidades do território e na valorização da especificidade. A compreensão do desenvolvimento regional como uma forma de intervenção, extensão e mediação implicaria em contribuir para transformação e para 
dar autonomia aos envolvidos, possibilitando que eles próprios sejam capazes de resolver seus problemas e de criar novas práticas ou processos apropriados às suas condições específicas e de acordo com a sua vontade.

$\mathrm{Na}$ próxima seção procuraremos analisar as ações realizadas pelo Núcleo de Extensão Tecnológica e Gestão Rural para a Agricultura Familiar (NEGAF) à luz dos conceitos acima descritos.

\section{Possibilidades metodológicas para ações de intervenção/extensão/mediação}

Nesta seção serão apresentadas e discutidas algumas experiências de extensão junto ao NEGAF. O Núcleo foi criado, oficialmente, no ano de 2017, para atender demandas dos agricultores familiares no Vale do Caí, mas os membros da equipe atuam desde 2012 quando da realização de um Projeto Piloto em que 10 famílias de agricultores familiares participavam. Tal situação contribuiu para a qualificação de algumas atividades e também para a reflexão sobre algumas ações. A proposta aqui apresentada não oferece uma receita pronta ou uma solução para ações de extensão, apenas busca o questionamento e a reflexão sobre os erros e os acertos metodológicos realizados. Em outros artigos ${ }^{3}$ já tratamos das ações realizadas pelo NEGAF e das estratégias utilizadas para o envolvimento do público. Assim, neste ensaio procuraremos discutir os resultados dessas estratégias metodológicas e as possibilidades de utilização em ambientes e contextos de desenvolvimento regional. Nesse sentido, a experiência de extensão tecnológica aqui apresentada representa uma forma de intervenção realizada por determinados atores em uma realidade concreta. Neste caso, o projeto ora analisado representa o processo de intervenção de uma equipe de alunos, de professores, de pesquisadores e de demais atores da sociedade em um ambiente de agricultura familiar no Vale do Caí.

Processos de intervenção na prática costumam ser bem mais complexos do que a teoria é capaz de observar. Quando se trata de mobilizar pessoas para certa atividade, primeiramente devemos considerar que estas pessoas carregam sistemas de sentido, trajetórias, histórias diferentes das nossas e que, provavelmente, não seja a primeira vez que irão participar de uma atividade como a que estamos propondo. De modo geral, os agentes envolvidos em processos de mediação e a literatura sobre o tema

3 Deponti et al (2018); Deponti, Kist e Arend (2019); Deponti, Arend e Kist (2017). 
destacam que "sempre são os mesmos que participam". Tal fato, enseja a necessidade de acionar a alteridade. Esse conceito irá nos permitir nos despojar de nós mesmos e olharmos o outro a partir dele. Situação bem difícil de ser realizada, pois, na maioria das vezes, nos deixamos guiar pelo nosso acúmulo e visão de mundo não vislumbrando o outro a partir de sua trajetória e visão de mundo.

Assim, sugerimos como primeira ação a escuta dos envolvidos, a partir de seu depoimento. O primeiro contato é onde se desenvolve a empatia entre os participantes e também onde se dá início ao processo de pertencimento. Sentir-se parte de algo é uma das palavras-chave do processo de intervenção, de extensão e de mediação. Quando os participantes se enxergam no processo, quando eles visualizam seus projetos no processo o engajamento começa a se definir. No entanto, destacamos que esta ação, embora considerada primordial para o processo, realizada de forma isolada de outras, não é garantia de sucesso.

Em nosso caso, mobilizamos os agricultores em uma reunião na qual o objetivo era ouvir suas demandas. Esta ação buscou aproximar os objetivos do Núcleo aos objetivos dos agricultores, o que possibilitou um processo de construção coletiva da aprendizagem e do conhecimento. $\mathrm{O}$ processo de construção coletiva é outro desafio, pois exige que tanto os mediados como os mediadores larguem suas amarras. Isso significa que considerem tanto o conhecimento popular como o científico válidos e relevantes.

O diálogo estabelecido deve ocorrer na horizontal e não na vertical, não havendo disputa do conhecimento, mas partilha. A palavra-chave seria a negociação que implica reconhecer o outro e reconhecer a horizontalidade na relação. Dessa forma, não se pretendeu substituir um conhecimento pelo outro, mas construí-lo coletivamente, considerando o modo de "pensar-agir-sentir" próprio do grupo. De acordo com Freire (1984), seria uma intervenção que possibilitasse a revitalização da informação conforme a dinâmica cultural própria do meio. No tocante a este fato, a equipe do Núcleo optou por uma construção coletiva, ou seja, de aproximação dos sistemas de sentido, de aproximação da Universidade à Comunidade e do conhecimento científico ao conhecimento popular. Esse encontro de mundos distintos é desafiador, principalmente para os mediadores, pois a necessidade de construir algo juntos não permite o planejamento anterior e coloca o mediador frente ao mediado numa relação horizontal, de igual para igual. 
Esse processo é caracterizado pela interface social, mais uma variável importante no processo de mediação. Quando a interface se estabelece, algo novo surge de um conhecimento que é híbrido e deve ser apropriado por todos os envolvidos. O estereótipo (rótulo) de que os agentes mediadores devem levar aos mediados soluções preparadas, prontas para melhorar a qualidade de vida e promover o desenvolvimento regional é um discurso de que o desenvolvimento seria algo generoso e com a intenção de mudar para melhor a vida dos outros. Entendemos e reforçamos que a ideia de desenvolvimento regional depende de outras variáveis e que o processo é dinâmico, complexo, multidimensional, multiator, multiescalar.

Outra questão que consideramos relevante em processos de desenvolvimento regional é a heterogeneidade de possibilidades, há um mosaico de práticas, de processos e de programas, mas também há especificidades no processo produtivo, na formação da família, na escolha dos cultivos. A grande dificuldade está em compreender cada caso e suas particularidades. Tal situação na prática também não é simples, pois geralmente os planos, programas e projetos são construídos desconsiderando essa heterogeneidade. O projeto de extensão tecnológica possibilitou a compreensão sobre a necessidade de se considerar as particularidades concretas de todos os agricultores, pois eles não podem ser analisados sob um mesmo patamar na medida em que se identificam diferenças no que tange aos sistemas de sentido, de significados e, especialmente, com relação as suas condições objetivas de vida (AREND; DEPONTI; KIST, 2016).

Os recursos dos agricultores são outros, são diferentes dos recursos dos mediadores, por isso, a consideração da assimetria de poder entre eles. O próprio silêncio pode ser considerado uma forma de poder. $\mathrm{O}$ silêncio do agricultor é, justamente, seu maior aliado, não representando aceitação, concordância, ou até mesmo passividade. O silêncio também é uma forma de manifestação, não sendo sinônimo de anulação. Os recursos dos agricultores concentram-se nas suas decisões, na forma de "tocar" o estabelecimento rural, nas redes formadas, nas suas organizações, nas diferentes maneiras de responder aos problemas. Esses recursos lhe dão a possibilidade de manobra e negociação (DEPONTI, 2010). Apesar de esses atores serem dotados de recursos de poder desiguais e desequilibrados, eles têm a capacidade, não retórica, mas real, de não fazer o que se espera deles ou de fazer diferentemente, apresentando margem de manobra, como a resistência e a recusa a participar, "formas invisíveis de agir dos mais desprovidos" (LONG, 2007, p.437). 
Um outro aspecto considerado foi a capacidade de agência que significa ser capaz de "atuar de outro modo", ser capaz de intervir no mundo, ou abster-se de tal intervenção, com o efeito de influenciar um processo ou estado específico de coisas. Embora, muitas vezes, a capacidade dos atores de responder a estas situações impliquem em reformular, traduzir significados, mudar definições e negociar posições, estas situações envolvem agência. Com base em Long (2007), verifica-se que a agência não é simplesmente o resultado de algum tipo de dom extraordinário, uma capacidade mística, um toque empreendedor ou um manifestação do espírito inovativo adquirido por talentos individuais. A agência é gerada socialmente e é um fenômeno definido culturalmente, o que leva a diferentes formas de manifestação dependendo do contexto analisado. Assim, em algumas situações podemos até concluir que dificilmente ela exista. A noção de agência está incorporada nas relações sociais e só pode ser efetivada através dela.

Long (2007) ainda salienta que a habilidade de influenciar a ação dos outros depende fundamentalmente da existência ou da criação de redes de relações com atores relevantes ou com atores que podem mobilizar e envolver colaboradores em alguma tentativa de alcançar fins comuns ou pelo menos compatíveis. A agência não é um conceito de fácil percepção, pois ela pode estar presente no cotidiano, mas de acordo com Long (2007), ela é reconhecida quando se torna amplamente pública.

Na experiência analisada, observamos que a agência se apresenta de diversas formas: no silêncio, na negociação, na margem de manobra, no boicote, etc. Essas situações podem ser exemplificadas: quando os agricultores não aceitam as propostas mesmo quando elas foram definidas no coletivo, não havendo interesse por parte do agricultor, e sim resistência; quando criam e reforçam uma imagem de identidade estereotipada, de subordinação e de submissão para conquistar recursos materiais e alcançar reivindicações; quando o silêncio dos agricultores pode representar uma situação de manobra, de negociação e de poder, pois se reveste da possibilidade de exercer, assim, certo controle, prerrogativa, autoridade e capacidade para ação, mesmo que essa seja nos "bastidores" em momentos flutuantes.

As relações de poder geram resistência, acomodação e submissão estratégica, e emergem da interação de elementos de acatamento, de conformidade, assim como de desafio e de oposição. A subordinação implica também uma condição auto-imposta. Os agricultores aprendem a tratar com as intervenções externas, contra-argumentando ou mesmo 
silenciando; criam espaços para manobrar, não se comprometendo com os planos elaborados ou improvisados pela parte externa e aprendendo a encontrar seu caminho, extrair benefícios, ainda quando isso signifique subordinar-se às normas externas, pelo menos na retórica.

A situação acima descrita pode ser somada a outra questão que é recorrente na literatura e no depoimento dos mediadores, a ausência ou o desinteresse por parte dos agricultores. A compreensão dessa situação pela equipe do NEGAF foi difícil, uma vez que a própria criação do Núcleo foi baseada na opinião e na demanda dos agricultores. Dessa forma, o desinteresse pelas discussões, palestras, reuniões, trabalhos de campo, visitas técnicas, etc. não se coadunava com a própria ação por eles demandada. Várias foram as tentativas de aproximação em torno dos processos de gestão rural, tais como: a seleção de multiplicadores entre os próprios agricultores; o acompanhamento dos agricultores em suas propriedades; o uso de caderno de controle de despesas e de receitas; o uso de cartilha para levantamento patrimonial; a realização de reuniões de análise individual de cada situação; a realização de diagnóstico para cada propriedade; a devolução das informações aos agricultores; a discussão em família dos resultados.

Em função do "descompasso entre inúmeros softwares e ferramentas de gestão e o baixo uso por parte dos agricultores, aliado à desconexão das ferramentas existentes com a capacidade e a necessidade dos agricultores" (DEPONTI, 2014, p. 11) nos sentimos desafiados a construir coletivamente alternativas de gestão e de controle mais apropriados pelos agricultores. No entanto, embora esta estratégia parecesse a mais acertada e consoante com a literatura no que se refere ao desenvolvimento do sentimento de pertencimento e de valorização do "saber-fazer" dos agricultores, na prática destacamos que a situação descrita exigiu a maturação de um processo de mediação social. Este processo não se assemelhou aos objetivos das políticas públicas e dos projetos de pesquisa e de extensão financiados pelas diversas organizações que em suas ações apresentam prazos definidos, objetivos específicos, resultados esperados, metas a serem alcançadas (DEPONTI; AREND; KIST, 2017, p.12). Além desta constatação, também verificamos que a homogeneidade dos processos de controle econômico não respondem à heterogeneidade do rural, há especificidades no processo produtivo, na formação da família, na escolha dos cultivos. Salientamos que nem todas as propriedades necessitam de complexos controles gerenciais e contábeis. A grande dificuldade está em compreender cada caso quando se trata de gestão rural para a 
agricultura familiar. Este descompasso entre o saber científico e o saberfazer dos agricultores dificulta a continuidade de processos de gestão na propriedade, porque a dificuldade em alcançar a autonomia desmotiva os agricultores.

Salientamos ainda que o material desenvolvido pela equipe encontrava-se distante da necessária apropriação pelos agricultores familiares da região, pois se baseou no conhecimento científico com pequenas aproximações às necessidades e à realidade desses agricultores. Tal fato, ao mesmo tempo que dificultou a apropriação pelos agricultores, colocava-se como imprescindível para a qualificação da tomada de decisão em processos de gestão rural. Repostas a esta contradição ainda continuam sendo estudadas.

Nesse sentido, observamos vários desafios com relação à intervenção propriamente dita realizada, que, embora tenha se proposto mediar para construção coletiva do conhecimento, ainda encontra dificuldades de atuação, pois reconhecemos que, além do distanciamento entre o conhecimento produzido na universidade e o conhecimento popular, o processo de interface social para o encontro de mundos distintos é conflituoso, contraditório, complexo e lento. Contudo, é nesta interface entre a pesquisa e a extensão que a Universidade aproxima-se dos problemas reais e concretos da sociedade e que o desenvolvimento regional poderá se efetivar.

\section{Considerações finais}

Nosso intuito com este ensaio foi propor uma reflexão sobre a intervenção/extensão/mediação em processos de desenvolvimento regional, procurando a partir dele abrir um diálogo entre autores que discutam o tema na área do planejamento urbano e regional. Nossas análises se concentraram muito mais no que não deu certo do que no que poderá dar certo. Algumas vezes chegamos a denominar de "metodologia do fracasso", já que nossa experiência nos ensinou mais com os erros do que com os acertos. Poderíamos aqui chamar, de acordo com Karen Knorr-Cetina (1981), de um processo de epistemologia da prática, em que a construção do conhecimento perpassa por processos empíricos que chamamos, coloquialmente, de "ensaio e erro".

No entanto, agora nos cabe a difícil tarefa de sintetizar algumas questões -chave que poderão ser trabalhadas em futuros artigos e, quiçá, tornarem-se esclarecedoras para aqueles que se ocupam do tema da extensão. 
- a participação limitada dos agricultores nas atividades de extensão realizadas, muitas vezes, independe do que será tratado. A atividade rural exige a dedicação do agricultor em diferentes horários e, este fato, dificulta a participação. No entanto, salientamos que quando o sentimento de pertencimento se apresenta, a participação torna-se mais efetiva. Assim, temos que pensar como desenvolver este sentimento de pertencimento? Como agir de forma que os agricultores se sintam parte do que está sendo realizado?

- a heterogeneidade dos agricultores no que se refere ao processo de produção (acesso aos mercados; capacidade de geração de renda e de acumulação; diversidade produtiva das propriedades; tipos de cultivo e de criações) e às características socioeconômicas (grau de escolaridade; composição familiar; disponibilidade de recursos) são elementos que dificultam uma generalização quanto à forma de ação. Assim, a prática da extensão geralmente, considera um determinado público, por exemplo: a agricultura familiar. No entanto, esta categoria é muito diversa, apresentando grandes disparidades, no tocante aos resultados e à forma de recepção das ações pelos mediados. Eles não podem ser analisados sob um mesmo patamar na medida em que se identificam diferenças no que tange aos sistemas de sentido, de significados e, especialmente, com relação às suas condições objetivas de vida. Devemos desenvolver a sensibilidade para tratar com esta situação, pois não podemos homogeneizar a heterogeneidade e também não podemos acionar uma forma de tratamento específica para cada agricultor, eis o grande dilema.

- os processos de intervenção/extensão/mediação devem priorizar a interface social que garanta o protagonismo dos agricultores. Esse protagonismo relaciona-se com a capacidade de agência, algo que acreditamos não poder ser desenvolvido entre os mediados. Há agricultores que apresentam agência e outros que não apresentam, por isso há comunidades que avançam em determinados processos e outras nas mesmas condições que não avançam. A compreensão do universo material, simbólico e intelectual dos agricultores familiares ainda se constitui como um desafio. Podemos aprender com as duas situações e desenvolver formas de aproximação entre mediados e mediadores.

Nesse sentido, o papel das Universidades torna-se fundamental especialmente no que se refere à garantia de que os agricultores familiares obtenham autonomia e tenham possibilidade de tomar suas decisões de forma segura, apropriados das informações necessárias para o processo de tomada de decisão (DEPONTI, 2014; AREND, DEPONTI, KIST, 2016). 
Salienta-se que a intervenção realizada a partir das atividades do Núcleo de Extensão Tecnológica e Gestão Rural para a Agricultura Familiar apresentou resultados positivos, pois verificamos maior inter -relação entre a universidade e a comunidade da região do Vale do Caí. Tal experiência nos permitiu a reflexão ao longo da prática sobre os processos de intervenção para o desenvolvimento regional. Nesta interface entre a pesquisa e a extensão que a Universidade aproxima-se dos problemas reais e concretos da sociedade.

Como resolver esta questão metodológica merece outro ensaio ou artigo, pois nossa limitação seguramente não poderá resolver. No entanto, sugerimos que possamos pensar através da experiência e criticar estes processos desde nossas próprias realidades.

\section{Referências}

AREND, S. C; DEPONTI, C. M.; KIST, R. B. B. O uso de TIC pela agricultura familiar no Território do Citrus Vale do Caí-RS. Informe GEPEC, Toledo, v. 2o. n. 2, p. 71-84, jul./dez. 2016. Disponível em <e-revista.unioeste.br/index.php/gepec/article/viewFile/15638/10982>. Acesso em 6 jul. 2018.

BOISIER, S. Desarrollo (Local): De qué estamos hablando? In: BECKER, D. F. e BANDEIRA, P. S. (Org.). Desenvolvimento Local-Regional: determinantes e desafios contemporâneos. V. o1. Santa Cruz do Sul: EDUNISC, 2000, p. 151-185.

VIVEIROS DE CASTRO, Eduardo. O nativo relativo. Mana, Rio de Janeiro, v. 8, n. 1, p. 113-148, Apr. 2002. Disponível em: <http://www.scielo.br/scielo. php?script=sci_arttext\&pid=So104=93132002000100005-\&lng=en\&nrmiso >. Acesso em: 14 maio 2020. http://dx.doi.org/10.1590/ S0104-93132002000100005.

DEPONTI, Cidonea Machado. Intervenção para o desenvolvimento rural: o caso da extensão rural pública do Rio Grande do Sul. 2010. 274f. Tese (Doutorado em Desenvolvimento Rural) - Universidade Federal do Rio Grande do Sul, Porto Alegre, 2010.

As "agruras" da gestão da propriedade rural pela agricultura familiar. Redes (St. Cruz Sul, Online), Santa Cruz do Sul, p. 9-24, 2014. ISSN 1982-6745. Disponível em: <https://online.unisc.br/seer/index. 
php/redes/article/view/5150>. Acesso em: 29 abr. 2020. doi:https://doi. org/10.17058/redes.v19i2014.5150.

DEPONTI, C. M. et al. O processo de intervenção em projetos de extensão e a apropriação de tecnologias de gestão pela agricultura familiar no Vale do Caí. Revista Jovens Pesquisadores, Santa Cruz do Sul, v. 8, n. 2, p. 61-70, jul. 2018. ISSN 2237-048X. Disponível em: <https://online.unisc. $\mathrm{br} / \mathrm{seer} /$ index.php/jovenspesquisadores/article/view/11819>. Acesso em: 02 maio 2020. doi:https://doi.org/10.17058/rjp.v8i2.11819.

DEPONTI, C.M., AREND, S. C., KIST, R.B.B. O uso e a apropriação de Tecnologias de Informação e de Comunicação (TICs) pela Agricultura Familiar no Vale do Caí - RS: Relatório de Pesquisa. Edital MCTI/CNPq/ Universal 14/2014. Programa de Pós-Graduação em Desenvolvimento Regional, Universidade de Santa Cruz do Sul, Santa Cruz do Sul, 2017. 121p.

DEPONTI, C.M.; KIST, R.B.B.; AREND, S. C. Ações de Extensão como Intervenção para o Desenvolvimento Regional: Relato de Experiência do NEGAF/UNISC-RS. In: ENCONTRO NACIONAL DA ASSOCIAÇÃO NACIONAL DE PÓS-GRADUAÇÃO E PESQUISA EM PLANEJAMENTO URBANO E REGIONAL, 18, 2019, Natal. Anais... Natal: Anpur, 2019. Disponível em <http://anpur.org.br/xviiienanpur/anaisadmin/capapdf. php?reqid=378>. Acesso em 12 maio 2020.

ETGES, Virginia Elisabeta; DEGRANDI, José Odim. Desenvolvimento regional: a diversidade regional como potencialidade. Revista Brasileira de Desenvolvimento Regional, Blumenau, v. 1, n. 1, p. 85-94, mar. 2013. ISSN 2317-5443. Disponível em: <https://proxy.furb.br/ojs/index.php/ rbdr/article/view/3649>. Acesso em: 14 maio 2020. doi:http://dx.doi. org/10.7867/2317-5443.2013vinıpo85-094.

FAVARETO, Arilson da Silva. Paradigmas do desenvolvimento rural em questão - do agrário ao territorial. 2006. 22of. Tese (Doutorado em Ciência Ambiental) - Universidade de São Paulo, São Paulo, 2006. doi:10.11606/T.90.2006.tde-24042008-113514. Acesso em: 18 mar. 2020.

FREIRE, Isa Maria. Comunicação de Informações tecnológicas para o meio rural. Ci Inf. v.13, n.1, p. 67-71, jan-jun, 1984.

GIDDENS, A. A constituição da sociedade. 3. ed. São Paulo: WMF Martins Fontes, 2009. 
The constitution of society: an outline of the theory of structuration. Cambridge: Polity Press, 1984.

KNORR-CETINA, Karen. The manufacture of knowledge: An Essay on the Constructivist and Contextual Nature of Science. Ozford: Pergamon Press, 1981. Disponível em <http://www.philsci.univ.kiev.ua/UKR/ courses/asp/asp-lit/[Karin_D._Knorr-Cetina,]_The_Manufacture_of_ Knowle(BookFi.org).pdf>. Acesso em 14 mar. 2020.

LATOUR, Bruno. Ciência em ação: como seguir cientistas e engenheiros sociedade afora. São Paulo: Editora Unesp, 200o. 438 p. (Biblioteca Básica).

LONG, Norman. Sociología del desarrollo: una perspectiva centrada en el ator. México: Centro de Investigaciones y Estudios Superiores en Antropología Social, 2007. 504 p.

LONG, N.; PLOEG, J. V. D. Heterogeneidade, ator e estrutura: para a reconstituição do conceito de estrutura. In: SCHNEIDER, S.; GAZOLLA, M. (Org.). Os atores do desenvolvimento rural: perspectivas teóricas e práticas sociais. Porto Alegre: Editora da UFRGS, p.21-47, 2011.

SARDAN, J. P. O. Anthropologie et développement: essai en socio-anthropologie Du changement social. Paris: APAD-Karthala, 1995. 221 p.

SILVEIRA, R. L. L. Oito observações para pensar teórica e metodologicamente o desenvolvimento regional: uma contribuição ao debate. In: SILVEIRA, R.L.L; DEPONTI, C.M.; FELIPPI, A.T. (Org.). Refletindo sobre o Desenvolvimento Regional: Contribuições do PPGDR da UNISC. Santa Cruz do Sul: Edunisc, 2020 (no prelo)

THEIS, I. M. O que é desenvolvimento regional? Uma aproximação a partir da realidade brasileira. Redes (St. Cruz Sul, Online), Santa Cruz do Sul, v. 24, n. 3, p. 334-360, set. 2019. ISSN 1982-6745. Disponível em: $<$ https://online.unisc.br/seer/index.php/redes/article/view/13670>. Acesso em: 18 mar. 2020. doi:https://doi.org/10.17058/redes.v24i3.13670. 


\title{
Celso Furtado, o (sub) desenvolvimento numa perspectiva cultural e a criatividade nos Maracatus Nação de Pernambuco ${ }^{1}$
}

\author{
Tiago Macedo Bezerra Maia \\ João Morais de Sousa ${ }^{3}$
}

\begin{abstract}
[...] Lá em casa eu toco bombo feito negro fez um dia. Para replantar a semente dessa gente, gente minha. [...] Lá em cassa eu canto a história que negro viveu um dia. Pra replantar a semente dessa gente, gente minha. ("Lá em casa" - Márcio Lozano)
\end{abstract}

1 Este capítulo é mais um fruto que brota como um dos resultados parciais de uma pesquisa maior em realização pela profícua parceria de estudos e pesquisas firmada entre a Universidade Federal Rural de Pernambuco (UFRPE) e a Universidade Federal de Pernambuco (UFPE), no âmbito do Grupo de Pesquisa em Ensino de Ciências e Contemporaneidade (GECIC/DED/UFRPE/CNPq), que colabora mutuamente com o Grupo Interdisciplinar de Estudos sobre Representações Sociais e Educação (GIERSE/ CE/UFPE/CNPq). Iniciada no ano de 2017, até o ano corrente de 2020, ainda está em andamento, pois foi projetada para ter continuidade e ser concluída até o ano de 2022.

2 Professor de Filosofia, Cooperativismo/Associativismo e Educação do Campo no Instituto Federal de Pernambuco (IFPE). Mestre, bacharel e licenciado em Filosofia pela Universidade Federal de Pernambuco (UFPE). Especialista em Ensino de Filosofia pelo Espaço Contemporâneo de Ensino e Pesquisa/Faculdades Integradas de Vitória de Santo Antão (ECEP/FAINTVISA). Bacharel em Direito pela Universidade Católica de Pernambuco (UNICAP). Especialista em Direito Público pela Escola Superior da Magistratura de Pernambuco/Centro Universitário Maurício de Nassau (ESMAPE/ UNINASSAU). Especialista em Gestão Pública pela Universidade Federal Rural de Pernambuco (UFRPE). Bacharelando concluinte em Ciências Sociais na Universidade Federal Rural de Pernambuco (UFRPE). Discente pesquisador do Grupo Interdisciplinar de Estudos sobre Representações Sociais e Educação (GIERSE/CE/UFPE/CNPq), do Grupo de Pesquisa em Ensino de Ciências e Contemporaneidade (GECIC/DED/UFRPE/ CNPq), e do Grupo Teoria Crítica (DECISO/UFRPE/CNPq). (tiagombmaia6@gmail.com).

3 Professor Associado do Departamento de Ciências Sociais da Universidade Federal Rural de Pernambuco (DECISO/UFRPE) e Professor Colaborador do Programa de Pós-Graduação em Desenvolvimento Regional da Universidade Estadual da Paraíba (PPGDR/UEPB). Doutor em Sociologia pela Universidade Federal de Pernambuco (UFPE). Mestre em Ciência Política pela Universidade Federal de Pernambuco (UFPE). Bacharel em Ciências Sociais pela Universidade Federal da Paraíba (UFPB). Docente pesquisador do Grupo Interdisciplinar de Estudos sobre Representações Sociais e Educação (GIERSE/CE/UFPE/CNPq) e do Grupo de Pesquisa em Ensino de Ciências e Contemporaneidade (GECIC/DED/UFRPE/CNPq). Ex-Secretário de Turismo e Cultura de Igarassu/PE (2015-2016). (joaomsousa@uol.com.br). 


\section{Introdução}

Celso Monteiro Furtado (1920-2004), nascido paraibano na cidade de Pombal, escreveu as linhas de sua vida como pensador cosmopolita de anseios pautados numa totalidade interdisciplinar e uma erudição global de pungente atualidade. Foi também um dos maiores expoentes intelectuais brasileiros do Século XX, gozando de reconhecimento e notoriedade nacional e internacional.

Na sua vida acadêmica, formou-se Bacharel em Direito pela UFRJ e Doutor em Economia na França, pela Paris I (Sorbonne), tendo passado por Universidades de renome mundial, como, por exemplo, Yale, nos EUA e Cambridge, no Reino Unido, dentre várias outras, e, suas reflexões, seus estudos, seus escritos e até suas entrevistas ou seus discursos deixam entrever seu ímpeto de transcender as fronteiras e limites dessas disciplinas, adentrando e ousando no caminho interdisciplinar que percorreu e através do qual estabeleceu o diálogo profícuo da economia com a filosofia, a literatura, a história, a geografia e, para efeito desse capítulo, mais especificamente e em especial, com a antropologia e a sociologia, dentre as ciências sociais (BORJA, 2013).

Na sua vida pública, inserido na política institucional brasileira, esteve sempre engajado e comprometido com seu projeto de um Estado intervencionista voltado para a transformação e a mudança social necessárias para um autêntico desenvolvimento, tendo participado, em funções diversas e cargos estratégicos, por seis vezes da Gestão Pública Federal do Brasil, deixando importantes contribuições, inclusive como Ministro da Cultura entre os anos de 1986 a 1988 (BORJA, 2019; D'AGUIAR, 2012).

Homem de reflexão e ação, sempre preocupado com os problemas que formaram e nutriram toda a amplitude dos horizontes de sua visão de mundo, da pobreza nordestina de suas origens às desigualdades patentes do mundo em constante ebulição. Sempre recorrendo ao enfrentamento da realidade de seu tempo, percebeu, a partir de seu aprofundamento no engajamento consciente de uma luta contra o subdesenvolvimento e a dependência cultural e técnica que, presentes na modernização trazida pela estrutura global do capitalismo e na lógica da dominação pelo poder econômico, foram instauradas como vetor de limitação do potencial dos países periféricos subdesenvolvidos, com relação aos países capitalistas centrais desenvolvidos.

Furtado elabora então a ideia de que, com a modernização crescente e a industrialização que gradualmente proporcionou uma forçosa 
transição, no Brasil, do antigo modelo econômico primário exportador ao novo industrial modelo econômico de substituição de importações, há como pressuposto deste movimento econômico, elementos do modo de vida da burguesia que desde o início da modernidade vinha se expandindo e consolidando em todo o mundo (FURTADO, 1978).

O economista paraibano destaca, assim, o papel da cultura que pode ser entendida como um sistematizado e complexo conjunto de valores e práticas que podem permear de sentido e significado o fazer e o agir, o pensar e o sentir, pois eis que, esta surge autêntica e espontaneamente do modo de vida cotidiana compartilhada socialmente, com finalidade de concretizar na realidade os anseios de uma sociedade.

É importante ressaltar que para Furtado, a cultura, como modo de vida voltada ao âmbito dos valores-fins partilhados em uma comunidade, pareceu anteceder e preparar espiritualmente a cosmovisão refletida nos caminhos para o ensejo e estabelecimento dos meios materiais que chegam com a modernização técnica. Isso se deu, numa constatação histórica furtadiana, que se funda no importante e imprescindível esteio do $a$ priori cultural que marca a produção e a reprodução social a posteriori das estruturas que edificam as bases do poder econômico burguês advindo do capital (KORNIS, 2013).

As reflexões furtadianas sempre buscaram trazer à tona toda a densidade desveladora acessada por meio e através de um uso pioneiro e ousado de uma perspectiva conjunta, que integrou conhecimentos de diversas ciências humanas, ciências sociais e ciências sociais aplicadas, tornando assim, possível e viável, um olhar inovador e desbravador sobre a origem dos problemas do subdesenvolvimento latino-americano e brasileiro.

Diante do exposto, este capítulo objetiva, não somente elucidar os caminhos traçados por Furtado na construção de sua compreensão sobre a cultura, mas, diante disso, trazer ao debate o potencial de criatividade e resistência da cultura popular negra pernambucana (os Maracatus Nação) como uma manifestação coletiva que faz emergir espontânea e autenticamente da vida cotidiana os ideais do povo e que com seus símbolos e práticas, transmitidas de geração em geração, mantém o modo de vida e os aspectos identitários da memória e do patrimônio cultural do Brasil, fundamentais para o entendimento da formação da sociedade brasileira.

Com o exemplo dos Maracatus Nação, ícones da cultura popular de Pernambuco, que guardam nas suas toadas e nos seus baques muitos elementos da construção da sociedade e da cultura brasileiras, estes lutam 
e resistem criativamente para se manterem vivos e ativos num cenário de negligência da gestão pública em todos os seus níveis federativos.

\title{
Da cultura à interdisciplinaridade: o encontro de Celso Furtado com a antropologia
}

Ao adentrar no pensamento furtadiano, se delineia um chamado ao desbravar da complexidade do mundo por meio de sua peculiar dinamicidade interdisciplinar através da qual estabelece diálogos entre os academicamente tão diversos quanto ainda isolados campos disciplinares das humanidades, das ciências sociais e das ciências sociais aplicadas.

Para Furtado, essa nova e integradora perspectiva de ampliação das possibilidades advindas do encontro e do diálogo entre as disciplinas que iluminaram seus estudos, foram cruciais para a formulação teórica e a ação prática, ambas comprometidas sempre com seu projeto maior de transformação e emancipação da realidade das sociedades latino-americanas, iniciando com a mudança estrutural do Brasil.

E sobre o caráter interdisciplinar de seu pensamento, confirma o próprio Furtado (1997), já criticando o isolamento disciplinar da economia de sua época:

\begin{abstract}
O pesado corpo da ciência econômica, concebido para funcionar em um universo onde a dimensão tempo inexiste, oferecia grande resistência [...] Mas [...] estava sob assédio. Em torno dela pipocavam ideias novas vindas da história econômica, da demografia, da antropologia, da sociologia, da história da ciência e das técnicas. Em pouco tempo mais, cristalizaria o paradigma do desenvolvimento, e um caudal de pesquisa que se esterilizava em áreas saturadas, encontraria novo canal por onde desaguar. Ao ganhar nitidez esse paradigma, impor-se-ia a necessidade de romper fronteiras e buscar a interdisciplinaridade, de afrouxar as camisas de força, [...] de recolocar o problema epistemológico da relação entre fins e meios nas ciências sociais (FURTADO, 1997, t. 1, p. 197).
\end{abstract}

Nesse sentido, pode-se verificar, em virtude de sua perspectiva interdisciplinar, uma gama de diversas influências das mais diferentes disciplinas das ciências humanas, ciências sociais e ciências sociais aplicadas que, em conjunto, formaram e integraram a unidade de seu pensamento, por isso, pioneiro e vanguardista. Dentre esses campos disciplinares, abordaremos, a seguir, de modo sucinto, os que mais podem contribuir para os objetivos reflexivos deste capítulo. 
Das ciências sociais aplicadas, tendo estudado profundamente economia, disciplina na qual realizou seus aprofundados estudos de pósgraduação e, tendo nela se especializado, desfere contra este campo científico-disciplinar contundentes críticas em todas as suas obras, principalmente, em virtude das limitações de objetividade e metodologia enfaticamente dedutiva, e, mesmo que sempre recorrendo aos economistas clássicos como Adam Smith (1983), David Ricardo (1982) e Karl Marx (1986; 2008), (este último em especial, com mais frequência), por exemplo e, neste ponto, sempre revisita esses autores numa perspectiva próxima aos estudos de Claudio Napoleoni (1988; 2000).

Essas e outras reflexões, notada e mormente influenciaram Furtado, pela sua ideia de modo de produção, a sua crítica das formas exploratórias e de dominação e controle derivada da organização das estruturas econômicas que fundam as bases materiais e condicionam objetivamente a dinâmica cultural e política de uma sociedade dentre outros contributos marxianos; assim como esteve sempre a dialogar com economistas contemporâneos do quilate de Paul Baran (1984), e Joseph Schumpeter (1961) e, principalmente John Keynes (1992) e o seu amigo argentino Raúl Prebisch (1982), dentre outros, todos estão presentes de modo recorrente em seus escritos.

E, dessa forma, nesse diálogo econômico, contundentemente ataca os limites da economia clássica e ortodoxa, e, comentando a origem de suas ideias desenvolvimentistas, Furtado afirma que:

[...] a apreensão do fenômeno do desenvolvimento exigia um enfoque mais amplo do que nos permitia a análise econômica, pois estávamos lidando com um amplo processo de mudança cultural, "força criadora das civilizações" (FURTADO, 1997, t. 1, p. 285).

Nas suas incursões na área Sociológica, se aprofundou em autores clássicos do pensamento social tais como Max Weber $(1967 ; 1992)$ e também Karl Marx (1986; 2008), por exemplo. Com Weber (1967; 1992), pôde aprender, sob o prisma da sociologia compreensiva, a importância da ação social e de seus sentidos individuais e, nas interações sociais, os significados para a vida em sociedade.

Isso o permitiu entender que, em certas sociedades, houve fatores peculiares no modo de vida e comportamentos de seus integrantesmembros que favoreceram a consolidação e a expansão do capitalismo, e, finalmente, pôde compreender a cultura como um sistema de símbolos criados pelo homem, na vida em sociedade, e sem os quais este homem 
não vive socialmente, atrelando-se a este conteúdo simbólico-cultural que permeia de sentido o cotidiano da comunidade. Marx $(1986 ; 2008)$, como já mencionado anteriormente, foi influência marcante nas reflexões furtadianas.

Do pensamento social marxiano, recuperou suas reflexões fundamentais como, por exemplo, a ideia de estrutura social (base, infraestrutura e superestrutura), modo de produção e mudança social, dentre outros. E, o aporte teórico marxista, seja ele econômico ou sócio-político, por exemplo, foi basilar para a construção do método furtadiano chamado histórico-estrutural.

Da Teoria Crítica da Escola de Frankfurt, ao estudar Adorno (1986; 2002), Horkheimer (2002), Marcuse (1973; 1999) e Benjamin (1989), que também, como Furtado, foram dialéticos e marxistas, acolhe as suas noções de indústria cultural, da cultura de massa, da razão instrumental, padronização social unidimensional e reprodutibilidade técnica, respectivamente, do mesmo modo que as críticas e teorias da modernidade e da modernização de todos eles, por exemplo, como aporte explicativo do (i) lógico e irracional capitalismo.

E preciso aqui salientar a importante distinção que, a partir dos frankfurtianos, se estabeleceu como forma de analisar e entender a sociedade capitalista, com a diferenciação da cultura de massa, voltada para o lucro e a objetividade e a padronização em virtude do acúmulo crescente e constante do capital, diante da cultura popular, autêntica e identitária que tem como as marcas que dão sentido à tradição revisitada cotidianamente por um povo; cosmovisão, autorrepresentação, pertencimento, autenticidade e espontaneidade, tudo isto e outros elementos populares mas, inclusive opondo-se como forma de resistência em suas expressões e manifestações como resistência à mercadológica cultura capitalista.

$\mathrm{Na}$ cultura popular, haveria a singularidade que abrilhanta o sentido de cada hábito ou símbolo pela sua singularidade experienciada e vivida comunitariamente, e de forma radicalmente distinta e bastante diferenciada da reprodutibilidade de mero caráter técnico, que também caracteriza a massificação cultural em escala industrial.

Entre os sociólogos brasileiros que influenciaram Furtado, destacamse Florestan Fernandes (1972; 1975; 1976), Darcy Ribeiro (1970; 1995; 2001) e Gilberto Freyre (1957, 1969, 1990, 2010), dentre outros. É de grande valia notar que todos estes deram significativas contribuições, cada qual ao seu modo, no que se refere à busca por uma identidade e uma interpretação sócio-político-cultural do Brasil. Florestan $(1972 ; 1975 ; 1976)$ enfrentou a 
problemática da formação e consolidação de uma burguesia brasileira e também os problemas raciais inerentes ao fato do que vive o negro num país que privilegia brancos. Ribeiro (1970; 1995; 2001) procurou entender as fases socioculturais do processo civilizatório na formação da sociedade brasileira e, também, os sentidos e os significados do Brasil, para o seu povo.

Com Freyre (1957; 1969; 1990; 2010), Furtado pôde melhor adentrar na dinâmica da colonização europeia no nordeste do Brasil e a formação da sua sociedade açucareira primário-exportadora e, como nela se davam as interações sócio-políticas e econômico-culturais. Salienta-se, no entanto, que, baseado, principalmente nestes três expoentes do pensamento social brasileiro, mesmo sem essa pretensão, Furtado refuta muitas das teses de interpretação do Brasil, por exemplo, alguns pontos de Sérgio Buarque de Holanda (2006) e Raymundo Faoro (2008).

Do ponto de vista da Antropologia, talvez o prisma mais vanguardista e pioneiro de todo o arcabouço pensado por Furtado, este parece ter situado e dado à cultura e às manifestações e fenômenos culturais, um papel de destaque no processo do desenvolvimento social e econômico. Isto ocorreu, certamente, por ter estado durante um bom tempo em sua formação nos Estados Unidos da América, lugar no qual passaria uma parte importante da sua vida, de tempos em tempos, visitando, para a realização de seus estudos e a concretização de objetivos acadêmicos de pesquisa.

Em virtude disto, constata-se, em muitos aspectos de suas análises culturais, fortes influências da antropologia americana, tais como da escola antropológica difusionista cultural ou particularista histórica, de Franz Boas (1996; 2004) e, da escola antropológica interpretativa ou simbólica, de Clifford Geertz (1978; 1999; 2001). É sabido, e aqui posteriormente será melhor analisado, que Furtado concebe a cultura como um sistema de fins que articula em seu bojo um complexo de valores e símbolos que confere ao modo de vida da comunidade seu horizonte de significados e sentidos cotidianamente vividos e partilhados.

Boas (1996; 2004), fortemente baseado nas teorias alemãs do espaço vital e no culturalismo historicista, desenvolve suas ideias de difusão cultural e ciclos (círculos) de cultura. Na antropologia difusionista boasiana, há centros geográficos que concentram num dado espaço a matriz da vitalidade cultural de uma dada sociedade que, ao manifestarem seus fenômenos, irradiam e difundem essa cultura e assim expandem em ciclos temporais (circularmente/ciclicamente), ampliando no tempo-espaço os raios de influência e impacto dos rudimentos basilares deste corpo 
sociocultural, ou seja, deste modo ocorreria a difusão das culturas, tal como o nome da escola indica e pressupõe.

Um outro ponto importante para Boas $(1996 ; 2004)$ é que a construção histórica dos hábitos e práticas compartilhados na vida social, devem ser abordados em suas específicas particularidades contextuais, e daí também se deriva um dos nomes desta corrente antropológica. Salienta-se que a influência de Boas no pensamento de Furtado foi, ao mesmo tempo, introduzida e reforçada pelas leituras e estudos das teorias sociológicas e culturais de Gilberto Freyre $(1957 ; 1969 ; 1990 ; 2010)$ (que foi aluno de Boas nos EUA), e ambos estiveram notadamente presentes na construção de sua metodologia de análise e compreensão das sociedades latino-americanas e da formação social brasileira.

É possível encontrar uma nítida relevância de Freyre e da antropologia, para Furtado, desde tenra idade de adolescente, sendo anterior, inclusive, a seus estudos econômicos, como o próprio testemunha e explicita em trecho das "Aventuras de um economista brasileiro" (Cf. FURTADO, 1997, t. 2, p. 16), em que ele mesmo, corrobora com a hipótese tal como postulada e demonstrada por César Bolaño abaixo, por exemplo.

E, sendo assim, Celso Furtado:

[...] reconhece a influência [...] "norte-americana" da teoria antropológica da cultura [...] pela primeira vez por intermédio do livro de Gilberto Freyre, "Casa grande e senzala", aos 17 anos de idade, esclarecendo, não obstante, que [...] sua importância [...] revelou todo um instrumental novo de trabalho [...]. Esse instrumental novo, a teoria antropológica da cultura, estava presente, portanto, no pensamento de Furtado, desde as suas primeiras leituras, ainda na adolescência. Mais ainda, a sua ideia de cultura antecede a economia [...] (BOLAÑO, 2015, p. 93).

No âmbito da também americana antropologia interpretativa ou simbólica de Geertz (1978; 1999; 2001), que se baseia na ideia de cultura sociológico-compreensiva weberiana, Max Weber $(1967 ; 1992)$ analisa os fenômenos e manifestações culturais como redes de sentido e símbolos criados, significados compartilhados, articulados e legitimados pelas práticas e costumes, saberes e comportamentos, fazeres e hábitos, como modos de vida próprios e autênticos de uma sociedade.

Partindo disso, Geertz $(1978 ; 1999 ; 2001)$, utilizando das contundentes críticas da fenomenologia e da hermenêutica direcionadas à razão moderna e ao viés científico das teorias antropológicas clássicas que desta racionalidade derivam e se fundaram, propõe uma antropologia que não se baseia no superficial e limitado objetivismo do ímpeto científico, mas 
sim, na densidade das singularidades subjetivas que, ao interagirem socialmente, se compreendidas, podem desvelar a profundidade de uma cultura, forjada nesses hábitos e valores coletivos, como modo de vida, a cultura é tecida tal como uma obra de arte, permeando de sentido, assim, as vivências e experiências socialmente compartilhadas.

É na busca do acesso a este denso complexo de sentidos individuais e significados coletivos simbólico-social e culturalmente presentes no modo de vida comunitário, que Geertz (1978; 1999; 2001) aplica pressupostos compreensivos fenomenológico-hermenêuticos, para acender a clareira da interpretação cultural.

Em vários momentos de sua obra, Furtado faz uso de termos e construções reflexivas, no tocante às limitações metodológico-objetivas das ciências econômicas e da racionalidade científica, por exemplo, que remetem à fenomenologia e à hermenêutica, indiretamente, mas que, também, pode se admitir, por isso, que a análise furtadiana da cultura seja compreendida, num viés antropológico-interpretativo, como o das ideias de Geertz (1978; 1999; 2001).

Isto posto, no tocante ao que se compreende como interdisciplinaridade, também sob a perspectiva de Celso Furtado, pode-se pontuar que:

A palavra interdisciplinaridade refere um modo de trabalhar o conhecimento [...] orientado pela reintegração dos aspectos que ficaram isolados ou dispersos em razão de certo tratamento dito disciplinar. $\mathrm{O}$ que se busca com esse expediente [...] é justamente uma visão não fragmentada, ampla e por isso mesmo mais adequada à realidade [...]. Em suma, a interdisciplinaridade busca compensar a fragmentação do saber que decorre não da realidade, mais dos meios que dispomos para conhecê-la. Em última análise, o que a interdisciplinaridade busca recompor [...] é a própria realidade em sua irredutível complexidade (OLIVEIRA, 2018, p.198).

Neste sentido e por tudo isso, no esteio compreensivo da sociedade e cultura brasileiras, Furtado pode ser considerado, também, um dos grandes intelectuais intérpretes do Brasil do século XX, e, com certeza, podese dizer que ele é um dos expoentes do chamado "pensamento social brasileiro".

Após se revisitar e reconstruir um pouco do caminho e da influência do conhecimento antropológico sobre a cultura e as suas correntes americanas na perspectiva interdisciplinar do pensamento furtadiano, bem como se resgatar de modo sucinto, também, como se deu o legado da antropologia e sua recepção em Furtado, o próximo tópico analisará uma 
de suas grandes contribuições para as ciências sociais e sociais aplicadas, o método histórico-estrutural, situando a cultura, a partir deste, no prisma do estruturalismo latino-americano.

\section{O método histórico-estrutural de Celso Furtado: um novo suporte para os estudos do (sub)desenvolvimento no estruturalismo latino-americano}

É importante salientar aqui que mesmo no tópico anterior tendo sido elencadas algumas das mais importantes influências formativas interdisciplinares do pensamento de Furtado, com menção especial à antropologia e à sociologia, dentre diversas outras que, neste texto, não foram mencionadas, articulam-se estas inspirações numa perspectiva de integração e diálogo interdisciplinar.

Celso Furtado, com todas as disciplinas (campos científico-disciplinares) que estavam em seu horizonte, delas muito recepcionou de modo a estabelecer um frutífero diálogo entre as mesmas, mas, sempre tecendo contundentes críticas a essas, ou seja, não apenas reproduziu ideias na construção de suas teorias e métodos, mas, ao recebê-las, as articulou de um modo peculiar e próprio no seu visionário projeto de compreensão, enfrentamento e transformação da realidade das sociedades latino americanas, com foco na mudança social, política e cultural do Brasil e seu potencial de desenvolvimento.

Sobre o prisma da interdisciplinaridade, notadamente presente na reflexão furtadiana, ressalta-se ainda que:

A postura interdisciplinar se dá por meio de um diálogo que articula os olhares de diversas disciplinas. É da ordem do conhecimento lato sensu. Do conhecimento confrontado com os objetos. Acontece que os objetos não existem atomisticamente separados e isolados. Eles existem numa rede, o que os insere numa totalidade, são sempre partes de um todo. Formam uma teia de significações que se interpenetram umas nas outras. Não de forma mecânica. É por isso que se fala da complexidade do real. O real não é simples. Ao isolarmos os objetos em múltiplas ciências, estamos tentando separá-los de sua unidade no todo. O olhar de uma única ciência não esgota o conteúdo significativo de um objeto, por mais que se possa isolá-lo. Mas também não basta somar, justapondo-os, múltiplos olhares. O olhar interdisciplinar procura exatamente recompor o tecido do real, na sua complexidade, tramando os significados (SEVERINO, 2011, p.85). 
Após esse aporte interdisciplinar da formação do pensamento furtadiano, como acima exposto, agora é o momento de se explicitar, sucintamente, pontos dorsais de seu método próprio de análise e compreensão da realidade, o método chamado por ele e assim conhecido como histórico-estrutural, um dos fundamentos de um grupo (toda uma escola) de pensadores, dentre os quais Celso Furtado, que ficou conhecido como estruturalismo latino-americano.

Sobre essa metodologia furtadiana, que se orienta interdisciplinarmente, Celso Furtado:

[...] no momento da gênese do método histórico-estrutural,
o seu formulador estava empenhado justamente em defen-
der uma visão interdisciplinar do problema do desenvolvi-
mento, com ênfase na necessidade de incorporação de um
paradigma antropológico [...[ (BOLAÑO, 2015, p. 99)

Furtado, em suas análises, leva em consideração os fatores históricos, sociais políticos e culturais constitutivos das particularidades, especificidades e singularidades de uma sociedade, especialmente, das sociedades da América Latina (e por isso, foi uma grande contribuição para uma compreensão mais profunda da realidade, das nuances formadoras da sociedade brasileira). Portanto, trata-se de uma abordagem que parte do princípio de que as regiões ou países possuem suas características heterogêneas próprias e precisam ser vistos em suas especificidades políticas, sociais e culturais (RODRÍGUEZ e BURGUEÑO, 2007).

Não há um modelo econômico único que se adeque e satisfaça toda e qualquer sociedade. Cada território, cada povo, cada cultura, cada sociedade tem as singularidades que são próprias de sua formação, vive suas particularidades, possui especificidades histórico-geográficas e político-culturais.

Até o pensamento de Furtado e a difusão do estruturalismo latino-americano, as metodologias econômicas pretendiam explicar o desenvolvimento econômico de forma estritamente objetiva, causal e abstrata. Por outro lado, o método histórico-estrutural busca uma compreensão do todo, leva em consideração que o sistema econômico internacional apresenta hierarquias e assimetrias econômicas e de poder que o fundam e estruturam, focando assim, no contexto histórico de maneira específica, analisando a dinâmica dos processos econômicos no tempo e no espaço, tendo como pano de fundo e fio condutor analítico, processos sociais, políticos e culturais contextualizados (RODRÍGUEZ, 2009). 
Neste sentido, os contributos de Celso Furtado:

[...] resultam da fundamentação das análises na consideração de características particulares - que determinam e são determinadas pelas transformações históricas, econômicas e sociais (nacionais e internacionais) - e do desenvolvimento e da aplicação do método histórico-estrutural, que ao incorporar análises historicamente contingentes com dimensões não-reducionistas, não-mecanicistas e nãodeterministas, [...] uma concepção de mundo que considera mais do que fatores meramente econômicos. Ademais, cumpre destacar a contribuição original quanto à compreensão do desenvolvimento e do subdesenvolvimento na condição de processos mutuamente constituídos dentro de um mundo economicamente integrado e o papel do Estado como agente indispensável neste processo (MISSIO; JAYME JR; OREIRO, 2012, p. 28-29).

E, ainda, sobre o método histórico-estrutural de Furtado, que sustentou os pilares teóricos empíricos de suas reflexões sobre o subdesenvolvimento da América Latina (e do Brasil, consequentemente), pode-se salientar que:

A tarefa de pensar o subdesenvolvimento latino-americano, [...] exigia, por um lado, a leitura crítica da produção teórica sobre a temática do desenvolvimento nas diferentes correntes de pensamento em voga para não incorrer num particularismo excludente e, por outro, aprofundar o conhecimento empírico da realidade latino-americana, aprendendo com ela. Tinha-se muito claro que só assim seria possível ensaiar uma interpretação do subdesenvolvimento latino-americano capaz de instrumentalizar decisões práticas com o objetivo de sua superação. [...] Já estava posto àquela época que não havia, pois, como pensar o subdesenvolvimento sem esforço analítico totalizador. Era indispensável partir de uma perspectiva analítica integradora, tanto do ponto de vista dos diferentes aspectos da realidade e das distintas realidades [...] latino-americanas, como também das diferentes disciplinas das ciências sociais (SANTOS, 2011, p. 59-60).

Desta forma, reitera-se uma vez mais que, esse método furtadiano de análise histórico-estrutural, muito ajudou a fornecer as bases e a consolidar as críticas e reflexões de toda uma corrente (escola) de pensadores a ele contemporâneos e também posteriores aqui já mencionada, o estruturalismo latino-americano. Desse modo, essa nova metodologia elaborada por Furtado faz compreender que:

Um esquema analítico adequado para o estudo do desenvolvimento e do subdesenvolvimento [...] deve [...] fundar-se [...] na observação [...[ sistemática na qual o subdesenvolvimento é parte do processo histórico global de 
desenvolvimento, que tanto o subdesenvolvimento como desenvolvimento, são duas faces de um mesmo processo histórico universal; que ambos os processos são historicamente simultâneos, que estão vinculados de modo funcional, ou seja, que interatuam e se condicionam mutuamente, e que suas expressões geográficas concretas, nas quais se observam dois grandes dualismos: de um lado, a divisão do mundo entre Estados nacionais industriais, avançados, desenvolvidos, centrais, e os Estados subdesenvolvidos, atrasados, pobres, periféricos, dependentes; e por outro, a divisão dentro dos próprios Estados nacionais, em áreas, grupos sociais e atividades avançadas e modernas, e em áreas, grupos e atividades atrasadas, rudimentares e dependentes (SUNKEL; PAZ, 1970, p. 37. Tradução livre dos autores).

Isto posto, no próximo tópico deste escrito, se busca apresentar a noção de cultura, no pensamento de Celso Furtado, se evidenciando, com o uso intrínseco de seu método histórico-estrutural, a importância crucial da perspectiva cultural para a consolidação de suas críticas reflexivas e ideias de desenvolvimento e subdesenvolvimento, e sublinhando o potencial cultural como fonte potencial de criatividade e um ponto forte nos horizontes de possibilidades para a transformação social no Brasil.

\section{O lugar da cultura e seus fundamentos antropológicos no pensamento de Celso Furtado}

A relevância do pensamento de Furtado sobre a cultura está em ele refletir contextualizada e criticamente no sentido de desvelar nuances pioneiras acerca do promissor potencial criativo das autênticas e identitárias manifestações e fenômenos culturais, em especial, da cultura popular, com foco para o desenvolvimento num prisma multireferencial e interdisciplinar, como já anteriormente mencionado, e que são analisadas por ele que isso desbravou, à sua maneira, através seu método histórico-estrutural, a busca pela identidade da sociedade brasileira.

O pensar cultural furtadiano pode proporcionar, também, assim, uma compreensão mais aprofundada dos modos de vida, hábitos, costumes, práticas, saberes, tradições, valores e símbolos culturalmente partilhados que formam o Brasil, sua cultura e sua sociedade.

A cultura popular tem importância singular na sociedade contemporânea e isso tem sido visibilizado pelas buscas das comunidades em geral à procura de suas raízes referenciais e tradicionais, das ancestralidades, das memórias, de suas identidades culturais e consciência histórica (BOSI, 2000; KEIM e SILVA, 2012). 
Nesse sentido, torna-se fundamental a reflexão sobre o papel das manifestações e fenômenos culturais populares, ressaltando seu potencial criativo e identitário para o desenvolvimento econômico e social, em especial às relacionadas à resistência da cultura afro-brasileira, tão importantes para a formação econômica, social e política brasileiras, um ponto de encontro com a ideia de cultura de Furtado.

Este início do século XXI tem exigido novas demandas sociais, políticas e culturais que sejam a concretização de uma nova, criativa e emancipadora ideia de desenvolvimento. $\mathrm{O}$ fortalecimento, o fomento e a preservação das manifestações e dos fenômenos culturais populares, como um criativo movimento de resistência diante de limitadoras imposições, constantes pressões e notórias exclusões da modernização e do capitalismo (CHAUI, 1986; FREIRE, 1996; BARROS, 2008).

A preservação e valorização da cultura popular, figura, então, como uma urgência para que a sociedade brasileira atinja um estágio satisfatório, mais amplo, genuíno e pleno de independência, criatividade e desenvolvimento, também numa perspectiva furtadiana (KORNIS, 2013).

Celso Furtado, então, como economista de formação acadêmica, mas também, como um intelectual de uma vida escrita como humanista, se propõe a enfrentar o problema de identificar qual o impacto da economia na elaboração de uma reflexão sobre a cultura, e, ao mesmo tempo, explicitar qual a força criativa da raiz cultural que pode impulsionar ao pleno desenvolvimento, a América Latina, o Brasil.

O pensamento furtadiano sobre os aspectos culturais, se elabora então, refletindo sobre os contextos em que o diálogo cultura-economia pode ser verificado no fluxo do tempo e na dinâmica do espaço. Assim, se desvela e elenca o potencial cultural, ponto crucial eivado de possibilidades de impactos diversos, também, sobre a construção das pressuposições sobre as quais se edificarão os pilares de mais viáveis e mais novos modelos econômicos que considerem esses parâmetros culturais. Furtado procura, de tal modo, realocar as temáticas da cultura, retirando -as da periferia na modelagem econômica, e, dando-a visibilidade sob o prisma da economia, para alçá-la à centralidade nos debates sobre o (sub) desenvolvimento (KORNIS, 2013).

Neste ponto crucial, figurará como protagonista e fio condutor o aporte antropológico que sai à frente da economia, e, por isso, tão defendido e apreciado em muitas das obras de Furtado, que categoricamente declara: “[...] posto que o subdesenvolvimento é uma manifestação cultural, era natural que antropólogos nos houvessem antecipado no terreno 
que agora explorávamos, não sendo pouco o que com eles tínhamos que aprender" (FURTADO, 1997, t. 1, p. 194).

Diante do polissêmico termo cultura, no ínterim das ciências humanas, sociais e sociais aplicadas, pode-se verificar que um dos seus mais notórios sentidos é o que a coloca como elemento que distingue o que é natural (disposto e dado na realidade pela natureza) e do homem (construído inventivamente e elaborado criativamente pelo ser humano, de modo situado no tempo e no espaço, para solução de seus problemas cotidianos e para atender suas necessidades sociais) - note-se aqui uma ênfase no potencial criativo e inventivo da vida em sociedade.

Mas, notou e explicitou Furtado, como argumento-base em muitas de suas obras, que a economia, em geral, em grande parte de sua história como ciência, desconsiderou as manifestações e os fenômenos culturais, deixando a cultura fora de sua objetividade analítica, e, a cultura assim, era relegada e excluída como fator/variável de impacto/análise. Desse modo, a economia buscou adequar e limitar o rico e ilimitado manancial da cultura e sua gama de possibilidades compreensivas, impondo ao âmbito cultural apenas e superficialmente modelos objetiva, quantificada, racional e utilitariamente (MIGUEZ, MACHADO, 2010; SILVA, 2007).

É muito importante, assim, para essa nova, mas ainda tímida perspectiva dentro da economia que se volta para a visualização da ideia que, de fato, as relações econômicas condicionam e são condicionadas, em simultâneo, pela cultura como modo de vida, no mundo capitalista da civilização industrial.

O conceito primeiro de cultura deriva etimologicamente da natureza. Sua acepção arcaica significa cultivo, colheita, lavoura, agricultura. Seu sentido é relativo ao cultivo das plantas, da terra. Esta definição abarca duplamente os significados de atividade/plantar e de passividade/esperar pela natureza. Deste modo, afirma-se que:

[...] de um ponto de vista etimológico cultura é um conceito que deriva da natureza. [...] Derivamos, assim, a palavra que utilizamos para descrever as [...] atividades humanas, do trabalho e da agricultura, das colheitas e do cultivo. [...] "cultura" designava um minucioso processo material, o qual veio a ser metaforicamente transposto para os assuntos do espírito. [...] A palavra cartografa, assim, no âmbito do seu desdobramento semântico, a própria transição da humanidade de uma existência rural para uma existência urbana [...] (EAGLETON, 2003, p. 11-12). 
No século XVI, o termo cultura foi tomado, em francês, ao que parece, para dizer os processos materiais de desenvolvimento humano, suas faculdades e realizações (CUCHE, 1999). Com o seguir da história, passa de um sentido mais técnico para uma palavra alemã que abrangeria, também e principalmente, aspectos espirituais, das potencialidades do pensar humano.

Ambos os significados falam de elaborações que surgem com as experiências e vivências da vida social de uma comunidade. Então, o vocábulo cultura estava ainda preso e cerceado em adjetivos que, como atributos de sua ideia, dava sentido a ela, mas, com o passar do tempo, foi liberto dessas limitações e tomado tal como forma ou modo de abstração em si mesma (EAGLETON, 2003). Em meados do século XVIII, essa perspectiva sobre a cultura será o seu prisma fundamental de compreensão e sentido.

Assim:

A ideia de cultura vem a aparecer em meados do ano de 1871. Considera-se a mesma como uma ideação sintética de duas noções anteriormente já existentes, a alemã Kultur e francesa Civilization. A noção germânica aponta para os conteúdos espirituais e simbólicos que fundam e plasmam o pensamento e a compreensão do sentido de uma cosmovisão compartilhada em um dado grupo social. A noção francófona liga-se mais às produçỗes materiais surgidas do enfrentamento das necessidades práticas cotidianas por uma coletividade humana [...]. Edward Tylor então, em 1871, opera tal síntese na noção anglófona de Culture. Assim, Tylor consegue reelaborar e reunir numa única palavra todas as manifestações e fenômenos provenientes das realizações simbólicas e materiais do ser humano na sua vida social [...] (MAIA e SOUSA, 2019, p. 148).

E, nesse âmbito, é importante ter em mente, também, que:

Há consensos sobre o fato de que cultura é apreendida, que ela permite a adaptação humana ao seu ambiente natural, que ela é grandemente variável e que se manifesta em instituições, padrões de pensamento e objetos materiais. [...] inclui todos os elementos do legado humano maduro que foi adquirido através do seu grupo pela aprendizagem consciente, ou [...] por [...] técnicas de várias espécies, sociais ou institucionais, crenças, modos padronizados de conduta (SANTAELLA, 2003, p. 30-31).

Deste modo, as manifestações e fenômenos da cultura estão em um movimento de se construir, desconstruir e reconstruir constante e, um dos objetivos para aqueles que estudam a temática, seria desvelar tais fenômenos manifestos no mundo social tão rico de encobertos sentidos 
e significados, podendo então interpretá-los e compreendê-los. Logo, é imprescindível partir desta perspectiva, de que a cultura não é só aprendida, mas também modificada, transformada através da inovação (MELLO, 2003), com o uso das faculdades da criatividade que emergem da vida em sociedade.

A cultura parece surgir pelas necessidades próprias de cada comunidade, pelas questões enfrentadas por cada grupo social, sejam tradições passadas, elementos que se enraízam e permanecem e, ao mesmo tempo, pelos novos dinâmicos e criativos conteúdos que, ao somarem-se, trazem inovações e mudanças ao cotidiano da comunidade. A cultura, então, é "[...] um todo complexo que inclui conhecimentos, crenças, arte, moral, leis, costumes ou qualquer outra capacidade ou hábitos adquiridos pelo homem como membro de uma sociedade" (LARAIA, 1986, p. 25).

$\mathrm{Na}$ origem científica dos estudos sobre o tema, enquanto Tylor apresentou um viés etnocêntrico e unilateral da cultura das sociedades, Boas propôs novas reflexões ao sugerir uma reconstrução mais ampla, histórica e geográfica das singularidades de uma comunidade, multilateralmente, portanto. Assim, as reflexões, percepções e experimentos sobre a ciência da cultura foram, ao longo do tempo, de interesse de nomes como Edward Tylor, Franz Boas, Bronislaw Malinowski e Claude LéviStrauss, dentre outros. E desta forma se fundaram os pilares da antropologia (MAIA e SOUSA, 2019).

Ainda na primeira metade do século XX, revelou-se a crise da racionalidade e das ciências e, desta maneira as reflexões fenomenológicas e hermenêuticas, em contraposição aos postulados epistemológicos vigentes, revelaram novas, amplas e profundas possibilidades de entendimento e compreensão dos fenômenos sociais e manifestações culturais em geral.

Neste sentido, tentando superar a superficialidade da ciência e propondo uma maior densidade no entendimento das questões culturais, Max Weber (1967; 1992), com sua sociologia compreensiva, elucida as bases de sua perspectiva ao afirmar que o homem é um animal que vive preso a uma teia de significados, uma rede de sentidos criada por ele mesmo, a cultura que, também, "[...] é um sistema de símbolos e significados. [...]” (LARAIA, 1986, p. 63).

E, são justamente esses emaranhados de símbolos que, ao serem sistematizados e compartilhados ao longo do tempo e num espaço, pelos integrantes de uma comunidade, formam a cultura e dão sentido à vida social. Este é o foco principal de toda atividade interpretativa antropológica, 
o conteúdo simbólico-cultural que pode ser, assim, compreendido, interpretativamente.

Destarte:

[...] essa interpretação cultural é cabível para que se possa desvelar os sentidos originários e mais autênticos significados da cosmovisão, das tradições ancestrais e das práticas e dos saberes cotidianos de um povo, alcançando, deste modo, a densidade de uma cultura. Portanto, a atividade antropológico-interpretativa se daria como que adentrando em um texto, uma interpretação, para que se possa então compreendê-la, como uma arte, para acessar assim aos conteúdos espirituais constitutivos de sentido mais densos e assim se contrapor aos limites descritivos que a superficialidade da ciência não alcança (MAIA e SOUSA, 2019, p. 150).

Em vista da análise deste mosaico encadeado de sentidos e labirinto articulado de significados que é a cultura, Geertz (1978; 1999; 2001) ensina que se deve elucidar esses sentidos e significações latentes mais rizomáticos e ancestrais das tradições, práticas e saberes, buscando relacioná -los quando vierem a emergir, também, como horizonte de compreensão do(s) modo(s) de vida partilhado(s) pelos membros integrantes de um grupo social. Interpretar a cultura, então, é "[...] tentar ler um manuscrito estranho, desbotado, cheio de elipses, incoerências, emendas suspeitas e comentários tendenciosos [...]" (GEERTZ, 1978, p. 20).

As teias de sentido da cultura crescem e se ampliam espontaneamente e criativamente, surgem mudanças e inovações naturalmente, sem que necessariamente aqueles que a produzem percebam claramente este movimento, esta dinâmica (GEERTZ, 1978; 1999; 2001). Para Geertz (1978), a cultura emerge e desvela-se contextualmente e, apenas tendo em vista este contexto singular, pode-se buscar decifrá-la de forma autêntica, inteligível, profunda e, portanto, densamente descritiva e compreensiva.

Assim, o antropólogo norte-americano, afirma, em síntese, que:

O conceito de cultura que eu defendo, [...] é [...], como Max Weber, que o homem é um animal amarrado a teias de significados que ele mesmo teceu, assumo a cultura como sendo essas teias e sua análise; portanto, não como uma ciência experimental em busca de leis, mas como uma ciência interpretativa, à procura do significado (GEERTZ, 1978, p. 15).

É importante ressaltar aqui que, se a cultura, por um lado "se operacionaliza como elemento prático e comportamental, instrumental e simbólico de superação das dificuldades e necessidades enfrentadas no 
cotidiano da vida social" (MAIA e SOUSA, 2019, p. 151); por outro, pode ser entendida como modo de vida capaz de assinalar a distinção entre grupos sociais, entre sociedades.

Sobre isto, e também sobre o potencial e as possibilidades de criatividade e das inovações culturais, se pontua aqui que:

\begin{abstract}
Uma cultura, enquanto está sendo vivida, é sempre em parte desconhecida, em parte irrealizada. A construção de uma comunidade é sempre uma exploração, pois a consciência não pode preceder a criação, e não existe nenhuma fórmula para uma experiência desconhecida. Uma boa comunidade, uma cultura viva, irá, por causa disso, não apenas dar espaço para, mas encorajar ativamente, todo e qualquer um que possa contribuir para o avanço em consciência que é a necessidade comum... Precisamos considerar com toda a atenção qualquer afeto, qualquer valor [...] (EAGLETON, 2003, p. 168).
\end{abstract}

Mais uma vez, faz-se necessário recordar, já como anteriormente citado, que Furtado recebeu forte influência antropológica de Franz Boas (1996; 2004), através de alguns de seus alunos e discípulos, a exemplo do culturalismo, também de caráter interdisciplinar, presente nas obras sociológicas de Gilberto Freyre (1957; 1969; 1990; 2010), e nos estudos africanistas e sobre mudança social de Melville Herskovits (1963), com quem realizou trocas a partir de sua amizade, diálogo e correspondências.

Para Furtado (1974; 1978), investigar a expansão da civilização industrial burguesa europeia, ao espalhar, no mundo, seu modo e padrão de vida e consumo capitalista, é a pedra de toque da compreensão do subdesenvolvimento, entre os povos e as culturas. Neste sentido, faz-se, para ele, importante o pensamento antropológico do também americano Melville Herskovits (1963), pois:

A exemplo de outros antropólogos de sua geração, ele se inclinava a sobrepor uma 'lógica da cultura' à história, o que o levava a ver na inovação (e na descoberta) mais uma resposta do que uma mutação. Estava longe de deslizar para o determinismo cultural, mas dava ênfase à preexistência de uma 'base cultural', sem o que a inovação não seria absorvida e tampouco a mudança cultural se apresentaria ordenada. Do mesmo ponto de vista, assegurava que a difusão também seguia uma linha de menor resistência, de alinhamento com respeito à orientação preexistente. No caso de uma sociedade de classes, com cortes culturais nítidos, o processo de difusão interna de valores dar-se-ia nas mesmas linhas (FURTADO, 1997, t. 1, p. 194-195).

Percebe-se que se vive hoje, no Brasil, um momento de "resgate da contribuição de Celso Furtado sobre a cultura” (ROCHA, 2012). Deste 
modo, revisitar os textos de Furtado tem especial utilidade quando se trata de se perquirir e se questionar sobre os sentidos e significados de cultura para o subdesenvolvimento tal como marcam a América Latina e o Brasil.

\section{Os Maracatus Nação de Pernambuco: criatividade, resistência e (sub)desenvolvimento numa perspectiva cultural furtadiana}

Furtado, como já mencionado anteriormente, recebeu forte influência das concepções da antropologia de Melville Herskovits (1963) e da sociologia da cultura de Gilberto Freyre (1957, 1969, 1990, 2010), mas também é importante pontuar que nele ecoa a perspectiva de um outro autor antropólogo que também fora, por alguns anos, aluno de Franz Boas (1996; 2004), tal como os dois intelectuais antes citados: Ralph Linton (1962; 1967). Neste sentido, Linton impactou Furtado por meio de seu contato com Herskovits, que assim chegou até ele e o economista paraibano, influenciado por suas ideias afirma que: "[...] as culturas têm uma área de preocupação dominante [...] cujo estudo é essencial para a compreensão da sua dinâmica" (FURTADO, 1997, t. 1, p. 195).

Assim, Furtado acolhe a ideia acima a partir do pensamento de Linton que indica que se traduziria na religião como manifestação cultural, do mesmo modo que simbólica e dinamicamente a religiosidade expressa a cultura e isto é bem verdadeiro e tem grande notoriedade quando se analisam os povos de matriz religiosa africana (afrodescendente) e afro -brasileira, enraizadas com a vinda das nações de escravos, desde a formação colonial da sociedade brasileira. Neste período histórico, "[...] os africanos haviam sido isolados de suas matrizes culturais respectivas e, ao serem posteriormente privados das próprias línguas, perdiam o senso da identidade cultural" (FURTADO, 1984, p. 20).

Neste sentido, compreende Furtado que nas comunidades negras que foram na África escravizadas e impositivamente alocadas no Brasil pela força do colonizador europeu, foi a religião um dos aspectos fundamentais, senão o principal, de sobrevivência destes povos africanos, e modo de se manter firme e resistir diante de tantas privações e atrozes sofrimento trazidos pela escravidão. Diante disto, elucida: que "[...] numa sociedade que os reprimia e mutilava. [...], não foi por acaso que a criatividade dos negros brasileiros se refugiara na esfera religiosa" (FURTADO, 1997, t. 1, p. 195). 
Então, Furtado explicita, nesta perspectiva que:

[...] a criatividade religiosa das populações brasileiras de origem africana, estimulada em luta secular pela sobrevivência, constitui elemento fundamental na formação da nossa cultura. Por outro lado, a corrente dominante da cultura brasileira teve sua área focal crescentemente deslocada para a inovação tecnológica, principalmente através de empréstimos de outras culturas. Essa dicotomia de orientação na área de percepção mais aguda da cultura não podia ser ignorada. Para pensar o Brasil era necessário começar pela antropologia (FURTADO, 1997, t. 1, p. 195).

Por isso, uma vez mais, consoante as supracitadas palavras de Celso Furtado, fica evidenciado o porquê da escolha dos autores deste texto terem se proposto a, a partir das contribuições da antropologia, com ênfase nos elementos, manifestações e fenômenos da cultura e seus símbolos, compreender o potencial criativo cultural na centralidade que este assume no pensamento desenvolvimentista furtadiano.

Celso Furtado então explicita, tal como anteriormente já mencionado em outro tópico deste texto, apesar de não ser o seu viés mais conhecido, sempre que possível, objetivando uma abordagem mais ampla e um conhecimento mais global dos problemas da América Latina e do Brasil, uma primazia da antropologia sobre a economia, ou seja, da análise engajada da cultura sobre o mero utilitarismo reprodutivista da técnica.

Pode-se dizer assim que, "[...] a cultura é determinante na gênese dos processos e das instituições econômicas e políticas. No caso brasileiro, por exemplo, a formação cultural do nosso povo é marcada por uma assimetria fundamental [...]" (BOLAÑO, 2011, p. 7). Tal assimetria também é demarcada, portanto, na permanência e manutenção dos vínculos culturais pelos europeus brancos e, por outro lado, de um brutal afastamento baseado em rígidos impedimentos para os negros, de suas matrizes africanas.

A partir disto, se pode perceber a importância tanto das proibições das práticas religiosas como ataque a este ponto cultural de unidade das comunidades dos escravos negros africanos, para a efetiva dominação branca; quanto, por outro lado, aponta para o sublime e intrínseco sentido que a manutenção destes ritos e a resistência da religiosidade africana dos escravos, eram fundamentais para que estes suportassem o cotidiano no escravismo, e assim conseguiram compartilhar, através das práticas religiosas em suas famílias, também fracionadas pelo colonizador, a mínima 
pertença e ligação com sua ancestralidade, suas tradições originárias. Dessa forma, Furtado elucida que:

É esta uma simples enumeração das formas correntes como se exterioriza o poder. Em todas as culturas existe um segundo plano de controle, que permeia todo o processo de socialização do indivíduo e assume a forma de um sistema de valores, [...] a religião e a família, graças ao qual o custo social da repressão pode ser consideravelmente reduzido (FURTADO, 1977, p. 29).

As manifestações multifacetadas e a diversidade dos fenômenos da cultura popular brasileira, com seus símbolos de presença e resistência de variadas tradições e ancestralidades que deram origem à mesma, foram permanecendo e se consolidando, de modo criativo, desde suas raízes, conjunta e concomitantemente, cada qual da sua maneira, no fluxo do tempo histórico e na dinâmica espacial que as formaram e onde surgiram (MAIA e SOUZA, 2019).

Dentre essas manifestações da cultura popular brasileira, as de raízes africana e afro-brasileira, que surgiram a partir da chegada das nações e etnias dos negros escravizados ao Brasil, destacam-se como uma das maiores expressões das bases formadoras socioculturais do Brasil. Estas práticas e costumes ancestrais mantiveram os escravos em unidade e coesão, em virtude da pertença a memórias sociais e históricas comuns partilhadas pela negritude, mesmo quando da proibição de cultos e ritos religiosos tradicionais que, desde a sua chegada às terras brasileiras, desvelam suas criativas soluções ao enfrentarem e resistirem através do sincretismo religioso, para que este elemento cultural de especial importância, a religião, fosse mantida e tivesse sobrevida. Diante disso, então:

Mesmo proibidos de praticarem a sua religião ancestral, os
negros e negras ao longo dos séculos, recriaram de forma
criativa a sua experiência religiosa, condensando-a em uma
nova constelação simbólica de valores e sentidos funda-
mentais para a sua existência. [...] Não cabia a estes homens
e mulheres outra atitude a não ser buscar, diante da nova
realidade social, produzir coletivamente uma reinterpreta-
ção dos seus valores e símbolos (VASCONCELOS, 2001, p.
294).

Desde então até os dias de hoje, as comunidades afro-brasileiras buscam manter suas ancestrais tradições e sua identidade cultural por meio de costumes e práticas já arraigadas e manifestas na cultura popular, como é o exemplo dos Maracatus Nação de Pernambuco. 
Através desses fenômenos culturais e religiosos populares, as próprias comunidades negras pernambucanas em que se originaram experienciaram, no dia-a-dia, e celebraram, até a atualidade, na vivência coletiva destas manifestações culturais populares-religiosas. Sobre este conteúdo originário de notória religiosidade dos Maracatus Nação, sabe-se que:

O fundamento religioso manifesta-se nas formas de interpretação da cantoria, nos temas cantados e também no uso de determinados instrumentos de função ritual e cunho religioso no batuque. Pode ocorrer também o empréstimo funcional de um modo de execução próprio da cerimônia religiosa [...] que é transferida [...] para um instrumento antes profano do batuque, que passa a ser concebido, no conjunto, como detentor de reverência e obrigação religiosa (GUILLEN, 2013, p. 66).

Neste sentido, eis que mesmo hoje, para a maioria dos maracatuzeiros e maracatuzeiras, dos negros e das negras que os Maracatus Nação integram e pelas suas raízes unem-se, a cada toada e baque, cantada e tocado, estes revisitam, resgatam, revivem e recriam, com toda sua criatividade, os símbolos da resistência de suas religiões ancestrais, das lutas cotidianas e das memórias das tradições fundadas pelos seus antepassados.

Logo, compreende-se aqui porque se configura gritante e urgentemente a manutenção e o fortalecimento das manifestações culturais populares de cada local, na medida em que estas demonstram com seus movimentos de resistência e preservação criativas de suas identidades (CHAUÍ, 1986; BARROS, 2008) - tal como se enquadram os notórios casos dos Maracatus Nação.

Então, para manterem erguidos os pilares de sua cultura, isto explica e faz compreender, em termos gerais, porque os negros escravos utilizaram estratégias de criatividade, como o sincretismo religioso. Portanto, por meio do uso estrategicamente (re)criativo sincrético nas suas manifestações culturais, disfarçavam sua religião ancestral, seus cultos perseguidos e ritos proibidos em expressões correntes nas artes e/ou na religiosidade do povo e socialmente aceita dos brancos. E assim, esses fatores ocasionaram essa junção religiosa sincrética de elementos basilares africanos fundidos com imagens, figuras e faces cristãs, e disso que se originou a cultura religiosa popular afro-brasileira (VASCONCELOS, 2001).

Desta maneira, dentre outras manifestações da cultura do povo brasileiro, surgiu o Maracatu Nação, e nele reside a importância do seu conteúdo religioso como símbolo e representação social da resistência das matrizes culturais tradicionais africanas e do potencial de criatividade 
presente neste fenômeno da cultura popular pernambucana (GUILLEN, 2013; LOSSIO, 2007; MARIOSA, 2007).

Estudos atuais de diversas áreas e disciplinas das ciências humanas e sociais compreendem e confirmam em uníssono que, os Maracatus Nação:

(...) passaram por transformações e mudanças ao longo do século XX, demonstrando sua capacidade de adaptação e permanência. Trata-se, portanto, de uma forma de expressão da cultura negra, que tem sido considerada primordial na definição das identidades culturais pernambucanas, herança e resistência de negros e negras [...] (GUILLEN, 2013, p. 9).

Isto acima é citado para comprovar que os Maracatus Nação, expressão cultural popular, até alguns anos atrás, estavam estabelecidos e circulavam apenas nos limites e arredores das comunidades negras e quilombolas, por exemplo, de Pernambuco. Deste modo, foi transmitida sua identidade cultural-religiosa e suas tradições ancestrais de geração em geração, e assim resistiu e sobreviveu (re)criativamente, e, difundindo-se e legitimando-se aos poucos, expandiu os seus limites iniciais e os horizontes de seus integrantes, saindo de suas cercanias de origem. Hoje, o maracatu ultrapassa as fronteiras das comunidades afrodescendentes e cantam suas toadas e tremem seus baques, de Pernambuco para o Brasil, para toda a América Latina e para todo o mundo (MAIA e SOUSA, 2019).

Estes elementos de identidade são compartilhados não só entre seus integrantes membros, mas também pelos indivíduos todos que vivenciam, experienciam e recebem o impacto da atmosfera dessas manifestações da cultura popular, que influenciam a dinâmica da comunidade, da região onde se constituem e das áreas de interação social circunvizinhas, e em constantes conflitos contra a desagregação social e o afastamento das raízes culturais "vendidas" pela lógica do mercado, em Pernambuco.

Isto posto, é de grande valia destacar que:

[...] carnavalescos, brincantes, artistas e intelectuais trataram de legitimar uma cultura [...] autêntica [...] além de representante do modo de ser local. Em meio à afirmação de uma identidade regional, às manifestações da cultura popular foram atribuídas virtudes capazes de agregar sentimentos e emoções que congregavam os pernambucanos como um povo único (GUILLEN, 2013, p. 45-46).

Para Furtado, o legado cultural de um povo inspira o horizonte da criatividade que não se apresenta apenas como mera negação, mas sim como 
um diálogo na forma de: "[...] ato criativo [...] tanto ruptura como processo que se alimenta da herança cultural [...]" (D’AGUIAR, 2012, p. 103).

Deste modo, a criatividade:

Como ato de ruptura, [...] alimenta-se com frequência da ação de grupos contestadores que, em uma sociedade aberta, devem encontrar espaço para atuar. Demais, como a herança cultural e a criatividade se inserem na pluralidade étnica do país, o avanço na conscientização das populações negras [...] é visto como ampliação do horizonte cultural (D'AGUIAR, 2012, p. 104).

O pensamento do economista paraibano sobre as manifestações e fenômenos culturais então, permite elaborar a ideia de que a valorização das expressões da cultura popular que desvelam e trazem à tona símbolos e experiências da vida e das lutas sociais, que emergem de minorias, coletivos ou grupos à margem e/ou segregados de algum modo da sociedade, mostra as distinções presentes na realidade sócio-histórica-cultural e que apontam para a compreensão de elementos de formação de identidades e pertenças locais, regionais, nacionais, brasileiras e latino-americanas. Sobre isto:

[...] o resgate das expressões populares que constituam aspectos relevantes do cotidiano, oriundos de segmentos sociais minoritários ou marginalizados, impõe-se como decisivo para que possamos ter uma clara percepção de nossa identidade (D'AGUIAR, 2012, p. 9o).

Numa perspectiva furtadiana, é de grande valia sempre ter em mente que esta não se propõe apenas a pensar que o drama da luta pelo livre exercício da criatividade, nas comunidades negras, que em sua grande maioria, ainda se situam em áreas periféricas e vulneráveis das cidades (periferias urbanas), teria resolução com a percepção, por parte dos populares, em sua tomada de consciência da realidade que põe num injusto abismo os valores de sua produção frente aos preços em depreciação atribuídos para venda de suas produções (bens culturais) no mercado.

No pensamento de Furtado (1978) não se enseja, de modo algum, a desconsideração de estudos sobre como os diversos âmbitos culturais comportam-se e impactam economicamente, mas com a ressalva de que noções econômicas, com toda a sua limitação objetiva encerrada em modelos superficiais, não alcançam a compreensão das dimensões mais densas e profundas de uma cultura e da criatividade que lhe é intrínseca. Estes aspectos que não têm visibilidade para a ciência econômica clássica 
que nem os tangencia (a não ser instrumentalmente), são em exato o que Celso Furtado buscará evidenciar e fazer emergir com a sua noção de (sub)desenvolvimento numa perspectiva cultural, lançando assim nova luz para a necessidade do diálogo economia-antropologia, que abre horizontes, possibilidades e novos caminhos para as constatações econômicas e o pensamento social, comprometidos com a urgente transformação do Brasil.

\section{Consideracões finais}

Este capítulo procurou mostrar a evidente e notória atualidade do pensamento sociocultural elaborado pelo economista, mas também e antes de tudo, intelectual e humanista, Celso Furtado. No intuito de fazer emergir a abissal dinâmica da formação econômica e social brasileira, ilumina os passos no caminho da compreensão do subdesenvolvimento da América Latina, sempre trazendo consigo, em suas reflexões críticas, o acento da esperança no potencial de desenvolvimento socioeconômico do Brasil.

Logo, ao perseguir a totalidade e a globalidade como horizontes reflexivos, funda, no pensar interdisciplinar, os rudimentos do método histórico-estrutural que elaborou e utilizou como lente de análise de seu mundo e de seu tempo, conseguindo assim, nacional e internacionalmente, uma posição de destaque entre os expoentes do estruturalismo latino-americano.

Furtado coloca a cultura num lugar central para a compreensão do subdesenvolvimento, de modo a buscar na antropologia e na sociologia os elementos cruciais para o entendimento mais aprofundado deste processo, objetivando ultrapassar as limitadas fronteiras do pensamento econômico de sua época.

Neste sentido traz à tona, com foco no potencial criativo da cultura popular, elementos que proporcionam a compreensão dos símbolos da criativa resistência dos símbolos da religiosidade negra como base da construção identitária do Brasil. Deste modo, se procurou analisar o fenômeno cultural popular dos Maracatus Nação de Pernambuco sob esta perspectiva furtadiana da cultura.

Com isto, os resultados que aqui se encontram, apontam para a abertura de novos caminhos possíveis como contribuição para futuras e certamente vindouras pesquisas que venham a abordar o multifacetado e criativo pensamento cultural de Celso Furtado. 


\section{Referencias}

ADORNO, Theodor W. Capitalismo tardio ou Sociedade Industrial. In: COHN, Gabriel. Sociologia: Theodor Adorno. São Paulo: Ática, 1986.

BARAN, Paul A. A economia política do desenvolvimento. São Paulo: Abril Cultural, 1984.

BARROS, José Marcio. Diversidade Cultural: da proteção à promoção. Belo Horizonte: Autêntica Editora, 2008.

BENJAMIN, WALTER. Charles Baudelaire, um lírico no auge do capitalismo. São Paulo: Brasiliense, 1989.

BOAS, Franz. A Arte Primitiva. Lisboa: Fenda, 1996.

BOAS, Franz. Antropologia cultural. Rio de Janeiro: Jorge Zahar, 2004.

BOLAÑO, César Ricardo Siqueira. O conceito de cultura em Celso Furtado. Salvador: Edufba, 2015.

BOLAÑO, César Ricardo Siqueira. Indústrias criativas e os conceitos de cultura, inovação e criatividade em Celso Furtado. Políticas Culturais em Revista, 2 (4), p. 3-14, 2011.

BORJA, Bruno. Desenvolvimento e política cultural: reflexões de Celso Furtado no caminho do Ministério da Cultura. Cadernos do desenvolvimento, Rio de Janeiro, vol. 14, n. 25, p. 39-56, jul.-dez. 2019.

BORJA, Bruno. A formação da teoria do subdesenvolvimento de Celso Furtado. 2013. 202f. Tese (Doutorado em Economia Política Internacional) - Instituto de Economia, Universidade Federal do Rio de Janeiro, Rio de Janeiro, 2013.

BOSI, Ecléa. Cultura de Massa e cultura popular. 10 ed. Petrópolis: Vozes, 2000.

CHAUÍ, Marilena. Conformismo e Resistência (Aspectos da cultura popular no Brasil). São Paulo: Brasiliense, 1986.

CUCHE, Denys. A noção de cultura nas ciências sociais. trad. Viviane Ribeiro. Bauru: EDUSC, 1999. 
D'AGUIAR, Rosa Freire. (Org.) Ensaios sobre cultura e o Ministério da Cultura. Rio de Janeiro: Contraponto / Centro Internacional Celso Furtado, 2012.

D'AGUIAR, Rosa Freire. Celso Furtado e a dimensão cultural do desenvolvimento. Rio de Janeiro: E-papers / Centro Internacional Celso Furtado, 2013.

EAGLETON, Terry. A ideia de cultura. Lisboa: Ed. Temas e Debates, 2003 (Coleção Memórias do Mundo).

FAORO, Raymundo. Os donos do poder: formação do patronato político brasileiro. 4. ed. São Paulo: Globo, 2008.

FERNANDES, Florestan. O negro no mundo dos brancos. São Paulo: Difel, 1972.

FERNANDES, Florestan. Capitalismo dependente e classes sociais na América Latina. 2ª edição. Rio de Janeiro: Zahar Editores, 1975.

FERNANDES, Florestan. A revolução burguesa no Brasil. 2ª Edição. Rio de Janeiro: Zahar Editores, 1976.

FREYRE, Gilberto. Casa-grande e senzala. Lisboa: Livros do Brasil, 1957. FREYRE, Gilberto. Novo mundo nos trópicos. São Paulo: Nacional/ EDUSP, 1969.

FREYRE, Gilberto. Sobrados e mucambos. Rio de Janeiro: Record, 1990. FREYRE, Gilberto. O mundo que o português criou. São Paulo: É realizações, 2010.

FREIRE, Paulo. Pedagogia da Autonomia: saberes necessários à prática educativa. Coleção leitura. São Paulo: Paz e Terra, 1996.

FURTADO, Celso. O mito do desenvolvimento econômico. Rio de Janeiro: Paz e Terra, 1974.

FURTADO, Celso. Prefácio a Nova Economia Política. 3.ed. São Paulo: Paz e Terra, 1977.

FURTADO, Celso. Criatividade e dependência na civilização industrial. São Paulo: Círculo do Livro, 1978. 
FURTADO, Celso. Cultura e desenvolvimento em época de crise. Rio de Janeiro: Ed. Paz e Terra, 1984.

FURTADO, Celso. A fantasia organizada. In: FURTADO, Celso. Obra autobiográfica de Celso Furtado: tomo I. São Paulo: Paz e Terra, 1997.

FURTADO, Celso. Aventuras de um economista brasileiro. In: FURTADO, Celso. Obra autobiográfica: tomo II. São Paulo: Paz e Terra, 1997.

GEERTZ, Clifford. A interpretação das culturas. Rio de Janeiro: Zahar, 1978.

GEERTZ, Clifford. O saber local: novos ensaios em antropologia interpretativa. Tradução Vera M. Joscelyne. Petrópolis: Vozes, 1999.

GEERTZ, Clifford. Nova luz sobre a antropologia. Rio de Janeiro: Jorge Zahar, 2001.

GUILLEN, Isabel Cristina Martins (Org.). Inventário cultural dos maracatus nação. Dossiê. INRC do Maracatu Nação - Inventário Nacional de Referências Culturais. Recife: Ed. Universitária da UFPE, 2013.

HERSKOVITS, Melville Jean. Antropologia cultural: man and his works. Tomo I. São Paulo: Mestre Jou, 1963.

HERSKOVITS, Melville Jean. Antropologia cultural: man and his works. Tomo Ii. São Paulo: Mestre Jou, 1963.

HOLANDA, Sérgio Buarque de. Raízes do Brasil. São Paulo: Cia. das Letras, 2006.

HORKHEIMER, Max; ADORNO, Theodor. A indústria cultural: o iluminismo como mistificação de massas. In: LIMA, Luiz Costa. Teoria da cultura de massa. São Paulo: Paz e Terra, 2002.

KEIM, Ernesto Jacob; SILVA, Carlos José. Capoeira e educação póscolonial: ancestralidade, cosmovisão e pedagogia Freiriana. 1. ed. São Paulo: Paco Editorial, 2012.

KEYNES, John Maynard. A Teoria Geral do Emprego, do Juro e da Moeda. São Paulo, Editora Atlas, 1992. 
KORNIS, George. A cultura no pensamento (e na ação) de Celso Furtado: desenvolvimento, criatividade, tradição e inovação. Novos estudos - CEBRAP, São Paulo, n. 96, p. 165-171, July 2013.

LARAIA, Roque de Barros. Cultura: um conceito antropológico. Rio de Janeiro: Zahar, 1986.

LINTON, Ralph. O Homem: uma Introdução à Antropologia. São Paulo: Martins, 1962.

LINTON, Ralph. Cultura e Personalidade. São Paulo: Mestre Jou, 1967.

LOSSIO, Rúbia Aurenívea Ribeiro; PEREIRA. César de Mendonça. A importância da valorização da cultura popular para o desenvolvimento local. Recife, 2007.

MAIA, Tiago Macêdo Bezerra; SOUSA, João Morais de. Contribuições da teoria das representações sociais e da teoria antropológica interpretativa para a compreensão dos símbolos da resistência religiosa afro-brasileira nos Maracatu Nação em Pernambuco. In: SILVA, Rejane Dias da; FREITAS, Vera Lúcia Chalegre de; SOUSA, João Morais de (Orgs.). Educação, formação docente e cultura: diálogos na perspectiva da teoria das representações sociais. Curitiba: CRV, 2019.

MARIOSA, Gilmara Santos. Memória e Representações Sociais de práticas religiosas de matriz africana. Dissertação de Mestrado, Programa de Pós-Graduação em Psicologia Social, Universidade do Estado do Rio de Janeiro, Rio de Janeiro. 2007.

MARCUSE, Herbert. A ideologia da sociedade industrial: $O$ homem unidimensional. Rio de Janeiro: Zahar, 1973.

MARCUSE, Herbert. Eros e civilização. Rio de Janeiro: LTC, 1999.

MARX, Karl. Formações econômicas pré-capitalistas. 5. ed. Rio de Janeiro: Paz e Terra,1986.

MARX, Karl. Contribuição à Crítica da Economia Política. $2^{\underline{a}}$ ed. São Paulo, Expressão Popular, 2008.

MELLO, Luiz Gonzaga de. Antropologia Cultural: iniciação, teoria e temas. 10. ed. Petrópolis: Vozes, 2003. 
MIGUEZ, Paulo; MACHADO, Ana Flávia. Estudo 45: Diversidade cultural: valorização e difusão. In: BANCO NACIONAL DE DESENVOLVIMENTO ECONÔMICO E SOCIAL; UNIVERSIDADE FEDERAL DE MINAS GERAIS. Projeto PIS: perspectivas dos investimentos sociais no Brasil. 2010. Disponível em:http://www.bndes.gov.br/SiteBNDES/export/sites/ default/bndes_pt/Galerias/Arquivos/conhe cimento/seminario/Car_ ima_NE_PauloMiguez.pdf >. Acesso em 15 abr. 2020.

MISSIO, Fabrício J.; JAYME JR, Frederico G.; OREIRO, José Luís. A tradição estruturalista em economia. 2012. Disponível em: http://joseluisoreiro.com.br/site/link/3b4c257c6943e21b64ado4a29763cb3685ea7215. pdf

NAPOLEONI, Claudio. Smith, Ricardo, Marx. 6a edição. Rio de Janeiro: Graal, 1988.

NAPOLEONI, Claudio. Curso de Economia Política. Rio de Janeiro: Graal, 2000.

OLIVEIRA, Cícero. Ensino de filosofia, formação e interdisciplinaridade. Griot: Revista de Filosofia, Amargosa/Bahia, v.17, n.1, p.193-203, junho/2018.

Prebisch, Raúl. El desarrollo económico de la América Latina y algunos de sus principales problemas. In: GURRIERI, A. La obra de Prebisch en la Cepal. México: Fondo de Cultura Económica, 1982.

RICARDO, David. Princípios de economia política e tributação, com a introdução de Piero Sraffa. Apresentação de Paul Singer. Tradução de Paulo Henrique Ribeiro Sandroni. São Paulo: Abril Cultural, 1982. (Os Economistas).

RIBEIRO, Darcy. As Américas e a Civilização Processo de formação e causas do desenvolvimento cultural desigual dos povos americanos. Rio de Janeiro: Civilização Brasileira,1970.

RIBEIRO, Darcy. O povo brasileiro: a formação e o sentido do Brasil. São Paulo: Companhia das Letras, 1995.

RIBEIRO, Darcy. O processo civilizatório. Etapas da evolução sociocultural. São Paulo: Companhia das Letras, 2001. 
ROCHA, Maria. Celso Furtado e a formação da cultura brasileira. Revista de Economía Politica de las Tecnologias de la Información y de la Comunicación, São Cristovão, v. 14, n.1, ene-abr, 2012.

RODRÍGUEZ, Octavio. O estruturalismo latino-americano. Rio de Janeiro: Civilização Brasileira, 2009.

RODRÍGUEZ, Octavio; BURGUEÑO, Óscar. Desenvolvimento e cultura: notas sobre o enfoque de Celso Furtado. In: SABOIA, J.; CARVALHO, F. C. (Orgs.). Celso Furtado e o século XXI. Rio de Janeiro: Instituto de Economia/UFRJ, 2007.

SANTAELLA, Lúcia. Cultura e artes do pós-humano: da cultura da mídia à cibercultura. São Paulo: Paulus, 2003.

SANTOS, Fábio Pádua dos. O enfoque histórico-estrutural e a crítica relegada. Textos de Economia, Florianópolis, v.14, n.1, p. 51-81, jan./jul. 2011.

SCHUMPETER, Joseph Alois. Teoria do Desenvolvimento Econômico. São Paulo: Nova Cultural, 1961.

SEVERINO, Antônio Joaquim. Do ensino da filosofia: estratégias interdisciplinares. Educação em Revista, Marília, v.12, n.1, p.81-96, Jan.-Jun., 2011.

SILVA, Frederico. Política cultural no Brasil, 2002-2006: acompanhamento e análise. In: BRASIL. Ministério da Cultura. Instituto de Economia Aplicada. Coleção cadernos de políticas culturais. Brasília: Ministério da Cultura, 2007. v. 2.

SMITH, Adam. A riqueza das nações: investigação sobre sua natureza e suas causas. São Paulo: Abril Cultural, 1983.

SUNKEL, Osvaldo; PAZ, Pedro. El subdesarrollo latinoamericano y la teoría del desarrollo. Mexíco, DF: Siglo XXI, 1970.

VASCONCELOS, Sérgio S. Douets. O sincretismo afro-católico: a solução de um trauma. In: BRANDÃO, Silvana (Org.). História das religiões no Brasil. Vol. 3. Recife: Ed. Universitária da UFPE, 2001.

WEBER, Max. A ética protestante e o espírito do capitalismo. São Paulo, Pioneira, 1967.

WEBER, Max. Metodologia das Ciências Sociais. 2 vols. São Paulo: Cortez e editora UNICAMP, 1992. 
Sobre o livro

\section{Editoração Eletrônica Leonardo Araujo}

Projeto gráfico Erick Ferreira Cabral

Capa Arão Azevedo

Mancha Gráfica 11,9 x 19,2 cm

Tipologias utilizadas Constantia 11/13,2 pt 
Ângela Cristina Trevisan Felippi

Aristides Monteiro Neto

Carlos Antônio Brandão

Cidonea Machado Deponti

Fernando Cézar de Macedo

Flávio Eliziário de Sousa

Francisco do O' de Lima Júnior

Grazielle Betina Brandt

Ivo Marcos Theis

Jandir Ferrera de Lima

João Morais de Sousa

Larissa da Silva Ferreira Alves

Luciléia Aparecida Colombo

Lívia Gabriela Damião de Lima

Marcos Antônio Mattedi

Maria Daniele Cruz dos Santos

Mariane Freiesleben

Monica Franchi Carniello

Moacir José dos Santos

Rainer Randolph

Rogério Leandro Lima da Silveira

Rosangela dos Santos Alves Pequeno

Tania Bacelar de Araújo

Thales Haddad Novaes de Andrade

Tiago Macedo Bezerra Maia

Thiago José Arruda de Oliveira

Virginia Elisabeta Etges

Waldecy Rodrigues

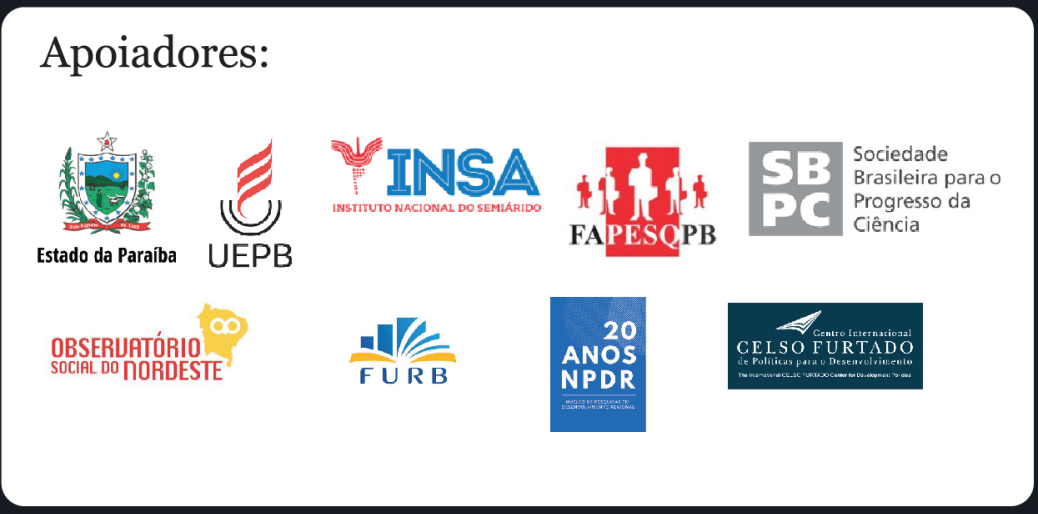

